\title{
Het inzagerecht : artikel 843a van het Wetboek van Burgerlijke Rechtsvordering
}

Citation for published version (APA):

Sijmonsma, J. R. (2010). Het inzagerecht : artikel 843a van het Wetboek van Burgerlijke Rechtsvordering. [Doctoral Thesis, Maastricht University]. Kluwer. https://doi.org/10.26481/dis.20100610js

Document status and date:

Published: 01/01/2010

DOI:

10.26481/dis.20100610js

Document Version:

Publisher's PDF, also known as Version of record

\section{Please check the document version of this publication:}

- A submitted manuscript is the version of the article upon submission and before peer-review. There can be important differences between the submitted version and the official published version of record.

People interested in the research are advised to contact the author for the final version of the publication, or visit the DOI to the publisher's website.

- The final author version and the galley proof are versions of the publication after peer review.

- The final published version features the final layout of the paper including the volume, issue and page numbers.

Link to publication

\footnotetext{
General rights rights.

- You may freely distribute the URL identifying the publication in the public portal. please follow below link for the End User Agreement:

www.umlib.nl/taverne-license

Take down policy

If you believe that this document breaches copyright please contact us at:

repository@maastrichtuniversity.nl

providing details and we will investigate your claim.
}

Copyright and moral rights for the publications made accessible in the public portal are retained by the authors and/or other copyright owners and it is a condition of accessing publications that users recognise and abide by the legal requirements associated with these

- Users may download and print one copy of any publication from the public portal for the purpose of private study or research.

- You may not further distribute the material or use it for any profit-making activity or commercial gain

If the publication is distributed under the terms of Article $25 \mathrm{fa}$ of the Dutch Copyright Act, indicated by the "Taverne" license above, 
Het inzagerecht

Artikel 843a van het Wetboek van Burgerlijke Rechtsvordering 
Serie Burgerlijk Proces en Praktijk

\section{Redactie:}

Prof. mr. G.R. Rutgers

Prof. mr. H.J. Snijders

Prof. mr. J.B.M. Vranken

\section{Eerder verschenen dissertaties:}

I. Derdenbeding

II. Rechtersregelingen in het burgerlijk (proces)recht

III. De Europese Executoriale Titel

IV. De goede procesorde

V. De dwangsom in het burgerlijk recht

VI. E-arbitrage

VII. Het hoger beroep en het cassatieberoep in burgerlijke zaken

VIII. Het inzagerecht

\section{Eerder verschenen monografieën:}

1. Procederen bij dagvaarding in eerste aanleg

2. Civiel appel

3. Bewijslastverdeling

4. De grenzen van de rechtsstrijd in hoger beroep in burgerlijke zaken

5. Herroeping, verbetering en aanvulling van burgerrechterlijke uitspraken

6. Procederen met of zonder procesvertegenwoordiging

7. Mediation in juridisch perspectief

8. Ontwikkelingen in het Europees civiel procesrecht

9. De grenzen van de rechtsstrijd in hoger beroep in burgerlijke zaken in de Nederlandse Antillen en Aruba

10. Artikel 6 EVRM en de civiele procedure

11. Vrijwaring en interventie 


\section{HET INZAGERECHT}

Artikel 843a van het Wetboek van Burgerlijke Rechtsvordering

\section{PROEFSCHRIFT}

ter verkrijging van de graad van doctor aan de Universiteit Maastricht, op gezag van de Rector Magnificus Prof. mr. G.P.M.F. Mols volgens het besluit van het College van Decanen,

in het openbaar te verdedigen

op donderdag 10 juni 2010 om 16.00 uur

door

Johannes Romke Sijmonsma 
Promotor:

Copromotor:

Beoordelingscommissie: prof. mr. J.G.J. Rinkes

mr.dr. A.L.H. Ernes

prof. mr. C.H. van Rhee (voorzitter)

mr. J. de Boer (lid Gemeenschappelijk Hof van Justitie van de

Nederlandse Antillen en Aruba)

mr. F.J. Fernhout

prof. mr. G.R. de Groot

Lay-out: Anne-Marie Krens - Tekstbeeld - Oegstgeest

ISBN 978-90-13-07660-8

NUR 822-209

\section{(C) 2010, J.R. Sijmonsma}

Alle rechten voorbehouden. Niets uit deze uitgave mag worden verveelvoudigd, opgeslagen in een geautomatiseerd gegevensbestand, of openbaar gemaakt, in enige vorm of op enige wijze, hetzij elektronisch, mechanisch, door fotokopieën, opnamen of enige andere manier, zonder voorafgaande schriftelijke toestemming van de uitgeverij.

Voor zover het maken van kopieën uit deze uitgave is toegestaan op grond van art. $16 \mathrm{~h}$ tot en met 16m Auteurswet 1912 jo. het Besluit van 27 november 2002, Stb. 2002, 575, dient men de daarvoor wettelijk verschuldigde vergoedingen te voldoen aan de Stichting Reprorecht (Postbus 3051, 2130 KB Hoofddorp). Voor het overnemen van gedeelte(n) uit deze uitgave in bloemlezingen, readers en andere compilatiewerken dient men zich tot de uitgever te wenden.

No part of this book may be reproduced in any form, by print, photoprint, microfilm or any other means without written permission from the publisher.

Hoewel aan de totstandkoming van deze uitgave de uiterste zorg is besteed, aanvaarden de auteur(s), redacteur(en) en uitgever(s) geen aansprakelijkheid voor eventuele fouten en onvolkomenheden, noch voor gevolgen hiervan.

Op alle uitgaven van Kluwer zijn de algemene leveringsvoorwaarden van toepassing. Deze kunt u lezen op www.kluwer.nl of opvragen via telefoonnummer 0570-67 3449. 


\section{Woord vooraf}

De uitkomst van veel procedures wordt bepaald door de bewijsmiddelen. Daaruit volgt dat het verstandig is om voor het uitbrengen van de dagvaarding de mogelijke bewijsmiddelen in kaart te brengen en zo mogelijk te vergaren. Het laatste, het vergaren van bewijsmiddelen, is niet altijd eenvoudig, zeker niet indien deze in andere handen zijn dan van de partij op wie de bewijslast rust. Het sinds 1 april 1988 in art. 843a van het Wetboek van Burgerlijke Rechtsvordering (hierna Rv) neergelegde recht op inzage is een bruikbaar hulpmiddel om bewijs te vergaren, niet alleen vóór de aanvang van, maar ook tijdens een eventuele procedure. Dit artikel omtrent het inzagerecht (benaderd vanuit het gezichtspunt van de partij die inzage wenst) of de exhibitieplicht (benaderd vanuit het gezichtspunt van de partij die inzage dient te geven), dat een lange voorgeschiedenis heeft, is pas de laatste jaren weer in de belangstelling komen te staan. ${ }^{1}$ Zo levert een kijkje in de kaartenbak van de NJ bij de artikelen 1922, 1922a en 1923 BW (de voorgangers van art. 843a Rv) over de periode 1925 tot en met 1 april 1988 slechts 17 uitspraken op. ${ }^{2}$ Het intikken van art. 843a Rv op 'rechtspraak.nl' waarbij naar dit artikel gezocht moet worden tot en met 1 november 2009 levert maar liefst 277 uitspraken op. Het is vanzelfsprekend dat waar een artikel tot zoveel uitspraken leidt, de literatuur niet achterblijft en al met al kan worden gezegd dat art. 843a Rv inmiddels één van de meest besproken artikelen uit het Wetboek van Burgerlijke Rechtsvordering is. ${ }^{3}$

1 Op het eind van de $19^{\text {de }}$ eeuw zijn er drie proefschriften over de artikelen 1922, 1922a en 1923 BW verschenen. De eerste van A.F. van Blommestein, De artt. 1922 en 1923 van het Burgerlijk Wetboek, Leiden, P. Somerwil,1885. De tweede van R.B. Ledeboer, Eenige opmerkingen over de verplichting tot overlegging van schriftelijke bewijsstukken, Amsterdam, De firma Holdert \& Co, 1888. De derde van H. Ligtenberg, De exhibitieplicht in het Nederlandsche recht (proefschrift), Leiden, Eduard Ijdo 1893. Nog in 2005 schrijven Haak en VerLoren van Themaat op p. 15 dat de rechtspraak zich op het terrein van art. 843a Rv verder dient te ontwikkelen en dat zij uit informele contacten met leden van de rechterlijke macht afleiden dat veel vaker van art. 843a Rv gebruik kan worden gemaakt dan wordt gedaan.

2 Asser-Anema, Handleiding tot de beoefening van het Nederlandsch burgerlijk recht, vijfde deel-van bewijs, 1940 schrijft op p. 244 dat de artt. 1922 en 1923 BW voorschriften bevatten tot verplichte overlegging van stukken in en buiten het proces, doch zo fragmentarisch zijn, dat zij niet veel waarde bezitten.

3 Ook het Post Academisch Onderwijs heeft dit onderwerp ontdekt. Zo staat in de aanbiedingsbrief 'Actualiteiten Civiel Bewijsrecht' van de Erasmus Universiteit voor de cursus van 26 maart 2009 
In deze studie wordt onderzoek gedaan naar het inzagerecht van art. 843a Rv. Hierbij wordt allereerst een beknopt overzicht van de historie van het inzagerecht in Nederland gegeven en een overzicht van de wetten en wetsontwerpen waar in de parlementaire geschiedenis art. 843a Rv aan de orde is geweest. Mede uit de historie blijkt dat het inzagerecht een onderdeel vormt van wat het algemene recht op informatie kan worden genoemd. Naar aanleiding daarvan komt dit recht op informatie in hoofdstuk drie ter sprake, waarbij aandacht wordt besteed aan de vraag waar het recht op inzage, of de plicht tot exhibitie, op is gebaseerd. Met andere woorden: waarom mag een partij inzage vragen en waarom is een ander verplicht om die inzage te geven.

Uit par. 2.3 blijkt dat een bijzondere regeling van het inzagerecht, en wel het inzagerecht bij een vordering wegens inbreuk op een recht van intellectuele eigendom, voortspruit uit Richtlijn nr. 2004/48/EG. Dit vormt de aanleiding om te bezien waar het inzagerecht binnen de $\mathrm{EU}$ nog meer aan de orde is geweest en in hoeverre de ontwikkelingen op het terrein van het inzagerecht binnen de EU van belang zijn voor dit onderdeel van 'ons' Wetboek van Burgerlijke Rechtsvordering. Het lijkt voor de hand te liggen om te denken dat procedurele bepalingen nauwelijks of niet in de belangstelling staan van de instituten van de EU, maar misschien heeft de verwevenheid van burgerlijk recht en burgerlijk procesrecht wel tot gevolg dat de ontwikkelingen in het materiële recht vanuit de EU ons procesrecht meer beïnvloeden dan op het eerste gezicht wordt gedacht. Mede op grond van de resultaten verkregen uit het onderzoek naar het inzagerecht binnen de EU, wordt in hoofdstuk vijf onderzocht welke ontwikkelingen er ter zake het inzagerecht in Nederland bestaan.

Art. 843a Rv is volgens mij vooral in het kader van het bewijsrecht van belang. Ik besteed in dit boek in hoofdstuk zes dan ook enige aandacht aan dit bewijsrecht voor zover art. 843a Rv daar een plaats in heeft of zou moeten hebben. Hierbij wordt ook stilgestaan bij de vraag op welke terreinen van het materiële recht een vordering tot inzage kan worden ingediend, zoals op het terrein van het rechtspersonenrecht, met name betreffende vorderingen tot inzage in due diligencerapporten, ${ }^{4}$ het gezondheidsrecht ${ }^{5}$ en het arbeidsrecht. ${ }^{6}$

Doel van deze studie is verder het in kaart brengen van de literatuur en de jurisprudentie betrekking hebbend op art. 843a Rv, hetgeen per lid van dit artikel wordt gedaan. De bestanddelen van lid 1 komen aan de orde in hoofdstuk zeven, waarna ik in hoofdstuk acht mijn opvattingen over de inhoud van de bestanddelen

onder andere dat in deze cursus aandacht zal worden besteed aan '... de vereisten voor een bewijsaanbod, de exhibitieplicht en de bewijswaardering ...'.

4 Zie bijvoorbeeld M.M. van den Broek, Gedwongen overlegging due diligence rapport, V\&O 2004, p. $122-125$

5 J. Ekelmans, Dient de verplichting om medische bescheiden te verstrekken gebaseerd te worden op artikel 843a Rv?, TVP 2007, p. 29-37.

6 H.A. Dragstra, De exhibitieplicht in het arbeidsrecht, Tijdschrift Recht en Arbeid 2009, p. 15-18. 
van lid 1 van art. 843a $\mathrm{Rv}$ op een rijtje zet. In de daarop volgende hoofdstukken negen, tien en elf worden respectievelijk de leden twee, drie en vier van art. 843a $\mathrm{Rv}$ aan de hand van literatuur en jurisprudentie geanalyseerd.

De Wetboeken van Burgerlijke Rechtsvordering van de Nederlandse Antillen en Aruba bevatten elk ook een artikel waarin het recht op inzage wordt geregeld. ${ }^{7}$ In beide landen is dit recht op inzage in het betreffende wetboek eveneens te vinden in art. 843a. De artikelen 843a in beide wetboeken zijn niet letterlijk gelijkluidend aan het Nederlandse artikel 843a Rv, maar lijken op het eerste gezicht wel dezelfde strekking te hebben. Dit betekent niet per definitie dat de rechtspraak in alle drie landen inhoudelijk ook gelijkluidend is. ${ }^{8}$ Verschillen in onder meer cultuur en welvaart brengen met zich dat de rechtspraak in de drie landen zich niet altijd gelijk ontwikkelt terwijl wetsartikelen wel dezelfde strekking hebben. In dit onderzoek wordt in hoofdstuk twaalf stilgestaan bij de vraag of de rechtspraak in alle drie landen ter zake dit artikel inhoudelijk gelijk is, waarbij ook aandacht wordt besteed aan art. 142 van de wetboeken van Burgerlijke Rechtsvordering van de Nederlandse Antillen en Aruba. Dit artikel lijkt de rechter 'in de West' meer armslag te geven wat betreft de plicht om stukken in te brengen dan de Nederlandse rechter heeft. ${ }^{9}$

In hoofdstuk dertien wordt onderzoek gedaan naar de vraag hoe art. 843a Rv zich verhoudt tot de wijze van gegevensverstrekking in enkele bijzondere wetten en wel de Wet Bescherming Persoonsgegevens, de Wet justitiële en strafvorderlijke gegevens en de Wet op de inlichtingen- en veiligheidsdiensten.

Onder meer uit de onderzoeksresultaten gevonden in hoofdstuk zeven blijkt dat men in de praktijk bang is dat de bescheiden waarvan om inzage wordt gevraagd, verdwijnen. Om dit te voorkomen, wordt verlof tot bewijsbeslag gevraagd. In hoofdstuk veertien komt deze bijzondere vorm van beslag aan de orde.

De bewijsrechtelijke bepaling van art. 843a Rv levert de nodige processuele vragen op, zoals op welk moment de vordering of het verzoek tot inzage kan worden gedaan en hoe expliciet een dergelijke vordering of verzoek dient te zijn. In hoofdstuk vijftien komen die processuele verwikkelingen aan bod.

In hoofdstuk zestien worden de onderzoeksresultaten in de voorgaande hoofdstukken verwerkt in een ontwerpwettekst.

7 Artikelen uit het Wetboek van Burgerlijke Rechtsvordering van de Nederlandse Antillen en Aruba zullen hierna worden aangeduid met het artikelnummer gevolgd door Rv-NA\&A. Indien het betreffende wetboek in Aruba een andere tekst heeft, zal dit worden vermeld. Met de afkorting 'Rv' wordt alleen het Nederlandse Wetboek van Burgerlijke Rechtsvordering bedoeld.

8 Zie over het concordantiebeginsel van rechtspraak onder andere G.C.C. Lewin, Concordantie en maatschappelijke opvattingen, TAR 2008, p. 194-199 en J.P. de Haan, Eendrachtig recht vormen? Het beginsel van concordantie van rechtspraak, NJB 2008, p. 2456-2460. Zie over verschillen in uitspraken terwijl de wetteksten gelijkluidend zijn J. de Boer in twee artikelen in het NJB en wel Het NBW in de West, NJB 2001, p. 289-294 en het artikel Burgerlijke Rechtsvordering in de West, NJB 2005, p. 1980-1984.

9 Zie voor de tekst van deze artikelen bijlage I achterin dit boek. 
De stelselmatige inzage in bescheiden voor dit manuscript is geëindigd op 30 november 2009.

Ik heb voor deze studie met succes naar de meningen gevist van mrs. Foppen, Lewin Mijnssen en drs. Nassy-Tseng. Ik ben hen daarvoor dankbaar. 


\section{Inhoudsopgave}

\section{Lijst van gebruikte afkortingen / XIII}

1. Inleiding / 1

2. Beknopt overzicht van de geschiedenis van het inzagerecht / 5

2.1 Het inzagerecht in (ontwerpen voor) het Burgerlijk Wetboek / 5

2.1.1 Het ontwerp $1820 / 5$

2.1.2 Het ontwerp 1824 en de wet 1825 / 6

2.1.3 De artikelen 1932 en 1937 BW-1830 / 8

2.1.4 De artikelen 1922 en 1923 BW / 11

2.2 Het inzagerecht in het Wetboek van Burgerlijke Rechtsvordering / 20

2.2.1 De wetsgeschiedenis van art. 843a Rv-oud (het nieuwe bewijsrecht) / 20

2.2.2 De wetsgeschiedenis van het op 1 januari 2002 in werking getreden art. 843a Rv / 24

2.3 Verspreide opmerkingen over art. 843a $\mathrm{Rv}$ in parlementaire stukken / 29

2.4 Conclusies uit de parlementaire geschiedenis / 40

3. Het recht op informatie / 43

3.1 De grondslagen van het recht op informatie / 43

3.2 Art. 843a Rv bezien in het licht van enkele andere 'informatieartikelen' / 51

3.3 De disclosure of discovery / 58

4. Het inzagerecht in het kader van de Europese Unie / 65

4.1 Het rapport van de Commissie Storme / 65

4.2 Richtlijn nr. 2004/48/EG betreffende de handhaving van intellectuele eigendomsrechten / 70

4.3 Schadevorderingen wegens schending van de communautaire antitrustregels / 73

4.4 Conclusies uit de EU-regels en EU-wensen / 74 


\section{Nieuwe ontwikkelingen in Nederland / 79}

5.1 Een uitgebalanceerde disclosure? / 79

5.2 De fundamentele herbezinning door de regering / 81

5.3.1 De Adviescommissie voor het Burgerlijk Procesrecht en de discovery / 83

5.3.2 De schets van de ABP / 85

5.3.3.1 Commentaar op de schets van de ABP / 87

5.3.3.2 Inhoudelijk commentaar op de schets / 90

5.3.3.3 Welke problemen worden door de schets opgelost? / 92

6. De plaats van art. 843a Rv in het bewijsrecht / 97

$6.1 \quad$ Inleiding / 97

6.2 Waarheidsvinding; stellen en onderbouwen en overlegging van stukken / 101

6.3 Exhibitie en bewijzen / 107

7. De inhoud van de bestanddelen van art. 843a lid $1 \mathrm{Rv}$ in de literatuur en de jurisprudentie / 117

7.1 Inleiding / 117

7.1.1 Het rechtmatig belang / 117

7.1.2 Het rechtmatig belang en de vordering tot inzage in medische gegevens / 132

7.1.3 Het rechtmatig belang bij inzage in het due diligencerapport / 136

7.2 Inzage, afschrift of uittreksel / 138

7.3 Bepaalde bescheiden / 140

7.4 Aangaande een rechtsbetrekking waarin hij partij is / 148

8. Eigen omschrijving van de inhoud van de bestanddelen van art. 843a lid 1 Rv / 159

8.1 Het rechtmatig belang / 159

8.2 Inzage, afschrift of uittreksel / 163

8.3.1 Bepaalde bescheiden / 164

8.3.2 Vissen naar stukken / 167

8.4 Aangaande een rechtsbetrekking waarin hij partij is / 169

9. Art. 843a lid 2 Rv, de wijze waarop inzage, afschrift of uittreksel wordt verschaft / 173

10. Art. 843a lid $3 \mathrm{Rv}$, degene die tot geheimhouding verplicht is / 177 
11. De afwijzingsgronden in art. 843a lid $4 \mathbf{R v} / 183$

11.1 Gewichtige redenen / 183

11.2 Redelijkerwijs is een behoorlijke rechtsbedeling ook zonder verschaffing van de gevraagde gegevens gewaarborgd / 194

12. Inzage en disclosure in de Nederlandse Antillen en Aruba / 199

13. Het inzagerecht en de Wet bescherming persoonsgegevens, de Wet justitiële en strafvorderlijke gegevens en de Wet op de inlichtingen- en veiligheidsdiensten 2002 / 207

14. Het bewijsbeslag / 215

15. Processuele verwikkelingen / 225

$16 \quad$ Een eigen ontwerp / 239

Samenvatting / 243

Summary / 251

Bijlagen

I De artikelen 141 en 142 van de Wetboeken van Burgerlijke Rechtsvordering van de Nederlandse Antillen en Aruba / 261

II De Franse tekst van art. 4, La découverte des documents van Rapprochement du Droit Judiciaire de 1'Union européenne / 263

III Kamerstukken / 265

Geraadpleegde literatuur / 267

Jurisprudentieregister / 275

Trefwoordenregister / 285

Curriculum vitae / 287 



\section{Lijst van gebruikte afkortingen}

$\begin{array}{ll}\text { AA } & \text { Ars Aequi } \\ \text { Adv. Blad } & \text { Advocatenblad } \\ \text { AMI } & \text { Tijdschrift voor auteurs-media- \& informatierecht } \\ \text { AV\&S } & \text { Aansprakelijkheid Verzekering en Schade } \\ \text { Awb } & \text { Algemene Wet Bestuursrecht } \\ \text { AWR } & \text { Algemene Wet inzake de Rijksbelastingen } \\ \text { Bb } & \text { Nieuwsbrief Bedrijfsjuridische berichten } \\ \text { BW } & \text { Burgerlijk Wetboek } \\ \text { IER } & \text { Tijdschrift Intellectuele Eigendom en reclamerecht } \\ \text { JAVI } & \text { Juridische Aspecten Van Internet } \\ \text { JBPR } & \text { Jurisprudentie burgerlijk procesrecht } \\ \text { JOR } & \text { Jurisprudentie Ondernemingsrecht, Jurisprudentie Onderneming \& } \\ & \text { Recht } \\ \text { KG } & \text { Kort Geding } \\ \text { LJN } & \text { Landelijk Jurisprudentie Nummer } \\ \text { L\&S } & \text { Letsel en Schade } \\ \text { MvV } & \text { Maandblad voor Vermogensrecht } \\ \text { NIPR } & \text { Nederlands Internationaal Privaatrecht } \\ \text { NJ } & \text { Nederlandse Jurisprudentie } \\ \text { NJF } & \text { Nederlandse Jurisprudentie Feitenrechtspraak } \\ \text { NTBR } & \text { Tijdschrift voor Nederlands burgerlijk recht } \\ \text { O\&F } & \text { Onderneming en Financiering } \\ \text { PP } & \text { Praktisch Procederen } \\ \text { RAR } & \text { Rechtspraak ArbeidsRecht } \\ \text { Rv } & \text { Wetboek van Burgerljke Rechtsvordering } \\ \text { Rv-oud } & \text { Wetboek van Burgerlijke Rechtsvordering, tekst tot 1 januari } \\ \text { RvdW } & \text { 2002 } \\ \text { S\&S } & \text { Rechtspraak van de Week } \\ \text { Stb } & \text { Staatsblad } \\ \text { Stct } & \text { Staatscourant } \\ \text { TRA } & \text { Tijdschrift Recht en Arbeid } \\ \text { TCR } & \text { Tijdschrift voor Civiele Rechtspleging } \\ \text { TVP } & \text { Tijdschrift voor Vergoeding Personenschade } \\ & \end{array}$


Lijst van gebruikte afkortingen

TVVS Maandblad voor ondernemingsrecht en rechtspersonen (eerst Tijdschrift voor Vennootschappen, verenigingen en stichtingen, nu Ondernemingrecht)

$\mathrm{V} \& \mathrm{O} \quad$ Vennootschap en Onderneming

Wbp Wet houdende regels inzake de bescherming van persoonsgegevens

Wjs Wet justitiële en strafvorderlijke gegevens

W Weekblad van het Recht

WIV Wet op de inlichtingen- en veiligheidsdiensten

WvhR Weekblad van het Regt

WPNR Weekblad voor Privaatrecht, Notariaat en Registratie 


\section{$1 \quad$ Inleiding}

Franchisegever A, zaken doende op het terrein van huisdierenvoeding- en verzorging, heeft diverse franchiseovereenkomsten gesloten met een aantal franchisenemers. De franchisenemers hebben onder meer beloofd dat zij alle hondenbrokken zullen afnemen van A waarbij A 5\% meer in rekening mag brengen aan de franchisenemer dan A zelf betaalt aan het bedrijf waarvan zij, A, de hondenbrokken afneemt. Op de facturen ter zake de hondenbrokken die A aan alle franchisenemers stuurt, staat vermeld dat de inkoopprijs van $A € 10$,- bedraagt zodat de franchisenemers $€ 10,50$ aan A dienen te betalen. Op een bepaald moment heeft franchisenemer $B$ redenen om aan te nemen dat $A$ de brokken niet voor $€ 10$,- heeft ingekocht doch voor $€ 9$,- en hij wenst dit te controleren. B vordert dan ook openlegging van de boeken van A zodat hij kan controleren wat de inkoopprijs van A is.

Advocatenkantoor Tripels heeft werkzaamheden voor Masson verricht voor ongeveer $€ 300.000$,- en wil deze werkzaamheden graag betaald hebben. Masson betaalt - grotendeels - niet omdat hij, naar eigen zeggen, geen geld heeft. Tripels gelooft dit niet en is van mening dat Masson als behoorlijk debiteur inzage moet verschaffen in zijn financiële handel en wandel en vordert daarom onder meer afgifte van afschriften van bank- en girorekeningen en effectenportefeuille en overzichten van deelnames van Masson in verschillende vennootschappen en afgifte van de boekhoudkundige administratie van te Jersey en Liechtenstein gevestigde vennootschappen vanaf 1976 tot de dag van het uitbrengen van de dagvaarding. ${ }^{1}$

Twee concrete voorbeelden van de abstract geformuleerde vraag of er onder omstandigheden een recht op informatie bestaat. Een partij is afhankelijk van informatie die een ander bezit, krijgt enige informatie maar wenst die informatie te controleren op juistheid en volledigheid of krijgt in het geheel geen informatie maar wenst die informatie op goede gronden wel te bezitten. Ledeboer schreef wat dit betreft al in 1888 het volgende:

'Het komt zeer dikwijls voor, dat in een proces de partij die de door haar beweerde feiten moet bewijzen, dit bewijs slechts zal kunnen putten, uit schriftelijke stukken, die zich in handen van hare tegenpartij of derden, niet in het proces betrokken personen bevinden, en de vraag doet zich dan voor, in hoeverre deze tegenpartij of derden verplicht zijn, die stukken aan de bewijsvoerende partij over te leggen.' ${ }^{2}$

1 Een kort geding leidend tot HR 20 september 1991, NJ 1992, 552 m.nt. Vranken.

2 P. 1 Ledeboer. 
De wens op het bezit van deze informatie kan benaderd worden vanuit meerdere gezichtspunten. Ten eerste vanuit het gezichtspunt van de informatiebezitter: bestaat er voor die informatiebezitter een mededelingsplicht in het burgerlijk procesrecht? ${ }^{3}$ Zo ja, vanaf welk moment bestaat die mededelingsplicht dan en moet er van rechtswege aan die plicht voldaan worden?

Een ander gezichtspunt is dat vanuit de wensende partij. Iemand wenst informatie te ontvangen. Hoe kan die wens worden afgedwongen en op welk moment? De vraag rijst verder of het feit dat een partij bepaalde informatie zou moeten meedelen, met zich brengt dat de andere partij afgifte van die informatie kan vorderen. Bij deze vraag blijft het niet. Indien er inderdaad een plicht bestaat om informatie te verschaffen, ${ }^{4}$ rijzen al snel vragen zoals hoever die plicht zich uitstrekt en welke informatie (mondelinge informatie, schriftelijke, digitale, visuele informatie, enz.) verschaft moet worden. De wet kent meerdere artikelen die betrekking hebben op informatieverstrekking. De wet beperkt zich wat dat betreft niet tot enkel het civiele recht. In het Wetboek van Strafvordering hebben onder meer de artt. 96a, 105, 125i en 126a betrekking op afgedwongen informatieverstrekking. In het belastingrecht kennen wij onder andere art. 47 jo. 49 Algemene Wet inzake Rijksbelastingen ${ }^{5}$ en de Faillissementswet kent art. 105 en $107 .{ }^{6}$ Het Wetboek van Burgerlijke Rechtsvordering heeft behalve art. 843a nog enkele artikelen die betrekking hebben op informatieverstrekking en wel art. 21, 22, 162, 475g en, sinds kort, 1019a. Ook het Burgerlijk Wetboek kent artikelen die betrekking hebben op informatieverstrekking zoals art. 1:377c, art. 2:345 e.v., ${ }^{7}$ art. $3: 15 j,{ }^{8}$ in titel 7.7 (opdracht) art. 7:403, ${ }^{9}$ in het verzekeringsrecht art. 7:932 en art. 7:941 en ten slotte

3 Zie W.A.J.P. van den Reek, Mededelingsplichten in het burgerlijk procesrecht.

4 Zie daarover hoofdstuk drie van dit boek en onder meer Asser-Vranken, Algemeen Deel 1995, nr 19 e.v. en HR 18 december 1925, NJ 1926, p. 228.

5 Art. 47 lid 1 AWR: Ieder is gehouden desgevraagd aan de inspecteur:de gegevens en inlichtingen te verstrekken welke voor de belastingheffing te zijnen aanzien van belang kunnen zijn; de boeken, bescheiden en andere gegevensdragers of de inhoud daarvan - zulks ter keuze van de inspecteur waarvan de raadpleging van belang kan zijn voor de vaststelling van de feiten welke invloed kunnen uitoefenen op de belastingheffing te zijnen aanzien, voor dit doel beschikbaar te stellen.Art. 49 lid 1 AWR: De gegevens en inlichtingen dienen duidelijk, stellig en zonder voorbehoud te worden verstrekt, mondeling of schriftelijk of op andere wijze - zulks ter keuze van de inspecteur - en binnen een door de inspecteur te stellen termijn.

6 Zie ook HR 22 december 2006, NJ 2007, 23.

7 Zie daarover B. Winters en J. Vossenberg, Vissen in het enquêterecht, Vennootschap\&Onderneming 2005, p. 62-65 en HR 20 november 2009, BJ7322.

8 Zie voor wat de betekenis van dit artikel in een faillissement onder meer de conclusie van AG Huydecoper bij HR 21 januari 2005, NJ 2005, 249 die zeer uitgebreid uitweidt over inzage en rechten op informatie voor betrokkenen bij een faillissement.

9 Zie bv Rb Utrecht 5 juni 2009, BI6346, waar de rechtbank SNS op grond van dit artikel verplicht achtte verantwoording af te leggen met betrekking tot de uitvoering van beleggingsopdrachten. Dit moest geschieden door het verstrekken van een afschrift van de Subscription Agreement tussen SNS en Aldarra Prime Advisor (koopovereenkomst), van het ontvangstbewijs als bedoeld in de e-mail van Ron Ward van 20 januari 2009 (interim receipt for this addition), van een schriftelijke 
art. 8:494 en art. 8: 495 BW (goederenvervoer over zee). Van de bijzondere wetten waarin een persoon verplicht wordt om soms informatie te geven noem ik art. 9.2 van de Wet op de Studiefinanciering 2000 (WSF 2000) waarin de verplichting is opgenomen om, kort gezegd, aan de IB-Groep de ten behoeve van de uitvoering van de WSF 2000 benodigde inlichtingen over zichzelf te geven. Art. 4:90b Wet op het Financieel Toezicht bepaalt in lid 9 dat een beleggingsonderneming op verzoek van een cliënt moet aantonen dat die onderneming voor hem een order heeft uitgevoerd in overeenstemming met het orderuitvoeringsbeleid. Hiermee is een mogelijk inzagerecht verleend.

In het hierna volgende staat echter art. 843a Rv centraal. Dit artikel regelt, kort gezegd, het recht op inzage in bepaalde bescheiden en valt daarmee onder het algemenere leerstuk van de informatieverstrekking, maar ook onder dat van het bewijsrecht. Andere artikelen die betrekking hebben op informatievoorziening komen in het hierna volgende niet, of hoogstens zijdelings aan de orde.

mededeling aan SNS van de beheerder van Aldarra Prime Advisor van begin 2009 waarin wordt gemeld dat naar verwachting het belegd vermogen van Aldarra Prime Advisor geheel is verdwenen, van de fax van 26 november 2008 van SNS aan de beheerder van Aldarra Prime Advisor waarin de kooporder namens eiser zou zijn omschreven, van de betalingsopdracht door SNS aan Fairfield Sigma dan wel aan de door dat fonds aangewezen Custodian Bank, van het na 11 december 2008 verzonden schriftelijk annuleringsverzoek van SNS terzake de op 21 november 2008 geplaatste kooporder aan (de beheerder van) Fairfield Sigma. 



\section{Beknopt overzicht van de geschiedenis van het inzagerecht}

\subsection{Het inzagerecht in (ontwerpen voor) het Burgerlijk Wetboek}

\subsubsection{Het ontwerp 1820}

Voordat op 1 april 1988 art. 843a Rv-oud ${ }^{1}$ in werking trad, werd de mogelijkheid op inzage geregeld in het Burgerlijk Wetboek van 1838. Voordat dit wetboek in werking trad, hadden de nodige teksten het licht gezien. Voor zover daarin aandacht is besteed aan het recht op inzage, komen zij hierna aan de orde.

Het op 22 november 1820 aan de Staten-Generaal aangeboden ontwerp van het Burgerlijk Wetboek voor het Koningrijk der Nederlanden, hierna ook wel genoemd 'het ontwerp 1820' bepaalde omtrent de inzage het volgende.

Art. 3344. Hij, die regt van eigendom of mede-eigendom op een geschrift heeft, kan, in het eerste geval, de uitlevering, in het andere geval de depositie van hetzelve geschrift vorderen.

Art. 3345. Ieder, die eenige geschriften, bij welker inhoud een ander een klaarblijkelijk belang heeft, onder zich heeft, kan verpligt worden, om zoodanige geschriften op eene door den regter te bepalen plaats te brengen, ten einde daarvan visie, en, des noods, kopij genomen, of daaruit extract gemaakt worde.

Van deze verplichting zijn echter vrijgesteld:

$1^{\text {ste }}$. Bloedverwanten en nabestaanden in de op- en nedergaande lijn, broeders of zusters en derzelver kinderen, echtgenooten, voogden, curatoren, gelijk ook die onder voogdij of curatele staan, in processen van derden tegen zoodanige personen, tot welke zij in eene der genoemde betrekkingen staan;

$2^{\text {de }}$. Allen, die zelven bij de zaak regtstreeks, of een aanmerkelijk zijdelings belang hebben;

$3^{\text {de }}$. Allen, die in de zaak eene der partijen als praktizijns of gemagtigden bedienen of bediend hebben.

Art. 3346. De uitzonderingen, in het vorig artikel vermeld, kunnen niet worden ingeroepen tegen dengene, die op eenige geschriften aanspraak heeft, uit hoofde van eigendom

1 In het hierna volgende wordt art. 843a Rv zoals dit artikel voor 1 januari 2002 luidde, aangehaald als 'art. 843a Rv-oud'. Indien alleen 'art. 843a Rv' is vermeld, wordt de huidige, sinds 1 januari 2002 luidende tekst bedoeld. 
of mede-eigendom, gelijk ook niet, wanneer het geschrift vervaardigd is in het belang van beide de partijen.

Ook zijn die uitzonderingen niet toepasselijk op het geval, waarin beide de partijen eene gelijke aanspraak op de geschriften hebben.

Art. 3347. Ieder belanghebbende kan van den regter de vernieuwing verzoeken van geschrift, hetwelk door ouderdom of ander oorzaken onleesbaar wordt, of gevaar loopt te bederven. ${ }^{2}$

Dit ontwerp is nooit verder dan ontwerp gekomen omdat uiteindelijk in de Kamer de voorstanders van de Code Civil sterker bleken te zijn dan de voorstanders van het oude van vóór de revolutie bestaande recht, en het ontwerp werd, zoals in Asser-Scholten valt te lezen, 'ter zijde gesteld'.

Lokin en Zwalve schrijven dat de behandeling van dit ontwerp, door hen ook 'gewijzigd ontwerp Kemper' genoemd, een drama werd omdat de Kamer artikel na artikel verwierp, vooral omdat het ontwerp Kemper en het ontwerp 1820 meer op juridische leerboeken leken dan op wetboeken. ${ }^{4}$

\subsubsection{Het ontwerp 1824 en de wet 1825}

De heersende opvatting in de Kamer na 1820 bleef dat de nog steeds geldende Code Civil moest worden vervangen, zodat het wetgevingswerk werd voortgezet. ${ }^{5}$

In het ontwerp-BW van 1824 werden twee inzage-artikelen voorgesteld en wel art. 19 en 24 die als volgt luidden. ${ }^{6}$

Art. 19. In elken stand van het geding, kan de eene partij van de andere vorderen, dat dezelve onder eede die stukken overlegge, welke onder hare berusting zijn en de zaak in geschil betreffen.

Indien het, in de loop van een geding, uitgemaakt is, dat eene der partijen een blijkbaar belang heeft bij de overlegging van eenen titel, welke in bezit van eenen derde is, zal deze, op bevel des regters, gehouden zijn om van dat stuk inzage te geven, en een

2 Aldus Ontwerp van het Burgerlijk Wetboek voor het Koningrijk der Nederlanden aan de statengeneraal aangeboden den 22sten november 1820, met eene voorrede van Jhr. Mr. J. De Bosch Kemper, Leiden, J.W. van Leeuwen 1864

3 Asser-Scholten, Algemeen Deel, W.E.J. Tjeenk Willink Zwolle, 1934, p. 231-233.

4 J.H.A. Lokin \& W.J. Zwalve, Hoofdstukken uit de Europese codificatiegeschiedenis, WoltersNoordhof/Egbert Forsten Groningen 1992, pag. 284-285.

5 J.H.A. Lokin \& W.J. Zwalve, Hoofdstukken uit de Europese codificatiegeschiedenis, WoltersNoordhof/Egbert Forsten Groningen 1992, p. 286.

6 Het ontwerp dateert van 21 oktober 1824 en de uiteindelijke tekst is in 1825 wet geworden (zie ook Blommestein, p.30). Dit BW kent verschillende boeken die allen beginnen met artikel 1, dus conform de nummering van het huidige BW. Het vierde boek is genaamd 'Van bewijs en verjaring', de eerste titel daarvan heet 'van bewijs in het algemeen' en de tweede titel 'van schriftelijk bewijs'. In die tweede titel staan de geciteerde art. 19 en 24 . De eerste titel van boek 4 is gepubliceerd in Stb 1825, nr. 32, de tweede titel is gepubliceerd in Stb 1825, nr. 33. 
afschrift, of uittreksel daarvan te laten nemen, naar den vorm, welke bij het wetboek van burgerlijke regtspleging is voorgeschreven.

Art. 24. Wanneer een en dezelfde titel tusschen verscheidene personen gemeen is, kan men vorderen, dat dezelve op eene derde plaats worde in bewaring gegeven.

In de aantekeningen van Daam Fockema zoals vermeld in Noordziek ${ }^{7}$ is over art. 19 het volgende te vinden:

'Hier zijn eenige wetsbepalingen betrekkelijk den eisch: de edende; doch de laatste alinea is mij al te onbepaald voorgekomen. Het regt van te vorderen de overlegging van alle stukken, welke onder partij berustende zijn en de zaak in geschil betreffen, en zulks onder eede, kan een gemoedelijk mensch in groote verlegenheid brengen, en eenen kwaadwilligen pleiter teveel steunen. Ik zoude althans noodig achten, dat de vordering vergezeld ga van eene oppervlakkige aanduiding van de soort der gevorderde bescheiden, en de regter de bevoegdheid hebbe, om die vordering naar bevind van zaken te matigen, voor zoo verre de bescheiden niet gemeenschappelijk zijn, of zoodanige, waarop deze partij zelve zich regtstreeks of van ter zijde beroept. Het zouden misschien ook niet ongepast zijn te bepalen:

$1^{\mathrm{e}}$ dat elk belanghebbende bevoegd is te vorderen, dat een gemeenschappelijk bescheid in bewaring van eenen openbaren ambtenaar worde gesteld; voorbehoudens dat de regter in bijzondere gevallen kan bevelen, indien het een meer algemeen stuk betreft, dat de bezitter een uittreksel daarvan, vergeleken in den vereischten vorm, ten koste van den eischer afgeve, met verklaring dat het oorspronkelijke onder hem berustende is; ... $2^{\mathrm{e}}$ dat elk die aantoont eenig belang te hebben, in eigen naam, of als erfgenaam, of bijzonder regtverkrijger, in zekere acte in de registers van eenen publieken ambtenaar opgenomen, bevoegd is daarvan afschriften of uittreksels te vragen ten zijnen koste.'

7 J.J.F. Noordziek, Geschiedenis der beraadslagingen gevoerd in de Tweede Kamer der StatenGeneraal over het ontwerp van Burgerlijk Wetboek onder toezigt der Commissie voor de huishoudelijke aangelegenheden der Tweede Kamer, Zittingjaar 1824-1825, Den Haag, Martinus Nijhoff 1878, p. 713. Op p. 723-724 van genoemd boek is bij de antwoorden op de aanmerkingen der Afdelingen het volgende te vinden: ' $\mathrm{V}$. Men heeft in eenige Afdeelingen het als eene hardheid aangemerkt, dat men bewijsstukken in den boezem van zijne wederpartij kan zoeken.A. Men heeft deze bepaling als hoogst zedelijk en billijk beschouwd, omdat dezelve strekt tot ontdekking der waarheid. Indien toch eene der partijen een stuk in haar bezit heeft, waaruit de wederpartij haar regt of de voldoening eener verbindtenis kan bewijzen, dan moet dat stuk gehouden worden, wat het gebruik daarvan betreft, aan beide partijen gemeen te zijn; en daaruit volgt dat de wet op zeer goede gronden het te berde brengen van zoodanige stukken kan bevelen. Indien de regel kon doorgaan, dat niemand kan worden genoodzaakt om een stuk te zijnen nadeele te berde te brengen, dan zoude ook het heilzaam middel, om op feiten en artikelen te hooren, moeten vervallen, omdat ook in dat geval de partij genoodzaakt wordt tegen haar zelve te getuigen. Overigens is de redactie van dit lid, door het inroepen van des regters tusschenkomst, in den geest ééner Afdeeling, veranderd geworden.'. 
De artikelen zoals uiteindelijk geplaatst in Stb 1825, no. 33 luidden als volgt.

Art. 19 In elken stand van het geding, kan de eene partij aan den regter verzoeken dat de wederpartij worde bevolen, om onder eede die stukken over te leggen, welke onder hare berusting zijn en de zaak in geschil betreffen.

Indien het, in den loop van een geding, uitgemaakt is, dat eene der partijen een blijkbaar belang heeft bij de overlegging van eenen titel, welke in het bezit van eenen derde is, zal deze, op bevel des regters, gehouden zijn om van dat stuk inzage te geven, en een afschrift, of uittreksel daarvan te laten nemen, naar den vorm, welke bij het wetboek van burgerlijke regtspleging is voorgeschreven.

Art. 24. Wanneer een en dezelfde titel tusschen verscheidene personen gemeen is, kan men vorderen, dat dezelve op eene derde plaats worde in bewaring gegeven.

Een opvallend verschil tussen art. 3344 van het ontwerp 1820 en art. 24 van de wet van 1825 is dat het eerste spreekt over 'regt van eigendom of mede-eigendom op een geschrift' terwijl art. 24 spreekt over 'een ... titel tusschen verscheidene personen gemeen'. Volgens Van Blommestein ${ }^{8}$ is met deze andere woorden ook een inhoudelijke wijziging beoogd, in die zin dat de vraag wie de eigenaar van het stuk is, met de regeling van art. 24 van geen belang is. Ter motivering wijst hij op het volgende antwoord van de regering, gegeven bij art. 19: 'Indien toch eene der partijen een stuk in haar bezit heeft waaruit de wederpartij haar recht of de voldoening eener verbintenis kan bewijzen, dan moet dat stuk gehouden worden, wat het gebruik daarvan betreft aan beide partijen gemeen te zijn.'

Het lijkt mij dat uit deze woorden inderdaad de conclusie mag worden getrokken dat met 'gemeen' op deze plaats niet 'gemeenschappelijke eigendom' wordt bedoeld. Vertaald naar hedendaagse opvattingen lijkt hier bedoeld te zijn 'bewijsrechtelijk van belang is'.

\subsubsection{De artikelen 1932 en 1937 BW-1830}

Tussen 1825 en 1830 is er nog een aantal wijzingen aangebracht in de al vastgestelde tekst van het BW. De in 1825 vastgestelde teksten van art. 19 en 24 zijn echter ongeschonden gebleven, behalve dan dat in art. 19 de verwijzing naar het 'wetboek van burgerlijke rechtspleging' is veranderd in een verwijzing naar het 'wetboek van burgerlijke regtsvordering'.

Het BW lag voor invoering gereed, en bij KB van 5 juli 1830, Stb no. 41 werd de invoering van (onder andere) het BW bepaald op het moment van de klokslag van middernacht tussen de laatste dag van januari 1831 en de eerste dag van februari 1831. Kort daarvoor was nog wel bij wet van 16 mei 1829, Stb 1829, no. 33 in art. 1 lid 7 bepaald dat ieder wetboek van het Koninkrijk (dus ook het BW)

8 Van Blommestein, p. 31.

9 Cursivering door Van Blommestein. 
in een doorlopende reeks van artikelen zou worden vervat. ${ }^{10}$ Door de uitvoering van deze wet werd het vastgestelde art. 19 vernummerd tot art. $1932 \mathrm{BW}$ en art. 24 werd vernummerd tot art. 1937 BW. De betreffende artikelen luidden als volgt.

Art. 1932 1. In elken stand van het geding kan de eene partij aan den regter verzoeken, dat de wederpartij worde bevolen, om onder eede die stukken over te leggen, welke onder hare berusting zijn, en de zaak in geschil betreffen.

2. Indien het, in den loop van een geding, uitgemaakt is, dat eene der partijen een blijkbaar belang heeft bij de overlegging van eenen titel, welke in het bezit van eenen derde is, zal deze, op bevel des regters, gehouden zijn om van dat stuk inzage te geven, en een afschrift of uittreksel daarvan te laten nemen, naar den vorm, welke bij het wetboek van burgerlijke regtsvordering is voorgeschreven.

Art. 1937 Wanneer een en dezelfde titel tusschen verscheidene personen gemeen is, kan men vorderen, dat dezelve op eene derde plaats worde in bewaring gegeven.

Opvallend in de tekst van art. 1932 BW is dat er eigenlijk nauwelijks een beperking in te vinden is in die zin dat elke partij die blijkbaar een belang heeft bij de overlegging van een titel die een derde bezit, die overlegging kan afdwingen. Een beperkingen is wel te vinden in de woorden '... in den loop van een geding', waaruit blijkt dat er wel al een procedure aanhangig moet zijn (geweest).

Interessant bij deze bepaling in het BW, is de formele bepaling in het Wetboek van Burgerlijke Rechtsvordering dat een vonnis kan worden herroepen indien de partij na het vonnis stukken van beslissende aard in handen heeft gekregen die door toedoen van de wederpartij waren achtergehouden. ${ }^{11}$ Ten Kate schrijft dat deze grond voor herroeping uit de Ordonnantie 1667 stamt. ${ }^{12} \mathrm{Zij}$ is, aldus Ten Kate, in weinig gewijzigde vorm via de Code de Procédure Civile terechtgekomen

10 Zie over de hernummeringen in die tijd F.J. Fernhout, Het verschoningsrecht van getuigen in civiele zaken, prfs 2004, p. 8, o.a. noten 7 en 8 en p. 12, o.a. noot 26. In het van genoemde schrijver in de serie Recht en Praktijk uitgekomen boek met dezelfde titel is dit vermeld op p. 8 en p. 10.

11 Request civiel, thans herroeping genaamd, te vinden in art. $382 \mathrm{Rv}$, tot 1 januari 2002 onder sub 8 , thans in art. 382 sub c Rv.

12 Th.B. Ten Kate, Het request-civiel, J.B. Wolters/Groningen 1962, p. 147 e.v. en 273 e.v. Zie ook Cassatie in burgerlijke zaken, D.J. Vegens, derde druk bewerkt door E. Korthals Altes en H.A. Groen, Tjeenk Willink Zwolle 1989, p. 108. In die Ordonnantie (de Code Louis) was titel XXXV, bestaande uit 42 artikelen aan het request civiel gewijd. Art. 12 luidde als volgt: Si les lettres en forme de requête civile contre les arrêts ou jugements en dernier ressort, ... sont fondées sur pièces fausses ou sur pièces nouvellement recouvrées qui etoient retenues ou détournées par le fait de la partie adverse, le temps d'obtenir et faire signifier les lettres ou requêtes, ne courra que du jour que la fausseté où les pièces auront été découvertes, ...'. Art. 34 luidde als volgt: Ne seront reçues autres ouvertures de requêtes civiles, à l'égard des majeurs, que le dol personnel, si la procédure par nous ordonnée n'a point été suivie; s'il a été prononcé sur choses non demandées ou non contestée; ... Il ya aura pareillement ouverture de requête civile, ... ou s'il y a des pièces décisives nouvellement recouvrées et retenues par le fait de la partie.'. 
in de wet van 29 maart $1828 .{ }^{13}$ Gelet op de ruime wijze waarmee het inzagerecht in art. 1932 van het BW van 1830 en in art. 19 van het BW van 1825 was verwoord, ligt het voor de hand om te concluderen dat ook de herroepingsgrond in die tijd met zich bracht dat een procespartij bewijs tegen zich zelf diende aan te dragen. De herroepingsgrond zou daarmee als het ware de 'postprocessuele' pendant vormen van de regeling van het inzagerecht in het toenmalige materiële burgerlijk recht. Het stond in elk geval de wetgever van het materiële recht voor ogen om een regeling te maken die diende in te houden een van rechtswege bestaande verplichting van een partij om voor of tijdens de procedure inzage te verschaffen.

De in 1825 vastgestelde tekst van het request civielartikel werd zonder commentaar bij wet van 10 mei 1837 overgenomen in art. $382 \mathrm{Rv}$ en is niet gewijzigd tot 1 januari 2002, terwijl de op 1 januari 2002 in werking getreden wijziging van dit onderdeel van de herroepingsbepaling slechts redactioneel van aard is geweest. Dit betekent dat aan de hand van een historische uitleg de herroepingsgrond in art. 382 onder c Rv een ruim toepassingsgebied zou moeten hebben. Deze historie is, zo blijkt uit wat Ten Kate verder over deze herroepingsgrond schrijft, uit het oog verloren. Hij vermeldt namelijk dat in 1865 in de memorie van toelichting ${ }^{14}$ bij dit artikel stellig is verdedigd, dat deze bepaling, gelet op de regel 'nemo contra se edere cogitur', ${ }^{15}$ slechts stukken kan bedoelen die aan beide partijen gemeen zijn. Die regel zou, aldus de toelichting, algemeen gelden in het Nederlandse recht. Juist uit par. 2.1.1 en uit deze paragraaf blijkt echter dat in de ontwerpen die aan het BW van 1838 vooraf gingen, een zeer ruim recht op inzage werd neergelegd, waarbij de regel 'nemo contra se edere cogitur' juist niet gold. Het lijkt er dan ook op dat de wijze waarop hier in 1865 bij een ontwerp van een Wetboek van Burgerlijke Rechtsvordering een en ander is verdedigd, in strijd is met de historische grondslag van het request civiel. Ik wijs er hierbij ook op dat de ruime formulering van het recht op inzage in art. 19 en 24 van het BW van 1825 en in art. 1932 van dat van 1830 beter past bij het ruim geformuleerde sub 8 in het toenmalige request civielartikel dan de beperkte opvatting zoals vermeld in de toelichting van 1865 .

13 Gepubliceerd in Stb. 1828, nr. 25, als achtste titel. Art. 1 luidt, voor zover van belang: De vonnissen op tegenspraak in het laatste ressort gewezen, ... kunnen herroepen worden, ... om de volgende redenen: ... $8^{\circ}$. Indien men na het vonnis stukken van een belissenden (typefout in het Staatsblad) aard nader in handen heeft bekomen, welke door toedoen van de wederpartij waren achter gehouden.

14 Het betreft hier het Ontwerp en memorie van toelichting 'Wetboek van Burgerlijke Rechtsvordering' uitgegeven onder toezicht van A.A. De Pinto in twee delen (Den Haag 1865-1867). Zie over dit nimmer ingediende ontwerp uitgebreider C.H. van Rhee, Ons tegenwoordig sukkelproces. Nederlandse opvattingen over de toekomst van het burgerlijk procesrecht rond 1920, Tijdschrift voor Rechtsgeschiedenis 2000, p. 331-346.

15 Niemand hoeft bewijs tegen zich zelf aan te dragen (ook nemo tenetur edere contre se of nemo tenetur armare adversarium contra se). 
De wetgever is niet lang bij de ruime opvatting van het recht op inzage gebleven. $\mathrm{Al}$ in de volgende versie van het (ontwerp) Burgerlijk Wetboek kwam een recht als hiervoor in het tweede lid verwoord, niet meer voor (zie hierna in par. 2.1.4) omdat

'... men steeds onder alle wetgevingen huiverig is geweest, om de bewijsmiddelen e domo adversarii op te zoeken, vermits de aanlegger verplicht is zijnen eisch op zich zelf te staven, en hij, bij gebreke van schriftelijk of testimoniaal bewijs, zijn toevlucht kan nemen tot den beslissenden eed, terwijl wat een derde betreft, deze wel als getuige, in een aan hem vreemd belang kan worden gehoord, doch niet behoort te worden blootgesteld om stukken, registers of papieren te berde te moeten brengen, welker openbaarmaking hem hinderlijk of onaangenaam zoude kunnen zijn. Om die reden heeft men de voorzeide wetsbepaling beperkt tot de stukken, die aan de partijen gemeen zijn. $^{16}$

Bij Koninklijk Besluit van 5 januari 1831, Stb no. 1 werd het invoeringsbesluit van 5 juli 1830, Stb no. 41 'opgeschorst, tot dat daaromtrent nader door Ons zal zijn beschikt' in verband met de 'uitgebarsten opstand in de zuidelijke gewesten'.

\subsubsection{De artikelen 1922 en $1923 \mathrm{BW}$}

De wetgever van na 1830 kon zich dus niet meer vinden in een ruim recht op inzage en achtte het noodzakelijk om beperkingen op te nemen in de wel vastgestelde, maar niet in werking getreden tekst van art. 1932 van het BW van 1830. Hij deed dit door in het nieuwe wetboek van 1838 art. 1932 BW te vervangen door art. 1922 en 1923 BW. $^{17}$

Art. 1922. 'Indien een titel gemeen is tusschen verscheidene personen, is ieder derzelve bevoegd te vorderen, dat die op eene derde plaats in bewaring wordt gebracht, mitsgaders om daarvan te zijnen koste een afschrift of uittreksel te laten maken'.

Art. 1923. 'In elken stand van een regtsgeding kan eene partij van den regter verzoeken, dat hare wederpartij bevolen worde om de stukken over te leggen, die aan beide partijen gemeen zijn, de zaak in geschil betreffen en zich onder hare berusting bevinden.'

16 Aldus Ligtenberg op p. 68-69.

17 Voor de volledigheid: de tekst van art. 1932 van het toenmalige BW was natuurlijk niet de reden om dat BW te vernieuwen. Zie voor die redenen E.O.H.P. Florijn, Ontstaan en ontwikkeling van het nieuwe Burgerlijk Wetboek, prfschr. 1994, Universitaire Pers Maastricht, p. 12-27. Zie ook Asser-Scholten, Algemeen Deel, Tjeenk Willink Zwolle 1974, p. 174-182. 
In Voorduin ${ }^{18}$ is bij deze artikelen te lezen dat de zeer ruime bepalingen van het ontwerp van 21 oktober 1824, art. 19 en 24, omstreeks 1824 als hoogst zedelijk en billijk werden beschouwd omdat deze strekten tot ontdekking van de waarheid, waarna op p. 495 de tekst is te vinden die aan het slot van par. 2.1.2 cursief is geciteerd. ${ }^{19}$

Met dit dus ook in Voorduin te vinden citaat uit de parlementaire geschiedenis zijn deze artikelen niet zonder meer duidelijk. Het woord 'gemeen' in de tekst van art. 24 betekende immers, gelet op de toelichting van de regering, niet 'medeeigendom'. In art. 1923 BW zou dit vervolgens anders zijn, zonder dat daarvoor een expliciete toelichting wordt gegeven. In elk geval, zo blijkt uit de in Voorduin te vinden opmerkingen van de regering, gaf art. 1923 BW dus geen algemene verplichting tot exhibitie.

Niet iedereen volgde dit in Voorduin te vinden standpunt van de regering. Zo schrijft Ligtenberg in de inleiding van zijn proefschrift dat de vraag of er krachtens een algemene verplichting tot exhibitie in het Nederlandse positieve recht kan worden geageerd, verschillend wordt beantwoord. De Nederlandse wetboeken bewaren in die tijd volgens hem in elk geval het stilzwijgen hierover. Hij gaat in zijn proefschrift vervolgens aan de hand van enkele voorbeelden op onderzoek. Ik noem hier de volgende voorbeelden (p. 3 en 4 van het proefschrift).

'Stel, dat van den eigenaar E. een gouden horloge gestolen of verloren is. Deze E. heeft nu een gegrond vermoeden eenen zekeren $\mathrm{H}$. te verdenken, dat horloge in zijn macht te hebben, onverschillig hoe die H. daaraan is gekomen. Kan nu E. in rechte de vertooning van dat horloge vorderen? ... Bij een slager S. komt plotseling een hond binnenloopen, pakt snel een stuk vleesch en verdwijnt daarmede. De slager meent met grond, dat dit dier een der honden is van den koopman K., een hondenvriend, die eenige huizen verder woont. ... Stel, dat bij den slager juist op het oogenblik dat die hond het vleesch wegkaapte, in den winkel eenige klanten waren, die beweren, dat zij den hond wel zouden herkennen, is het dan den slager geoorloofd in rechte te eischen de vertooning der honden van den koopman ...?'.

Op p. 60 en verder analyseert hij vervolgens de exhibitie-actie bezien vanuit de hoek van het rechtsmiddel (waarmee hij 'middel tot handhaving van een recht' bedoelt). Hij onderscheidt daarbij de exhibitie-actie als voorbereidend rechtsmiddel enerzijds en deze actie als hoofdactie anderzijds. De actie als voorbereidend rechtsmiddel koppelt hij enkel aan de revindicatievordering of andere zakelijke vorderingen en wel daar waar een dergelijke vordering al bestaat, maar niet met zekerheid kan worden aangewend. Wat de hoofdactie betreft loopt hij de wet langs, daarbij

18 J.C. Voorduin, Geschiedenis en beginselen van Nederlandsche Wetboeken, V. Deel, Burgerlijk Wetboek, art. 1269-2030, de beraadslaging deswege gehouden door de Tweede Kamer der Staten Generaal, Utrecht, Robert Natan, Akademie-Boekhandelaar 1838. Het boek is met een mooi voorwoord opgedragen aan 'Zijne Majesteit den Koning der Nederlanden'.

19 P. 494-495. 
het onderscheid makend tussen de exhibitie van stukken en oorkonden en exhibitie van zaken.

Dit onderscheid tussen stukken en oorkonden enerzijds en zaken anderzijds is niet terug te vinden in Van Blommestein. Die begint zijn proefschrift uit 1885 met de volgende woorden:

'Geschriften zijn zaken, i.e. zij kunnen bestanddeel van vermogen uitmaken, zij zijn roerende zaken. Alle rechten dus, die men op roerende zaken hebben kan kan men op geschriften hebben. 't Geschrift is echter een zeer eigenaardig species van zaken, daar niet alleen anderen uitsluitende rechten daarop van belang zijn, maar reeds inzage daarvan, kennis van datgene wat het geschrift inhoudt ... Wanneer mag men verlangen bekend te worden met den inhoud van geschriften die anderen in handen hebben?'.

Hij komt op p. 11 tot de conclusie

'... dat de verplichting tot editie slechts bestaat ten opzichte van die geschriften die opgemaakt zijn ten behoeve van den persoon die daarvan de editie vraagt, ...'.

Van Blommestein merkt op p. 18 op dat er, bewijstechnisch gezien, maar één overeenkomst is tussen een getuige en een edent ${ }^{20}$ en dat is dat zij beiden wetenschap hebben van een zaak die voor procederende partijen van belang is. Verder bestaat er tussen hen geen overeenkomst.

Van Blommestein merkt op p. 25 over de plaats van art. 1922 en 1923 BW op dat de wetgever met deze artikelen een algemene regel heeft gegeven over het recht op inzage en dat deze regeling terecht in het vierde boek is geplaatst omdat het hier niet betreft

'... de regeling van medegerechtigheid op een stuk papier, ... maar het gold hier de regeling van de medegerechtigheid op geschrift als bewijsmiddel. ${ }^{21}$ Hiervoor alleen was eene bijzondere bepaling noodig en deze kon nergens anders geplaatst worden dan in dat gedeelte van het Burgerl. Wetboek dat over het bewijs handelt. ... De bepalingen van de artt. 1922 en 1923 B.W. zijn - het opschrift van den titel, waaronder zij staan, wijst het voldoende aan- bepalingen omtrent het bewijs.'

Ik leid uit deze formulering af dat art. 1922 BW een regel van materiële aard is. Het geeft een actie tot exhibitie van 'gemeene' stukken en titels en spreekt over het bewijsmiddel zelf. Art. 1923 BW geeft meer een formeelrechtelijke regel weer omdat deze regel bepaalt hoe men een 'gemeen stuk' als bewijsmiddel kan gebruiken in een procedure. Verder vermeldt dit artikel wie verplicht is mee te werken

20 Een edent is iedereen, procespartij of niet, die in het bezit is van geschriften, bij welker inzage procederende partijen belang hebben en die verplicht is om die geschriften op aanvraag over te leggen, tenzij hij onder ede verklaart dat hij door die openlegging een groot nadeel zal lijden.

21 Cursivering door Van Blommestein. 
aan het verschaffen van schriftelijke bewijsmiddelen. De beperkte bruikbaarheid van de artikelen voor de dagelijkse rechtspraktijk wordt veroorzaakt door het woord 'gemeen' in beide artikelen. Dit woord bracht met zich dat het niet voldoende was dat de betreffende stukken beide partijen aangingen. Volgens velen, waaronder de Hoge Raad ${ }^{22}$ moesten de stukken het gemeenschappelijk eigendom zijn van beide partijen. ${ }^{23}$ Die uitleg was volgens onder meer Ledeboer wel juist, maar niet gewenst. Hij schrijft op p. 50 dat het zeer wenselijk zou zijn om bij wet zowel aan derden als aan de tegenpartij de verplichting op te leggen alle voor het bewijs belangrijke 'oorkonden' over te leggen, niet alleen op conclusie van de tegenpartij maar ook op ambtshalve bevel van de rechter. Aldus zou de wet een bepaling bevatten ' $\ldots$ die het vinden van de werkelijke waarheid omtrent beweerde daadzaken niet weinig zou bevorderen'. ${ }^{24}$

Van Blommestein gaat in 1885 op p. 27 en verder vol vuur in tegen de toen heersende opvatting dat de betekenis van het woord 'gemeen' mede-eigendom zou zijn. Hij schrijft daar dat hij '.. door eene onbevooroordeelde lezing van de artt. niet tot datzelfde resultaat ...' is gekomen. ${ }^{25}$

'Integendeel, wanneer men slechts den tekst der wet leest, geloof ik dat men met vooroordelen moet toegerust zijn om de artt. in dien beperkten zin op te vatten. De reden waarom? Omdat geschriften een zeer eigenaardige soort van zaken zijn, die hun karakter, hun reden van bestaan geheel ontleenen aan hun inhoud, de waarde die deze voor bepaalde personen heeft. Cijfert men dezen inhoud nu weg en let men uitsluitend op de materie, dan stelt men geschrift -i.e. een van te voren opgemaakt bewijsstukgelijk met misdruk, waarvoor de bepalingen van den derden titel van het $2^{\text {de }}$ Boek B.W. allezins ${ }^{26}$ voldoende zouden kunnen geacht worden. ... En, als de wetgever dan spreekt van gemeene geschriften, dan wordt de medegerechtigheid tot den inhoud bedoeld, welke zeer goed kan bestaan onafhankelijk van de medegerechtigheid tot de materie.'.

22 HR 23 maart 1849, WvhR 1036, HR 12 november 1875, WvhR 3917, HR 12 december 1879, WvhR 4455 en HR 20 oktober 1911, W 9283.

23 Aldus bijvoorbeeld Ligtenberg, p. 67 en Ledeboer op p. 30 en p. 192 van Het Nederlandsche Burgerlijk Procesrecht door Van Boneval Faure, 1896. De laatste is zeer beslist : 'Dat in art. 1922 en 1923 onder aan partijen gemeene stukken of titels zoodanige zijn te verstaan welke aan partijen gezamenlijk in eigendom toebehoren volgt èn uit de woorden èn uit de geschiedenis dezer bepalingen'.

24 Opvallend is dat Ledeboer in het eerste hoofdstuk van zijn proefschrift op p. 15 e.v. de stelling heeft verdedigd dat de Staat zelf ook belang heeft bij een bepaling die het vinden van de werkelijke waarheid bevordert.

25 Dit vuur is aangestookt door G. Diephuis, Het Nederlandsch Burgerlijk Regt, tweede deel, tweede druk, Wolters te Groningen, 1885. Diephuis schrijft op p. 444 in dat boek over de zinsnede 'stukken die aan beide partijen gemeen zijn' in art. 1923 het volgende:'Wat dit zeggen wil, kan bij eene onbevooroordeelde lezing hier zoo min als in art. 1922 twijfelachtig zijn. Het is niet voldoende dat de stukken beide partijen aangaan, voor beide waarde hebben; zij moeten het gemeenschappelijk eigendom zijn van beide partijen, zoodat beide daarop gelijkelijk regt hebben, en de eene in het genot daarvan niet beperkt moet worden, doordien de andere ze onder zich heeft'.

26 De schrijffout is van Van Blommestein. 
Op p. 41 komt hij vervolgens tot de volgende conclusie: 'Stukken en titels zijn gemeen tusschen hen ten wier behoeve zij zijn opgemaakt en hen die daarvan eigenaars, possessoren of detentoren mochten zijn.' Schriftelijke bewijsmiddelen zijn volgens hem geschriften die zijn opgemaakt met de bedoeling om tot bewijs te dienen, maar soms kunnen geschriften ook bij toeval tot bewijs dienen, bijvoorbeeld brieven. Indien het van het begin af aan de bedoeling is geweest van het geschrift om tot bewijs te dienen, is dat de reden van zijn bestaan. De inhoud staat dan op de voorgrond en de materie op de achtergrond. De rechthebbende is dan in elk geval degene ten behoeve van wie het is opgemaakt. Het antwoord op de vraag wie dan een recht op het papier, de materie, heeft, mag bij dit bewijsrechtelijk onderwerp dan geen doorslag geven.

Het is duidelijk dat indien de stukken gemeenschappelijk eigendom dienen te zijn, het aantal stukken behoorlijk geringer is dan indien het zou gaan om stukken 'die de zaak in geschil' betreffen. Het kan dan ook niet anders dan dat de beperkte uitleg van het begrip 'gemene stukken' een belangrijke oorzaak is van het geringe aantal uitspraken dat betrekking heeft op deze art. 1922 en 1923 BW. Een voorbeeld van die beperkte uitleg is te vinden in de volgende casus uit $1911 .^{27}$ In deze zaak beheert Van de Waal het vermogen van Schlesinger. Van de Waal houdt hiertoe een kasboek bij. Op enig moment overlijdt Van de Waal en vraagt Schlesinger rekening en verantwoording aan de weduwe van Van de Waal, Snijders genaamd. In dit kader wenst hij overlegging van het kasboek. Snijders weigert dit kasboek over te leggen en het hof Den Bosch fiatteert deze weigering waarop Schlesinger in cassatie gaat. AG Ledeboer ${ }^{28}$ schrijft dat de Hoge Raad herhaaldelijk geroepen is zijn oordeel te geven over de betekenis van art. $1923 \mathrm{BW}$ en dat hij steeds met een beroep op de wetsgeschiedenis heeft beslist dat onder de uitdrukking 'stukken die aan beide partijen gemeen zijn' verstaan dient te worden de zodanige stukken die aan beide partijen toebehoren. 'Het woord 'gemeen' heeft alzoo hier dezelfde

27 HR 20 oktober 1911, W 9283, Schlesinger-Snijders w/v van de Waal. De Hoge Raad week met het hier gegeven oordeel over de betekenis van 'gemeen' niet af van zijn arresten van 23 maart 1849, WvhR 1036, 12 november 1875, WvhR 3917 en 12 december 1879, WvhR 4455. In dat laatste arrest werd door Dubois e.a. in een procedure tegen de Staat der Nederlanden gesteld dat zij erfgenamen waren van een Dubois die in Batavia was overleden en wiens nalatenschap toen in handen en onder beheer van de Nederlandsche Oost-Indische Compagnie was gekomen. De Staat was de Compagnie opgevolgd in alle rechten en plichten. Dubois e.a. vorderden dat de Staat veroordeeld zou worden om aan hen af te geven die stukken, boeken en bescheiden waaruit de omvang en de bestanddelen van de nalatenschap kon blijken en overigens afschriften of uittreksels te vervaardigen ten koste van eisers. De Hoge Raad wijst de vordering af met onder meer de volgende overweging:'dat daarenboven de eischers niet beweren, dat de bedoelde stukken deel uitmaken van de nalatenschap, waartoe zij beweren geregtigd te zijn, of wel dat deze uit andere hoofde hun eigendom of wel tusschen hen en den ged. gemeen zijn in den zin van art. 1922 B.W.'

28 Inderdaad R.B. Ledeboer van het proefschrift 'Eenige opmerkingen over de verplichting tot overlegging van schriftelijke bewijsstukken' en die in dat proefschrift op p. 30 al schreef dat het woord 'gemeen' taalkundig betekent 'het aan meerderen in eigendom toebehoren'. 
beteekenis als in de artt. 662, 681, 706, 1212 enz. B.W. nl. van gezamenlijk eigendom'. De Hoge Raad is kort en krachtig:

'dat het Hof die beslissing terecht primair grondt op de stelling, dat in art. 1923 B.W. onder 'stukken, die aan beide partijen gemeen zijn', moeten worden verstaan stukken, die aan beide partijen gemeenschappelijk toebehoren; dat immers de geschiedenis der wet duidelijk aantoont, dat ook in art. 1923 BW die beteekenis aan de uitdrukking 'gemeen' moet worden gegeven'.

In 1921 overweegt de Hoge Raad in de zaak Weisbard dat het stuk waarvan overbrenging en nederlegging ter Griffie is gevraagd, een stuk is dat ten bewijze van een gesloten overeenkomst (betreffende de stichting en exploitatie van een bioscoop) door samenwerking van alle partijen is voortgebracht en bij gebreke van medewerking van één der partijen nimmer had kunnen ontstaan, waaruit het Hof terecht heeft afgeleid dat de vordering een stuk betreft dat bij zijn geboorte èn door de wil en door de daad van partijen tussen haar gemeen is geworden. ${ }^{29}$ De Hoge Raad verwijst hierbij wederom naar de wetsgeschiedenis, maar thans naar het OudHollandse recht. Uit deze geschiedenis blijkt volgens de Hoge Raad dat de wetgever de bevoegdheid tot het vorderen van uitlevering wilde toekennen aan een ieder, die op het stuk als bewijsstuk enig recht kan doen gelden. ${ }^{30}$ Van Kuyk acht deze beslissing 'even juist, als gelukkig onder woorden gebracht. ${ }^{31}$ Hij schrijft verder dat de wetgever bij het ontwerpen van de tekst van de artt. 1922 en 1923 BW van mening was dat de voorganger van deze twee artikelen (art. 1932 BW), inhoudende dat een partij overlegging van stukken kon vorderen indien zij daarbij belang heeft, te ver ging. Om die reden werd de bepaling beperkt tot die stukken die aan beide partijen gemeen zijn. Hiermee zou die wetgever hebben willen aanduiden dat het een stuk moest betreffen waarop een partij enig recht kan doen gelden. Het criterium waaraan getoetst moet worden is volgens hem dus niet of op het stuk 'een gemeenschappelijk eigendomsrecht' bestaat, maar slechts of de vragende partij 'een recht' op het stuk heeft, waarbij het onverschillig is welk recht. Het woord

29 HR 20 mei 1921, NJ 1921, p. 788 e.v., Weisbard e.a.-de Ridder. F.G. Scheltema, Nederlandsch Burgerlijk Bewijsrecht, deel II, 1938 schrijft op p. 402 over dit arrest dat het verheugend is dat de Hoge Raad in dit arrest zijn vroegere opvatting heeft prijsgegeven door te beslissen dat een akte waarvan maar één exemplaar bestaat dat in bezit is van de tegenpartij, een 'gemeen stuk' is.

30 Ongetwijfeld geïnspireerd door PG Noyon. In zijn conclusie schrijft hij onder meer dat de Hoge Raad in zijn arrest van 20 oktober 1911 over het hoofd heeft gezien dat de Regering in het ontwerp van 1824 heeft vermeld dat als een partij een stuk in haar bezit heeft, waaruit de wederpartij haar recht op voldoening van een verbintenis kan bewijzen, dat stuk gehouden moet worden aan beide partijen gemeen te zijn.

31 J. van Kuyk, De beteekenis van 'gemeen' in de artt. 1922 en 1923 B.W., WPNR 16 juli 1921, nr. 2690. Hij legt in dit artikel omstandig uit dat volgens hem de Hoge Raad niet is omgegaan maar slechts een verduidelijking heeft gegeven. 
'recht' is dan gebruikt als beperking omdat het criterium 'belang' te ruim werd geacht.

Eggens merkt in 1933 op dat uit de tekst van art. 1921 BW, waarin de woorden 'eigenaar van eenen titel' ${ }^{32}$ zijn opgenomen, afgeleid zou kunnen worden dat in art. 1922 en 1923 BW, welke spreken over 'gemeene titels en stukken' slechts bedoeld zijn medeëigenaren van een titel. Hij vervolgt echter met de opmerking dat aanvaard is dat mede bedoeld zijn degenen tot wie het stuk zich richt en te wier behoeve als partijen het is opgemaakt. Waar de parlementaire geschiedenis een ruime redactie beperkte met het beroep op het beginsel 'nemo cogitur edere contra se', ${ }^{33}$ noemt hij dit beginsel niet meer van deze tijd. Men heeft zich in het maatschappelijk verkeer immers behoorlijk te gedragen. ${ }^{34}$

Scheltema schrijft dat, mede gelet op HR 20 mei 1921 (het hiervoor genoemde arrest Weisbard), de bevoegdheden van art. 1922 en 1923 BW toekomen aan hen, die partij waren bij de bewijshandeling. Aldus komt de bevoegdheid om bewaring en overlegging te vorderen toe aan de ondertekenaar van het stuk en aan hem, te wiens behoeve het stuk als bewijsstuk is opgemaakt. ${ }^{35}$

Voor zover er nog onduidelijkheid bestond over de inhoud van het begrip 'gemeen', maakte de Hoge Raad daar in 1947 een eind aan in Baus - NV de Koedoe. ${ }^{36}$ In die zaak vordert Baus van De Koedoe betaling van de door hem voor De Koedoe verrichte werkzaamheden als commissaris. De hoogte van het door De Koedoe te betalen bedrag was afhankelijk van haar statutaire overwinst en Baus stelde dat de cijfers die door De Koedoe waren overgelegd om die overwinst te berekenen, niet deugdelijk waren. Baus vraagt op enig moment het hof dan ook om De Koedoe te bevelen haar boeken over te leggen. Het hof weigert om dit bevel te geven omdat er geen sprake is van stukken ' $\ldots$ die in de zin van art. 1923 B.W. aan partijen gemeen zijn' ${ }^{37}$ Baus stelt in zijn cassatiemiddel dat het hof, nu hij als commissaris deelgerechtigd was in de winst van De Koedoe, ten onrechte zijn verzoek tot openlegging van de boeken heeft afgewezen met de overweging dat er geen sprake is van stukken die in de zin van art. $1923 \mathrm{BW}$ aan

32 Met het woord 'titel' wordt hier bedoeld een stuk waarin is neergelegd een nog na te komen verbintenis. Vergelijk Pitlo, Bewijs en Verjaring 1968, p. 78 en Asser-Anema-Verdam, Handleiding tot de beoefening van het Nederlands Burgerlijk Recht, vijfde deel - van het bewijs,$- 5^{\text {de }}$ druk 1953 , p. 233.

33 Niemand hoeft bewijs tegen zich zelf aan te dragen, zie ook par. 3.1.

34 Land's Verklaring van het Burgerlijk Wetboek, bewerkt door Eggens, zesde deel, tweede druk 1933, p. $130-131$.

35 F.G. Scheltema, Nederlandsch Burgerlijk Bewijsrecht, deel II, 1938, p. 402-404. Zie ook nog de bijdrage van Ploum in de onder redactie van Sterk en Carels in november 1990 verschenen 'Leidse procesrechtelijke geschriften', genaamd 'Exhibitieplicht: nachtmerrie of noodzaak?'.

36 HR 31 januari 1947, NJ 1948, 115.

37 Het hof ziet evenmin een grondslag in art. $8 \mathrm{~K}$. omdat Baus zonder goede gronden de cijfers van de winst en verliesrekeningen betwist en openlegging van de boeken door de vennootschap hierin geen verandering zou kunnen brengen. 
partijen gemeen zijn. De Hoge Raad overweegt dat het in art. 1923 BW neergelegde recht op uitlevering van bescheiden is toegekend aan hem, die daarop als bewijsstuk, enig recht kan doen gelden, waarmee dus dezelfde woorden worden gebruikt als in het hiervoor behandelde arrest van de HR van 20 mei 1921, NJ 1921, p. 788 (Weisbard e.a.-de Ridder). Het hof heeft daarom terecht beslist, '... dat dit niet het geval is met een commissaris eener vennootschap, deelgerechtigde in haar winst, ten opzichte van de gehele boekhouding der vennootschap.' Een verdere motivering ontbreekt, maar ik denk dat de Hoge Raad de woorden 'deelgerechtigd in de winst' en 'de gehele boekhouding' in dezelfde zin tegenover elkaar heeft geplaatst om aan te geven dat Baus inzage wilde in meer dan noodzakelijk was.

Aldus maakt de Hoge Raad enerzijds een eind aan de beperkte opvatting dat er alleen inzage in een stuk kon worden gevraagd indien het betreffende stuk gemeenschappelijk eigendom was van de verzoeker en de tegenpartij, waarmee Scheltema dus zijn gelijk krijgt. Anderzijds blijft een forse beperking bestaan want de Hoge Raad accepteert kennelijk niet dat het recht op informatie de grondslag kan vormen voor het recht op afgifte van stukken. Al met al heeft de verruiming die de arresten Weisbard en Baus met zich brachten dan ook niet geleid tot een toename van een beroep op de exhibitieartikelen. De ouderwetse Jurisprudentiebak van de NJ levert namelijk zoals reeds vermeld, slechts 17 uitspraken op bij art. 1922, 1922a en 1923 BW.

Het ging inmiddels om drie artikelen omdat bij wet van 23 juli 1953, Stb. 359 art. 1922a BW werd ingevoegd. Dit artikel luidde als volgt.

1. Hij die een schriftelijk bewijsmiddel heeft verloren, kan van degene, die de beschikking heeft over een geschrift, hetwelk tot bewijs kan dienen van enig feit, waarop het verloren bewijsmiddel betrekking had, of die zodanig geschrift onder zijn berusting heeft, vorderen, te zijnen behoeve op zijn kosten, voor zover nodig, inzage, afschrift of uittreksel van dat geschrift te verschaffen.

2. De rechter bepaalt zo nodig de wijze, waarop inzage, afschrift of uittreksel zal worden verschaft.

3. Hij, die uit hoofde van zijn beroep, stand of wettige betrekking tot geheimhouding verplicht is, is niet gehouden aan deze vordering te voldoen, indien het geschrift uitsluitend uit dien hoofde te zijner beschikking staat of onder zijn berusting is.

De voorganger van art. 1922a BW is te vinden in het Besluit van 15 september 1941 houdende voorzieningen ten aanzien van door oorlogsgeweld verloren gegane bewijsmiddelen. ${ }^{38}$ Lid 1 van art. 1 van dat Besluit luidde als volgt:

Wie als partij bij een overeenkomst weet of redelijkerwijs moet vermoeden, dat door oorlogsgeweld hier te lande schriftelijke bewijsmiddelen of andere bescheiden betreffen- 
de de overeenkomst of eenige daarmede verband houdende rechtshandeling verloren zijn gegaan, is verplicht:

1) indien de wederpartij inzage of afschrift verzoekt van geschriften, bestemd om tot bewijs van eenig feit te dienen, zoodanige inzage of zoodanig afschrift, voor zoover nodig, te verschaffen;

2) indien de wederpartij, buiten het geval, vermeld onder 1, bepaalde gegevens verzoekt, deze, indien hij daarover zelf beschikt, voor zover noodig, te verschaffen.

Volgens de Memorie van Toelichting op art. 1922a BW, wetsvoorstel 2897, behoeft de materie inzake verloren gegane bewijsmiddelen een blijvende voorziening. Aan een afzonderlijke bepaling van het in sub 2 van art. 1 van het Besluit geregelde bestaat volgens de memorie geen behoefte

'... naast de processuele mededelingsplicht van de wederpartij, de bevoegdheid om de eis tot de afloop van het geding te veranderen of te vermeerderen ... en de mogelijkheid tot het houden van voorlopige getuigenverhoren, ...'.

De inzageartikelen speelden niet alleen in de praktijk nauwelijks een rol, ook de handboeken hielden zich nauwelijks met deze artikelen bezig. ${ }^{39}$

Al met al dus een kwijnend bestaan voor het exhibitierecht. Dit zal vooral veroorzaakt zijn geweest doordat het leerstuk van de mededelingsplicht in ons materiële burgerlijk recht pas laat tot ontwikkeling is gekomen. ${ }^{40}$ Die late ontwikkeling is niet helemaal begrijpelijk juist omdat de Hoge Raad in het procesrecht al vroeg oordeelde dat een partij gehouden was om soms informatie ten nadele van zich zelf te verschaffen. De Hoge Raad bepaalde immers al in 1953 dat er in het civiele recht geen regel bestaat inhoudende dat van een partij niet kan worden

39 Zo zijn in 'Grondtrekken van het Nederlands Burgerlijk Procesrecht', Tjeenk Willink-Zwolle, negende druk, 1980, bewerkt door P. Zonderland, R.C. Schlingemann en W.G. Dolman, nog geen twee pagina's (110-111) gewijd aan 'Dwanguitgifte van akten'. In de paragraaf waar deze twee pagina's onder vallen, wordt stil gestaan bij art. 833 e.v. Rv. Men zou hier een ruime behandeling verwachten van het trio artikelen 1922, 1922a en 1923 BW, doch dit geschiedt niet. Art. 1923 BW wordt alleen maar aangehaald en vervolgens wordt zonder verder commentaar verwezen naar de handboeken van burgerlijk recht. Art. 1922a BW wordt eveneens expliciet genoemd maar ook wat dit artikel betreft volstaan de auteurs met het parafraseren daarvan. In Asser-Anema-Verdam, $5^{\text {de }}$ Deel, Bewijs, 1953 is op de pagina's 232 tot en met 237 nog wel enige informatie over art. 1922 BW en verder te vinden. In Pitlo, Bewijs en Verjaring, 1968 is op de pagina's 78-79 eigenlijk niet meer te vinden dan een vermelding van deze artikelen.

40 Eén van de eerste gevallen van informatieplicht in het materiële recht is te vinden in HR 15 november 1958, NJ 1958, 67 (Baris-Riezenkamp). Zie over deze verplichting in het procesrecht par. 3.1 en 3.2 van dit boek. Zie verder W.A.J.P. van den Reek in 'Mededelingsplichten in het burgerlijk procesrecht' en Asser-Vranken, Algemeen Deel 1995, nr. 19-nr 29. Zie voor het materiële recht J.B.M Vranken in Mededelings-, informatie- en onderzoeksplichten in het verbintenissenrecht. 
verlangd dat zij aan een wederpartij in een procedure de door deze verlangde gegevens voor tegenbewijs tegen zichzelf verschaft. ${ }^{41}$

\subsection{Het inzagerecht in het Wetboek van Burgerlijke Rechtsvordering}

\subsubsection{De wetsgeschiedenis van art. $843 a$ Rv-oud (het nieuwe bewijsrecht)}

Op 1 april 1988 trad het nieuwe bewijsrecht in werking. ${ }^{42}$ Vele artikelen werden uit het Burgerlijk Wetboek verplaatst naar het Wetboek van Burgerlijke Rechtsvordering. Deze verplaatsing gold ook voor art. 1922, 1922a en 1923 BW. Deze drie artikelen werden niet alleen verplaatst, zij werden ook gecomprimeerd. Art. 1922 en 1923 werden samengevoegd tot één artikel en wel art. 843a Rv. Dit artikel, hierna aangeduid als 843a Rv-oud, luidde als volgt.

Lid 1 : Hij die daarbij rechtmatig belang heeft, kan op zijn kosten inzage, afschrift of uittreksel vorderen van een onderhandse akte aangaande een rechtsbetrekking waarin hij of zijn rechtsvoorgangers partij zijn, van degene die deze akte te zijner beschikking of onder zijn berusting heeft.

Lid 2 : De rechter bepaalt zo nodig de wijze waarop inzage, afschrift of uittreksel zal worden verschaft.

Art. 1922a BW werd overgebracht naar art. 843b Rv.

Art. 1922 en 1923 BW stonden in boek 4 (later boek 5), genaamd 'Van bewijs en verjaring' in de Tweede titel, genaamd 'van schriftelijk bewijs'. Hiermee had de toenmalige wetgever duidelijk aangegeven hoe hij deze artikelen zag: het waren artikelen van belang voor het bewijsrecht. In de parlementaire geschiedenis van het Nieuwe Bewijsrecht van 1988 gaat men vergeefs op zoek naar een motivering voor de verwijdering van de vernieuwde artikelen omtrent de inzage uit de afdeling in de wet over het bewijsrecht en opname van die artikelen in Boek 3, 'Van rechtspleging van onderscheiden aard', Titel 7, 'Enige bijzondere rechtsplegingen',

41 Zie HR 12 juni 1953, NJ 1954, 61 (bloedproefarrest). Een en ander werd herhaald door de HR op 28 september 2001, NJ 2002, 104 (Rowa-Hooters) : 'De klacht berust op de opvatting dat (ook) in een civiele procedure niemand gedwongen kan worden eraan mee te werken bewijs tegen zichzelf of te zijnen nadele bij te brengen. Deze opvatting kan echter in haar algemeenheid niet als juist worden aanvaard'. Overigens schreef Meijers al in zijn noot onder HR 18 december 1925, NJ 1926, p. 226-231'Men kan thans zonder twijfel constateren, dat in onze procedure een mededeelingsplicht voor partijen bestaat, krachtens welke telkens als de rechter de overtuiging heeft, dat als een partij meer van de geschilpunten afweet, dan hij in zijn conclusie neerschrijft, hij de conclusie als onvoldoende gemotiveerd ter zijde kan stellen'.

42 Wet van 3 december 1987, Stb. 590 en Stb. 1988, 9. Het nummer van de Kamerstukken is 10377. De kamerstukken zijn gebundeld in 'Parlementaire Geschiedenis van de nieuwe regeling van het bewijsrecht in burgerlijke zaken', redactie G.R. Rutgers en R.J.C. Flach, Kluwer, Deventer 1988. 
Eerste afdeling, 'Afschrift, uittreksel en inzage van akten en andere bewijsmiddelen'.

Uit de woorden van de minister van justitie Korthals Altes bij de mondelinge behandeling in de Eerste Kamer valt wel een reden te bedenken voor deze niet vanzelfsprekende plaats. De minister zei bij de mondelinge behandeling dat de exhibitieplicht slaat op de situatie, dat de inhoud van een schriftelijk bewijsmiddel aan een partij in beginsel wel bekend is, maar dat zij het niet in haar bezit heeft, terwijl zij het desbetreffende stuk bij voorbeeld in een procedure zou willen overleggen. Kennelijk was het bezit van het stuk bij de beslissing over de plaats in Rechtsvordering doorslaggevend en niet (meer?) de bewijsfunctie van het stuk. ${ }^{43}$ Verder kan hebben meegespeeld de gedachte dat volgens de minister de exhibitieplicht binnen de procedure niet (meer) mogelijk was (zie daarover hierna), zodat de vordering tot inzage als een vorm van 'bijzondere rechtspleging' moest worden gezien.

In zijn uitgebreide publicatie over het nieuwe bewijsrecht lijkt Beekhuis de verplaatsing van het recht op inzage naar art. 843a Rv juist te vinden, evenals de toevoeging in het artikel dat de inzage betrekking moet hebben op een onderhandse akte. Hij uit in elk geval in zijn publicatie geen enkele kritiek op het nieuwe $\operatorname{artikel.~}^{44}$

Een vergelijking tussen de artt. 1922 en 1923 BW enerzijds en art. 843a Rv-oud anderzijds brengt enkele opvallende zaken aan licht.

Ten eerste bevat art. 843a Rv-oud naar de letter een beperking die art. 1922 en 1923 BW niet kenden omdat art. 843a Rv-oud enkel spreekt over 'een onderhandse akte', dus een ondertekend geschrift, bestemd om tot bewijs te dienen. ${ }^{45}$ De betreffende BW-bepalingen beperkten zich echter niet tot dergelijke akten. Ook 'geschriften-niet akten' vielen volgens de toenmalige leer onder de inzagebepalingen van het $\mathrm{BW}$, waarmee die bepalingen dus ruim waren. ${ }^{46}$ In de parlementaire geschiedenis wordt geen enkele melding gemaakt van het hoe en waarom van deze beperking. Ik sluit niet uit dat de wetgever toen over het hoofd heeft gezien dat er een forse beperking werd geformuleerd. Zo ook Veegens-Wiersma, die in nr. 52 schrijft dat de woorden 'onderhandse akte' in art. 843a Rv-oud op grond van een misverstand in de wet zijn gekomen. Hij heeft in literatuur, rechtspraak noch

43 Zie over deze opmerking, die volgens mij niet letterlijk mag worden genomen, verder par. 7.3 en 8.3 .

44 C.H. Beekhuis, Het nieuwe Nederlandse wetsontwerp voor het bewijsrecht, Tijdschrift voor Privaatrecht 1970, p. 143-144.

45 Voor alle duidelijkheid: de regeling van het recht op toegang tot authentieke aktes is telkens te vinden in de regeling waarin de betreffende akte wordt 'gecreëerd'. Zie voor het recht op toegang tot bijvoorbeeld notariële aktes de Notariswet en Veegens-Wiersma, nr 62 en voor andere 'overheidsstukken' art. $838 \mathrm{Rv}-\mathrm{Ned}$ en het min of meer gelijkluidende art. $838 \mathrm{Rv}$-NA en Aruba.

46 Zie onder meer Veegens-Wiersma, p. 14-15 en p. 114-118, waar als voorbeeld bankafschriften en salarisstroken worden genoemd. 
toelichting op art. 843a Rv-oud enige aanleiding gevonden om te veronderstellen dat de wetgever in 1988 een beperktere inzageplicht wilde formuleren dan in art. 1922 BW tot dat moment was opgenomen. AG Strikwerda concludeert bij NI c.s.ABN dat vrij algemeen aanvaard wordt dat aan het begrip 'onderhandse akte' in de zin van art. 843a Rv een ruimere betekenis mag worden toegekend dan uit art. $183 \mathrm{Rv}$ (JRS: het huidige art. $156 \mathrm{Rv}$ ) zou voortvloeien. Ook documenten als bankafschriften zouden volgens hem geacht kunnen worden onder de exhibitieplicht van art. 843a Rv-oud te vallen. ${ }^{47}$ De Hoge Raad heeft zich in die zaak niet over deze vraag uitgelaten. Ik sluit niet uit dat de Hoge Raad dat toen niet heeft gedaan omdat hij op 22 januari 1999 in een aanbestedingszaak het volgende had overwogen: ${ }^{48}$ Onderdeel 2.b strekt, naar uit de toelichting blijkt, ten betoge dat De Vliert op grond van art. 843a Rv gehouden is inzage te verschaffen in aanbestedingsstukken. Dit onderdeel faalt reeds omdat Uneto niet heeft gesteld en ook overigens niet is gebleken dat de stukken waarvan zij inzage verlangt, onderhandse akten zijn als in die bepaling bedoeld.

Uit dit citaat leid ik af dat de Hoge Raad de tekst van art. 843a Rv, in elk geval wat dit onderdeel betreft, conform het toenmalige art. $183 \mathrm{Rv}$ (sinds 1 januari 2002 art. $156 \mathrm{Rv}$ ) wilde uitleggen. Indien de Hoge Raad namelijk onder 'onderhandse akte' ook documenten als bankafschriften en salarisstroken, zoals bijvoorbeeld Veegens-Wiersma schreef, had willen brengen, had het voor de hand gelegen om ook aanbestedingsstukken daar onder te brengen. Opvallend is wel dat Strikwerda in zijn net genoemde conclusie niet naar dit citaat verwijst. Ik denk dat hij deze passage over het hoofd heeft gezien.

Een ander opvallend feit in de wettekst is dat er geen onderscheid wordt gemaakt tussen het exhibitierecht binnen en buiten het geding zodat een lezer de conclusie zou kunnen trekken dat dit recht te allen tijde zou kunnen worden afgedwongen. Dit blijkt, gelet op de Toelichting, niet juist te zijn. De Toelichting meldt hierover namelijk dat in de praktijk binnen het geding niet aan de rechter wordt gevraagd om een bevel te geven tot overlegging van aan beide partijen gemeen zijnde stukken. ${ }^{49}$ Meent een partij tijdens het geding dat een bewijsstuk zich in handen van de wederpartij bevindt, dan sommeert zij die partij om dit stuk over te leggen. Daarna volgt meestal vrijwillige overlegging, aldus de Toelichting, omdat de wederpartij een voor haar nadelige gevolgtrekking uit een afwijzende houding niet wil riskeren.

47 HR 18 februari 2000, NJ 2001, 259, NI c.s.-ABN.

48 HR 22 januari 1999, NJ 2000, 305. AG Mok concludeert ter zake dit cassatiemiddel dat het hof klaarblijkelijk geen aanleiding heeft gezien om ambtshalve te onderzoeken of de vordering op art. 843a Rv gebaseerd kon worden. Indien het hof dat zou hebben gedaan, zou het ambtshalve een nieuwe grondslag onder de vordering hebben geplaatst, waarmee het hof, aldus de AG, de grenzen van de rechtsstrijd zou hebben overschreden.

49 Zie Parl. Gesch. nieuw bewijsrecht, p. 415 en verder. 
Die motivering vind ik niet deugdelijk. Een recht als het onderhavige is er immers juist mede voor om iets af te dwingen van een partij die daar geen zin in heeft en mogelijk het bezit ervan ontkent. De minister zegt niets over dit aspect. Het verschil tussen het exhibitierecht binnen en buiten het geding komt in de parlementaire geschiedenis van art. 843a Rv-oud wel uitgebreid aan de orde bezien in het licht van art. 19a (op te nemen in het Wetboek van Burgerlijke Rechtsvordering) van een ander wetsvoorstel dat er toen ook al lag, en wel wetsvoorstel 19574. In dit voorgestelde artikel krijgt de comparitie na antwoord een meer uitgewerkte regeling en wordt de rechter onder meer de bevoegdheid gegeven om aan partijen bevel te geven bepaalde bescheiden over te leggen. ${ }^{50}$ In de Eerste Kamer is bij de behandeling van wetsvoorstel 10377, gelet op het ontwerp van art. 19a in dus een ander wetsvoorstel (19574), opgemerkt dat er een 'weinig overwogen' stelstel zou ontstaan. In het nieuwe bewijsrecht van wetsvoorstel 10377 zou immers de mogelijkheid om in iedere stand van het geding een bevel te geven om stukken over te leggen worden afgeschaft, terwijl in het ontwerp 19574 aan de rechter de mogelijkheid wordt gegeven om partijen te verplichten om stukken over te leggen. ${ }^{51}$

Deze kritiek wordt door de minister niet beantwoord. Hij merkt enkel op dat de regeling van de exhibitieplicht, waarop art. 1923 BW doelt, niet vervalt, maar is ondergebracht in art. 843a van het ontwerp ${ }^{52}$ en dat het wetsvoorstel ervan uit gaat dat de exhibitieplicht binnen de procedure geschrapt wordt. ${ }^{53}$ Een antwoord op de vraag waarom art. 843a Rv niet binnen een procedure ingeroepen zou mogen worden werd niet gegeven. Evenmin werd duidelijk gemaakt waarom in een ander wetsontwerp een artikel wordt voorgesteld waarmee hetzelfde resultaat kan worden bereikt als met het inroepen van art. 843a Rv binnen de procedure. De minister lijkt op 15 juni 1989 een schuldbelijdenis te doen. In zijn Memorie van Antwoord aan de Eerste Kamer schrijft hij op p. 1-2 het volgende: $:^{54}$

'Het nieuwe, ... artikel 843a Rv regelt deze materie. Dit artikel is blijkens zijn bewoordingen niet beperkt tot de situatie buiten geding. Het werkt dus zowel in als buiten het geding. ... Ik geef wel toe dat de passage in de memorie van toelichting bij wetsontwerp 10377 ... niet geheel duidelijk is in dit opzicht en aanleiding kan geven tot misverstand, voor zover aldaar wordt gesteld dat aan overname van artikel 1923 BW oud geen behoefte bestaat omdat er een minder omslachtige, in de praktijk bevredigende wijze van handelen is ... Mijn conclusie is derhalve dat nog steeds zowel in als buiten het geding een exhibitieplicht bestaat, ...'

50 Zie thans art. $22 \mathrm{Rv}$ : de rechter kan in alle gevallen en in elke stand van de procedure partijen bevelen bepaalde bescheiden over te leggen.

51 P. 416 Parl. Gesch. nieuw bewijsrecht. De woorden 'weinig overwogen' zijn van Wagemakers.

52 P. 417 Parl. Gesch. nieuw bewijsrecht.

53 P. 418 Parl. Gesch. nieuw bewijsrecht.

54 Memorie van antwoord bij het wetsvoorstel 19574, Wijziging van bepalingen die verband houden met de persoonlijke verschijning van partijen in civiele procedures. 
Dit is een tamelijk onverwachte plek om duidelijkheid te geven over de aard en strekking van een ruim een jaar eerder in werking getreden wetsartikel en de opmerking is dan ook in de literatuur niet terug te vinden. Ik heb evenmin jurisprudentie gevonden waarin een beroep wordt gedaan op deze passage. ${ }^{55}$

Een derde opvallend aspect is dat het woord 'gemeen' niet terugkwam. Dit is in het kader van het vinden van de materiële waarheid een gelukkig verschil, waar de wetgever wel bij heeft stilgestaan. In de parlementaire geschiedenis valt namelijk te lezen dat met de woorden 'een rechtsbetrekking waarin de aanvrager partij is' een wat ruimer criterium is geformuleerd dan de Hoge Raad heeft gehanteerd toen hij 'een gemene titel' in art. 1922 BW uitlegde met de woorden 'een bewijsstuk waarop die aanvrager redelijkerwijze enig recht kan doen gelden'. Expliciet merkt de wetgever ter toelichting wel op dat de eiser tot inzage wel een rechtmatig belang moet hebben (zoals de wettekst vermeldt), zodat de houder van de akte niet nodeloos wordt lastig gevallen.

Hiermee is meteen een opvallend kenmerkend verschil tussen enerzijds de artt. 1922 en 1923 BW en anderzijds art. 843a Rv-oud gegeven: de verzoekende (of vorderende) partij dient een rechtmatig belang te hebben. Een nadere omschrijving van hetgeen de woorden 'rechtmatig belang' inhouden wordt eigenlijk niet gegeven. De enige zin in de Toelichting hierover, 'De eiser tot inzage enz. moet daarbij een rechtmatig belang hebben, opdat de houder der akte niet nodeloos wordt lastig gevallen' zegt namelijk niets over de wijze waarop 'rechtmatig belang' concreet moet worden ingevuld en uitgelegd..$^{57}$

\subsubsection{De wetsgeschiedenis van het op 1 januari 2002 in werking getreden art. $843 a R v$}

Sinds 1 januari $2002^{58}$ luidt art. $843 \mathrm{a} \mathrm{Rv}$ als volgt:

1. Hij die daarbij rechtmatig belang heeft, kan op zijn kosten inzage, afschrift of uittreksel vorderen van bepaalde bescheiden aangaande een rechtsbetrekking waarin hij of zijn rechtsvoorgangers partij zijn, van degene die deze bescheiden te zijner beschikking of onder zijn berusting heeft. Onder bescheiden worden mede verstaan: op een gegevensdrager aangebrachte gegevens.

2. De rechter bepaalt zo nodig de wijze waarop inzage, afschrift of uittreksel zal worden verschaft.

55 Zie over 'binnen en buiten het geding' verder hoofdstuk 16, waarin onder meer HR 6 oktober 2006, NJ 2006, 547 nader wordt besproken.

56 P. 416 Parl. Gesch. nieuw bewijsrecht. Voor het door de Hoge Raad geformuleerde criterium wordt verwezen naar HR 31 januari 1947, NJ 1948, 115.

57 Zie voor het citaat p. 416 Parl. Gesch. nieuw bewijsrecht.

58 Wet van 6 december 2001, Stb. 580. 
3. Hij die uit hoofde van zijn ambt, beroep of betrekking tot geheimhouding verplicht is, is niet gehouden aan deze vordering te voldoen, indien de bescheiden uitsluitend uit dien hoofde te zijner beschikking staan of onder zijn berusting zijn.

4. Degene die de bescheiden te zijner beschikking of onder zijn berusting heeft, is niet gehouden aan deze vordering te voldoen, indien daarvoor gewichtige redenen zijn, alsmede indien redelijkerwijs aangenomen kan worden dat een behoorlijke rechtsbedeling ook zonder verschaffing van de gevraagde gegevens is gewaarborgd.

Het lijkt erop dat de wetgever bij de wijziging van dit artikel niet heeft voorzien hoe belangrijk het artikel zou worden. De Toelichting en het verdere debat beslaan namelijk in totaal nauwelijks anderhalve pagina. ${ }^{59} \mathrm{Er}$ wordt weinig belangrijks vermeld. De wetgever onderschrijft de wenselijkheid van een verruiming van de stukken waarvan inzage verschaft moet kunnen worden. De woorden 'onderhandse akte' in art. 843a, lid $1 \mathrm{Rv}$-oud worden dan ook vervangen door 'bescheiden' terwijl de laatste zin van lid 1 van art. 843a Rv bepaalt dat onder bescheiden mede wordt verstaan 'op een gegevensdrager aangebrachte gegevens'. Aldus staat centraal de informatie die gegeven moet worden en is de aard van de gegevensdrager van geen enkel belang meer. Foto's, films, geluidsbanden, cd's, dvd's, computerbestanden: er bestaat recht op inzage ongeacht de vraag op welke wijze de informatie is opgeslagen. Verder vermeldt de wetgever dat voordat een vordering tot overlegging van stukken op grond van art. 843a Rv kan worden toegewezen, vast moet staan dat er sprake is van een 'rechtmatig belang' en dat slechts inzage is gevraagd van 'bepaalde bescheiden'. Deze twee beperkingen zouden samen voorkomen dat er naar stukken wordt gevist. ${ }^{60} \mathrm{Bij}$ de Toelichting op het nieuwe art. $22 \mathrm{Rv}$ is verder

59 Zie p. 553-554 van de Parl. Gesch. burgerlijk procesrecht.

60 Behalve waar geciteerd wordt, gebruik ik het Nederlandse woord 'vissen' of 'vistocht' in plaats van de bijna altijd gebruikte Engelse woorden 'fishing expeditions'. Zie ook Ledeboer die in 1888 in goed Nederlands op p. 20 al schreef dat als de bewijsvoerende partij het recht heeft om overlegging van stukken te eisen, de tegenpartij beschermd moet worden tegen ongegronde lichtvaardige vorderingen. De Staat der Nederlanden verdedigde zich in HR 12 december 1879, Weekblad van het Regt 4455 met de woorden dat eisers 'ook niet aantoonen, van welke bepaalde stukken zij inzage of afschrift of ... uittreksel verlangen,'. Ook in Noordziek is al een opmerking over dit vissen te vinden. Op p. 750-751 is in noot 1 de nadere door Daam Fockema opgestelde nota te vinden met de volgende inhoud: 'Bij de behandeling ... is aangevoerd, dat het $19^{\text {de }}$ artikel $1^{\text {ste }}$ alinea eene te uitgebreide strekking had; de verpligting voor eene partij namelijk om over te leggen: die stukken welke onder hare berusting zijn, en de zaak in geschil betreffen; en om met eede te bevestigen, dat men aan die verpligting door de overlegging voldoet. Men was niet tegen de verpligting tot overlegging van stukken: men begreep ook, dat er andere middelen waren om bewijzen te bekomen, gehaald uit de boezem van partij zelve; maar men vermeende, dat partij althans eenige oppervlakkige aanduiding van de stukken moest doen, welke hij verlangde dat overgelegd zouden worden, en dat de regter dit naar bevind van zaken zoude kunnen wijzigen. Men stelle zich voor eenen man van naauwgezette pligtsbetrachting, die als erfgenaam uit sterfhuizen heeft ontvangen eene verzameling van oude papieren, welke, door een opschrift of anderszins, geacht konden worden van geene waarde te zijn. Deze wordt verpligt, zonder eenige aanduiding, over te leggen de onder hem berustende stukken welke de zaak in geschil betreffen. Zal hij nu, 
nog de opmerking te vinden dat de verplichtingen van de artt. 21 en $22 \mathrm{Rv}$ van procesrechtelijke aard zijn waartegenover niet zonder meer een vorderingsrecht staat. Een dergelijk vorderingsrecht kan wel bestaan indien de partij een vorderingsrecht kan ontlenen aan art. 843a Rv. ${ }^{61}$

Het vierde lid geeft twee beperkingen die, aldus de Toelichting, duidelijk maken dat er grenzen zijn aan de verplichting tot het produceren van stukken. De eerste beperking houdt in dat gewichtige redenen in de weg kunnen staan aan het verstrekken van informatie. Aldus is aansluiting gezocht bij art. $22 \mathrm{Rv}$. In de tweede plaats is exhibitie niet nodig indien productie van bewijsmiddelen uit het oogpunt van een behoorlijke rechtsbedeling gemist kan worden (het subsidiariteitsbeginsel).

Volgens de Toelichting kunnen de beperkingen 'gewichtige redenen kunnen aan inzage in de weg staan' en 'er is geen goede grond voor exhibitie indien productie van bewijsmiddelen uit het oogpunt van een behoorlijke rechtsbedeling kan worden gemist' in lid 4 van art. 843a Rv met elkaar verweven raken en vergen zij soms een onderlinge afweging. Soms zullen redenen die zijn aangevoerd tegen een verplichting tot inzage immers minder zwaar wegen dan de eisen van een behoorlijke rechtsbedeling. In beginsel komt het erop aan of een partij een onredelijk voordeel geniet, of haar wederpartij een onredelijk nadeel lijdt doordat informatie in de procedure niet als bewijsmiddel beschikbaar komt. In het algemeen, aldus de Toelichting, zal aangenomen kunnen worden dat een behoorlijke rechtsbedeling ook gewaarborgd is indien bewijs van de feiten redelijkerwijs ook langs andere weg, bijvoorbeeld door het horen van getuigen, kan worden verkregen. Als de getuigen in een ver land wonen, aldus nog steeds de Toelichting, kan dat echter anders zijn. Ik neem aan dat moeilijk te lokaliseren getuigen hier ook onder vallen.

De Toelichting wekt vervolgens de indruk dat de rechter, met toepassing van het nieuwe recht in een zaak als de zaak die heeft geleid tot de uitspraak van 30 januari $1998,{ }^{62}$ wel inzage in een schriftelijke overeenkomst dient te bevelen. In die zaak tussen Rosier bv en Interforce bv diende Rosier te bewijzen dat tussen haar en Habo bv op 14 december 1989 een koopovereenkomst tot stand was gekomen. Rosier bedient zich ten bewijze hiervan enkel van getuigen en wordt geslaagd geacht in het bewijs. Interforce voert in cassatie aan dat het hof ten onrechte heeft overwogen dat Rosier niet gehouden was om een afschrift van de

om met volkomen bewustheid dit na te komen, verpligt kunnen worden alles te onderzoeken en na te zien? Men had daarom te kennen gegeven, dat deze verpligting te onbepaald in de wet schijnt gelegd te zijn. Het zal mij aangenaam zijn, dat ik worde onderrigt, dat de regter, welke volgens de veranderde redactie het bevel van overlegging zal verleenen, bevoegd zal zijn dat onbestemde in dit artikel te matigen.'.

61 Parl. Gesch. burgerlijk procesrecht p. 154. Zie ook par. 3.2.

62 HR 30 januari 1998, NJ 1998, 459, m.nt. Vranken. Zie over dit arrest ook M. de Tombe-Grootenhuis, Voorstel voor een Europese disclosure, Liber Amicorum Paul Meijknecht, van Nederlands naar Europees procesrecht?!, onder redactie van E.H. Hondius, A.W. Jongbloed en R.Ch. Verschuur, Deventer, Kluwer 2000, p. 301-313. 
koopovereenkomst tussen haar en Habo over te leggen. De Hoge Raad oordeelt hierover als volgt:

'Nu Rosier zich ten bewijze van de door haar gestelde koopovereenkomst niet heeft beroepen 'op eenig stuk' als bedoeld in art. 147 , lid $1 \mathrm{Rv},{ }^{63}$ was Rosier ... niet op grond van die bepaling gehouden (een afschrift van) de koopovereenkomst ten processe over te leggen. ... Nu het Hof kennelijk niet heeft getwijfeld aan de geloofwaardigheid van de door Rosier voorgebrachte getuigen, noopten ook de beginselen van een goede procesorde het Hof niet ertoe gevolg te geven aan het door Interforce bij pleidooi na enquête gedane verzoek om Rosier te bevelen (een afschrift van) de koopovereenkomst over te leggen. Ook art. 6 lid 1 EVRM noopte het Hof niet daartoe, nu partijen beide in de gelegenheid zijn geweest haar zaak toe te lichten aan de hand van de haar ter beschikking staande middelen bewijs en tegenbewijs te leveren ... Niet kan derhalve gezegd worden dat geen sprake is geweest van 'a fair (...) hearing' als bedoeld in die bepaling'.

De Toelichting zegt, onder verwijzing naar dit arrest, dat door de aanvulling in lid 4 de wederpartij thans, met een beroep op haar belang om (tegen)bewijs te kunnen leveren, kan vorderen dat de koopovereenkomst in het geding wordt gebracht. De rechter zal vervolgens op een daartoe strekkend verweer beslissen of gewichtige redenen zich tegen overlegging verzetten en of redelijkerwijs kan worden aangenomen dat een behoorlijke rechtsbedeling ook zonder overlegging is gewaarborgd.

Ik vind dat de zaak er door die verwijzing niet bepaald duidelijker op is geworden. Aan de ene kant wordt immers gezegd dat een behoorlijke rechtsbedeling ook gewaarborgd is indien bewijs van de feiten redelijkerwijs ook langs andere weg, bijvoorbeeld door het horen van getuigen, kan worden verkregen. Anderzijds wekt de Toelichting de indruk dat het oordeel van de Hoge Raad op 30 januari 1998 onder de nieuwe tekst anders zou kunnen (of zelfs moeten?) luiden. Dit is vreemd omdat de Toelichting voorop lijkt te stellen dat een vordering tot afgifte pas met succes kan worden ingesteld indien bewijs van feiten niet langs een andere weg kan worden verkregen. Aldus zou art. 843a Rv kennelijk een soort uiterste redmiddel behoren te zijn. In het geval Rosier was er zonder meer een andere weg. Interforce zou immers bijvoorbeeld personeel van Habo als getuigen kunnen laten horen over de vraag of er al dan niet een overeenkomst tussen Habo en Rosier was gesloten. ${ }^{64}$ Dat zou een langdurig en duur onderzoek met zich brengen, waar overlegging van de betreffende overeenkomst door een enkele simpele (rol)handeling kan. Een motivering waarom het recht op inzage niet als nevenschikkend bewijsmiddel naast andere bewijsmiddelen als bijvoorbeeld het recht om getuigen te horen mag worden gezien, maar als een subsidiair bewijsmiddel wordt niet

63 Thans art. $85 \mathrm{Rv}$, inhoudende dat indien een partij zich bij dagvaarding, conclusie of akte op enig stuk beroept, die partij verplicht is een afschrift van dat stuk bij te voegen.

64 Zie ook par. 3.2 en par. 7.2. 
gegeven. Het heeft er aldus de schijn van dat de minister het bewijskarakter van art. 843a Rv onvoldoende heeft onderkend en het slechts als een soort laatste redmiddel heeft gezien. Waarom dit een laatste redmiddel zou moeten zijn, wordt niet duidelijk gemaakt, terwijl dit toch vereist is alleen al omdat ons bewijsrecht geen hiërarchie in bewijsmiddelen kent. Niet elk bewijsmiddel heeft evenveel waarde (zo heeft de in art. 157 lid $1 \mathrm{Rv}$ omschreven authentieke akte dwingende bewijskracht) maar er bestaat geen regel dat deze akte eerst in het geding gebracht moet worden voordat bijvoorbeeld bewijs door getuigen kan worden geleverd. Verder lijkt een toelichting broodnodig te zijn omdat deze zinsnede aanleiding kan geven om te menen dat bij de beantwoording van de vraag of er recht op inzage is een bewijsprognose moet worden gemaakt. Uit deze zinsnede volgt immers dat de rechter anticipeert op het eindoordeel aan de hand van mogelijk aanwezige andere bewijsmiddelen en vervolgens tot de conclusie komt dat nog meer bewijsmiddelen, en wel de bewijsmiddelen die via de weg van art. 843a Rv ingebracht kunnen worden, niet meer ingebracht hoeven te worden, of juist wel. Een zeer beperkte uitleg van deze zinsnede lijkt dan ook voor de hand te liggen. ${ }^{65}$

Naar aanleiding van een opmerking in het Verslag van de Tweede Kamer vermeldt de minister bij Nota ${ }^{66}$ nog dat het naar zijn oordeel in de lijn ligt van de met het wetsvoorstel beoogde verruiming van art. 843a Rv om in elk geval voor het komende recht ook een verbintenis uit onrechtmatige daad aan te merken als een rechtsbetrekking als bedoeld in art. 843a Rv. De betreffende opmerking in het Verslag vindt haar grondslag in de volgende casus. ${ }^{67}$ In Engeland procedeert News International (hierna NI) tegen Clinger. NI stelt dat Clinger, kort gezegd, via slinkse wegen gelden van NI heeft overgeboekt of laten overboeken naar Clinger. Er zijn aanwijzingen dat overboekingen zijn verricht naar rekeningen gehouden bij de ABNAMRO bank (hierna de bank). De Engelse rechter vaardigt een rogatoire commissie uit, waarin onder meer wordt verzocht om documenten betrekking hebbend op bankrekeningen van Catalyst Micro Inc. en Mykanos Ltd. bij de bank. NI stelt dat er met betrekking tot de betalingen aan Catalyst Micro Inc. en Mykanos Ltd. een rechtsbetrekking bestaat, en wel de onrechtmatige daad door Clinger gepleegd ten opzichte van NI. De rechtbank overweegt dat deze ruime uitleg van het woord rechtsbetrekking in art. 843a Rv-oud geen steun vindt in het recht zodat NI niet

65 Onder meer Von Schmidt auf Altenstadt in Opening van zaken, TCR 2002, p. 8-14 lijkt op p. 13 juist gelukkig te zijn met dit subsidiariteitsbeginsel omdat dit beginsel een van de gereedschappen is om nodeloze overlast en vissen tegen te houden. Als ik echter de last van inzage afzet tegen het horen van een getuige, lijkt mij de inzage aanmerkelijk minder belastend te zijn. Ik laat het verschil in de kwaliteit van het bewijsmiddel nog in het midden.

66 P. 554 Parl. Gesch. burg. procesrecht.

67 HR 18 februari 2000, NJ 2001, 259 (NI-ABN), m.nt Vlas. Hartkamp verwijst in zijn conclusie bij HR 13 september 2002, NJ 2003, 400 ook naar dit arrest en merkt op dat omdat eiser bij de rechtsbetrekking waaruit de verdeling van de belangen voortvloeit niet zelf partij is, hij niet op grond van art. 843a Rv een afschrift kan vorderen van de betreffende onderhandse akte. Dat kan slechts indien de onderhandse akte ziet op een rechtsbetrekking waarin de eiser partij is. 
kan worden aangemerkt als partij in de rechtsbetrekking tussen de bank en haar rekeninghouders Catalyst Micro Inc. en Mykanos Ltd. De Hoge Raad laat in het midden of art. 843a Rv-oud betrekking kan hebben op niet ondertekende geschriften én laat in het midden of rechtsbetrekkingen uit onrechtmatige daad onder het begrip rechtsbetrekking van art. $843 \mathrm{a}$ Rv-oud vallen. ${ }^{68}$ De Hoge Raad volstaat met het oordeel dat de omstandigheid dat Clinger geldbedragen van NI naar zich heeft laten toevloeien en dat er aanwijzingen zijn dat een aantal van die betalingen is verricht op rekeningen van Catalyst Micro Inc. en Mykanos Ltd., op zichzelf niet meebrengen dat er sprake is van een rechtsbetrekking tussen NI en de bank. De vordering tot inzage is, zo concludeert de Hoge Raad, terecht afgewezen. ${ }^{69}$

\subsection{Verspreide opmerkingen over art. 843a $\mathrm{Rv}$ in parlementaire stukken}

Zoals uit par. 2.2.1 al bleek, heeft de wetgever niet alleen in de parlementaire stukken betrekking hebbend op de herzieningen van het inzagerecht van art. 843a $\mathrm{Rv}$ over het inzagerecht gesproken. In het hierna volgende zullen in chronologische volgorde de parlementaire stukken de revue passeren waarin gesproken is over art. 843a Rv terwijl dit artikel in het betreffende wetsvoorstel geen onderwerp van wetgeving was. Ik laat hierbij in deze paragraaf buiten beschouwing hetgeen over het inzagerecht is te vinden in Kamerstuk 30951, Herbezinning burgerlijk procesrecht, omdat dit uitvoerig wordt besproken in par. 5.2 van dit boek.

Het in de tijd eerste wetsvoorstel waarin art. 843a Rv werd genoemd, was het ontwerp van boek 6 van het NBW. De wetgever was er wat de verwijzing naar art. 843a Rv betreft al snel bij: voordat dit artikel in werking was getreden verwees de minister er al naar en wel in het stuk nr. 59, ingediend in het vergaderjaar 1979-

68 Bij deze weigering om duidelijkheid te verschaffen, past een kritisch vraagteken. Het in het midden laten van zo'n belangrijke maar simpel te beantwoorden vraag kan er immers toe leiden dat die vraag nogmaals wordt voorgelegd. Dit kost niet alleen veel geld en tijd doch leidt ook weer tot extra werk bij de HR. Zie ook Vranken in zijn noot onder HR 3 juni 2005, NJ 2005, 324. Indien ik Vranken in Asser-Vranken, Vervolg, in onder meer nr. 10 goed begrijp heeft ook hij voor deze manier van doen niet veel bewondering. Hij spreekt over 'de remmende werking van het denkraam van juristen' en zoekt in hoofdstuk 3 van dit boek naar achterliggende argumenten. Ter zake de inhoud van het begrip 'onderhandse akte' lijkt de HR op 22 januari 1999, NJ 2000, 305 duidelijkheid te hebben gegeven. Zie par. 2.2.1.

69 Zie over dit arrest uitgebreid par. 9.4, J.M. Hebly, Exhibitieplicht bij rogatoire commissie, TCR 2001, p. 1-3 en Van der Wiel die op p. 50 zegt dat de HR hiermee in elk geval onder 843a Rv-oud de enge opvatting, inhoudende dat eiser partij moet zijn bij de rechtsbetrekking waarvan de gevorderde bescheiden de neerslag vormen, aanhangt. Haak en VerLoren van Themaat (redactie) schrijven op p. 13 in 'De mogelijkheden voor civielrechtelijke handhaving van de mededingingsregels in Nederland.' Een inventarisatie in opdracht van het Ministerie van Economische Zaken, Amsterdam, 3 november 2005, dat het verwarringwekkend is dat de Hoge Raad met dit arrest heeft geoordeeld dat ook tussen de aanvrager en de houder van de bescheiden een rechtsverhouding moet bestaan, waarmee de Hoge Raad lijkt af te wijken van de wettekst, die slechts een rechtsbetrekking vereist waarbij de aanvrager zelf partij is. 
1980, behorend bij kamerstuk 7729. In dat stuk deelt de minister aan de Eerste Kamer mee dat aan art. 6.1.17 lid 2 (nu art. 6:48 BW, betreffende de kwitantie) niet toegevoegd hoefde te worden dat de schuldenaar in elk geval recht heeft op een afschrift van het bewijsstuk. De reden daarvoor was dat als de schuldenaar uit andere hoofde dan subrogatie een belang heeft waarbij hij aan moet kunnen tonen welke schuld hij precies heeft voldaan, uit de eisen van redelijkheid en billijkheid voortvloeit dat hij een bewijsstuk moet kunnen vragen. De minister verwees vervolgens zonder nadere toelichting ook naar art. 843a Rv, zoals voorgesteld in het ontwerp bewijsrecht (wetsontwerp nr. 10377).$^{70}$

Art. 843a Rv is verder tamelijk uitgebreid aan de orde geweest in het in par. 2.2.1 genoemde en kort besproken wetsvoorstel 19574, Wijziging van bepalingen die verband houden met de persoonlijke verschijning van partijen in civiele procedures. In de parlementaire stukken bij dit wetsvoorstel 19574 is namelijk niet alleen over 'in en buiten het geding' in de zin van 843a Rv gesproken. Er is ook het nodige gezegd over de aard en strekking van art. 843a Rv. Zo vergelijkt de minister in de op 15 juni 1989 door de Eerste Kamer ontvangen Memorie van Antwoord op p. 1-2 het bevel dat de rechter op grond van het voorgestelde art. 19a Rv (thans art. $22 \mathrm{Rv}$ ) aan een partij kan geven om bepaalde bescheiden over te leggen met art. 843a Rv. Hij zegt daarover dat hij dit bevel niet wil aanduiden met het begrip exhibitieplicht omdat hij dit technische, nergens in de wet gebruikte woord, gereserveerd wil houden voor art. 843a Rv. Er zijn bij het bevel van art. 19a Rv weliswaar mogelijke raakvlakken met het bewijsrecht, maar het accent bij art. 19a Rv ligt duidelijk anders. Naast de exhibitieplicht is er volgens hem een gerechtvaardigde behoefte aan een formalisering van een rechterlijke bevoegdheid om voor het welslagen van een comparitie na antwoord stukken op te vragen. Bij de mondelinge behandeling in de Eerste Kamer houdt het kamerlid Wagemakers op 24 oktober 1989 een lang betoog over een aantal mogelijke raakvlakken tussen het bevel van de rechter aan een partij om stukken over te leggen op de voet van (thans) art. $22 \mathrm{Rv}$ en art. 843a Rv. ${ }^{71} \mathrm{Hij}$ trekt in zijn betoog een aantal conclusies ten aanzien van het in het geding brengen van stukken en wel de volgende:

- Een verplichting om afschriften van stukken te verschaffen aan een wederpartij bestaat in beginsel uitsluitend in de in art. 843a en $843 \mathrm{~b} \mathrm{Rv}$ genoemde gevallen;

- Het is in beginsel aan iedere procespartij zelf om schriftelijke stukken in het geding te brengen ter onderbouwing en adstructie van haar stellingen en ter bestrijding van die van de wederpartij;

- De rechter kan een partij bevelen om stukken in het geding te brengen maar hij mag daarbij niet de feitelijke grondslag van het geding veranderen, ook

70 Lid 2 van art. 6:48 BW bepaalt nu dan ook alleen maar dat de debiteur een ter zake van de schuld afgegeven bewijsstuk van de debiteur kan vorderen. Over een afschrift of kopie wordt niet gesproken.

71 Handelingen Eerste Kamer 24 oktober 1989, p. 32 e.v. 
niet als het de bedoeling van hem is om de eventuele discrepantie tussen materiële en processuele waarheid te verkleinen;

- Het ambtshalve bevel van de rechter kan alleen betrekking hebben op stukken die al voldoende bepaald in de processtukken zijn aangeduid.

De minister antwoordt dezelfde dag. Hij is van mening dat de woorden 'bepaalde, op de zaak betrekking hebbende bescheiden' in het voorgestelde art. 19a Rv voldoende duidelijke beperkingen inhouden. Zo is het, gelet op die woorden, niet mogelijk om een bevel te geven om in het algemeen bescheiden over te leggen die op de zaak betrekking hebben. De algemene plicht tot 'disclosure' die, aldus de minister, in het Angelsaksische ${ }^{72}$ rechtssysteem ook wel wordt aangeduid als 'fishing expedition', bestaat niet.

In wetsvoorstel 17779, Vaststelling en invoering van de titels 7.7 (Opdracht) en 7.15 (Vaststellingsovereenkomst) van het Nieuwe BW, merkt de minister op p. 17 van zijn op 28 oktober 1991 door de Tweede Kamer ontvangen Memorie van Antwoord op dat het eerste lid van art. 68a lid $1 \mathrm{WvK}$, bepalend dat de rechter aan makelaars overlegging van hun gehouden aantekeningen betrekking hebbend op door hen gesloten overeenkomsten kan bevelen teneinde de afschriften te vergelijken en toelichting te vorderen, kan vervallen in verband met het bepaalde in art. 843a Rv. ${ }^{73}$ Die opmerking is merkwaardig: art. 843a Rv geeft de rechter immers niet de ambtshalve bevoegdheid om overlegging te bevelen die het toenmalige art. 68a WvK wel kende, zodat de verwijzing naar art. 843a Rv niet deugdelijk is. De motivering voor de vervallenverklaring van dit art. $68 \mathrm{a} \mathrm{WvK}$ moet dus maar voor niet geschreven worden gehouden.

In wetsvoorstel 23024, Wijziging van het $\mathrm{BW}, \mathrm{WvK}$ en enige andere wetten ter zake van het voeren van een administratie, is in Kamerstuk 3, de in het vergaderjaar 1992-1993 ingediende Memorie van Toelichting, de volgende opmerking te vinden:

'Bij dit alles bedenke men dat de betekenis van de bewaarplicht voor het bewijs in burgerlijke zaken beperkt is. Het gaat hier niet om het belang van de bewaarplichtige, maar juist om dat van zijn eventuele tegenpartijen die zelf de stukken die zij als bewijs willen bezigen niet (meer) hebben. Dit betekent dat men terecht komt bij situaties als die van de artt. 147, 843a, 843b Rv, bij bepalingen die in de praktijk van het recht een zeer geringe rol spelen en die ook niet zo mogen worden uitgelegd dat niet alleen een verplichting bestaat om, zo het stuk voor handen is, daarvan inzage of afgifte te geven, maar ook om het stuk met het oog daarop ten behoeve van eventuele tegenpartijen (of andere belanghebbenden) te bewaren.'

72 Vaak worden gebruikt de woorden 'Angelsaksisch recht' of Angelsaksische rechtssystemen'. Volgens mij bedoelt men dan 'Anglo-Amerikaans recht' of 'Common law'.

73 Het artikel stond in de vierde titel, tweede afdeling, Van makelaars. 
Inhoudelijk komt hier op een verscholen wijze een relevant punt voor het hier behandelde onderwerp aan de orde en wel dat de minister van mening is dat een partij die op de voet van art. 843a Rv verplicht kan worden om inzage te geven, niet verplicht is om stukken te bewaren zodat een andere partij dit recht op enig moment kan verwezenlijken. Opmerking verdient verder dat de wetgever ook hier laat zien dat het in de toekomst kijken niet echt zijn sterkste punt is, gelet op de opmerking, dat art. 843a Rv in de praktijk van het recht een zeer geringe rol speelt..$^{74}$

In de Memorie van Toelichting bij wetsvoorstel $25753,{ }^{75}$ stuk nummer 3, merkt de minister in vergaderjaar 1997-1998 op dat de betekenis van de verkorting van de termijn voor de bewaarplicht van verschillende in onder meer Boek 2 BW genoemde stukken voor het bewijs beperkt is. In slechts enkele gevallen wordt in een procedure een beroep gedaan op de artt. 843a en 843b Rv. Uit deze artikelen volgt volgens de minister niet dat een partij gehouden is om stukken voor dit doel (dus het mogelijk maken van het hebben van inzage) te bewaren. Opmerkingen die dus niet afwijken van wat is verteld bij wetsvoorstel 23024.

De wetgever lijkt eerder dan de procespraktijk gecharmeerd te zijn van art. 843a Rv. In een door de Tweede Kamer op 21 augustus 2000 ontvangen nota noemt de minister dit artikel tenminste als één van de bruikbare instrumenten ten behoeve van een werknemer die moet bewijzen dat zijn werkgever discrimineert op grond van geslacht. ${ }^{76}$ Aan de hand van onder meer art. 843a Rv kan de werknemer van zijn werkgever, zo begrijp ik de minister, inzage vragen in gegevens van de werkgever aan de hand waarvan via statistische berekeningen kan worden bewezen dat de werkgever discrimineert.

Een inhoudelijke toelichting op art. 843a Rv geeft de minister in zijn door de Eerste Kamer op 5 oktober 2004 ontvangen Memorie van Antwoord bij wetsvoorstel

74 Overigens wordt in deze memorie onder nr. 7 nog opgemerkt dat de term 'bescheiden' niet slechts betrekking heeft op papieren stukken. Onder de wettelijke term 'geschrift' of 'schriftelijk' kunnen onder omstandigheden mede de moderne elektronische gegevensdragers begrepen worden geacht. Dit was ook al verdedigd door J. de Boer, De elektronische schriftelijke vorm, NJB 1992, p. 670672. Bij de uitleg van de toen geldende tekst van art. 843a Rv is deze mening van de minister interessant. De in die tijd geldende tekst van art. 843a Rv repte weliswaar over inzage van een 'onderhandse akte' maar het lijkt toch een kleine stap om van 'onderhandse akte' via 'geschrift' bij 'bescheid' uit te komen, zodat al vanaf 1 april 1988 een verzoek tot inzage in elektronisch opgeslagen gegevens niet zonder meer kansloos was. Zie nu bijvoorbeeld art. 3:15a BW, regelend de elektronische handtekening.

75 Wetsvoorstel 25753, Wijziging van Boek 2 van het BW en van enige andere wetten in verband met de verkorting van de bewaartermijn van boeken, bescheiden en andere gegevensdragers.

76 Wetsvoorstel 27026, Wijziging van de Wet gelijke behandeling van mannen en vrouwen en van Titel 7.10 van het BW ter uitvoering van de EG-richtlijn inzake de bewijslast in gevallen van discriminatie op grond van geslacht. 
19529. ${ }^{77}$ In deze memorie reageert hij onder meer op in het NJB 2002, p. 18031804 geuite kritiek van L. Mok. Mok is in dat artikel van mening dat de bepaling van art. 7.17.1.8 lid $3^{78}$ inhoudende dat de verzekeraar in voorkomende gevallen een verloren gegaan bewijsstuk vervangt, overbodig is gelet op de artt. 843a en $843 \mathrm{~b}$ Rv. De minister denkt daar anders over. Hij schrijft dat met deze artikelen in het Wetboek van Burgerlijke Rechtsvordering in veel gevallen wel hetzelfde kan worden bereikt als met genoemd lid 3. Een verschil is dat het in lid 3 gaat om een regel van materieel recht tussen partijen in plaats van een 'bijzondere rechtspleging' in het Wetboek van Burgerlijke Rechtsvordering. Een ander verschil is dat in het wetsvoorstel rekening wordt gehouden met de bijzondere eisen die op zijn plaats zijn voor handelsverzekeringen als bedoeld in de tweede zin van lid 3.

Helemaal consistent is het allemaal niet: op 21 augustus 2000 wordt in wetsvoorstel 27026 art. 843a Rv nog gepromoot en is er geen sprake van dat de werknemer een 'materieel recht' dient te krijgen, en vier jaar later is alleen de hulp van dit artikel in het Wetboek van Burgerlijke Rechtsvordering niet goed genoeg meer voor een verzekerde. Chronologisch bezien laat het zich ook niet goed begrijpen. In 2000 werd in de praktijk nog nauwelijks gebruik gemaakt van art. 843a Rv, maar noemt de minister het zelf. In 2004 werd daarentegen blijkens de jurisprudentie al behoorlijk gebruik gemaakt van art. 843a Rv, maar komt de minister tot de conclusie dat het artikel niet bruikbaar is. Gelet op de tekst en inhoud van art. 843a en $843 \mathrm{~b} \mathrm{Rv}$ denk ik dat de mogelijkheid die het huidige art. 7:932 lid 3 BW biedt ter zake van afgifte van een nieuw bewijsstuk door de verzekeraar indien het afgegeven bewijsstuk verloren is geraakt, best gemist had kunnen worden omdat art. 843a Rv en/of art. 843b Rv hier al in voorzien.

De minister heeft formeel gelijk als hij zegt dat bij opname in het BW de verzekerde een materieel recht heeft. Inhoudelijk zie ik echter geen verschil tussen het bezit van dit recht op grond van het BW en het bezit van dit recht op grond van het Wetboek van Burgerlijke Rechtsvordering.

Asser/Clausing-Wansink verwijzen in hun commentaar bij art. 7:932, lid 3 BW wat betreft de verhouding tussen de verzekeraar en de polishouder die zijn polis kwijt is, niet naar art. 843a of 843b Rv. Zij merken wel op dat derden een gerechtvaardigd belang kunnen hebben bij inzage in, dan wel het verkrijgen van een afschrift van de polis. Grondslag voor een vordering tot het verkrijgen van een

77 Wetsvoorstel 19529, Vaststelling van titel 7.17 (verzekering) en titel 7.18 (lijfrente) van het nieuwe Burgerlijk Wetboek. De Memorie van Antwoord aan de Eerste Kamer is genummerd B.

78 Thans art. 7:932 lid 3 BW luidend: 'Indien een door een verzekeraar afgegeven bewijsstuk verloren is gegaan, geeft hij desverlangd tegen vergoeding van de kosten een nieuw bewijsstuk af. Indien het bewijsstuk aan toonder of order is gesteld en bij een verzekering van zaken die door middel van documenten plegen te worden verhandeld, kan de verzekeraar als voorwaarde voor het doen van een uitkering aan de houder van een nieuw bewijsstuk verlangen, dat hem door de houder gedurende de tijd dat de verzekeraar tot betaling kan worden gedwongen, zekerheid wordt gesteld. 
afschrift of inzage in een dergelijk geval is dan volgens hen art. 843a Rv. ${ }^{79}$ Overigens was de Raad van toezicht op het schadeverzekeringsbedrijf al in 1992 van oordeel dat de eigenaresse van een in brand gestoken gebouw, van de AVP-verzekeraar van de brandstichter de van toepassing zijnde verzekeringsvoorwaarden diende te ontvangen. ${ }^{80}$ De Raad vond de weigering van de verzekeraar om de van toepassing zijnde voorwaarden aan de eigenaresse te zenden, niet in overeenstemming met de goede naam van het schadeverzekeringsbedrijf.

Mijn inziens voegt de eerste zin van art. 7:932 lid 3 BW niets toe aan de mogelijkheid die art. 843a Rv wat dit betreft biedt. De zin kan dan ook geschrapt worden. Een behoorlijke rechtvaardiging voor deze dubbele wetgeving is er niet, zeker niet waar het kennelijk de bedoeling van de wetgever is om versnippering te voorkomen. ${ }^{81}$

De minister van economische zaken is kritisch over de mogelijkheden die art. 843a Rv biedt in Kamerstuk 22112. ${ }^{82}$ Bij brief van 28 april 2006 reageert hij op het Groenboek 'Schadevorderingen wegens schending van de communautaire antitrustregels' van de Commissie van de Europese Gemeenschappen van 19 december 2005.

Par. 2.1 van dit Groenboek gaat over de toegang tot bewijsmateriaal bij het vermoeden van schending van mededingingsregels en stelt als vraag A aan de orde of er bijzondere voorschriften moeten zijn inzake de openbaarmaking van schriftelijke bewijzen in civiele schadeprocedures in het kader van de artt. 81 en 82 van het Verdrag. Het Groenboek noemt enkele opties bij deze vraag en wel de volgende.

1. Documenten moeten openbaar worden gemaakt zodra een partij de relevante feiten van de zaak omstandig heeft uiteengezet en het redelijkerwijze beschikbare bewijsmateriaal heeft overgelegd tot staving van haar stellingen (fact pleading). Openbaarmaking moet worden beperkt tot relevante en redelijkerwijze geïdentificeerde individuele documenten en moet door een rechter worden bevolen.

79 Asser/Clausing-Wansink nrs. 143 en 144. De vraag of de eerste zin in art. 7:932 lid 3 BW luidend 'Indien een door een verzekeraar afgegeven bewijsstuk verloren is gegaan, geeft hij desverlangd tegen vergoeding van de kosten een nieuw bewijsstuk af' wordt gesteld noch beantwoord.

80 Uitspraak van 6 oktober 1992, Verkeersrecht 1993, 121

81 In zijn brief aan de Tweede Kamer van 30 juni 2008, kamerstuk 22112, nr. 660 merkt de minister van economische zaken tenminste op dat de Europese Commissie nog steeds een versnipperde aanpak (specifieke regels voor mededingingsrecht) voorstaat die ten koste gaat van de interne samenhang van de nationale systemen van burgerlijk procesrecht hetgeen tot onduidelijkheid en complicaties kan leiden.

82 Kamerstuk 22112, nr. 439, Nieuwe Commissievoorstellen en initiatieven van de lidstaten van de Europese Unie. Zie over de in dit kamerstuk behandelde problematiek omtrent het mededingingsrecht ook 'De mogelijkheden voor civielrechtelijke handhaving van de mededingingsregels in Nederland.' Een inventarisatie in opdracht van het Ministerie van Economische Zaken, Amsterdam, 3 november 2005, Redactie M.F.J. Haak en I.W. VerLoren van Themaat. 
2. Onder voorbehoud van fact pleading, moet -op bevel van een rechter- verplichte openbaarmaking van categorieën documenten tussen partijen mogelijk zijn.

3. Onder voorbehoud van fact pleading, rust op elke partij de verplichting de andere partijen in het geding een lijst te verstrekken van relevante documenten die in haar bezit zijn en voor haar toegankelijk zijn.

4. Het opleggen van sancties ingeval bewijsmateriaal wordt vernietigd om de onder de opties 1 tot en met 3 beschreven openbaarmaking te waarborgen.

5. De verplichting relevant bewijsmateriaal te bewaren. Overeenkomstig dit voorschrift kan een rechter nog voor het begin van een civiele procedure bevelen dat bewijsmateriaal dat relevant is voor de daaropvolgende procedure wordt bewaard. De partij die om een dergelijk rechterlijk bevel verzoekt, moet evenwel het redelijkerwijze beschikbare bewijsmateriaal overleggen om te staven dat er op het eerste gezicht sprake is van een inbreuk.

In Nederland geeft, aldus de minister, art. 843a Rv voor het Nederlandse procesrecht aan binnen welke grenzen de rechter personen kan verplichten tot het verschaffen van inzage in stukken. Volgens hem bestaat er nog discussie over de vraag of art. 843a Rv in de praktijk voldoende ruimte biedt voor het vergaren van bewijsmateriaal, terwijl de rechter verder op grond van art. $162 \mathrm{Rv}$ in de loop van het geding op verzoek of ambtshalve aan partijen openlegging van boeken, bescheiden of geschriften kan bevelen.

Optie 1 beschrijft volgens de minister de huidige gang van zaken, zoals die momenteel in Nederland bestaat. ${ }^{83}$ De in het Groenboek gesignaleerde problemen rond bewijsgaring kunnen echter niet altijd binnen het kader van art. 843a Rv voldoende worden opgelost.

De minister vermeldt niet welke problemen rond de bewijsgaring onvoldoende binnen het kader van art. 843a Rv kunnen worden opgelost. Ik neem aan dat hij in elk geval denkt dat art. 843a Rv alleen een recht tot inzage geeft aan die personen die samen de partijen zijn in een rechtsbetrekking. Concreter: het lijkt erop dat de minister van mening is dat indien er een overeenkomst tussen partij A en partij B bestaat, partij A geen inzage kan vorderen in stukken die zich onder C bevinden maar die van belang zijn voor de rechtsverhouding tussen A en B. De rechter kan op grond van dit artikel ambtshalve geen bevel tot inzage gelasten. Waar hij verder de voorkeur geeft voor optie 2 zal de minister waarschijnlijk ook voor ogen hebben gestaan dat art. 843a Rv, gelet op de woorden 'bepaalde bescheiden' geen mogelijkheid lijkt te bieden tot inzage in categorieën documenten.

83 Zie daarover verder W.A.J. van Lierop en E.H. Pijnacker Hordijk, Privaatrechtelijke aspecten van het mededingingsrecht, Preadvies 2007 uitgebracht voor de Vereniging voor Burgerlijk Recht, Kluwer 2007 die op p. 93-95 onder meer schrijven over de bewijsvoering in (mededingingsrechtelijke) schadevergoedingszaken, waarbij zij erop wijzen dat art. 843a Rv daarbij een steeds belangrijker procedureel hulpmiddel wordt. 
De minister steunt optie 2 waarbij hij met name vermeldt dat een rechter een partij zou moeten kunnen bevelen om categorieën van documenten openbaar te maken. De documenten moeten wel met enige nauwkeurigheid zijn aan te duiden. Wat precies het verschil is tussen de woorden 'bepaalde bescheiden' in art. 843a $\mathrm{Rv}$ en de woorden 'de documenten moeten wel met enige nauwkeurigheid zijn aan te duiden' legt de minister niet uit. Dit is merkwaardig omdat hij verder opmerkt dat als de mogelijkheid bestaat dat een vermeende overtreder verplicht kan worden veel informatie vrij te geven, dit kan leiden tot het vissen naar (inzage in) stukken, een volgens hem ongewenste ontwikkeling. ${ }^{84}$

In haar Witboek betreffende schadevergoedingsacties wegens schending van de communautaire mededingingsregels van 2 april 2008 blijft de Europese Commissie bij haar standpunt dat op dit terrein het nodige dient te gebeuren omdat slachtoffers van schendingen van de communautaire mededingingsregels meerdere miljarden euro per jaar schade zouden lijden. Wat de toegang tot bewijsmateriaal betreft wenst zij verzekering van een minimale openbaarmaking tussen procespartijen van bewijsmateriaal waarbij zij wil voortbouwen op de benadering van Richtlijn 2004/48/EG inzake intellectuele eigendomsrechten. ${ }^{85}$

Enige angst bij de minister voor art. 843a Rv blijkt uit de door de Tweede Kamer op 4 mei 2006 ontvangen nota van wijziging bij wetsvoorstel $30336 .{ }^{86}$ Elke medewerker van de Autoriteiten Financiële Markten (AFM) heeft namelijk een geheimhoudingsplicht behoudens voor zover enig wettelijk voorschrift hem tot mededeling verplicht. Volgens de minister is art. 843a Rv een dergelijk wettelijk voorschrift. ${ }^{87}$ Het moet echter voorkomen worden dat bepaalde door de AFM ontvangen gegevens door medewerkers van de AFM in een procedure op voet van art. 843a Rv tegen hen, verstrekt moeten worden. In genoemde nota stelt de minister dat naar zijn mening art. 843a Rv niet moet kunnen worden ingeroepen tegen de AFM en haar medewerkers. Aldus bepaalt art. 2 lid 2 van de Wet toezicht financiële verslaggeving thans dat de AFM verplicht is tot geheimhouding, en zijn de AFM en haar

84 Voor de volledigheid: de minister steunt optie 3 niet omdat deze te ingrijpend is voor partijen. Het opmaken van een dergelijke lijst is disproportioneel. Optie 4 wordt niet gesteund omdat het opleggen van sancties onredelijk is en omdat dit dan verder zou gaan dan voor andere rechtsgebieden. Optie 5 is volgens de minister al opgenomen in het Nederlandse procesrecht. Hij noemt met name de mogelijkheid van conservatoire beslaglegging waarbij het verlof wordt verleend onder de voorwaarde dat binnen een bepaalde termijn een bodemprocedure wordt ingesteld.

85 Zie hierover in deze paragraaf de bespreking van Wetsvoorstel 30392 en hoofdstuk 4 waarin het inzagerecht in EU-verband wordt besproken.

86 Wetsvoorstel 30336, Regels inzake het toezicht op en de handhaving van de voorschriften voor financiële verslaggeving van effectenuitgevende instellingen alsmede tot wijziging van enige wetten (Wet toezicht financiële verslaggeving).

87 In hoofdstuk 10, waar de geheimhoudingsplicht van art. 843a lid 3 Rv wordt besproken, komt deze problematiek inhoudelijk aan de orde. 
Beknopt overzicht van de geschiedenis van het inzagerecht

medewerkers niet gehouden te voldoen aan een vordering als bedoeld in art. 843a Rv.

In de parlementaire stukken van wetsvoorstel $30392^{88}$ is bij het onderwerp 'handhaving van intellectuele eigendomsrechten' ook het nodige over art. 843a Rv gezegd terwijl het geen onderwerp van wetgeving was.

In het aan de Raad van State aangeboden ontwerp luidde art. 1019a Rv als volgt:

1. Artikel $843 \mathrm{a}$, eerste tot en met derde lid, is van overeenkomstige toepassing in het geval van inbreuk op een recht van intellectuele eigendom.

2. Naast de in artikel 843a, eerste lid, genoemde inzage, afschrift of uittreksel van bescheiden kan ook overlegging gevorderd worden van andere zaken.

3. De rechter wijst de vordering af indien de bescherming van vertrouwelijke informatie niet is gewaarborgd.

In lid 2 van het voorstel wordt het recht op inzage bij handhaving van intellectuele eigendomsrechten sterk uitgebreid in vergelijking tot de mogelijkheden van art. 843a Rv. Naast de mogelijkheid van inzage, afschrift of uittreksel van bescheiden zoals genoemd in art. 843a Rv, biedt het voorstel zoals aan de Raad van State aangeboden ook de mogelijkheid om overlegging van 'andere zaken' te vorderen. Dit is een belangrijke uitbreiding die zeker bewijsrechtelijk grote voordelen met zich kan brengen, onder andere omdat er geen beperking wordt gegeven naar de aard en de soort van de zaken. Opvallend in het voorstel is ook de afwezigheid van een regel inhoudende dat een partij alleen verplicht is om die zaken af te geven die zij in bezit heeft. Een partij kan dus worden gedwongen om bewijsmateriaal over te leggen dat zich niet in haar macht bevindt. ${ }^{89}$ Het dwangmiddel bij uitstek om een partij zover te krijgen, lijkt mij de dwangsom te zijn.

De Raad van State was over de voorgestelde tekst van art. 1019a Rv niet enthousiast. ${ }^{90}$ De Raad merkt allereerst op dat uit de toelichting blijkt dat het uitgangspunt is dat de algemeen geldende regels van het Wetboek van Burgerlijke Rechtsvordering van toepassing blijven. Gelet op dat uitgangspunt is lid 1 overbodig en zou dus geformuleerd moeten worden dat lid 4 van art. 843a Rv niet van

88 Wetsvoorstel 30392, Aanpassing van het Wetboek van Burgerlijke Rechtsvordering, de Auteurswet 1912, de Wet op de naburige rechten, de Databankwet, de Handelsnaamwet, de Wet van 28 oktober 1987, houdende regelen inzake de bescherming van oorspronkelijke topografieën van halfgeleiderproducten (Stb. 484), de Zaaizaad- en plantgoedwet 2005 en de Landbouwkwaliteitswet ter uitvoering van Richtlijn nr. 2004/48/EG van het Europees Parlement en de Raad van 29 april 2004 betreffende de handhaving van intellectuele eigendomsrechten (PbEG L 195). Zie hierover ook par. 4.2 .

89 De afwezigheid van deze beperking is geen toeval. Zie hierover ook hoofdstuk 5, de schets van de Adviescommissie voor het Burgerlijk Procesrecht.

90 Advies Raad van State en nader rapport, Kamerstukken 30392, nr. 4. Het stuk is vastgesteld op 29 november 2005. 
toepassing is. De Raad merkt ook op dat de woorden 'andere zaken' in lid 2 een ruimere bevoegdheid geven dan art. 6 van Richtlijn 2004/48/EG bepaalt. De Raad adviseert om de mogelijkheid van lid 2 wel te beperken tot 'bewijsmateriaal dat zich in de macht van de wederpartij bevindt'. De Raad van State stelt verder dat in art. 843a Rv weliswaar wordt gesproken over 'degene die deze bescheiden te zijner beschikking heeft of onder zijn berusting heeft' maar deze beperking dient duidelijker uit het wetsontwerp te blijken. Ten slotte is, aldus de Raad, de tekst van lid 3 te strikt geformuleerd. Indien de tekst letterlijk wordt genomen, moet de hele vordering van een partij worden afgewezen indien van die vordering slechts een deeltje betrekking heeft op vertrouwelijke informatie waarvan bescherming niet gewaarborgd zou kunnen worden.

De minister accepteert de kritiek van de Raad en past het wetsontwerp aanzienlijk aan.

Een belangrijk uitgangspunt bij het uiteindelijk aan de Tweede Kamer aangeboden ontwerp is dat bij procedures op grond van art. 1019a Rv e.v. art. 843a Rv ook van toepassing is. De woorden 'specialis' en 'generalis' worden niet gebruikt, maar de bedoeling van de wetgever lijkt duidelijk: in een procedure op grond van art. 1019a e.v. $\mathrm{Rv}$ is art. 843a $\mathrm{Rv}$ in zijn geheel van toepassing, tenzij art. 1019a e.v. $\mathrm{Rv}$ een expliciet andere regel geven.

In de Memorie van Toelichting, stuk nr. 3, licht de minister toe dat in het eerste lid van art. 1019a Rv voor alle duidelijkheid wordt aangegeven dat een verbintenis uit onrechtmatige daad wegens inbreuk op een recht van intellectuele eigendom een rechtsbetrekking is als bedoeld in art. 843a Rv. Hoewel de parlementaire geschiedenis van art. 843a Rv dit al vermeldt, is deze stelling, aldus de Toelichting, in de literatuur niet algemeen aanvaard en in de jurisprudentie nog niet expliciet uitgesproken.

Een belangrijke aanvulling op art. $843 \mathrm{a} \mathrm{Rv}$ is volgens de minister lid 2 van art. 1019a Rv omdat krachtens dit lid ook overlegging kan worden gevorderd van ander bewijsmateriaal dan de in art. 843a lid 1 Rv genoemde 'bepaalde bescheiden aangaande een rechtsbetrekking'. De minister noemt met name cd's, kledingstukken, speelgoed en parfumerieartikelen. De kosten van een en ander mogen op grond van art. 14 van de Richtlijn niet worden afgewikkeld op voet van art. 843a Rv. Art. 1019h Rv bepaalt de wijze waarop de kosten wel afgewikkeld behoren te worden.

Lid 3 van art. 1019a Rv regelt de bescherming van vertrouwelijke informatie als grond voor afwijzing van de vordering. Dit lid gaat, aldus de minister, verder dan art. 843a Rv welk artikel in lid 3 alleen geheimhouders beschermt tegen gegevensverstrekking. Volgens de minister heeft lid 4 van art. 843a Rv, en dan betreft het hier de woorden 'gewichtige redenen', meer een materieelrechtelijke betekenis, die voortvloeit uit de omstandigheid dat art. 843a Rv binnen en buiten het geding van toepassing is terwijl de Richtlijn daarentegen het formele procesrecht betreft, waarbij beter een weigeringsgrond voor de rechter past dan een bevoegdheid voor gedaagde. Een wat merkwaardige overweging. Het lijkt mij namelijk aan een 
partij om het verweer te voeren dat een gewichtige reden als bijvoorbeeld onvolkomen bescherming van vertrouwelijkheid met zich brengt dat de vordering, of onderdelen daarvan, moet worden afgewezen (zie daarover hoofdstuk 15). Ik zie dan ook niet in dat lid 3 van art. 1019a $\mathrm{Rv}$ tot andere resultaten kan leiden dan toetsing aan de woorden 'gewichtige redenen' in lid 4 van art. 843a Rv.

De minister had verder in eerste instantie lid 3 van art. 1019a Rv zo ruim geformuleerd dat de volledige vordering moest worden afgewezen 'indien de bescherming van vertrouwelijke informatie niet werd gewaarborgd'. Deze ruime formulering paste niet in de bedoeling van Richtlijn 2004/48/EG en het woord 'indien' is dan ook vervangen door 'voor zover'. Hiermee is duidelijk gemaakt dat in één en dezelfde procedure bepaalde onderdelen van de vordering kunnen worden afgewezen terwijl andere onderdelen van die vordering kunnen worden toegewezen.

Er worden verder geen opmerkingen gemaakt die betrekking hebben op art. 843a Rv en in Staatsblad 2007, 108 wordt vervolgens de 'Wet van 8 maart 2007 tot aanpassing van het Wetboek van Burgerlijke Rechtsvordering, de Auteurswet 1912, de Wet op de naburige rechten, de Databankwet, de Handelsnaamwet, de Wet van 28 oktober 1987, houdende regelen inzake de bescherming van oorspronkelijke topografieën van halfgeleiderproducten (Stb. 484), de Zaaizaad- en plantgoedwet 2005 en de Landbouwkwaliteitswet ter uitvoering van Richtlijn nr. 2004/48/EG van het Europees Parlement en de Raad van 29 april 2004 betreffende de handhaving van intellectuele eigendomsrechten (PbEG L 195)' geplaatst.

Sinds 1 mei 2007, de dag dat deze Wet van 8 maart 2007 in werking is getreden, luidt art. 1019a Rv als volgt. ${ }^{91}$

1. Een verbintenis uit onrechtmatige daad wegens inbreuk op een recht van intellectuele eigendom geldt als een rechtsbetrekking als bedoeld in artikel 843a.

2. In de procedure op de voet van artikel 843a kan ook overlegging gevorderd worden van ander bewijsmateriaal dat zich in de macht van de wederpartij bevindt.

3. De rechter wijst de vordering af voor zover de bescherming van vertrouwelijke informatie niet is gewaarborgd. Artikel 843a, vierde lid, is niet van toepassing.

91 Zie over onder meer dit artikel R.R. Verkerk, Procesrechtelijke aspecten van het wetsvoorstel handhaving intellectuele eigendom, TCR 2006, p. 110-115, F.W.E. Eijsvogels en C. de Meyer, Enkele procesrechtelijke aspecten van handhaving van intellectuele-eigendomsrechten na implementatie van de Handhavingsrichtlijn, Tijdschrift voor Computerrecht 2009, p. 12-20, M. Rieger-Jansen, Twee jaar ervaring met het bewijsbeslag. Een overzicht van de ontwikkelingen in Nederland en een kijkje over de landsgrenzen, AMI 2009, p. 91-96 en G. van der Wal en F. van Schaick, Handhavingsinstrumenten in het intellectuele eigendomsrecht: het op de loer liggende risico van 'fishing expeditions' vergt kritische rechterlijke toetsing, IER 2009, afl. 3. 
Ten slotte komt art. 843a Rv ter sprake in wetsvoorstel 31358 betreffende het elektronisch verkeer. ${ }^{92}$ In zijn Memorie van Toelichting schrijft de minister dat art. 843a Rv ook geldt ten aanzien van op gegevensdragers aangebrachte gegevens. Indien bijvoorbeeld een elektronische akte is kwijtgeraakt omdat een computer onklaar is geraakt of een bestand verloren is geraakt, kan op grond van dit artikel een nieuw bewijsstuk worden gevraagd. Hetzelfde geldt volgens de minister ook voor de in art. 7:932 lid $3 \mathrm{BW}$ bedoelde afgifte van een verloren polis.

Indien de minister Mok had gevolgd in zijn hiervoor gegeven commentaar ter zake dit lid 3 bij wetsontwerp 19529 B, had de minister deze opmerking niet hoeven maken. Zuinig wetgeven loont. ${ }^{93}$

\subsection{Conclusies uit de parlementaire geschiedenis}

Uit het onderzoek in dit hoofdstuk naar de geschiedenis van het inzagerecht blijkt dat dit recht al vroeg in de belangstelling stond. De inhoud en het bereik van het inzagerecht hing sterk af van welk beginsel de wetgever op dat moment vooropstelde. Indien de wetgever de waarheidsvinding voorop stelde, was sprake van een ruim inzagerecht. Het beginsel dat niemand verplicht is mee te werken om bewijs tegen zichzelf of te zijnen nadeel bij te brengen verdween dan achter de coulissen. Indien de wetgever van mening veranderde, kreeg het recht een beperktere inhoud. Een afweging van de twee beginselen waarbij werd geprobeerd om een zo evenwichtig mogelijke balans te vinden, was zeker in de $19^{\text {de }}$ en het begin van de $20^{\text {ste }}$ eeuw nog niet duidelijk aan de orde.

De rechtspraak had een lange aanloop voordat duidelijk werd welke personen recht hadden op inzage. Uiteindelijk oordeelt de Hoge Raad in het arrest van 20 mei 1921, NJ 1921, p. 788 e.v. dat uit de wetsgeschiedenis volgt dat de wetgever de bevoegdheid tot het vorderen van uitlevering wilde toekennen aan een ieder, die op het stuk als bewijsstuk enig recht kan doen gelden.

Met de ontwikkeling van de mededelingsverplichtingen in het materiële recht ongeveer halverwege de $20^{\text {ste }}$ eeuw, werd ook meer aandacht besteed aan mededelingsverplichtingen in het procesrecht. Het lijkt erop dat de woorden van Eggens uit 1933, 'het beginsel 'nemo cogitur edere contra se' is niet meer van deze tijd', breed worden gedragen. Een duidelijke aanwijzing waarom niet vaker een beroep werd gedaan op het inzagerecht ondanks de maar liefst drie proefschriften aan het eind van de $19^{\text {de }}$ eeuw, behalve dan de jarenlang bestaande gedachte dat het stuk

92 Wetsvoorstel 31358, Wijziging van enige bepalingen van Rv en het BW teneinde naast het in deze bepalingen gestelde vereiste van schriftelijkheid ook ruimte te bieden aan de ontwikkelingen op het gebied van elektronisch verkeer. Zie over dit ontwerp ook H.P.A.J. Martius, Enige opmerkingen aangaande wetsvoorstel 31.358 in het Nederlands Tijdschrift voor Handelsrecht 2008, p. 237 251.

93 Zie ook F. Fernhout, Kunnen ze daar wel Googlen, NJB 2008, p. 1800, die in dat artikel laat zien hoe eenvoudig wettelijke bepalingen bij herziening van wetgeving over het hoofd worden gezien. 
waarin inzage werd gevorderde gemeenschappelijk eigendom moest zijn, heb ik niet gevonden.

Bij de herziening en herplaatsing van het bewijsrecht naar het Wetboek van Burgerlijke Rechtsvordering in 1988 heeft de wetgever zich onvoldoende rekenschap gegeven van de mogelijkheden van het inzagerecht. De wetgever heeft de grote bewijsrechtelijke implicaties niet begrepen, hetgeen blijkt uit het feit dat het inzagerecht is verstopt in art. 843a Rv, waarbij de wetgever in eerste instantie ook nog eens zonder enige tekst of uitleg een grote beperking aanbracht door op te nemen dat slechts inzage gevraagd kon worden van onderhandse aktes. Er is vervolgens zo zelden een beroep gedaan op dit artikel, dat de rechtspraak nooit de kans heeft gehad om dit feilen aan de kaak te stellen en te oordelen dat hier sprake is van een onbedoelde beperking.

Bij de wijziging van het Wetboek van Burgerlijke Rechtsvordering in 2002 wordt de inhoud van het inzagerecht verruimd. Veel tekst en uitleg wordt er niet bij verschaft. Het is juist zo dat de wetgever het nodige over het inzagerecht uitlegt op plaatsen waar dat niet meteen voor de hand ligt. Uit de verschillende parlementaire stukken die hiervoor aan de orde zijn geweest, lijken de volgende conclusies getrokken te kunnen worden:

a. De rechter mag niet op eigen houtje op onderzoek uitgaan en stukken opvragen;

b. Het is de rechter niet mogelijk om een bevel te geven om in het algemeen al die bescheiden over te leggen die betrekking op de zaak zouden kunnen hebben;

c. Uit art. 843a Rv vloeit niet de verplichting voort om stukken ten behoeve van andere partijen te bewaren;

d. Op grond van dit artikel kan een werknemer die stelt dat zijn werkgever discrimineert, bijvoorbeeld op grond van geslacht, inzage in de administratie van zijn werkgever vragen;

e. De woorden 'bepaalde bescheiden' geven voor sommige casusposities, in elk geval voor schadevorderingen wegens schending van de communautaire antitrustregels, een ongewenste beperking;

f. Met de zinsnede 'bepaalde bescheiden aangaande een rechtsbetrekking waarin hij of zijn rechtsvoorgangers partij zijn' in lid 1 worden aanzienlijk (?) minder bescheiden bedoeld dan met de zinsnede 'bewijsmateriaal dat zich in de macht van de wederpartij bevindt' in art. 1019a lid 2 Rv. 



\section{Het recht op informatie}

\subsection{De grondslagen van het recht op informatie}

Zeker in de tijd dat het inzagerecht nog was opgenomen in het BW, stond het artikel min of meer op zichzelf. Voor zover er in de twintigste eeuw tot omstreeks 1980 al over een procesrechtelijke informatieplicht werd gesproken, werd het inzageartikel in het BW daar niet of nauwelijks bij betrokken. Het uitgangspunt leek te zijn dat er geen informatieplicht bestond. Bezien in het licht van de omstandigheid dat het processuele recht op informatie vooral in de bewijsrechtelijke sfeer ligt, spreekt het volgende citaat van Meijers voor zich:

'Dit arrest doet weder een trede verder op een merkwaardige weg, waarop de H.R. zich sinds 1901 begeven heeft. ... De oude jurisprudentie van den H.R. was dat met een ontkentenis alleen gelijk te stellen was die verwering, waarbij niet bleek wat men wilde ontkennen of welk verdedigingsmiddel bedoeld werd; naast een duidelijke ontkenning behoefde echter niet de gronden der ontkenning vermeld te zijn. Wegens het verlangen van iets meer dan een duidelijke ontkenning zijn aldus arresten van Hoven vernietigd'.

De beperkte ruimte die de herroepingsgrond inhoudende dat een vonnis kan worden herroepen indien de partij na het vonnis stukken van beslissende aard in handen heeft gekregen die door toedoen van de wederpartij waren achtergehouden (thans art. 382 sub c Rv) volgens de Regering in 1865 bood, zal misschien ook wel hebben bijgedragen aan het weinige gebruik dat van het inzagerecht is gemaakt en van het op zichzelf staan van het inzagerecht.

Pas nadat de informatieplicht zich als leerstuk in het verbintenissenrecht begon te ontwikkelen, is een soortgelijke ontwikkeling in het procesrecht ontstaan. Deze ontwikkeling is vooral op gang gebracht door de gedachte dat ook in de civiele procedure de materiële waarheid aan het licht moest komen. ${ }^{2}$ Een dergelijke

1 Noot E.M.M. onder HR 18 december 1925, NJ 1926, p. 228-231 (N.V. Batava Margarine Fabrieken-Salomonsky). Dit arrest komt verder in deze paragraaf uitgebreid aan de orde.

2 In dit licht bezien is de afspraak die bij de mediationovereenkomst wordt gemaakt om alles vertrouwelijk te houden (daargelaten de houdbaarheid van een dergelijke overeenkomst), een forse stap terug. Gelukkig heeft de Hoge Raad op 10 april 2009, BG9470, geoordeeld dat niet spoedig mag worden aangenomen dat een overeenkomst een bewijsovereenkomst is, die ertoe strekt om een verklaring van een mediator als getuige in een rechtsgeding als bewijsmiddel uit te sluiten. 
zoektocht kan succesvoller eindigen als de tegenpartij er op de een of andere manier toe kan worden gebracht om ook die informatie in te brengen die haar minder welgevallig is. Met als uitgangspunt dat de materiële waarheid gevonden dient te worden, heeft de wetgever dan ook de stelling omarmd dat een partij verplicht kan worden om in het procesrecht bepaalde mededelingen te doen. ${ }^{3}$ Die wens om in een civiele procedure de materiële waarheid aan het licht te brengen, is overigens lang niet nieuw. Ledeboer schreef in 1888 dat de wetgever van 1824 van mening was dat een stuk waardoor een partij haar recht kon bewijzen, maar dat in bezit van de tegenpartij was, beschouwd moest worden als een gemeenschappelijk stuk dat afgegeven moest worden. Derden konden zelfs tot afgifte van stukken worden gedwongen indien dit kon bijdragen aan het ontdekken van de waarheid. Dat vond de wetgever rond het jaar 1824 een zaak van het hoogste belang. ${ }^{4}$ De wetgever van 1830 dacht daar al weer anders over. Die was van mening dat het zoeken van de waarheid in een civiele procedure werd begrensd door het principe dat men geen bewijsstukken bij de tegenpartij mocht zoeken. De wetgever verandert dus nog al eens van principe. Dat kan ook vrij eenvoudig omdat tot heden geen enkele wetgever, ook niet die van 1988 en 2002, in het Wetboek van Burgerlijke Rechtsvordering een algemeen artikel heeft opgenomen waarin partijen verplicht worden om alle relevante informatie die zij hebben, over te leggen. ${ }^{5}$ Voor alle duidelijkheid: art. 21 en $22 \mathrm{Rv}$ geven een dergelijke verplichting niet. Art. $21 \mathrm{Rv}$ bepaalt alleen dat een partij de van belang zijnde feiten volledig en naar waarheid moet aanvoeren. Art. $22 \mathrm{Rv}$ bepaalt dat de rechter in alle gevallen en in elke stand van de procedure partijen kan bevelen een toelichting te geven of bescheiden over te leggen. Beide artikelen zijn wel de eerste stappen op weg naar een algemene verplichting inzake informatieverschaffing maar zijn, ook in onderling verband en samenhang bezien, nog steeds vrij beperkt, zeker met inachtneming van art. $24 \mathrm{Rv}$, het artikel dat bepaalt dat de rechter niet buiten de door partijen aangevoerde grondslagen mag treden. Een wettelijk beginsel op algemene informatieverschaffing bestaat dus niet. De vraag rijst dan of een andere bron kan worden gevonden waaruit een informatieplicht kan worden geput.

Een enkele overeengekomen geheimhoudingsplicht wettigt nog niet de conclusie dat er een bewijsuitsluitingsovereenkomst is gesloten.

3 Zie W.A.J.P. van den Reek, Mededelingsplichten in het burgerlijk procesrecht, nr. 111 en verder. Ik zal in dit boek verder niet stilstaan bij het verschil tussen enerzijds een partij dwingen om bewijs tegen zichzelf te leveren en anderzijds van een partij verlangen om ook haar onwelgevallige informatie in te brengen. Zie daarover onder andere I. Giesen, p. 21.

4 Ledeboer, p. 32

5 Uit Van den Reek en Van Nispen, Informatieplicht van partijen en bewijsgaring, blijkt dat in 1997 de stelling 'de civiele procedure behoort langs de meest doelmatige weg bij te dragen tot het vaststellen van de materiële waarheid. Iedere procespartij is in redelijkheid verplicht daaraan mee te werken, ook indien haar belang daarmee niet is gediend' velen te ver ging. 
Een dergelijke bron lijkt betrekkelijk snel gevonden te zijn in de 'eisen van een goede procesorde'. ${ }^{6}$ Eén van deze eisen is dat een procespartij ook moet letten op de belangen van de andere partij zoals de Hoge Raad in de volgende zaak heeft overwogen. ${ }^{7}$ De Rabobank Gorinchem wenst de arbeidsovereenkomst die zij met $\mathrm{G}$ heeft te beëindigen. Deze wens leidt tot een ontbindingsprocedure waarin $\mathrm{G}$ een schadevergoeding wordt toegekend. Na afloop van dit geding komt boven water dat $G$ heeft verzwegen dat zij tijdens de ontbindingsprocedure de mogelijkheid had een nieuwe baan te accepteren bij de Rabobank Altena-Biesbosch. Zij had deze mogelijkheid niet benut. Op enig moment ontdekt de Rabobank Gorinchem een en ander en start zij een herroepingsprocedure tegen G. De Hoge Raad is van oordeel dat

'... reeds van bedrog in de zin van art. 382, aanhef en onder a Rv., sprake is indien een partij door haar oneerlijke proceshouding belet dat in de procedure feiten aan het licht komen die tot een voor de wederpartij gunstige afloop van die procedure zouden hebben kunnen leiden. De kantonrechter heeft klaarblijkelijk op grond van deze maatstaf geoordeeld dat G. ... ook tijdens de ontbindingsprocedure ... met het oog op de hoogte van een aan haar toe te kennen vergoeding niet had mogen verzwijgen dat zij de mogelijkheid had (vrijwel onmiddellijk) elders weer aan het werk te gaan. Dit oordeel is niet onbegrijpelijk, nu dit verzwegen feit van belang is voor de beantwoording van de vraag of, en zo ja, tot welke hoogte, aan G. een vergoeding toekwam bij de ontbinding van de arbeidsovereenkomst'.

Aldus kan worden geconcludeerd dat in het burgerlijk procesrecht relevante feiten niet bewust mogen worden achtergehouden. Daar waar feiten niet mogen worden achtergehouden, zie ik geen enkele reden waarom dit niet voor stukken zou behoren te gelden.

Hoe past dit in het adagium dat niemand bewijs tegen zich zelf hoeft te leveren? ${ }^{9}$ Dit adagium wordt ook in het civiele recht regelmatig gebruikt, maar zonder succes. ${ }^{10}$ Van Blommestein vond in 1885 de vraag of art. 1922 en $1923 \mathrm{BW}$ in strijd waren met de regel 'nemo tenetur edere contre se' zelfs weinig belangrijk. Die twee artikelen kunnen volgens hem alleen in strijd zijn met dit beginsel indien

6 Zie bijvoorbeeld hof Den Haag 14 december 1979, NJ 1981, 651, H.W. Wiersma, Recht op meewerking bij bewijsvoering in Effectieve rechtsbescherming en constitutionele rechtsorde, Nederlandse Vereniging voor Procesrecht, Tjeenk Willink Zwolle 1983, p. 77-78 en Van der Wiel, nr. 51 en verder. Waarschijnlijk anders V.C.A. Lindijer, nr. 212. In nr. 424 e.v. is Lindijer duidelijker. Daar schrijft hij dat de eis van een goede procesorde zelf geen beginsel is.

7 HR 19 december 2003, NJ 2005, 181.

8 Zie overigens ook reeds HR 4 oktober 1996, NJ 1998, 45 (Goosen-Goosen en Dekkers). Dit arrest wordt met grote instemming door de wetgever aangehaald in zijn MvA I, Parl. Gesch. burgerlijk procesrecht, p. 152.

9 Nemo tenetur edere contre se (of nemo tenetur armare adversarium contra se).

10 Zie ook par. 2.1.2 en de in die paragraaf genoemde arresten HR 12 juni 1953, NJ 1954, 61 (bloedproefarrest) en HR 28 september 2001, NJ 2002, 104 (Rowa-Hooters). 
dit beginsel door een betreffende regel wet zou zijn. Die regel bestaat volgens hem niet en heeft volgens hem ook in het Romeinse recht niet bestaan. Hij vermoedt dat 'de regel' ten onrechte is afgeleid uit de hoofdregel van het bewijsrecht, toen art. $1902 \mathrm{BW}$, inhoudende dat, in zijn formulering, iemand die iets beweert, zulks ook zelf moet bewijzen. ${ }^{11}$

Een andere grondslag voor het recht op inzage is te vinden in algemene maatschappelijke ontwikkelingen, vooral de toegenomen snelheid waarmee alles gedaan moet worden. Er werd steeds meer geklaagd over de duur van de civiele procedure (en terecht klaagt men daar nog steeds over). Die lange duur werd en wordt mede veroorzaakt door de vele tussenvonnissen met daarin bewijsopdrachten. Niet elke bewijsopdracht zou nodig zijn geweest indien tijdig alle van belang zijnde stukken in het geding zouden zijn gebracht. Aldus vormen ook overwegingen van efficiency, stroomlijning, versnelling en kostenbesparing een oorzaak voor het recht op inzage. $^{12}$

Ten slotte heeft ook de Hoge Raad zich niet onbetuigd gelaten. Waar Ledeboer in 1888 nog opmerkt dat de bewijsregels met zich brachten dat een nauwkeurige verdeling van de bewijslast over de partijen noodzakelijk was omdat de rechter zelf niet mocht meewerken om de werkelijke waarheid omtrent strijdige feiten te vinden, maar moest oordelen op grond van door partijen aangebracht bewijsmateriaal, ${ }^{13}$ oordeelde de Hoge Raad in 1925 in aanzet anders. Uit het in dat jaar gewezen arrest Batava-Salomonsky kan worden afgeleid dat de Hoge Raad toen al van oordeel was dat de rechter zijn onderzoekstaak serieus mag nemen. ${ }^{14}$ In die zaak had Batava toegezegd de ontslagen commissaris Salomonsky een jaarlijkse toelage te verstrekken onder het voorbehoud dat hij na zijn vertrek de belangen van Batava niet zou schaden, een en ander ter beoordeling aan de raad van commissarissen. Op enig moment ontvangt Salomonsky de toelage niet. Hij stelt dat dit ten onrechte is. Batava stelt in de procedure niet meer dan dat de raad van commissarissen heeft geoordeeld dat hij de belangen van Batava wel degelijk heeft geschaad en dat de feiten op grond waarvan de raad tot dit oordeel is gekomen, ten processe niet ter zake doen omdat beslissend is het te goeder trouw gegeven oordeel van de raad en dat de bewijslast van het niet te goeder trouw zijn van dit oordeel op Salomonsky rust. Het hof Arnhem overweegt dat het de rechter mogelijk moet zijn om te beoordelen of de raad al dan niet te goeder trouw was bij het geven van de beslissing. Nu Batava kennis van de feiten waarop het oordeel van de raad beruste, aan de rechter heeft onthouden, heeft zij het de rechter onmogelijk gemaakt te beoor-

11 Van Blommestein, p. 72. Hij houdt zich ook aan zijn opmerking dat de vraag van weinig belang is. Hij besteedt aan het antwoord 2 pagina's en drie regels.

12 Aldus Van den Reek, nr. 111.

13 Ledeboer, p. 5.

14 Hoge Raad 18 december 1925, NJ 1926, p. 228 (Batava-Salomonsky). 
delen of inderdaad aan art. 1374 en 1375 BW-oud is voldaan. Dit oordeel wordt door de Hoge Raad in stand gelaten. ${ }^{15}$

In Van Vliet-Vricon wordt nog duidelijker gesteld dat de rechter op onderzoek mag uitgaan. ${ }^{16}$ In dat arrest overweegt de Hoge Raad dat vaagheid, duisterheid of onvolledigheid van de als grondslag van de eis gestelde feiten aan toewijzing van de vordering in de weg kan staan. De vraag of dit zo is, dient echter wel beantwoord te worden aan de hand van alles wat in de gehele procedure aan feiten naar voren is gekomen. Er is dus geen reden om dit onderzoek te beperken tot wat in de dagvaarding is vermeld. Als de eiser echter in de gehele procedure onvoldoende feiten heeft gesteld, kan

'... de rechter ambtshalve de eiser door een comparitie van partijen of door een bewijsopdracht de gelegenheid ... geven zijn stellingen met het oog op de ontvankelijkheid van zijn vordering nader te preciseren ...'.

De arresten Batava en Van Vliet laten zien dat de rechter al ver voor omstreeks 1998, de tijd waarin de inlichtingencomparitie bij wijze van spreken als iets nieuws werd geïntroduceerd, een procedure een zodanige richting kon geven dat een partij eigenlijk niets anders meer kon doen dan de betreffende informatie verschaffen. ${ }^{17}$ Anders gezegd: indien het zoeken naar de materiële waarheid een klimtocht via een touw is, bestaat dit touw uit een vlechtwerk van drie strengen en wel een streng bestaande uit een zich minder lijdelijk opstellende rechter, een streng bestaande uit de verplichting die partijen hebben om stellingen nader te onderbouwen en een streng inhoudende de verplichting om inlichtingen te verschaffen (bijvoorbeeld door het overleggen van stukken), ook al zijn deze nadelig voor de partij die ze verschaft.

15 De Hoge Raad overweegt nog dat het hof de bewijslast van de goede trouw niet bij Batava heeft gelegd, maar slechts van Salomonsky terecht geen verder bewijs heeft verlangd van een bewering die door Batava onvoldoende was weersproken. Meijers schrijft in zijn noot onder dit arrest dat de Hoge Raad weer een stap verder is op een merkwaardige weg. Volgens hem kan na dit arrest zonder twijfel geconstateerd worden dat in de procedure een mededelingsplicht voor partijen bestaat. Deze plicht leidt ertoe dat als de rechter de overtuiging heeft, dat een partij meer van de geschilpunten afweet dan zij in haar conclusie schrijft, de rechter die conclusie als onvoldoende gemotiveerd ter zijde kan stellen.

16 Hoge Raad 24 mei 1957, NJ 1959, 10, m.nt. D.J.V.

17 Het regelmatig gehoorde verzet tegen de informatievergarende rechter die op zitting zijn lijdelijk boekje te buiten zou gaan, lijkt onvoldoende rekening te houden met in elk geval deze arresten. Ledeboer schrijft op p. 15 dat de toepassing van de lijdelijkheid des rechters ten aanzien van bewijsmateriaal volgens hem een gevolg is van de gedachte dat men meende daardoor de onpartijdigheid beter te waarborgen. Zie verder de door Van den Reek in nr 112 genoemde uitvoerige literatuur over 'rechterlijk activisme'. 
Tevens kan aan de hand van het voorgaande geconcludeerd worden dat het recht op inzage op drie zwaarwegende beginselen rust. ${ }^{18}$ Ten eerste het beginsel dat in een civiele procedure de materiële waarheid aan het licht moet komen. Het enkele belang op winst van de procedure is daaraan ondergeschikt. Ten tweede berust de inzageplicht op overwegingen van efficiency, stroomlijning, versnelling en kostenbesparing. Ten slotte behoort een rechter zijn werk te kunnen doen, hetgeen niet of minder goed lukt als een partij niet verplicht zou kunnen worden om ook voor haar ongunstige informatie in het geding te brengen. ${ }^{19}$

Toch kan er het nodige worden ingebracht tegen in elk geval de beginselen 'gij, rechter dient op zoek te gaan naar de materiële waarheid' en 'gij, partij, dient de waarheid te vertellen'. Dit wordt ook al wel gedaan. Laat ik hier beginnen met de opmerking dat in elk geval tot het begin van de jaren negentig van de vorige eeuw uit de lagere rechtspraak niet valt af te leiden dat rechters op grond van de arresten Batava-Salomonsky en Van Vliet-Vricon meer op zoek zijn gegaan naar de materiële waarheid. De ontdekking dat ook rechters op zoek konden of moesten gaan naar de materiële waarheid is pas gemeengoed geworden in de jaren negentig. Dat is eigenlijk pas recent, misschien zelfs wel zo recent dat de stelling dat rechters op zoek moeten gaan naar de materiële waarheid (nog) niet eens een zwaarwegend beginsel kan worden genoemd. Van Schaick verdedigt de stelling dat de rechter niet ambtshalve op zoek dient te gaan naar de materiële waarheid. ${ }^{20} \mathrm{Hij}$ is van mening dat niet alleen in het materiële recht, maar ook in het procesrecht de partijautonomie voorop staat. ${ }^{21}$ In het burgerlijk procesrecht wordt de omvang van een aan de beoordeling van de civiele rechter onderworpen geschil bepaald door partijen. De rechter moet het geschil daarom beoordelen binnen de door partijen getrokken grenzen en die grenzen laten niet altijd een eigenmachtige rechterlijke zoektocht toe. Twee voorbeelden uit de genoemde oratie van Van Schaick.

18 Ik volg hier Lindijer, nr. 424 e.v. die van mening is dat de (eis van een) goede procesorde zelf geen beginsel van procesrecht is. Eén van de kenmerken van een beginsel is namelijk het vermogen om de vorming en wijze van toepassing van andere normen mede te bepalen. De eis dat een procedure voldoet aan de eisen van een goede procesorde, mist dat vermogen omdat die verwijzing onvoldoende zelfstandig richtinggevend is. Verwijzing naar een goede procesorde is niet meer dan een verwijzing naar een verzameling van eisen, niet naar een zelfstandig beginsel.

19 Zie verder ook Van der Korst e.a.

20 A.C. van Schaick, Het burgerlijk recht de baas? Over de verwevenheid van burgerlijk recht en burgerlijk procesrecht, oratie, Kluwer 2009.

21 Hij wordt hierin niet gesteund door de minister van justitie. Deze schrijft in zijn brief van 5 februari 2007 aan de Tweede Kamer, Kamerstuk 30951, onder de nrs. 21 e.v. dat hij de gedachte van de auteurs van het rapport 'Uitgebalanceerd' onderschrijft voor zover zij als kerngedachte hebben dat de partijautonomie moet worden teruggedrongen ten gunste van de op partijen en de rechter rustende gezamenlijke verantwoordelijkheid, naar, zo begrijp ik, het vinden van de waarheid. De minister merkt wel op dat hij liever spreekt over 'eigen verantwoordelijkheid' van rechter en partijen dan over 'gezamenlijke verantwoordelijkheid'. 
In HR 25 november 2005, AU2403 wordt door alle drie rechterlijke instanties een erfdienstbaarheid aangenomen die op grond van de Overgangswet BW niet kan bestaan maar die door de ene partij is gesteld en door de andere is erkend. De rechter ging hier niet op zoek naar de materiële waarheid en dat op grond van de procesregel dat wat wordt gesteld en erkend, vast staat. Als een gewone procesregel een andere regel opzij zet, mag die opzij gezette regel misschien geen zwaarwegend beginsel worden genoemd.

Het tweede voorbeeld is te vinden in het arrest Van Mierlo-Dimopoulos. ${ }^{22}$ Daar gebeurde het tegendeel, waarbij de Hoge Raad zelfs de op ontdekkingsreis gaande rechter tot de orde heeft geroepen. Een ingebrekestelling die zich in een enorme stapel producties (waaronder de processtukken van eerdere procedures) bevond, maar waarop niet specifiek een beroep werd gedaan, werd gevonden door de rechter en de rechter maakte daarvan gebruik. Dat mocht niet van de Hoge Raad zodat een crediteur die feitelijk een ingebrekestelling had gestuurd die zich ook nog eens in het dossier bevond, de procedure verloor omdat het er rechtens voor gehouden moest worden dat geen ingebrekestelling was gestuurd.

Ik voeg hier nog een derde arrest aan toe. Cybul stelt in cassatie dat het onbegrijpelijk is dat het Hof heeft vastgesteld dat hij zich borg heeft gesteld gelet op de inhoud van de aan de achterzijde van de borgtochtakte geplaatste verklaring van een Panamese notaris. De Hoge Raad overweegt dat de klacht faalt omdat in de feitelijke instanties op deze verklaring geen beroep is gedaan. ${ }^{23}$ Opvallend is dat AG Hartkamp in zijn conclusie bij dit arrest het niet doorslaggevend noemt dat Cybul in feitelijke instanties niet heeft gewezen op hetgeen op de achterzijde van de borgtochtakte was vermeld, omdat het hem niet teveel van de feitenrechter gevraagd lijkt om het formulier van een akte, waaruit een schuld van ruim vijf miljoen dollar moet blijken en waarvan de echtheid wordt betwist, aan de voorén achterzijde te bezien. Hij komt tot de conclusie dat dit middel daarom wel slaagt.

Drie arresten waaruit blijkt dat de rechter niet zomaar op zoek mag gaan naar die materiële waarheid. Het valt kennelijk dus wel mee met 'het maatschappelijk belang van de eerste orde dat de waarheid aan het licht komt' of 'het grote belang van de waarheidsvinding'? ?' Ook uit art. $149 \mathrm{Rv}$ vloeit een oorzaak voort voor het feit dat de rechter de materiële waarheidsvinding met een korreltje zout moet nemen. Hij moet namelijk ook als vaststaand beschouwen dat wat de andere partij niet voldoende heeft betwist. Indien de waarheidsvinding prioriteit zou hebben, zou al het gestelde, en zelfs meer, onderzocht moeten worden. Natuurlijk is dat

22 HR 24 juni 2005, NJ 2006, 46.

23 HR 19 april 1991, Rek.nr. 7744, Cybul-Towerbank International INC., niet gepubliceerd. Zie over dit arrest G.C.C. Lewin, Het hoger beroep en het cassatieberoep in burgerlijke zaken in de Nederlandse Antillen en Aruba, par. 3.6.1, p. 129, Kluwer 2010.

24 Aldus nog steeds Van Schaick, waarbij de eerste zinsnede is uitgesproken door D. Asser in zijn jaarrede voor de NJV 'Da mihi facta', NJB 1999, p. 1253. De tweede zinsnede is afkomstig van de Hoge Raad en wel HR 13 september 1996, NJ 1996, 731. 
niet mogelijk, maar dan dient de 'rechterlijke strijdkreet' dat de rechterlijke macht op zoek is naar de materiële waarheid misschien toch wat minder voorop te worden gesteld. ${ }^{25}$ Ten slotte mogen partijen zelf bij overeenkomst afwijken van de regels van het bewijsrecht voor zover het maar geen betrekking heeft op het bewijs van feiten, waaraan rechtsgevolgen worden verbonden die niet ter vrije bepaling van partijen staan. ${ }^{26}$ Ook hieruit blijkt dat het niet aan de rechter is om eigenmachtig er voor te zorgen dat de onderste steen boven komt.

Er valt dus het nodige in te brengen tegen de stellingen dat de rechter naar de materiële waarheid moet zoeken en dat partijen verplicht zijn om spontaan alle informatie te verschaffen, ook die informatie die voor hen minder gunstig is. Andere belangen wegen kennelijk regelmatig zwaarder. Het betreft dan bijvoorbeeld het belang van een snelle procedure, een voorspelbare procedure en een procedure tegen relatief beperkte kosten. Ik voeg aan de door Van Schaick gegeven argumenten nog toe dat ook uit een arrest als Lightning Casino, ${ }^{27}$ waar de Hoge Raad overweegt dat vooropgesteld moet worden dat de op partijen rustende verplichting om in het kader van een procedure inlichtingen te verstrekken dan wel stukken over te leggen niet onder alle omstandigheden geldt en dat gewichtige redenen een weigering om aan die verplichting te voldoen kunnen rechtvaardigen, blijkt dat ultieme waarheidsvinding niet altijd het doel van de civiele procedure is. $\mathrm{Al}$ deze belangen en gewichtige redenen vallen volgens Van Schaick uiteindelijk in het niet bij het uitgangspunt dat partijen uiteindelijk gewoon de rechter de baas zijn. Zij bepalen in alle instanties samen wat de waarheid is. ${ }^{28}$ Van Schaick is niet de eerste die dit uitgangspunt verdedigt. $\mathrm{Al}$ in 1997 vond op een bijeenkomst in Leiden de meerderheid van de aanwezigen dat de stelling 'de civiele procedure behoort langs de meest doelmatige weg bij te dragen tot het vaststellen van de materiële waarheid. Iedere procespartij is in redelijkheid verplicht daaraan mee te werken, ook indien haar belang daarmee niet is gediend' te ver ging. ${ }^{29}$ Ook tijdens de op 1 november 2007 in Amsterdam gehouden vergadering van de Neder-

25 Zie voor een rechterlijk staaltje medeplegen aan liegen ook de 'grote leugen' praktijk onder het oude echtscheidingsrecht. Geen enkele rechter zocht zelfstandig naar het antwoord op de vraag of er inderdaad wel door de andere echtgenoot overspel was gepleegd. Van andere orde, maar voor de volledigheid: de Hoge Raad oordeelde op 27 november 1987, NJ 1988, 722 nog dat degene die vervalste Chloé-parfum op de markt bracht, niet gehouden was om opgave te doen van de bron waaruit de parfums kwamen. Huydecoper schrijft in zijn conclusie onder HR 25 november 2005, AU4019 dat die rechtsopvatting toen en nu niet de zijne is omdat volgens hem die opgaveplicht bestond en bestaat.

26 C.H. Beekhuis, Het nieuwe Nederlandse wetsontwerp voor het bewijsrecht, Tijdschrift voor Privaatrecht 1970 , p. 99.

27 HR 20 december 2002, NJ 2004, 4.

28 Zie ook G.C.C. Lewin, De grenzen van de rechtsstrijd in hoger beroep in burgerlijke zaken in de Nederlandse Antillen en Aruba, Deventer, Kluwer 2008 die op p. 30, kort gezegd, betoogt dat het goed is/zou zijn indien de appelrechter buiten de grieven om oordeelt, terwijl J.L.R.A. Huydecoper in zijn bespreking van dit boek in TCR 2009, p. 87-88 hier ernstig bezwaar tegen heeft.

29 Aldus Van den Reek en Van Nispen, Informatieplicht van partijen en bewijsgaring. 
landse Vereniging voor Burgerlijk Procesrecht vond menigeen dat de rechterlijke bemoeienis in vele gevallen te groot is. De vaststelling van de grens van rechterlijk activisme is misschien wel zo moeilijk dat de neiging bestaat om de rechter terug te sturen in het hok van de lijdelijkheid teneinde te voorkomen dat rechters door deze onduidelijke grens te zeer procedures gaan maken en breken. ${ }^{30}$ Een oplossing biedt dat volgens mij niet: het vinden van de grenzen van de lijdelijkheid kon wel eens net zo moeilijk zijn als het vaststellen van de grens van het rechterlijk activisme. Van der Korst merkt op dat de rechterlijke bevoegdheid tot waarheidsvinding is ingebed in een stelsel waarbij nog steeds de procespartijen, niet de rechter, de grenzen van het geschil bepalen. De transparantieplicht van procespartijen in Nederland levert volgens hem een onevenwichtig beeld op bij gebreke aan een voldoende duidelijk kader waarbinnen procespartijen over en weer gegevens in het geding moeten brengen. ${ }^{31}$ Ten slotte lijkt het erop dat het ook van belang is welke persoon schuil gaat achter 'de wetgever'. Uit par. 2.1.2 blijkt immers dat de wetgever uit het jaar 1830 en de wetgever van het ontwerp van 21 oktober 1824 een vergaande verplichting tot het overleggen van stukken 'als hoogst zedelijk en billijk' beschouwden. De wetgever van het BW van 1838 was echter huiverig om een ruime verplichting op te nemen om de bewijsmiddelen 'e domo adversarii' over te leggen. Indien fundamentele beginselen botsen, blijkt het moeilijk om oplossingen te vinden waarbij kool en geit worden gespaard.

\subsection{Art. 843a Rv bezien in het licht van enkele andere 'informatie- artikelen'}

Behoudens de in de vorige paragraaf genoemde algemene rechtsbeginselen waarop het recht op inzage kan rusten, dient art. 843a Rv ook bezien te worden in het licht van enkele andere artikelen in het Wetboek van Burgerlijke Rechtsvordering die betrekking hebben op de verplichting om informatie te verschaffen. Het betreft hier dan met name art. 21, 22, 85 en $162 \mathrm{Rv}$.

Art. $21 \mathrm{Rv}$ bepaalt dat partijen verplicht zijn de voor de beslissing van belang zijnde feiten volledig en naar waarheid aan te voeren. Art. $22 \mathrm{Rv}$ bepaalt dat de rechter in alle gevallen en in elke stand van de procedure partijen kan bevelen bepaalde, op de zaak betrekking hebbende bescheiden ${ }^{32}$ over te leggen. De rechter

30 Zie Verschoof e.a., De regiefunctie van de rechter, Boom Juridische uitgevers 2008 en mijn verslag van de vergadering van de Nederlandse Vereniging voor Procesrecht over dat onderwerp in PP 2008, p. 11-14.

31 Van der Korst, p. 87.

32 AG Spier schrijft in zijn conclusie bij HR 31 oktober 2008, BF1179 dat uit de op dit punt niet erg heldere parlementaire geschiedenis op art. 843a Rv opgemaakt zou kunnen worden dat het begrip bescheiden in art. 22 Rv ruim moet worden opgevat. Hij verwijst hierbij naar TK 1999-2000, 26855 , nr. 3, p. 188, waarbij hij uitdrukkelijk vermeldt dat art. $22 \mathrm{Rv}$ niet de zinsnede kent dat onder bescheiden mede 'op een gegevensdrager aangebrachte gegevens' vallen. AG Wattel schrijft in zijn conclusie bij HR 18 september 2009, BI5906, NJ 2009, 566, m.nt. J.W. Zwemmer, dat 
kan uit de niet-naleving van de verplichting of de niet-opvolging van het bevel de gevolgtrekking maken die hij geraden acht. Art. $85 \mathrm{Rv}$ verplicht een partij die zich bij dagvaarding, conclusie of akte beroept op enig stuk, een afschrift van dat stuk bij te voegen. ${ }^{33}$ Dit beroep hoeft overigens niet letterlijk te worden gedaan. De minister heeft tenminste op 24 oktober 1989 opgemerkt dat de rechter best een bevel tot overlegging van niet door partijen genoemde stukken mag geven indien het gaat om zulke voor de hand liggende bescheiden dat het zelfs niet bij partijen opkwam om in de stukken expliciet naar die betreffende bescheiden te verwijzen. ${ }^{34}$ Art. $162 \mathrm{Rv}$ geeft de rechter de bevoegdheid om in de loop van het geding, op verzoek of ambtshalve, een partij te bevelen om open te leggen boeken, bescheiden en geschriften die de betreffende partij ingevolge de wet moet houden, maken of bewaren.

Opvallend is dat de wetgever geen algemene beschouwing heeft gegeven over deze vier artikelen waarvan art. 21, 22 en $85 \mathrm{Rv}$, gelet op hun gemeenschappelijke achtergrond, als een 'drie-eenheid' mogen worden beschouwd. In de algemene opmerkingen van de minister bij het wetsontwerp $26855^{35}$ wordt in de paragraaf met de titel 'modernisering van de verhouding tussen de rechter en partijen' alleen art. $22 \mathrm{Rv}$ aangehaald en besproken. ${ }^{36}$ Met dit artikel is, aldus de minister, de lijdelijkheid van de rechter ten aanzien van de voortgang van de procedure teruggedrongen in verband met het streven naar een meer doelmatig verloop van de procedure. Verder is het een voorschrift dat ten behoeve van de feitenvinding beperkingen oplegt aan de partijautonomie. ${ }^{37}$ De bedoeling van art. $21 \mathrm{Rv}$ is volgens de minister om de bewuste leugen uit te bannen. Het artikel moet duidelijk maken dat het ook in een civiele procedure niet aangaat dat partijen relevante feiten bewust achterhouden of onjuist weergeven. Het artikel zou geen inbreuk op de partijautonomie zijn omdat partijen ook met inachtneming van de verplichting van art. $21 \mathrm{Rv}$ nog steeds de aard en omvang van het geschil bepalen. Vraagt een eiser op grond van een bepaalde feitenconstellatie aan de rechter een beslissing, dan gaat het niet aan om de rechter de beslissing te bemoeilijken of zelfs onmogelijk te maken, door hem benodigde gegevens, die wel binnen het bedoelde kader vallen, te onthouden. ${ }^{38}$ Een niet zo duidelijk uit de parlementaire geschiedenis blijkende

de civiele procedure niet een met art. 8:42 Awb vergelijkbare plicht kent tot disclosure van alle op de zaak betrekking hebbende stukken. Art. 22 Rv, zo vervolgt hij, geeft de burgerlijke rechter slechts een discretionaire bevoegdheid de partijen te bevelen bepaalde bescheiden over te leggen.

33 Zie over dit artikel, maar dan de versie van voor 1 januari 2002, onder meer Veegens-Wiersma nr. 63 e.v.

34 Mondelinge behandeling in de Eerste Kamer van het wetsontwerp 19574, Wijziging van bepalingen die verband houden met de persoonlijke verschijning van partijen in civiele procedures, p. 34 .

35 Wetsvoorstel tot herziening van het procesrecht voor burgerlijke zaken, in het bijzonder de wijze van procederen in eerste aanleg.

36 Parl. Gesch. burgerlijk procesrecht p. 5-6.

37 Parl. Gesch. burgerlijk procesrecht p. 5-6.

38 Parl. Gesch. burgerlijk procesrecht p. 146-147. 
bedoeling wordt gegeven door Visser. Zij is van mening, dat art. $21 \mathrm{Rv}$ mede is ingevoerd om civiele procedures sneller te laten verlopen. Alles wat relevant is, moet zo snel mogelijk worden aangevoerd. ${ }^{39}$

In de Toelichting op art. 21 wordt verder geschreven dat er wel een verband bestaat tussen art. $21 \mathrm{Rv}$ en art. $22 \mathrm{Rv}$. Dat verband is dan kennelijk, want zo vervolgt de toelichting, dat de artt. 21 en $24 \mathrm{Rv}^{40}$ aangeven hoever de rechter kan gaan bij de toepassing van art. $22 \mathrm{Rv}$, waarbij de verplichting van art. $21 \mathrm{Rv}$ correspondeert met het rechterlijk bevel van art. $22 \mathrm{Rv}$. Hierbij is volgens de minister de verplichting van art. $21 \mathrm{Rv}$ echter breder.

Zoals hiervoor blijkt, komt bij een en ander ook art. $24 \mathrm{Rv}$, het artikel over de partijautonomie, om de hoek kijken. Waar partijen, kort gezegd, de baas zijn, kunnen zij afspreken wat zij wel en niet aan de rechter meedelen, of, beter gezegd, wat zij aan de rechter willen voorhouden ter oplossing van hun geschil. In dat verband kunnen zij de nodige afspraken maken over wat zij wel en niet in de procedure willen vertellen. Zo komen partijen regelmatig overeen dat een door een partij opgemaakt due diligencerapport niet aan de wederpartij verschaft hoeft te worden.

Het trio artikelen 21, 22 en $24 \mathrm{Rv}$ veroorzaakt wat dat betreft een behoorlijk spanningsveld. Partijen moeten volgens art. $21 \mathrm{Rv}$ de voor de beslissing van belang zijnde feiten volledig en naar waarheid aanvoeren, maar bepalen op grond van art. $24 \mathrm{Rv}$ zelf wat de grenzen van het geschil zijn, omdat zij beslissen welke feiten zij aanvoeren, erkennen en/of betwisten bij hun vordering, verzoek of verweer en de rechter daar niet buiten mag treden. Zie het net door mij genoemde voorbeeld over de al dan niet inbreng van het due diligencerapport. Een ander voorbeeld van het uitgangspunt dat partijen de baas zijn is de bewijsovereenkomst waarbij partijen bepaalde bewijsmiddelen kunnen uitsluiten of kunnen opwaarderen. Brink schrijft wat dit betreft zelfs dat de verschaffer van informatie er goed aan doet om in een zo vroeg mogelijk stadium goede afspraken te maken over de omstandigheden waaronder vertrouwelijke informatie aan welke personen zal worden verschaft en welk gebruik zal zijn toegestaan. ${ }^{41}$

De andere elektrische lading in dit spanningsveld is de vrij wroetende rechter die een bevel geeft om bepaalde bescheiden over te leggen terwijl partijen dat op grond van art. $24 \mathrm{Rv}$ niet willen. Van der Korst signaleert dit spanningsveld ook en noemt dit ene uitgangspunt van de waarheidzoekende rechter en het andere

39 E.T. Visser, Het exhibitionisme in arbeidszaken en de fundamentele herbezinning, Arbeidsrecht 2007, afl. 6-7, p. 15.

40 Het grondslagartikel.

41 Brink, p. 200-201. 
uitgangspunt van de afbakening van de rechtsstrijd door de procespartijen twee wettelijk vastgelegde onverenigbare uitgangspunten. ${ }^{42}$

In abstracto lijkt mij dit wel mee te vallen, indien tenminste art. $24 \mathrm{Rv}$ als uitgangspunt wordt beschouwd. Partijen behoren de inhoud en grenzen van het debat te bepalen en binnen dat speelveld mag de rechter zich vrij bewegen. In concreto is het echter in de nodige gevallen buitengewoon moeilijk om de begrenzing en omvang van het geschil zoals partijen dat wensen voor te leggen, te bepalen. De vraag of de rechter zich wel aan die begrenzing houdt is regelmatig evenmin makkelijk te beantwoorden.

In de MvT bij art. $22 \mathrm{Rv}$ worden nog enkele opmerkingen gemaakt die van belang zijn voor de aard en inhoud van art. 843a Rv. Zo stelt de minister dat de verplichtingen van art. 21 en $22 \mathrm{Rv}$, verplichtingen van procesrechtelijke aard zijn waar niet zonder meer een vorderingsrecht van een partij tegenover staat. ${ }^{43}$ Dit kan anders zijn indien de wederpartij een vorderingsrecht kan ontlenen aan art. 843a $\mathrm{Rv}$, waarbij de beperkingen in art. 843a Rv het gevaar van vissen naar stukken uitsluiten. ${ }^{44}$ Verder is er een tamelijk uitgebreide gedachtewisseling geweest over de vraag wie allemaal kennis moet nemen van de stukken die op grond van een op art. $22 \mathrm{Rv}$ gebaseerd rechterlijk bevel moeten worden overgelegd. Zo is de mogelijkheid geopperd dat de raadsman van de wederpartij, maar niet de wederpartij zelf kennis neemt van vertrouwelijke informatie van de andere partij. ${ }^{45}$ De minister is in zijn antwoord stellig: 'In een gerechtelijke procedure brengt art. 6 EVRM mee dat gegevens die de rechter aan de beslissing ten grondslag legt, niet aan één der partijen onthouden mogen worden'. De leden van de Eerste Kamer hebben kennelijk ook naar Amerikaanse juridische tv-series gekeken. Zij hebben zelfs geopperd om de rechter de mogelijkheid te geven om in raadkamer te beslissen over de vraag of vertrouwelijke stukken al dan niet geheel of gedeeltelijk moeten worden ingebracht waarbij de rechter buiten aanwezigheid van partijen alleen de raadslieden hoort. De minister verwerpt ook dit voorstel met een verwijzing naar

42 Van der Korst, p. 99. Dat in dit spanningsveld kortsluiting kan optreden blijkt wel uit mijn verslag van de op 1 november 2007 gehouden vergadering van de Nederlandse Vereniging voor Procesrecht, 'De regiefunctie van de rechter, PP 2008, p. 10-14.

43 Zie inmiddels HR 27 maart 2009, BH1986, NJ 2009, 254, m.nt. S.F.M.W. In deze alimentatiezaak verzoekt de man dat wordt bepaald dat de vrouw de jaarcijfers 2000 tot en met 2003 van haar onderneming, de aangiftes inkomstenbelasting en definitieve aanslagen inkomstenbelasting 2000 tot en met 2002, 2004 en 2005 in het geding dient te brengen. Het hof heeft dit verzoek afgewezen omdat de stukken slechts betrekking zouden hebben op de executie van de alimentatie, die niet in geschil was. De Hoge Raad overweegt:'Het verzoek betreffende de overlegging van stukken strekt bovendien in wezen ertoe dat de rechter verzocht wordt gebruik te maken van zijn in art. 22 Rv. neergelegde bevoegdheid om de vrouw te bevelen bepaalde stukken over te leggen.'

44 Parl. Gesch. burgerlijk procesrecht p. 154.

45 Parl. Gesch. burgerlijk procesrecht p. 158 e.v. Zie ook HR 20 december 2002, NJ 2004, 4 (Lightning Casino cs - Nederlandse Antillen) en HR 11 juli 2008, BC8421. 
art. 6 EVRM en de opmerking dat partijen in een civiel geding het recht hebben om zich over alle tot het geding behorende stukken uit te laten.

De minister is verder nog van mening dat art. $22 \mathrm{Rv}$ de rechter een discretionaire bevoegdheid geeft waaruit voortvloeit dat geen hoge eisen aan de motivering van de rechter worden gesteld. Indien een partij wat dat betreft meer wil horen, dient zij die kwestie in het kader van de verdeling van de bewijslast en van art. 843a Rv aan de orde te stellen. De vrije beoordelingsruimte van de rechter is dan kleiner terwijl ook hogere motiveringseisen gelden. ${ }^{46}$

Van der Korst stelt dat art. $22 \mathrm{Rv}$ en art. 843a Rv kunnen cumuleren. Hij noemt dit niet logisch omdat de exhibitieplicht (zijn aanduiding) van art. 843a Rv een aantal beperkingen kent dat voor de rechterlijke exhibitieplicht (eveneens zijn aanduiding) van art. $22 \mathrm{Rv}$ niet geldt. Volgens hem kan een rechter zelfs op grond van art. $22 \mathrm{Rv}$ overlegging van een due diligencerapport bevelen terwijl partijen zijn overeengekomen dat de niet-bezitter van dit rapport geen inzage kan vorderen. ${ }^{47}$ Deze samenloop van partij- en rechterstransparantie noemt hij het onvermijdelijk gevolg van de huidige combinatie tussen partijautonomie en waarheidsvinding door de rechter. ${ }^{48} \mathrm{Ik}$ kan hem in zijn voorbeeld niet volgen. Waar partijen hebben afgesproken dat de niet-bezitter van het rapport geen inzage kan vorderen, hebben zij volgens mij een bewijsuitsluitingsovereenkomst gesloten waarop de rechter geen inbreuk mag maken.

Een belangrijk verschil tussen art. $22 \mathrm{Rv}$ en art. $843 \mathrm{a} \mathrm{Rv}$ is door de minister in zijn Memorie van Antwoord bij kamerstuk $19574^{49}$ gegeven. Hij merkt in dat stuk op p. 2 op dat er naast het bestaan van art. 843a Rv, welk artikel voor partijen is geschreven, een gerechtvaardigde behoefte bestaat aan een formalisering van een rechterlijke bevoegdheid om voor het welslagen van een comparitie na antwoord stukken op te vragen. Deze rechterlijke bevoegdheid is niet in tegenspraak met art. 843a Rv omdat het verschillende zaken betreft.

Op zichzelf beschouwd geven art. 21 en $22 \mathrm{Rv}$ geen recht op inzage of afgifte van stukken..$^{50}$ Tekst noch strekking van beide artikelen geeft aanleiding om tot de conclusie te komen dat een partij de wederpartij inzage in stukken moet geven. De artikelen geven wel een belangrijk processueel opstapje naar art. 843a Rv. Dit

46 Parl. Gesch. burgerlijk procesrecht p. 159.

47 Van der Korst, p. 88.

48 Van der Korst zet op p. 88 de pre-processuele informatierechten en de processuele transparantieverplichtingen tegenover elkaar. Het pre-processuele informatierecht komt de wederpartij buiten enige rechterlijke procedure toe; de processuele transparantieplicht wordt door de rechter ten processe bepaald. In dat proces is art. 843a Rv een voorbeeld van partijtransparantie (een partij vordert/verzoekt immers inzage) terwijl art. $22 \mathrm{Rv}$ een voorbeeld is van rechterstransparantie (de rechter verzoekt ambtshalve overlegging van stukken).

49 Het voorstel 'Wijziging van bepalingen die verband houden met de persoonlijke verschijning van partijen in civiele procedures'. Zie ook par. 2.2.3.

50 Zie ook W.P. Wijers en A.J. Haasjes, Exhibitieplicht in het (ondernemings)recht in: Onderneming en Financiering 2006, p. 49-62. 
opstapje geldt dan vooral voor art. $22 \mathrm{Rv}$. Daarin is immers vermeld dat de rechter in elke stand van de procedure een bevel aan een partij kan geven om op de zaak betrekking hebbende bescheiden over te leggen. De stap van het 'volledig en naar waarheid aanvoeren van feiten' in art. $21 \mathrm{Rv}$ en de mogelijkheid die de rechter heeft om een bevel te geven om bepaalde bescheiden over te leggen naar het 'inzage geven in bescheiden waarmee de juistheid of onjuistheid van die gestelde feiten kan worden aangetoond', is immers niet groot. De schakel met art. $85 \mathrm{Rv}$ is te vinden in het feit dat stukken waarop bij dagvaarding, conclusie of akte een beroep wordt gedaan, ter inzage moeten worden overgelegd. Uit het arrest Interforce-Rosier ${ }^{51}$ kan de conclusie worden getrokken dat de Hoge Raad art. $85 \mathrm{Rv}$ (in die tijd nog art. $147 \mathrm{Rv}$ ) beperkt wenst uit te leggen. Indien niet letterlijk een beroep op een stuk wordt gedaan, doch een dergelijk stuk zijdelings aan de orde komt, valt het niet onder art. $85 \mathrm{Rv}$.

Vranken verzet zich in zijn noot onder dit arrest naar mijn mening terecht tegen een dergelijke beperkte uitleg. In de onderhavige zaak, zo schrijft hij, voert Rosier in de procedure expliciet aan dat zij met een derde een koopovereenkomst heeft gesloten. Duidelijk is dat deze overeenkomst op schrift staat en het antwoord op de vraag of die koopovereenkomst inderdaad bestaat is van belang voor de procedure tegen Interforce. Indien de Hoge Raad vervolgens vindt dat met de wijze waarop Rosier de koopovereenkomst aan de orde heeft gesteld, niet 'een beroep op enig stuk' is gedaan, aldus Vranken, weet hij niet meer wanneer dan nog wel sprake is van een beroep op enig stuk. Het lijkt er dus op alsof de Hoge Raad een en ander wel heel eng uitlegt. Ik vraag mij af of de Hoge Raad onder het procesrecht van na 1 januari 2002 nog tot een zelfde uitspraak zou zijn gekomen. Gelet op de tendens tot verruiming van de informatieplicht lijkt het mij waarschijnlijk dat Interforce-Rosier op dit punt geen geldend recht meer is.

Over art. $162 \mathrm{Rv}$ valt vanuit de praktijk niet veel bijzonders op te merken. Het artikel is bij de herziening van het Burgerlijk Procesrecht overgebracht van het Wetboek van Koophandel, waar het bij wet van 5 mei 1922, Stb. 246 als art. 8 was opgenomen, naar het Wetboek van Burgerlijke Rechtsvordering. Ik heb niet kunnen ontdekken dat er veel gebruik van dit artikel werd en wordt gemaakt. Theoretisch gezien hebben Rutgers en Wisse wel het nodige over dit artikel op te merken. ${ }^{52}$ Uit de parlementaire geschiedenis van art. $8 \mathrm{Kh}$ blijkt namelijk dat het de rechter is die een partij beveelt om stukken alleen aan hem, de rechter, over te leggen, waarna de rechter de stukken doorbladert en beslist wat de wederpartij mag inzien. Wat er ook zij van die parlementaire geschiedenis: een dergelijke wijze

51 HR 30 januari 1998, NJ 1998, 459 m.nt Vranken. Zie voor een beschrijving van de feiten in deze zaak par. 2.2.2.

52 G.R. Rutgers en Lisette R. Wisse, Art. 162 Rv: rara avis in exhibitieland, Ondernemingsrecht 2005, p. 91-93. 
van hantering van de mogelijkheid van art. $162 \mathrm{Rv}$ kan natuurlijk al vele jaren niet meer omdat het strijd met het beginsel van hoor en wederhoor oplevert. ${ }^{53}$

Zoals hiervoor is vermeld kan wel worden verdedigd dat art. 21, 22 en $85 \mathrm{Rv}$ een processueel opstapje vormen naar de vordering tot inzage. Indien immers op voet van art. $21 \mathrm{Rv}$ een feit wordt aangevoerd dat berust op één of meer bescheiden, kan zonder meer inzage worden gevorderd van die bescheiden op voet van art. 843a Rv. Niet gezegd kan worden dat de artikelen in een bepaalde hiërarchie tot elkaar staan. Zij vullen elkaar eerder aan, waarbij sprake kan zijn van een overlapping. Uit niets valt verder uit deze artikelen te concluderen dat daar waar niet ingebracht schriftelijk bewijs voorhanden is, het bewijs niet door getuigen geleverd zou kunnen worden. Een voorbeeld ter verduidelijking. Indien vast staat dat er een schriftelijk koopcontract bestaat, kan en mag het bewijs hiervan geleverd worden door het horen van getuigen. Dit is nogal vanzelfsprekend, alleen al omdat het schriftelijk stuk verloren geraakt kan zijn. ${ }^{54}$ Een opvallend, hiervoor vanuit een andere gezichtshoek aan de orde gekomen verschil tussen art. $22 \mathrm{Rv}$ en 843a Rv, is dat art. $22 \mathrm{Rv}$ de rechter een discretionaire bevoegdheid geeft. De rechter kan partijen ambtshalve een bevel geven. Een verzoek van een partij gegrond op art. 843a $\mathrm{Rv}$ daarentegen moet worden toegewezen indien de daartegen gevoerde verweren tenminste zijn verworpen en de beperkingen van de leden 3 en 4, voor zover door de wederpartij aangevoerd, niet aan toewijzing in de weg staan. Indien geen verweren worden gevoerd, moet de rechter het verzoek toewijzen. ${ }^{55}$

Uit art. $21 \mathrm{Rv}$ valt niet zonder meer af te leiden dat partijen bescheiden in het geding moeten brengen. De feiten die zij stellen, dienen volledig en naar waarheid te worden aangevoerd. Dat een en ander met alle bestaande bescheiden onderbouwd dient te worden, volgt niet uit dit artikel. Indien art. $21 \mathrm{Rv}$ en 843a Rv samen met de stel- en onderbouwingsplicht van art. $149 \mathrm{Rv}$ in onderling verband worden bezien, kan art. $21 \mathrm{Rv}$ toch iets extra's brengen. ${ }^{56}$ Indien een partij immers voldoet aan haar verplichting volgend uit dit art. $21 \mathrm{Rv}$, is het mogelijk dat de wederpartij feiten te horen krijgt die zij nog niet kende. Het is vervolgens geenszins onmogelijk dat bepaalde bescheiden ten grondslag liggen aan die feiten waarna de wederpartij op voet van art. 843a Rv inzage in die bescheiden kan vorderen. Het woord feit van art. $21 \mathrm{Rv}$ mag niet te ruim uitgelegd worden. Indien een partij van mening is dat een huis bepaalde bouwtechnische gebreken vertoont, mag zij dit als feit presenteren, waarbij in elk geval niet op grond van art. $21 \mathrm{Rv}$ melding gemaakt moet worden van een deskundigenrapport dat als conclusie heeft dat het huis geen

53 Ook zonder HR 20 december 2002, NJ 2004, 4, Lightning Casino c.s. - de Nederlandse Antillen (zie over dit arrest uitvoeriger hoofdstuk 9 en par. 11.1), was dit al duidelijk.

54 Zie onder meer HR 30 januari 1998, NJ 1998, 459, Interforce-Rosier.

55 HR 6 oktober 2006, NJ 2006, 547 (Meijer-VOF Gbr. Cornelis).

56 Voor de volledigheid wijs ik ook nog op de artt. 111 lid 3 en 128 lid 5 Rv waarin onder meer is vermeld dat partijen ook de bewijsmiddelen waarover zij beschikken, dienen te vermelden. 
gebreken vertoont. De inhoud van en de conclusie in een dergelijk rapport zijn immers geen feiten. Van een dergelijk rapport dat in bezit van een partij is, kan de wederpartij wel zonder meer op grond van art. 843a $\mathrm{Rv}$ inzage vorderen.

Bijzonder bezien in het licht van de lijdelijkheid van de rechter is wel dat art. $22 \mathrm{Rv}$ tekstueel gezien aanmerkelijk minder beperkingen kent dan art. 843a Rv. Art. 22 Rv spreekt immers over 'bepaalde, op de zaak betrekking hebbende bescheiden'. Beperkingen als 'aangaande een rechtsbetrekking' of 'inzage, afschrift of uittreksel' die wel vermeld zijn in art. 843a Rv, zijn niet genoemd. Een nadere en duidelijk toelichting van deze verschillen ontbreekt in de wetsgeschiedenis en ik veronderstel dan ook dat de wetgever de samenhang tussen art. 21, 22 en 85 Rv enerzijds en art. 843a Rv anderzijds niet duidelijk voor ogen heeft gehad. Een sluitend en logisch systeem kan in elk geval niet uit de betreffende wetteksten en/of wetsgeschiedenis worden gehaald. Zonder meer is in ieder geval niet begrijpelijk dat de rechter in een civiel geding, nota bene ambtshalve, in elk geval op grond van de wet tot meer in staat is dan een procederende partij. Alleen al wat dat betreft is het wenselijk dat de wetgever alle 'informatie-artikelen' in het Wetboek van Burgerlijke Rechtsvordering eens systematisch op onder meer samenhang nader gaat beschouwen. Een dergelijke beschouwing valt niet binnen het bereik van mijn onderzoek, maar zijdelings komt een en ander in dit boek wel aan de orde. ${ }^{57}$

\subsection{De disclosure of discovery}

In hoofdstuk 1 is het arrest Tripels-Masson genoemd.$^{58}$ In die zaak wees de president van de rechtbank Den Haag toe de vordering tot afgifte van afschriften van bank- en girorekeningen en effectenportefeuille en overzichten van deelnames van Masson in verschillende vennootschappen en afgifte van de boekhoudkundige administratie van te Jersey en Liechtenstein gevestigde vennootschappen vanaf 1976 tot de dag van het uitbrengen van de dagvaarding. Het hof dacht hier anders over. Het overwoog dat met dit onderdeel van de vordering het afleggen van rekening en verantwoording van Masson tegenover Tripels wordt verlangd met betrekking tot de financiële handel en wandel van Masson in het verleden en heden. Dit kan Tripels echter niet verlangen omdat hiervoor geen wettelijke grondslag bestaat. De wet verplicht een debiteur als Masson immers niet tot een dergelijke openbaarmaking, terwijl partijen evenmin een overeenkomst van dien aard hebben gesloten en ten slotte heeft Masson geen beheer gevoerd. Ter zake de gevorderde

57 Eigenlijk kan niet worden volstaan met alleen maar een totale beschouwing van de betreffende artikelen in het Wetboek van Burgerlijke Rechtsvordering. Zo komt J.A.C. van Veersen in V\&O, jrg. 2006, p. 6-10 'Exhibitieplicht ex art. 3:15j BW; een ondergeschoven kindje' tot de conclusie dat de krachten van art. 3:15j BW en art. 843a Rv gebundeld kunnen worden en dat een gecombineerd beroep op beide artikelen de mogelijkheden tot het verkrijgen van inzage in documenten van een andere partij veelvuldig aanwezig doet zijn.

58 HR 20 september 1991, NJ 1992, 552, m.nt. J.B.M.V. 
overlegging van de boekhoudingen is het hof van oordeel dat zich de gevallen van art. 8 en art. $11 \mathrm{WvK}$ niet voordoen. De vordering wordt dus afgewezen. Volgens de Hoge Raad is een schuldenaar verplicht om een schuldeiser met een opeisbare vordering inlichtingen omtrent zijn inkomens- en vermogenspositie en omtrent voor verhaal vatbare goederen te verschaffen. ${ }^{59}$ Het strookt echter, aldus de Hoge Raad, niet met het wettelijk stelsel om aan deze verplichting een zodanig praktische uitwerking te geven dat een vordering als de onderhavige zou kunnen worden toegewezen. Er is immers slechts een beperkte kring van personen die van de schuldenaar rekening en verantwoording of overlegging van de boekhouding kan vergen. Een vordering tot afgifte van een zo groot aantal bescheiden is voorbehouden aan de curator in een faillissement.

De vordering van Tripels was te ruim en overschreed daarmee de grenzen van art. 843a Rv of, zoals AG Huydecoper bij een ander arrest concludeerde, dat het

'...wel als bezwaarlijk wordt aangemerkt (iets wat ik van harte onderschrijf), dat voorlopige instructiemaatregelen zo zouden worden toegepast, dat de verzoeker de ruimte krijgt om naar eigen goeddunken (allerlei hem welgevallige) informatie ten laste van zijn wederpartij te gaan verzamelen (uit de angelsaksische rechtspraktijk kennen wij hiervoor de beeldende uitdrukking "fishing expedition"). Waarom dat laatste niet behoort te worden toegestaan, kan als volgt worden toegelicht: zoiets zou zich niet verdragen met het naar Nederlands recht aanvaarde uitgangspunt, dat men niet "zomaar" toegang kan verlangen tot alle informatie waarover een ander beschikt ... ${ }^{60}$

De vordering van Tripels past wel in het stelsel van Engelse en Amerikaanse 'discovery-mogelijkheden'. ${ }^{61}$

59 De HR verwijst hierbij naar art. 475g Rv en de MvA bij de Invoeringswet boeken 3-6 Nieuw BW, eerste gedeelte bevattende wijziging van Rv, RO en Fw p. 11-12. Aldaar is vermeld dat een geëxecuteerde verplicht is tot medewerking aan de tenuitvoerlegging en dat deze plicht voortvloeit uit zijn verplichting om aan de executoriale titel te voldoen. Deze verplichting brengt in het licht van art. 6:2, lid 1 en art. 3:45 BW en art. $444 \mathrm{Rv}$ bijkomende verplichtingen mee, waaronder die om geen goederen aan een rechtmatig verhaal te onttrekken. De minister acht het echter niet wenselijk om hieromtrent een uitdrukkelijke regel op te nemen omdat het volgens hem niet goed mogelijk is om aan zo'n regel een redelijke praktische uitwerking te geven. Gelet op deze door de Hoge Raad geformuleerde verplichting is de afwijzing van Rb Amsterdam 7 september 2006 AY7784 van een vordering tot inzage van bepaalde financiële stukken omdat eiser inzicht in de verhaalsmogelijkheden van gedaagde wenste, onjuist. Beter is Rb Dordrecht 5 januari 2006, SES 2006, 104 overwegende dat '. . . niet op voorhand wordt uitgesloten dat art. 843a Rv mede strekt tot verkrijging van informatie om verhaalsmogelijkheden zeker te stellen ...'.

60 HR 24 december 2004, AR4980.

61 Zie ook J. Ekelmans, U.S. disclosure and discovery of documents, TvPP 2009, p. 179-187. Zie over de mogelijkheid om via de Amerikaanse rechter bewijsmateriaal te vergaren voor een in Nederland op te starten geding Tom Claassens, Discovery in de VS voor procedures in Nederland, Adv. Blad 2004, p. 754-760 en Simone Hoogeveen, Fishing expeditions versus exhibitieplicht in Adv. Blad 2005, p. 678-681. 
De woorden discovery en disclosure worden veel door elkaar gebruikt en dat niet alleen in Nederland. ${ }^{62}$ Mede gelet op het woordgebruik van de commissie Storme (zie Hoofdstuk 4), zal ik in het hierna volgende onder discovery verstaan 'het ontdekken van het bestaan van een document' of 'de zoektocht naar het al dan niet bestaan van een document'; disclosure is vervolgens het openbaren van de inhoud van het ontdekte document. ${ }^{63}$ In Engeland wordt overwegend het woord 'disclosure' gebruikt. Zie onder meer de tekst van de 'Civil Procedure Rules' die in Part 31, de 'disclosure and inspection of documents' een heel hoofdstuk met 23 artikelen besteedt aan de disclosure. In par. 31.2 wordt onder het hoofd 'Meaning of disclosure' vermeld 'A party discloses a document by stating that the document exists or has existed'.

Een zoektocht in de United States Code op de woorden 'discovery' en 'disclosure' geeft op beide woorden veel treffers. Uit die treffers kan voorzichtig de conclusie worden getrokken dat in de discoveryfase nog geen duidelijkheid bestaat over het bestaan van het document, terwijl de disclosurefase betrekking heeft op de vraag of de inhoud van een document, waarvan het bestaan zeker is, moet worden meegedeeld.

In Engeland en in de Verenigde Staten bestaat de zogenaamde 'pre-trial-discovery-fase'. Een partij kan in deze fase verlangen dat de andere partij hem kennis laat nemen van de inhoud van die stukken die van belang zijn voor de procedure. ${ }^{64}$ Een beperking zoals in art. 843a Rv wordt gegeven met de woorden 'rechtmatig belang' en 'bepaalde bescheiden' bestaat niet of nauwelijks. ${ }^{65}$ Het ontbreken van dergelijke beperkingen kan tot gevolg hebben dat de omvang van de procedure schrikbarend toeneemt, terwijl verder de gelegenheid tot het vissen naar stukken wordt geboden. Naar ons recht zou een en ander niet mogelijk zijn omdat de combinatie van de woorden 'rechtmatig belang' en 'bepaalde bescheiden' in de weg staat aan dergelijk vissen naar stukken. In de parlementaire geschiedenis bij art. $21 \mathrm{Rv}$ vroegen de leden van de VVD in de Eerste Kamer of dit artikel niet een uitvloeisel is van het Anglo-Amerikaanse systeem van disclosure waarbij eindeloos wordt geprocedeerd over de vraag welke stukken wel of niet overgelegd moeten worden. De minister is van mening dat art. $21 \mathrm{Rv}$ past binnen een op het continent reeds langer bestaande ontwikkeling die geen uitvloeisel is van het AngloAmerikaanse systeem. ${ }^{66}$ Ook Kremer en Rehbock zijn van mening dat de dis-

62 Zo staat in 'Een nieuwe balans' op p. 100-101, waar het Engelse rechte wordt weergegeven, 'Ook bij de 'disclosure of documents' (discovery) is nu steeds rechterlijke tussenkomst vereist, ...'.

63 Van der Korst, p. 109 schrijft dat disclosure wil zeggen de verklaring door een procespartij dat een document bestaat of heeft bestaan. Op p. 121 lijkt hij te vinden dat discovery een middel is om bewijs te verzamelen. K.J. Krzeminski, U.S. discovery for use in Dutch civil proceedings, TCR 2008, p. 47-55, schrijft op p. 47 'Discovery can be defined as the pre-trial phase in a lawsuit in which litigant parties can obtain information from the opposing party'.

64 Zie ook p. 26 e.v. van Haak en VerLoren van Themaat (redactie).

65 Zie ook Asser-Vranken Algemeen Deel 1995, nr. 19 e.v.

66 Parl. Gesch. burgerlijk procesrecht p. 152-153. 
covery, ook het 'pre-trial-deel' niet past in het Nederlandse systeem. ${ }^{67}$ Kort gezegd zijn zij van mening, mede aan de hand van het proefschrift van Van den Reek, dat discovery niet een op zichzelf staand figuur is maar een specifieke functie vervult binnen een groter geheel. Ten tweede lijkt het volgens hen in de praktijk tot weinig verschil te leiden omdat ook in Nederland een partij die voldoende zeker weet dat de andere partij informatie achterhoudt, de betreffende informatie weet te vergaren. Ten derde staan in beide systemen de partijen die onvoldoende zeker weten welke informatie de andere partij bezit, met lege handen. AG Spier lijkt evenmin een voorstander van 'full disclosure' te zijn. In een zeer uitvoerige conclusie wijst hij uitgebreid op de nadelen, vooral op de vismogelijkheden die volgens hem voorkomen moeten worden, en vindt hij een dergelijke ontwikkeling weinig aantrekkelijk ${ }^{68}$ Krans, ten slotte, schrijft in het kader van The Principles of Transnational Civil Procedure (hierna PTCP) dat het Engelse en Amerikaanse recht met hun disclosure (waar in deze Principles aansluiting bij is gezocht) ruimere mogelijkheden geven tot toegang tot informatie dan het Nederlandse recht. Dat gat is echter minder gapend omdat ook in de PTCP geen onvoorwaardelijke toegang wordt erkend, waar de discovery als limited wordt aangemerkt. De uitgangspunten van de PTCP (en, zo begrijp ik, de disclosure in Engeland en Amerika omdat de PTCP bij het recht in die landen kennelijk aansluiting heeft gezocht) en het Nederlandse recht verschillen, maar de uitkomsten hoeven minder ver uit elkaar te liggen. ${ }^{69}$

De jurisprudentie is niet altijd even terughoudend. Zo beslist de Rb Rotterdam op 3 oktober 1996 dat Center Parcs en S\&N aan ex-aandeelhouders van Center Parcs inzage moeten geven in de notulen van bepaalde vergaderingen van de raden van bestuur, zonder dat een beperking naar bijvoorbeeld onderwerp wordt gegeven. ${ }^{70}$

Waar de wereld steeds kleiner wordt, is het mogelijk dat een Nederlandse gedaagde onder de jurisdictie van de Amerikaanse of Engelse rechter valt. Deze gedaagde kan verplicht worden om op grond van Amerikaanse of Engelse regels documenten over te leggen. Indien een dergelijk verzoek bij wijze van rogatoire commissie vanuit bijvoorbeeld Engeland aan de Nederlandse rechter wordt gedaan, zal dit verzoek gegrond zijn op het Haags Bewijsverdrag. ${ }^{71}$ Aan een dergelijk verzoek aan een Nederlandse rechter kan slechts gehoor worden gegeven met inachtneming van de verklaring die Nederland op grond van art. 23 van dit bewijsverdrag heeft

67 M. Kremer en E. Rehbock, Discovery en andere wegen der (ge)lijdelijkheid, Ars Aequi 1998, p. 448-457.

68 AG Spier in zijn conclusie bij HR 22 februari 2008, BB5626.

69 H.B. Krans, De Principles of Transnational Civil procedure en het Nederlandse bewijsrecht, TCR 2009, p. 58-66. Het hier opgemerkte is vermeld op p. 61-62.

70 Zie J.W. Winter, 'Center Parcs, art. 843a Rv., discovery op z'n Hollands.', TVVS 1997, p. 55-56.

71 Verdrag van 18 maart 1970, Trb. 1979, 38. Zie hierover ook J.M. Hebly, Exhibitieplicht bij rogatoire commissie, TCR 2001, p. 1-3. 
afgelegd. Art. 23 van het Haags bewijsverdrag bepaalt dat een verdragsluitende staat kan verklaren dat hij geen uitvoering geeft aan een rogatoire commissie tot het houden van een procedure die in de staten waar de Common Law geldt bekend is als 'pre-trial discovery of documents'. Nederland heeft een dergelijke verklaring afgelegd. Die verklaring is te vinden in het Tractatenblad 1981, nr. $70 .{ }^{72}$ Uit de tekst van de verklaring in Trb. 1981, nr. 70 die Nederland heeft afgelegd, blijkt dat de wetgever in elk geval de hand wil houden aan het beginsel dat vissen naar stukken in Nederland niet geoorloofd is, waarbij het mij overigens niet duidelijk is geworden of de toenmalige Nederlandse wetgever voldoende inzicht had in de grenzen van de 'pre-trial discovery of documents' in de Common Law landen of dat er sprake was van koud water vrees. De bewoordingen van de tekst van deze verklaring zijn duidelijk en dus de wens van de wetgever ook. In elk geval in 1981 gaf de wetgever in dit kader dus een visverbod. De vraag rijst natuurlijk of bij de uitleg van art. 843a $\mathrm{Rv}$ in 2010 nog met deze wens rekening moet worden gehouden. Indien met die wens of dat inzicht uit 1981 rekening gehouden moet worden, betekent dit dat de grenzen van de uitleg van woorden als 'rechtmatig belang' en 'bepaalde bescheiden' getrokken moeten worden langs hetgeen is vermeld als verklaring van de regering in het Tractatenblad. Ik ben van mening dat dat standpunt niet houdbaar is. De rechtsontwikkeling op dit terrein is de afgelopen jaren zo snel gegaan, dat hetgeen een wetgever bijna 30 jaar geleden heeft opgemerkt, waarbij het opgemerkte (nog) niet in de sleutel van de waarheidsvinding werd gezet, niet meer een al te belangrijke rol mag spelen. Het is hierbij tevens van belang dat de wetgever van de versies van art. 843a Rv noch in 19871988 noch in 2001 heeft verwezen naar het in het Tractatenblad 1981, nr. 70 gemaakte voorbehoud. Ik denk dus dat bij de uitleg van art. 843a Rv in 2010 niet al te zeer meer naar dit op het Haags Bewijsverdrag gegronde voorbehoud moet

72 Les Pays-Bas n'exécutent pas les commissions rogatoires qui ont pour objet une procédure connue dans les Etats du Common law sous le nom de «pre-trial discovery of documents ». Par commissions rogatoires qui ont pour objet une procédure, connue dans les Etats du Common law sous le nom de «pre-trial discovery of documents » lesquelles les Pays-Bas n'exécutent pas, le Gouvernement ... entend toute commission rogatoire exigeant d'une personne : $\mathrm{d}^{\prime}$ indiquer quels documents pertinents pour la procédure à laquelle se rapporte la commission rogatoire sont ou ont été en sa possession, garde ou pouvoir ; oude produire tous les documents autres que les documents particuliers specifiés dans la commission rogatoire comme étant des documents qui, pour le tribunal saisi, sont ou vraisemblablement sont en sa possession, garde ou pouvoir. 
worden gekeken. ${ }^{73}$ Het wordt misschien zelfs wel tijd om dit voorbehoud te schrappen.

Voor de volledigheid wijs ik nog op HR 11 maart 1994, NJ 1995, 3. De Hoge Raad parafraseerde hier het door Nederland gemaakte voorbehoud als volgt:

'Voor wat betreft het opgeven en overleggen van documenten die iemand onder zich heeft, is daarbij mede van belang het voorbehoud dat Nederland op de voet van art. 23 van het Verdrag heeft gemaakt en dat er -kort gezegd- op neerkomt dat niet gevraagd kan worden om een opgave of overlegging van documenten ten einde op grondslag daarvan een procedure te beginnen. ${ }^{, 74}$

73 Zie verder Van der Korst, hoofdstuk 8, Grensoverschrijdende bewijsverkrijging. Zie in dit verband ook hof Amsterdam 25 november 2008, NJF 2009, 31 waar deze overweegt dat het van de USA afkomstige rechtshulpverzoek is gedaan in het kader van de 'discovery' fase in de procedure in de USA tussen Net2Phone en Ebay terwijl Nederland betreffende de toepasselijkheid van het Bewijsverdrag in art. 23 een voorbehoud heeft gemaakt inhoudende dat geen uitvoering zal worden gegeven aan rogatoire commissies tot het houden van een procedure welke in de staat waarin de Common Law geldt, bekend is als de Pre-Trial Discovery of Documents. Het rechtshulpverzoek wordt vervolgens afgewezen. In mijn AA-cahier nam ik aanmerkelijk minder afstand van het voorbehoud in het Trb. 1981, nr. 70. Er is wat dat betreft sprake van voortschrijdend inzicht.

74 Zie ook D.M. Buné, De naleving van Europese privacy regels bij grensoverschrijdende civiele procedures, Bb 2009, afl. 11, 25. In het artikel is geen verwijzing te vinden naar het in par. 3.3 besproken voorbehoud dat Nederland heeft gemaakt terzake pre-trial discovery. 



\section{$4 \quad$ Het inzagerecht in het kader van de Europese Unie}

\subsection{Het rapport van de Commissie Storme}

In een interview vertelt Marcel L.L.V. Storme ${ }^{1}$ dat gezegd kan worden dat hij het initiatief heeft genomen tot het doen van een studie naar de harmonisering van procesrecht in Europa. Die studie is verricht door de Commissie Storme, en het resultaat is neergelegd in het in 1994 tot stand gekomen Rapport Storme. ${ }^{2}$ In dat interview vertelt Storme dat het idee ontstond in Milaan in 1986 waar hij tijdens een gastcollege heeft gepleit voor eenmaking van het procesrecht in Europa. Met beperkte fondsen van de EG is hij vervolgens met de naar hem genoemde commissie aan het werk gegaan. Vooral wegens geldgebrek heeft de commissie zich beperkt tot 15 onderwerpen en één daarvan was 'la découverte des documents-discovery'.

In de EG-landen, aldus hoofdstuk vier van het rapport, zijn grote verschillen wat de bepalingen omtrent inzage betreft. Dit geldt vooral voor gegevens ${ }^{4}$ die in bezit zijn van procespartij A, maar waarop procespartij A in het geding geen beroep doet. In de Common Law landen is er voor die gevallen een algemene verplichting om het bestaan van alle mogelijk relevante gegevens te openbaren. In de andere landen kan een partij wel inzage afdwingen, maar voorafgaand aan dat afdwingen staat de bekendheid met het bestaan van die gegevens en niet elke partij weet af van het bestaan van bepaalde gegevens. Dit verschil in regelgeving heeft tot gevolg dat niet elke procespartij in de EU (toen dus nog EG) dezelfde rechten en mogelijk-

1 Prominenten kijken om. Achttien rechtsgeleerden uit de Lage Landen over leven, werk en recht. Bijdragen tot de rechtsgeschiedenis der Nederlanden, 2004, C.H. van Rhee en L. Coenraad, Jurist zonder grenzen: interview met M.L.L.V. Storme, p. 144-167.

2 M. Storme (ed), Rapprochement du Droit Judiciaire de l'Union européenne/Approximation of Judiciary Law in the European Union, Kluwer Rechtswetenschappen België, Martinus Nijhoff Publishers, Dordrecht 1994. In het in de vorige noot genoemde interview vertelt Storme dat elk commissielid minimaal 1 onderwerp kreeg waarover hij een rechtsvergelijkende studie moest schrijven en een concepttekst van wetsartikelen. Gezamenlijk werd dan een toelichting bij de wetsartikelen geschreven.

3 Enkele andere onderwerpen waren 'respect voor het partijdebat', 'de wijze waarop getuigen gedwongen kunnen worden te verschijnen en te verklaren', 'de wijze van registratie van de getuigenverklaring', 'de kosten van de civiele procedure', 'voorlopige voorzieningen', 'het bevel tot betaling' en 'de dwangsom'.

4 Zoals ik 'document(s)' in deze tijd maar vertaal. 
heden heeft in elk land. ${ }^{5}$ De commissie komt dan ook tot de conclusie dat harmonisering van dit onderwerp gewenst is. De meest geschikte wijze van harmonisering in het kader van het volledig informeren van de rechter volgens de commissie

'...would be the one which requires as substantial a disclosure or communication of documents as is reasonably possible. If this proposal is included in any future Directive, only those documents under a party's control which, according to national law, are protected against disclosure or communication will not be open to inspection by an opposing party. ${ }^{6}$

Na een lange considerans op de pagina's 172-173, komt de commissie met het volgende tekstvoorstel voor een exhibitieartikel. ${ }^{7}$

4.1 Lists of documents

4.1.1 It shall be the obligation of every party to an action to serve on all other parties a list of the documents which are in his possession, custody or power, which relate to any question in issue in the action and which have not previously been communicated to those parties:

a) where a general rule of national law so requires or

b) where the court, after all parties have been given the opportunity to be heard, so orders.

4.1.2 The list of documents shall indicate which, if any, of the documents the party objects to disclose or communicate on the ground of privilege against disclosure or communication.

4.1.3 The grounds of privilege against disclosure or communication shall be determinated by national law.

4.2 Communication and inspection of documents

4.2.1 Subject to 4.2.2, a party who has served a list of documents in accordance with article 4.1 shall communicate to or allow all other parties to inspect and to take copies of all or any of the document listed other than those in respect of which a claim of privilege against disclosure or communication has been made

4.2.2 Where the court is satisfied, on the application of a party and after all parties have been given the opportunity to be heard, that the communication or the inspection and copying of a document contained in a list of documents would cause undue harm to the party making the list or to any other person, it may relieve that party of the obligation contained in 4.2.1 in respect of the document.

5 De commissie komt dus tot een andere conclusie dan de hiervoor in par. 3.3 door Kremer en Rehbock en Krans getrokken conclusies.

6 Rapprochement DJ p. 97. Dit rapport bevat teksten in het Frans en in het Engels waarbij niet alle teksten in twee talen zijn verschenen. Onder andere de rechtsvergelijkende studie 'la découverte des documents-discovery' is enkel in het Engels. Waarschuwing: de inhoudsopgave in het Rapprochement DJ op p. 223 e.v. vermeldt foute paginaverwijzingen.

7 In de Rapprochement DJ wordt de disclosure in hoofdstuk 4 besproken. Om die reden is ook het exhibitie-artikel als vier genummerd. 
4.3 Order for disclosure or communication

Provided that no order shall be made under this article unless the court is satisfied, after all parties have been given the opportunity to be heard, that such order is necessary for the just determination of the action, the court may order a party to disclose or communicate:

a) document in respect of which an unjustified claim of privilege against disclosure or communication had been made

b) a particular document which has not been included in any list of documents served by that party and which is shown both to be in the possession, custody or power of the party and to relate to a question in issue in the action.

4.4 Consequences of failure to disclose or communicate

A document which has not been disclosed or communicated to all parties to the action in advance of any proof-taking procedure in or trial of (or? JRS) the action, shall not be taken into account by the court in the formation of its decision, unless, decision made after all parties have been given the opportunity to be heard, the court orders otherwise.

4.5 Third parties

4.5.1 Subject to 4.5.2, the court may, upon the application of a party, order a person not a party to the action to disclose or communicate to the parties any document which he has in his possession, custody or power and which relates to a question in issue in the action.

4.5.2 No order shall be made under 4.5.1, unless:

a) the court is satisfied, after all parties and the person against whom the order is sought have been given the opportunity to be heard, that:

i) the document to which the application relates is in the possession, custody or power of the person against whom the order is sought;

ii) the order is necessary to the just determination of the action; and

iii) the order does not extend to any document which would be privileged form (from? JRS) disclosure or communication if it were in the custody(,? JRS) power or control of a party to the action; and

b) the party applying for the order undertakes to indemnify the person against whom the order is sought in respect of all costs reasonably incurred by him. ${ }^{8}$

Uit de toelichting op de artikelen in het rapport ${ }^{9}$ haal ik het volgende.

Art. 4.1.1 heeft twee doelstellingen. Ten eerste harmonisatie van regelgeving: een procespartij moet in elke lidstaat dezelfde mogelijkheden hebben om gegevens in te zien. Ten tweede maakt dit artikel het mogelijk dat een partij ook die gegevens van de tegenpartij in kan zien die de tegenpartij niet in het geding wil brengen, maar die wel relevant zijn voor het betreffende dispuut. Het is niet de bedoeling dat alle gegevens terstond in het geding worden gebracht. Een partij moet allereerst

8 Zie bijlage II van dit boek voor de Franse tekst van het voorstel.

9 P. 128 tot en met 135 . 
een lijst maken van gegevens waarop alle relevante gegevens worden genoemd, waaruit de andere partij een keus kan maken. Dit voorkomt dat de wederpartij ook afschriften ontvangt van stukken die zij niet wenst te hebben. Een overvloed aan stukken kan immers ook de belangen van de ontvanger frustreren omdat het hem onmogelijk is om alles te lezen.

Elke lidstaat mag volgens sub a van art. 4.1.1 een algemene, voor alle verschillende zaken geldende regel maken, maar elk land moet ook de mogelijkheid hebben om bepaalde onderwerpen van de algemene regel uit te zonderen. In dat geval dient de rechter per zaak te beslissen of een lijst van gegevens moet worden verstrekt (sub b van art. 4.1.1).

Met de woorden 'possession, custody or power' wordt een zo breed mogelijk spectrum bedoeld. Het gaat niet alleen om gegevens in bezit van de wederpartij, maar ook om gegevens over welke zij rechtmatig de beschikking kan krijgen. ${ }^{10}$

Art. 4.1.2: de lijst met gegevens moet compleet zijn. Dit betekent dat ook vermeld moet worden dat er gegevens zijn die afkomstig zijn van geheimhouders. Indien immers niet vermeld zou hoeven worden dat er gegevens van geheimhouders of verschoningsgerechtigden bestaan, kan geen procedure worden gestart om een antwoord te krijgen op de vraag of het betreffende gegeven ook geheim mag worden gehouden. ${ }^{11}$

Met het woord 'disclose' bedoelt de commissie de wijze waarop het gegeven beschikbaar wordt gesteld, bijvoorbeeld inzage van het origineel of het verstrekken van een kopie. Met 'communicate' wordt het feitelijk beschikbaar stellen bedoeld.

De commissie acht het zeer wenselijk, maar desondanks onhaalbaar om de regels omtrent verschoningsrecht en geheimhoudingsplicht te harmoniseren. Elk land mag wat dit onderwerp betreft (nog) zijn eigen regels handhaven (of nog scheppen).

Art. 4.2.1: lidstaten hebben de bevoegdheid om een procespartij te verplichten om alle gegevens feitelijk beschikbaar te stellen. De commissie vindt een dergelijke ruime regeling overbodig en te veel van het goede. Het is minder verspillend om een wederpartij te laten bepalen welke gegevens zij wenst in te zien en welke niet. De feitelijke uitvoering van één en ander zal volgens de commissie normaliter plaats vinden in het kantoor van de gemachtigde van de partij die de lijst heeft gemaakt. Het is aan elke staat zelf om de wijze waarop dit plaatsvindt, te bepalen waarbij de betreffende staat ook redelijke termijnen mag stellen om de betreffende rechten uit te oefenen.

Art. 4.2.2: het recht op inzage mag niet worden uitgeoefend indien dit de gegevens verstrekkende partij onevenredig nadeel toebrengt. ${ }^{12}$ De commissie

10 Ik gebruik hier de woorden zoals vermeld in art. 155a lid 1 van de schets van de Adviescommissie voor het Burgerlijk Procesrecht (ABP).

11 Dit lijkt een inbreuk te zijn op de wijze waarop in Nederland inhoud wordt gegeven aan de geheimhoudingsplicht van bijvoorbeeld een advocaat of arts. Zij hoeven immers zelfs niet te vertellen of iemand 'bij hen aan de deur is geweest'. Dat lijken zij nu wel te moeten vertellen.

12 De commissie spreekt over 'excessive harm'. 
verwacht dat deze beperking slechts heel zelden zal worden toegepast. Het verschoningsrecht en de geheimhoudingsplicht vallen niet onder het begrip 'onevenredig nadeel'. Beiden zijn immers al in art. 4.1.2 geregeld.

In art. 4.3 wordt een regeling gegeven om te voorkomen dat door een onterecht beroep op een geheimhoudingsplicht/verschoningsrecht een document niet ter inzage wordt gelegd. Tevens wordt de situatie geregeld indien een gegeven ten onrechte niet op de lijst is vermeld. Bij een en ander behoort een belangenafweging plaats te vinden. Een gegeven dat formeel niet onder een verschoningsrecht of geheimhoudingsplicht valt maar waarvan de inhoud een partij zeer in verlegenheid brengt, hoeft niet ter inzage te worden gegeven. Bij de vraag of er recht op inzage is, dient rekening gehouden te worden met alle omstandigheden van het geval en het belang van de goede rechtspleging.

Art. 4.4: dit 'uitsluitingsartikel' is alleen maar duidelijk bij een goed begrip van het systeem. Voorop staat dus de door alle partijen te verstrekken lijst. Die lijst behoort compleet te zijn en uit die lijst moet elke partij tijdig een keuze maken welke gegevens zij wenst in te zien. Nadat deze keuze is gemaakt, valt de bijl: gegevens die op de lijst stonden maar waarvan geen inzage is gevraagd, worden niet meer in de procedure toegelaten. De rechter kan, gehoord partijen, toch nog anders beslissen.

Art. 4.5.1: er zijn landen, aldus de commissie, die in verschillende variaties een regeling kennen waarbij niet in de procedure betrokken derden verplicht kunnen worden om inzage in bepaalde gegevens te verstrekken. In het kader van de harmonisatie van procesregels acht de commissie het noodzakelijk dat een dergelijke regeling in de onderhavige regeling wordt opgenomen. De betreffende regeling mag niet ambtshalve door de rechter worden toegepast en dient omzichtig te worden gehanteerd waarbij de rechter een eigen toetsingsverantwoordelijkheid heeft, tenzij de derde zonder voorbehoud instemt met inzage. Degene die stelt dat de derde een gegeven in bezit heeft dient, bij ontkenning van die stelling door de derde, dit te bewijzen.

De in art. 4.5.2 aanhef, onder a sub ii verwoorde voorwaarde is strikt. Het moet niet betreffen een gegeven dat 'bruikbaar' is; de inzage in het in bezit van de derde zijnde gegeven moet noodzakelijk zijn voor de uitslag van het geschil. De rechter dient hier onafhankelijk en volledig te toetsen.

De verplichting onder sub b van dit artikel acht de commissie vanzelfsprekend. Het is soms noodzakelijk om een derde in het geschil te betrekken. Soms is dit vervelend voor die derde en soms zelfs meer dan vervelend. Er is echter geen enkele reden om de derde zelf enige kosten te laten dragen. Alle door die derde redelijk gemaakte kosten moeten dan ook meteen worden vergoed door de partij die de derde in het geschil heeft betrokken. Aan het eind van de procedure dient de rechter te bepalen ten laste van welke procespartij die kosten uiteindelijk komen. 


\subsection{Richtlijn nr. 2004/48/EG betreffende de handhaving van intellectuele eigendomsrechten}

Zoals hiervoor in par. 2.3 is vermeld, is het inzagerecht op specifieke terreinen onderwerp van, inmiddels, EU-recht. Zo diende de Commissie van de Europese Gemeenschappen (hierna de Europese Commissie) op 15 oktober 1998 een Groenboek Bestrijding van namaak en piraterij in de interne markt in. Namaak en piraterij moeten volgens de Europese Commissie worden bestreden omdat zij tot verlies van vertrouwen in de interne markt leiden, tot een daling van het investeringsniveau en afbreuk doen aan de bescherming van de consument en de openbare veiligheid verminderen. Het Groenboek geeft een ruime betekenis aan de woorden namaak en piraterij en vermeldt

'... dat ze betrekking hebben op alle producten, werkwijzen en diensten die het voorwerp of het resultaat zijn van een inbreuk op een intellectueel eigendomsrecht, d.w.z. een industrieel eigendomsrecht (fabrieks- of handelsmerk, tekening of model van nijverheid, octrooi, gebruiksmodel, geografische aanduiding), een auteursrecht of een naburig recht (recht van uitvoerende kunstenaars, recht van producenten van fonogrammen, recht van producenten van de eerste vastleggingen van films, recht van omroeporganisaties), of het recht sui generis van de fabrikant van de databank.'

De bestrijding van dit fenomeen noemt de Europese Commissie van groot belang. Zij constateert dat civielrechtelijke handhaving niet in alle EU-landen gelijk is en dat voorlopige maatregelen, bijvoorbeeld om bewijsstukken veilig te stellen, geboden zijn. Het verzamelen en bewaren van bewijs is een belangrijk element in de strijd tegen namaak en piraterij en een regeling van beslag op namaakproducten noemt de Europese Commissie een doeltreffend middel om bewijzen te verzamelen en te bewaren. ${ }^{13}$

Een andere mogelijke maatregel die doeltreffend kan zijn in de strijd tegen namaak is het recht op informatie. Die, in de TRIPS-overeenkomst facultatieve, ${ }^{14}$ maatregel is onafhankelijk van de schadevordering en is gericht tegen elke inbreukmaker die op straffe van een sanctie kan worden gelast inlichtingen te verstrekken over de herkomst van de inbreukmakende goederen, de distributiekanalen en de identiteit van de bij de productie en de distributie van de goederen betrokken derden. Dit recht op informatie moet, aldus de Europese Commissie, wel gepaard

13 De EG-Commissie noemt met name de in het Britse recht geldende 'Anton Piller Order' (na de invoering van de Civil Procedure Act 1997 inmiddels eigenlijk genaamd 'Search Order') en de Franse regeling 'procédure de saisie-contrefaçon' zeer doeltreffend.

14 Art. 43 van deze 'Agreement on Trade Related Aspects of Intellectual Property Rights' bepaalt in lid 1, kort gezegd, dat de rechterlijke autoriteiten de bevoegdheid hebben om, als een partij heeft gewezen op bewijsmateriaal dat zich in de macht van de wederpartij bevindt, die wederpartij te gelasten dit materiaal over te leggen, eventueel met inachtneming van voorwaarden die de bescherming van vertrouwelijke informatie verzekeren. 
gaan met doeltreffende beschermingsmaatregelen teneinde de vertrouwelijkheid van de verstrekte gegevens te verzekeren. ${ }^{15}$ Op grond hiervan stelt de Europese Commissie aan de EG-leden onder meer de vraag of de verplichting van de inbreukmaker om bepaalde gegevens te verstrekken (recht op informatie) een dienstige maatregel is in de strijd tegen de namaak en de piraterij.

Op 29 april 2004 wordt vervolgens Richtlijn nr. 2004/48/EG uitgevaardigd. De nummers 20 en 21 van de considerans stellen dat het bewijs een uiterst belangrijk element is voor de vaststelling van inbreuken op intellectuele eigendomsrechten en dat er dus voor moet worden gezorgd dat effectieve middelen voor het overleggen, verkrijgen en beschermen van bewijsmateriaal beschikbaar zijn. Bij deze procedures moeten de rechten van de verdediging worden geëerbiedigd en moeten de noodzakelijke waarborgen worden geboden, waaronder de bescherming van vertrouwelijke informatie. In het geval van inbreuken die op commerciële schaal plaatsvinden, is het voorts van belang dat de rechter desnoods inzage kan gelasten van bancaire, financiële of commerciële documenten waarover de inbreukmaker beschikt. In alle lidstaten moeten maatregelen beschikbaar zijn om een hoog niveau van bescherming mogelijk te maken. Dit geldt voor het recht op informatie waardoor waardevolle gegevens kunnen worden verkregen over de herkomst van de inbreukmakende goederen of diensten, de distributiekanalen en de identiteit van de bij de inbreuk betrokken derden. Na deze considerans volgen 22 artikelen.

Van belang voor het recht op inzage zijn in de tweede afdeling genaamd Bewijsmateriaal, art. 6 en art. 7, lid 1 en in de derde afdeling genaamd Recht op informatie art. 8, de leden 1 en $2 .{ }^{16}$ De teksten van deze artikelen, voor zover van belang, luiden als volgt.

Art. 6 lid 1. De lidstaten dragen er zorg voor dat de bevoegde rechterlijke instanties op verzoek van de partij die redelijkerwijs beschikbaar bewijsmateriaal heeft overgelegd dat voldoende is om haar vorderingen te onderbouwen, en voor de staving van haar vorderingen bewijsmateriaal heeft genoemd dat zich in de macht van de wederpartij bevindt, overlegging van dit bewijsmateriaal door de wederpartij kunnen gelasten, behoudens bescherming van vertrouwelijke informatie. Voor de toepassing van dit lid

15 De EG-Commissie schrijft dat dit recht op informatie onder andere met succes is ingevoerd in de Beneluxmerkenwet. Ik neem aan dat art. 13 bis lid 5 van die wet wordt bedoeld inhoudende 'De rechter kan, op vordering van de merkhouder, degene die inbreuk op diens recht heeft gemaakt, bevelen al hetgeen hem bekend is omtrent de herkomst van de zaken, waarmee die inbreuk is gepleegd, aan de merkhouder mee te delen en alle daarop betrekking hebbende gegevens aan deze te verstrekken'. Er wordt niet verwezen naar de Rapprochement DJ. In een ander verband vertelde Storme in het in het begin van par. 4.1 genoemde interview dat het in die tijd nog ondenkbaar was om te denken en schrijven over harmonisatie van procesrecht.

16 Voor de volledigheid vermeld ik nog dat art. 9, lid 3 bepaalt dat de rechterlijke instanties voorof bij het opleggen van maatregelen tegen de vermeende inbreukmaker de bevoegdheid hebben om van de eiser te verlangen dat hij redelijkerwijs beschikbaar bewijsmateriaal overlegt opdat zij zich er met voldoende mate van zekerheid van kunnen vergewissen dat de eiser de houder is van het recht en dat er inbreuk op zijn recht wordt gemaakt of dreigt te worden gemaakt. 
kunnen de lidstaten bepalen dat een redelijk monster van een belangrijk aantal exemplaren van een werk of enig ander beschermd voorwerp door de bevoegde rechterlijke instanties als aanvaardbaar bewijsmateriaal moet worden beschouwd.

Lid 2. De lidstaten treffen de noodzakelijke maatregelen teneinde de bevoegde rechterlijke instanties onder dezelfde omstandigheden in staat te stellen, in geval van inbreuk op commerciële schaal, op verzoek van een partij in voorkomend geval overlegging te kunnen gelasten van bancaire, financiële of handelsdocumenten die zich onder de macht van de tegenpartij bevinden, mits de bescherming van vertrouwelijke informatie wordt gewaarborgd.

Art. 7 Maatregelen ter bescherming van bewijsmateriaal

Lid 1. De lidstaten dragen er zorg voor dat de bevoegde rechterlijke instanties, reeds voordat een bodemprocedure is begonnen, op verzoek van een partij die redelijkerwijs beschikbaar bewijsmateriaal heeft overgelegd tot staving van haar beweringen dat er inbreuk op haar intellectuele-eigendomsrechten is gemaakt of zal worden gemaakt, onmiddellijk afdoende voorlopige maatregelen kunnen gelasten om het relevante bewijsmateriaal in verband met de vermeende inbreuk te beschermen, mits de bescherming van vertrouwelijke informatie wordt gewaarborgd. Tot deze maatregelen kunnen behoren de gedetailleerde beschrijving, met of zonder monsterneming, dan wel de fysieke inbeslagneming van de litigieuze goederen en, in voorkomend geval, de bij de productie en/of distributie daarvan gebruikte materialen en werktuigen en de desbetreffende documenten. Deze maatregelen worden genomen, zo nodig zonder dat de wederpartij wordt gehoord, met name indien het aannemelijk is dat uitstel de rechthebbende onherstelbare schade zal berokkenen, of indien er een aantoonbaar gevaar voor vernietiging van bewijsmateriaal bestaat.

Art. 8 Recht op informatie

Lid 1. De lidstaten dragen er zorg voor dat de bevoegde rechterlijke instanties, tijdens een gerechtelijke procedure wegens inbreuk op een intellectuele-eigendomsrecht, op gerechtvaardigd en redelijk verzoek van de eiser kunnen gelasten dat informatie over de herkomst en de distributiekanalen van de goederen of diensten die inbreuk maken op een intellectuele-eigendomsrecht, wordt verstrekt door de inbreukmaker en/of door een andere persoon die:

a) de inbreukmakende goederen op commerciële schaal in zijn bezit blijkt te hebben;

b) de inbreukmakende diensten op commerciële schaal blijkt te gebruiken;

c) op commerciële schaal diensten bij inbreukmakende handelingen worden gebruikt, blijkt te verlenen;

of:

d) door een onder a), b) of c) bedoelde persoon is aangewezen als zijnde betrokken bij de productie, de fabricage of de distributie van deze goederen of bij het verlenen van deze diensten.

Lid 2. De in lid 1 bedoelde informatie omvat naargelang passend is:

a) de naam en het adres van de producenten, fabrikanten, distributeurs, leveranciers en andere eerdere bezitters van de goederen of diensten, alsmede van de beoogde grooten kleinhandelaren;

b) inlichtingen over de geproduceerde, gefabriceerde, geleverde, ontvangen of bestelde hoeveelheden, alsmede over de voor de desbetreffende goederen of diensten verkregen prijs. 
Eerder is in par. 2.3 vermeld op welke wijze deze Richtlijn in het Wetboek van Burgerlijke Rechtsvordering is verwerkt via wetsvoorstel $30392 .{ }^{17} \mathrm{Ik}$ volsta hier met verwijzing naar die paragraaf.

\subsection{Schadevorderingen wegens schending van de communautaire anti- trustregels}

In par. 2.3 is het Groenboek Schadevorderingen wegens schending van de communautaire antitrustregels dat de Europese Commissie op 19 december 2005 heeft ingediend, al aan de orde geweest. Ik voeg daar nog het volgende aan toe.

De Europese Commissie stelt in het Groenboek voorop dat een felle concurrentie op een open interne markt de beste garantie biedt voor een toename van de productiviteit. Handhaving van het mededingingsrecht is dan ook een essentieel onderdeel van de 'strategie van Lissabon', gericht op de groei van de economie en de schepping van arbeidsplaatsen. Een soepelere regeling inzake schadevorderingen wegens schending van de antitrustwetgeving, zal tot gevolg hebben dat consumenten en ondernemingen die schade hebben geleden als gevolg van een inbreuk op de antitrustregels gemakkelijker schadevergoeding van de inbreukmaker kunnen krijgen, maar zal ook leiden tot betere handhaving van het mededingingsrecht.

De Europese Commissie stelt voorop dat schadevorderingen in antitrustzaken meestal een uitgebreid feitenonderzoek vergen. Een specifiek probleem bij dit soort geschillen is dat het relevante bewijsmateriaal vaak niet gemakkelijk verkrijgbaar is en zich meestal bevindt bij de partij die zich schuldig heeft gemaakt aan mededingingsverstorende gedragingen. Toegang van verzoekers tot dit bewijsmateriaal is van essentieel belang om op doeltreffende wijze schadevorderingen te kunnen instellen. De Europese Commissie wil daarom nagaan of partijen verplicht moeten worden om documenten te verstrekken of om op een andere wijze toegang te verlenen tot bewijsmateriaal.

Voor de reactie van de Nederlandse regering op 28 april 2006 op dit Groenboek volsta ik met verwijzing naar par. 2.3 hiervoor.

Het Groenboek is, op verzoek van het Europees Parlement, gevolgd door het op 2 april 2008 door de Europese Commissie ingediende Witboek betreffende schadevergoedingsacties wegens schending van de communautaire mededingingsregels. ${ }^{18}$ De Europese Commissie benadrukt nog stelliger dat schadevergoedings-

17 Wetsvoorstel 30392, Aanpassing van het Wetboek van Burgerlijke Rechtsvordering, de Auteurswet 1912, de Wet op de naburige rechten, de Databankwet, de Handelsnaamwet, de Wet van 28 oktober 1987, houdende regelen inzake de bescherming van oorspronkelijke topografieën van halfgeleiderproducten (Stb. 484), de Zaaizaad- en plantgoedwet 2005 en de Landbouwkwaliteitswet ter uitvoering van Richtlijn nr. 2004/48/EG van het Europees Parlement en de Raad van 29 april 2004 betreffende de handhaving van intellectuele eigendomsrechten (PbEG L 195).

18 De woorden 'schadevorderingen' en 'antitrustregels' in het Groenboek zijn dus vervangen door de woorden 'schadevergoedingsacties' en 'mededingingsregels'. 
acties wegens schending van de mededingingsregels een aantal specifieke kenmerken hebben waarmee onvoldoende rekening wordt gehouden in de klassieke regels inzake civiele aansprakelijkheid. Die kenmerken zijn onder meer de bijzonder complexe feitelijke en economische analyse die moet worden uitgevoerd, het feit dat cruciaal bewijsmateriaal vaak niet toegankelijk is en door gedaagden wordt achtergehouden en de vaak ongunstige kosten/batenverhouding voor eisers.

Feiten spelen een erg belangrijke rol, terwijl veel van het cruciale bewijsmateriaal dat voor de bewijsvoering in een zaak van schadevergoedingsacties wegens schending van mededingingsregels nodig is, wordt achtergehouden en vaak in handen is van gedaagde of derden. De Europese Commissie noemt dit een structurele informatieasymmetrie die moet worden ondervangen, waarbij de negatieve effecten van te brede en belastende openbaarmakingsverplichtingen vermeden moeten worden. De Europese Commissie wenst een minimale openbaarmaking tussen de procespartijen en wil hierbij voortbouwen op de benadering die is gehanteerd in Richtlijn 2004/48EG. De Europese Commissie stelt voor dat de nationale rechter in specifieke omstandigheden de bevoegdheid moet krijgen om procespartijen of derden te bevelen welomschreven categorieën van relevant bewijsmateriaal openbaar te maken. Bij de toekenning van deze bevoegdheid hebben in elk geval de volgende voorwaarden te gelden:

1. eiser moet alle feiten en bewijsmiddelen hebben gepresenteerd die redelijkerwijs voor hem beschikbaar zijn;

2. eiser moet de rechter genoegzaam hebben aangetoond dat hij niet in staat is op een andere wijze het verlangde bewijsmateriaal over te leggen;

3. eiser moet voldoende hebben angegeven welke precieze categorieën bewijsmateriaal openbaar moeten worden gemaakt;

4. eiser moet de rechter genoegzaam overtuigd hebben dat de beoogde openbaarmaking zowel relevant is voor de zaak als noodzakelijk en evenredig.

De rechter dient verder de bevoegdheid te krijgen om, teneinde te voorkomen dat relevant bewijsmateriaal wordt vernietigd, afdoende sancties met een afschrikwekkende werking op te leggen. Zo zou het de rechter mogelijk gemaakt moeten worden om uit een dergelijke vernietiging van bewijsmateriaal voor de vernietiger van bewijsmateriaal ongunstige conclusies te trekken in de civiele schadeprocedure. ${ }^{19}$

\subsection{Conclusies uit de EU-regels en EU-wensen}

De instituten van de EU, vooral de Europese Commissie die immers de meeste voorstellen doet, bewegen behoedzaam bij de uniformering van regelgeving, zeker

19 Zie verder W.A.J. van Lierop en E.H. Pijnacker Hordijk, Privaatrechtelijke aspecten van het mededingingsrecht, Preadvies 2007 uitgebracht voor de Vereniging voor Burgerlijk Recht, Kluwer 2007. 
indien het betreft initiatieven waarbij ook regels van rechtsvordering in beeld komen. Politiek gezien is dat nog te begrijpen, maar waarom veel nationaal georiënteerde juristen zo aan eigen regels vasthouden alsof hetgeen zelf is verzonnen beter is dan hetgeen in andere ons omringende landen als wetgeving is verzonnen, blijft voor mij niet goed te begrijpen. Het niet bereid zijn om eigen wetgeving in te ruilen voor wetgeving met een grotere regionale reikwijdte doet denken aan hetgeen Drion ooit eens heeft geschreven over de tegenstanders van de invoering van het NBW. Hij zag tegenstanders van die invoering als A. Pitlo, die het oude BW wilde handhaven, in bed stappen met het oud BW als vertrouwd, afgesabbeld, kaalgeplukt en onooglijk teddybeertje tegen zich aan geknuffeld. Drion vond dat hartverwarmend, maar geen reden om de vooruitgang, het Nieuwe BW, tegen te houden. ${ }^{20}$ Ik zou denken dat die gedachte van Drion ook dient post te vatten in EU-verband. Enge nationale regels hebben hun tijd gehad en vormen nu barrières die zulke problemen opwerpen dat eigen, nationaal belang daaraan moet worden opgeofferd. Het is even wennen, maar initiatieven als die van de commissie Storme zijn niet genoeg te prijzen en behoren niet in een bureaulade te verdwijnen. Voorzichtige en verdedigende overwegingen in een considerans als

'De verschillen tussen de regelingen van de lidstaten inzake de middelen tot handhaving van intellectuele eigendomsrechten zijn nadelig voor de goede werking van de interne markt en maken het onmogelijk te waarborgen dat de intellectuele eigendomsrechten op het gehele grondgebied van de Gemeenschap een gelijkwaardige bescherming genieten. Deze situatie is niet bevorderlijk voor het vrije verkeer in de interne markt, noch voor het scheppen van een gunstig klimaat voor de gezonde mededinging. ... Deze richtlijn heeft niet ten doel geharmoniseerde regels betreffende justitiële samenwerking, rechterlijke bevoegdheid, erkenning en tenuitvoerlegging van beslissingen in burgerlijke en handelszaken vast te stellen, noch over de toepasselijke wetgeving te handelen. Er zijn communautaire instrumenten die deze onderwerpen in het algemeen regelen en die, in beginsel, ook van toepassing zijn op de intellectuele eigendom', ${ }^{21}$

behoren in een verregaand samenwerkingsverband als de EU niet meer voor te komen.Voorspelbaar is dat de Europese Commissie op meerdere terreinen met gelijke overwegingen langzaam maar zeker onder het mom van handhaving en verbetering van de economische markt, meerdere onderdelen van burgerlijke rechtsvordering zal gaan regelen. Landen zelf nemen immers nauwelijks of geen initiatieven tot harmonisatie van wetgeving. Een andere manier dan de Europese Commissie nu tactisch hanteert, probeer per onderwerp tot harmonisering te komen, lijkt niet goed mogelijk.

20 H. Drion, Praten over rechtsvinding, de verhouding wet-rechter en het NBW, NJB 1983, p. 12201223.

21 Aldus de nummers 8 en 11 van de considerans van Richtlijn 2004/48/EG. 
Waar de Nederlandse regering bij mijn weten nog niet heeft toegezegd bereid te zijn om onze Oude Teddybeer (lees 'het Wetboek van Burgerlijke Rechtsvordering') te vervangen door een Europees Wetboek van Burgerlijke Rechtsvordering, valt het op dat de minister van economische zaken schrijft

'Nederland heeft er begrip voor dat de Commissie zich richt op het stimuleren van civielrechtelijke handhaving van het mededingingsrecht, dat traditioneel een van de speerpunten van de Europese Unie is. Nederland betreurt echter de gefragmenteerde aanpak. De Commissie stelt op diverse dossiers -mededingingsrecht, aanbestedingsrecht, intellectuele eigendomsrecht, consumentenrecht- specifieke maatregelen voor, die het nationale burgerlijk procesrecht raken. Hierdoor wordt miskend dat het burgerlijk procesrecht in iedere Lidstaat een innerlijk consistent systeem is. Indien men de uit diverse systemen als best practice geselecteerde procedures, maatregelen en rechtsmiddelen toevoegt of bestaande maatregelen wijzigt, heeft dat tot gevolg dat het nationale systeem uit balans raakt. Wanneer de Commissie van mening is dat er op diverse terreinen problemen bestaan met zaken als schadevergoedingsvorderingen, bewijsgaring, kostenveroordeling en dergelijke, zou Nederland het zeer op prijs stellen indien dat tevens in het Comité Civiel Recht op de agenda wordt gezet om daar deze problemen in een breder verband te bezien ....22

Die treurnis is volgens mij niet vrij van enige hypocrisie omdat de Nederlandse wetgever er telkens voor kiest om niet meer dan het minimaal noodzakelijke te doen. Zo is richtlijn nr. 2004/48/EG uitgevaardigd op 29 april 2004. De Richtlijn bepaalt in art. 20 dat de lidstaten de nodige wettelijke en bestuursrechtelijke bepalingen in werking doen treden om uiterlijk op 29 april 2006 aan de richtlijn te voldoen ${ }^{23}$ De Nederlandse regering gebruikt die tijd niet om algemeen onderzoek te doen naar bijvoorbeeld herformulering van art. 843a Rv of herplaatsing van dit artikel naar de bewijsregels, maar ontwerpt een inzageregel voor alleen het terrein van de intellectuele eigendom en wel art. 1019a Rv. Het is hiermee niet zozeer de Europese Commissie die fragmentarisch te werk gaat. De keus om slechts het minimale te doen is van de Nederlandse regering. Uit tactische overwegingen valt te billijken dat de Europese Commissie grote waarde hecht aan het terrein van de intellectuele eigendom, maar ik zie eigenlijk niet waarom dit terrein bevoordeeld zou moeten worden boven andere terreinen als letselschadezaken, franchisezaken, verzekeringzaken, enz. Kortom, ik begrijp niet waarom de Nederlandse wetgever, die drie jaar de tijd heeft genomen, niet meteen een algemene regel heeft gemaakt waarin het recht op inzage werd verruimd. Het zal toch geen grote verrassing zijn

22 Kamerstuk 22112, nr. 439, citaat uit de bij brief van 28 april 2006 van de minister van economische zaken aan de Tweede Kamer aangeboden 'Nederlandse reactie op het Groenboek inzake schadevorderingen wegens schending van de communautaire antitrustregels'.

23 Alleen kniesoren merken nog op dat Nederland dit natuurlijk niet heeft gehaald. De betreffende wettelijke bepalingen zijn pas bij wet van 8 maart 2007, Stb 2007, 108 met ingang van 1 mei 2007 in werking getreden. 
geweest dat bij het volgende door de Europese Commissie ter hand genomen onderwerp waarbij het terrein van het bewijsrecht werd betrokken, schadevergoedingsacties wegens schending van de communautaire mededingingsregels, de Europese Commissie verklaart dat zij wil voortbouwen op de benadering die is gehanteerd in Richtlijn 2004/48EG. De telkens fragmentarische reactie van de Nederlandse wetgever op verplichtingen die in Europese richtlijnen worden voorgeschreven, veroorzaakt de schade aan het 'innerlijk consistente systeem'. Het lijkt dan ook tijd te worden dat de Nederlandse wetgever aan de slag gaat om een inzageregel te ontwerpen die voor alle terreinen van het recht geldt, al was het alleen maar om te voorkomen dat in ons Wetboek van Burgerlijke Rechtsvordering straks op verschillende plaatsen zelfstandige regelingen voor het inzagerecht staan in plaats van een algemene regeling op inzage bij de regeling van het bewijsrecht (om alvast maar een voorschot te nemen op onder meer het volgende hoofdstuk). 



\section{$5 \quad$ Nieuwe ontwikkelingen in Nederland}

\subsection{Een uitgebalanceerde disclosure?}

De schrijvers van 'Uitgebalanceerd' betogen dat er meer studie naar de inhoud van de disclosure moet worden verricht. Zij zijn namelijk van mening dat art. 843a Rv weliswaar vrij ruim geformuleerd is, doch naar zijn aard te beperkt van opzet. Het probleem bij art. $22 \mathrm{Rv}$ is volgens hen dat dit artikel slechts geldt indien er al een geding loopt. Naar hun mening bestaat er behoefte aan een mogelijkheid om in een vroegtijdig stadium een wederpartij te dwingen om in haar bezit zijnd bewijsmateriaal over te leggen. Dit zou procedures kunnen voorkomen of in een vroegtijdig stadium beëindigen. ${ }^{1} \mathrm{Zij}$ vinden dat er voldoende aanleiding is om een regeling in te voeren die tot doel heeft een partij of een derde te dwingen tot 'disclosure of documents' welke desgewenst en waar nodig, op verzoek en onder rechterlijk toezicht, kan worden toegepast. Een nieuwe regeling zou de voorkeur verdienen boven uitbreiding van art. 843a Rv. Het hele stuk in Uitgebalanceerd is tamelijk abstract. Er worden geen concrete redenen gegeven waarom art. 843a Rv niet voldoet. Van enig jurisprudentieonderzoek blijkt niet. De advocatuur schijnt volgens het rapport behoefte te hebben aan rechtsmiddelen om de wederpartij te dwingen om in een vroegtijdig stadium bewijsmateriaal over te leggen, maar waarom art. 843a Rv niet voor dit doel geschikt is, wordt niet vermeld. Nogal apodictisch schrijven de rapporteurs dat er in de praktijk weinig mogelijkheden zijn om de wederpartij te dwingen relevante gegevens over te leggen. Indien preprocessuele protocollen worden ingevoerd kan de preprocessuele exhibitieplicht in de vorm van een pre-action disclosure een belangrijk ondersteunend middel zijn voor de toepassing van zo'n protocol. Daarom is er aanleiding voor een ruimere regeling die tot doel heeft een partij of een derde te dwingen tot disclosure of documents.

In het voorwoord bij deze studie heb ik een kort cijfermatig overzicht gegeven waaruit blijkt dat art. 843a Rv pas recent door de praktijk is ontdekt. Er is vervolgens de laatste jaren zeer gretig gebruik van gemaakt en anders dan de rapporteurs in Uitgebalanceerd lijken aan te nemen, blijkt vooralsnog uit niets dat art. 843a $\mathrm{Rv}$ een te beperkte strekking heeft. De grenzen zijn zeker nog niet duidelijk, waarschijnlijk vooral omdat de Hoge Raad zich nog nauwelijks over art. 843a Rv 
heeft uitgelaten, maar veel fundamentele kritiek is er niet. Er is discussie over de inhoud en strekking van enkele begrippen als 'rechtmatig belang', 'bepaalde bescheiden' en 'rechtsbetrekking' maar ook een andere regeling die waarschijnlijk 'disclosure of documents' genoemd zal gaan worden, zal die begrippen of begrippen van gelijke strekking bevatten. Een andere tekst zal dus dezelfde vragen oproepen en, herhaal ik, in Uitgebalanceerd wordt op geen enkele manier aangetoond dat het huidige art. 843a Rv al op de schop moet voordat aard en inhoud van het artikel zijn uitgekristalliseerd.

Ook Ekelmans en Ynzonides zien die noodzaak tot verandering of aanvulling niet.

Ekelmans schrijft dat weliswaar niet alle normen van art. 843a Rv op dit moment al even duidelijk door literatuur en rechtspraak zijn ingevuld, maar tot op heden kan volgens hem niet worden gezegd dat de inhoud van dit artikel te beperkt is, terwijl een nieuw artikel hoogstwaarschijnlijk soortgelijke open normen zal bevatten. ${ }^{2}$ Ynzonides is van mening dat de Commissie op dit punt wellicht verder gaat dan gewenst en dat het proces over de vraag welke documenten in een procedure noodzakelijk zijn, niet al te veel naar voren moet worden gehaald omdat pas in de loop van de procedure blijkt of een partij een zaak heeft waarbij de documenten noodzakelijk zijn. ${ }^{3}$

Ik vind het verder merkwaardig dat de auteurs van Uitgebalanceerd geen aandacht besteden aan de vraag of ook voorafgaand aan een procedure art. 843a Rv kan worden ingeroepen. Er wordt namelijk veel aandacht aan de 'pre-trial fase' besteed waarbij de mogelijkheden of onmogelijkheden van art. 843a Rv in die fase niet of nauwelijks aan de orde komen. ${ }^{4}$ Naar mijn mening laat art. 843a Rv op dit moment echter toe dat inzage in stukken wordt verzocht terwijl er nog geen procedure is. Zie de hoofdstukken 14 en 15 waar uitspraken worden genoemd waarin bewijsbeslag is toegestaan, waarna in kort geding inzage wordt gevorderd en toegestaan. Niet precies een 'pre-trial fase', maar er is dan ook nog geen sprake van een bodemprocedure, terwijl de inzagemogelijkheid die de kort gedingrechter heeft gegeven, ertoe kan leiden dat één van de partijen eieren voor zijn geld kiest en toegeeft, waarmee een bodemprocedure wordt voorkomen. Al met al begrijp ik die voorliefde voor dit Anglo-Amerikaanse middel niet en ik denk dat de minister enkele jaren geleden terecht van mening is geweest dat er geen behoefte is aan

2 J. Ekelmans, Een onbalans in de eindbalans: de exhibitieplicht revisited in TCR 2006, p. 101-102.

3 M. Ynzonides, Uitgebalanceerd, in 'Beschouwingen over het Eindrapport Fundamentele herbezinning Nederlands burgerlijk procesrecht', Procesrechtelijke reeks NVvP nr. 16, Boom Juridische uitgevers Den Haag, 2007.

4 Ik sluit niet uit dat de auteurs van Uitgebalanceerd, die een zeer ruime uitleg van de artikelen 21 en $22 \mathrm{Rv}$ voorstaan, in het kader van die uitleg ook niet veel behoefte meer hebben aan art. 843a Rv. 
dit Anglo-Amerikaanse disclosure-systeem. ${ }^{5}$ De auteurs hebben eigenlijk niets in de weegschaal gelegd ten gunste van de instandhouding van art. 843a Rv terwijl aan de 'disclosure-zijde' van die weegschaal nauwelijks of geen aandacht is besteed aan de nadelen van onder meer weer nieuwe regelgeving en de nadelen van de disclosure en de resultaten daarvan. Er lijkt nogal naar een resultaat toegeschreven te zijn. Al met al denk ik dan ook dat er naast art. 843a Rv, welk artikel misschien enkele kleine aanpassingen nodig heeft, geen nieuwe mogelijkheden geschapen hoeven te worden, in elk geval niet voordat is gebleken dat het huidige art. 843a Rv fundamentele problemen geeft.

De auteurs van 'Herbalans' ${ }^{6}$ hebben geen noemenswaardig commentaar op de 'disclosure-voorstellen' van de auteurs van Uitgebalanceerd. Zij schrijven op p. 54 dat een gedwongen disclosure of documents een aan te bevelen optie is om te komen tot vroegtijdige uitwisseling van informatie tussen partijen, tot het geven van complete openheid van zaken en tot het stroomlijnen van procedures. $\mathrm{Zij}$ vinden in dit kader een uitbreiding van art. 843a Rv gewenst.

\subsection{De fundamentele herbezinning door de regering}

De minister van justitie heeft bij brief van 5 februari 2007 het rapport 'Uitgebalanceerd' aan de Tweede Kamer aangeboden. De brief is een reactie van het kabinet op het rapport en telt 31 pagina's. $^{7}$ De minister merkt op p. 2 op dat het voorstel in het rapport omtrent de verruiming van de disclosure om een nadere uitwerking vraagt voordat het in de wet kan worden opgenomen. De uitwerking die hij dan voor ogen heeft moet bijdragen aan een tijdige (efficiënte) informatie-uitwisseling en aan een verder informatie- en daarmee machtsevenwicht tussen partijen. Uit nummer 44 van zijn brief blijkt dat andere ministers andere kansen en andere prijzen geven. Minister Hirsch Ballin wil namelijk wel een soort disclosure. ${ }^{8} \mathrm{Hij}$ schrijft onder dit nummer het volgende.

'Hoewel art. 843a Rv bij de herziening van het procesrecht in 2002 is uitgebreid om partijen ruimere mogelijkheden te geven om stukken te verkrijgen, blijkt hiervan in de praktijk tot nu toe maar beperkt gebruik te worden gemaakt. Tegelijkertijd acht de rechtspraktijk de informatiemogelijkheden op dit moment te beperkt. In kostbare disclosure of discovery procedures voorafgaand aan of bij het begin van de procedure

5 Parl. Gesch. burgerlijk procesrecht p. 153. De minister schrijft in het kader van art. $21 \mathrm{Rv}$ dat het Anglo-Amerikaanse disclosure-systeem van geheel andere orde is dan de door de artt. 21 en $22 \mathrm{Rv}$ ingekaderde waarheidsplicht. Uit het feit dat hij vervolgens geen enkel initiatief neemt om enige nieuwe exhibitieregels te ontwerpen, leid ik af dat hij geen reden zag om in Nederland aan Anglo-Amerikaans regelgeving gelijke regels in te voeren.

6 A.W. Jongbloed, A.L.H. Ernes e.a., Herbalans. Beschouwingen naar aanleiding van het rapport Uitgebalanceerd, Ars Aequi Libri Nijmegen 2007.

7 Kamerstuk $3095 \mathrm{nr}$. 1, Herbezinning burgerlijk procesrecht.

8 Dus anders dan zijn voorganger die hier niet van wilde weten (zie par. 3.3.2). 
schuilt een gevaar. Het jaagt partijen op kosten en is lang niet altijd nuttig voor een efficiënt verloop van de verdere procedure (en kan leiden tot fishing expeditions). De uitdaging is om hierin een balans te zoeken. De Adviescommissie voor het burgerlijk procesrecht heeft zich bereid verklaard dit onderwerp op te pakken en nader uit te werken. Ik maak graag gebruik van de expertise en bereidheid van de Adviescommissie op dit punt. De Europese bepalingen over disclosure in de richtlijn handhaving IErechten en het wetsvoorstel ter implementatie van die richtlijn (Kamerstukken II, 30392, $\mathrm{nr}$ 2) en de voorstellen van de Europese Commissie in het kader van de private handhaving van het mededingingsrecht kunnen een bijdrage vormen aan de gedachtevorming hierover. Anderzijds kunnen de bevindingen van de Adviescommissie voor het burgerlijk procesrecht bijdragen aan een coherente en goed onderbouwde Nederlandse inbreng in Brussel.'

In de geciteerde tekst staat in elk geval één onjuistheid en op één punt doet de wetgever zich wat beter voor dan hij in werkelijkheid is geweest. Waar in de eerste zin wordt vermeld dat in de praktijk maar beperkt gebruik wordt gemaakt van art. $843 \mathrm{a} \mathrm{Rv}$ is dit echt onjuist en getuigt het van onzorgvuldig onderzoek. Indien op 1 januari 2007 op 'rechtspraak.nl' werd gezocht op 'art. 843a Rv' waarbij de zoekopdracht inhield dat alleen gezocht moest worden in de periode 1 januari 2002 tot 1 januari 2007 leverde dat maar liefst 77 uitspraken op. Met zoveel 'hits' kan toch werkelijk niet worden volgehouden dat de praktijk maar beperkt gebruik maakt van de mogelijkheden die art. 843a Rv biedt. Ook de literatuur heeft zich voor 1 januari 2007 niet onbetuigd gelaten over de exhibitie want er waren voor die datum al minstens 10 artikelen verschenen over dit onderwerp, waaruit eveneens blijkt dat het artikel sterk in de belangstelling stond. Opmerking verdient verder het feit dat in een substantieel deel van die 77 net genoemde uitspraken de vordering geheel of gedeeltelijk werd toegewezen. De nodige procedures hadden dus een succesvol eind. Het is mij dan ook een raadsel hoe de minister op 5 februari 2007 kan schrijven dat de praktijk maar beperkt gebruik maakt van de mogelijkheden die art. 843a Rv biedt.

De minister doet zich in die eerste zin wat beter voor dan hij in werkelijkheid is geweest omdat uit de hiervoor in paragraaf 2.2.2 behandelde wetsgeschiedenis niet echt blijkt dat de wetgever toen werkelijk het fundamentele idee heeft gehad om art. 843a Rv serieus zodanig te verruimen dat partijen werkelijk ruimere mogelijkheden kregen om stukken te verkrijgen. Dit lijkt dus een beetje op public relation werk. 


\subsubsection{De Adviescommissie voor het Burgerlijk Procesrecht en de discovery}

De Adviescommissie voor het Burgerlijk Procesrecht (hierna de $\mathrm{ABP}^{9}$ ) heeft het onderwerp inderdaad opgepakt en heeft bezien of de huidige regeling van de exhibitieplicht van art. 843a Rv aanpassing behoeft en, zo ja, op welke wijze.

Het advies is aan de minister van justitie angeboden bij brief van 14 juli 2008. ${ }^{10}$ Opvallend is dat in het advies geen enkele uitspraak van welke feitenrechter dan ook is genoemd waarin die rechter heeft geoordeeld over het inzagerecht van art. 843a Rv, terwijl er op 1 juli 2008 over de periode vanaf 1 januari 2002 al 181 uitspraken over dit artikel op rechtspraak.nl waren gepubliceerd. Het is mij ook niet duidelijk geworden of de leden wel kennis hebben genomen van die gepubliceerde uitspraken, maar ze alleen niet hebben vermeld.

Uit niets blijkt dat de leden van de ABP kennis hebben genomen van bijvoorbeeld Ekelmans, die in zijn boekje bijna alle, zo niet alle rechtspraak tot begin 2007 heeft vermeld betrekking hebbend op art. 843a Rv. ${ }^{11}$ Er wordt verder geen aandacht besteed aan hetgeen ik al eerder had geschreven over de vraag of de praktijk uit de voeten kon met de huidige tekst van art. 843a Rv. ${ }^{12}$ Dit heeft geleid tot een toch wel eenzijdig advies dat toegeschreven lijkt te zijn naar de wens van een nieuwe op Anglo-Amerikaanse leest geschoeide regeling, waarbij bijvoorbeeld geen woord is gewijd aan hetgeen de commissie Storme in haar Rapprochement DJ heeft opgemerkt en voorgesteld over de inzage in stukken. Een voorbeeld van die eenzijdigheid van het advies: art. 843a Rv lid 4 bepaalt dat aan de vordering tot afgifte van stukken geen gehoor hoeft te worden gegeven indien redelijkerwijs kan worden aangenomen dat een behoorlijke rechtsbedeling ook zonder verschaffing van de gevraagde gegevens is gewaarborgd. De ABP schrijft dat in de praktijk deze bepaling wel wordt uitgelegd dat als bewijs ook langs andere weg kan worden verkregen, afgifte van bescheiden niet nodig is en een daarop gerichte vordering wordt afgewezen. Op zich zelf zijn dergelijke praktijkvoorbeelden in de vorm van verschillende uitspraken inderdaad te vinden. Er zijn echter net zoveel uitspraken te vinden waarin de feitenrechter zonder al teveel omhaal van woorden dit bestanddeel naast zich neerlegt. Zo overweegt het hof Den Bosch in een zaak waarin zeven jaar daarvoor een onderzoek is geweest dat is neergelegd in een rapport, dat reeds op grond van dit tijdsverloop een verhoor van getuigen niet meer als substituut kan dienen van terbeschikkingstelling van het rapport. De inhoud van een getuigenverklaring is immers afhankelijk van hetgeen de getuige zich herinnert omtrent

9 De Adviescommissie is ingesteld bij Besluit van 24 september 1997, Stcr. 1998, 51.

10 Zie voor commentaar op het advies ook P.J. van der Korst, Discovery in het Nederlands burgerlijk procesrecht. 'Advies over gegevensverstrekking in burgerrechtelijke zaken' van de Adviescommissie voor Burgerlijk Procesrecht becommentarieerd, TCR 2009, p. 140-143.

11 Ekelmans, De exhibitieplicht in kort bestek, Uitgeverij Paris 2007.

12 J.R. Sijmonsma, Art. 843a Wetboek van Burgerlijke Rechtsvordering ont(k)leed, Ars Aequi cahier 2007. 
hem bekende, uit 1997 daterende feiten, waarbij niet onaannemelijk is dat de betrokken partijen niet alle details zullen hebben onthouden. Daar tegenover staat dat in het rapport die feiten in 1997 zijn vastgelegd en het rapport dus een authentieke bron vormt. Het genuanceerde beeld dat het rapport kan verschaffen, kan niet eenvoudig door het horen van getuigen worden verkregen. ${ }^{13}$ Ekelmans en ik hebben in onze eerdere boekjes ook al gemotiveerd uiteengezet dat dit bestanddeel zodanig abstract van aard is en in de parlementaire geschiedenis zo rudimentair is ingevuld, dat aan de woorden 'redelijkerwijs kan aangenomen worden dat een behoorlijke rechtsbedeling ook zonder de verschaffing is gewaarborgd' een beperkte, zo niet uiterst beperkte, werking kan (en moet) worden gegeven. Een herschrijving van art. 843a $\mathrm{Rv}$ is daarvoor niet nodig. ${ }^{14}$

Ekelmans en ik stonden overigens niet alleen in dit standpunt. Asser schreef over deze woorden in lid 4 van art. 843a Rv al in 2002 dat op dit punt niet te hoge drempels moeten worden opgeworpen. Het verkrijgen van inzage, afschrift of uittreksel van een stuk is in de regel een veel effectiever middel om de benodigde gegevens te verkrijgen dan het horen van getuigen. Hij verdedigt zelfs letterlijk dat er in het algemeen niet te krenterig moet worden gedaan met de mogelijkheid om belangrijke stukken op tafel te krijgen in het kader van de feitenvaststelling. ${ }^{15}$

De ABP stelt in haar Advies een zevental uitgangspunten voorop en wel, zakelijk weergegeven, de volgende.

1. De commissie beveelt aan dat zowel op partijen als op derden een verplichting rust om mee te werken aan de opheldering van het voor een burgerrechtelijk geschil relevant feitencomplex. Dit zou al geldend Nederlands recht zijn.

2. Een partij dient niet alleen die informatie mee te delen waarover zij beschikt, maar dient zich ook binnen redelijke grenzen in te spannen om informatie te achterhalen waarover zij nog niet beschikt maar waartoe zij wel toegang kan verkrijgen.

3. Elke medewerkingsplicht veronderstelt een welomschreven burgerrechtelijke aanspraak met een voldoende nauwkeurige omschrijving van het geschil.

4. Elke medewerkingsplicht vindt zijn grens in de proportionaliteit waarbij een marginale toets moet worden toegepast. De medewerkingsplicht kan alleen worden doorbroken indien een verzoek tot medewerking kennelijk disproportioneel is.

5. Naar mate het geschil zich in de loop van de tijd ontwikkelt (allereerst zullen partijen praten waarbij geen sprake is van een omschreven vordering. Vervolgens kan er een voorlopig getuigenverhoor of voorlopig deskundigenonderzoek

13 Hof Den Bosch 28 september 2004, JOR 2004, 23.

14 Zie Ekelmans p. 44-45 en in mijn AA-cahier p. 20-22 en 54-55.

15 W.D.H. Asser, Bewijsrecht in de nieuwe wet, PP 2002, p. 26-30. Hij herhaalde deze woorden letterlijk in M.L. Hendrikse en A.W. Jongbloed (red.), Burgerlijk procesrecht praktisch belicht, Deventer, Kluwer, 2007, p. 262-263. 
zijn gelast waarbij het geschil al enigszins is omschreven en ten slotte kan er een procedure komen waarin een vordering duidelijk omschreven moet worden en van die vordering kunnen ook weer details nader onderzocht worden), kan men meer aan medewerking van partijen en derden verlangen, maar zal ook specifieker moeten worden aangegeven wat wordt verlangd.

6. Er moet een adequaat en evenwichtig sanctiestelsel komen waarbij degene die zijn medewerkingsplicht verzaakt wordt gestraft, maar ook degene die, naar achteraf blijkt, de ander ten onrechte tot medewerking heeft gedwongen.

7. Er is gelijkheid tussen partijen: gedaagde dient mee te werken aan het vergaren van bewijsmiddelen ter ondersteuning van de vordering van eiser en eiser dient mee te werken aan vergaring van bewijsmiddelen die kunnen dienen tot afwijzing van een vordering.

\subsubsection{De schets van de ABP}

Aan de hand van deze uitgangspunten komt de ABP tot een schets (haar woord) voor een wettelijke regeling, op te nemen bij de bewijsrechtelijke bepalingen met de volgende inhoud:

Art. 155a: 1. Een ieder die de beschikking heeft over gegevens als in het tweede lid bedoeld of die over dergelijke gegevens rechtmatig de beschikking kan krijgen is verplicht om die gegevens, na die zo nodig te hebben opgespoord, op de voet van het hierna bepaalde te verstrekken. Eventueel met deze verstrekking gemoeide kosten komen voor rekening van de persoon die aanspraak maakt op verstrekking.

2. De in het eerste lid bedoelde gegevens zijn alle gegevens die van belang zijn voor de beoordeling van het wel of niet bestaan, de inhoud of de omvang van een burgerrechtelijke rechtsbetrekking. Verstrekking kan worden verlangd door elke persoon die partij is bij de bedoelde rechtsbetrekking, dan wel een zodanig belang bij die rechtsbetrekking heeft, dat deze persoon met een partij op één lijn te stellen is.

3. De verstrekking geschiedt door het geven van inzage in de desbetreffende gegevensdrager of het verstrekken van een kopie daarvan. Wanneer inzage wordt gegeven wordt de gelegenheid geboden om zich uittreksel of kopie te verschaffen. Voorzover de persoon ten behoeve van wie gegevens worden verstrekt hiertoe behoefte heeft aan deskundige bijstand, wordt hem de gelegenheid geboden zich daarvan te bedienen.

Art. 155b: 1. De in art.155a bedoelde verplichting tot het verstrekken van gegevens geldt slechts voorzover dat met het oog op de in aanmerking te nemen belangen niet als kennelijk onevenredig is aan te merken. Bij de beoordeling of dit geval zich voordoet houdt de rechter rekening met de belangen van de betrokkenen, daaronder mede begrepen het gewicht van de burgerrechtelijke rechtsbetrekking waarop de aanspraak betrekking heeft, de belasting die van de tot verstrekking aangesprokene of van anderen gevergd wordt en gerechtvaardigde aanspraken op het inachtnemen van vertrouwelijkheid of het respecteren van de persoonlijke levenssfeer. Tot de in aanmerking te nemen belangen behoren ook aspecten betreffende de goede procesorde. De rechter houdt tevens, en zo nodig ambtshalve, rekening met aspecten van algemeen belang, 
2. Aan de hand van de in het eerste lid bedoelde afweging kan de rechter ook besluiten de verstrekking slechts onder voorwaarden of met inachtneming van zekere beperkingen te gelasten.

3. Voorzover met betrekking tot de tot het verstrekken van gegevens aangesprokene een verschoningsrecht als bedoeld in art. 165 lid 2 van toepassing is, wordt dat recht gerespecteerd.

Art. 155c: 1. In een aanhangig geding betreffende de burgerrechtelijke rechtsbetrekking waaromtrent gegevens worden verzocht dan wel gevorderd, wordt de aanspraak op verstrekking overeenkomstig de regels voor het desbetreffende geding aan de rechter voorgelegd.

2. Indien geen geding als in het eerste lid bedoeld aanhangig is kan aan de rechter een verzoek tot het gelasten van gegevensverstrekking worden gedaan.

3. Wanneer verstrekking van gegevens wordt verzocht dan wel gevorderd, wordt de burgerrechtelijke rechtsbetrekking waarvoor de gegevens van belang zijn nauwkeurig aangegeven en wordt het gerezen geschil daaromtrent, dan wel het geschil dat de aanlegger verwacht, duidelijk omschreven. Tevens wordt nauwkeurig aangegeven ten laste van welke personen aanspraak op gegevensverstrekking wordt gemaakt, met aanduiding van de redenen waarom aangenomen wordt dat zij over relevante gegevens kunnen beschikken. De voormelde gegevens worden zo nauwkeurig mogelijk omschreven. Art. 111 derde lid, eerste volzin is van overeenkomstige toepassing. Voorzover dat niet reeds uit de voormelde gegevens blijkt, wordt het belang omschreven dat de aanlegger bij de eerderbedoelde rechtsbetrekking heeft.

4. Voordat op een verzoek of vordering tot gegevensverstrekking wordt beslist worden belanghebbenden in de gelegenheid gesteld te worden gehoord. In ieder geval wordt die gelegenheid geboden aan de partijen bij de gestelde rechtsbetrekking en aan degene jegens wie aanspraak op verstrekking van gegevens wordt gemaakt.

5. In de beslissing waarbij de verstrekking van gegevens wordt gelast geeft de rechter nauwkeurig aan in welke omvang en vorm en, voor zover van toepassing, onder welke voorwaarden of met inachtneming van welke beperkingen de verstrekking dient te geschieden.

6. De redelijke kosten die voor het verstrekken van gegevens overeenkomstig dit artikel worden gemaakt, komen ten laste van de partij die op verstrekking aanspraak maakt. Deze kosten worden vergoed aan degenen ten laste van wie die kosten zijn gevallen. Op hun verlangen veroordeelt de rechter degene die op verstrekking van gegevens aanspraak heeft gemaakt, daartoe. De rechter stelt desverzocht een voorschot vast waaruit de bedoelde kosten kunnen worden bestreden. De rechter kan bepalen dat verstrekking niet hoeft plaats te vinden voordat het voorschot is voldaan.

7. De in lid 6 bedoelde kosten kunnen in aanmerking worden genomen als kosten op de voet van art. 6:96 lid 2 onder b van het Burgerlijk Wetboek.

Art. 155d: 1. De rechter kan op verlangen van betrokkenen bepalen dat de partij op wier vordering of verzoek de verstrekking van gegevens wordt gelast, ten gunste van een of meer door de rechter aan te wijzen betrokkenen een door de rechter vast te stellen bedrag verbeurt, wanneer alsnog wordt vastgesteld dat de rechtsbetrekking waarop de aanspraak werd gebaseerd niet bestond of, in het geval dat de aanlegger het niet-bestaan van een rechtsbetrekking vastgesteld wil zien, dat die rechtsbetrekking wel bestond; of dat de aanspraak op de verlangde gegevens op kennelijk ondeugdelijke gronden of lichtvaardig geldend werd gemaakt. 
2. De rechter kan bepalen dat voor het in het vorige lid bedoelde bedrag zekerheid wordt gesteld en dat de verstrekking van gegevens niet eerder hoeft plaats te vinden dan nadat de bevolen zekerheid is gesteld.

\subsubsection{Commentaar op de schets van de ABP}

Hierna zal ik eerst een korte samenvatting geven van de artikelen in de schets. Daarna worden de door de Commissie genoemde uitgangspunten bezien in het kader van de gegevensverstrekking en zal in de volgende paragraaf inhoudelijk commentaar op de artikelen worden gegeven. Ten slotte zal in paragraaf 5.3.3.3 worden bezien welke huidige problemen door de voorgestelde artikelen worden opgelost.

In het kort weergegeven houden de artikelen het volgende in.

Art. 155a geeft een algemene verplichting tot, en een abstracte omschrijving van, de exhibitie. Gegevensverstrekking is hierbij een plicht, zoals blijkt uit het gebruik van dit woord in art. 155a lid 1.

Art. $155 \mathrm{~b}$ vermeldt de normen waaraan de rechter de vraag of gegevens verstrekt moeten worden dient te toetsen.

Art. $155 \mathrm{c}$ bepaalt dat een verzoek tot gegevensverstrekking gedaan kan worden in de vorm van een procedure binnen een andere procedure maar ook als zelfstandige procedure.

Art. 155d bepaalt dat de rechter desgevraagd al op voorhand een bedrag kan vaststellen dat degene die de verstrekking wenst, verbeurt indien achteraf blijkt dat er toch geen grond voor de verstrekking bestond.

Het eerste probleem bij de geformuleerde uitgangspunten is dat ons huidige Wetboek van Burgerlijke Rechtsvordering niet is geschreven met inachtneming van al die uitgangspunten. Zo is het door de commissie geformuleerde tweede uitgangspunt, dat een partij zich binnen redelijke grenzen dient in te spannen om informatie te achterhalen, geen vanzelfsprekend uitgangspunt bij het vraagstuk van de bewijslevering, laat staan dat een partij de verplichting heeft om 'op te sporen' zoals de schets in art. 155a lid 1 eist. Twee voorbeelden. Ten eerste een arrest van de Hoge Raad van 19 september 2003. ${ }^{16}$ De raadsheer-commissaris overweegt in deze zaak dat de enkele stelling van de getuige Van Hulst omtrent het gebrek aan wetenschap

16 HR 19 september 2003, NJ 2005, 454 (Van Hulst-arrest of Opfrisplichtarrest). Vergelijk wat dit betreft art. 55 van het vierde hoofdstuk 'Van bewijzen door brieven' van de 'Wetten omtrent het bewijs' uit 1804. Dit art. 55 luidt: 'Gelijk elk verpligt is, daar toe behoorlijk opgeroepen zijnde, getuigenis der waarheid te geven, zoo moet ook elk, die eenige bewijsstukken onder zich heeft, welke tot ontlasting of bezwaar, 't zij in burgerlijke, 't zij in misdadige zaken, strekken, dezelve aan den belanghebbenden, of die daar recht op hebben, uitreiken', aldus 'Bronnen van de Nederlandse codificatie sinds 1798, I, Stukken van algemene aard de gedrukte ontwerpen van 1804 en hun voorgeschiedenis, verzameld door H. AA, uitgegeven door J.Th. de Smidt en A.H. Huussen Jr, Keming en zoon N.V. over den dom te Utrecht 1968'. 
van de te bewijzen feiten onvoldoende is om hem vrij te houden van getuigenverhoor, nu denkbaar is dat de getuige deze wetenschap alsnog vergaart hetzij door het raadplegen van het archief hetzij door enige andere vorm van intern onderzoek. De Hoge Raad oordeelt dat deze overweging blijk geeft van een onjuiste rechtsopvatting. Weliswaar kan onder omstandigheden van een getuige worden verlangd dat hij zich ter voorbereiding van een door hem af te leggen verklaring op de hoogte stelt van schriftelijke stukken of kennis neemt van andere gegevens die eraan kunnen bijdragen dat hij zijn geheugen opfrist en op een adequate wijze op vragen zal kunnen antwoorden, doch het vereiste van art. $163 \mathrm{Rv}$ dat de verklaring betrekking moet hebben op aan de getuige uit eigen waarneming bekende feiten, staat eraan in de weg dat de getuige verplicht wordt ter voorbereiding van het verhoor een onderzoek in stellen naar hem niet uit eigen wetenschap bekende feiten. ${ }^{17}$ Uit de zinsnede 'onder omstandigheden kan van de getuige worden verlangd dat hij ter voorbereiding op zijn verhoor kennis neemt van stukken' leid ik af dat de hoofdregel juist anders is. Normaliter hoeft de getuige dit niet te doen, maar omstandigheden kunnen anders met zich brengen. Asser schrijft in zijn noot onder dit 'Opfrisplichtarrest' dat het goed is dat de Hoge Raad met dit arrest (impliciet) een stokje steekt voor ongecontroleerde en mogelijk zelfs ontoelaatbare discovery-technieken. ${ }^{18}$ Ook uit een door de Hoge Raad op 11 juni 2004 gewezen arrest blijkt niet dat er een uitgangspunt is dat een partij zich moet inspannen om informatie voor de tegenpartij te vergaren. ${ }^{19}$ In dat arrest speelt het volgende. $\mathrm{R}$ start een vaderschapsactie waarin moet worden vastgesteld dat de overleden C.K. haar vader is. De rechtbank stelt vast dat C.K inderdaad haar vader is. $\mathrm{K}$ jr., de zoon van C.K., gaat in appel maar het hof wijst zijn bezwaren af. Hij gaat vervolgens in cassatie en in één van zijn cassatiemiddelen stelt hij dat hoewel in een

17 AG Huydecoper verwijst in zijn conclusie bij HR 25 november 2005, AU4019 (Lycos-Pessers) naar HR, NJ 2005, 454 en schrijft dat een opgeroepen getuige die over informatie beschikt die voor de beslissing van belang is, in het algemeen, na oproeping, verplicht is om de informatie die hij bezit (onder omstandigheden: met inbegrip van informatie die door onderzoek van zijn administratie kan worden verkregen) aan de procespartijen en de rechter te openbaren. Volgens mij legt hij hier de getuige een verdergaande plicht op dan de Hoge Raad op 19 september 2003, NJ 2005, 454 heeft geformuleerd.

18 Vergelijk ook HR 11 maart 1994, NJ 1995, 5 waar deze overweegt dat naar Nederlands recht noch de bevoegdheid bestaat om van een getuige afgifte van documenten te verlangen, noch bestaat er een middel om een getuige die de stukken waarover hij een verklaring moet afleggen, niet overlegt, daartoe te dwingen.

19 HR 11 juni 2004, NJ 2005, 116. In HR 15 februari 2008, NJ 2008, 106 overweegt de Hoge Raad dat een DNA-onderzoek in een zaak waarbij de echtgenoot ontkent de vader van een kind te zijn, rechtens niet afdwingbaar is. De Hoge Raad overweegt verder dat aan de weigering van de moeder om DNA af te staan, niet de conclusie kan worden verbonden dat de man erin is geslaagd om tegenbewijs te leveren tegen de stelling dat hij de vader is omdat dit een rechtsgevolg is dat niet ter vrije beschikking van partijen staat. Aan de processuele opstelling van de moeder inhoudende weigering om DNA af te staan, kan daarom niet het gevolg worden verbonden dat de andere partij (de vader) tegenbewijs heeft geleverd. 
procedure als de onderhavige het gewone bewijsrecht van toepassing is, het biologisch afstammelingschap dient te worden vastgesteld aan de hand van een DNAonderzoek. De Hoge Raad stelt voorop dat de wet niet voorschrijft door welke bewijsmiddelen aangetoond moet worden dat een persoon de verwekker is van een andere persoon. Weliswaar blijkt uit de parlementaire geschiedenis dat ambtshalve DNA-onderzoek kan worden gelast, maar wet noch parlementaire geschiedenis bieden aanknopingspunten voor de stelling dat dit ambtshalve zou dienen te geschieden of dat er dan sprake is van een verzwaarde stelplicht of omkering van de bewijslast. Indien het door de ABP geformuleerde tweede uitgangspunt rechtens geldig zou zijn, zou in dit geval R. toch zonder meer haar DNA voor onderzoek beschikbaar hebben moeten stellen. ${ }^{20}$ Met het laatst genoemde arrest in de hand, is men evenmin geneigd om het vierde uitgangspunt volledig te onderschrijven. De ABP is daarin van mening dat iemand alleen maar niet hoeft mee te werken indien de medewerkingsplicht in de betreffende casus kennelijk disproportioneel is. Het afstaan van DNA voor onderzoek lijkt mij in het kader van het onderzoek naar de vraag wie de vader is, niet heel erg moeilijk of inspannend en al zeker niet bij zo'n, niet alleen voor R maar ook voor K jr., zeer belangrijke vraag.

Dit vierde uitgangspunt, een partij of een derde moet meewerken tenzij deze medewerking disproportioneel is, past in de regel wel in ons bewijsstelsel. Zo behoort een getuige, ook een partijgetuige, eigenlijk altijd te komen om een verklaring af te leggen, waarbij het onbelangrijk is of de inzet een vordering van $€ 50$,of $€ 50$ miljoen betreft. Er wordt ook in het huidige bewijsrecht al veel verlangd van partijen en derden als bijvoorbeeld getuigen. Een verzoek tot medewerking mag dus niet vrij snel disproportioneel worden genoemd.

Het zesde uitgangspunt, het uitdelen van straf (in de vorm van schadevergoeding?) indien iemand achteraf ten onrechte tot medewerking gedwongen blijkt te zijn, is een vreemde eend in onze algemene procesrechtelijke bijt. Het tegendeel geldt eerder. De doorsnee getuige ontvangt immers slechts een fooi als vergoeding voor zijn diensten ${ }^{21}$ en de verliezer in een dagvaardingsprocedure wordt evenmin in de werkelijke kosten van de tegenpartij veroordeeld. Het uitgangspunt lijkt

20 Overigens zou Van Schaick (zie hiervoor par. 3.1) ook dit arrest als voorbeeld hebben kunnen geven voor zijn stelling dat de rechter niet zo'n serieuze zaak maakt van het vinden van de waarheid. Een ambtshalve onderzoek had hier toch wel zeer voor de hand gelegen. Aan de twee arresten van de Hoge Raad voeg ik toe een uitspraak van de rechtbank Amsterdam van 2 april 2008, BC9315. Die rechtbank legt de woorden 'te zijner beschikking of onder zijn berusting heeft' in lid 1 van art. 843a Rv letterlijk uit waar het oordeelt dat zelfs als juist is dat de gedaagde de bescheiden van een ander kan verkrijgen, dit niet betekent dat de inzagevordering toewijsbaar is.

21 De in art. 57 Wet tarieven in burgerlijke zaken genoemde AMvB is het Besluit tarieven in burgerlijke zaken en dit besluit verwijst in art. 2 weer naar het Besluit tarieven in strafzaken en dat Besluit (Stb 2003, 330) bepaalt in art. 8 dat 'gewone' getuigen een onkostenvergoeding van $€$ 6,81 per uur krijgen. In de Nederlandse Antillen is dit tarief op grond van art. 14 Landsbesluit Tarieven burgerlijke zaken maximaal NAF. 55,- per uur, ruim $€ 20$,- 
afgekeken te zijn van art. $1019 \mathrm{~g} \mathrm{Rv} .^{22}$ Dit artikel bepaalt dat de rechter op vordering van iemand die getroffen is door een specifiek in dat artikel genoemde beslagsoort, schadevergoeding kan vorderen. Waarom dit uitgangspunt plotseling moet gelden bij het ter beschikking stellen van gegevens, is mij een raadsel.

\subsubsection{Inhoudelijk commentaar op de schets}

Laat ik bij het inhoudelijk commentaar allereerst beginnen met de opmerking dat de schets zeer lang is. Alleen al door die lengte zal het niet eenvoudig werken zijn met de regeling. Er zijn meerdere oorzaken voor de grote omvang van dit voorstel. De eerste oorzaak is gelegen in het vele overbodige dat erin is vermeld.

Zo staan in de tekst diverse zinnen en zinsneden die niet alleen voor een exhibitieprocedure gelden maar voor het hele procesrecht of onderdelen daarvan. Het lijkt mij overbodig om expliciet op te nemen dat voor zover een persoon ten behoeve van wie gegevens worden verstrekt hiertoe behoefte heeft aan deskundige bijstand, hem de gelegenheid wordt geboden zich daarvan te bedienen. Zie de laatste zin van lid 3 van art. 155a. Het recht op inzage is immers inhoudsloos indien de gegevens zodanig zijn versleuteld dat zij zonder hulp niet te achterhalen zijn. De zin getuigt verder van een wat 'letterknechterige' opvatting van het begrip inzage. De ABP is kennelijk van mening dat inzage alleen maar betekent 'een blik werpen' en dat er daarom iets moet worden geregeld voor het geval dat de gegevens zonder decodering of versleuteling onbegrijpelijk zijn. Waar het gaat om informatieverschaffing aan een andere partij, betekent inzage natuurlijk 'kennis nemen van een begrijpelijk weergegeven inhoud'. Daar waar de ABP verder voorstelt dat een gegevensverstrekker verplicht is om gegevens op te sporen, valt het enigszins uit de toon indien die zelfde verstrekker niet zijn best hoeft te doen om de gegevens begrijpelijk te verstrekken. Ik zou zeggen dat hier sprake is van 'overregulering'.

Ik begrijp verder niet waarom de tamelijk lange omschrijving van de mogelijke rechtsbetrekking moet worden opgenomen. Ook met de huidige tekst inhoudende 'de partij bij een rechtsbetrekking', wordt een vordering van persoon A, die het standpunt inneemt dat hij juist geen partij is bij een rechtsbetrekking tussen alleen de personen $\mathrm{B}$ en $\mathrm{C}$, tot inzage in het schriftelijk stuk waarin de namen staan van de werkelijke contractspartijen B en C, toegewezen in een procedure tussen A en B waarin B stelt dat A wel contractspartij is.

Overbodig is ook de opmerking in art. $155 \mathrm{~b}$ lid 1 dat bij de door de rechter in aanmerking te nemen belangen ook aspecten betreffende de goede procesorde horen. Het lijkt mij dat inmiddels wel duidelijk is dat bij elke beslissing die de rechter in het kader van het Wetboek van Burgerlijke Rechtsvordering neemt, de goede procesorde door hem in de gaten gehouden moet worden. Het ligt dan toch

22 Ingevoegd bij wet van 8 maart 2007, Stb. 2007, 108 tot aanpassing van het Wetboek van Burgerlijke Rechtsvordering, de Auteurswet 1912, de wet op de naburige rechten, enz die in werking is getreden op 1 mei 2007. 
niet voor de hand om een dergelijke regel alleen bij de exhibitie op te nemen. Ik sluit niet uit dat in een volgend proefschrift een promovendus gaat verdedigen dat omdat de regel niet in bijvoorbeeld de regeling over het getuigenverhoor is opgenomen, een getuige gehoord mag worden zonder de regels van een goede procesorde in acht te nemen. De betreffende norm is verder dermate open dat hij alleen al daarom niets toevoegt.

Overbodig omdat dit als fundamentele regel van het procesrecht geldt, is de regel in art. 155c lid 4 inhoudende dat belanghebbenden in de gelegenheid worden gesteld om gehoord te worden. ${ }^{23}$

Overbodig en gevaarlijk is verder dat telkens de combinatie 'verzocht dan wel gevorderd' wordt gemaakt. ${ }^{24}$ Overbodig omdat uit de voorgestelde nummering blijkt dat de regeling moet worden opgenomen tussen de 'bewijsartikelen'. Die artikelen zijn weliswaar geschreven voor de dagvaardingsprocedure, maar zijn op grond van art. 284 lid $1 \mathrm{Rv}$ in beginsel ook van toepassing op de verzoekschriftprocedure.

De combinatie 'verzocht dan wel gevorderd' is gevaarlijk omdat met deze tekst verdedigd kan worden dat in alle verzoekschriftprocedures de exhibitieregeling van toepassing is. Dat zou dan opvallend zijn omdat alle andere bewijsregels volgens genoemd art. 284 lid $1 \mathrm{Rv}$ van overeenkomstige toepassing zijn op de verzoekschriftprocedures, tenzij de aard van de procedure zich daartegen verzet. Indien dat wel de bedoeling is van de ABP verdient dat nadere, goede motivering.

De regeling is verder lang omdat de kostenvergoeding twee keer wordt geregeld. Art.155a lid 1 bepaalt dat eventueel met de verstrekking gemoeide kosten voor rekening komen van de persoon die aanspraak maakt op verstrekking. Art. 155c lid 6 bepaalt dat de redelijke kosten die voor het verstrekken van gegevens overeenkomstig art. 155c worden gemaakt, ten laste komen van de partij die op verstrekking aanspraak maakt. Bijzonder is dat op grond van art. 155a alle met de verstrekking gemoeide kosten voor rekening lijken te komen van de persoon die aanspraak maakt op verstrekking, terwijl het zesde lid van art. 155c bepaalt dat alleen de redelijke kosten ten laste komen van de partij die op verstrekking aanspraak maakt.

De schets is verder te omvangrijk omdat in de betreffende artikelen in elk geval één onderwerp is geregeld dat niet bij een incidentele regeling als het recht op inzage geregeld dient te worden, maar bij de algemene leerstukken thuis hoort. Het is de tot dusverre in ons procesrecht onbekende figuur van de processuele boete, in de schets te vinden in art. $155 \mathrm{~d}$. Dit voorgestelde artikel is tot dusverre een onbekend fenomeen in ons procesrecht. Indien achteraf blijkt dat, kort gezegd, de gegevensverstrekker ten onrechte is lastig gevallen, kan hij een geldbedrag krijgen. Dat bedrag kan niet de kostenvergoeding zijn: die krijgt de gegevensverstrekker al op grond van art. $155 \mathrm{c}$ lid 6 . Het moet dus wel een boetebepaling zijn. Opname 
van deze regeling betekent ook hier een regeling voor een incidentele gebeurtenis terwijl bij soortgelijke incidenten een dergelijke boetebepaling niet voorkomt. De bepaling zou ook kunnen zijn geschreven ten gunste van de getuige die is verschenen maar wiens verklaring nutteloos blijkt te zijn. Die getuige krijgt slechts een wettelijke kostenvergoeding die ook nog eens beschamend laag is. Er valt misschien wel iets voor de gedachte van art. $155 \mathrm{~d}$ te zeggen, maar dan moet die gedachte verwoord worden bij alle soortgelijke gevallen. Het artikel lijkt verder een trendbreuk te zijn. Tot dusverre moest een procesdeelnemer het wel heel bont maken voordat hij werd veroordeeld in de echte kosten, laat staan dat hij een soort boete verbeurde. Waarom nu juist bij gegevensverstrekking dit anders moet en dan ook nog eens aan de hand van een tamelijk lichte maatstaf, is mij niet duidelijk geworden. De eventuele wens om vissen tegen te gaan, kan toch niet voldoende zwaar van gewicht zijn. De last door vissen veroorzaakt, is immers te onbeduidend in vergelijking tot een jarenlang durende bodemprocedure waarin tegen beter weten in bijvoorbeeld wanprestatie wordt ontkend en waarin die ontkennende partij niet wordt gestraft met een realistisch berekende proceskostenveroordeling.

Overbodig lijkt verder lid 1 van art. 155c. In de jurisprudentie is al lang uitgemaakt dat inzage kan worden gevraagd in een procedure door het opwerpen van een incident. De letterlijke tekst van lid 1 lijkt dat uit te sluiten. Dat lid vermeldt immers dat in een aanhangig geding de aanspraak op gegevensverstrekking overeenkomstig de regels van het desbetreffende geding aan de rechter wordt voorgelegd. Letterlijk betekent dit dat in een dagvaardingsprocedure nogmaals een dagvaarding moet worden uitgebracht. Dat zal de commissie wel niet bedoelen. Indien dit al geregeld moet worden, lijkt een simpele toevoeging van een artikel aan de tiende afdeling, Incidentele vorderingen, meer op zijn plaats. De commissie lijkt wat doorgeschoten door ook bij dit incident te verlangen dat de vragende partij handelt conform art. 111 lid 3 eerste zin Rv. Het exploot moet dus de door gedaagde tegen de eis aangevoerde verweren en gronden vermelden. Dit is voor geen enkel incident nodig. Waarom het hier zou moeten is mij niet duidelijk.

\subsubsection{Welke problemen worden door de schets opgelost?}

De hamvraag is natuurlijk of deze schets problemen oplost die de huidige tekst van art. 843a $\mathrm{Rv}$ onopgelost laat. Op een enkele uitzondering na eigenlijk niet. Uit de hoofdstukken zeven en acht van dit boek blijkt dat de problemen met de tekst van art. 843a Rv vooral worden veroorzaakt door de woorden 'rechtmatig belang', 'rechtsbetrekking waarin hij partij is' en 'bepaalde bescheiden'. Deze begrippen bieden ruimte voor velerlei verschillende opvattingen. Diezelfde probleemgebieden bestaan echter ook in de schets, alleen zijn die gebieden gecamoufleerd met meer woorden. Zo komt het woord 'rechtsbetrekking' terug in een lange zinsnede die echter niets verduidelijkt. Ik begrijp in elk geval niet welke duidelijkheid de woorden 'het wel of niet bestaan, de inhoud of de omvang van een burgerrechtelijke rechtsbetrekking' wel bieden die het simpele woord 'rechtsbetrekking' 
niet biedt. Het begint een beetje op Amerikaans contracteren te lijken: schrijf zoveel mogelijk op in een poging alles te regelen. Hierbij worden in elk geval twee dingen vergeten. Ten eerste wordt vergeten dat hoe meer er wordt opgeschreven, hoe meer tekst er is om verschil van mening over te hebben. Ten tweede leidt veelschrijverij bij wetgeving al snel tot a-contrario redeneringen terwijl het vaak maar de vraag is of de wetgever het geval dat niet is genoemd maar zich op dat moment voordoet, wel heeft voorzien.

De schets omschrijft de huidige in art. 843a Rv neergelegde woorden 'rechtmatig belang' in art. 155b lid 1 en wel met de woorden dat de verplichting tot gegevensverstrekking slechts bestaat

'voorzover dat met het oog op de in aanmerking te nemen belangen niet als kennelijk onevenredig is aan te merken. Bij de beoordeling of dit geval zich voordoet houdt de rechter rekening met de belangen van de betrokkenen, daaronder mede begrepen het gewicht van de burgerrechtelijke rechtsbetrekking waarop de aanspraak betrekking heeft, de belasting die van de tot verstrekking aangesprokene of van anderen gevergd wordt en gerechtvaardigde aanspraken op het in acht nemen van vertrouwelijkheid of het respecteren van de persoonlijke levenssfeer. Tot de in aanmerking te nemen belangen behoren ook aspecten betreffende de goede procesorde. De rechter houdt tevens, en zo nodig ambtshalve, rekening met aspecten van algemeen belang'.

Een prachtige omschrijving van rechtmatig belang, maar zo abstract dat met die woorden geen enkel probleem wordt opgelost dat niet valt op te lossen of al is opgelost met de woorden 'rechtmatig belang'. Het is met deze omschrijving in vergelijking met het huidige art. 843a Rv wel duidelijker dat bij het oordeel rekening moet worden gehouden met de belangen van beide partijen. Art. 843a Rv bepaalt op dit moment immers niet met zoveel woorden dat bij de beantwoording van de vraag of er sprake is van rechtmatig belang, ook het belang van de wederpartij in overweging genomen moeten worden. Uit het hierna in par. 8.1.1 nader te bespreken 'Observatiearrest' ${ }^{25}$ blijkt overigens dat in de rechtspraak bij de uitleg van het woordenpaar 'rechtmatig belang' thans al wel rekening wordt gehouden met de belangen van anderen. Voor zover dit niet bij de beoordeling van dit begrip al gebeurde, verplicht lid 4 van art. 843a Rv de rechter om rekening te houden met de gerechtvaardigde belangen van derden.

Ik vermoed dat de rechter met deze lange omschrijving van de ABP in zijn vonnis braaf zal opschrijven dat hij bij de toetsing rekening heeft gehouden met onder meer alle in lid 1 van art. 155b genoemde gevallen en het daar vervolgens bij laat, tenzij een partij met zoveel woorden over een of meerdere onderdelen van het lid om een oordeel vraagt.

De woorden 'bepaalde bescheiden' komen in die combinatie niet voor in de schets. Dat is niet alleen omdat het woord 'bescheiden' is vervangen door 'gege- 
vens'. De ABP heeft deze woorden wel proberen te vangen en dat is in die zin gelukt dat eigenlijk de hele regeling doordrenkt is met de geest van deze twee woorden. Zo is het woord 'bepaald' omschreven in de eerste zin van lid 2 van art. 155 a en ook lid 3 van art. $155 \mathrm{c}$ bevat een regel waarin de woorden 'bepaalde bescheiden' zijn omschreven en wel in de regel 'De voormelde gegevens worden zo nauwkeurig mogelijk omschreven'. Hieraan wordt dan nog toegevoegd dat art. 111 derde lid, eerste volzin van het Wetboek van Burgerlijke Rechtsvordering van overeenkomstige toepassing is. Lid 5 van art. $155 \mathrm{c}$ geeft de rechter ook een taak bij de invulling van 'bepaalde bescheiden'. De rechter moet namelijk nauwkeurig formuleren in welke omvang en vorm en, voor zover van toepassing, met inachtneming van welke beperkingen de verstrekking dient te geschieden. Meer duidelijkheid over de inhoud van het woordenpaar 'bepaalde bescheiden' wordt met al deze woorden niet gegeven.

Wat zijn de zinvolle toevoegingen of veranderingen?

Opname van de regeling omtrent inzage in de regeling van het bewijsrecht is een verademing. De bewijsimplicaties van dit recht zijn zo groot dat het zonder meer een plaats in het bewijsrecht verdient. Het artikel lijkt mij verder inderdaad zo belangrijk dat het terecht wordt opgenomen als (slot)bepaling in de eerste paragraaf, genaamd 'Algemene bepalingen van bewijsrecht'. Indien de wetgever dit plaatsingsvoorstel van de ABP overneemt, zal dat zijn op basis van voortschrijdend inzicht gebaseerd op historisch besef. De wetgever van het BW van 1830 plaatste de voorganger van art. 843a Rv, art. $1932 \mathrm{BW}$, immers al tussen de artikelen betrekking hebbend op het bewijsrecht en daar zijn alle opvolgers van art. 1932 BW telkens blijven staan, totdat de wetgever van 1988 het artikel overbracht naar art. 843a Rv in de afdeling 'Afschrift, uittreksel en inzage van akten en andere bewijsmiddelen'. Deze beslissing zal zeker hebben bijgedragen aan het geringe gebruik dat na 1988 van het artikel is gemaakt.

De schets maakt een eind aan de woorden 'inzage, afschrift of uittreksel'. Dit trio wordt vervangen door het simpele 'inzage of het verstrekken van een kopie'. Waar ruzie kan ontstaan over de vraag of een uittreksel wel de lading dekt, is het verstandig om die mogelijkheid uit te sluiten. Ik merk hierbij wel op dat ik in de jurisprudentie geen gevallen heb gezien waarin problemen waren omtrent het verschaffen van een uittreksel.

Het is verder verstandig, zoals de schets in art. $155 \mathrm{~b}$ lid 2 vermeldt, om te bepalen dat de rechter ook kan besluiten om de verstrekking onder voorwaarden of beperkingen te gelasten.

Bezien vanuit de wetsgeschiedenis kan zonder meer worden verdedigd dat het woord 'bescheiden' in art. 843a Rv uitgelegd moet worden aan de hand van het woord 'stukken'. Het moet dan dus gaan over schriftelijke bescheiden en, gelet op de laatste zin van lid 1 van art. 843a Rv, mede om op een gegevensdrager aangebrachte gegevens. De vraag of ook een bij een botsing betrokken auto, waarbij eventueel uit de aard en plaats van de schade afgeleid zou kunnen worden aan wie de aanrijding moet worden toegerekend, een bescheid is in de zin van dit artikel 
waarvan men 'inzage' kan vragen, werd overwegend negatief beantwoord. ${ }^{26}$ De ruimere tekst van de schets in de leden 1 en 2 van art. 155a maakt een eind aan deze discussie. De betreffende beschadigde auto bevat zonder meer gegevens die van belang zijn voor de beoordeling van een rechtsbetrekking en de gegevens kunnen ook worden verstrekt. Ik denk dat ook een slecht gebouwd huis wat dat betreft gegevens bevat die van belang zijn voor de beoordeling van de vraag of er tussen partijen een rechtsbetrekking bestaat die 'wanprestatie' kan worden genoemd. Als de ABP ook dit huis onder art. 155a heeft willen laten vallen, lijkt dit te worden uitgesloten door de beperkte formulering van lid 3 van art. 155a. Daar is immers vermeld dat de verstrekking geschiedt door het geven van inzage in de desbetreffende gegevensdrager of het verstrekken van een kopie daarvan. Dat is niet echt een formulering waaruit zonder meer kan worden afgeleid dat de auto of een gebrekkig gebouwd huis onder de bepalingen van de schets valt.

Concluderend geeft de schets een wel hele lange regeling waarin maar enkele kleine problemen die het huidige art. 843a Rv kent worden opgelost.

26 Zie onder meer mijn bespreking van het boekje van Ekelmans, De exhibitieplicht in kort bestek, TCR 2008, p. 60-64. Een ander voorbeeld is het flesje nepparfum. Zie ook het in 1893 door Ligtenberg gegeven 'hondenvoorbeeld', genoemd in par. 2.1.2 van dit boek. Asser-Anema-Verdam schrijft op p. 234 dat het exhibitierecht in de ruimere zin van het woord zich uitstrekt over geschriften en andere goederen (in het Romeinse recht de 'actio ad exhibendum'), maar dat het antwoord op de vraag in hoeverre een dergelijk algemeen vertoningsrecht van zaken in het Nederlandse recht bestaat, terzijde kan worden gelaten. 



\section{De plaats van art. 843a $\mathrm{Rv}$ in het bewijsrecht}

\subsection{Inleiding}

Uit de paragrafen 2.1.1 en 2.1.2 van dit boek blijkt dat de wetgever in de negentiende eeuw het inzagerecht vond vallen onder de bewijsregels. Zo is in Voorduin al de opmerking te vinden dat de wetgever ter zake het onderwerp betreffende de afgifte van stukken in het ontwerp van 1824 de verplichting tot afgifte als 'hoogst zedelijk en billijk beschouwt, omdat dezelve strekt tot ontdekking der waarheid'.

Indien een partij, zo vervolgde die wetgever, een stuk in haar bezit heeft waaruit een wederpartij haar recht kan bewijzen, is dit stuk, wat het gebruik daarvan betreft, aan beide partijen gemeen. Uit het woord 'bewijzen' dat de wetgever hier gebruikt, blijkt zonder meer dat het inzagerecht, in elk geval volgens de toenmalige wetgever, onder de bewijsregels kan vallen.

Het inzagerecht werd dan ook vanaf 1824 telkens opgenomen bij de bepalingen van het bewijsrecht.

Ledeboer schrijft in 1888 zelfs dat bij de beantwoording van de vraag wat de grondslag is voor de 'editionsplicht', ${ }^{2}$ het standpunt waarop men zich stelt ten opzichte van het vraagstuk van de verdeling van de bewijslast van groot gewicht is. ${ }^{3}$ Zolang het de eiser, aldus Ledeboer, niet lukt om het ontstaan van zijn recht te bewijzen, kan gedaagde volstaan met zwijgen, ook als het hem gemakkelijk zou vallen de juistheid van zijn standpunt te staven. Deze volgens Ledeboer heersende opvatting omtrent het zwijgrecht kan ernstige gevolgen hebben. Waar een partij immers mag zwijgen, kan men haar ook niet het recht ontzeggen om voor de tegenpartij voordelige bewijsstukken achter te houden. Hij komt vervolgens met een 'art. $21 \mathrm{Rv}$ avant la lettre' opvatting. Op p. 8 schrijft hij dat het in het belang is van een, met het werkelijk gebeurd zijn van de feiten zo juist mogelijk overeenstemmende uitspraak, indien aan partijen de verplichting wordt opgelegd om alle bewijsmiddelen, die op de beslissing van het geschil van invloed kunnen zijn, naar beste weten bij te brengen. Met het vooropstellen van dit principe, moet men een partij ook het recht toekennen om gebruik te maken van bewijsmiddelen die zich in handen van de tegenpartij bevinden, waarbij die partij een middel moet hebben

Voorduin, p. 494-495.

2 Zoals hij op p. 1 de verplichting tot het overleggen van stukken aan de bewijsvoerende partij door de andere procespartij of een derde noemt. De opmerking over de grondslagvraag staat op p. 4 . 3 P. 5. 
om die tegenpartij hier desnoods toe te dwingen. Als men, aldus Ledeboer, van oordeel is dat bij de vaststelling van de ware toedracht ook het publiek belang betrokken is, dan is zelfs een vordering tot overlegging van stukken niet noodzakelijk.

Van Boneval Faure schrijft dat als iemand een geschrift in rechte als bewijs wil overleggen, hij dit stuk onder zich moet hebben. Hij benadert dit probleem vervolgens vanuit de eigendomshoek waar hij schrijft dat er in het algemeen geen reden is om onderscheid te maken tussen schriftelijke bewijsstukken en andere roerende zaken. Zij kunnen alle van iedere houder door de eigenaar opgevorderd worden. Ook de schriftelijke bewijsstukken zijn stoffelijke voorwerpen waarop het adagium 'bezit geldt als volkomen titel' van toepassing is. Uit het vervolg van zijn betoog blijkt dat ook hij de artikelen plaatst in het bewijsrecht. De vordering, zo vervolgt hij, kan in elke stand van het geding worden ingesteld, waaruit volgt dat, wanneer een partij in een geding van dergelijke, onder haar niet berustende, doch haar met de tegenpartij gemeenschappelijk toebehorende en onder deze berustende stukken gebruik wil maken, zij daartoe de gelegenheid heeft, zolang het geding niet is gesloten. ${ }^{4}$

Scheltema schrijft ${ }^{5}$ dat het verheugend is dat de Hoge Raad in zijn arrest van 20 mei $1921^{6}$ heeft beslist dat een in één exemplaar opgemaakte akte die in het bezit is van één der partijen, een 'gemeen stuk' is en dat de vordering tot de uitlevering van dat stuk toekomt aan een ieder, die op die titel, als bewijsstuk, enig recht kan doen gelden. Deze overweging van de Hoge Raad roept volgens hem wel de vraag op welk recht de Hoge Raad bedoelt. In de wet is immers nergens een regeling te vinden omtrent 'bewijsrechtelijke rechten' op bewijsstukken behoudens dan juist de toenmalige art. 1922 en 1923 BW.

In de literatuur tot 1988 is nergens een opmerking te vinden inhoudende dat de exhibitie niet bij de bewijsregels hoort. Een ieder leek het daar over eens te zijn. Logisch dus dat de vraag rijst waarom bij de vernieuwing van het bewijsrecht in 1988 de exhibitie werd verplaatst, verbannen lijkt misschien een beter woord, naar het derde boek van het Wetboek van Burgerlijke Rechtsvordering, genaamd 'Van rechtspleging van onderscheiden aard' en in de zevende titel, genaamd 'Enige bijzondere rechtsplegingen', een vergaarbakafdeling. Een antwoord op die vraag is niet te vinden. Er wordt nergens in de parlementaire stukken ter zake het nieuwe bewijsrecht een rechtvaardiging gegeven voor het voorstel om de regels omtrent exhibitie niet op te nemen in de negende afdeling regelend het bewijs. Ook in de parlementaire stukken betrekking hebbend op het op 1 januari 2002 in werking getreden vernieuwde procesrecht wordt niet gesproken over de plaats van art. 843a $\mathrm{Rv}$ in dit wetboek. Ik vermoed dat het weinige gebruik dat van de artt. 1922 en $1923 \mathrm{BW}$ is gemaakt, de reden is geweest dat de wetgever meer heeft gekeken 
naar het dwangkarakter van de afgifte dan naar de bewijsbetekenis van het gevraagde stuk.

Ik denk verder dat Giesen in 2001 terecht heeft opgemerkt dat in elk geval tot aan zijn proefschrift ${ }^{7}$ het bewijsrecht en de verdeling van de bewijslast (Giesen gebruikt hier in plaats van het woord 'bewijslast' het woord 'bewijsrisico') er nogal bekaaid vanaf zijn gekomen in juridisch Nederland. ${ }^{8}$ Ik weet niet of zijn woorden dit hebben veranderd maar in elk geval is er vanaf het begin van 2000 een keur aan literatuur over bewijs en bewijslastverdeling op de voet van het huidige art. 150 Rv. ${ }^{9}$

Waar het bewijsverdelingsvraagstuk in zijn algemeenheid tot 2000 dus nauwelijks of niet in de literatuur aan de orde is geweest, is de vraag waar art. 843a Rv in het bewijsrecht moet worden geplaatst in het geheel niet aan de orde geweest.

7 I. Giesen, Bewijs en aansprakelijkheid. Een rechtsvergelijkend onderzoek naar de bewijslast, de bewijsvoeringslast, het bewijsrisico en de bewijsrisico-omkering in het aansprakelijkheidsrecht, Boom Juridische uitgevers Den Haag 2001, p. 7.

8 Ik wil hier overigens enkele 'oude' bijdragen niet onvermeld laten. Ten eerste M.J.P. Verburgh, De bewijslastverdeling in de zestiger jaren, Openbare les, Tjeenk Willink Zwolle 1970, VeegensWiersma, Het nieuwe bewijsrecht in burgerlijke zaken, I. Algemene grondslagen en verdeling van de bewijslast, Tjeenk Willink Zwolle, 1973, Pitlo, Bewijs en verjaring, druk 1968 en, met T.R. Hidma, drukken 1981, 1994 en 2003 (de drukken 1994 en 2003 zijn genaamd 'Bewijs') en H.C.F. Schoordijk, De bewijslastverdeling onder het nieuwe bewijsrecht in WPNR 1989, 5937 (p. 680-698).

9 Een willekeurige greep, exclusief alles over de omkeringsregel: W.D.H. Asser, Bewijslastverdeling, Serie Burgerlijk Proces \& Praktijk dl 3, 2004, ${ }^{\text {ste }}$ druk, B. Allemeersch en P. Schollen, Behoorlijk bewijs in burgerlijke zaken over het geoorloofdheidsvereiste in het burgerlijk bewijsrecht, Rechtskundig Weekblad nr. 2, sept. 2002, de noot van Rutgers in AA 2003, p. 307 tot en met 313, en over die noot J.R. Sijmonsma, Tegenbewijs en tegendeel bewijs, AA 2003, p. 636-637 en over Sijmonsma voornoemd weer Rutgers, AA 2003, p. 637, C. Bosse, Bewijslastverdeling in het Nederlandse en Belgische arbeidsrecht, Kluwer, 2003 (prfs), W.D.H. Asser, Bewijslastverdeling in verband met art. 7:658, lid 2 BW in de bundel van C.J.M. Klaassen (red), Aansprakelijkheid in beroep, bedrijf of ambt, Kluwer 2003, T.R. Hidma, Bewijswaardering in civilibus, Trema 2005, p. 301-306, N.J. Margetson, Bewijslastverdeling in geval van schade door rsi: een duivels dilemma, PP 2005, p. 161-167, D. Reisig, Het aanbieden van bewijs (prfs), Jongbloed 2005, H.J.W. Alt, bewijslastverdeling werkgeversaansprakelijkheid voor RSI, Arbeidsrecht 2005, p. 10-14, Bewijzen en beslissen. Bijdragen aan het symposium, dat ter afscheid van prof. Mr. W.D.H. Asser op 7 oktober 2005 aan de Universiteit van Leiden werd gehouden, onder redactie van Y.E. Schuurmans, Kluwer 2005, J.R. Sijmonsma, Enige literatuur en rechtspraak over de hoofdregel van artikel 150 Wetboek van Burgerlijke Rechtsvordering, Praktisch Procederen 2008, p. 31-38, N. van Tiggelenvan der Velde, Bewijsrechtelijke verhoudingen in het verzekeringsrecht, Kluwer 2008, H.W.B. thoe Schwartzenberg, Civiel bewijsrecht voor de rechtspraktijk, Apeldoorn-Antwerpen, Maklu 2008 en W.D.H. Asser, J.E. Nijboer en Y.E. Schuurmans, Bewijsrecht: het bewijs geregeld?, Preadvies voor de Nederlandse Vereniging Voor Rechtsvergelijking, Wolf Legal Publishers, Tweede herstelde druk 2010. 
Bij de mondelinge behandeling in de Eerste Kamer van wetsvoorstel $195744^{10}$ werd het nodige over art. 843a Rv opgemerkt, maar dat was vooral in de sleutel van de partijautonomie en de lijdelijkheid van de rechter, waarbij zijdelings ook het bewijsrecht aan de orde kwam. Wagemakers verwijst tijdens die mondelinge behandeling naar het preadvies van Vranken voor de NJV van $1986 .{ }^{11}$ Ter verduidelijking eerst het volgende. Vranken stelt op p. 51 in zijn preadvies onder meer dat het verschoningsrecht een uitzondering inhoudt op het ten processe bekend worden en vaststellen van de relevante feiten en omstandigheden. Hij stelt hierbij de vraag of er een inlichtingen-, mededelings-, documentatie- en/of waarheidsplicht voor partijen bestaat met als tegenhanger een onderzoeksrecht voor de rechter. Die achtergrond is natuurlijk ruimer dan de achtergrond of er een getuigplicht bestaat. Vranken schrijft dat die ruimere achtergrond ook gebleken is uit ontwikkelingen in Engeland. Daar hebben volgens hem de verruiming van de discovery samen met het toelaten van de partij als getuige, het karakter van de professionele privileges diepgaand beïnvloed. In par. 2.3 stelt hij vervolgens dat partijen in een Nederlandse civiele procedure de omvang en grenzen van de rechtsstrijd bepalen en dat de rechter alleen feiten en omstandigheden in aanmerking mag nemen, die partijen hebben gesteld of die uit het gestelde kunnen worden afgeleid.

Wagemakers haalt uit dit preadvies van Vranken het volgende. Partijen hebben het voor het zeggen bij het bepalen van de feitelijke grondslag van het geding, maar de rechter heeft het voor het zeggen in de sfeer van het bewijsrecht. Bij de bewijsvoering komt de rechter namelijk een grote invloed toe. Hij bepaalt wat een partij dient te bewijzen en hij is vrij in de bewijswaardering. In het kader van die bewijslevering komt ook art. 843a Rv aan de orde waarbij de rechter twee hindernissen heeft waar hij niet omheen kan en in beginsel niet omheen mag. ${ }^{12}$ De eerste hindernis is dat partijen anders dan in landen met een Anglo-Amerikaans ${ }^{13}$ rechtssysteem, niet verplicht zijn om uit eigen beweging alle op de zaak betrekking hebbende relevante documenten, stukken en informatie kenbaar te maken. De tweede hindernis voor de rechter is gelegen in het feit dat hij buiten de door partijen bepaalde omvang van het geschil de materiële waarheid niet mag achterhalen. De rechter mag namelijk niet zelf een onderzoek instellen of gegevens verzamelen. De minister onderschrijft in zijn antwoord op het betoog van Wagemakers dat een verplichting van een partij om afschriften van stukken te verschaffen in beginsel uitsluitend bestaat in de in art. 843a en 843b Rv genoemde gevallen.

10 Wetsvoorstel Wijziging van bepalingen die verband houden met de persoonlijke verschijning van partijen in civiele procedures. Zie de Handelingen EK van 24 oktober 1989, p. 31 e.v. Zie ook par. 2.3 van dit boek.

11 J.B.M. Vranken, Het professionele (functionele) verschoningsrecht, Preadvies voor de Nederlandse Juristen-Vereniging 1986.

12 Er wordt inderdaad gesproken over 'duidelijke hindernissen waar de rechter niet omheen kan', dus niet over hordes die door de rechter genomen moeten of kunnen worden.

13 In het verslag staat hier het woord 'Angelsaksisch'. 


\subsection{Waarheidsvinding; stellen en onderbouwen en overlegging van stuk- ken}

Vranken merkt in zijn preadvies voor de NJV van 1986 op dat vrij algemeen wordt gesteld dat ook in Nederland partijen verplicht zijn mee te werken aan het bijeenbrengen van het nodige feitenmateriaal, ongeacht of dit in haar voordeel strekt. Hij onderschrijft die stelling niet. Volgens hem moet een partij in een procedure haar standpunt motiveren, toelichten en adstrueren of dat van de tegenpartij bestrijden. Dit kan met zich brengen dat stukken in het geding gebracht moeten worden maar op een enkele uitzondering na kan een partij niet worden gedwongen om daadwerkelijk openheid van zaken te geven of om daadwerkelijk stukken te verschaffen. Met deze opmerking stond Vranken in die tijd min of meer alleen, zoals overigens ook uit de eerste zin van deze paragraaf blijkt. Die eenzaamheid is ook wel terecht. Ten eerste vergelijkt hij bij de onderbouwing van die stelling naar mijn idee appels met peren. Hij begint namelijk te redeneren vanuit het Engelse recht waarin volgens hem de advocaat verplicht is de zaak tot op de bodem uit te zoeken en van de resultaten daarvan met het volledige dossier mededeling te doen aan de rechter of de wederpartij, of, met de woorden van de rechter in de zaak Rockwool Machine Tool Ltd. vs. E.P. Barries:

'In preparing for trial solicitors bear a great responsibility and a heavy burden. Not the least of these burdens is that of discovery. ... Many litigants ... have little appreciation of the scope of discovery, and the duty of making full disclosure ...Accordingly, it seams (nt. JRS: seems) to me necessary for solicitors to take positive steps to ensure that their clients appreciate at an early stage of the litigation, promptly after writ issued, not only the duty of discovery and its width but also the importance of not destroying documents which might by possibility have to be disclosed. ${ }^{14}$

Daargelaten dat uit dit citaat eerder blijkt dat de rechter het graag zo ziet, maar dat het talloze malen in de rechtspraktijk in Engeland kennelijk anders geschiedt (waarom anders een dergelijk cri de coeur-achtige overweging?), is het volgens mij onjuist om vanuit een kennelijk zeer ruime regel in Engeland, een land met andere procesregels (de appels dus), te stellen dat in Nederland met zijn eigen anders luidende procesbeginsels (de peren), een dergelijk regel niet geldt. Ten tweede stond Vranken alleen omdat de literatuur in die tijd overwegend anders leerde. Ik verwijs hiervoor naar Hoofdstuk 3 van dit boek en voeg daar nog de volgende meningen aan toe.

Meijers signaleerde al in 1926 dat de Hoge Raad volgens hem een merkwaardige weg ging waarbij hij al het punt had bereikt dat

14 Het citaat is te vinden op p. 54 van het preadvies. Het betreft de zaak Rockwool Machine Tool Ltd. vs. E.P. Barries (1968) 2 All ER 98/9. 
'in onze procedure een mededelingsplicht voor partijen bestaat, krachtens welke telkens als de rechter de overtuiging heeft, dat een partij meer van de geschilpunten afweet, dan hij in zijn conclusie neerschrijft, hij de conclusie als onvoldoende gemotiveerd ter zijde kan stellen'. ${ }^{15}$

Veegens-Wiersma I ${ }^{16}$ schrijft dat de wetgever zuinig moet zijn met bewijsbelemmerende voorschriften om tot beantwoording te komen van het doel van het proces, namelijk het vinden van de materiële waarheid. Iedere regeling van de rechtsgang is dan het zoeken naar het juiste midden tussen de wens van partijen hun processuele rechtspositie zelf af te bakenen en het streven van de rechter naar een materieel juiste beslissing. Om te komen tot de materieel juiste beslissing staan voor de rechter eigen wegen open om te komen tot een feitenvaststelling. Zo kan de rechter een inlichtingencomparitie bevelen (toen neergelegd in het in 1923 ingevoegde art. 19a Rv), een bevel geven tot openlegging van bedrijfsboeken en bedrijfscorrespondentie (toen neergelegd in art. $8 \mathrm{WvK}$ ), getuigenbewijs, deskundigenonderzoek en plaatsopneming bevelen en ten slotte mocht de rechter ambtshalve de aanvullende (gerechtelijke) eed van art. 1977 BW opdragen. Verder bepaalt het Wetboek van Burgerlijke Rechtsvordering dat de conclusies van partijen met redenen omkleed moeten zijn, hetgeen volgens Veegens-Wiersma I door de rechtspraak is ontwikkeld tot een processuele mededelingsplicht ingeval een partij meer van de geschilpunten moet afweten dan zij aan het papier wenst toe te vertrouwen. ${ }^{17}$

Van belang bij dit onderwerp is verder het antwoord op de vraag in welke gevallen herziening mogelijk is. Indien herziening immers mogelijk is als een partij feiten heeft verzwegen die verteld hadden moeten worden, betekent dit tevens dat een partij stukken ten nadele van zich zelf zou moeten overleggen. Van Rossem/ Cleveringa $^{18}$ vermeldt bij art. $382 \mathrm{Rv}$ (het toenmalige request-civielartikel) dat in de heersende leer de woorden 'bedrog of arglist' niet eng worden opgevat en onder sub 1 van dat artikel te brengen elke oneerlijke proceshouding die tot strekking heeft de waarheid te verdoezelen en hierdoor het materiële recht in zijn tegendeel te verkeren; ook een zwijgen kan aldus bedrog opleveren.

Het lijkt er wat dit betreft op dat Vranken de oorzaak voor het kennelijk in de praktijk veel gehoorde klagen over het gebrek aan succes wat het vinden van de materiële waarheid betreft, zonder meer in de regelgeving heeft gevonden zonder de in elk geval theoretische mogelijkheden die ook al omstreeks 1986 bestonden, voldoende te onderkennen. Hiermee wil ik niet zeggen dat de praktijk niet terecht

15 Noot E.M.M. onder HR18 december 1925, NJ 1926, p. $228-231$ (N.V. Batava Margarine FabriekenSalomonsky).

16 Veegens-Wiersma, Het nieuwe bewijsrecht in burgerlijke zaken, I. Algemene grondslagen en verdeling van de bewijslast, Tjeenk Willink Zwolle, 1973, p. 19 e.v.

17 Veegens-Wiersma I, p. 37.

18 Mr. W. van Rossem's verklaring van het Nederlands wetboek van burgerlijke rechtsvordering, door R.P. Cleveringa, Deel I, vierde druk, Tjeenk Willink-Zwolle, 1972, aantekening 5. 
zou hebben geklaagd (en nog steeds klaagt) over de weinig succesvolle zoektocht naar de materiële waarheid. Ik wil hier wel mee zeggen dat die zoektocht met de wettelijke middelen die er al waren en met steun van de literatuur die hiervoor is genoemd, vaker succesvol had kunnen eindigen. Kort gezegd: partijen en de rechter gebruikten lang niet alle instrumenten die er wel waren. Ik sluit niet uit dat één van de oorzaken van het gebrek aan rechterlijk ingrijpen gelegen is in een te ruime uitleg door de rechterlijke macht in die tijd van het begrip lijdelijkheid.

Uit in elk geval een drietal arresten, alle van na het preadvies van Vranken voor de NJV van 1986, valt af te leiden dat er voor een procespartij een verplichting kan bestaan om feiten mee te delen die mogelijk in haar nadeel werken.

In zijn arrest van 5 november 1993, NJ 1994, 154 overweegt de Hoge Raad dat niet zonder meer kan worden gezegd dat beginselen van een goede procesorde de werknemer Van den Berg ertoe verplichtten om melding te maken van het feit dat hij op de dag dat hij zijn (ex-)werkgever meedeelde dat hij voor werk beschikbaar was, ook elders in dienst was getreden. Hier zou uit afgeleid kunnen worden dat er zich dus situaties kunnen voordoen waarin wel een spreekplicht bestaat. Lindijer ${ }^{19}$ vindt het interessant dat de Hoge Raad in dit arrest een verband legt tussen de beginselen van een goede procesorde en de vraag of een partij in de procedure bepaalde feiten had moeten melden, zonder dat in het cassatiemiddel of in de conclusie van de AG voor dit arrest is betoogd dat deze beginselen die partij daartoe zouden verplichten.

Dat er een verplichting kan bestaan om informatie te verschaffen, blijkt duidelijk uit HR 4 oktober 1996, NJ 1998, 45. ${ }^{20}$ Voor zover van belang hield deze requestcivielcasus (tegenwoordig herroeping geheten) het volgende in: partijen stonden in een zakelijke relatie tot elkaar waarbij over en weer geld was geleend en één partij borg was. De partij die borg was, had het volledige bedrag waarvoor hij zich borg had gesteld, betaald. Na die betaling ontdekte hij dat de crediteur (een groot deel van) de schuld aan de hoofdschuldenaar had kwijtgescholden. Die kwijtschelding was informatie die de hoofdschuldenaar volgens de Hoge Raad had dienen te geven. Met de woorden van de Hoge Raad: het woord bedrog onder sub 1 in art. $382 \mathrm{Rv}$ moet samen met de woorden 'of arglist' worden opgevat als de weergave van één, als 'bedrog' aan te duiden maatstaf.

'Van bedrog in deze zin is reeds sprake wanneer een partij door haar oneerlijke proceshouding belet dat in de procedure feiten aan het licht komen die tot een voor de tegenpartij gunstige afloop van die procedure zouden hebben kunnen leiden. Dit zal zich onder meer voordoen wanneer een partij feiten als hiervoor bedoeld verzwijgt, terwijl zij wist of behoorde te weten dat de tegenpartij niet met die feiten bekend was of redelijkerwijs bekend behoorde te zijn.'

19 Lindijer, nr. 144.

20 Dit arrest, Goosen-Goosen en Dekkers, is hiervoor in par. 3.1 ook even aan de orde geweest. 
Ten slotte verdient hier vermelding HR 19 december 2003, NJ 2005, 181. In deze eerste herroepingszaak die is berecht volgens de regels van het per 1 januari 2002 gewijzigde procesrecht, had een werkneemster van de Rabobank op grond van een ontbindingsprocedure een schadevergoeding ontvangen. Na afloop van dit geding komt boven water dat zij heeft verzwegen dat zij tijdens de ontbindingsprocedure de mogelijkheid had een nieuwe baan te accepteren bij een andere Rabobank, hetgeen zij echter niet heeft gedaan. In de herroepingszaak overweegt de Hoge Raad dat van bedrog in de zin van art. $382 \mathrm{Rv}$ reeds sprake is indien een partij door haar oneerlijke proceshouding belet dat in de procedure feiten aan het licht komen die tot een voor de wederpartij gunstige afloop van die procedure zouden hebben kunnen leiden. De kantonrechter heeft klaarblijkelijk op grond van deze maatstaf geoordeeld dat de werknemer ook tijdens de ontbindingsprocedure met het oog op de hoogte van een aan haar toe te kennen vergoeding niet had mogen verzwijgen dat zij de mogelijkheid had (vrijwel onmiddellijk) elders weer aan het werk te gaan. Dit oordeel is niet onbegrijpelijk, nu dit verzwegen feit van belang is voor de beantwoording van de vraag of, en zo ja, tot welke hoogte, aan werknemer een vergoeding toekwam bij de ontbinding van de arbeidsovereenkomst.

Uit bovenstaande literatuur en drie arresten in onderling verband en samenhang bezien, zou de conclusie kunnen worden getrokken dat art. $21 \mathrm{Rv}$, inhoudende dat partijen verplicht zijn de voor de beslissing van belang zijnde feiten volledig en naar waarheid aan te voeren, te beperkt is. Een partij dient niet alleen de van belang zijnde feiten aan te voeren, maar is tevens verplicht al voor de fase van bewijsvergaring alle relevante informatie over te leggen. Dit zou bijvoorbeeld betekenen dat een partij die op eigen initiatief een deskundigenrapport heeft laten opstellen waarvan de conclusie haar niet bevalt, wel verplicht is om dit rapport in het geding te brengen. De heersende opvatting is dat dit niet zou hoeven omdat een conclusie van een deskundige nog geen 'feit' is in de zin van art. $21 \mathrm{Rv}^{21}{ }^{21}$ Die opvatting onderschrijf ik, maar de eisen van een goede procesorde lijken met zich te brengen dat een dergelijk stuk toch moet worden ingebracht. Voor de andere partij is het immers relevante informatie. Art. $21 \mathrm{Rv}$ geeft dan dus niet het volledige plaatje. Heel boud gedacht zou dit zelfs betekenen dat art. 843a Rv geen bestaansrecht heeft tussen procederende partijen. Ook zonder een vordering ex art. 843a Rv zou namelijk een franchisegever aan een franchisenemer inzage moeten geven in zijn boekhouding indien de franchisenemer redenen heeft om te vermoeden dat de inkoopprijs van de zaken die in het kader van de franchise worden verkocht, lager is dan de franchisegever zegt.

Stellen en onderbouwen zouden dan werkwoorden zijn die partijen over en weer letterlijk aan het werk moeten zetten. Een stelling naar waarheid van partij A mag niet alleen niet worden ontkend door B, maar B zou zelfs stukken ter 
onderbouwing van die stelling van A in het geding moeten brengen. ${ }^{22}$ Deze abstracte woorden zijn inmiddels zeker niet meer illusoir. Zo zal een chirurg die op de operatietafel een kunstfout heeft gemaakt terwijl de patiënt onder narcose is gebracht en door deze wordt aangesproken, ter onderbouwing van zijn ontkenning een fout te hebben gemaakt, het operatieverslag moeten overleggen en in elk geval de patiënt daar inzage in moeten geven. ${ }^{23}$

Een moeder die pas in hoger beroep tegen haar dochter, die wil weten wie haar vader is, voor het eerst zegt dat zij door een onbekende is verkracht en daardoor zwanger is geraakt, had die stelling nader moeten toelichten, mede nu in haar 'zwangerschapsdossier' dat bij de Stichting Valkenhorst aanwezig was, wordt gesproken over een 22-jarige militair. ${ }^{24}$ Die betreffende stelling wordt dan ook gepasseerd.

Over de vraag of er een algemene plicht voor een partij bestaat om ook voor haar ongunstige informatie te verschaffen, zijn inmiddels vele boekdelen geschreven. ${ }^{25}$ Heel kort samengevat lijkt het erop dat men een algemene mededelingsplicht wenselijk vindt, maar dat tussen droom en daad weerbarstige partijen (en advocaten) staan die maken dat een artikel als 843a Rv zonder meer bestaansrecht heeft en houdt. In hoeverre moet bij de beantwoording van de vraag of er een dergelijke mededelingsplicht bestaat, niet alleen naar rechtstheoretische wensen gekeken worden, maar ook naar het antwoord op de vraag wat, realistisch bezien, praktisch haalbaar is? Wat is met andere woorden de menselijke maat? Heeft het zin om de lat zo hoog te leggen dat partijen misschien niet in staat zijn daarover heen te springen? Het valt immers niet mee om als procespartij je eigen glazen in te gooien. Ik vind uiteindelijk toch dat het doel van het burgerlijk proces het vinden van de materiële waarheid is. Het is te makkelijk om je neer te leggen bij de verzuchting dat het te moeilijk is om van partijen te verlangen de volle waarheid te vertellen en alle stukken over te leggen ter inzage. Een artikel als bijvoorbeeld art. 843a Rv zal zeker noodzakelijk blijven om af te dwingen waar een partij recht op heeft, maar uitgangspunt behoort te zijn dat verwacht mag worden dat een partij alle

22 Ten behoeve van dit theoretisch model laat ik even terzijde dat niet betwiste gestelde feiten niet onderbouwd hoeven te worden.

23 Zie onder meer HR 24 mei 1987, NJ 1988, 500 en HR 13 januari 1995, NJ 1997, 175. Ik realiseer mij wel dat de gevolgen anders zijn: het niet voldoen aan de verplichting van art. 21 Rv kan leiden tot verlies van de zaak of tot een bewijsrechtelijke achterstand. Art. 843a Rv geeft daarentegen een afdwingbaar recht op inzage.

24 HR 3 januari 1997, NJ 1997, 451, m.nt. JdB.

25 Zie onder meer Asser-Vranken, nr. 19 en de literatuur zoals vermeld in de voetnoten bij dat nummer en I. Giesen, p. 20-24 en de in de voetnoten 22 tot en met 50 op die pagina's opgenomen literatuuren jurisprudentieverwijzingen en Lindijer, nrs. 212 e.v. en nrs. 419 e.v. 
relevante informatie verstrekt. ${ }^{26}$ Van Schaick behoort geen gelijk te krijgen waar hij zegt:

'buiten gevallen van misleiding of bedrog heeft het burgerlijk procesrecht weinig boodschap aan de waarheid, hetgeen inherent is aan een systeem als het onze dat de partijautonomie tot uitgangspunt heeft' ${ }^{27}$

Met hem is het weliswaar ook mijn ervaring dat gewoonlijk procespartijen niet zomaar een conflict hebben, maar een (sterk) geëscaleerd conflict dat zij niet meer zakelijk kunnen bekijken, maar dat wil niet zeggen dat het recht zich daar bij neer moet leggen. ${ }^{28}$ Het lijkt mij een mooie taak voor elke advocaat om zijn cliënt zover te krijgen, dat juist wel alle informatie wordt verstrekt. Het scheelt waarschijnlijk procedures.

$\mathrm{Al}$ met al is het een lastig in concrete woorden te vatten problematiek, mede omdat ook rekening moet worden gehouden met de partijautonomie. De lat ter zake de informatieverstrekking, en daar vloeit ook uit voort het spontaan ter inzage verstrekken van stukken, ligt hoog. Zie daarvoor bijvoorbeeld het hiervoor behandelde arrest HR 19 december 2003, NJ 2005, 181. ${ }^{29}$ Duidelijk is dat bedrog niet mag worden gepleegd. Met de woorden van Lindijer: geconcludeerd lijkt te mogen worden dat het antwoord op de vraag of een partij verplicht is om in een procedure bepaalde feiten te melden, die mogelijk in haar nadeel werken, mede afhankelijk kan zijn van de beginselen van een goede procesorde. ${ }^{30}$ Meer dan deze ijkpunten of grenzen zijn in abstracto ter beantwoording van de vraag of een partij moet meewerken aan de onderbouwing van de stellingen van de tegenpartij, niet te geven.

Resteert mij nog om hier te vermelden dat het in het begin van deze paragraaf weergegeven standpunt van Vranken inzake de verplichting van een procespartij om ook nadelige informatie te vertellen, in de loop van de tijd wat opgeschoven lijkt te zijn. Met zijn woorden in nr. 21 in Asser-Vranken 1995 inhoudende dat partijen in Nederland niet de vrijheid hebben om bij hun informatieverstrekking

26 Zie ook M.A. Loth, 'Tussen eenheid en verscheidenheid: contextualisme in taal, wetenschap en samenleving, p. 19-41 in de bundel van A.M.P. Gaakeer en M.A. Loth (redactie), Eenheid en verscheidenheid in recht en rechtswetenschap, Deventer Kluwer 2002, die op p. 33 opmerkt dat er sprake is van moralisering van het recht, door Pitlo aangeduid als 'de instroming van de ethiek in het recht'.

27 Van Schaick, p. 29.

28 Van Schaick, p. 30 schrijft dat het tamelijk naïef is om te veronderstellen dat de waarheid wel boven tafel zal komen doordat gedaagde alleen die stellingen van eiser zal betwisten die geen grond vinden in de werkelijkheid.

29 Ik heb deze casus vaak voorgelegd in het kader van het bewijsrecht aan advocaten die de beroepsopleiding volgden. Meestal was een kleine meerderheid van mening dat de werkneemster niet hoefde te vertellen dat zij een aanbod voor een andere baan had gehad.

30 Lindijer, nr. 144. 
alleen datgene te vermelden of als productie over te leggen dat de eigen stellingen ondersteunt en versterkt, neemt hij volgens mij afstand van zijn hiervoor weergegeven stelling in het preadvies inhoudende dat een partij in een procedure haar standpunt moet motiveren, toelichten en adstrueren of dat van de tegenpartij bestrijden, maar dat een partij niet kan worden gedwongen om daadwerkelijk openheid van zaken te geven. Uit de hiervoor weergegeven arresten blijkt dat ook de Hoge Raad van een procespartij verwacht dat ongevraagd nadelige informatie wordt verteld.

\subsection{Exhibitie en bewijzen}

Tjittes schreef in 1988 dat op grond van de regel dat een partij die een conclusie neemt, gehouden is deze met redenen te omkleden, deze partij verplicht kan worden zijn wederpartij, die met de bewijslast is bezwaard, zodanige informatie te verschaffen, dat daardoor het bewijsrisico wordt verlicht. ${ }^{31}$ Uit het artikel blijkt niet dat hij bij het schrijven ervan ook art. 843a Rv voor ogen heeft gehad, maar dit wetsartikel laat zich goed in zijn bijdrage inpassen. Dit blijkt ook wel uit een arrest waarop Tjittes wijst. ${ }^{32}$ In deze zaak stelt eiser een vordering in tegen een informatiebureau omdat dit bureau onware informatie over hem zou hebben verstrekt. Eiser zal dienen te bewijzen dat die informatie door het bureau is verstrekt, maar, zo zeg ik nu aan de hand van art. 843a Rv, gedaagde zal thans desgevraagd ${ }^{33}$ zijn knipselarchief ter inzage moeten geven. Zo gedaagde dit al niet moet in de fase van stellen en onderbouwen, zal hij dat in elk geval moeten doen in het kader van de enquête.

In dit soort gevallen is er dus sprake van een inzagerecht. Dit soort onevenwichtigheden in bewijsmogelijkheden, waarbij een partij die niet wordt belast met het bewijs wel over de nodige bewijsmiddelen beschikt, lost zich tot heden op door aanpassing van de stelplicht van partijen, door het aannemen van een rechterlijk vermoeden of zelfs door een echte omkering van de bewijslast. ${ }^{34}$ Het lijkt mij

31 R.P.J.L. Tjittes, Een mededelingsplicht voor een procespartij als tegemoetkoming aan een onredelijk bewijsrisico voor diens wederpartij, NJB 1988, p. 1128-1130.

32 HR 10 juni 1966, NJ 1966, 390, m.nt. G.J.S.

33 Voor de conclusie dat die vraag is gesteld, is, gelet op HR 6 oktober 2006, NJ 2006, 547, JBPR 2007, 6, m.nt. J.G.A. Linssen, AA 2007, p. 371-374, m.nt. H.B. Krans, niet veel nodig.

34 Aldus Lindijer, nr. 212. Zie voor een opzienbarend staaltje HR 20 januari 2006, NJ 2006, 78. Interpolis diende te bewijzen dat A wist of behoorde te weten dat de klachten die zij aan haar huisarts heeft gemeld, vielen onder 'rug- of Ischiasklachten'. Interpolis roept als getuigen op de huisarts en een neuroloog. De advocaat van A deelt mee dat hij er bezwaar tegen heeft indien die artsen hun geheimhoudingsplicht zouden schenden en de artsen beroepen zich op hun verschoningsrecht. De rechtbank wijst daarop een nieuw tussenvonnis waarin A wordt opgedragen te bewijzen dat zij NIET wist of behoorde te weten dat de klachten die zij aan haar huisarts heeft gemeld, vielen onder 'rug- of Ischiasklachten'. De Hoge Raad merkt vervolgens over deze omkering van de bewijslast op dat als uitgangspunt terecht heeft gediend dat Interpolis die feiten dient te bewijzen die zij ten grondslag legt aan haar stelling dat er sprake is van verzwijging. Terecht is echter uit het feit dat de getuigen zich grotendeels hebben verschoond omdat A's advocaat hen 
dat niets zich ertegen verzet om deze problematiek in de sleutel van art. 843a Rv te passen en in dergelijke gevallen aan te nemen dat er zonder meer een recht op inzage bestaat. Verplaatsing van art. 843a Rv naar bijvoorbeeld art. 155a Rv zou dit recht waarschijnlijk verduidelijken en meer inhoud geven. Het zou ook bijdragen aan een betere ontwikkeling van ons bewijsrecht. Het verkrijgen van inzage, afschrift of uittreksel van een stuk is in de regel immers een veel effectiever middel om gegevens te verkrijgen dan het horen van getuigen. ${ }^{35}$

In een door de Vereniging van Effectenbezitters (VEB) tegen Philips Electronics N.V. aangespannen zaak, zijn wat dit betreft enige stappen te vinden. ${ }^{36}$ VEB verwijt Philips, kort gezegd, in persconferentie(s) en jaarverslag(en) onjuiste informatie te hebben verstrekt. Een dergelijke stelling dient bij gebreke aan een bijzondere bewijsregel, door de VEB te worden bewezen. De rechtbank Den Bosch overweegt dat VEB niet over informatie beschikt om te kunnen vaststellen of bewijzen of de mededelingen van Philips juist en tijdig waren, terwijl Philips die informatie wel bezit. Teneinde tegemoet te komen aan de aan de bewijslevering door VEB verbonden bezwaren, mag van Philips worden verwacht dat zij bij haar betwisting voldoende feitelijke gegevens verstrekt ter staving van haar verweer om VEB voldoende aanknopingspunten te verschaffen voor bewijslevering. De Hoge Raad overweegt dat in cassatie niet bestreden is dat het vermoeden bestaat dat Philips in een bepaalde periode wel over informatie beschikte waaruit bleek, kort gezegd, dat de zaken niet goed gingen en zij bij de positieve wijze van presentatie een voorbehoud had behoren te maken, zodat het op de weg van Philips ligt om duidelijk te maken wat de oorzaken waren van de discrepantie tussen de op 10 april 1990 uitgesproken verwachtingen en de amper drie weken later bekend geworden 'rampzalige' gegevens en waarom desondanks de op 10 april 1990 geuite prognoses gerechtvaardigd waren. Het hiervoor weergegeven deel van het vonnis van de rechtbank wordt vervolgens bekrachtigd. Grundman-van de Krol annoteert onder dit in de JOR gepubliceerde arrest, dat de vraag rijst welk wetsartikel ten grondslag ligt aan de nu op Philips opgelegde plicht om voldoende feitelijk gegevens te verstrekken teneinde VEB voldoende aanknopingspunten te verschaffen voor haar bewijslevering, en noemt vervolgens art. 843a Rv.

Die visie deel ik niet. Ten eerste bestaan er zuivere rechtsvorderlijke problemen zoals het feit dat er dan sprake moet zijn van een vordering, al dan niet incidenteel

niet uit de geheimhoudingsplicht heeft willen ontslaan, afgeleid dat op de voet van de laatste zinsnede van art $150 \mathrm{Rv}$ de eisen van redelijkheid en billijkheid omkering van de bewijslast meebrengen.

35 Zoals Asser terecht opmerkt op p. 262-263 van Burgerlijk procesrecht praktisch belicht, onder redactie van M.L. Hendrikse en A.W. Jongbloed, Kluwer-Deventer-2007. Zie ook Snijders c.s., nrs. 143 en 203.

36 HR 7 november 1997, NJ 1998, 268, m.nt. Ma, JOR 1998, 9, m.nt. C.M. Grundman-van de Krol. 
en daarvan is niets gebleken ${ }^{37}$ Verder heeft de wijze waarop een en ander is geformuleerd veel weg van vissen. Met andere woorden: art. 843a Rv kan in dit geval niet de grondslag zijn omdat de rechtbank haar overweging te ruim heeft geformuleerd. De formulering van de rechtbank geeft eerder aanleiding om te denken dat de rechtbank van oordeel is dat er toch een soort 'disclosure' bestaat. De overweging komt namelijk dichter in de buurt van een algemene verplichting om inlichtingen te verschaffen dan van het inzagerecht van art. 843a Rv. Ik ben dan ook van mening dat de rechtbank hier los van art. 843a Rv een extra trede op de stelplichten bewijslastladder formuleert. Kort gezegd houdt die trede in dat waar een partij eenvoudig aan informatie kan komen die van groot belang is voor het bewijs van de feitelijke stellingen van de tegenpartij, die partij die informatie in het geding moet brengen. Grondslag van dit beginsel kan volgens mij alleen maar zijn dat in het geding zoveel mogelijk de materiële waarheid gezocht moet worden.

In de noot vermeldt Grundman-van de Krol verder dat de door de rechtbank opgelegde verplichting materieel overeenkomt met omkering van de bewijslast. Die conclusie vind ik veel te ver gaan, alleen al vanwege de ernstige gevolgen daarvan, zoals bijvoorbeeld het feit dat dan ook art. 164 lid $2 \mathrm{Rv}$ van toepassing zou zijn. Het betreft hier weliswaar schriftelijke bescheiden en daar is dit artikel niet op van toepassing ${ }^{38}$ maar het moet niet worden uitgesloten dat Philips eventueel met een partijgetuige als bewijsmiddel komt. Nog belangrijker is dat die conclusie miskent dat het bewijsstadium nog niet is aangebroken. Philips hoeft nog steeds niet meer te doen dan haar betwisting van de gestelde feiten behoorlijk te onderbouwen of, desnoods, de gestelde feiten te ontzenuwen, en dat laatste is iets anders dan bewijzen. Dat de Hoge Raad ook nog niet zover is als Grundmanvan de Krol blijkt ook wel uit de samenvatting van het door de rechtbank gegeven dictum door de Hoge Raad. Die overweegt namelijk dat 'de rechtbank een tussenvonnis heeft gewezen waarin, kort gezegd, Philips in de gelegenheid is gesteld nadere feitelijke gegevens te verschaffen.'

Een mooi voorbeeld van de relatie bewijsrecht-art. 843a Rv is te vinden in de volgende zaak van het hof Arnhem..$^{39}$ De gemeente Harderwijk is van mening dat $\mathrm{A}$ in strijd met een bepaald besluit een vakantiewoning permanent heeft bewoond en dwangsommen verschuldigd is. Zij vordert die dwangsommen en dient vervolgens te bewijzen dat die bewoning inderdaad heeft plaatsgevonden. Er worden in eerste aanleg getuigen gehoord. In hoger beroep wenst de gemeente ook op voet van art. 843a $\mathrm{Rv}$ inzage in de afrekeningen voor gas, water en licht over de jaren 2003, 2004 en 2005, waartegen A zich verzet. Het hof komt aan de hand van de in eerste aanleg gehoorde getuigen tot de slotsom dat de gemeente het bewijs heeft

37 Uit HR 6 oktober 2006, NJ 2006, 547, AA 2007, p. 371-374 (Meijer-VOF Gebr. Cornelis) blijkt dat een vraag of verzoek snel vertaald moet worden als een vordering, maar er moet minimaal gevraagd zijn.

38 HR 24 januari 2003, NJ 2003, 166.

39 Hof Arnhem 18 december 2007, BC5303. 
geleverd en stelt A in staat om tegenbewijs te leveren waarbij het hof overweegt dat dit tegenbewijs onder meer kan worden geleverd door het overleggen van schriftelijk bewijs, bijvoorbeeld door het alsnog in het geding brengen van de betreffende afrekeningen. Het oordeel over de incidentele vordering wordt aangehouden.

In een andere zaak stellen verweerders in het kader van een procedure ter zake de Wet Voorkeursrecht Gemeente (Wvg) dat de ene verweerder met betrekking tot het perceel in geschil aan de andere verweerder een hypotheekrecht heeft verleend. De gemeente Katwijk stelt dat de vestiging van dit hypotheekrecht de kennelijke strekking heeft gehad om afbreuk te doen aan het voorkeursrecht van de gemeente. Stelplicht en bewijslast van die stelling liggen bij de gemeente, maar de rechtbank stelt bij beschikking van 1 augustus 2007 verweerders in de gelegenheid om over te leggen de overeenkomst welke ten grondslag ligt aan het tussen verweerders gevestigde hypotheekrecht. Het is mij uit hetgeen is gepubliceerd niet duidelijk geworden of die inzageplicht in de beschikking van 1 augustus 2007 was gebaseerd op art. $22 \mathrm{Rv}$, art. 843a Rv of art. $26 \mathrm{Wvg}$. Verweerders weigeren gehoor te geven aan die beschikking, stellende zwaarwichtige redenen te hebben waarover niet meer wordt gesteld dan dat door het bekend maken van de inhoud van die overeenkomst een grote inbreuk op hun privacy wordt gemaakt en dat overlegging botst met de bescherming van hun persoonlijke levenssfeer. Alleen al omdat een verdere feitelijke toelichting ontbreekt, passeert de rechtbank het verweer, constateert dat verweerders dus weigeren die overeenkomst in het geding te brengen en verbindt daaraan het gevolg dat aan de stelplicht van de gemeente geen hoge eisen gesteld kunnen worden en komt tot het oordeel dat de gemeente aan haar stelplicht heeft voldaan. De rechtbank gaat vervolgens uit van de juistheid van die stellingen als onvoldoende gemotiveerd betwist omdat is nagelaten de overeenkomst in het geding te brengen. De rechtbank komt niet meer toe aan bewijslevering en het verzoek van de gemeente wordt toegewezen. ${ }^{40}$

De rechtbank Alkmaar plaatst art. 843a Rv duidelijk in de sleutel van het bewijsrecht en geeft aan de niet nakoming van een bevel tot inzage bewijsrechtelijke gevolgen. Nadat de rechtbank namelijk heeft geconstateerd dat de partij die inzage moest geven (gedaagde in hoofdzaak en in het incident), dit bevel niet heeft opgevolgd, overweegt de rechtbank dat thans lichtere eisen worden gesteld aan de stelplicht van eiser in de hoofdzaak omdat gedaagde het goeddeels onmogelijk voor eiser heeft gemaakt om haar stellingen nader te onderbouwen. Daarnaast geldt dat de rechtbank zwaardere eisen zal stellen aan de betwisting (JRS: de motivering daarvan, neem ik aan) van de stellingen van gedaagde. Eén en ander leidt ertoe dat gedaagde onvoldoende heeft betwist dat er sprake was van betalingsonwil. ${ }^{41}$

40 Rb Den Haag 19 december 2007, BC0911, NJF 2008, 55.

41 Rb Alkmaar 18 februari 2009, BH5897. Zie ook Rb Arnhem 22 april 2009, BI3338 die overweegt dat gedaagde, een autohandel die lampen verkoopt die lijken op de lampen van eiseres, ontwerpster van exclusieve kunst- en lichtobjecten, door het overleggen van facturen zijn stelling dat het wel originele, van eiseres afkomstige lampen betrof, had behoren te onderbouwen. 
Dit is een aantal mooie voorbeelden van de bewijsuitwerking van het inzagerecht.

Uit de hiervoor gegeven gevallen blijkt dat het mogelijk is om de gewone regels inzake stellen en onderbouwen op zij te zetten, althans deze te nuanceren. In dat verband verdient het opmerking dat er nogal wat voor nodig is voordat de rechter tot het oordeel komt dat de normale stel- en bewijsregels en de sancties daarop bij niet nakoming, niet van toepassing zijn. Dat blijkt uit een door De Telegraaf gestart kort geding, ${ }^{42}$ waarin de Staat als gedaagde verdedigt dat het in de Wet op de inlichtingen- en veiligheidsdiensten (WIV) neergelegde geheimhoudingssysteem er impliciet toe strekt dat van onder meer de grondregels van stelplicht en bewijslast zou moeten worden afgeweken. De regels van de WIV brengen namelijk volgens de Staat met zich dat hij slechts in zeer beperkte mate openheid van zaken kan geven, zodat in dit soort zaken de Staat niet is onderworpen aan die stelplicht en bewijslastregels. AG Huydecoper formuleert het in zijn conclusie als volgt:

'De Staat verdedigt immers dat uit het bedoelde systeem van de WIV zou voortvloeien dat hij - de Staat - met een beroep op de geheimhoudingsregels van de WIV in een burgerlijk geding ervan kan afzien om tegen hem (ik bedoel weer: de Staat) aangevoerde stellingen te weerspreken; en in aansluiting daarop kan betogen dat de rechter ervan uit moet gaan dat hem (deze keer bedoel ik: de rechter) geen feitelijke grondslag ter beschikking staat om een oordeel op te baseren: de Staat heeft immers wat betreft de relevante feiten er het (door de WIV "opgelegde") stilzwijgen toe gedaan en "dus" kan de rechter niet beoordelen hoe die feiten liggen en wat daarvan als basis voor zijn oordeel mag dienen. Ik stel daar, voor alle duidelijkheid, de "gewone" regel van burgerlijk procesrecht tegenover: als stellingen van één partij door de andere partij niet deugdelijk (wat meestal ook betekent: deugdelijk gemotiveerd) worden betwist, is de rechter gehouden die stellingen, althans voorzover het gaat om rechten waarover partijen de vrije beschikking hebben, als vaststaand aan te nemen (zie bijvoorbeeld art. 149 lid 1 Rv.).'

Mede naar aanleiding van dit arrest rijst de vraag of er onderdelen van het materiële privaatrecht zijn waarin een vordering tot inzage in het kader van stellen en bewijzen minder snel of in beginsel niet toewijsbaar is. Op sommige terreinen als het gezondheidsrecht zal meen ik niet elke vordering worden toegewezen gelet op 'de gewichtige redenen' van lid 4 van art. 843a Rv, maar ook op dat terrein behoren vorderingen tot inzage in beginsel mogelijk te zijn. Dit geldt ook voor het specifieke terrein van koop-verkoop van ondernemingen waarbij een due diligenceonderzoek is uitgevoerd. Indien geen nadere afspraken zijn gemaakt, behoort een vordering tot inzage in een rapport dat van een dergelijk onderzoek is opgemaakt, aan niet meer te worden getoetst dan aan die bestanddelen van art. 843a Rv waarvan de 
wederpartij betwist dat deze aanwezig zijn. Ik zie geen redenen dat die bestanddelen vervolgens anders zouden moeten worden ingevuld dan bij een verzoek tot inzage van een ander stuk. Indien in het kader van dit onderzoek een geheimhoudingsbeding is afgesproken, dient onderzocht te worden of partijen hiermee een overeenkomst tot het uitsluiten van bewijs hebben willen sluiten. ${ }^{43}$

Het personen- en familierecht is een gebied waarop nader onderscheid gemaakt moet worden. In scheiding- en delingsprocedures en alimentatiezaken moeten volgens mij verzoeken tot inzage welwillend beoordeeld worden. Ook bij de bestaande goederengemeenschap indirect betrokken derden als banken, rechtspersonen en dergelijke waar een ex-partner eventueel vermogen naar toe heeft gebracht of in de vorm van aandelen in heeft gestopt, dienen aan een verzoek tot inzage gehoor te geven. In die gevallen is sprake van een zodanige feitelijke samenhang tussen de verschillende rechtsposities, dat die personen gehouden zijn om informatie te verschaffen. ${ }^{44}$

Bij de vraag of er tussen bepaalde personen familierechtelijke betrekkingen bestaan, zoals die zich voordoet bij bijvoorbeeld een vaderschapsactie waarin (inzage in) DNA wordt gevorderd, wordt het terrein van de grondrechten betreden en gelden andere regels en moet een andere afweging worden gemaakt. Dit is ook zo omdat het bestaan en ontstaan van familierechtelijke rechtsbetrekkingen rechtsgevolgen met zich brengen die niet ter vrije beschikking van partijen staan. ${ }^{45}$ Een weigering om DNA af te staan, kan dus niet zonder meer worden 'bestraft' door daar bewijsrechtelijke gevolgen aan vast te knopen. Volgens Voorhoeve kan echter ook op dit terrein niet alles ongestraft geweigerd worden. $\mathrm{Zij}$ is van mening dat weigering tot medewerking om DNA af te staan door een man die door een kind wordt aangemerkt als biologische vader, in strijd is met de maatschappelijke betamelijkheid ex art. 6: $162 \mathrm{BW}$ en dat medewerking aan een DNA-onderzoek op die basis kan worden gevorderd. ${ }^{46}$ De vraag die vervolgens moet worden beantwoord, is of de inbreuk die een DNA-onderzoek op de lichamelijke integriteit vormt, kan worden gerechtvaardigd in de zin van art. 8 lid 2 EVRM. Zij vindt van wel: de inbreuk is voorzien bij wet (en wel art. 6:162 BW). Het doel, het recht op afstammingsgegevens, is geoorloofd. Tenslotte kan in een concreet geval het recht op afstammingsgegevens zwaarder wegen dan het recht op lichamelijke integriteit, bijvoorbeeld indien de mate van verwekkerschap al aannemelijk is en het bijvoorbeeld in verband met erfelijke aandoeningen voor het kind belangrijk

43 Zie over due diligence en geheimhouding uitgebreid de hoofdstukken 10 en 11 van M. Brink, Due diligence. Een beschouwing over het due diligence onderzoek volgens het Nederlandse recht, Maastricht 2008.

44 M.J. van Laarhoven, Samenhang in rechtsverhoudingen, p. 1.

45 HR 15 februari 2008, BC1860, NJ 2008, 106.

46 M. Voorhoeve, Waarheid bij de gerechtelijke vaststelling van het vaderschap van de verwekker, bijdrage aan de bundel 'Rechten van het kind en ouderlijke verantwoordelijkheid', p. 43-58, Ars Aequi 2008. 
is om te weten wie de vader is. Zij verdedigt dat vervolgens op grond van art. 491 $\mathrm{Rv}$ tot reële executie kan worden overgegaan en de deurwaarder bijvoorbeeld een bevel tot afgifte van een roerend goed als een tandenborstel kan geven. ${ }^{47} \mathrm{Zij}$ rept niet over art. 843a Rv. Toch strandt het schip volgens haar omdat zonder wettelijke regeling het toestemmingsvereiste van art. 7: 450 BW (afd. 7.7.5, de overeenkomst inzake geneeskundige behandeling) in samenhang met art. 8 lid 2 EVRM in de weg staan aan verder onderzoek. Een bevel tot onderzoek kan wel worden gegeven en soms worden afgedwongen; voor een onderzoek zonder medewerking van degene van wie het DNA afkomstig is, is een uitdrukkelijke wetsbepaling nodig, die nog niet bestaat. Een kind kan echter op eigen houtje het materiaal laten onderzoeken omdat, aldus nog steeds Voorhoeve, het leerstuk van onrechtmatig verkregen bewijs niet geldt in het burgerlijk procesrecht. Daar gaat zij volgens mij te kort door de bocht. Dit leerstuk bestaat wel degelijk, doch de Hoge Raad heeft tot dusverre nog geen gevallen voor zich gehad waarbij de inbreuk die op de rechten van een partij is gemaakt, zodanig ernstig waren dat het door die inbreuk verkregen materiaal niet mocht worden gebruikt. ${ }^{48} \mathrm{Ik}$ denk dat in het door Voorhoeve geschetste geval, gelet op het grote belang van de lichamelijke integriteit, de Hoge Raad het bewijsmateriaal buiten beschouwing zal laten. Al met al dient de wetgever hier in te grijpen, waarbij volgens mij de kortste weg die via een ruim geformuleerde inzageregeling is, waarbij ook lichaamsstoffen voortaan mogen worden aangemerkt als een bescheid.

Aan het begin van deze paragraaf heb ik gewezen op het feit dat onevenwichtigheden in bewijsmogelijkheden regelmatig worden opgelost door aanpassing van de stel- en onderbouwingsplicht (of zelfs door een rechterlijk vermoeden of omkering van de bewijslast ${ }^{49}$ ). Uit twee arresten (eventueel bezien in samenhang met het hiervoor behandelde Philips Electronics-VEB-arrest) zou misschien afgeleid kunnen worden dat de Hoge Raad inmiddels bereid is ook een andere weg in te slaan. ${ }^{50} \mathrm{Ik}$ schrijf inmiddels, omdat genoemde twee arresten zich niet goed laten verenigen met Interforce-Rosier, ${ }^{51}$ en dat arrest dan als achterhaald moet worden beschouwd. Uit Interforce-Rosier blijkt dat de Hoge Raad van oordeel is dat aan hoge eisen moet zijn voldaan, voordat de conclusie kan worden getrokken 'dat een partij zich op enig stuk beroept' in de zin van art. $85 \mathrm{Rv}$ en verplicht is dat stuk over te leggen. Vranken heeft in zijn noot in de NJ forse kritiek op dat arrest

47 Zie wat dit betreft ook de noot van J. de Boer onder HR 22 september 2000, NJ 2001, 647.

48 Zie onder meer HR 9 januari 1987, NJ 1987, 928 (Edamse bijstandtrekster), HR 7 februari 1992, NJ 1993, 78 en HR 31 mei 2002, NJ 2003, 589 (Observatiearrest) en M. Kremer, Onrechtmatig verkregen bewijs in civiele zaken, Deventer 1999.

49 Zie Lindijer, nr. 212

50 HR 6 oktober 2006, NJ 2006, 547, JBPR 2007, 6, m.nt. J.G.A. Linssen, AA 2007, p. 371-374, m.nt. H.B. Krans, Meijer-VOF Gebr. Cornelis en HR 27 maart 2009, BH1986, NJ 2009, 254, m.nt. S.F.M.W.

51 HR 30 januari 1998, NJ 1998, 459. 
geuit (zie hiervoor par. 3.2). Die kritiek is volgens mij terecht en dat brengt met zich dat aan dit arrest (inmiddels) niet al te veel waarde moet worden gehecht, en dat elke mogelijkheid om de regel uit dit arrest als achterhaald te beschouwen, moet worden aangegrepen.

Die mogelijkheden zijn te vinden in de twee net genoemde arresten. In de zaak Meijer-VOF gebr. Cornelis vordert Meijer, matroos, achterstallig loon. ${ }^{52} \mathrm{Hij}$ stelt in de systeemvaart te hebben gewerkt en recht te hebben op betaling conform de daarop betrekking hebbende regeling. De stelling in systeemvaart gewerkt te hebben, laat zich goed bewijzen door middel van getuigen als mede-bemanningsleden. Meijer laat dan ook ten overstaan van de rechtbank drie getuigen horen. De rechtbank oordeelt dat het bewijs niet is geleverd en wijst de vordering af. In hoger beroep rept Meijer niet over art. 843a Rv. Hij stelt wel dat de rechtbank de CAO onjuist heeft uitgelegd omdat zij Cornelis niet heeft gelast om het vaartijdenboek in het geding te brengen. Het hof overweegt dat als Meijer met zijn grief wil betogen, dat Cornelis hem voor zijn bewijslevering het vaartijdenboek ter beschikking had moeten stellen, die grief niet slaagt omdat Meijer, mede nu hij drie getuigen heeft laten horen, onvoldoende heeft gesteld

'om de conclusie te kunnen wettigen dat hij in redelijkheid slechts bewijs zou kunnen leveren aan de hand van de in het bezit van Cornelis zijnde gegevens, zodat de eisen van een goede procesorde met zich zouden hebben meegebracht dat Cornelis hem (de gegevens uit) het vaartijdenboek ter beschikking had behoren te stellen.'

Het cassatiemiddel bevat de klacht dat het hof met deze overweging art. 843a Rv heeft geschonden. De Hoge Raad overweegt dat het hof het verzoek van Meijer om Cornelis te gelasten het vaartijdenboek over te leggen, kennelijk heeft opgevat als een vordering tot exhibitie op grond van art. 843a Rv en dat er, gelet op de inhoud van het geschil, sprake is van een geval waarin Meijer overeenkomstig art. 7: $619 \mathrm{BW}$ het recht heeft van Cornelis overlegging te verlangen van zodanige bewijsstukken als hij nodig heeft.

'Uit een en ander volgt dat Meijer een rechtmatig, want uit art. 7: 619 BW voortvloeiend, belang had om op de voet van art. 843a Rv overlegging van het vaartijdenboek van Cornelis te verlangen, zonder gehouden te zijn te stellen, laat staan in voldoende mate, 'dat hij in redelijkheid slechts bewijs zou kunnen leveren aan de hand van in het bezit van Cornelis zijnde gegevens'. 53

526 oktober 2006, NJ 2006, 547, JBPR 2007, 6, m.nt. J.G.A. Linssen, AA 2007, p. 371-374, m.nt. H.B. Krans, Meijer-VOF Gebr. Cornelis.

53 Zie Lindijer, nr. 435 die het mogelijk acht dat de rechter aan de eisen van een goede procesorde, ambtshalve aan te vullen rechtsgronden ontleent. In Interforce-Rosier was dat niet het geval; in Meijer-vof Cornelis (van na het proefschrift van Lindijer) wel? 
Het tweede arrest betreft een alimentatiegeschil waarin de man onder meer vraagt dat het hof zal bepalen dat de vrouw de jaarcijfers 2000 tot en met 2003 van haar onderneming, de aangiftes inkomstenbelasting en definitieve aanslagen inkomstenbelasting 2000 tot en met 2002, 2004 en 2005 in het geding moet brengen. ${ }^{54}$ Het hof wijst dit deel van de vordering af omdat het van oordeel is dat dit deel van de vordering tot een mogelijk executiegeschil behoort. De Hoge Raad oordeelt onder meer dat het verzoek betreffende de overlegging van stukken er in wezen toe strekt dat de rechter verzocht wordt gebruik te maken van zijn in art. $22 \mathrm{Rv}$ neergelegde bevoegdheid om de vrouw te bevelen bepaalde stukken over te leggen.

Met deze twee arresten, in onderling verband en samenhang bezien, kan verdedigd worden dat de rechter onder omstandigheden gehouden is om een bevel te geven aan een partij om een bepaald stuk in het geding te brengen. Aldus hoeven onevenwichtigheden in bewijsmogelijkheden niet alleen opgelost te worden door een aanpassing van de stel- en onderbouwingsplicht, maar is het ook mogelijk om deze onevenwichtigheden op te lossen via de weg van art. 22 en/of 843a Rv. 



\section{De inhoud van de bestanddelen van art. 843a lid $1 \mathrm{Rv}$ in de literatuur en de jurisprudentie}

\subsection{Inleiding}

\subsubsection{Het rechtmatig belang}

In dit hoofdstuk passeert de literatuur en de jurisprudentie betrekking hebbend op lid 1 van art. 843a Rv de revue. ${ }^{1}$ Dat gebeurt per bestanddeel, te beginnen met het begrippenpaar 'rechtmatig belang'.

De grenzen van de exhibitieplicht hebben niet alleen veel hoofdbrekens gekost, zoals in het losbladig commentaar Burgerlijke Rechtsvordering onder nr. 5 valt te lezen, die grenzen doen dat nog steeds. Die zitten niet in de abstracte formulering: het woordduo 'rechtmatig belang' is eenvoudig genoeg te formuleren. De inhoud en grenzen van dit begrippenpaar zijn minder eenvoudig vast te stellen. Dit ligt niet alleen aan deze twee woorden, maar ook aan juridisch-maatschappelijke ontwikkelingen, waarin steeds meer rechten met elkaar in botsing komen. Tenslotte is de mate waarin men de waarheidsvinding van belang acht, eveneens van invloed op de inhoud van 'rechtmatig belang'. Uit de voorgaande hoofdstukken blijkt immers dat de invulling van de diverse bestanddelen van art. 843a Rv mede afhangt van de wijze waarop tegen de civiele procedure wordt aangekeken. Indien het uitgangspunt is dat in een civiele procedure de materiële waarheid aan het licht moet komen, brengt dit uitgangspunt al snel mee dat het recht op inzage ruimhartig wordt uitgelegd. Daar waar de materiële waarheidsvinding minder van belang wordt geacht, gaat men al snel over tot een minder ruime uitleg van het recht op inzage. Het vraagstuk omtrent de partijautonomie en de lijdelijkheid van de rechter is hierbij tevens van belang in die zin dat de invulling van deze begrippen ook afhangt van de wijze waarop de rechter zich opstelt: sterk activistisch of enkel en alleen lezend wat partijen hem voorleggen en luisterend naar wat partijen hem vertellen. Ook in de hierna aan de orde gestelde literatuur blijkt dat de nadere, concrete invulling van de inhoud van de verschillende bestanddelen afhangt van het standpunt van de schrijver omtrent de bedoeling van de civiele procedure: materiële waarheidsvinding of strijd tussen partijen waarin zij zelf aan de orde moeten stellen wat zij van belang vinden en willen inzien. Bijna alle schrijvers stellen bij de uitleg van

1 Zie voor een kort algemeen overzicht M.E.L. Klein, De verplichting tot het overleggen van bescheiden in het familie- en erfrecht, EB Tijdschrift voor scheidingsrecht 2009, p. 68-71. 
'rechtmatig belang' voorop dat hiermee wordt voorkomen dat een partij op goed geluk aan het vissen slaat. ${ }^{2}$

Hoyng kan de eerste worden genoemd die zich bezig heeft gehouden met de inhoud van verschillende begrippen in art. 843a Rv. Hij is ruimhartig in de uitleg van de woorden 'rechtmatig belang'. Hij is van mening dat er sprake is van rechtmatig belang indien een partij de stukken nodig heeft ter bepaling van feiten op grond waarvan een rechtsbetrekking kan worden vastgesteld. ${ }^{3}$

In 1994 kwamen Barendrecht en Van den Reek na een korte weergave van de geschiedenis van het recht op inzage, tot de conclusie dat de woorden 'het enkele belang op vertoning' te ruim zijn, en daarmee ontoereikend, om de inhoud van 'rechtmatig belang' weer te geven. ${ }^{4}$ Er moet sprake zijn van een door het objectieve

2 Voor de zekerheid herhaal ik dat ik het begrip 'fishing expedition' zoveel mogelijk vervang door 'vissen'. Over dit visverbod onder andere W.A. Hoyng, Vier procesrechtelijke wensen, In het nu, wat worden zal (Schoordijkbundel), Kluwer 1991, p. 105-118, J.G.A. Linssen in zijn noten in JBPR bij Rb Zutphen, 7 mei 2003, AI1718, JBPR 2003, 66 en bij HR 6 oktober 2006, JBPR 2007, 6, A.I.M van Mierlo en J.H. van Dam-Lely, Procederen bij dagvaarding in eerste aanleg, Serie burgerlijk proces en praktijk, Kluwer, Deventer 2003, p. 73, J.F. Garvelink en P.F. Hopman, Verboden te vissen: informatieplicht van banken en afdwingbaarheid daarvan, Tijdschrift voor Effectenrecht 2004, p. 11-15, B. Winters en J. Vossenberg, Vissen in het enquêterecht, Vennootschap\&Onderneming 2005, p. 62-65, Ekelmans in TCR en in zijn boek en N.J. Margetson, De grenzen van de exhibitieplicht, Praktisch Procederen 2007, p. 143-146. Laatstgenoemde stelt dat het niet de bedoeling is om als een jager zonder te kijken een schot hagel in de lucht af te vuren waarna pas wordt gekeken wat er zoal uit de lucht is komen vallen. Rb Den Bosch 22 maart 2007, BA1352, NJF 2007, 213 overweegt dat niet met voldoende stelligheid kan worden aangenomen dat Novio Net valse declaraties heeft ingediend, zodat de vordering tot inzage, mede nu de frauduleuze handelingen onvoldoende zijn omschreven, als een vordering tot het vissen naar stukken moet worden afgewezen. Hof Den Haag 9 oktober 2007, BB6971 overweegt dat er geen sprake is van rechtmatig belang omdat verzoeker Deloitte\&Touche eigenlijk geen idee heeft of er in de door haar gevraagde stukken iets staat wat haar standpunten kan ondersteunen. Nu zij niet met voldoende concreetheid heeft gesteld wat de vele door haar gevraagde stukken te harer voordele inhouden, kan niet goed worden beoordeeld of zij wel een rechtmatig belang heeft. Rb Rotterdam 1 april 2009, BI1747 overweegt dat de strenge eisen die aan een verzoek ex art. 843a Rv in de jurisprudentie en literatuur waarop PWS zich beroept worden gesteld, met name zien op situaties waarin het de eisende partij in de (veelal nog aanhangig te maken) procedure was die een dergelijk verzoek deed. In die situaties doet zich het risico van de fishing expedition immers het meest gevoelen. Als, zoals in dit geval, gedaagden in een reeds aangevangen procedure een dergelijk verzoek doen, vloeit het rechtmatig belang veel sneller voort uit het gegeven dat, ook als de bewijslast bij de eisende partij ligt, een verweer gemotiveerd en onderbouwd moet worden om te kunnen voorkomen, dat de vordering aanstonds wordt toegewezen.

3 W.A. Hoyng, Vier procesrechtelijke wensen, In het nu, wat worden zal (Schoordijkbundel), Kluwer 1991, p. 105-118.

4 J.M. Barendrecht en W.A.J.P. van den Reek, Exhibitieplicht en bewijsbeslag, WPNR 6155 (1994), p. 739-745. In HR 23 februari 1996, NJ 1996, 434, een zaak waarin een partij vordert dat de wisselcrediteur veroordeeld wordt om de wissels voor handtekeningonderzoek bij een notaris te deponeren voor grafologisch onderzoek, wijst AG Vranken op deze bijdrage in het WPNR en concludeert dat hij even aan art. 843a Rv heeft gedacht maar er aan twijfelt, zonder die twijfel verder uit te werken, of dit wetsartikel in deze zaak wel van toepassing is. Vletter-van Dort volgt 
recht erkend bijzonder belang op vertoning dat zwaarder weegt dan een ander betrokken belang als bijvoorbeeld het bedrijfsgeheim. ${ }^{5}$ Duidelijk is volgens hen dat het om een bewijsbelang moet gaan. ${ }^{6}$ Een tweede relevant gezichtspunt is volgens hen dat de eisen van een goede procesorde meebrengen dat partijen in een procedure zoveel mogelijk over gelijke mogelijkheden moeten kunnen beschik-

op p. 252-253 Barendrecht en Van den Reek waar zij schrijft dat inzage wordt verleend indien dit noodzakelijk is wegens het processuele gelijkheidsbeginsel in verband met het vaststellen van een rechtsbetrekking waarin degene die inzage vordert, partij is.

5 Volgens T. Koopmans in zijn noot onder HR 29 september 2000, NJ 2001, 95 heeft een nietgeorganiseerde werkgever op de voet van art. 843a Rv het rechtmatig belang om van een werkgeversorganisatie overlegging te vorderen van stukken waaruit zou moeten blijken dat aan de representativiteitseis is voldaan. Als ondernemers een werkgeversorganisatie verlaten uit afkeer van CAO-beleid, hebben zij er duidelijk belang bij dat de CAO niet, via de omweg van de verbindendverklaring, toch op hun ondernemingen zal worden toegepast. En als hun uittreden uit de organisatie deze minder representatief heeft gemaakt, hebben zij er zeker rechtmatig belang bij te weten op welke wijze toch aan de representativiteitseis kan zijn voldaan.

6 Zie bijvoorbeeld Pres. Rb Amsterdam 15 mei 1997, KG 1997, 212 die overweegt dat ‘... de Nederlandse procesorde aldus is ingericht, dat partijen eerst aan hun stelplicht dienen te voldoen, waarna het woord aan de rechter is om te beslissen welke stellingen door welke partij bewezen dienen te worden. Het is in het algemeen in strijd met die procesorde om -zoals BAM in dit geding vordert- de andere partij reeds voordat de hiervoor bedoelde beslissingen genomen zijn, te dwingen het bewijsmateriaal waarover zij beschikt over te leggen of opgave op grond daarvan te verlangen,...'. Hof Den Haag 11 april 2008, BD0694, NJF 2008, 245 (ook genoemd en besproken door H.A. Dragstra, De exhibitieplicht in het arbeidsrecht, TRA 2009, p. 15-18) overweegt dat indien eisers de inzage wensen voor zover zij zouden moeten aantonen dat hun inkomen niet aanzienlijk te hoog was, er geen sprake is van rechtmatig belang omdat ten tijde van de uitspraak van het vonnis in het incident geenszins vaststaat dat op eisers een dergelijke bewijslast zal komen te rusten. Zie ook Rb Middelburg 7 mei 2008, BD3047 oordelend dat nu gedaagde de stelling waar de bescheiden betrekking op zouden hebben nog niet specifiek heeft betwist omdat gedaagde nog geen conclusie van antwoord heeft genomen, gedaagde geen onredelijk voordeel geniet en eiser geen onredelijk nadeel lijdt. Daarom is niet voldaan aan het criterium redelijk belang. Rb Zutphen 23 juli 2008, BD8506 is van oordeel dat het bezien in het licht van de ontkenning van de bewoning (van een vakantiehuis) door gedaagde voldoende aannemelijk wordt geacht dat de gemeente er belang bij heeft om kennis te nemen van de gegevens van het nutsgebruik omdat geoordeeld kan worden dat het gebruik van de nutsvoorzieningen een aanwijzing kan vormen voor de wijze waarop de woning wordt bewoond. De mate van gebruik van die nutsvoorzieningen vormen niet hét bewijs, maar kan wel aan het te leveren bewijs bijdragen.A.A.M. Menken, Exhibitieplicht ex art. 843a Rv, V\&O 1998, p. 53-56 schrijft dat daar waar op het moment van het instellen van een vordering nog geen rechtmatig belang bestaat, dit rechtmatig belang wel is ontstaan op het moment dat de verzoekende partij een bewijsopdracht heeft gekregen in een procedure. P. van Uchelen en B. Verbunt, Vordering tot overlegging van due diligencerapporten ex art. 843a Rv, Ondernemingsrecht 2005, merken op p. 56 op dat het vereiste van een rechtmatig belang de bewijspositie van eiser betreft ten aanzien van stukken die alleen de tegenpartij bezit. Uit het oogpunt van equality of arms mag dan van de wederpartij worden verwacht dat het ontbrekende stuk wordt geproduceerd. H. Uittien, Gedwongen verstrekking van due diligence-rapportages, Tijdschrift voor de ondernemingsrechtpraktijk 2007, p. 19-23 meent dat er sprake is van 'rechtmatig belang' indien het belang een rechtsvordering rechtvaardigt conform het bepaalde in art. 3:303 BW waarbij de hoofdvordering nog niet volledig duidelijk hoeft te zijn. 
ken om hun standpunten te onderbouwen. Ruimhartig zijn zij niet: zij formuleren namelijk als regel dat inzage, afschrift of uittreksel gelet op het processuele gelijkheidsbeginsel noodzakelijk dient te zijn in verband met de vaststelling van een rechtsbetrekking waarin degene die vertoning vordert partij is. Zij komen waarschijnlijk an dit 'noodzakelijkheidscriterium' omdat zij in hun artikel vooral rekening houden met een tegenpartij die onwillig is om inzage te verschaffen omdat de informatie betrekking heeft op bedrijfsgeheimen. ${ }^{7}$

Conform Barendrecht en Van den Reek in hun bijdrage in het WPNR en de laatste opmerking van Van den Reek in zijn boek ook Van der Wiel in zijn artikel en in zijn boek. ${ }^{8} \mathrm{Hij}$ stelt bij zijn uitleg van de woorden 'rechtmatig belang' in navolging van de parlementaire geschiedenis voorop dat dit begrip ruimer is dan 'enig recht kan doen gelden'. Het feit dat het moet gaan om het bewijsbelang brengt volgens hem met zich dat rechtmatig belang ontbreekt indien de te bewijzen feiten niet worden weersproken ${ }^{9}$ en indien de door eiser gestelde inhoud van het document waarvan inzage wordt gevraagd niet geschikt is om bij te dragen aan het bewijs van de door eiser ingenomen stelling of wanneer bewijs van deze stellingen niet kan leiden tot toewijzing van het gevorderde. Van der Wiel is verder van mening dat bij de uitleg van 'rechtmatig belang' ook lid 4 van art. 843a Rv in ogenschouw moet worden genomen voor zover inhoudende 'indien redelijkerwijs aangenomen kan worden dat een behoorlijke rechtsbedeling ook zonder verschaffing van de gevraagde gegevens is gewaarborgd'. In zijn boek noemt Van der Wiel het vereiste van rechtmatig belang de belangrijkste drempel voor toewijzing van een vordering op grond van art. 843a Rv. Het is krachtens de parlementaire geschiedenis ruimer bedoeld dan 'enig recht kan doen gelden'. ${ }^{10}$

Winter noemt in een noot onder een vonnis van de rechtbank Rotterdam het woord 'relevant' waarmee hij ook een nadere inhoud aan de woorden 'rechtmatig

7 In zijn boek schrijft Van den Reek op p. 49 dat het in elk geval dient te gaan om een bewijsbelang en dat dit belang in het (objectieve) recht verankerd dient te zijn. A.A.M. Menken, Exhibitieplicht ex art. 843a Rv, V\&O 1998, p. 53-56 is ook van mening dat het belang van eiser bewijsrechtelijk van aard moet zijn, waaraan hij nog toevoegt dat voor toewijzing van de vordering het belang van eiser zwaarder moet wegen dan het belang van gedaagde.

8 B.T.M. van der Wiel, De exhibitieplicht te terughoudend opgevat, NbBW 2004, p. 58-60, in zijn boek op p. 52 en verder.

9 Rb Amsterdam 22 juli 2009, BJ4427: het ligt voor de hand dat A de rekeningafschriften waarin Dexia inzage vordert heeft bekeken, waaraan het (bewijs)vermoeden wordt ontleend dat zij vanaf de eerste (termijn)betaling van voormelde rekening met betrekking tot de lease-overeenkomst wetenschap heeft gehad van het bestaan van deze lease-overeenkomst, zodat de inzagevordering kan worden afgewezen.

10 A. Keizer, Exhibitieplicht bij overnamegeschillen, V\&O 2008, p. 53-57 schrijft dat het vereiste van 'rechtmatig belang' slechts marginaal mag worden getoetst, omdat art. 843a Rv ziet op verstrekking zowel binnen als buiten rechte en dat het dient te gaan om bewijsbelang. 
belang' lijkt te willen geven. ${ }^{11}$ Hij schrijft dat een procespartij inzage dient te kunnen krijgen voor zover inzage noodzakelijk is om bewijs te kunnen leveren. Wat interne stukken betreft als notulen e.d. zou volgens hem een terughoudende opstelling zijn geboden.

Von Schmidt auf Altenstadt ${ }^{12}$, Linssen ${ }^{13}$, Van Mierlo ${ }^{14}$ en Van der Wiel ${ }^{15}$ herhalen allen de woorden van de minister uit de parlementaire geschiedenis waar hij zegt dat de bezitter van het stuk niet nodeloos mag worden lastiggevallen.

Linssen noemt bij de uitleg van de woorden 'rechtmatig belang' niet alleen de nodeloosheid. Volgens hem brengen deze woorden ook met zich dat de vordering tot het verstrekken van informatie er niet op gericht mag zijn om bescheiden te verkrijgen ter onderbouwing van een vorderingsrecht waarvan men überhaupt niet of niet met (voldoende) zekerheid weet of men dit geldend kan maken. ${ }^{16}$

11 J.W. Winter, Center Parcs, art. 843a Rv, discovery op z'n Hollands, TVVS 1997, p. 55-56. Hij annoteert hier een niet gepubliceerd vonnis van 3 oktober 1996, rolnr. 92/5269 van de Rb Rotterdam. W.P. Wijers en A.J. Haasjes, Exhibitie in het (ondernemings)recht, O \& F 2006, p. 49-62 schrijven dat het bij 'rechtmatig belang' moet gaan om bescheiden die relevant zijn voor een door de rechter te nemen beslissing. Op voorhand moet vaststaan dat de opgevraagde bescheiden kunnen bijdragen aan de onderbouwing van stellingen.

12 P.J.M. von Schmidt auf Altenstadt, Opening van zaken, TCR 2002, p. 8-14. Zie par. 2.2.1.

13 J.G.A. Linssen in zijn noot onder Rb Zutphen, 7 mei 2003, AI1718, JBPR 2003, 66.

14 A.I.M van Mierlo en J.H. van Dam-Lely, Procederen bij dagvaarding in eerste aanleg, Serie burgerlijk proces en praktijk, Kluwer, Deventer 2003, p. 73.

15 B.T.M. van der Wiel, De exhibitieplicht (te) terughoudend opgevat, NbBW 2004, p. 58-60. B. Winters en J. Vossenberg, Vissen in het enquêterecht, Vennootschap\&Onderneming 2005, p. 62-65 menen dat art. 843a Rv een beperkte reikwijdte heeft hetgeen mede wordt veroorzaakt door de woorden 'rechtmatig belang'. Ekelmans schrijft in zijn artikel in TCR 2005 en in zijn boek dat het bestanddeel 'rechtmatig belang' de mogelijkheid biedt om belangen bij verstrekking van bescheiden vrijmoedig af te wegen. Hierbij kan plaats zijn voor enige lankmoedigheid, zoals ook vragen aan een getuige niet strikt tot het probandum beperkt plegen te blijven. Het verzoek op inzage mag niet te ver verwijderd raken van wat relevant is, want dan verschiet het, zo meent hij, van kleur richting ongeoorloofd vissen. Hij bepleit een voor verzoeker milde benadering, die hij vanzelfsprekend vindt indien bijvoorbeeld de tegenpartij eerst bewijsvergaring heeft verhinderd of gewoon geweigerd. De milde benadering past volgens hem ook bij de meer actieve opstelling die de rechter zich heeft eigen gemaakt bij het gebruik van de comparitie na antwoord. Zie ook AG Timmerman, nr. 4.8 van zijn conclusie bij HR 23 oktober 2009, BJ7331.

16 J.G.A. Linssen in zijn noot onder Rb Zutphen, 7 mei 2003, AI1718, JBPR 2003, 66. Linssen heeft deze woorden herhaald in zijn noot onder HR 6 oktober 2006, JBPR 2007, 6, waaraan hij daar nog toevoegt dat de bescheiden naar maatstaven van redelijkheid noodzakelijk zijn. E.M. Wesselingvan Gent, To fish or not to fish, that's the question, Het verzamelen van feiten en bewijs: begrenzing versus verruiming, een kruisbestuiving tussen civiel procesrecht en ondernemingsprocesrecht, Nederlandse Vereniging voor Procesrecht, Boom Juridische uitgevers Den Haag 2006, p. 105 vindt dat de vordering tot het verstrekken van informatie er niet op gericht mag zijn bescheiden te verkrijgen ter onderbouwing van een vorderingsrecht waarvan men überhaupt niet met zekerheid weet of men dit geldend kan maken. Nagegaan moet worden of het verstrekken van de gegevens noodzakelijk is voor effectuering van het materiële recht dat de eisende partij geldend maakt respectievelijk wil maken. Janssen schrijft in zijn noot in JBPR onder Rb Den Haag 21 september 2005, AV7698, JBPR 2006, 25, B9-954 bijna letterlijk hetzelfde. Hij voegt daar nog wel aan toe 
De jurisprudentie over het begrip rechtmatig belang is weinig richtinggevend en bestaat voor het overgrote deel uit uitspraken die enkel van belang zijn voor de betreffende specifieke casus. De enkele uitspraken waarin meer is te vinden dan een casuïstisch oordeel worden hierna in de tekst behandeld. De overige jurisprudentie is in voetnoten vermeld.

In het Observatiearrest is art. 843a Rv niet uitgebreid aan de orde gekomen, maar het arrest is wel van belang bij de uitleg van het bestanddeel 'rechtmatig belang' in art. 843a Rv omdat het arrest een nadere inkleuring van het begrip 'rechtmatig belang' geeft, maar dan vanuit een vordering waarbij geen inzage in stukken maar juist vernietiging van stukken werd gevraagd. ${ }^{17}$ In het kort geding dat tot dit arrest leidde, vraagt eiser aan de WA-verzekeringsmaatschappij Aegon om ter beschikkingstelling van alle foto- en filmopnames en wel zodanig dat Aegon geen enkele opname of kopie daarvan meer bezit. Van belang is dat deze eiser in een al aanhangig zijnde bodemzaak schadevergoeding eist wegens een door hem bij een aanrijding opgelopen whiplash. Tijdens deze bodemprocedure bleek dat hij door de WA-verzekeringsmaatschappij met behulp van camera's is geobserveerd omdat die maatschappij wilde controleren of de door de man gestelde fysieke beperkingen wel bestonden. Voordat die foto- en filmopnames in de bodemprocedure werden overgelegd, vordert de man in kort geding onder meer dat deze opnames eerst aan hem ter beschikking gesteld moeten worden. In essentie legt hij aan deze vordering ten grondslag dat de nadere onderzoeken en in het bijzonder de stelselmatige observaties van hemzelf, inbreuk hebben gemaakt op zijn privéleven en jegens hem onrechtmatig zijn. Hij beroept zich hierbij op art. 8 EVRM en art. 10 van de Wet persoonsregistratie. De president wijst de vordering af. Het hof is het met deze afwijzing eens en overweegt dat zo al door de gedragingen van Aegon inbreuk is gemaakt op het privéleven van de man, daarmee niet zonder meer is gegeven dat Aegon onrechtmatig heeft gehandeld. Dat hangt immers af van de omstandigheden van het geval, zoals de wijze waarop inbreuk is gemaakt, de duur en intensiteit daarvan en het doel waarmee dit is geschied. De Wet persoonsregistratie bevat in elk geval geen verbod op handelingen zoals Aegon heeft verricht. Op de cassatieklacht, inhoudende dat Aegon verplicht is het door haar

\footnotetext{
dat de rechter bij de beantwoording van de vraag of er sprake is van rechtmatig belang zorgvuldig moet nagaan of het verstrekken van gegevens noodzakelijk is voor effectuering van het materieel recht dat de eisende partij geldend maakt of wil maken. J.F. Garvelink en P.F. Hopman, Verboden te vissen: informatieplicht van banken en afdwingbaarheid daarvan, Tijdschrift voor Effectenrecht 2004, p. 11-15 geven meer een uitgangspunt dan een definitie, waarbij dit uitgangspunt een zo beperkt mogelijke uitleg lijkt te zijn. Zij stellen namelijk bij hun uitleg van dit bestanddeel voorop dat een belangenafweging moet worden gemaakt waarbij, als ik hen goed begrijp, alle belangen nauwkeurig moeten worden afgewogen en dat ook nog eens met een terughoudend uitgangspunt. Dit leiden zij af uit de Memorie van Toelichting. Zie ook hof Leeuwarden 4 augustus 2009, BJ4901 die de gestelde rechtsbetrekking onvoldoende aannemelijk acht en de inzagevordering afwijst als 'fishing expedition'.

17 HR 31 mei 2002, NJ 2003, 589, m.nt. Vranken.
} 
verzamelde feitenmateriaal aan de man ter beschikking te stellen zodat hij dat materiaal desgewenst zelf in het geding kan brengen en de volledigheid en authenticiteit kan controleren, antwoordt de Hoge Raad dat een zo vergaande verplichting noch uit het bepaalde van art. 843a Rv noch uit het beginsel van 'equality of arms' voortvloeit. Deze zaak betreft dus min of meer een 'omgekeerd inzagerecht', waarbij niet de verkrijging van bewijsmateriaal het doel was, maar juist de vernietiging van bewijsmateriaal: de man vorderde afgifte van het materiaal om het te vernietigen. Het mocht volgens hem niet in de bodemprocedure worden ingebracht. Zoals Vranken in zijn noot stelt, gaat een dergelijke vordering alle perken van de exhibitieplicht van art. 843a Rv te buiten. Aldus bezien heeft de man geen rechtmatig belang op afgifte van het materiaal.

Het hof Den Bosch is van oordeel dat het bij de vraag of er sprake is van rechtmatig belang moet gaan om stukken waarbij eiseres een direct en concreet belang heeft welk belang in het voorliggende geval aanwezig is omdat zij inzage in de gevraagde stukken nodig heeft ter voorbereiding van een contra-enquête aan haar $^{\text {zijde. }}{ }^{18}$

De rechtbank Utrecht geeft in twee uitspraken een algemene beschouwing over de inhoud van het bestanddeel rechtmatig belang. Zij oordeelt dat het niet noodzakelijk is dat de gevraagde bescheiden van doorslaggevende betekenis zijn voor het nemen van de beslissing omdat een inzagevordering ook buiten het kader van een procedure kan worden ingesteld. Er is sprake van rechtmatig belang indien de gevraagde bescheiden relevant zijn voor het bepalen door de verzoekende partij

18 Hof Den Bosch 14 oktober 2003, AM7927. In Rb Zutphen 7 mei 2003, Jbpr 2003, 66 m.nt. Linssen, wenst Leisureplan op de voet van art. 843a Rv-oud onder meer 'de volledige correspondentie' tussen de Rabobank en partij B over de periode november 2001 tot en met april 2002, betrekking hebbend op de ingeleide executoriale verkoop. De rechtbank overweegt dat niet bij voorbaat kan worden uitgesloten dat Leisureplan als gevolg van de door haar aan de Rabobank verweten gedragingen, waarbij het niet alleen gaat om de concrete voorbereiding van de voorgenomen executoriale verkoop maar ook om de daaraan voorafgaande besprekingen tussen de Rabobank enerzijds en B anderzijds, schade geleden heeft. Aldus heeft Leisureplan een rechtmatig belang bij haar vordering tot inzage. Idem Rb Groningen 22 november 2002, NJ 2003, 102 in een zaak waarin Dekker bv bij werkzaamheden een glasvezelkabel van de KPN beschadigt, waardoor een waarschuwingssysteem van een klimaatregelingcomputer van een kuikenfokbedrijf van Jonkman uitvalt. De klimaatregeling valt door niet aan Dekker toe te rekenen oorzaken uit. Jonkman kan niet gewaarschuwd worden omdat het waarschuwingssysteem is uitgevallen en een groot aantal kuikens overlijdt. Jonkman vordert schadevergoeding van Dekker. In die procedure vordert Dekker in een incident op de voet van art. 843a Rv-oud 'afschriften van stukken met betrekking tot de contractuele verhouding tussen Jonkman enerzijds en KPN, de leveranciers en onderhoudsmonteurs van het waarschuwingssysteem anderzijds evenals de relevante correspondentie tussen deze partijen in verband met en naar aanleiding van de schade aan Dekker te verschaffen'. De rechtbank oordeelt 'dat Dekker ... voldoende gemotiveerd haar rechtmatig belang bij het verkrijgen van afschriften van genoemde stukken -de bepaling van de mogelijkheid tot het nemen van regres op mogelijke hoofdelijke mededebiteuren- heeft aangegeven' en wijst de vordering toe. Rb Alkmaar 30 augustus 2007, BB2608 oordeelt dat een vereniging van eigenaars die bouwtekeningen vordert van de verkoper van de appartementen rechtmatig belang heeft. 
van haar rechtspositie. Indien het verzoek wordt gedaan binnen een gerechtelijke procedure, is onder meer aan deze eis voldaan, indien de bescheiden van belang zijn voor het onderbouwen van een niet op voorhand kansloze vordering of verweer. ${ }^{19}$

Het hof Arnhem oordeelt dat het op de weg ligt van de partij die exhibitie verlangt om voldoende concrete feiten en omstandigheden te stellen waaruit naar normale ervaringsregels de mogelijkheid van aansprakelijkheid kan worden afgeleid; voorts zal deze partij aannemelijk moeten maken dat de verwezenlijking en handhaving van het materiële recht de gevraagde exhibitie verlangt. ${ }^{20}$

In de jurisprudentie is enkele malen de vraag aan de orde geweest of een crediteur inzage kan vorderen in financiële gegevens van een debiteur ter beantwoording van de vraag of verhaal op de debiteur mogelijk is. Richtinggevend zou wat dat betreft kunnen zijn HR 20 september $1991 .{ }^{21}$ In dat arrest overweegt de Hoge Raad namelijk dat een schuldenaar in beginsel verplicht is

'... een schuldeiser die een veroordeling tot betaling van een geldsom jegens hem verkreeg, inlichtingen omtrent zijn inkomens- en vermogenspositie en omtrent voor verhaal vatbare goederen te verschaffen'.

19 Rb Utrecht 12 september 2007, BB3722, NJF 2007, 544. Op 18 maart 2009, BH6556 overweegt dezelfde rechtbank dat er sprake is van rechtmatig belang indien de gevraagde bescheiden relevant zijn voor het bepalen door de verzoekende partij van haar rechtspositie. Indien het verzoek binnen een procedure wordt gedaan, is onder meer aan deze eis voldaan, indien de bescheiden van belang zijn voor het onderbouwen van een niet op voorhand kansloze vordering of kansloos verweer. Zie ook Rb Den Haag 23 oktober 2003, JOR 2004, 63. In deze zaak waarin eisers van hun beleggingsbank kopieën van op band opgenomen gesprekken tussen hen en de bij de bank werkzame beleggingsadviseur vragen, wijst de rechtbank de vordering af omdat op voorhand een aantal omstandigheden erop wijst dat eisers in een bodemprocedure niet in het gelijk gesteld zullen worden. Uitgebreid over dit vonnis B.T.M. van der Wiel, De exhibitieplicht (te) terughoudend opgevat, NbBW 2004, p. 58-60.

20 Hof Arnhem 2 december 2008, BH2816. Hetzelfde hof overweegt op 28 april 2009, BI4184 dat zolang nog niet vaststaat dat met het gepachte een melkquotum samenhangt, de verpachter die ontbinding van de pachtovereenkomst vordert (nog) geen belang heeft bij het overzicht van de Centrale Organisatie Superheffing.

21 HR 20 september 1991, NJ 1992, 552, m.nt. J.B.M.V. (Tripels-Masson), zie over dit arrest ook par. 3.3. Zie ook AG Huydecoper bij HR 21 januari 2005, AS3534, NJ 2005, 249 die opmerkt dat voor een ieder geldt, dat hij ten opzichte van zijn crediteuren tot een zekere medewerking/ informatieverschaffing verplicht is indien het gaat om verhaal voor vorderingen van crediteuren en dat in dat verband art. 843a Rv aan iedereen die een rechtmatig belang heeft, aanspraak toekent op inzage van gegevens aangaande een rechtsbetrekking. Deze bepaling, zo vervolgt hij, geeft aan de ene kant een ruim bemeten aanspraak, doordat niet meer wordt vereist dan een beroep op een rechtmatig belang. 
De rechtbank Zwolle-Lelystad en de rechtbank Arnhem wijzen een dergelijke vordering af. ${ }^{22}$ De rechtbank Dordrecht wijst een dergelijke vordering toe. ${ }^{23}$

In een aantal uitspraken wordt de vraag beantwoord in hoeverre het bestaan van de achterliggende vordering, al dan niet voorshands, aannemelijk moet zijn. De rechtbanken Amsterdam ${ }^{24}$, Rotterdam ${ }^{25}$ en Alkmaar ${ }^{26}$ zijn van oordeel dat er geen sprake is van rechtmatig belang indien die achterliggende vordering voorshands niet aannemelijk is ${ }^{27}$ maar als motivering wordt ook gebruikt dat een stelling te zeer berust op vermoedens en hypotheses, ${ }^{28}$ of dat bij de voorshands

22 Rb Zwolle-Lelystad 11 mei 2007, BA502: eiseres, alimentatiegerechtigde, vordert in kort geding veroordeling van gedaagde om alle justificatoire bescheiden waaruit zijn inkomen en vermogenspositie blijkt, over te leggen. De rechtbank is van oordeel dat deze vordering vooral is gericht op het realiseren van verhaal en dat art. 843a Rv niet is geschreven om een verhaalsonderzoek te doen. Rb Arnhem 26 maart 2008, BC8823: Ballast Nedam vordert op grond van onrechtmatige daad grote geldbedragen van een aantal gedaagden. In diezelfde dagvaarding vordert zij in een incident op de voet van art. 843a Rv dat gedaagden worden veroordeeld om inlichtingen te verschaffen omtrent hun inkomen en vermogenspositie en voor verhaal vatbare goederen. De rechtbank wijst de vordering af omdat art. $475 \mathrm{~g} \mathrm{Rv}$, inhoudende dat een schuldenaar verplicht is desgevraagd zijn bronnen van inkomsten op te geven, in de afdeling staat die over executoriaal derdenbeslag handelt en op die situatie is toegeschreven. De situatie van HR 20 september 1991, NJ 1992, 552 doet zich volgens de rechtbank niet voor omdat daarin wordt gesproken over de verplichting van de schuldenaar om 'een schuldeiser die een veroordeling tot betaling van een geldsom jegens hem verkreeg' inlichtingen omtrent zijn inkomens- en vermogenspositie te verschaffen.

$23 \mathrm{Rb}$ Dordrecht 5 januari 2006, AU9320, overwegende dat niet wordt uitgesloten dat art. 843a Rv ook strekt tot verkrijging van informatie om verhaalsmogelijkheden zeker te stellen, welk verzoek in dit geval ook voldoende specifiek is.

$24 \mathrm{Rb}$ Amsterdam 6 april 2006, B9 1899 (te vinden via www.boek9.nl, in zoekvenster invoeren 1899) waar een vordering tegen de krant De Telegraaf om aan eiseres af te geven kopieën van een geluidsband, dan wel een kopie, alsmede een typoscript daarvan waaruit volgens de krant in een publicatie zou blijken dat de directeur van eiseres opdracht zou hebben gegeven tot het stelen van een auto van een collega, wordt afgewezen omdat volgens de rechtbank uit art. 843a Rv niet voortvloeit dat op De Telegraaf een exhibitieplicht rust. Een enkel belang tot afgifte is voor toewijzing van de vordering op grond van art. 843a Rv niet voldoende. Voorshands is namelijk niet aannemelijk dat De Telegraaf met de publicatie onrechtmatig heeft gehandeld en de opvatting dat De Telegraaf de geluidsband ter beschikking moet stellen opdat $\mathrm{X}$ zelf de authenticiteit van die band kan controleren, kan niet als juist worden aanvaard omdat een zo vergaande verplichting niet uit art. 843a $\mathrm{Rv}$ voortvloeit.

25 Rb Rotterdam 17 mei 2006, AX6815, NJF 2006, 388: de vordering van booteigenaar Saipem om inzage in een (vermoedelijk) in opdracht van Joanna Shipping opgesteld schaderapport naar aanleiding van een brand aan boord van een boot van Saipem (ten tijde van de brand, die is ontstaan door werkzaamheden door derden, was de kapitein van de boot in dienst van Joanna Shipping) wordt afgewezen omdat de stelling van Saipem dat de brandveroorzakende werkzaamheden zijn uitgevoerd onder supervisie van de kapitein door Joanna Shipping voldoende is betwist.

26 Rb Alkmaar 21 mei 2008, BD2570.

27 Rb Haarlem 18 juni 2008: eiser heeft voldoende annemelijk gemaakt dat de gevorderde inzage in de 'Services Agreement (meer) duidelijkheid over de (contractuele) verplichtingen van gedaagde kan geven.

28 Hof Arnhem 31 maart 2009, BI2138. 
vastgestelde gang van zaken er een gerede kans is dat het gestelde recht niet bewezen kan worden. ${ }^{29}$

Het hof Arnhem ${ }^{30}$ en de rechtbank Zwolle ${ }^{31}$ zijn van oordeel dat een vordering tot inzage kan worden toegewezen indien eiser voldoende heeft gesteld. De rechtbank Arnhem ${ }^{32}$ acht het voldoende indien de achterliggende grondslag (een onrechtmatige daad) voldoende is onderbouwd, de rechtbank Den Haag is van oordeel dat een gestelde onrechtmatige daad voldoende gesubstantieerd moet zijn ${ }^{33}$ en de rechtbank Maastricht is van oordeel dat het bij de vraag of er sprake is van rechtmatig belang niet noodzakelijk is dat al in rechte is vastgesteld dat er sprake is van inbreuk op het betreffende recht. ${ }^{34}$ De rechtbank Utrecht gebruikt als criterium het woord 'aanwijzingen'. ${ }^{35}$

29 Rb Den Haag 26 mei 2009, B9 7928 (te vinden via www.boek9.nl, in zoekvenster invoeren 7928).

30 Hof Arnhem 25 maart 2008, BC9246. B stelt in die zaak dat het door particulier recherchebureau Gawain in opdracht van Stichting A gedane onderzoek gedaan naar mogelijke malversaties gepleegd door B, een werknemer van A, niet goed is gedaan, hetgeen jegens hem onrechtmatig is en B wil een lijst van namen van personen die Gawain heeft gesproken in het kader van zijn onderzoek. Het hof is van oordeel dat B een rechtmatig belang heeft bij inzage in die lijst omdat hij stelt dat teveel en verkeerde mensen zijn benaderd terwijl hij, B, in de betreffende sector wil blijven werken en de gehoorde mensen wil benaderen om te proberen zijn blazoen te zuiveren. Daarnaast is het belang gelegen in het feit dat hij wenst te bezien of het rapport wel een voldoende objectief beeld geeft in die zin dat ook ontlastende verklaringen juist zijn verwerkt.

31 Rb Zwolle 15 mei 2006, AY6815 die overweegt dat het rechtmatig belang tot inzage gelegen is in het feit dat wel voldoende is gesteld dat A, een directeur van eiseres, in strijd met zijn rechtsplicht heeft gehandeld door buiten eiseres om met Adboard te handelen, terwijl door eiseres eveneens voldoende gemotiveerd is gesteld dat zij meer aan Adboard heeft betaald dan zij verschuldigd was.

32 Rb Arnhem 26 maart 2008, BC8823 die op het verweer van gedaagden dat Ballast Nedam geen vordering op hen heeft, overweegt dat Ballast Nedam aan haar inzagevordering een onrechtmatige daad ten grondslag legt en die daad voldoende heeft onderbouwd. Dezelfde rechtbank oordeelt op 16 maart 2009, BH6158 in een zaak waarin VIA (Vereniging van Internationale Arbeidsbemiddelaars) onder de Internetvakbond (hierna Iv) bewijsbeslag heeft gelegd 'op alle gegevensdragers waaruit kan blijken dat de ledenraadpleging als door VIA bedoeld, heeft plaatsgevonden' omdat partijen een geschil hebben over de vraag of Iv haar leden op een juiste wijze heeft geraadpleegd over het tussen Iv en VIA bereikte principeakkoord, dat voorshands niet zonder meer valt uit te sluiten dat de onjuiste wijze van raadpleging door Iv zoals door VIA gesteld als een toerekenbare tekortkoming of als een onrechtmatige daad jegens VIA moet worden aangemerkt. Nu aangenomen moet worden dat VIA daarvan in een bodemprocedure bewijs zal moeten leveren en de in beslag genomen gegevens daarbij van belang kunnen zijn, heeft VIA een rechtmatig belang op inzage. Vergelijkbaar Rb Den Haag 21 september 2005, AV7698, JBPR 2006, 25, m.nt. M.A.J.G. Janssen en B9 954 (te vinden via www.boek9.nl, in zoekvenster invoeren 954).

$33 \mathrm{Rb}$ Den Haag 16 april 2008, B9 6133 (open www.boek9.nl, voer in het zoekvenster 6133 in).

$34 \mathrm{Rb}$ Maastricht 29 juli 2008, BD9036.

35 Rb Utrecht 18 maart 2009, BH6128 waarin theaterbureau A stelt dat theaterbureau B stukken van A onder zich heeft en bewijsbeslag heeft gelegd, dat zich tevens uitstrekt over stukken van B zelf waaruit zou blijken dat B onrechtmatig klanten van A benaderd en/of opdrachten van A afwerkt. De rechtbank overweegt dat de vordering tot inzage terughoudend moet worden beoordeeld omdat partijen concurrenten zijn, maar dat B niet voldoende gemotiveerd heeft weersproken dat een aantal 
De rechtbank Utrecht acht het voldoende indien eiser iets wenst te controleren, ${ }^{36}$ maar, zo blijkt uit andere uitspraken, dan moet wel duidelijk zijn waarom eiser dit wil controleren, ${ }^{37}$ of hetgeen eiser wil controleren moet voldoende rele-

in beslag genomen bescheiden aan A toebehoort en dat A deze in haar administratie mist. Het is op voorhand niet te zeggen of de ontbrekende stukken zich onder de in beslaggenomen bescheiden bevinden, maar er zijn wel aanwijzingen dat althans een deel van de stukken zich onder de in beslaggenomen documenten bevindt.

$36 \mathrm{Rb}$ Utrecht 13 februari 2008, JAR 2008, 83. Ter controle of werkgever Oskam BV de reiskostenregeling juist naleeft vorderen twee vakbonden veroordeling van Oskam BV tot verstrekking aan hen van een deugdelijke lijst van werknemers en gewezen werknemers die voor het woon-werkverkeer gebruikmaken van een door Oskam BV ter beschikking gesteld voertuig. De rechtbank overweegt dat er sprake is van rechtmatig belang omdat de vakbonden willen voorkomen dat Oskam $\mathrm{BV}$, die zich beroept op afspraken binnen het bedrijf, de betrokken werknemers zal houden aan die van de CAO afwijkende en dus nietige afspraken. Zo ook Rb Haarlem 16 juli 2008, BD7632 waar een VOF van iemand die voor haar heeft gewerkt, inzage in alle bankafschriften van drie op haar naam staande bankrekeningen in de periode 1 april 2004 tot 21 mei 2008 vordert omdat er kastekorten zijn en gedaagde de vrije hand had wat kasontvangsten en dergelijke betrof. De rechtbank oordeelt dat er sprake is van een rechtmatig belang omdat gedaagde de kastekorten niet heeft betwist noch haar verantwoordelijkheid voor de kasadministratie, terwijl het kasboek ontbreekt. Hoewel dus de oorzaak van de kastekorten nog niet duidelijk is, kan inzage in de bankafschriften van gedaagde meer duidelijkheid verschaffen. De rechtbank weegt mee dat gedaagde vroeger geen bezwaar had tegen inzage door de VOF in haar bankafschriften. Controle is ook voldoende reden voor Rb Zutphen 4 maart 2009, BH7615, NJF 2009, 168 om A in een procedure tegen B inzage toe te staan in twee tussen $\mathrm{B}$ en $\mathrm{C}$ gesloten vaststellingsovereenkomsten, daarbij overwegende: 'aangezien bedoelde overeenkomsten ook van belang kunnen zijn voor de rechtsbetrekking tussen hem en B. Daaraan doet -anders dan uit de tekst van artikel 843a lid $1 \mathrm{Rv}$ zou kunnen worden afgeleid- niet af dat A geen partij is bij de vaststellingsovereenkomsten. Uit de parlementaire geschiedenis Herziening Burgerlijk procesrecht (MvT, bladzijde 553 en 554) per 1 januari 2002 kan immers worden afgeleid dat de wetgever met het herziene artikel 843a Rv heeft beoogd aan te sluiten bij de verruiming van de processuele mededelingsplicht, die onder meer in artikel 22 Rv haar beslag heeft gekregen. Meer in het bijzonder wordt in de parlementaire geschiedenis verwezen naar het arrest van de Hoge Raad van 30 januari 1998 (NJ 1998,459), waarbij een partij een schriftelijke koopovereenkomst, waarbij de wederpartij in de procedure geen partij was, niet in het geding wenste te brengen, welke weigering door de Hoge Raad gegrond werd bevonden. Uit de opmerkingen van de minister kan worden afgeleid dat deze beslissing van de Hoge Raad onder het gewijzigde artikel 843 a Rv anders zou moeten hebben geluid.'. Ook de Rb Rotterdam 3 juni 2009, BI9158 wijst de door X gevorderde inzage in een schikkingsovereenkomst tussen Osfi en $\mathrm{Z}$ toe.

37 Hof Den Haag 12 juni 2007, S\&S 2009, 34, Rb Rotterdam 30 januari 2008, zaak-/rolnummer 279904/HA ZA 07-674 (niet gepubliceerd): Kleinstra c.s., huurders van een boot die zij lek aan de verhuurder hebben teruggegeven, vorderen afschrift van een dispache (een door deskundige(n) opgemaakte verdeling van de averij-grosse). De rechtbank overweegt dat de dispache voor de beoordeling van de vraag of Kleinstra c.s. aansprakelijk zijn voor dit lek zonder nadere toelichting, die ontbreekt, niet van belang lijkt te zijn omdat de aansprakelijkheid wordt gegrond op de tussen partijen gesloten huurovereenkomst. De vordering wordt afgewezen. In hun incidentele conclusie hadden Kleinstra c.s. gesteld dat afschrift van de dispache diende te worden verschaft omdat 'daaruit de berekening en verdeling ten aanzien van de kosten in averij grosse dient te blijken. Welke berekening en verdeling van kosten en ook dat hoeft eigenlijk geen betoog, van belang zijn voor de weren van Kleinstra.'. 
vant $^{38}$ of concreet ${ }^{39}$ zijn of de stukken die eiser wenst in te zien moeten in verband staan met de stellingen die hij wenst te bewijzen. ${ }^{40}$

De vordering tot inzage mag niet ontijdig zijn. ${ }^{41}$ Van een bijzondere vorm

38 Rb Den Bosch 16 april 2008, BC9695, JA 2008, 68, m.nt. J. Ekelmans, NJF 2008, 228: verzekeraar Allianz vordert op de voet van art. 843a Rv inzage in een opleveringsrapport van een hoogwerker, stellende dat een ondeugdelijkheid in de hoogwerker een brand heeft veroorzaakt. Dit rapport kan informatie verschaffen omtrent de technische staat van de hoogwerker bij oplevering. Die informatie kan relevant zijn voor Allianz die deze stukken nodig heeft ter bepaling van feiten op grond waarvan een rechtsbetrekking kan worden vastgesteld. Onbekendheid met de inhoud van het rapport staat niet aan inzage in de weg omdat dat argument op een te restrictieve uitleg van art. 843a Rv berust. Een dergelijke uitleg zou namelijk met zich brengen dat van toepassing van dit artikel in de praktijk weinig terecht zou komen en zou indruisen tegen de bedoeling van de wetgever om de processuele mededelingsplichten te verruimen. Hof Amsterdam 2 december 2008, BG9050, NJF 2009, 39 vernietigt een uitspraak van Rb Amsterdam 19 juni 2008, BD4818 en wijst toe een vordering van KSK om een scheidsgerecht dat heeft geoordeeld over een geschil tussen KSK en een ander, te bevelen om over te leggen een afschrift van het originele verslag van de hoorzitting (HR 29 januari 2010, BK2007 vernietigt dit arrest omdat de beleidsvrijheid van arbiters om de procesvoering te bepalen niet kan worden doorkruist door een beroep op het algemeen geformuleerde, en niet specifiek op het arbitrale geding toegesneden art. 843a Rv). Rb Breda 18 juli 2008, BD7674 oordeelt dat de door aannemingsbedrijf Van Herwijnen van de gemeente Werkendam gevorderde inzage in de bescheiden betrekking hebbend op de inschrijving van een concurrent bij een aanbestedingsproject moet worden afgewezen omdat de gemeente in redelijkheid tot het oordeel kon komen dat het door Van Herwijnen opgegeven referentiewerk niet van vergelijkbare aard is als het werk dat de gemeente wenste aan te besteden. De inschrijving van Van Herwijnen was al uit de competitie genomen, zodat hem de opdracht niet meer kon worden gegund. Soortgelijk in een aanbestedingszaak Rb Rotterdam 5 maart 2009, BH6004 en zie ook in het kader van het auteursrecht met een gelijksoortige motivering Rb Utrecht 29 oktober 2008, BG3678.

39 Rb Haarlem 7 januari 2009, BH2081.

$40 \mathrm{Rb}$ Rotterdam 7 mei 2008, BD4074. Een belegger die wenst te bewijzen dat Fortis advies gaf en het initiatief nam tot het doen van bepaalde overboekingen en transacties (die overwegend fout afliepen) en in dat kader de bandopnames zelf wil beluisteren, heeft rechtmatig belang.

$41 \mathrm{Rb}$ Amsterdam 3 november 2004, AR5041, Rb Utrecht 28 mei 2008, BD2666: Shipcon vordert slechts een verklaring voor recht met verwijzing naar de schadestaatprocedure zodat de op de voet van art. 843a Rv door BDO ingestelde incidentele vordering dat Shipcon inzage of afschriften moet geven in bepaalde bescheiden waaruit zou blijken dat er geen schade is geleden afgewezen moet worden omdat de hoogte van de geleden schade nog niet aan de orde is. Rb Rotterdam 4 juni 2008, BD9249 oordeelt dat voor zover eiser in het incident 'bedoelt gebruik te maken van de gevorderde bescheiden ten behoeve van een eventueel door haar te voeren verweer ten aanzien van het tenietgaan van de vordering, ... kan de vordering tot overlegging van afschriften eerst aan de orde komen wanneer zodanig verweer in de hoofdzaak wordt gevoerd'. Rb Amsterdam 11 september 2008, BF0587 gelast inzage omdat er voldoende belang is, ook indien de partij die inzage vordert in beginsel kan volstaan met een kale betwisting van de stellingen van de eiser in de 'hoofdprocedure', omdat niet valt uit te sluiten dat eiseres in de hoofdprocedure voldoende bewijs heeft en het dan aan gedaagde in de hoofdprocedure tevens eiser in het incident is om tegenbewijs te leveren. Een bijzondere vorm van ontijdigheid valt te lezen in Rb Rotterdam 8 oktober 2008, BG3804 waar verzekeraar Son zonder meer een schade-uitkering heeft geweigerd en pas nadat de penningen bij dagvaarding zijn gevorderd, inzage vordert in ladingrapporten, vaartijdenboeken, agenda's en journalen, reisboekingen en andere registraties. De rechtbank wijst de vordering af omdat Son, kennelijk zonder de beschikking over deze stukken te hebben, haar 
van ontijdigheid kan sprake zijn bij een vordering tot inzage in medische stukken. ${ }^{42}$

Een belangenafweging kan met zich brengen dat ondanks de aanwezigheid van rechtmatig belang de vordering tot inzage toch wordt afgewezen. ${ }^{43}$

Als een vordering is verjaard bestaat er geen rechtmatig belang meer om op die vordering betrekking hebbende bescheiden in te zien $^{44}$ en de wens om onderliggende motieven te onthullen levert evenmin rechtmatig belang op. ${ }^{45}$

Het rechtmatig belang is soms, aldus Ekelmans in zijn boek, al in een bijzondere wettelijke regeling gegeven. Daar waar een wettelijke bepaling in een specifiek geval recht op inzage geeft, komt volgens hem geen verdere afweging meer aan de orde. Zo heeft een werknemer wiens loon van enig gegeven uit de administratie van de werkgever afhankelijk is, op grond van art. 7:619 BW recht op inzage. ${ }^{46}$

dekkingsplicht heeft afgewezen, zodat zonder nadere, niet gegeven, toelichting niet valt in te zien ten behoeve van welk verweer Son die bescheiden nodig heeft. Rb Haarlem 7 januari 2009, BH2081 overweegt dat de enkele stelling dat X niet alleen in de jaren 1993-1994 en 1998-1999 smeergelden heeft ontvangen onvoldoende is om inzage te verkrijgen in de bankafschriften over de hele periode dat de bankrekening heeft bestaan. Indien, zo overweegt de rechtbank, het casino van mening is dat ook in die andere jaren smeergelden zijn ontvangen, moet zij haar vordering aanpassen en zal in het kader van bewijslevering moeten worden beslist of inzage gegeven moet worden. Zie ook Rb Rotterdam 24 juni 2009, NJF 2010, 31.

$42 \mathrm{Rb}$ Arnhem 26 juni 2009, BJ4425 wijst af een vordering tot inzage van Allianz door haar dan wel door haar advocaat dan wel door haar medisch adviseur van het volledig huisartsendossier van B en het USZO/GAK dossier van B -die van Allianz schadevergoeding vordert omdat hij is aangereden door een bij Allianz verzekerde auto-, aansluiting zoekend bij de arresten van de Hoge Raad van 22 februari 2008, BB5626 en BB3676. De rechtbank overweegt dat uit de overwegingen van de Hoge Raad in die arresten duidelijk naar voren komt '... dat het in beginsel uitsluitend aan de onafhankelijke, door de rechtbank te benoemen deskundige(n) is te beoordelen welke medische gegevens voor de uitvoering van het hem opgedragen onderzoek noodzakelijk zijn en derhalve door de benadeelde dienen te worden verschaft. Voor een op voorhand af te geven bevel om nadere medische gegevens te verschaffen, is geen plaats. Hiermee strookt dan ook niet de handelwijze van Allianz, om via een omweg, te weten een vordering in kort geding, op grond van art. $843 \mathrm{a} \mathrm{Rv}$ te trachten dergelijke gegevens te bemachtigen ....'.

$43 \mathrm{Rb}$ Zutphen 20 augustus 2008, JAR 2008, 255.

$44 \mathrm{Rb}$ Zwolle-Lelystad 5 maart 2008, BD8262.

45 Rb Den Bosch 21 mei 2008, BD2308 wijst af de vordering tot inzage omdat niet '...valt in te zien dat PF, gelet op haar uitgebreid gemotiveerde stellingen in de dagvaarding, de betreffende bescheiden nodig heeft voor het bewijs van die stellingen. Met Laurus is de rechtbank van oordeel dat de onderliggende motieven van Laurus rechtens niet relevant zijn voor de beantwoording van de vraag of Laurus zich onvoldoende heeft ingespannen'.

46 Zie ook het in par. 6.3 aan de orde geweest zijnde arrest HR 6 oktober 2006, NJ 2006, 547, JBPR 2007, 6, m.nt. J.G.A. Linssen, AA 2007, p. 371-374, m.nt. H.B. Krans, Meijer-VOF Gebr. Cornelis. De Hoge Raad overweegt dat er sprake is van een geval waarin Meijer overeenkomstig art. 7:619 BW het recht heeft om van de V.O.F. overlegging te verlangen van zodanige bewijsstukken als hij nodig heeft om de gegevens vast te stellen voor de bepaling van zijn aanspraak op loon. Hieruit volgt dat Meijer een rechtmatig, want uit art. 7:619 BW voortvloeiend belang, heeft om op de voet van art. $843 \mathrm{a} R \mathrm{v}$ de overlegging van het vaartijdenboek te verlangen, zonder gehouden te 
Op grond van art. 3:15j BW kunnen erfgenamen ten aanzien van de boekhouding van de erflater openlegging van tot een administratie behorende boeken, bescheiden en andere gegevensdragers vorderen. ${ }^{47}$ Laatstgenoemd artikel geeft hetzelfde vorderingsrecht aan deelgenoten in een gemeenschap ten aanzien van de boekhouding betreffende de gemeenschap, vennoten ten aanzien van de boekhouding van de vennootschap en schuldeisers in het geval van faillissement ${ }^{48}$ of

zijn te stellen 'dat hij in redelijkheid slechts bewijs zou kunnen leveren aan de hand van de in het bezit van de V.O.F. zijnde gegevens'. Na verwijzing gelast het hof Den Bosch op 30 oktober 2007, BB8632 de VOF het vaartijdenboek in het geding te brengen en wijst het hof de niet verschenen VOF erop dat als zij dit niet doet, het hof daaraan de gevolgtrekking verbindt dat het vonnis van de kantonrechter zal worden vernietigd onder toewijzing van de vordering van de werknemer. K. Teuben, 'De verplichting tot het overleggen van stukken ex art. 843a Rv' in MvV 2006, p. 218-221 vermeldt dat uit dit arrest van 6 oktober 2006 lijkt te volgen dat wanneer een wettelijke bepaling recht geeft op overlegging van, of inzage in, bepaalde stukken, een nadere afweging tussen de belangen van de eisende partij en de belangen van de partij die de bescheiden onder zich heeft, in beginsel niet meer nodig is. De achterliggende gedachte zou dan zijn dat de wetgever hier de afweging reeds heeft gemaakt. T.S. Jansen, Art. 843a Rv in de ondernemingsrechtpraktijk. Verboden te vissen, maar vragen mag, Tijdschrift voor de ondernemingsrechtpraktijk 2009, p. 89-94 wijst bij zijn omschrijving van de inhoud van het begrip 'rechtmatig belang' ook op dit arrest van 6 oktober 2006, waaruit volgens hem volgt dat voor zover er een materieelrechtelijke aanspraak op overlegging van bepaalde bewijsstukken bestaat, het rechtmatig belang is gegeven. Zie ook E.T. Visser, Het exhibitionisme in arbeidszaken en de fundamentele herbezinning, Arbeidsrecht 2007, afl. 6-7 p. 14-17. AG Timmerman concludeert bij HR 30 januari 2009, BG5847, RvdW 2009, 252 dat het hof Arnhem van oordeel is dat het, gelet op de artt. 7:626 en 619 BW en mede gelet op art. 843a Rv, aan de werkgever is om de tachograafschijven over een bepaalde periode in het geding te brengen (een motivering ontbreekt, de HR doet de zaak af op de voet van art. $81 \mathrm{RO})$.

47 Zie ook hof Arnhem 17 mei 2005, LJN AT6104, oordelend dat een erfgenaam rechtmatig belang heeft bij inzage in de administratieve bescheiden van de erflater en Rb Maastricht, 7 maart 2002, AE0630. Rb Arnhem 19 april 2006, AX7332 wijst een vordering tot inzage in bankafschriften gericht tegen iemand die jarenlang het beheer over het vermogen van een erflater heeft gevoerd af, omdat niet is onderbouwd welke aanleiding er is om te veronderstellen dat er nog aanspraken op delen van de opengevallen nalatenschap zijn, waarbij de rechtbank het tevens van belang vindt dat degene die de afschriften vordert, zelf de laatste jaren het betreffende beheer heeft gevoerd en dus de positie had om inzage te krijgen.

48 Zie daarover uitvoerig AG Huydecoper bij HR 21 januari 2005, AS3534, NJ 2005, 249. De AG merkt daar tevens op dat art. 843a Rv aan iedereen die daarbij een rechtmatig belang heeft, een aanspraak toekent op o.a. inzage van gegevens, waarbij deze bepaling een ruim bemeten aanspraak geeft doordat niet meer wordt vereist dan een beroep op een rechtmatig belang en dat een beperking op de aanspraak op informatie wordt gegeven door de eis dat er (nauw) verband moet bestaan met de rechtsbetrekking waarbij men partij is. Zie voor een curator die inzage vordert Rb Zutphen 21 maart 2007, BA8996. In deze zaak is de failliet Van de Meene aansprakelijk voor aan MPS veroorzaakte schade waarvoor de failliet is verzekerd bij Fortis. De curator stelt dat MPS en Fortis bepaalde afspraken hebben gemaakt wat de uitkering van de schadepenningen betreft en wenst inzage in die afspraken. De rechtbank wijst de vordering af omdat de curator voorlopig geen belang heeft omdat er van moet worden uitgegaan dat de gewraakte afspraak tussen MPS en Fortis inderdaad bestaat. 
toepassing van de schuldsaneringsregeling natuurlijke personen ten aanzien van de boekhouding van de failliet of de saniet.

Anders dan de woorden van Ekelmans suggereren, vindt ook bij de toepassing van art. 3:15j BW een toetsing plaats. Het artikel bepaalt immers dat de genoemde personen die de openlegging kunnen vorderen, een rechtstreeks en voldoende belang moeten hebben, waarmee dus een belangenafweging is voorgeschreven ${ }^{49}$ Openlegging in de zin van dit artikel kan plaatsvinden door inzage, door het verschaffen van een uittreksel of anderszins. ${ }^{50}$ Het tot dusverre weinig gebruikte artikel is op twee onderdelen tekstueel ruimhartiger dan art. 843a Rv. De beperkingen van lid 4 van art. 843a Rv zijn in de tekst van art. 3:15j BW niet te vinden en er is niet bepaald dat er sprake moet zijn van een rechtsbetrekking. Dit artikel stond tot 21 mei 2003 in het Wetboek van Koophandel met dezelfde opsomming van personen die openlegging konden vorderen. In Koophandel was die opsomming limitatief. In de Memorie van Toelichting bij het ontwerp waarbij dit art. $11 \mathrm{Kh}$ is geschrapt en overgebracht naar art. 3:15b BW, is echter vermeld dat niet uitgesloten kan worden dat zich ook buiten de in art. $11 \mathrm{Kh}$ genoemde gevallen verhoudingen kunnen voordoen waarin openlegging gevorderd kan worden, zodat het limitatieve karakter van art. $11 \mathrm{Kh}$ niet is gehandhaafd. ${ }^{51} \mathrm{In}$ dit verband is nog opvallend dat in het hele wetgevingstraject dat dit art. 3:15j BW heeft doorlopen, art. 843a $\mathrm{Rv}$ niet is genoemd. Het woord 'openlegging' uit art. $11 \mathrm{Kh}$ is gehandhaafd omdat er volgens de minister geen goede grond bestond voor een afwijkende terminologie. ${ }^{52}$

Ekelmans noemt verder als voorbeeld van een wettelijke bepaling die in een specifiek geval recht op inzage geeft, art. 4:78 BW waarin is vermeld dat de legitimaris die niet erfgenaam is aanspraak heeft op inzage en afschrift van alle bescheiden die hij voor de berekening van zijn legitieme portie nodig heeft $\mathrm{t}^{53}$ en art. 7:433 BW, bepalende dat de agent wiens inkomen gerelateerd is aan hetgeen

49 Aldus ook Van der Korst, p. 92. Rechtstreeks belang in de zin van dit artikel is een ander begrip dan rechtmatig belang in de zin van art. 843a Rv. Ik kan, mede gelet op dit verschil, niet doorgronden waarom $\mathrm{Rb}$ Arnhem in haar vonnis van 21 oktober 2008, BG3613 na uitvoerige overwegingen toegeschreven op art. 3:15j BW, plotsklaps overschakelt naar art. 843a Rv.

50 Zie J.A.C. van Veersen, Exhibitieplicht ex art. 3:15j BW; een ondergeschoven kindje, V\&O 2006, p. 6-10.

51 Wetsvoorstel 27824, p. 8-9 nr 3, Memorie van Toelichting.

52 Voor de volledigheid: in wetsvoorstel 27824 werd art. 3:15b BW ingevoegd. Bij KB Stb. 2001, 581 werd bepaald dat, kort gezegd, na invoering van de Wet elektronische handtekening (27743) art. $15 \mathrm{~b}$ vernummerd zou worden tot art. $15 \mathrm{j} \mathrm{BW.}$

53 Art. 4:39 BW geeft de personen aan wie de rechten van de artt. 4: 29 tot en met 33, 35, 36, en 38 toekomen (de echtgenoot van de erflater onder bepaalde omstandigheden, de erfgenamen die moeten meewerken aan de vestiging van een recht van vruchtgebruik en een kind, stiefkind, pleegkind, behuwd kind of kleinkind van de erflater) onder bepaalde omstandigheden de bevoegdheden die zijn genoemd in art. 4:78 BW. 
hij weet te verkopen, recht op inzage heeft in de nodige bewijsstukken. De agent kan echter krachtens dit artikel geen afgifte verlangen. ${ }^{54}$

\subsubsection{Het rechtmatig belang en de vordering tot inzage in medische gegevens}

Afzonderlijke vermelding verdient hier de medische problematiek. Deze is tweeledig. Ten eerste kan de patiënt zelf inzage willen hebben in zijn gegevens. Ten tweede kan het geval zich voordoen dat, na bijvoorbeeld een ongeval waardoor de aansprakelijke partij A letsel heeft veroorzaakt bij de schadevergoeding vorderende partij B, partij A inzage wenst in de medische gegevens van partij B om te controleren of het gestelde letsel er wel is maar ook om te controleren of het gestelde letsel niet een andere oorzaak heeft dan het ongeval.

De relatie arts-patiënt in het kader van de medische behandelingsovereenkomst legt volgens Van Ginneken de hulpverlener de verplichting op om de patiënt ook ongevraagd informatie te verschaffen over onderzoek en therapie. ${ }^{55}$ Dit is een verplichting in het kader van de behandelingsovereenkomst, maar die verplichting is natuurlijk ook afdwingbaar in een procedure, voor zover al niet op grond van de enkele behandelingsovereenkomst, dan in elk geval op grond van art. 843a Rv. Hier is het de inhoud van de behandelingsovereenkomst die maakt dat het verzoek om informatie een rechtmatig belang heeft. Dit betekent dat de patiënt zijn volledige dossier rechtstreeks mag inzien. ${ }^{56}$

54 In het rijtje past ook art. 7:403 lid 2 BW, inhoudende dat de opdrachtnemer aan de opdrachtgever verantwoording doet van de wijze waarop hij zijn opdracht heeft gekweten. Zie daarover Rb Utrecht 5 juni 2009, BI6346.

55 P.P.J.N. van Ginneken, Centrale Raad wil patiënt meer rechten geven, Tijdschrift voor Gezondheidsrecht 1983, p. 237-255.

56 Dit recht op volledige inzage wordt door J.L.M. van der Beek, Enkele opmerkingen over het inzagerecht, Tijdschrift voor Gezondheidsrecht 1984, p. 80-81, een grove inbreuk (JRS: hij schrijft niet waarop, maar hij lijkt te bedoelen op de normale verhoudingen arts-patiënt) genoemd die zal leiden tot veel juridische conflicten. Dit zal een einde maken aan het harmoniemodel waarin patiënt en arts naar tevredenheid kunnen functioneren. Rb Zwolle-Lelystad 20 december 2007, BC1286, JA 2008, 24 oordeelt over een vordering van X tegen de IJsselmeerziekenhuizen om hem afschrift te verschaffen van alle feitenrelazen die zijn opgemaakt in het kader van het door de ziekenhuizen gehouden interne onderzoek naar aanleiding van het overlijden van zijn vrouw na een operatie in de IJsselmeerziekenhuizen. De ziekenhuizen weigeren om X inzage te geven in de verslaglegging van het interne onderzoek omdat dit onderzoek is verricht door de Melding Incidenten Patiëntenzorg Commissie (MIP-cie) en vertrouwelijk is. De rechtbank acht rechtmatig belang aanwezig omdat de echtgenote geheel onverwacht en onverklaard na een operatie is overleden. De inzage is van belang voor de verwerking van het verlies en met het oog op een eventueel te voeren procedure. De rechtbank oordeelt dat vaststaat dat er sprake is van een calamiteit, terwijl evenmin is betwist dat het operatieverslag zo summier was dat op basis daarvan geen conclusies konden worden getrokken en dat onder die omstandigheden het belang van de melder om niet bang te hoeven zijn voor repercussies, minder zwaar weegt dan het belang van $\mathrm{X}$ om op de hoogte te raken van de feiten. Dat de feiten ook via bijvoorbeeld een getuigenverhoor aan het licht kunnen komen, en dat een behoorlijke rechtsbedeling dus ook zonder de gevraagde gegevens is gewaarborgd maakt 
De tweede situatie is gecompliceerder. Dat blijkt ook uit de literatuur die inmiddels over de inzage in de patiëntenkaart van het slachtoffer door de dader bestaat. ${ }^{57} \mathrm{Bij}$ de toetsing van de vraag of hier rechtmatig belang aanwezig is, komt het volgens Elferink aan op een belangenafweging tussen het recht op privacy en het belang dat de dader heeft bij wetenschap omtrent de mate van gezondheid van het slachtoffer. Een belangrijke mee te wegen factor is of sprake is van een relevante voorgeschiedenis bij het slachtoffer. Ook voor de beantwoording van die vraag is er echter vaak inzage in de kaart nodig. Verder lijken mee te moeten wegen de vragen of het gestelde door het ongeluk veroorzaakte letsel al dan niet atypisch is, de hoogte van de gevorderde schadevergoeding en de bewijslastverdeling.

Van Dijk spreekt over twee grondrechten die in het geding zijn en wel de equality of arms van art. 6 EVRM en het recht op privacy van art. 8 EVRM. Waar alle medische informatie van vóór en ná het ongeval relevant kan zijn voor het beoordelen van de juridische causaliteit, brengt dit volgens hem onvermijdelijk met zich dat alle medische informatie van vóór en ná het ongeval wordt verstrekt aan de onafhankelijke deskundige. Ekelmans ziet, naar het mij voorkomt terecht, bij het antwoord op de vraag of er sprake is van rechtmatig belang op inzage in de patiëntenkaart geen verschil tussen deze kaart en een ander bescheid. Hij stelt dat het antwoord op de vraag of sprake is van schade, een vergelijking vergt van de situatie met en de situatie zonder ongeval, zodat ruimhartige inzage in de medische voorgeschiedenis voor de hand ligt. Hij komt tot de conclusie dat voor de verstrekking van bescheiden in letselzaken de weg gevolgd kan worden die ook openstaat in andere zaken. Hij lijkt daarmee van mening te zijn dat alle problemen zijn opgelost, wat volgens mij onjuist is. Dezelfde vragen die Elferink, Van Dijk en Kolder \& Schultz hebben opgeworpen, dienen ook te worden beantwoord indien een vorderende partij expliciet de weg van art. 843a Rv kiest. Anders dan Ekelmans stelt, zal dan bij de beantwoording van de vraag of er sprake is van rechtmatig belang, een afweging moeten worden gemaakt tussen het belang op inzage en het belang op privacy. Daarmee is niet gezegd dat die afweging zonder meer kan

dit niet anders omdat voordat de betreffende getuigen feitelijk gehoord zullen zijn, er inmiddels bijna twee jaar zijn verstreken en de getuigen minder onbevangen zullen zijn dan tijdens de eerste gesprekken, terwijl inmiddels is gebleken dat bewijsvoering op deze manier erg omslachtig is. Een behoorlijke rechtsbedeling is dan ook niet gewaarborgd wanneer X niet de beschikking krijgt over deze gegevens 'uit de eerste hand'.

57 M.H. Elferink, Inzage in de patiëntenkaart, TVP 2003, p. 111-119, Chr.H. van Dijk, Ter beschikking stellen van de patiëntenkaart: aan wie?, TVP 2006, p. 8-17, A. Kolder en J.F. Schultz, De patiëntenkaart: knel- en strijdpunt, TVP 2007, p. 5-17, J. Ekelmans, Dient de verplichting om medische bescheiden te verstrekken gebaseerd te worden op artikel 843a Rv?, TVP 2007, p. 29-37, E.M. Deen, De patiëntenkaart en de beschikkingen van de Hoge Raad van 22 februari 2008, TVP 2009, p. 41-48. 
worden beantwoord aan de hand van art. 6 en 8 EVRM, maar de in die artikelen geformuleerde rechten behoren wel in de discussie te worden betrokken. ${ }^{58}$

Taminiau en Swagemakers zijn van mening dat bij een mogelijke vordering tot inzage in de patiëntenkaart op de voet van art. $843 \mathrm{a} \mathrm{Rv}$ de jurisprudentie omtrent deze problematiek, maar dan gebaseerd op art. $22 \mathrm{Rv}$, van overeenkomstige toepassing is. Er zal een afweging van de belangen van beide partijen dienen plaats te vinden. Zij vinden dat bij de vraag of er sprake is van rechtmatig belang gekeken moet worden naar de vraag of een partij die niet de beschikking krijgt over het stuk waarvan zij inzage wenst, hierdoor wordt benadeeld dan wel in een nadeligere positie komt te verkeren. Ekelmans vergelijkt volgens hen appels met peren omdat een verzoek tot overlegging van een patiëntendossier niet vergelijkbaar is met het overleggen van andere, minder privacy gevoelige gegevens. Ook een vordering tot inzage in een volledig patiëntendossier gebaseerd op art. 843a Rv dient getoetst te worden aan de artt. 6 en 8 EVRM. ${ }^{59}$

De Hoge Raad heeft zich nog slechts met deze problematiek beziggehouden in het kader van een voorlopig deskundigenbericht tijdens welk onderzoek Fortis vorderde dat $\mathrm{X}$ zou worden bevolen om al zijn medische gegevens van voor en na het ongeval over te leggen aan de medische adviseur van Fortis en aan de te benoemen deskundige. Volgens de Hoge $\mathrm{Raad}^{60}$ is beoogd om antwoord van de deskundige te krijgen, welk antwoord hij onpartijdig en naar beste weten moet geven. Dit brengt met zich dat hij bepaalt welke door partijen te verschaffen

58 Waar Ekelmans op p. 34 van het artikel in TVP schrijft dat hij de indruk heeft dat de discussie over artikel 6 en 8 EVRM in rechterlijke uitspraken van stal is gehaald, omdat de rechter zich er niet aan wilde wagen om klip en klaar te zeggen dat de inzichten over de wenselijke invulling van mededelings- en informatieplichten met de tijd kunnen veranderen, en dat ook hij terecht meegaat met een tijdgeest die prijs stelt op het sneller en opener oplossen van geschillen en minder discussie wil besteden aan issues die side-issues behoren te zijn, is mij niet duidelijk wat hij precies wil zeggen en evenmin is het mij duidelijk waar hij die indruk op baseert.

59 H.W.P.B. Taminiau en C.A.M. Swagemakers, Procedurele obstakels voor de zieke werknemer, Arbeid Integraal 2007, p. 109-124. Zie ook S.M. Christiaan en W.J. Hengeveld, Februari-arresten: de patiëntenkaart; partijen wikken, de deskundige beschikt, TVP 2008, p. 51-56 die van mening zijn dat indien inzage in de patiëntenkaart op grond van art. 843a Rv wordt gevraagd, de artikelen 6 en 8 EVRM nog een rol spelen. Alle belangen, ook die van het recht op privacy, dienen immers te worden afgewogen en uiteindelijk kan een beroep op de gewichtige redenen van lid 4 aan inzage in de weg staan.

60 HR 22 februari 2008, BB5626, De volgende overweging van de Hoge Raad in dit arrest brengt met zich dat de strijd niet gestreden hoeft te zijn nadat het voorlopig deskundigenbericht is uitgebracht: 'Indien in de procedure waarin het voorlopige deskundigenbericht wordt overgelegd, blijkt dat voor de beoordeling daarvan of voor een aanvullend onderzoek dergelijke gegevens nodig zijn, dan zal de rechter in de procedure op de voet van art. $22 \mathrm{Rv}$. de partij die het aangaat een bevel tot het overleggen daarvan kunnen geven. Eventueel kan, waar dat mogelijk is, art. 843a Rv. toepassing vinden.' Uit de laatste zin van het citaat kan in elk geval de conclusie worden getrokken dat de Hoge Raad het niet onmogelijk acht dat via de weg van art. 843a Rv medische bescheiden in het geding gebracht moeten worden. Zie ook HR 22 februari 2008, BC4874 en Rb Utrecht 21 oktober 2009, BK2302, NJF 2009, 505. 
gegevens voor de uitvoering van zijn onderzoek noodzakelijk zijn waarbij partijen de door hem gevraagde gegevens dienen te verschaffen. Uit een weigering om hem die gegevens te verschaffen zal de rechter die gevolgtrekking kunnen maken die hij geraden acht. In dit stelsel past het niet dat een verzoeker die de rechtbank verzoekt deskundigen te benoemen, tevens een nevenverzoek doet om de wederpartij op voorhand te bevelen bepaalde gegevens aan de deskundige te verschaffen. De slotzin van het tweede lid van art. $198 \mathrm{Rv}$ (Indien een partij schriftelijke opmerkingen aan de deskundige doet toekomen, verstrekt zij daarvan terstond afschrift aan de wederpartij) alsmede het contradictoire beginsel, gelden niet onverkort voor medische gegevens die aan de deskundige worden verstrekt door de partij die eventueel gebruik kan maken van het blokkeringsrecht van art. 7:464 lid 2 aanhef en onder b BW. Die partij is in beginsel niet verplicht de door haar aan de deskundige verschafte medische gegevens tegelijkertijd aan de wederpartij te verschaffen. Dit is weer anders indien de wederpartij een verzekeraar is, die beschikt over een medisch adviseur omdat die adviseur, ook ten opzichte van de verzekeraar, de medische informatie als hem onder zijn geheimhoudingsplicht toevertrouwd zal dienen te beschouwen en te behandelen. Indien een partij geen gebruik maakt van haar blokkeringsrecht, moet zij desgevraagd alle door haar aan de deskundige verstrekte medische gegevens in de procedure brengen. ${ }^{61}$

Een heel specifiek onderdeel van medische problematiek en informatieverstrekking komt voor in het arbeidsrecht en betreft de vraag welke informatie omtrent een zieke werknemer verstrekt kan worden of moet worden door de arts aan de werkgever. Deze vraag is tot op heden gesteld noch beantwoord in de sleutel van art. 843a Rv. Willems en Van der Meer hebben zich deze vraag gesteld met als grondslag de arbeidsovereenkomst. ${ }^{62} \mathrm{Zij}$ stellen dat de arts in dit soort gevallen twee verschillende boodschappen heeft. Eén boodschap aan de werknemer die uitgebreid en volledig is; één boodschap aan de werkgever waarbij de arts alleen gerichte informatie mag verschaffen over de werkzaamheden waartoe de werknemer nog wel of niet in staat is, de verwachte duur van het verzuim, de mate waarin de werknemer arbeidsongeschikt is en de eventuele aanpassingen op de werkplek die moeten worden aangebracht. Zoals gezegd: grondslag voor een en ander is de arbeidsovereenkomst, bezien in samenhang met art. 14 van de Arbeidsomstandighedenwet, inhoudende dat de werkgever verplicht is zich te laten bijstaan door, kort gezegd, een bedrijfsarts bij de begeleiding van werknemers die door ziekte

61 Zie ook E.M. Deen, De patiëntenkaart en de beschikkingen van de Hoge Raad van 22 februari 2008, TVP 2009, p. 41-48.

62 J.H.B.M. Willems en H.C.B. van der Meer, Uitwisseling van medische gegevens van zieke werknemers - niet alles wat kan mag, en niet alles wat mag kan -, Het Verzekeringsarchief 2009, p. 64-72. Rb Utrecht 18 april 2007, BA3557 wijst een vordering van London Verzekeringen om medische en arbeidskundige gegevens af omdat dit geen vordering is betreffende met name genoemde stukken. De rechtbank overweegt daarbij nog expliciet dat daargelaten kan worden het aan de andere partij toekomende blokkeringsrecht. 
niet in staat zijn hun arbeid te verrichten. Een en ander is zo specifiek geregeld in het kader van de arbeidsovereenkomst dat art. 843a Rv hier geen rol kan spelen.

\subsubsection{Het rechtmatig belang bij inzage in het due diligencerapport}

Bij het bestanddeel 'rechtmatig belang' verdient het onderwerp due diligence rapport, gelet op de literatuur en jurisprudentie over dit onderwerp, een zelfstandige bespreking. Een due diligencerapport is een rapport dat, kort gezegd, een overzicht geeft van de vermogenstoestand van een onderneming, inclusief mogelijke verborgen verliezen of te verwachten verliezen. Populair gezegd: de rapporteur probeert alle 'kasten' in de onderneming te vinden en te openen om te zien of er mogelijk 'lijken in de kast' liggen. Een dergelijk rapport wordt meestal in opdracht van de potentiële koper opgemaakt. Inzage in een dergelijk rapport wordt regelmatig door de verkoper gevorderd indien de koper na de koop een procedure tegen de verkoper is angevangen omdat de koper van mening is dat er wanprestatie is gepleegd. De verkoper probeert via inzage in een opgemaakt due diligencerapport aan te tonen dat de koper kennis droeg van de gestelde gebreken.

De literatuur is overwegend van mening dat een vordering tot inzage moet worden afgewezen. ${ }^{63}$

Eén van de redenen daarvoor is het ontbreken van het rechtmatig belang, vooral omdat er teveel onzekerheid zou bestaan over het antwoord op de vraag of in het rapport wel iets te vinden is ter zake de feiten die tot de conclusie zouden kunnen leiden dat er sprake is van de gestelde wanprestatie. Verder is de verkoper geen partij in de rechtsbetrekking tussen de koper en degene die op verzoek van de koper het rapport heeft opgesteld en, ten slotte, bevatten dergelijke rapporten niet alleen feiten, maar ook onlosmakelijk aan die feiten verbonden adviezen.

De jurisprudentie ziet niet veel in deze argumenten en verzoeken tot inzage in due diligencerapporten worden meer wel dan niet toegewezen. Zo deed BDO in de zaak Ho-Cla Beheer tegen BVR op verzoek van koper BVR, die aandelen wilde kopen in twee vennootschappen van Ho-Cla, onderzoek naar verliesgevende projecten. Indien dergelijke projecten niet zouden worden gevonden, zou Ho-Cla een winstgarantie verstrekken. BDO vond beweerdelijk geen verliesgevende projecten, Ho-Cla gaf een winstgarantie en de BVR kocht de betreffende aandelen. Na de overdracht blijkt een project verliesgevend en BVR doet een beroep op de winstgarantie. Ho-Cla stelt ter verdediging onder meer dat dit verlies in het due diligence rapport gesignaleerd had behoren te zijn en wenst ter controle en onderbouwing van dit verweer inzage in het rapport. Het verweer dat rechtmatig belang op inzage ontbreekt, wordt door de rechtbank Breda verworpen, omdat vaststaat

63 Zie onder meer M.M. van den Broek, Gedwongen overlegging due diligencerapport in V\&O 2004, p. 122-125 die zich verzet tegen een ruime interpretatie, K.I.A. Middelkoop, 'Due diligence rapporten : plicht tot overleggen?' in V\&O 2005, p. 196-199 en J.A.C. van Veersen in V\&O 2006, p. 6-10 'Exhibitieplicht ex art. 3:15j BW; een ondergeschoven kindje'. 
dat het onderzoek heeft plaatsgevonden in het kader van de voorgenomen aandelenoverdracht en dat Ho-Cla BVR (in de persoon van BDO) in de gelegenheid heeft gesteld de administratie van de vennootschappen in te zien. Nu het niet is uitgesloten dat het rapport zelf ter zake de door BVR gestelde en door Ho-Cla betwiste feiten in verband met verzwijging van nadere informatie nadere aanwijzingen bevat, heeft Ho-Cla met het oog op een nadere onderbouwing van haar verweer rechtmatig belang bij afgifte van het rapport. ${ }^{64}$

De rechtbank Utrecht overweegt dat er zelfs een rechtmatig belang is bij sommige met name genoemde bescheiden die zijn gebruikt bij de vervaardiging van het due diligencerapport omdat partijen onder meer een geschil hebben over de vraag of een bepaald beding al dan niet een garantie is en bij het antwoord op die vraag de Haviltexmaatstaf gehanteerd moet worden. De rechtbank acht het aannemelijk dat die achterliggende stukken meer duidelijkheid kunnen geven. ${ }^{65}$

De rechtbank Amsterdam oordeelt in beginsel positief over een vordering tot inzage in een zeer veel omvattend due diligence rapport opgemaakt in verband met de verkoop door Aegon van haar aandelen Labouchere aan Dexia. De rechtbank overweegt dat aan de vordering tot afgifte van de documenten terzake 'finance and accounting, MIS, risk management policies and procedures, tax, legal audit, product manegement, marketing, sales organisation, IT en human resources' ten grondslag ligt de stelling van Aegon dat Dexia in dit geding inzage dient te geven in de mate waarin zij in het kader van het due diligenceonderzoek bepaalde risico's in de onderneming van Labouchere heeft onderkend of heeft kunnen onderkennen, opdat mede aan de hand daarvan kan worden beoordeeld of Dexia zich op dwaling kan beroepen en kan worden vastgesteld welke betekenis aan de door Aegon gegeven warranties moet worden toegekend. In het licht van onder meer HR 22 december 1995, NJ 1996, 300 is de aan het due diligenceonderzoek ontleende of te ontlenen wetenschap van Dexia in beginsel relevant voor de beoordeling van haar vordering door de rechtbank. Daarom kan van Dexia in beginsel worden

64 Rb Breda 14 januari 2004, JOR 2004, 70. Het vonnis is bekrachtigd door het hof Den Bosch op 28 september 2004, JOR 2005, 23. Rb Amsterdam 13 april 2005, JOR 2005, 142 staat inzage eveneens toe, maar geeft eiseres wel een verbod om gegevens uit het rapport aan derden mee te delen. In HR 23 september 2005, JOR 2005, 264 oordeelt de HR dat de inspecteur der belastingen wegens het beginsel van fair play niet via art. 47 AWR inzage in een due diligencerapport kan afdwingen.

65 Rb Utrecht 12 september 2007, BB3722, NJF 2007, 544. Rb Rotterdam 19 maart 2008, BC9708 gelast Adicom een afschrift te geven van de due diligencerapportage, adviezen en correspondentie aan Slotboom en Acquimer omdat het due diligenceonderzoek is verricht naar aanleiding van een tussen Adicom enerzijds en Slotboom en Acquimer anderzijds gesloten intentieverklaring. Na dit onderzoek heeft Slotboom 77,5\% van haar aandelen in ICS aan Adicom verkocht en geleverd. De verkoopprijs is onder meer afhankelijk van de brutowinst van ICS. Slotboom en Acquimer stellen dat uit het due diligencerapport blijkt dat Adicom wist dat de winst van ICS over 1999 lager zou uitvallen dan in 1998. Aldus hebben Slotboom en Acquimer een redelijk belang bij afschriften van de due-diligencerapportage, adviezen en correspondentie. Rb Rotterdam 4 maart 2009, BH5652 gelast eveneens inzage in een due diligencerapport. 
gevergd dat zij daarover ten aanzien van elk van de door haar gestelde gebreken nadere informatie verstrekt in dit geding. ${ }^{66}$

\subsection{Inzage, afschrift of uittreksel}

In de literatuur komen de woorden 'inzage, afschrift of uittreksel' alleen maar aan de orde bij de vraag of het bewijsbeslag op grond van dit artikel mogelijk is. Hoyng heeft daarover opgemerkt dat geschriften in Nederland gemakkelijker verdwijnen dan getuigen en is van mening dat om die reden bewijsbeslag moet worden toegestaan. ${ }^{67}$ Dit houdt dan in dat conservatoir beslag wordt gelegd op bepaalde (originele) bewijsstukken ter voorkoming dat deze verdwijnen. Gelet op deze reden voor het bewijsbeslag lijkt het voor de hand te liggen dat eveneens om sequestratie wordt verzocht. Na Barendrecht en Van den Reek en Hoyng is het in de literatuur even stil geweest over dit bewijsbeslag, maar Wesseling-van Gent heeft er weer de nodige aandacht aan besteed. ${ }^{68} \mathrm{Zij}$ merkt op dat art. 843a Rv ook wordt gebruikt als juridische grondslag voor een bewijsbeslag. ${ }^{69}$

Uit de rechtspraak blijkt dat deze simpele woorden 'inzage, afschrift of uittreksel' toch ook vragen kunnen oproepen. Volgens de rechtbank Zwolle moet, gelet op deze woorden, een vordering tot afgifte worden afgewezen. Uit wetsgeschiedenis noch jurisprudentie valt volgens deze rechtbank af te leiden dat met inzage, afschrift of uittreksel ook afgifte wordt bedoeld. ${ }^{70}$ De rechtbank Dordrecht is daarentegen van oordeel dat waar bewijsbeslag is gelegd, art. 843a Rv onder bepaalde omstandigheden recht geeft afgifte te vorderen van bepaalde bescheiden. ${ }^{71}$ Het hof Den

66 Rb Amsterdam 3 november 2004, AR5041. Uiteindelijk wordt de vordering afgewezen omdat de vraag naar de omvang van de informatieplicht van Dexia als eisende partij in dit geding een integrale beoordeling door de rechtbank vraagt en wel na een daarop toegespitst volledig debat tussen partijen. Eerst wanneer de omvang van de informatieplicht van Dexia is vastgesteld, kan de rechtbank toekomen aan de vraag welke documenten Dexia dient over te leggen en overgaan tot toetsing per onderdeel van de opgevorderde documenten aan de vereisten en uitzonderingen van art. 843a Rv.

67 W.A. Hoyng, Vier procesrechtelijke wensen in 'In het nu wat worden zal' (Schoordijkbundel), p. 105-118, Kluwer 1991.

68 E.M. Wesseling-van Gent, To fish or not to fish, that's the question, Het verzamelen van feiten en bewijs: begrenzing versus verruiming, een kruisbestuiving tussen civiel procesrecht en ondernemingsprocesrecht, Nederlandse Vereniging voor Procesrecht, Boom Juridische uitgevers Den Haag 2006.

69 Zie verder hoofdstuk 14 van dit boek.

70 Voorzieningenrechter Rb Zwolle 24 februari 2004, AO5169.

71 Rb Dordrecht 23 juni 2004, AP3695. Deze uitspraak wordt door H.A. Dragstra, de exhibitieplicht in het arbeidsrecht, Tijdschrift Recht en Arbeid 2009, afl. mei 2009, op p. 16, noot 7 onjuist gedateerd op 24 juni 2008. Anders ter zake bewijsbeslag Rb Den Haag 27 maart 2008, B9 6004 (open www.boek9.nl, voer in het zoekvenster 6004 in) overwegende dat, anders dan Nike betoogt, een recht op afgifte van de bescheiden waarop het beslag betrekking heeft, niet voortvloeit uit art. 843a Rv. Hof Den Haag 24 augustus 2006, AY7534 overweegt ter zake een vordering tot afgifte van een originele tekening, dat op grond van art. 843a Rv een partij in beginsel geen afgifte 
Bosch oordeelt eveneens dat onder omstandigheden een vordering tot afgifte onder 'inzage' kan worden gebracht. ${ }^{72}$ Linssen merkt hierover op dat de verwezenlijking van de ratio van art. 843a Rv soms juist een verplichting tot (tijdelijke) afgifte vergt.

In par. 7.1.1 is het Observatiearrest ${ }^{73}$ aan de orde geweest en de opvatting van Vranken dat niet valt uit te sluiten dat op grond van dit arrest kan worden geconcludeerd dat een vordering tot afgifte van materiaal om het te vernietigen alle perken van de exhibitieplicht te buiten gaat. Art. 843a Rv kan geen grond voor een dergelijke vordering zijn. Uit HR 11 juli $2008^{74}$ kan wel worden geconcludeerd dat een vordering tot afgifte voor vernietiging wel mogelijk is. In die zaak oordeelt de Hoge Raad in overweging 3.8.6 over een op art. 6:162 BW gebaseerde vordering tot vernietiging van onder meer persoonsgegevens dat de eisende partij (De Telegraaf) desnoods opnieuw bij de burgerlijke rechter een bevel tot vernietiging of verbod tot gebruik van de informatie kan vorderen.

Het feit dat in een enkele uitspraak afgifte wordt gelast, doet de vraag rijzen of inzage van of in DNA kan worden verzocht, zodat ik hier ook enkele 'bloeden/of DNA-uitspraken' de revue laat passeren.

In HR 22 september $2000^{75}$ gaf de rechtbank ambtshalve een bevel tot DNAonderzoek. Het hof is van oordeel dat de toenmalige art. 221 en 182 lid $1 \mathrm{Rv}$ (nu respectievelijk 194 en, min of meer, $284 \mathrm{Rv}$ ) grondslag voor zo'n bevel vormen. De Hoge Raad is van oordeel dat het de rechter vrijstaat om een deskundigenonderzoek te bevelen, ook als het gaat om verkrijging van bewijs tegen de man, waarbij geoordeeld kan worden dat de inbreuk op de lichamelijke integriteit van de man

van bescheiden kan vorderen zodat de vordering tot afgifte van de originele tekening zonder nadere gronden niet voor toewijzing vatbaar is.

72 Hof Den Bosch 4 april 2006, AW4335, JBPR 2007, 12 m.nt. J.G.A. Linssen onder JBPR 2007, $\mathrm{nr}$ 6, Philips consumer communications bv tegen Altimex International. Altimex dient tien originele schrijfproeven voor schriftkundig onderzoek aan Philips geven omdat, alhoewel de tekst van art. 843a Rv het niet mogelijk maakt om afgifte van bescheiden te gelasten, de beginselen van een goede procesorde met zich brengen dat Altimex de originelen moet overleggen omdat de deskundige bij voorkeur originele handtekeningen wenst te onderzoeken. Afgifte dient plaats te vinden aan de procureur van Philips tegen verstrekking van een ontvangstbewijs. Rb Arnhem 12 april 2006, AY0152, stelt dat de vordering er toe strekt dat gedaagde het complete strafdossier dient over te leggen en lijkt dit toe te wijzen.

73 HR 31 mei 2002, NJ 2003, 589, m.nt. Vranken.

74 HR 11 juli 2008, BC8421, NJ 2009, 451, m.nt. E.J. Dommering.

75 HR 22 september 2000, NJ 2001, 647, m.nt.JdB. In zijn noot schrijft De Boer dat in dit geval, waar het gaat om de verwerkelijking van een persoonlijkheidsrecht van een kind, de man gedwongen kan worden mee te werken aan bewijslevering, in het bijzonder door toe te staan dat wangslijmvlies wordt afgenomen. Naar ongeschreven recht zou de man jegens het kind in het maatschappelijk verkeer hiertoe verplicht zijn, waarbij misschien zelfs directe reële executie mogelijk is door de deurwaarder met analogische toepassing van art. 491 e.v. Rv buiten de man om een koffiekopje of tandenborstel onder zich te laten nemen. Het lijkt na die opmerking niet meer zo'n grote stap te zijn om de verplichting tot afname van wangslijmvlies te gronden op art. 843a Rv, zeker gelet op het bewijskarakter van dit artikel en de mogelijkheid van bewijsbeslag. 
die wordt veroorzaakt door een DNA-onderzoek gerechtvaardigd is. Niemand rept over art. 843a Rv, maar eigenlijk is hier uiteindelijk sprake van het krijgen van inzage in bepaalde gegevens.

In een zaak waarin de man een verzoek heeft ingediend tot ontkenning van het vaderschap, bepaalt het hof in een tussenbeschikking dat een DNA-onderzoek dient plaats te vinden. De moeder weigert mee te werken en het hof legt zich daar bij neer. In zijn conclusie schrijft Langemeijer dat als een partij niet vrijwillig meewerkt aan een DNA-onderzoek, er geen mogelijkheid is om deze medewerking af te dwingen. Ook al is de inbreuk op het lichaam gering (wangslijm afnemen), het blijft een aantasting van het lichaam waarvoor art. $11 \mathrm{Gw}$ een wettelijke basis vereist. De Hoge Raad deelt die mening en overweegt dat het verlenen van medewerking aan een DNA-onderzoek niet rechtens afdwingbaar is. ${ }^{76}$

\subsection{Bepaalde bescheiden}

De woorden 'bepaalde bescheiden' werden pas bij de wijziging van het Wetboek van Burgerlijke Rechtsvordering met ingang van 1 januari 2002 in art. 843a Rv opgenomen. Voor die tijd kon volgens de letterlijke bewoordingen van art. 843a $\mathrm{Rv}$ alleen inzage van onderhandse aktes worden gevorderd. ${ }^{77}$

Bij het bestanddeel 'bepaalde bescheiden' rijzen de volgende vragen: wat valt onder 'een bescheid', hoe bepaald moet 'bepaald' zijn, moet de inhoud van het bescheid bekend zijn en, tenslotte, hoe zeker moet het bestaan van het bescheid waarvan inzage wordt gevorderd zijn.

Von Schmidt auf Altenstadt is van mening dat het woord 'bescheid' een ruime omschrijving verdient. ${ }^{78}$ Film, foto, video, geluidsbanden, computerbestanden,

76 HR 15 februari 2008, BC1860, NJ 2008, 106.

77 W.A. Hoyng, Vier procesrechtelijke wensen, In het nu, wat worden zal (Schoordijkbundel), Kluwer 1991, p. 108 schrijft dat het eerste struikelblok (hij zal 'horde' bedoelen) bij een exhibitieverzoek, te weten de beperking die wordt gegeven met de woorden 'onderhandse akte' snel is genomen omdat het niet de bedoeling van de wetgever is geweest om wat dit betreft het oude art. 1922 BW te beperken. Zie ook par. 2.2.1.

78 P.J.M. von Schmidt auf Altenstadt, Opening van zaken, TCR 2002, p. 13. Hij wijst er wel op dat de wetgever in art. $19 \mathrm{Rv}$ heeft opgenomen 'alle bescheiden en andere gegevens' waarmee de indruk wordt gewekt dat er ook informatie bestaat die niet op bescheiden staat of onder bescheiden valt. A.I.M van Mierlo en J.H. van Dam-Lely, Procederen bij dagvaarding in eerste aanleg, Serie burgerlijk proces en praktijk, Kluwer, Deventer 2003, p. 73 lijken te zeggen dat de wetgever met de laatste zin van het eerste lid (onder bescheiden worden mede verstaan op een gegevensdrager aangebrachte gegevens) van art. 843a Rv ook toekomstige technische ontwikkelingen alvast onder het begrip bescheid heeft willen brengen. Aldus is de elektronische akte ook een bescheid in de zin van art. 843a Rv. Zie over die elektronische akte H.P.A.J. Martius, Enige opmerkingen aangaande wetsvoorstel 31.358 in het Nederlands Tijdschrift voor Handelsrecht 2008, p. 237-251. Laatstgenoemde verdedigt in Elektronisch handelsrecht, De juridische aspecten van elektronische communicatie in het handelsrecht, Deel 8 in de NTHR-reeks, uitgeverij Paris, 2008, p. 55-58 aan de hand van de laatste zin van lid 1 dat onder het begrip 'bescheiden' ook de elektronische 
het valt er volgens hem allemaal onder. Daar lijkt niemand anders over te denken en in de jurisprudentie zijn evenmin beperkingen te vinden. ${ }^{79}$ Een tot dusverre nog niet gestelde en beantwoorde vraag is wat ik maar noem 'de DNA-vraag'. In de biologie zijn een losse haar, een druppel bloed, wangslijm, enz. dragers van gegevens. Die gegevens bestaan dan uit het DNA. Zijn deze objecten daarmee ook bescheiden in de zin van art. 843a Rv? Uit niets in de parlementaire geschiedenis blijkt dat bij 'bescheiden' in de eerste zin van lid 1 van art. 843a Rv aan andere zaken is gedacht dan aan door mensen gemaakte zaken die bestemd zijn om gegevens te dragen. Daarmee worden voorwerpen als een haar, een druppel bloed en wangslijm uitgesloten indien art. $843 \mathrm{a} \mathrm{Rv}$ wetshistorisch wordt uitgelegd. Uit de zinsnede 'op een gegevensdrager aangebrachte gegevens' in de laatste zin van dit lid, kan volgens de letterlijke tekst evenmin worden afgeleid dat de genoemde zaken 'bescheiden' kunnen worden genoemd. Ik meen tenminste dat met het woord 'aangebracht' een bedoelde of onbedoelde menselijke handeling wordt bedoeld. DNA is niet door menselijk handelen op een losse haar, een druppel bloed of wangslijm aangebracht.

De laatste zin van lid 1 van art. 843a Rv luidt volledig 'Onder bescheiden worden mede verstaan: op een gegevensdrager aangebrachte gegevens'. Uit het woord 'mede' dient afgeleid te worden dat deze zin een eneuntiatieve opsomming

gegevens vallen van een internetprovider waaruit bijvoorbeeld blijkt dat een bericht via het internet naar een bepaalde geadresseerde is gestuurd. Het achterhalen hiervan kan van groot belang zijn indien verzending en ontvangst van een emailbericht moet worden bewezen. Volgens hem slaagt een vordering van de verzender tegen de provider waarin inzage wordt gevraagd van de 'verzendgegevens'. Een betreffende vordering tot inzage in elektronische ontvangstgegevens, voor zover bestaand, tegen de ontvanger is, zo begrijp ik hem, zonder meer toewijsbaar. P.M. Leerink, Schorsing van de dekking wegens te late premiebetaling, AV\&S 2009, p. $92-99$ is ook van mening dat de provider van de geadresseerde zo nodig met een beroep op art. 843a Rv kan worden gedwongen de noodzakelijke data aan te leveren. Onder die druk zal volgens hem het betwisten van de ontvangst van een emailbericht minder vaak voorkomen. Zie ook HR 25 november 2005, AU4019, JOL 2005, 683, Lycos-Pessers. In 'Hoe schriftelijk is elektronisch? Over post, e-post en e-akte', WPNR 6710 (2007), p. 456 merkt Martius in het kader van de waardering van voorgebracht bewijs op dat het ontvangstmoment van een elektronisch bericht niet eenvoudiger is te vervalsen dan dat van een gewoon schriftelijk bericht. B.T.M. van der Wiel, De exhibitieplicht (te) terughoudend opgevat, NbBW 2004, p. 59 is van mening dat de door een beleggingsbank met een klant opgenomen telefoongesprekken onder bepaalde bescheiden vallen.

79 Op Rb Zwolle 15 mei 2006, AY5717 na die van oordeel is dat een calculatie van een verkoopprijs in het algemeen niet kan worden aangemerkt als een bescheid in de zin van art. 843a Rv, tenzij het een stuk betreft dat door de verkoper reeds eerder aan de koper is afgegeven of toegezonden. Zie ook HR 29 januari 2010, BK2007: persoonlijke aantekeningen van de secretaris van het scheidsgericht of de arbiters zelf die tijdens of na de zitting zijn gemaakt van hetgeen tijdens de zitting is gezegd en voorgevallen, en waarin informatie is neergelegd over hetgeen door de partijen en de arbiters met betrekking tot de inhoud of de behandeling van de zaak op de zitting is meegedeeld, zijn bescheiden aangaande de rechtsbetrekking die tussen partijen in de arbitrage aan de orde is. Ook indien niet uitdrukkelijk is overeengekomen dat arbiters beslissingen, afspraken of erkenningen moeten vastleggen in een schriftelijk verslag, zijn arbiters gehouden dit op verzoek van een partij te doen. 
geeft. Aan de hand daarvan kan worden verdedigd dat een losse haar, een druppel bloed en wangslijm 'bescheiden' in de zin van art. 843a Rv zijn. Het gaat mij echter te ver om het menselijk lichaam of onderdelen daarvan zoals haren in dit verband een 'bescheid' te noemen zonder expliciete instemming van de wetgever. Die instemming dient dan rekening te houden met art. $11 \mathrm{Gw}$, het artikel waarin de onaantastbaarheid van het menselijk lichaam is neergelegd.

Wel een bescheid waarvan in het kader van bijvoorbeeld een vaderschapsactie inzage kan worden gevraagd, is het kaartje van de bloedbank van een persoon, bijvoorbeeld een bloeddonateur, waarop bloedgroep en resusfactor staan. Met de informatie verkregen na inzage in dit kaartje, kunnen de eerste stappen op weg naar het antwoord of een bepaalde man de vader van een kind is, zonder meer worden gezet. ${ }^{80}$

Het woord 'bepaald' voorkomt het maken van vistochten ${ }^{81}$ Er kan echter bij wijze van spreken wel om 'vrachtwagens papier' worden gevraagd. ${ }^{82}$ Het gaat erom dat de vordering betrekking moet hebben op bepaalde, dus concreet aangeduide, bescheiden. Met de woorden 'bepaalde bescheiden' wordt echter niet bedoeld dat elk stuk met naam, toenaam en datum gespecificeerd moet worden. Het gaat erom dat in het licht van de vordering voldoende duidelijk is om welke bescheiden het gaat en om welke reden zij van belang zijn en dat de plicht om inzage te geven niet verder strekt dan noodzakelijk is. ${ }^{83}$

Voldoende bepaald is een vordering tot inzage van Aegon tegen Dexia in alle documenten die betrekking hebben op de mate waarin Dexia als koper van de Bank

80 Reeds in 1953 was het mogelijk om in sommige gevallen enkel met behulp van een bloedonderzoek vast te stellen dat een bepaalde man niet de vader van een kind was, aldus AG Eggens bij HR12 juni 1953, NJ 1954, 61 (bloedproefarrest). Ik wijs verder op het wetsvoorstel 31241, verplichte medewerking aan een bloedtest in strafzaken, op 18 september 2008 in de TK aangenomen (zie voor meer daarover J. Schrover, Verplichte HIV-test versus het nemo teneturbeginsel, AA 2009, p. 298-305). In civiele zaken zijn reeds uitspraken gewezen waarin een verdachte/dader werd verplicht om bloed af te staan met het oog op een HIV-test. Zie HR 18 juni 1993, NJ 1994, 347 en HR 12 december 2003, NJ 2004, 117. In het laatstgenoemde geval werd een patiënt wiens bloed per ongeluk in aanraking kwam met een bloedende vinger van een opererende arts verplicht om bloed af te staan. De patiënt had niets onrechtmatigs gedaan.

81 J.F. Garvelink en P.F. Hopman, Verboden te vissen: informatieplicht van banken en afdwingbaarheid daarvan, Tijdschrift voor Effectenrecht 2004, p. 13 schrijven dat de woorden 'bepaalde bescheiden' met zich brengen dat een schot hagel niet voldoet. Eiser zal man en paard moeten noemen.

82 Rb Groningen 22 november 2002, NJ 2003, 102 gelast in het dictum 'afschriften van de stukken met betrekking tot de contractuele verhouding tussen Jonkman enerzijds en KPN Telecom respectievelijk de leveranciers dan wel onderhoudsmonteurs van computer en alarmbel anderzijds evenals de relevante correspondentie tussen genoemde partijen in verband met en naar aanleiding van de schade aan Dekker te verschaffen'.

83 W.P. Wijers en A.J. Haasjes, Exhibitie in het (ondernemings)recht, O \& F 2006, p. 53. Waar het voldoende is om slechts een deel van de boekhouding in te zien, hoeft niet de hele boekhouding ter inzage te worden gegeven. 
Labouchere in het kader van het door Dexia gedane due diligenceonderzoek enkele risico's in de onderneming van Labouchere heeft onderkend, ${ }^{84}$ een vordering tegen een aandeelhouder om inzage in het aandeelhoudersregister ${ }^{85}$ een vordering tot het verschaffen van afschriften van

'agenda's, notulen, agendastukken etc. met bijlagen van de Raad van Toezicht van PWS over de periode 15 juli 1998- 31 december 2005 voor zover daarin sprake is van de projecten Aelbrechtskade, Giam-pakketten, Rijnhotel, TKN-pakketten A+B, Vissersdijk, ATTA-pakket, Schoterbos, St. Jacobsplaats, Woonplus I en II, Slaakhuys, Rijnhotel, Pleinweg, Dunehold, Hooge Marinier en Branderspoor' ${ }^{86}$

Onvoldoende bepaald is een verzoek tot inzage in 'de volledige correspondentie' tussen de Rabobank en partij B over de periode november 2001 tot en met april 2002 , betrekking hebbend op de ingeleide executoriale verkoop ${ }^{87}$ een vordering tot inzage in een volledig cliëntendossier, ${ }^{88}$ een vordering tot inzage in justifica-

$84 \mathrm{Rb}$ Amsterdam 3 november 2004, AR5041. Zie ook voor voldoende bepaald Rb Rotterdam 5 december 2007, BC0225, NJF 2008, 95 en Rb Dordrecht 19 december 2007, BC1176 (de volledige polisdocumenten).

85 Hof Amsterdam 17 juni 2008, BE2917. Rb Amsterdam 3 juli 2008, B9 6521 (open www.boek9.nl, voer in het zoekvenster $6521 \mathrm{in}$ ) geeft verlof tot inzage in met toestemming van de rechter in beslag genomen (elektronische) documenten betreffende de handel in Lifescan OneTouch test strips en/of verpakkingen, bijsluiters en/of andere productbescheiden of verpakkingsmaterialen voor Lifescan OneTouch test strips, houdende de merken van J\&J.

86 Rb Rotterdam 1 april 2009, BI1747.

$87 \mathrm{Rb}$ Zutphen 7 mei 2003, JBPR 2003, 66. Ook een vordering tot inzage in alle stukken van een strafdossier is te algemeen en onbepaald van aard aldus de Rb Arnhem 12 april 2006, AY0152. Onvoldoende specifiek is volgens Rb Den Haag 20 februari 2008, B9 5659 (open www.boek9.nl, voer in het zoekvenster 5659 in) de vordering van Duplico om afschriften van alle licentieovereenkomsten van alle vennootschappen behorende tot de Philipsgroep die in een bepaalde periode zouden zijn gesloten die de naam 'Philips Only DVD Video and DVDROM DISC Patent License Agreement of Patent Manufacturing Agreement' dragen. Zij stelt dat zij op grond van contacten in de markt het vermoeden heeft dat Philips haar benadeelt ten opzichte van andere licentiehouders.

88 Rb Amsterdam 2 februari 2005, AT1558, JOR 2005, 71 oordelend dat een vordering op de voet van art. 843a Rv tot inzage in het volledige cliëntendossier dat X NV in het kader van het beheer van het vermogen van A BV heeft aangelegd geen 'vordering tot inzage in of het verstrekken van een afschrift van bepaalde, met name genoemde, bescheiden is'. Afwijzend wat inzage in het eigen volledige cliëntendossier bij de (voormalig) eigen advocaat betreft Rb Arnhem 11 april 2007, BA5534. Ook de vordering tot inzage (of afgifte) tegen een observatiebureau dat eiser in opdracht van een schadeverzekeraar had geobserveerd van het complete onderzoeksdossier wordt afgewezen omdat deze vordering niet voldoet aan het vereiste van bepaalde en met name genoemde bescheiden (Rb Zutphen 9 mei 2007, BB1491). Afwijzend wat inzage in een schadedossier betreft hof Den Haag 12 juni 2007, S\&S 2009, 34. Rb Utrecht 23 januari 2008, BC4019 is van oordeel dat een vordering om afschriften van 'het volledige dossier, in ieder geval bestaande uit: verzoek tot plaatsopneming, memorie van eis, memorie van antwoord/eis, memorie van repliek/antwoord, memorie van dupliek/repliek, memorie van dupliek, aantekeningen Teluy, aantekeningen Drost, akte na mondelinge behandeling, antwoordakte na mondelinge behandeling, aantekeningen Teluy, proces-verbaal plaatsopneming, correspondentie waaronder brieven, emailberichten en faxen tussen 
toire bescheiden waarmee opdrachtgeefster haar vorderingsrecht zou kunnen bewijzen, zoals een verklaring van de goederenverzekeraars van opdrachtgeefster in de vorm van een uitkeringsbericht of enig ander besluit van verzekeraars onder de polis met daarbij een door de directeur van opdrachtgeefster getekende verklaring omtrent de volledigheid daarvan. ${ }^{89}$ Een vordering tot veroordeling om over te

Drost en eiser en tussen gedaagde en eiser, aantekeningen/diverse stukken, foto's en CD-Rom van Zoelen, bankafschriften depositorekening, bouwvergaderingverslagen', voldoet aan het in art. 843a Rv bedoelde vereiste van 'bepaalde bescheiden'. Rb Zwolle-Lelystad 5 maart 2008, BD8262 wijst een vordering die ziet op 'alle bescheiden, van welke aard ook, voor zover verband houdend met de Turnkey-overeenkomsten en de objecten gebouw F en gebouw E' als te vaag af. Rb Arnhem 26 maart 2008, BC8823 oordeelt over inzage in bescheiden die zijn in beslaggenomen op grond van een verlof op een verzoek 'op het in gerechtelijke bewaring nemen van alle roerende zaken op de kantoor- en woonadressen van gedaagden'. Ballast Nedam stelt dat die in beslag genomen zaken betrekking hebben op fraude gepleegd door gedaagde(n). De zaken betreffen ordners, bankafschriften, correspondentie en computergegevens. Een nadere specificatie is er (nog) niet. De rechtbank: het standpunt van Ballast Nedam dat de bescheiden betrekking hebben op de fraude, kan ten dele juist zijn, maar dan alleen voor zover Ballast Nedam bedoelt dat het allerminst is uitgesloten dat zich onder die bescheiden bewijsstukken van de fraude bevinden omdat het plegen van frauduleuze handelingen dagelijks praktijk was. 'Daarmee zijn de stukken nog geen schriftelijke bewijsmiddelen waarvan Ballast Nedam de inhoud in beginsel kent zonder over de bewijsmiddelen zelf te beschikken. Haar vordering ... is ...(een) fishing expedition ... in die zin dat zij de bescheiden vooralsnog voor geen ander doel nodig kan hebben dan om na te gaan of de bescheiden nader bewijs van het door haar gestelde ...inhouden...' en voldoet daarmee niet aan de eis van art. 843a $\mathrm{Rv}$ dat zij bepaalde bescheiden moet betreffen. Zie ook Rb Utrecht 2 april 2008, BC8153 en Rb Utrecht 9 april 2008, BC9990.

89 Rb Arnhem 21 december 2005, AV1977, de vordering tot inzage in mogelijke verzekeringspolissen wordt afgewezen omdat 'Europe Flyer verlangt immers afschriften van een ongelimiteerde lijst van mogelijk bestaande verzekeringsstukken. Het gaat derhalve niet om specifieke bewijsmiddelen waarvan de inhoud bij haar in beginsel bekend is'. Indien inzage in de notulen van de vergaderingen van raden van bestuur en commissarissen over de jaren 1997, 1998 en 2000 wordt gevorderd voor zover die betrekking hebben op bepaalde transacties, is dat onvoldoende concreet gespecificeerd volgens het hof Arnhem 13 februari 2007, BA0018. Rb Den Haag 21 maart 2007, BC5652 wijst een vordering ex art. $843 \mathrm{a} \mathrm{Rv}$ tegen de curator waarbij de curator aan de crediteur de volledige administratie moet overleggen subsidiair de crediteur zes weken toegang en inzage in die stukken moet geven af als te onbeperkt (er is geen beroep gedaan op art. 3:15j BW). Ook afwijzend wat inzage in financiële administratie betreft Rb Leeuwarden 24 juni 2009, BI9925. Hof Arnhem 17 april 2007, NJF 2007, 391 overweegt in een boedelscheidingsprocedure tussen voormalige echtgenoten, dat een vordering betrekking hebbend op 'de correspondentie (waaronder de verzonden documenten en de concepten daarvan) zoals gevoerd door Kindt $\mathrm{Fb}$ of diens kantoorgenoten bij Berk accountants en fiscalisten met achtereenvolgens de fiscus, de notaris, de huisbankier en de man, voor zover betrekking hebbende op de waardering en mogelijke overdracht van de Benpuck Tiel West BV, de Benpuck Batavierenweg BV en de eenmanszaak McDonald's Kronenburg alsmede de correspondentie van Kindt $\mathrm{Fb}$, R. van Leeuwen RA en R. van Zanen RA betrekking hebbende op de uitbreiding van de kring van consolidatie zoals doorgevoerd in de jaarrekening van de Benpuck Holding BV over 2003, zulks over de periode van 1 januari 2002 tot en met 30 juni 2006' teveel weg heeft van het vissen naar stukken. Rb Den Bosch 16 juli 2009, BJ2913 wijst af een vordering tussen erfgenamen naar inzage in a. successieaanslag en de aan de successieaangifte ten grondslag liggende bescheiden; b. jaarstukken, belastingaangiftes IB/VB en bijbehorende 
leggen alle justificatoire bescheiden waaruit het inkomen en vermogenspositie van een alimentatieplichtige blijkt, is onvoldoende bepaald, waardoor de vordering van eiseres dreigt te ontaarden in vissen..$^{90}$

aanslagen; c. de bankafschriften, zowel zakelijk als privé, zowel lopende rekeningen als spaarrekeningen; d. schenkingen, bijbehorende aktes en aangifte/aanslag schenkingsrecht; e. notariële bescheiden betreffende de door vader bewoonde woningen, waaronder hypotheekaktes en overeenkomst, waaronder overeenkomsten van geldlening; ee. idem voor wat betreft de woning aan de Molenstraat 17; f. overzicht van investeringen in de woning dan wel zakelijke rechten, verbouwingen woningen derden, kopie offertes en betalingen; ff. idem voor wat betreft de start van het eigen bedrijf van Z; g. voor het overige alle onderliggende bescheiden omdat A ‘ ... vraagt om overlegging van een groot aantal bescheiden, waarbij hij zich kennelijk voorstelt dat een uitgebreide studie daarvan klaarheid zal brengen over een mogelijke toekomstige overbedeling van $\mathrm{Z}$ en vaststelling van onderbedeling van hemzelf... De bepaling van artikel $843 \mathrm{a} \mathrm{Rv}$ bevat geen blanco cheque om ongebreideld bescheiden op te vragen die men graag met het oog op een en ander belang zou willen inzien of hebben;... Uit het feit dat A niet aangeeft welke stukken hij precies wenst te ontvangen maar vordert dat een groot aantal weinig bepaalde stukken wordt afgegeven, volgt reeds dat sprake is van een fishing expedition..... Rb Rotterdam 12 augustus 2009, BJ5752 wijst inzage in een kredietdossier af als te algemeen geformuleerd.

90 Rb Zwolle-Lelystad 11 mei 2007, BA5021. Rb Rotterdam 9 januari 2008, BC4119 ooordeelt dat onvoldoende bepaald is een vordering tot inzage in 'alle informatie die Amev via haar Brand Acceptatie Systeem heeft over een aantal met name genoemde polissen' en 'het volledige schadedossier'. Rb Amsterdam 23 juli 2008, B9 6517 (open www.boek9.nl, voer in het zoekvenster 6517 in) wijst af een vordering tot overlegging van 'alle door ATP gesloten overeenkomsten en/of alle door ATP met derden gevoerde correspondentie met betrekking tot het vervaardigen en openbaar maken van televisiecommercials, audioboardings, billboards en alle overige uitingen, met uitzondering van een bepaalde website, waarin of waarop gebruik is gemaakt van het portret van Meeus.' als niet omschreven op welke specifieke bepaalde bescheiden zij daarbij het oog heeft. Zie hierover G. van der Wal en F. van Schaik, Handhavingsinstrumenten in het intellectuele eigendomsrecht: het op de loer liggende risico van 'fishing expedions' vergt kritische rechterlijke toetsing, IER 2009, p. 119-123. Rb Rotterdam 29 juli 2008, BD9031: de tabaksfabrikant BAT, aansprakelijk gesteld door een roker, wenst die door de roker gestelde schade te verhalen op haar verzekeraar HDI. HDI vordert in dat verband van BAT onder meer 'alle zowel intern als extern opgemaakte rapporten die van belang zijn voor de beoordeling van de aansprakelijkheid van BAT, de verslavende werking van sigaretten en de mogelijkheid te stoppen met roken, alle documenten die inzicht verschaffen in de aard en eigenschappen van tabak en de stoffen die tabak van nature bevat of die door bewerking ontstaan, zoals onder andere nicotine, en de waarde die die stoffen hebben voor sigaretten en alle documenten die inzicht verschaffen in de aard van alle eigenschappen van alle stoffen die naast tabak aan het eindproduct sigaret worden toegevoegd, zoals aromaten, conserveringsmiddelen, papier, filter, enz.' De rechtbank is van oordeel dat dit overwegend onvoldoende bepaald is en neigt naar het vissen naar stukken. Ook afwijzend Rb Breda 31 juli 2008, BD9054 vwb inzage in een in beslaggenomen harde schijf van een laptop van een bedrijfsjurist en Rb Utrecht 1 oktober 2008, BF7386 waar de gestelde fraude onvoldoende aannemelijk is zodat de vordering een vistocht is en $\mathrm{Rb}$ Arnhem 21 oktober 2008, BG3613 waar een crediteur tegen een curator inzage in de volledige financiële administratie van de failliet vordert en hof Amsterdam 2 december 2008, BG9051 omdat de gevraagde inzage is bedoeld om na te kunnen gaan of er voldoende feitelijke grondslag bestaat voor een vordering uit wanprestatie en/of onrechtmatige daad tegen een ex-werknemer. Rb Utrecht 18 maart 2009, BH6128 overweegt dat een deel van de inzagevordering van A, en wel het deel waarin inzage wordt gevorderde in 'alle gegevens- 
In de literatuur wordt regelmatig verdedigd dat de inhoud van het bescheid waarvan inzage wordt gevorderd, bekend moet zijn. Ter verdediging van dit standpunt wordt gewezen op de parlementaire geschiedenis van het nieuwe bewijsrecht. Daar heeft de minister gezegd dat de zogeheten exhibitieplicht slaat op de situatie dat de inhoud van een schriftelijk bewijsmiddel aan een partij in beginsel wel bekend is, maar dat zij het niet in haar bezit heeft. ${ }^{91}$ Ekelmans neemt dat letterlijk omdat hij opmerkt dat de praktijk niet meer zo terughoudend is als deze wetgever van 1988 omdat uit de nodige uitspraken inmiddels blijkt dat inzage wordt gegeven in bescheiden waarvan de inhoud volledig onbekend is en alleen het bestaan bekend..$^{92} \mathrm{Hij}$ acht een concrete omschrijving zodat duidelijk is waarop wordt gedoeld, voldoende.

Het hof Den Haag en de rechtbank Breda lijken van oordeel te zijn dat met 'bepaald bescheid' niet wordt bedoeld dat de inhoud globaal bekend moet zijn. De verzoekende partij hoeft namelijk geen kennis van de inhoud te hebben. ${ }^{93}$ De rechtbank Utrecht is van oordeel dat voor zover de minister heeft gezegd dat de inhoud van de bescheiden waarvan inzage wordt gevraagd, bekend moet zijn, dat is gezegd in het kader van de wetsgeschiedenis van art. 843a Rv-versie 1988 en niet is herhaald in 2002. De opmerking van de minister is verder begrijpelijk onder de oude tekst gelet op de woorden 'onderhandse akte' in die tekst, terwijl verder een rechtsbetrekking uit onrechtmatige daad nog niet viel onder het woord rechtsbetrekking in art. 843a Rv. Ten slotte wordt inmiddels in de jurisprudentie een ruimere uitleg gehanteerd en zou een eis dat er kennis van de inhoud moet zijn

dragers die communicatieverband houden met relaties van A, alsmede betaalverkeer van en naar relaties van A vanaf juni 2008' onvoldoende bepaalbaar is.

91 P. 417 Parl. Gesch. nieuw bewijsrecht, onder andere geciteerd in Rb Den Haag 27 juli 2005, AU5178. S. Hoogeveen, Fishing expeditions versus exhibitieplicht, Advocatenblad 2005, p. 680 meldt dat de bijzondere exhibitieplicht van art. 843a Rv ziet op de situatie dat de inhoud van een schriftelijk bewijsmiddel aan een partij in beginsel wel min of meer bekend is, maar dat zij niet in haar bezit heeft. W.P. Wijers en A.J. Haasjes, Exhibitie in het (ondernemings)recht, O \& F 2006, p. 53 verdedigen dat art. 843a Rv ziet op situaties waarbij de inhoud van een schriftelijk bewijsmiddel aan een wederpartij weliswaar bekend is, maar zij dit niet in haar bezit heeft. Wesseling-van Gent schrijft in Van der Korst e.a., p. 106 dat het hierbij gaat om bepaalde, gespecificeerde bescheiden, zij het in de ruimste zin van het woord. De 'bepaalde bescheiden' moeten documenten en gegevens betreffen, waarvan men het bestaan weet of vermoedt, maar die men (slechts) niet onder zich heeft. H. Uittien, Gedwongen verstrekking van due diligence-rapportages, Tijdschrift voor de ondernemingsrechtpraktijk 2007, p. 20 is van mening dat in de context van de vordering voldoende duidelijk moet zijn om welke bescheiden het gaat en om welke reden deze van belang (kunnen) zijn.

92 Ekelmans in zijn artikel in TCR 2005 en op p. 63 van zijn boek. Ook R.E.N. Ploum, Exhibitieplicht: nachtmerrie of noodzaak? In 'Leidse procesrechtelijke geschriften', Gouda Quint BV Arnhem, 1990, p. 61 en A.A.M. Menken, Exhibitieplicht ex art. 843a Rv, V\&O 1998, p. 54 lijken deze uitleg voor te staan.

93 Respectievelijk hof Den Haag 20 mei 2003, S\&S 2004, 59 (verzekeringspolis) en Rb Breda 14 januari 2004, JOR 2004, 70. Zo vermoedelijk ook Rb Rotterdam 23 februari 2005, BB6038, S\&S $2009,85$. 
slechts bij hoge uitzondering met zich brengen dat een recht tot inzage bestaat. Dat laatste verdraagt zich niet goed met de opmerking in de parlementaire geschiedenis dat in een geval als HR 30 januari 1998, NJ 1998, 459 onder het nieuwe recht wel een recht tot inzage bestaat hoewel bij de verzoeker alleen het bestaan van de overeenkomst en niet de inhoud daarvan bekend was. ${ }^{94}$

Onder meer het hof Den Haag komt tot een ander oordeel waar het overweegt dat bij de totstandkoming van art. 843a Rv-nieuw niet is gebleken dat de minister is teruggekomen op zijn opmerking dat de exhibitieplicht slaat op de situatie dat de inhoud van een bewijsmiddel in beginsel wel bij de verzoekende partij bekend is. $^{95}$

Het vierde probleem dat bij de uitleg van de inhoud van het begrip 'bepaalde bescheiden' aan de orde komt is de vraag hoe zeker het bestaan van het bescheid moet zijn.

Uitgangspunt is dat met voldoende zekerheid moet kunnen worden vastgesteld dat het stuk waarvan inzage wordt gevraagd bestaat. ${ }^{96}$ Bij een ontkenning van het bestaan van het bescheid waarvan inzage wordt gevorderd, brengt behoorlijke rechtspleging met zich dat een partij, mits die behoorlijk bewijs van het bestaan van het bescheid heeft aangeboden, wordt toegelaten bewijs te leveren dat het bescheid daadwerkelijk bestaat en wel op grond van de hoofdregel van art. 150 $\mathrm{Rv} .{ }^{97}$ De jurisprudentie is wisselend wat het antwoord op de vraag betreft of het

94 Rb Utrecht 12 september 2007, BB3722, NJF 2007, 544.

95 Hof Den Haag 9 oktober 2007, BB6971. Ook zo Rb Arnhem 21 december 2005, AV1977 die een vordering tot inzage in mogelijke verzekeringspolissen afwijst omdat het niet gaat om specifieke bewijsmiddelen waarvan de inhoud bij eiseres in beginsel bekend is, en Rb Middelburg 5 april 2006, AZ0931overwegende dat art. 843a Rv ziet op de situatie 'dat de inhoud van een schriftelijk bewijsmiddel aan een partij in beginsel wel bekend is, maar dat zij niet in bezit heeft en Rb Arnhem 25 juli 2007, BB1988.

96 Rb Den Haag 27 juli 2005, AU5178. Zie ook Rb Haarlem 18 juni 2008, BD6490. Hof Leeuwarden 13 januari 2009, BH2762 wijst af het volgens het hof 'verholen' verzoek van eiser, een mesothelioomslachtoffer, gestoeld op art. 843a Rv, dat Eternit haar dealerslijst in het geding moet brengen, omdat Eternit gemotiveerd heeft gesteld dat zij niet meer over dergelijke lijsten beschikt. Hof Arnhem 28 april 2009, BI4184 overweegt dat het verweer dat het stuk niet bekend is, niet in de weg staat aan toewijzing van een vordering tot inzage. Aan toewijzing staat wel in de weg dat onvoldoende zeker is dat het gedaagde over het stuk kan beschikken. Zie ook Rb Rotterdam 19 juli 2006, AZ4042, NJF 2006, 556 en Rb Rotterdam 30 januari 2008, Zaak-/rolnummer 279904/HA ZA 07-674 waaruit blijkt dat indien voldoende vast is komen te staan dat het stuk niet bestaat, de vordering tot inzage als onvoldoende bepaald wordt afgewezen.

97 Rb Rotterdam 5 juli 2006, AY3959. Ook zo Rb Rotterdam 4 maart 2009, BH5652. Zie ook HR 3 januari 1997, NJ 1997, 451, m.nt. JdB. Het hof Den Haag passeerde in deze zaak als onvoldoende toegelicht het verweer van een moeder dat zij geen (mondelinge) informatie kan verschaffen betrekking hebbend op de vraag wie de vader van de eisende partij (haar dochter) is, omdat de verwekking door een verkrachting is geschied, mede omdat zij dit verweer pas voor het eerst in hoger beroep voert. Aldus kan worden verdedigd dat waar een partij pas in hoger beroep stelt dat de bescheiden niet bestaan, dit verweer als minder geloofwaardig kan worden gepasseerd indien 
stuk feitelijk al moet bestaan of dat er nog 'geknutseld' mag worden. De rechtbank Rotterdam is van oordeel dat het om een bestaand bescheid moet gaan ${ }^{98}$, terwijl de rechtbank Utrecht oordeelt dat uit het volledige personeelsbestand een lijst moest worden gemaakt van werknemers en gewezen werknemers die vanaf 1 januari 2002 de bedrijfsvestiging van Oskam BV als vaste werklocatie hadden en/of hebben en een bedrijfvervoermiddel ter beschikking hadden gekregen. ${ }^{99}$

\subsection{Aangaande een rechtsbetrekking waarin hij partij is}

De woorden 'aangaande een rechtsbetrekking waarin hij of zijn rechtsvoorgangers partij zijn' zijn ingevoegd bij de invoering van het nieuwe bewijsrecht op 1 april 1988. Uit hoofdstuk 2 blijkt dat de wetgever nauwelijks of geen uitleg over deze zinsnede heeft gegeven. In de literatuur is hierover wel het nodige te vinden. Hoyng schrijft dat art. 843a Rv ook de mogelijkheid biedt om van derden afschriften van stukken te vragen. Dit betekent volgens hem dat ook afschriften van geschriften kunnen worden gevraagd waaruit de namen van toeleveranciers respectievelijk afnemers blijken. Het woord 'aangaande' heeft immers een zeer ruime betekenis en omvat stellig ook het bekend worden uit geschriften van een tot dan toe onbekende doch vermoede rechtsbetrekking. ${ }^{100}$ Van den Reek stelt dat de exhibitie-

niet duidelijk wordt gemaakt waarom dit pas voor het eerst in hoger beroep wordt aangevoerd. Zie ook Rb Rotterdam 23 februari 2005, BB6038, S\&S 2009, 85

98 Rb Rotterdam 4 juli 2007, BA9918 overwegende dat de betreffende vordering strekt tot het door de andere partij fabriceren en vervolgens overleggen van een thans niet bestaand overzicht waarin gedaagde bepaalde, uit ruim 4.000 schadedossiers te putten gegevens zou moeten samenvatten. Als de ratio van de artt. 843a, 21 en $22 \mathrm{Rv}$ al met zich kan brengen dat het vervaardigen van nog niet bestaande bescheiden kan worden gevergd, zijn in deze zaak te omvangrijke werkzaamheden te verwachten om een vordering toe te wijzen.

$99 \mathrm{Rb}$ Utrecht 13 februari 2008, JAR 2008, 83. H.A. Dragstra trekt in De exhibitieplicht in het arbeidsrecht, Tijdschrift Recht en Arbeid 2009, afl. mei 2009 op p. 16 uit dit vonnis de conclusie dat er op voet van art. 843a Rv kan worden gevorderd dat uit een bestaand bestand een nieuw bestand (lijst) dient te worden gemaakt ten behoeve van inzage. Ik weet dit niet zo zeker omdat het erop lijkt dat de werkgever niet het verweer heeft gevoerd dat om inzage in een niet bestaande lijst wordt gevraagd, terwijl uit HR 6 oktober 2006, NJ 2006, 547, JBPR 2007, 6, m.nt. J.G.A. Linssen, AA 2007, p. 371-374, m.nt. H.B. Krans, Meijer-VOF Gebr. Cornelis blijkt dat een rechter bij een procedure op de voet van art. 843a Rv niet ambtshalve mag controleren of aan alle bestanddelen is voldaan. Rb Amsterdam 31 december 2008, BH1550, NJF 2009, 85 oordeelt dat niet kunnen vinden niet betekent dat het stuk niet bestaat.

100 W.A. Hoyng, Vier procesrechtelijke wensen, In het nu, wat worden zal (Schoordijkbundel), Kluwer 1991, p. 108. Burgerlijke Rechtsvordering (voorheen de losbladige Van den Dungen) geeft bij de uitleg van dit begrip bij het commentaar onder art. 843a Rv niet meer dan een weergave van HR 18 februari 2000, NJ 2001, 259 en de opmerking in de parlementaire geschiedenis van de op 1 januari 2002 in werking getreden vernieuwingen van het Wetboek van Burgerlijke Rechtsvordering dat het in de lijn van de met dit wetsvoorstel beoogde verruiming van art. 843a Rv ligt om in elk geval ook een verbintenis uit onrechtmatige daad als een rechtsbetrekking, als bedoeld in deze bepaling aan te merken. Vranken in Asser-Vranken Algemeen Deel 1995, nr. 24 droomt in 1995 van een verregaande informatieplicht van partijen. De tekst van art. 843a Rv zoals deze 
plicht niet met een zekere opportunistische willekeur tegen een ieder kan worden ingezet. Art. 843a Rv eist dat tussen partijen een -vermeende- juridische gebondenheid, een rechtsbetrekking, moet bestaan. Hierbij kan worden gedacht aan alle verbintenissen uit de wet en aan verbintenissen uit overeenkomst. ${ }^{101}$ Menken maakt duidelijk dat degene tegen wie de vordering ex art. 843a Rv wordt ingesteld, niet degene hoeft te zijn tegenover wie de eiser van het bewijsmiddel gebruik wenst te maken zodat die derde geen partij hoeft te zijn bij de rechtsbetrekking waar eiser op doelt. ${ }^{102}$ Von Schmidt auf Altenstadt noemt het vereiste een vergaande en oneigenlijke beperking en uit alles wat hij daarover schrijft blijkt dat hij die beperking afwijst. De beperking is volgens hem oneigenlijk omdat deze ook niet wordt aangelegd bij de vraag of een getuige moet worden gehoord. De vereisten 'rechtmatig belang' en 'bepaalde bescheiden' zijn voldoende om misbruik zoals vistochten te voorkomen. ${ }^{103}$ Volgens Van den Broek ziet het woord rechtsbetrekking in art. 843a Rv op de rechtsbetrekking in het kader waarvan het stuk waarvan inzage wordt gevraagd, is opgemaakt. ${ }^{104}$ Het komt Van der Wiel voor dat de Hoge Raad op

in 1995 bestond, bood volgens hem weinig mogelijkheden omdat de partij die de inzage vraagt, partij moet zijn bij de in een dergelijke akte opgenomen rechtsbetrekking. Slechts een ingrijpen van de wetgever kan ertoe leiden dat een ieder met een rechtmatig belang inzage in stukken kan vorderen op grond van art. 843a Rv.

101 Van den Reek, p. 47-48.

102 A.A.M. Menken, Exhibitieplicht ex art. 843a Rv, V\&O 1998, p. 54. Hij heeft moeite met enkele uitspraken waarin rechters een 'aannemelijkheidscriterium' hebben toegepast. Hij vindt dat een te lichte maatstaf en bepleit een meer terughoudende uitleg.

103 P.J.M. von Schmidt auf Altenstadt, Opening van zaken, TCR 2002, p. 12-13. M. Freudenthal, Internationale bewijsverkrijging: van Haagse en Europese samenwerking in NIPR 2002, p. 109-117 omschrijft de rechtsbetrekking niet, maar is stellig van mening dat het verzoek van de Engelse rechter in de zaak NI-ABN (HR 18 februari 2000, NJ 2001, 259) onder het recht van 2002 wel ingewilligd zal kunnen worden.

104 M.M. van den Broek, Gedwongen overlegging due diligence rapport, V\&O 2004, p. 124. Hij vervolgt dat nu de verkoper geen partij is geweest bij de overeenkomst van opdracht tussen de koper en de onderzoeker die het due diligencerapport heeft opgemaakt, de verkoper geen inzage in een due diligencerapport kan vorderen. Het is in dit kader volgens hem aanvechtbaar om als rechtsbetrekking voor ogen te hebben de overnameovereenkomst. P. van Uchelen en B. Verbunt, Vordering tot overlegging van due diligence rapporten ex art. 843a Rv, Ondernemingsrecht 2005, hangen op p. 57de enge opvatting aan en zijn van mening dat A geen inzage kan vorderen in een door $\mathrm{Z}$ op verzoek van B opgemaakt rapport over een onderwerp waarbij ook A is betrokken (geweest) omdat A niet betrokken is bij de rechtsbetrekking tussen $\mathrm{Z}$ en B. Zie ook voor een beperkte opvatting S.C. de Lange, Due diligence openbaar. Exhibitieplicht in overnamegeschillen, Fusie en Overname 2006, p. 14 en W.P. Wijers en A.J. Haasjes, Exhibitie in het (ondernemings)recht, O \& F 2006, p. 54-56. H. Uittien, Gedwongen verstrekking van due diligencerapportages, Tijdschrift voor de ondernemingsrechtpraktijk 2007, p. 21 is van mening is dat een koper die wordt geconfronteerd met een vordering van een verkoper tot verstrekking van een due diligencerapport, succes dient te hebben met het verweer dat het rapport is opgesteld in zijn opdracht en dat de verkoper geen partij is bij de rechtsbetrekking tussen de koper en zijn adviseur die het rapport heeft opgesteld. In de rechtspraak wordt een vordering tot inzage in een due diligencerapport toegewezen met als redenering, kort gezegd, dat partijen een boekenonderzoek 
18 februari 2000, NJ 2001, 259 (NI-ABN) de enge opvatting heeft aanvaard, dat eiser partij moet zijn bij de rechtsbetrekking waarvan de gevorderde bescheiden de neerslag vormen. Voor art. 843a Rv zoals luidend sinds 2002 is volgens hem een ruimere opvatting denkbaar en wenselijk. Er wordt volgens hem, indien een eiser van mening is dat er tegen hem onrechtmatig is gehandeld, juist inzage in de betreffende bescheiden gevraagd om te kunnen vaststellen óf er onrechtmatig is gehandeld. Het bestaan van een rechtsbetrekking in de zin van art. 843a Rv moet aldus wel worden aangenomen. Hij is verder van mening dat indien partij A bijvoorbeeld op acceptabele gronden van mening is dat partij B tegen hem onrechtmatig heeft gehandeld door een overeenkomst met $\mathrm{C}$ te sluiten, de bescheiden die de weerslag vormen van de relatie B-C betrekking kunnen hebben op de vraag of er tussen A en B een rechtsbetrekking uit onrechtmatige daad is ontstaan. Het bescheid waar het om gaat (de schriftelijke overeenkomst tussen B en C), is weliswaar primair een bescheid betrekking hebbend op de rechtsbetrekking B-C, maar het heeft tevens betekenis voor de inhoud van de rechtsbetrekking A-B. Aldus moeten de woorden 'aangaande een rechtsbetrekking' zo worden opgevat, dat deze zien op alle stukken, die voor het bepalen van de inhoud van een rechtsbetrekking van betekenis zijn. ${ }^{105}$ Ekelmans is van mening dat, nu het begrip rechtsbetrekking niet is uitgewerkt, het logisch lijkt dat daaronder iedere rechtsbetrekking valt. Op grond van de parlementaire geschiedenis van het in 2002 vernieuwde art. 843a $\mathrm{Rv}$ komt hij tot de conclusie dat de beperkte interpretatie dat houder en aanvrager beiden rechtstreeks als partij bij de bescheiden betrokken dienen te zijn, niet meer houdbaar is. De bescheiden waarvan inzage wordt gevraagd, dienen relevant te kunnen zijn voor de rechtsbetrekking tussen aanvrager en houder. ${ }^{106}$ De

zijn overeengekomen (Rb Breda 14 januari 2004, JOR 2004, 70, hof Den Bosch 28 september 2004, JOR 2005, 23, m.nt. Van der Korst, Rb Amsterdam 13 april 2005, JOR 2005, 142, Rb Amsterdam 24 januari 2007, AZ7826 en Rb Utrecht 12 september 2007, BB3722, NJF 2007, 544). Afwijzend Rb Amsterdam 23 februari 1995, KG 1995, 136.

105 Van der Wiel, nrs. 50 en 51. Volgens T.S. Jansen, Art. 843a Rv in de ondernemingsrechtpraktijk. Verboden te vissen, maar vragen mag, Tijdschrift voor de ondernemingsrechtpraktijk 2009, p. 91-92 bestaan er rechtsbetrekkingen tussen partijen die met elkaar in onderhandeling treden (ook zo Rb Amsterdam 31 december 2008, BH1550, NJF 2009, 85), tussen een rechtspersoon en degenen die krachtens wet en statuten bij de organisatie zijn betrokken, of tussen de betrokkenen onderling. Aan de hand van het voorbeeld dat een verzekeraar inzage kan vorderen in een in opdracht van de verzekerde opgesteld expertiserapport verdedigt hij hier een ruime leer. Hij signaleert wel een 'catch 22 ' indien de exhibitie juist wordt gevraagd om een gestelde, door de andere partij ontkende, rechtsverhouding te bewijzen. Hij lijkt het eens te zijn met de jurisprudentie waarin in dit soort gevallen getoetst wordt aan het criterium of summierlijk van de ondeugdelijkheid van de grondslag van de vordering is gebleken.

106 Ekelmans, TCR p. 60-61. Hij twijfelt nog over het antwoord op de vraag of reeds voldoende is dat de bescheiden waarvan inzage wordt gevraagd, relevant kunnen zijn voor een rechtsbetrekking waarin de aanvrager partij is. In zijn boek blijft hij op p. 14-24 bij zijn mening en voegt daar nog aan toe dat hij het meest voelt voor het aanvaarden van ten minste de mogelijkheid dat ook bij derden informatie kan worden opgevraagd, vooral omdat derden ook als getuigen kunnen worden opgeroepen. Ook M.A.J.G. Janssen hangt een ruime opvatting aan in zijn noot onder Rb Den Haag 
jurisprudentie laat dezelfde tweedeling tussen een enge opvatting en een ruime opvatting van het begrip 'rechtsbetrekking' zien als de literatuur, waarbij in beide opvattingen regelmatig HR 18 februari 2000, NJ 2001, 259, NI-ABN als peilbaken wordt gebruikt. Kort gezegd is in dat arrest aan de Hoge Raad de vraag voorgelegd of de ABN bank verplicht kon worden om in een zich in Engeland afspelende rechtszaak tussen NI en Clinger inzage te geven in bankrekeningen van anderen dan NI en Clinger en wel Catalyst en Mykanos. De Hoge Raad overweegt dat het oordeel van de rechtbank dat NI niet kan worden aangemerkt als partij in de rechtsbetrekking tussen de bank en de rekeninghouders Catalyst en Mykanos niet blijk geeft van een onjuiste rechtsopvatting. De omstandigheid dat Clinger aanzienlijke geldbedragen van NI naar zich zelf heeft doen vloeien en de omstandigheid dat er aanwijzingen zijn dat een aantal van die betalingen is verricht op de rekeningen van Catalyst en Mykanos, brengen op zich zelf niet mee dat sprake is van een rechtsbetrekking tussen NI en de bank. ${ }^{107}$ De eerste uitspraak

21 september 2005, AV7698, JBPR 2006, 25, waar hij verdedigt dat het voldoende is dat de gevraagde bescheiden relevant moeten kunnen zijn voor de rechtsbetrekking tussen de aanvrager en de houder van de stukken. Ook Haak en VerLoren van Themaat hangen een ruime opvatting aan in 'De mogelijkheden voor civielrechtelijke handhaving van de mededingingsregels in Nederland. Een inventarisatie in opdracht van het Ministerie van Economische Zaken, Amsterdam, 3 november 2005, redactie M.F.J. Haak en I.W. VerLoren van Themaat' waar zij op p. 13 schrijven dat het verwarringwekkend is dat de Hoge Raad in het arrest van 18 februari 2000, NJ 2001, 259 heeft geoordeeld dat ook tussen de aanvrager en de houder van de bescheiden een rechtsverhouding moet bestaan, waarmee de Hoge Raad lijkt af te wijken van de wettekst, die slechts een rechtsbetrekking vereist waarbij de aanvrager zelf partij is. Westenberg bepleit in Van der Korst e.a., p. 44 een ruime opvatting. Hij vindt dat anno 2005/2006 een ruimhartiger opvatting op zijn plaats is dan de tot 2002 gehuldigde opvatting. Het gaat tenslotte om een processueel belang en als de rechter het stuk op grond van art. $22 \mathrm{Rv}$ kan opvragen aan de hand van het criterium of het relevant is, moet een partij op de voet van art. 843a Rv met hetzelfde relevantiecriterium inzage kunnen vorderen. Aan de hand van de andere bestanddelen van art. 843a Rv kan vervolgens misbruik worden voorkomen. Volgens van der Korst op p. 96-97 past een ruime uitleg van de woorden 'aangaande een rechtsbetrekking' goed in het sinds 1 januari 2002 in art. $21 \mathrm{Rv}$ wettelijk neergelegde uitgangspunt van de waarheids- en volledigheidsplicht voor procespartijen. Het lijkt erop dat hij een beperkte interpretatie van deze woorden niet vindt passen, daar waar de rechter op grond van art. $22 \mathrm{Rv}$ een discretionaire bevoegdheid heeft om stukken op te vragen. Ten slotte is een beperkte uitleg niet noodzakelijk omdat art. 843a Rv met de woorden 'bepaalde bescheiden' in lid 1 en 'gewichtige redenen' in lid 4 afdoende waarborgen bevat tegen onevenredige last en buitenproportionele wensen tot informatie.

107 De volgende uitspraken volgen de beperkte opvatting van de Hoge Raad: Rb Amsterdam 22 mei 2000, KG 2000, 129 oordeelt in een zaak waarin aandeelhouders van World Online N.V. van deze N.V. en van haar 'oprichtster' Nina Brink en van de AMB-AMRO Bank stukken wensen te hebben op grond van een op de artikelen 6:162, 194 en 195 BW gebaseerde vordering, dat rechtsbetrekkingen gebaseerd op deze artikelen, geen rechtsbetrekkingen zijn in de zin van art. 843a Rv. Hartkamp schrijft in zijn conclusie bij HR 13 september 2002, AE3383, NJ 2003, 400, dat de Staat der Nederlanden, procederend tegen de economische eigenaar van een stuk grond, geen afschrift of uittreksel kan vorderen van de tussen de economische eigenaar en de juridische eigenaar opgemaakte verdelingsakte omdat de Staat bij die rechtsbetrekking niet zelf partij is geweest. Rb Amsterdam 4 september 2002, AG8155, JOR 2002, 176 is van oordeel dat Walmaro, een persoon die aandelen 
waarin een ruime opvatting omtrent de inhoud van het woord 'rechtsbetrekking' wordt gegeven, is van het hof Den Haag. ${ }^{108}$ In deze zaak geeft Mullglen, eigenaar

hield in Uni-Invest, geen inzage kan vorderen in een dadingovereenkomst die Uni-Invest met een andere aandeelhouder had gesloten waarbij een schadevordering was afgekocht die de andere aandeelhouder had ingesteld omdat er sprake was van wanbeleid bij Uni-Invest. Walmaro was volgens de rechtbank geen partij bij die dadingovereenkomst en aldus geen partij bij de rechtsbetrekking waarop het document ziet. De rechtbank oordeelde vervolgens wel dat het, mede gelet op art. 2:92 BW, materieel- en procesrechtelijk onaanvaardbaar is als Uni-Invest Walmaro kennisname zou onthouden van de dadingsovereenkomst en verwees de zaak naar een rolzitting voor akte aan de zijde van Uni-Invest om een kopie van de op schrift gestelde overeenkomsten tussen Uni-Invest en de andere aandeelhouder over te leggen. Hof Den Bosch 27 maart 2003, JBPR 2003, 63, m.nt. Linssen: er bestaat geen rechtsregel die een getuige verplicht om stukken waarover hij verklaart, desgevraagd aan een partij ter hand te stellen. Rb Arnhem 29 september 2004, AR3532: verkopers van een huis vorderen na een door kopers gedaan beroep op een financieringsvoorbehoud overlegging van alle originele financieringsaanvragen met documentatie die zijn ingediend bij twee banken en de originele aangiften inkomstenbelasting over het jaar 2002. De rechtbank is van oordeel dat deze stukken niet de rechtsbetrekking betreffen waarin de verkopers partij zijn. De rechtbank gelast in hetzelfde vonnis de kopers op de voet van art. 22 Rv de complete financieringsaanvragen met bijlagen zoals die bij de beide banken zijn ingediend, twee weken voor de in het vonnis gelaste comparitie over te leggen. Rb Middelburg 18 januari 2006, AY7116 oordeelt in een vrijwaringzaak tussen B en C, waarin C op voet van art. 843a Rv van B inzage vordert in de processtukken in de hoofdzaak tussen A en B zodat hij, C, kan beslissen of hij zich zal voegen in de hoofdzaak of zal tussenkomen, dat $\mathrm{C}$ geen partij is in de hoofdzaak. De betreffende processtukken in de hoofdzaak zijn derhalve geen bescheiden aangaande een rechtsbetrekking waarin $\mathrm{C}$ partij is. Hof Arnhem 29 augustus 2006, AY9096 oordeelt in een procedure waarin A van de gemeente Steenwijkerland inzage vordert in dossiers betrekking hebbende op de bouw van woningen op andere kavels dan de kavel die de gemeente aan A heeft verkocht, dat A geen partij is bij de rechtsbetrekking waarop die documenten betrekking hebben. Rb Dordrecht 3 mei 2007, BA5179 oordeelt in een zaak waarin ex-werkgever van der Gijp stelt dat een ex-werknemer X in strijd met een relatiebeding relaties van Van der Gijp benadert en daarom van $\mathrm{X}$ een overzicht van de mailing van X met de relaties van Van der Gijp vordert, dat Van der Gijp geen partij is bij de contacten tussen X en zijn relaties zodat de vordering moet worden afgewezen. Zie verder voor de enge opvatting $\mathrm{Rb}$ Zutphen 9 mei 2007, BB1491, Rb Rotterdam 4 juli 2007, BA9918, Rb Maastricht 3 oktober 2007, zaaknummer 120430 /HA ZA 07-551, Rb Den Haag 5 december 2007, BB9517, vermoedelijk ook Rb Rotterdam 9 januari 2008, BC4119, Hof Den Haag 11 april 2008, BD0694, NJF 2008, 245 (besproken door H.A. Dragstra, de exhibitieplicht in het arbeidsrecht, TRA 2009, p. 15-18), Rb Dordrecht 17 december 2008, BG7840, Rb Utrecht 21 januari 2009, B9 7517 (open www.boek9.nl, voer in het zoekvenster 7517 in) Rb Dordrecht 23 maart 2009, BH7581 wijst af een door een werkneemster tegen de werkgever ingestelde vordering tot inzage in een in opdracht van de werkgever opgestelde 'risico management audit'. Werkneemster is arbeidsongeschikt en stelt dat uit dit rapport blijkt dat de werkgever zijn zorgplicht onvoldoende is nagekomen en Hof Arnhem 31 maart 2009, BI2138. Zie ook Rb Zwolle 25 februari 2009, BH9274 oordelend dat het enkele feit dat Cambrium aandelen houdt in iBiz terwijl iBiz aandelen Telebyte bezit en Cambrium in deze procedure van Telebyte inzage in stukken van Telebyte vordert, geen rechtsbetrekking doet bestaan tussen Cambrium en Telebyte.

108 Hof Den Haag 20 mei 2003, S\&S 2004, 59. De voorzieningenrechter Rotterdam 25 november 2004, NJF 2005, 2 geeft ook een ruime uitleg waar deze eiseres ICS, die bepaalde stukken nodig heeft ten behoeve van een in de Verenigde Staten tussen haar en Citibank gevoerde procedure, op de voet van art. 843a Rv tegen gedaagde de Staat der Nederlanden (die bepaalde bescheiden 
onder Ocean strafvorderlijk in beslag had genomen) toestemming tot inzage geeft van onder Ocean in beslag genomen stukken betrekking hebbend op de rechtsverhouding Ocean en een zekere P. Hij verwerpt het verweer van de Staat dat ICS geen partij is omdat als rechtsbetrekking ook dienen de rechten en verplichtingen die als gevolg van de uit hoofde van de overeenkomst tussen Ocean en $\mathrm{P}$ gedane betalingen zijn ontstaan tussen $\mathrm{P}$ als kaarthouder, de City Bank als issuer, ICS als acquirer en Ocean als acceptant, welke rechten en verplichtingen mede worden bepaald door de inhoud van de overeenkomt tussen Ocean en P. Er wordt hoger beroep en vervolgens cassatie ingesteld (hof Den Haag op 4 mei 2006, AW8455 resp. HR 21 december 2007, BB9133, NJ 2008, 31), maar art. 843a Rv komt in die instanties niet meer aan de orde (zie over deze zaak ook hoofdstuk 13). Rb Amsterdam 24 augustus 2005, AU4935: kinderen van erflater vorderen inzage in bankafschriften van een bankrekening in Luxemburg die op naam staat van de vriendin van de erflater. Het staat vast dat inkomsten van erflater bij zijn leven op een Duitse bankrekening werden uitbetaald en dat die bij het overlijden van erflater op een Duitse bankrekening op naam van die vriendin stonden. Die vriendin had in eerste instantie het saldo van deze op haar naam staande rekening verzwegen. De rechtbank oordeelt dat de kinderen recht hebben op informatie over de bankrekening omdat zij ten aanzien van het saldo van die rekening moeten worden beschouwd als partijen bij de rechtsbetrekking van de vriendin tot die bank. Een onrechtmatige daad is een rechtsbetrekking ex art. 843a Rv aldus Rb Den Haag 21 september 2005, (B9 954, te vinden via www.boek9.nl, in zoekvenster invoeren 954), Rb Zwolle 30 maart 2006, AY5714, Rb Haarlem 2 februari 2007, AZ7827, AG Spier bij HR 22 februari 2008, BB5626, Rb Utrecht 18 maart 2009, BH6128, Rb Amsterdam 3 juli 2008, B9 6521 (open www.boek9.nl, voer in het zoekvenster 6521 in) en Rb Rotterdam 3 juni 2009, BI9158.Rb Middelburg 6 juli 2006, AZ0501: CdMR is een stuwadoorsbedrijf welk bedrijf duizenden nieuwe auto's voor doorvervoer op haar terrein heeft staan. Haar buurman is Scheldepoort BV, een reparatiewerf. Op die werf wordt in opdracht van Scheldepoort BV door Den Breejen BV geverfd. CdMR stelt in een procedure tegen Scheldepoort BV en Den Breejen BV dat een groot aantal van bij haar opgeslagen auto's is vervuild door verfnevel afkomstig van schilderwerkzaamheden op de werf. Er wordt door CdMR conservatoir beslag tot afgifte gelegd op stukken betrekking hebbend op verfspecificaties en stukken die Den Breejen BV ter zake die verfwerkzaamheden aan de werf ter beschikking heeft gesteld. De rechtbank oordeelt dat de bescheiden zien op de door CdMR gestelde onrechtmatige daad en dat niet ondenkbaar is dat deze daad zich ook ten aanzien van Den Breejen BV kan uitstrekken zodat aan het vereiste van een rechtsbetrekking waarvan partijen deel uitmaken, is voldaan. Rb Utrecht 12 september 2007, BB3722, NJF 2007, 544 overweegt dat uit de woorden 'aangaande een rechtsbetrekking waarin hij of zijn rechtsvoorganger partij zijn' al blijkt dat alleen vereist is dat de bescheiden betrekking hebben op een rechtsbetrekking waarbij verzoeker partij is, en dat niet vereist is dat ook degene tot wie het verzoek zich richt, partij bij de betreffende rechtsbetrekking is. Rb Maastricht 12 maart 2008, BC6796 (de wijzend rechter was de schrijver van dit boek) oordeelt in een procedure waarin een ex-echtgenote van de Rabobank inzage vordert in de op naam van haar ex-man bij die bank staande rekeningen en de door haar ex-man met de bank gesloten geldleningen, dat er sprake is van een rechtsbetrekking in de zin van art. 843a Rv tussen man-vrouw en bank. Waar de vrouw aandeelhouder is van de Holding en in gemeenschap was gehuwd met de enige andere aandeelhouder van de Holding, trekt de rechtbank de conclusie dat er ook sprake is van een rechtsbetrekking tussen die Holding, de vrouw en de bank, zodat de bank ook wat dat betreft inzage moet verschaffen in het verloop van de bankrekeningen van de Holding en de geldleningen van de Holding. De rechtbank oordeelt dat er geen sprake is van een rechtsbetrekking in de zin van dit artikel tussen de vrouw en de vier BV's waarvan alle aandelen in bezit van de Holding zijn. De huwelijksgoederengemeenschap is wat dat betreft een te ver verwijderd verband. Een ruime opvatting is ook te vinden in Rb Den Bosch 16 april 2008, BC9695, JA 2008, 68 m.nt. J. Ekelmans, NJF 2008, 228, Rb Rotterdam 4 juni 2008, BD9249, Hof Amsterdam 17 juni 2008, BE2917 oordelend dat bescheiden als een aandeelhoudersregister waaruit blijkt hoeveel aandelen 
van het schip Pacelli aan Visser opdracht om de Pacelli te repareren. Gedurende de uitvoering van die reparatiewerkzaamheden door Visser ontstaat schade aan het schip door brand. De schade die Mullglen niet van haar verzekeraar vergoed krijgt, wenst Mullglen te verhalen op Visser. In kort geding met als gedaagden Visser en haar verzekeringsmakelaar Sluyter stelt Mullglen dat er gegronde redenen zijn om aan te nemen dat de brandschade ook gedekt is onder een door Visser afgesloten scheepsaanbouwverzekering, waarbij Mullglen als medeverzekerde onder de polis kan worden aangemerkt en uit dien hoofde een zelfstandig vorderingsrecht jegens die verzekeraar heeft. Mullglen vordert, kort gezegd, vervolgens afgifte van de betreffende polis op grond van art. 843a Rv. Het hof is van oordeel dat de polis kan worden aangemerkt als een bescheid aangaande een rechtsbetrekking waarin Mullglen partij is. Die rechtsbetrekking in de zin van art. 843a Rv is volgens het hof in dit geval het samenstel van de tussen Mullglen en Visser gesloten reparatieovereenkomst, de als gevolg van de brand ontstane vordering van Mullglen op Visser en de door Visser ten behoeve van alle door haar te sluiten overeenkomsten gesloten polis. De vordering tegen Visser én Sluyter wordt vervolgens toegewezen.

In het kader van het bestanddeel 'rechtsbetrekking' wordt regelmatig aan de rechter de vraag voorgelegd in hoeverre het bestaan van die rechtsbetrekking al zeker moet zijn. Een mooi voorbeeld is de volgende zaak: Sutfene kookt zelf voor

de man in een bepaalde periode toen het huwelijk tussen partijen nog bestond, had, bescheiden zijn aangaande de gemeenschap van goederen die partijen toen hadden en daarmee dus vallen onder het criterium 'een rechtsbetrekking waarin de vrouw partij is', Rb Haarlem 18 juni 2008, BD6490 oordelend dat het verweer van Broersma dat Arvato geen partij is bij de bescheiden waarvan inzage wordt gevraagd, stoelt op een restrictieve uitleg van art. 843a Rv, namelijk dat het zou gaan om bescheiden waarbij de eiser en de houder van de bescheiden zelf beide rechtstreeks als partij betrokken zijn, welke uitleg de rechtbank niet volgt, Rb Haarlem 16 juli 2008, BD7632 herhaalt deze overweging, Rb Zutphen 23 juli 2008, BD8506 waar gedaagde inzage moet geven in zijn nutsvoorzieningengebruik van zijn vakantiehuis aan de gemeente (zie voor soortgelijk geval hof Arnhem 3 november 2009, NJF 2010, 25: de bescheiden bevattende gegevens omtrent het nutsverbruik, zijn bescheiden aangaande de verhouding tussen de gemeente en $S$ waarin aan de orde is of dwangsommen zijn verbeurd omdat $\mathrm{S}$ het zomerhuis permanent heeft bewoond en betreft daarmee een rechtsbetrekking in de zin van art. 843a Rv. S dient ook inzage te verschaffen in de nutsverbruikgegevens van het huis waarin hij beweerdelijk met een ander in die tijd woonde), Rb Amsterdam 11 september 2008, BF0587, hof Amsterdam 25 november 2008, NJF 2009, 31 (uitvoerig genoemd aan het slot van hoofdstuk drie) en Hof Amsterdam 2 december 2008, BG9050, NJF 2009, 39, oordelend dat procespartijen in een zodanige rechtsbetrekking met hun arbiters staat dat zij van arbiters inzage in het zittingsproces-verbaal kunnen vorderen. In cassatie stelt de Hoge Raad voorop dat persoonlijke aantekeningen van de secretaris van het scheidsgericht of de arbiters zelf die tijdens of na de zitting zijn gemaakt van hetgeen tijdens de zitting is gezegd en voorgevallen, en waarin informatie is neergelegd over hetgeen door de partijen en de arbiters met betrekking tot de inhoud of de behandeling van de zaak op de zitting is meegedeeld, bescheiden zijn aangaande de rechtsbetrekking die tussen partijen in de arbitrage aan de orde is. Zij kunnen ook de rechtsbetrekking tussen de arbiters, hun secretaris en de partijen betreffen (HR 29 januari 2010, BK2007). Zie ook voor een ruime opvatting Rb Rotterdam 10 juni 2009, BJ8968, NJF 2010, 30 betreffende inzage in een door een procespartij met derden gesloten vaststellingsovereenkomsten. 
haar bewoners, maar draagt dit over aan Atlant waarbij Atlant keukenpersoneel van Sutfene overneemt. Sutfene is niet tevreden over de kwaliteit van het eten en zegt de overeenkomst op. Atlant stelt in de daarop volgende bodemprocedure dat zij met Sutfene afspraken heeft gemaakt inzake de terugname van personeel, waarbij het volgens Atlant ook van belang is welke personeelsafspraken Sutfene met haar nieuwe cateraar, Albron, heeft gemaakt. Atlant vordert op voet van art. 843a Rv afschriften van stukken betreffende de afspraken tussen Sutfene en Albron over de betrokken medewerkers. De rechtbank wijst de vordering af omdat in geschil is of er tussen Sutfene en Atlant concept-beëindigingsovereenkomsten bestaan over de (terug)overname van werknemers, maar ook bij welke partij deze werknemers in dienst zijn, zodat een rechtsbetrekking tussen Atlant en Albron nog niet kan worden aangenomen. ${ }^{109}$ In aanbestedingsprocedures wordt met enige regelmaat door een inschrijver aan wie niet is gegund, inzage gevraagd in stukken onder de aanbesteder. Dergelijke vorderingen worden afgewezen. ${ }^{110}$ Buiten het kader van ruime of enge opvatting valt de volgende zaak waarin een gedaagde is veroordeeld om aan eiseres alimentatie te betalen, waarna eiseres in kort geding veroordeling van gedaagde vordert om alle justificatoire bescheiden waaruit zijn inkomen en vermogenspositie blijkt, over te leggen. De rechtbank is van oordeel dat art. 843a $\mathrm{RV}$

'slechts (is) geschreven in verband met het vaststellen van een rechtsbetrekking. In het onderhavige geval staat die rechtsbetrekking tussen partijen echter vast. In de echtscheidingsbeschikking is immers de hoogte van de alimentatie reeds vastgesteld'.

109 Rb Zutphen 17 januari 2007, BA4428. Soortgelijk Rb Amsterdam 5 oktober 2006, AY9545 en Rb Haarlem 2 februari 2007, AZ7827 overwegende dat er voldoende aanknopingspunten zijn om aannemelijk te achten dat bestuurders van XSGrand zonder zakelijke grond gelden aan XSGrand hebben onttrokken hetgeen onrechtmatig ten opzichte van MBlox kan worden genoemd. Zie ook Rb Zwolle 15 mei 2006, AY5717, Rb Arnhem 26 oktober 2007, BB8052, hof Den Haag 22 november 2007, BB8556, NJF 2008, 3, Rb Den Haag 20 februari 2008, B9 5659 (open www.boek9.nl, voer in het zoekvenster 5659 in), Rb Rotterdam 29 juli 2008, BD9031, Rb Arnhem 3 september 2008, BF0614 oordelend dat onvoldoende is onderbouwd dat de verslagen waarvan inzage wordt gevorderd informatie bevatten aangaande de rechtsbetrekking tussen beide partijen en Rb Utrecht 28 november 2008, BG5823.

$110 \mathrm{Rb}$ Amsterdam 28 maart 2007, BG3882, ook gepubliceerd onder BA3125: de inschrijver is slechts uit dien hoofde partij bij de daaruit tussen haarzelf en de NOS (de aanbesteder) voortvloeiende rechtsbetrekking en niet ook bij die tussen de NOS en elk van haar concurrenten. Ook zo Rb Dordrecht 12 maart 2009, BH5742 oordelend dat 'de stukken van de overige inschrijvers in beginsel geen onderdeel geacht kunnen worden van een rechtsbetrekking waarin Urbis partij is. Voor een uitzondering op dit beginsel zou plaats kunnen zijn indien het in de rede ligt te veronderstellen dat de inschrijving van OD205 of één of meer van de overige inschrijvers op dezelfde gronden als de inschrijving van Urbis ongeldig is.' 
De vordering wordt afgewezen. ${ }^{111}$

Een bijzonder geval is verder aan de orde geweest bij de rechtbank ZwolleLelystad. In deze zaak stelt JMB een vordering te hebben op Boeren BV. De fiscus legt op grond van een belastingaanslag op Boeren $\mathrm{BV}$ conservatoir beslag onder Boeren BV. Gevolg van dit beslag is dat Boeren BV niet aan JMB kan betalen, waardoor JMB kennelijk in grote problemen komt. JMB vordert in een geding tegen alleen de fiscus onder meer een verklaring dat de fiscus in redelijkheid niet tot de aanslag had kunnen komen en een gebod aan de fiscus om stukken aan Boeren $\mathrm{BV}$ ter beschikking te stellen. De rechtbank geeft het gebod niet omdat de grondslag van het gevorderde gebod art. 843a $\mathrm{Rv}$ is, maar dit artikel recht geeft op inzage van stukken aangaande een rechtsbetrekking waarin de eiser zelf partij is. ${ }^{12}$

De Inspecteur der Belastingen ziet zich graag in rechtsbetrekking tot verschillende personen staan, en het is goed te verdedigen dat de betrekking tussen de Inspecteur der Belastingen en de belastingplichtige een rechtsbetrekking in de zin van art. 843a Rv is. De vraag rijst dan ook of de Inspecteur naast de weg van art. 47 AWR ook een vordering ex art. 843a Rv zou kunnen indienen. Voor de praktijk is een antwoord op die vraag nauwelijks relevant omdat art. 47 AWR de Inspecteur meer mogelijkheden biedt dan art. 843a Rv. De enige reden die de Inspecteur tot voor kort nog had om eventueel de weg van art. 843a Rv te kiezen, was gelegen in het feit dat het onduidelijk was of an een vordering tot inzage ex art. 47 AWR een dwangsom kon worden verbonden. Deze vraag is door de Hoge Raad op 18 september 2009 beantwoord. ${ }^{113}$ Volgens de Hoge Raad kan uit het stelsel van de AWR niet worden afgeleid dat het volgen van de privaatrechtelijke weg door het instellen van een vordering tot nakoming van de in art. 47 AWR verwoorde opgaveverplichting op straffe van verbeurte van een dwangsom is uitgesloten. De Hoge Raad is van oordeel dat alle in de AWR voorziene sancties op het niet nakomen van de opgaveverplichting niet kunnen waarborgen dat de gegevens daadwerkelijk worden verschaft, zodat de effectuering van deze plicht door middel van het opleggen van een dwangsom de publiekrechtelijke weg niet doorkruist.

Het behoeft geen nadere toelichting dat de Inspecteur der Belastingen graag inzage wenst in due diligencerapporten. De vraag of die inzage op grond van art. 47 AWR kan worden afgedwongen is ook al aan de Hoge Raad voorgelegd. De Hoge Raad is van oordeel dat de Inspecteur op grond van art. 47 AWR geen inzage kan vorderen in een due diligencerapport omdat het tot de algemene beginselen van behoorlijk bestuur te rekenen beginsel van fair play zich er tegen verzet dat

111 Rb Zwolle-Lelystad 11 mei 2007, BA5021. Rb Breda 31 juli 2008, BD9054 wijst af een vordering tot inzage door de curator van failliet Rynart Transport bv tegen X, bedrijfsjurist van de Rynart Groep ter zake de laptop van $\mathrm{X}$ waarbij de curator een vermoeden heeft dat de failliet fraude heeft gepleegd wegens afwezigheid van een rechtsbetrekking zonder verdere motivering.

112 Rb Zwolle-Lelystad 6 juli 2007, BB9222.

113 HR 18 september 2009, BI5906, NJ 2009, 566, m.nt. J.W. Zwemmer. 
De inhoud van de bestanddelen van art. $843 a$ lid $1 R v$ in de literatuur en jurisprudentie

een Inspecteur van zijn bevoegdheid ex art. 47 AWR gebruik maakt om kennis te krijgen van rapporten en andere geschriften van derden voor zover zij ten doel hebben de fiscale positie van de belastingplichtige te belichten of hem daaromtrent te adviseren. ${ }^{114}$

114 HR 23 september 2005, JOR 2005, 264, m.nt. P. van der Korst. 



\section{Eigen omschrijving van de inhoud van de bestanddelen van art. 843a lid $1 \mathrm{Rv}$}

\subsection{Het rechtmatig belang}

Een handzame formulering van het begrippenpaar rechtmatig belang is tot dusverre nog door niemand gegeven. Vooral een concrete omschrijving van het begrip 'rechtmatig' is in een maatschappij waarin normen in beweging zijn niet te geven. Er kunnen wel enkele grenzen worden getrokken.

Buiten de grenzen van de inhoud van het bestanddeel 'rechtmatig belang' valt de problematiek van het vissen naar stukken. Indien in een vijver vol documenten ook een stuk 'zwemt' waarmee de vorderende partij zijn geschil zou winnen, maar die partij weet niet meer dan dat, mag een vordering tot inzage niet worden afgewezen omdat die partij geen rechtmatig belang zou hebben om in die vijver te vissen. Dit geldt in elk geval zolang partijen niet verplicht zijn om, zoals de commissie Storme wenst, een lijst van mogelijk relevante documenten over te leggen. Pure nieuwsgierigheid mag niet worden bevredigd, maar daarvoor moet het vereiste van 'bepaalde bescheiden' worden gebruikt.

Het belang dient binnen het kader van de stel- en bewijsproblematiek te liggen en dient er op gericht te zijn het bestaan en/of de inhoud van een rechtsbetrekking vast te stellen. Waar de wetgever het vinden van de materiële waarheid steeds belangrijker acht, dienen de woorden 'rechtmatig belang' niet terughoudend te worden opgevat.

Het belang kan in een zeer vroeg stadium aanwezig zijn. Een eiser moet immers op grond van art. 111 lid $3 \mathrm{Rv}$ in zijn dagvaarding vermelden de bewijsmiddelen waarover hij kan beschikken. Aan deze eis kan werkelijk inhoud worden gegeven indien een eiser in een zeer vroeg stadium inzage kan krijgen. Voor gedaagde geldt dat hij in het huidige procesrecht, waar in beginsel na de conclusie van antwoord geen verdere schriftelijke ronde meer komt, in het kader van de onderbouwing van zijn verweer belang in de zin van art. 843a Rv kan hebben op inzage in bescheiden voordat hij zijn antwoord indient. Om die reden hoeft een prudente inzage vorderende partij niet af te wachten wat het standpunt van de wederpartij is op de door de inzage vorderende partij te onderbouwen stelling. Dat kan immers al te laat zijn. Dit betekent dat een eiser in zijn dagvaarding een inzage-incident mag instellen en gedaagde mag dit evenzeer voordat hij zijn antwoord neemt.

De vordering kan eigenlijk niet worden afgewezen met als motivering dat het standpunt van de wederpartij nog niet duidelijk is: in het debat over de vraag of inzage moet worden verleend, dient de wederpartij immers zijn standpunt te vermel- 
den omtrent het punt waarover de gevorderde inzage duidelijkheid zou kunnen verschaffen. ${ }^{1}$

Het belang is er niet meer indien de wederpartij de te onderbouwen stelling zonder enig voorbehoud en volledig erkent. Er bestaat dan geen processuele noodzaak meer. Het woord noodzakelijk kan dus van belang zijn bij de toetsing aan het woord belang, maar dan niet in de zin van 'inzage in de stukken is noodzakelijk', omdat in dat geval met het woord noodzakelijk een te zware eis wordt gesteld. Het woord noodzaak dient alleen te worden gebruikt in de negatieve zin: inzage is niet meer noodzakelijk, omdat inzage wordt gevraagd van bescheiden betrekking hebbend op een al door de tegenpartij erkend feit. Het woord noodzaak mag evenmin in bevestigende zin worden gebruikt omdat dan de weg openstaat naar afwijzing omdat er bijvoorbeeld ook andere bewijsmiddelen zijn. Het is niet aan de rechter om te beslissen welke bewijsmiddelen een partij als eerste in het geding moet brengen. Voor zover dit al zou moeten, dient deze toets plaats te vinden in het kader van één van de twee criteria van lid 4 van art. 843a $R v$ en wel het criterium of een behoorlijke rechtsbedeling ook zonder verschaffing redelijkerwijs is gewaarborgd.

Toepassing van een 'noodzakelijkheidscriterium' is verder niet wenselijk omdat dit te dicht in de buurt komt van overtreding van het zogenaamde prognoseverbod. ${ }^{2}$

De door Barendrecht en Van den Reek ${ }^{3}$ gewenste toetsing aan het processueel gelijkheidsbeginsel, welk beginsel het Europese Hof heeft genoemd in het Domboarrest, ${ }^{4}$ heeft volgens mij geen nut omdat er in het kader van het recht op inzage geen parallel bestaat met het Dombo-arrest. In die zaak mocht de bank het eigen personeel dat op de vergaderingen met Dombo BV aanwezig was geweest, als getuige laten horen omdat het functioneel 'lagere' personeelsleden betrof die niet gelijk konden worden gesteld met hun werkgever, terwijl van de tegenpartij, een $\mathrm{BV}$, alleen de directeur bij de vergaderingen aanwezig was geweest en in die tijd een partijgetuige zoals een directeur, niet mocht worden gehoord. Dat is een fundamentele ongelijkheid. Het feit dat partij A die het bestaan van de overeenkomst ontkent, in het bezit is van het schriftelijk contract terwijl de kopie daarvan

1 Wat dit betreft behoort een partij in de hoofdzaak gebonden te zijn aan hetgeen hij heeft verklaard in een incident en behoort dus HR 30 juni 1989, NJ 1990, 382, m.nt. J.B.M.V., waarin de Hoge Raad oordeelde dat een uitspraak over een bevoegdheidsincident in de hoofdzaak de rechter niet bindt, niet analogisch te worden toegepast.

2 Zie onder meer AG Verkade bij HR 16 maart 2007, AZ6530, NJ 2007, 232.

3 J.M. Barendrecht en W.A.J.P. van den Reek, Exhibitieplicht en bewijsbeslag, WPNR 6155 (1994), p. $739-745$.

4 EHRM 27 oktober 1993, NJ 1994, 534. 
die partij B bezat in het ongerede is geraakt, betekent niet dat partij A op grond van het gelijkheidsbeginsel dat stuk in het geding moet brengen. ${ }^{5}$

Uit de wettekst blijkt niet dat er een evenwichtige belangenafweging gemaakt moet worden. Het belang van eiser moet wel zwaar genoeg zijn om de vordering toe te wijzen of, met de woorden van de Adviescommissie voor het Burgerlijk Procesrecht, het belang op toewijzing van de vordering mag niet kennelijk onevenredig zijn ten opzichte van het belang van de andere partij.

Waar het moet gaan om stel- en bewijsbelang dient geen verdere toets te worden aangelegd dan de te hanteren toets bij het antwoord op de vraag of een bepaalde getuige kan worden gehoord. Een serieuze discussie over een dergelijke toets is tot dusverre niet gehouden en bepleit ik ook niet, mede omdat ik geen overtuigende verschillen zie tussen een verschijnings- en antwoordplicht van een getuige en de verplichting die een bezitter van stukken heeft (in elk geval moet hebben) om desgevraagd inzage te verschaffen. Er is dan ook geen reden om bij het ene bewijsmiddel (het recht op inzage) te toetsen aan de vraag of er sprake is van 'nodeloosheid' terwijl bij het andere bewijsmiddel (het horen van een getuige) zonder meer een derde naar het gerecht wordt ontboden. ${ }^{6}$ Hierbij hoort verder te worden meegewogen dat er geen hiërarchie in bewijsmiddelen bestaat, zodat er geen redenen zijn om bij de vraag of een getuige gehoord mag worden, een ander toetsingscriterium te hanteren als bij de vraag of er inzage in gegevens moet worden verstrekt. Het is verder merkwaardig dat een getuige die toevallig iets heeft gezien of gehoord zonder meer als getuige kan worden opgeroepen of gedagvaard, terwijl het bezit van een stuk waarvan inzage wordt gevorderd, zelden toevallig zal zijn. Kortom, bij de concrete invulling en omschrijving van 'rechtmatig belang' behoort volgens mij dan ook niet een woord als 'nodeloosheid' te worden gebruikt.

Dit standpunt van mij brengt tevens met zich dat ik Linssen ${ }^{7}$ onvoldoende ruimhartig vind, waar hij schrijft dat de rechter zorgvuldig dient na te gaan of het verstrekken van de gegevens noodzakelijk is voor de effectuering van het materiële

5 Zie ook HR 31 mei 2002, NJ 2003, 589, m.nt. J.B.M.V. (het Observatiearrest) waarin eiser in cassatie aanvoert dat het 'equality of arms-beginsel' ertoe noopt dat hij al in het door hem aangevangen kort geding vrijelijk de beschikking dient te krijgen over door Aegon Schadeverzekering gemaakt videomateriaal waaruit eventueel zou blijken dat hij in feite beweeglijker is dan hij beweert. De Hoge Raad overweegt dat de klacht van eiser berust op de opvatting dat Aegon verplicht is het door haar verzamelde feitenmateriaal aan eiser ter beschikking te stellen, opdat hij dit materiaal kan controleren. Dat een dergelijke verplichting op Aegon zou rusten vloeit echter niet uit het 'equality-beginsel' voort.

6 Voor de volledigheid: op grond van het tot 1 april 1988 geldende art. 115 Rv kon een partij die meer getuigen dan vijf over hetzelfde feit had doen horen, de kosten van de zesde en volgende getuige(n) niet aan de wederpartij in rekening brengen. Sinds 1 april 1988 kan de rechter bij de kostenveroordeling rekening houden met het feit dat een partij meer getuigen heeft voorgebracht dan redelijkerwijs noodzakelijk was (zie art. 196 lid 1 Rv-oud en art. 170 lid 1 Rv). Voor zover ik weet wordt zelden of nooit van deze mogelijkheid gebruik gemaakt.

7 J.G.A. Linssen in zijn noten in JBPR bij Rb Zutphen, 7 mei 2003, AI1718, JBPR 2003, 66 en bij HR 6 oktober 2006, JBPR 2007, 6. 
recht dat de eisende partij geldend maakt respectievelijk geldend wil maken. Ik voel meer voor een aansluiting bij het criterium waarmee een vordering tot verwijzing naar de schadestaat kan worden toegewezen: heeft eiser de mogelijkheid aannemelijk gemaakt dat de inhoud van het stuk waarvan inzage wordt gevorderd opheldering kan verschaffen. ${ }^{8}$

Bij het belang dient geen rekening te worden gehouden met de vraag hoe kansrijk toewijzing van de vordering is of hoe kansrijk honorering van het verweer is. In dat geval wordt namelijk het verboden gebied van de prognose betreden. Het laatste oordeel in het geding is het oordeel omtrent de toewijzing, voordien mag niet worden gespeculeerd of die toewijzing wel of niet te verwachten is. Het belang moet voldoende worden omschreven, wat dat betreft heeft toevoeging van het woord 'concreet', zoals ook bij een bewijsaanbod, wel enige waarde. Toevoeging van een woord als 'direct' heeft volgens mij geen extra waarde. Ik zie tenminste niet waarom een indirect belang geen belang in de zin van art. 843a Rv zou kunnen zijn. Zo kan bijvoorbeeld het belang om te weten of de tegenpartij een eventuele vordering wel kan betalen, een indirect belang worden genoemd, maar de wetenschap omtrent die solvabiliteit lijkt mij toch wel een belang in de zin van art. 843a Rv. Kort en krachtig: iemand die verhaalsonderzoek wil doen, heeft voldoende belang.

Bij de uitleg van het woord belang kan worden aangesloten bij art. 3:303 BW: er moet voldoende belang zijn in de zin van dat artikel. Rechtmatig betekent dat er recht op moet bestaan en omdat het gaat om bewijsposities dient het om een processuele bevoegdheid te gaan. Het betreft geen vermogensrecht. De verzochte inzage moet ter zake dienend en voldoende concreet zijn. De woorden rechtmatig belang laten zich ook min of meer omschrijven als 'redelijkerwijs nodig'. Ook dit zijn abstracte woorden maar zij geven wel een beetje houvast. Deze woorden staan in art. 26 Besluit medezeggenschap defensie, waarin is bepaald dat die inlichtingen en gegevens verstrekt moeten worden die redelijkerwijs nodig zijn.

Het lijkt mij verder gepast om aansluiting te zoeken bij andere artikelen in het Wetboek van Burgerlijke Rechtsvordering omtrent waarheidsvinding. Waar de rechter in art. $22 \mathrm{Rv}$ een zeer ruime bevoegdheid heeft om ambtshalve onderzoek te doen, terwijl er een zekere samenhang bestaat tussen art. $22 \mathrm{Rv}$ en art. 843a $\mathrm{Rv}$, mag het in het kader van de partijautonomie niet zo zijn dat de rechter op de weg naar de waarheidsvinding minder hordes te nemen heeft dan een procespartij. Het lijkt ook voor de hand te liggen om bij de uitleg van de woorden 'rechtmatig belang' aansluiting te zoeken bij andere onderzoeksmogelijkheden naar bewijsmiddelen die het Wetboek van Burgerlijke Rechtsvordering biedt. Zo zijn met name de toelatingsgronden voor een voorlopig getuigenverhoor zeer ruim. Een dergelijk verhoor strekt er immers ook toe belanghebbenden bij een eventueel naderhand 
aanhangig te maken geding de gelegenheid te bieden opheldering te verkrijgen omtrent de nog niet precies bekende feiten, zulks teneinde hen in staat te stellen hun positie beter te beoordelen. ${ }^{9}$ Voorwaar een formulering waar zeer veel onder valt te brengen. Het aangevoerde belang moet, zoals gezegd, in elk geval ter zake dienend zijn en voldoende concreet aangeduid. In dit kader lijkt het voor de hand te liggen om, daar waar een getuige gedwongen kan worden om te verklaren omtrent de inhoud van elk willekeurig bescheid zolang het maar in voldoende verband staat met het probandum, ook een vordering tot inzage van een dergelijk bescheid toe te wijzen.

Al met al kom ik tot de conclusie dat de erkenning van het belang van de waarheidsvinding zo groot is en de laatste jaren zo sterk is gegroeid dat een juiste omschrijving van de inhoud van het woord 'rechtmatig' eerder is dat er geen 'onrechtmatig' belang mag zijn, waarbij de onrechtmatigheid ook nog eens voor ieder redelijk denkend mens duidelijk moet zijn.

In een enkel geval bestaat er een rechtstreeks materieel belang, dat door de wetgever is gegeven: zie onder andere de artt. 3:15j BW, 4:78 BW, 7:433 BW en 7:619 BW. Daarmee is niet altijd het probleem omtrent 'rechtmatig belang' opgelost. Ondanks de verenging bij deze artikelen van rechtmatig belang naar wetmatig belang, dient er soms toch weer dezelfde toets plaats te vinden. Zo spreekt art. 3:15j BW over 'een rechtstreeks en voldoende belang'.

\subsection{Inzage, afschrift of uittreksel}

Inzage, afschrift of uittreksel zijn op het eerste gezicht drie duidelijke woorden. Een origineel kan in elk geval op grond van de letterlijke tekst van art. 843a eerste lid Rv niet worden opgevraagd. Waar op gegevensdragers aangebrachte gegevens van allerlei aard op grond van art. 843a lid 1, laatste zin, Rv inmiddels ook bescheiden zijn, dient het maken van een digitale kopie of het versturen van een digitaal bestand ook onder 'afschrift of uittreksel' begrepen te worden. Het enkele feit dat het door de kwaliteit van de techniek mogelijk kan zijn dat er geen verschil meer wordt gezien tussen het origineel en het verstuurde bestand, maakt dit niet anders.

Die grammaticaal duidelijke drie woorden zijn in het recht toch niet altijd even duidelijk, omdat de grammatica in het recht niet de enige uitlegvorm is. Soms is kennisname van de gegevens zo belangrijk, dat geen gebruik wordt gemaakt van een grammaticale uitleg, maar eerder van een uitleg waarmee een maatschappelijk aanvaardbaar resultaat wordt bereikt. Aan dit trio woorden mag dus in een voldoende zwaarwegend geval, bijvoorbeeld bij onderzoeksdoeleinden waarbij het onderzoek alleen maar kan plaatsvinden aan de hand van een origineel stuk (onderzoek

9 Aldus HR 24 maart 1995, NJ 1998, 414. Zie verder M.A.J.G. Janssen, Criteria voor de beoordeling van een verzoek om een voorlopig getuigenverhoor of voorlopig deskundigenbericht, JBPR 2005, p. 216-228. 
van een handtekening) het woord 'afgifte' worden toegevoegd, maar dan wel met een plicht tot teruggave. In het belang van de waarheidsvinding zou hierbij, in bijvoorbeeld afstammingsprocedures, met verlof van de rechter kunnen worden overgegaan tot bewijsbeslag, waarbij met behulp van beslagverlof een tandenborstel in beslag wordt genomen voor DNA-onderzoek. Aldus is sprake van analoge toepassing van art. 1019a lid $2 \mathrm{Rv}$, inhoudende dat overlegging kan worden gevorderd van ander bewijsmateriaal dat zich in de macht van de wederpartij bevindt. Ik zou zeggen dat waar dit kan op een terrein waar het (alleen maar?) om geld gaat, het terrein van de intellectuele eigendom, het voor de hand ligt om daar waar het om menselijke (en misschien wel fundamentele) belangen gaat als afstamming, die mogelijkheid, waartegen de wet zich niet uitdrukkelijk verzet, voor bestaand moet worden gehouden en kan worden gebruikt. Ik vind het argument dat eerst alle onderdelen van het materiële recht nauwkeurig moeten worden bestudeerd op de vraag of een en ander wel toelaatbaar is in ons systeem, nauwelijks waarde heeft. Waar de EU de lidstaten immers opname van een artikel als 1019a Rv heeft 'opgedragen' zonder een dergelijk onderzoek, is het merkwaardig om een dergelijk onderzoek voor andere terreinen van het materiële recht wel te doen, alleen al omdat een dergelijk onderzoek de nodige tijd zal kosten. Ik ben van mening dat door dergelijke incidentele wetgeving het bestaande systeem uit het Wetboek van Burgerlijke Rechtsvordering steeds meer wordt ondermijnd. Er komen teveel regelingen en uitzonderingsbepalingen voor individuele vakgebieden in plaats van een algemeen geldende regeling. De woorden van de Europese Commissie dat feiten een belangrijke rol spelen, terwijl veel van het cruciale bewijsmateriaal wordt achtergehouden (structurele informatieasymmetrie) gelden volgens mij ook op andere terreinen zoals het verzekeringsrecht en het personen- en familierecht. ${ }^{10}$ Kortom, ik bepleit een ruime uitleg van de woorden 'inzage, afschrift of uitreksel' in die zin dat als de waarheidsvinding belangrijker is dan de rechtszekerheid, afgifte eveneens gevorderd moet kunnen worden. In bijvoorbeeld afstammingszaken acht ik die waarheidsvinding belangrijker.

\subsubsection{Bepaalde bescheiden}

Bij de omschrijving van de inhoud van het bestanddeel 'bepaalde bescheiden' dienen de volgende vier vragen aan de orde te komen:

a. wat is een bescheid;

b. hoe bepaald moet 'bepaald' zijn;

c. moet de inhoud van het bescheid bij eiser bekend zijn;

d. hoe zeker moet het bestaan van het bescheid zijn. 
De authentieke akte valt niet onder een bescheid in de zin van art. 843a. Het recht op toegang tot een dergelijke akte is te vinden in de wettelijke regeling van de ambtelijke bevoegdheid van degene die de betreffende akte opmaakt. ${ }^{11}$ Die regeling is daarmee een specialis die voorgaat op de generale regel van art. 843a Rv. Dit betekent dus dat bijvoorbeeld een makelaar niet op de voet van art. 843a Rv een afschrift van een notariële akte kan vorderen indien een ex-klant van hem buiten hem om zijn huis heeft verkocht.

Een bescheid is grammaticaal bezien een 'geschreven stuk' of een 'schriftuur'. Het begrip 'bescheiden' in art. 843a Rv moet ruimer worden opgevat dan die grammaticale omschrijving gelet op de laatste zin van lid 1 van art. 843a Rv. Die zin luidt dat onder bescheiden mede wordt verstaan 'op een gegevensdrager aangebrachte gegevens', waarmee onder andere op een USB-stick aangebrachte informatie (foto's teksten, formules, enz.) onder dit woord 'bescheiden' valt. Betekent dit nu ook dat de tandenborstel van een beweerdelijke vader een bescheid is omdat die tandenborstel drager is van DNA? Uit de tekst van lid 1 blijkt dat de wetgever geen limitatieve opsomming heeft willen geven van wat allemaal onder 'bescheid' moet worden verstaan. Grammaticaal en wetshistorisch bezien, staat het woord 'stukken' voorop bij de uitleg van het woord 'bescheid'. Aan de hand van een meer maatschappelijke uitleg en het woord 'mede' in de laatste zin van lid 1 van art. 843a Rv zou verdedigd kunnen worden dat elk voorwerp waar informatie van af is te halen, een bescheid is. Zo heb ik eerder verdedigd dat een bij een botsing beschadigde auto een gegevensdrager is: uit de aard van de beschadigingen kan soms worden afgeleid op welke wijze de botsing is veroorzaakt en hoe hard er mogelijk is gereden door een bij het ongeval betrokkene. ${ }^{12}$ Op grond van die mening, waar ik bij blijf, is art. 1019a Rv overbodig, behalve dan dat het bestaan van dit artikel voorkomt dat de Hoge Raad mogelijk tot een ander oordeel zou komen. Verder is de invoering van genoemd art. 1019a Rv waarschijnlijk noodzakelijk geweest omdat wat dit punt betreft de wet (art. 843a Rv) en de jurisprudentie over dat artikel niet duidelijk genoeg zijn om de EG-commissie te overtuigen dat overlegging gevorderd kon worden van bewijsmateriaal als nagemaakte producten zoals parfums. Al met al zie ik onvoldoende bezwaren om bescheid niet zo ruim uit te leggen dat daar tevens onder is te verstaan 'zich op, aan of in voorwerpen bevindende gegevens'. Dit brengt met zich dat ook het speeksel op de hiervoor al genoemde tandenborstel en de losse haar in de kam beschouwd kunnen worden als 'bescheid'. De op straat gevonden druppel bloed kan als voorwerp zonder eigenaar worden gebruikt. Een vordering tot inzage is dan niet nodig. Indien de haar nog aan het lichaam zit, het bloed en speeksel nog in het lichaam, enz. verzet art. $11 \mathrm{Gw}$ (de onaantastbaarheid van het lichaam), zich tegen gedwongen afname

11 Aldus Veegens-Wiersma, p. 115

12 Zie mijn bespreking van het boekje van Ekelmans, De exhibitieplicht in kort bestek, in TCR 2008, p. 61. 
zolang er nog geen duidelijke regelgeving is die ook dergelijke ingrepen in bepaalde gevallen toestaat.

Tenslotte kan bij de definitie van het woord 'bescheid' nog worden gewezen op de betekenis van het woord 'bestand' in art. 1 onder c Wbp. Een bestand in de zin van de Wbp is elk gestructureerd geheel van persoonsgegevens, ongeacht of dit geheel van gegevens gecentraliseerd is of verspreid is op een functioneel of geografisch bepaalde wijze, dat volgens bepaalde criteria toegankelijk is en betrekking heeft op verschillende personen. ${ }^{13}$

Het bescheid waarvan inzage wordt gevraagd, moet bepaald zijn in die zin dat duidelijk moet zijn waarin inzage wordt gevorderd. Dit betekent dat inzage kan worden gevraagd in karrenvrachten vol bescheiden indien zij maar voldoende bepaald zijn omschreven of geïndividualiseerd. Dit betekent niet dat van elke brief waarvan inzage wordt verzocht, bijvoorbeeld de datum moet worden genoemd. Voldoende bepaald is naar mijn mening een vordering van partij A inhoudende inzage in 'correspondentie tussen de Rabobank en partij B met als inhoud de executoriale verkoop van een bepaalde zaak'. ${ }^{14}$ Dit geldt eens te meer omdat een andere opvatting tot uitholling van art. 843a Rv zou leiden. Bezien in het licht van de achterliggende rechtsbetrekking moet voldoende duidelijk zijn om welke bescheiden het gaat, zodat bijvoorbeeld in het kader van een beleggingsrelatie een vordering van een belegger tot inzage in het op zijn naam staande cliëntendossier bij de beleggingsinstantie voldoende bepaald is. Indien de rechter van oordeel is dat een vordering tot inzage onvoldoende bepaald is, er wordt bijvoorbeeld inzage verzocht in een heel strafdossier, behoort dit niet meteen te worden afgewezen, maar dient de rechter bij tussenuitspraak een nadere 'verfeitelijking' te vragen zodat eiser de kans krijgt om te vermelden dat hij alleen inzage in bijvoorbeeld het politieproces-verbaal verlangt en niet in het reclasseringsrapport en/of het uittreksel uit het Documentatieregister. Het feit dat degene die inzage moet verschaffen wordt opgezadeld met een enorme zoekklus, brengt niet met zich dat de gevorderde inzage onvoldoende 'bepaald' is, waarmee dus een vordering tot inzage door iemand die stelt dat misbruik van haar portretrecht is gemaakt in

'alle door ATP gesloten overeenkomsten en/of alle door ATP met derden gevoerde correspondentie met betrekking tot het vervaardigen en openbaar maken van televisiecommercials, audioboardings, billboards en alle overige uitingen, met uitzondering van een bepaalde website, waarin of waarop gebruik is gemaakt van haar portret...'

voldoende bepaald is. ${ }^{15}$

13 Zie uitgebreid AG Verkade in zijn conclusie bij HR 29 juni 2007, AZ4664, NJ 2007, 638.

14 Anders Rb Zutphen 7 mei 2003, JBPR 2003, 66.

15 Anders Rb Amsterdam 23 juli 2008, B9 6517 (open www.boek9.nl, voer in het zoekvenster 6517 in). 
De inhoud van het bescheid hoeft bij eiser niet bekend te zijn. Dit blijkt al impliciet uit HR 31 januari 1947, NJ 1948, 115. ${ }^{16}$ Weliswaar heeft de minister tijdens de behandeling van het nieuwe bewijsrecht gezegd dat de zogeheten exhibitieplicht slaat op de situatie dat de inhoud van een schriftelijk bewijsmiddel aan een partij in beginsel wel bekend is, maar dat zij het niet in haar bezit heeft, ${ }^{17}$ maar dat is gezegd bij de mondelinge behandeling in de Eerste Kamer in een andere context. Uit de volledige tekst van het toen gevoerde debat lijkt het waarschijnlijker dat de minister toen bedoeld heeft om te zeggen dat het bestaan van het bescheid bekend moest zijn en niet de inhoud daarvan. Dit deel van het debat betrof namelijk niet de uitleg van de inhoud van het ontwerp 843a Rv, maar de tegenstelling tussen de ruime mogelijkheid die de rechter zou krijgen inzake het vragen van stukken ten behoeve van de comparitie in tegenstelling tot de mogelijkheid van het verkrijgen van stukken indien een partij een en ander diende te bewijzen, waarbij de toenmalige artikelen 1922 en 1923 BW bij het debat in zicht kwamen. Uit niets blijkt dat de minister in die tijd wat dit betreft een beperking in art. 843a Rv wilde opnemen die het voorgaande art. 1922 BW niet kende.

Tenslotte moet vaststaan dat het bescheid bestaat. Iemand kan immers niet worden veroordeeld om inzage te geven in een bescheid als niet eerst is vastgesteld dat dit bestaat. Bestaan betekent hierbij niet dat de gevraagde vorm al moet bestaan. De informatie waarvan inzage wordt gevraagd, bestaat ook terwijl nog handelingen verricht moeten worden, zoals bijvoorbeeld het nog opmaken van een proces-verbaal van een zitting of het maken van een lijst van personeelsleden die tussen de $€ 2.000$,- en $€ 4.000$,- verdienen uit het totale bestand van werknemers. Met andere woorden indien met een (simpel) zoekprogramma de gevraagde informatie kan worden geïndividualiseerd, wordt die informatie geacht al te bestaan.

\subsubsection{Vissen naar stukken}

Zoals uit par. 7.1 blijkt zijn vele schrijvers van mening dat met de woorden 'rechtmatig belang' onder meer wordt voorkomen dat partijen naar stukken gaan vissen. Ik ben van mening dat dit vissen wordt voorkomen met het bestanddeel 'bepaalde bescheiden', waarbij bepaald betekent 'voldoende nauwkeurig aangewezen'. Een mogelijke oorzaak voor dit verschil in opvatting is dat de schrijvers die stellen

16 HR 31 januari 1947, NJ 1948, 115 (Baus-NV de Koedoe), waarin Baus onder de werking van het toenmalige art. 1922 BW inzage werd vergund in de in de boeken neergelegde administratie, waarvan de inhoud hem volledig onbekend was. Hij wist alleen dat die administratie er moest zijn. Vergelijk ook Parl. Gesch. Burg. Procesrecht, Van Mierlo/Bart, p. 553, waar de minister verklaart dat onder het nieuwe recht in een geval als zich voordeed in HR 30 januari 1998, NJ 1998, 459 de overeenkomst, waarvan de inhoud onbekend was, wel in het geding gebracht zou moeten worden.

17 P. 417 Parl. Gesch. nieuw bewijsrecht. 
dat vissen wordt voorkomen met behulp van de woorden 'rechtmatig belang', zich onvoldoende rekenschap geven van het feit dat de woorden 'bepaalde bescheiden' pas op 1 januari 2002 in de wet zijn opgenomen. Voor die tijd beperkte de tekst van art. 843a $\mathrm{Rv}$ zich tot 'onderhandse akte', zodat via een andere weg vissen voorkomen moest worden. Dat niet naar stukken mag worden gevist, is een breed gedragen uitgangspunt, dat ik niet zonder meer onderschrijf. Zo zijn er bepaalde rechtsverhoudingen waar de aard met zich brengt dat ter controle een vrijwel onbeperkte inzage gevorderd moet kunnen worden. Denk hierbij aan rechtsverhoudingen waarin rekening en verantwoording moet worden afgelegd, maar ook een verhouding als franchise. De aard van de verhouding brengt dan met zich dat een partij de verstrekte informatie moet kunnen controleren of zelfs inzage moet kunnen vragen voordat de wederpartij informatie verstrekt. Ook in rechtsverhoudingen waarin een partij een klantdossier aanlegt, moet ter controle op de belangen van de klant de klant ruime inzage kunnen vorderen. Ik zie geen enkele reden waarom een klant van een beleggersinstelling geen inzage in zijn hele dossier zou kunnen vorderen. Met het woord dossier is toch een voldoende nauwkeurig bescheid omschreven of een voldoende bepaald object waarin zich informatie bevindt aangewezen. In het kader van de waarheidsvinding zie ik aan de zijde van bijvoorbeeld de beleggersinstelling geen steekhoudende argumenten tegen een verzoek tot inzage in het complete van de klant opgemaakte dossier ter controle van een en ander. Hetgeen de laatste jaren is geschied bij de effectenleaseproblematiek geeft volgens mij voldoende rechtvaardiging om een dergelijke inzage ter controle eenvoudig te kunnen afdwingen. Hierbij is voor de afweging mede van belang de grote belangen die zeker de minder vermogende particuliere belegger heeft om te weten wat er nu eigenlijk is geschied. Ik ben dan ook van mening dat een vordering tot inzage niet snel mag worden afgewezen omdat er sprake zou zijn van vissen naar inzage. De partij die zich tegen inzage verzet omdat er sprake zou zijn van vissen, mag niet met die enkele stelling volstaan. Hij zal die stelling voldoende concreet moeten onderbouwen en bijvoorbeeld stellen in welke belangen hij wordt geschaad indien de verzochte inzage wordt afgewezen. Een algemene opmerking als bijvoorbeeld dat er wordt geprobeerd om vertrouwelijke bedrijfsinformatie te verkrijgen of om marktgevoelige informatie boven water te krijgen, acht ik niet voldoende. ${ }^{18}$ Een goede procesorde brengt volgens mij verder mee dat bij een verweer inhoudende dat zich in, bijvoorbeeld, het klantendossier van een beleggingsinstelling vele stukken zitten, degene die dit verweer voert, gehouden is om een inhoudsopgave van het dossier te geven. ${ }^{19}$

18 Ik vind wat dat betreft dat G. van der Wal en F. van Schaik, Handhavingsinstrumenten in het intellectuele eigendomsrecht: het op de loer liggende risico van 'fishing expedions' vergt kritische rechterlijke toetsing, IER 2009, p. 119-123, op grond van te abstracte stellingen te snel tot de conclusie komen dat er sprake is van vissen naar inzage.

19 Dit klinkt natuurlijk nogal theoretisch: de bezitter van zo'n dossier heeft in de praktijk de gelegenheid die stukken er stiekem uit te halen. 


\subsection{Aangaande een rechtsbetrekking waarin hij partij is}

De woorden rechtsbetrekking en rechtsverhouding zijn synoniem..$^{20}$ Ik sluit mij aan bij de door Van der Wiel gegeven definitie van rechtsverhouding: het moet gaan om een juridische verhouding, een samenstel van tussen rechtssubjecten bestaande, onderling samenhangende rechten en verplichtingen. ${ }^{21}$ Hieronder vallen in elk geval alle verbintenissen, ongeacht of zij zijn ontstaan uit overeenkomst of uit de wet. ${ }^{22}$ Het bestaan van de rechtsbetrekking op grond waarvan de inzage wordt gevorderd, hoeft niet meer dan aannemelijk te zijn. Een grotere graad van waarschijnlijkheid doet afbreuk aan de reden waarom inzage wordt gevraagd. Die reden is immers om het bestaan en/of de inhoud van die betrekking aan te tonen.

De tekst van lid 1 van art. 843a Rv schrijft niet voor dat er een rechtsbetrekking moet bestaan tussen de partij die inzage vordert en de partij die de inzage kan geven. Er staat immers in die tekst niet meer dan dat een partij inzage kan vorderen in bescheiden aangaande een rechtsbetrekking, van degene die de bescheiden onder zich heeft. Er staat niet dat de vordering tot inzage alleen maar gericht kan worden tot de partij waarmee de eiser die rechtsbetrekking heeft. ${ }^{23}$

20 Van Dale, $14^{\text {de }}$ herziene uitgave:rechtsbetrekking:juridische verhouding; rechtsverhouding:door wettelijke bepalingen geregelde verhouding. Aldus ook Pitlo, Het systeem van het Nederlandse Privaatrecht, negende druk 1988, p. 71. Zie ook nog AG Huydecoper die in zijn conclusie onder nr. 1 bij HR 2 oktober 2009, BJ1257, NJ 2009, 478 de volgens hem kleurloze aanduiding 'zakelijke betrekking' gebruikt omdat hij het woord rechtsverhouding, dat een twistpunt tussen partijen vormt, (nog) niet wenst te gebruiken.

21 B.T.M. van der Wiel, De rechtsverhouding tussen procespartijen, serie recht en praktijk 128, Kluwer 2004, p. 3-4.

22 HR 29 januari 2010, BK2007: persoonlijke aantekeningen van de secretaris van het scheidsgericht of de arbiters zelf die tijdens of na de zitting zijn gemaakt van hetgeen tijdens de zitting is gezegd en voorgevallen, en waarin informatie is neergelegd over hetgeen door de partijen en de arbiters met betrekking tot de inhoud of de behandeling van de zaak op de zitting is meegedeeld, zijn bescheiden aangaande de rechtsbetrekking die tussen partijen in de arbitrage aan de orde is. Zij kunnen ook de rechtsbetrekking tussen de arbiters, hun secretaris en de partijen betreffen.

23 Anders HR 18 februari 2000, NJ 2001, 259, m.nt. Vlas, News International PLC, News Publishers Limited, News Datacom Limited en News Cayman Holdings Limited tegen de ABN AMRO Bank NV. In deze zaak was tussen News International c.s. enerzijds en Michael Clinger c.s. anderzijds in Engeland een procedure aanhangig, waarin News International c.s. schadevergoeding vorderen van Clinger c.s. In die procedure hebben News International c.s. gesteld dat Clinger c.s. op frauduleuze wijze hebben bewerkstelligd dat enkele met News International c.s. verbonden ondernemingen gebonden werden aan bezwarende contracten en door fraude via geheime en ongeoorloofde betalingen aanzienlijke geldbedragen van News International c.s. naar Clinger hebben doen vloeien. Er zijn aanwijzingen dat een aantal van die betalingen is verricht op bankrekeningen die bij de ABN-AMRO of haar rechtsvoorgangster werden aangehouden. Ingevolge een beschikking van 8 oktober 1997 van de Queen's Bench Division van het Hooggerechtshof is op grond van het Verdrag inzake de verkrijging van bewijs in het buitenland in burgerlijke en handelszaken, Trb. 1979, 38 bij wege van rogatoire commissie aan de officier van justitie in Nederland verzocht om hem bepaalde documenten, waaronder bankafschriften, te doen overleggen die de ABN AMRO onder zich heeft. De rogatoire commissie strekt ertoe helderheid te verkrijgen omtrent de stellingen 
Ik bepleit dat bij de uitleg van de inhoud van het woord 'rechtsbetrekking' aansluiting gezocht moet worden bij Vleesmeesters-Alog. ${ }^{24}$ Hetgeen de Hoge Raad in die zaak heeft geoordeeld over 'de betrokken derde' is volgens mij bruikbaar bij de uitleg van het woord rechtsbetrekking in art. 843a Rv. De Hoge Raad stelt in Vleesmeesters-Alog het volgende voorop. Wanneer iemand zich contractueel heeft gebonden, waardoor de contractsverhouding waarbij hij partij is in het rechtsverkeer een schakel is gaan vormen waarmee de belangen van derden, die aan dit verkeer deelnemen, in allerlei vormen kunnen worden verbonden, staat het hem niet onder alle omstandigheden vrij de belangen te verwaarlozen die derden bij de behoorlijke nakoming van het contract kunnen hebben. Daar waar de Hoge Raad van oordeel is dat er dus een regel bestaat inhoudende dat partijen die, geschakeld door verschillende overeenkomsten, verbonden zijn en elkaars belangen niet zonder meer mogen verwaarlozen, lijkt het mij dat, deze regel bezien in samenhang met de opmerking van de wetgever inhoudende dat ook een verbintenis uit onrechtmatige daad een 'rechtsbetrekking in de zin van art. 843a Rv' oplevert, thans de stelling juist is dat partij $\mathrm{A}$, die procedeert tegen partij $\mathrm{B}$, van een partij $\mathrm{C}$, die in enige geschakelde relatie staat met partij B, inzage in bescheiden kan vragen. Zoals hiervoor al is geconstateerd, is het overbrengen van een dergelijke materieelrechtelijke norm naar het procesrecht niet nieuw. Ook de verplichting om (ongevraagd) inlichtingen en informatie te verschaffen heeft zich allereerst in het materiële recht ontwikkeld, waarna die verplichting ook in het formele recht nader is uitgewerkt en geconcretiseerd. ${ }^{25}$ Eventueel noodzakelijke beperkingen dienen vervolgens aangebracht te worden via de bestanddelen rechtmatig belang in lid 1 en gewichtige redenen in lid 4 van art. 843a Rv. Aldus blijkt dat het materieelrechtelijk leerstuk van de samenhangende rechtsverhoudingen ook een procesrechtelijke component heeft.

De parlementaire geschiedenis staat in elk geval niet in de weg aan zo een ruime uitleg van het begrip rechtsbetrekking, dat ook een partij $C$ inzage moeten geven aan partij A en/of partij B in stukken die van belang zijn voor de rechtsbetrekking tussen partij A en B. De vraag of een inbreuk op de privacy van derden toelaatbaar is, dient in het licht van de woorden 'gewichtige redenen' in lid 4 van art. 843a Rv beantwoord te worden. Ook bij de uitleg van het woord rechtsbetrek-

van News International c.s. De Hoge Raad verwerpt het beroep tegen de beschikking van de rechtbank waarin het verzoek is afgewezen en overweegt: 'Immers, de omstandigheid dat Clinger en de zijnen ... aanzienlijke geldbedragen van News International c.s. naar Clinger hebben doen vloeien en de omstandigheid dat er aanwijzingen zouden zijn dat een aantal van die betalingen is verricht op de rekeningen van evenvermelde rekeninghouders, brengen op zichzelf niet mee dat sprake is van een rechtsbetrekking tussen News International c.s. en de Bank. Voorts is niet gesteld dat anderszins sprake is van een rechtsbetrekking tussen News International c.s. en de Bank.'.

24 HR 24 september 2004, NJ 2008, 587, m.nt. C.E. du Perron. Zie ook HvJEG 4 oktober 2007, NJ 2008, 37 (Rampion).

25 Zie nader par. 2.1.3. 
king dient gewezen te worden op het feit dat waar het mogelijk is om derden of vierden als getuigen te horen over zaken die zich in beginsel tussen die derde en vierde hebben afgespeeld, maar die van belang kunnen zijn om de rechtsbetrekking tussen A en B te verduidelijken, het ook mogelijk moet zijn om die derde of vierde te gelasten om inzage te geven in bepaalde bescheiden. Wat dat betreft bestaat er geen rechtens relevant verschil tussen het bewijsmiddel 'getuige' en het bewijsmiddel 'inzage'.

De wijze waarop ik de verwoording van dit bestanddeel in lid 1 van art. 843a Rv lees, lijkt ook beter te passen bij het gegroeide inzicht in het belang van de waarheidsvinding en de reeds bestaande mogelijkheden van het vergaren van andere bewijsmiddelen, zoals bewijs door getuigenverklaringen, bewijs in het kader van een voorlopig getuigenverhoor en/of voorlopig deskundigenonderzoek. Vergaring van bewijs via deze bewijsmiddelen lukt immers alleen niet indien, kort gezegd, misbruik van de betreffende bevoegdheid wordt gemaakt of anderszins sprake is van strijd met een goede procesorde (inclusief het hebben van geen belang en misbruik van recht) of indien het verzoek van de met het bewijs belaste afstuit op een zwaarwichtiger geoordeeld bezwaar. ${ }^{26}$ Met Van der Wiel ben ik dan ook van mening dat wanneer partij A voldoende onderbouwd heeft gesteld dat hij met partij B bijvoorbeeld een overeenkomst heeft, in het kader van welke overeenkomst $\mathrm{B}$ wanprestatie heeft gepleegd omdat hij met partij $\mathrm{C}$ een schriftelijke overeenkomst heeft gesloten, er sprake is van een rechtsbetrekking tussen A en B. In het kader van de wanprestatievordering die A tegen B kan instellen, dient A vervolgens met succes op de voet van art. 843a lid $1 \mathrm{Rv}$ van C inzage in de overeenkomst B-C te kunnen vorderen. ${ }^{27}$ Ook indien A stelt dat B hem heeft opgelicht en het aldus buitgemaakte geld heeft overgemaakt op de bankrekening van $\mathrm{C}$ dient $\mathrm{A}$ inzage in de bankrekening van $\mathrm{C}$ te kunnen vorderen teneinde te kunnen controleren of $\mathrm{B}$ inderdaad geld heeft gestort op de rekening van C. Ik wijs er hierbij op dat A $\mathrm{C}$ ook als getuige kan oproepen om dezelfde informatie te vergaren. Het tot dusverre enkel in het materiële recht gehanteerde leerstuk van de samenhangende rechtsverhoudingen kan ook hier toegepast worden. Bij de beantwoording van de vraag of er sprake is van een dergelijke rechtsverhouding kan aan een aantal factoren worden getoetst. Sommige van de hierna door mij te noemen factoren zijn afgeleid van de door Van Laarhoven genoemde factoren waarbij ik die factoren, voor zover noodzakelijk, heb vertaald van het materiële recht naar het proces-

26 Zie verder M.A.J.G. Janssen, Criteria voor de beoordeling van een verzoek om een voorlopig getuigenverhoor of voorlopig deskundigenbericht, JBPR 2005, p. 216-228.

27 Van der Wiel, p. 51. In zijn conclusie bij HR 11 maart 1994, NJ 1995, 3 heeft Asser, in een andere context, gewezen op het (nu althans) voormalige art. 839 Rv. In dit artikel werd onder meer notarissen bevolen om afschriften van onder andere akten uit te reiken aan 'onmiddellijk belanghebbenden'. Ik geloof niet dat deze woorden ons dichter bij een nadere concretisering van het woord rechtsbetrekking brengen. 
recht. ${ }^{28}$ Mogelijke relevante factoren aan de hand waarvan getoetst kan worden of er sprake is van een processueel samenhangende rechtsverhouding zijn de volgende: de feitelijk en/of economische samenhang tussen de betrokkenen, het inzicht dat de betrokkenen in deze samenhang hadden, de onderlinge verhouding en hoedanigheid van partijen, de schade en overlast die de vordering tot inzage bij de derde kan veroorzaken en het belang van de waarheidsvinding. ${ }^{29} \mathrm{Zo}$ zal dit laatste belang in een afstammingsactie groter zijn dan in een zaak met een klein financieel belang. Bezien in het hiervoor geschetste kader hebben personen die binnen een uitstraalstoot van afvalstoffen van een fabriek wonen en die stellen dat de uitstoot onrechtmatig is ten opzichte van hen, een rechtsbetrekking met die fabriek op grond waarvan zij inzage in bescheiden kunnen vorderen. Hun gezondheid vormt in dat geval het rechtmatige belang.

Concluderend: het bestaan van een rechtsbetrekking behoort slechts marginaal te worden getoetst, waarbij een verhouding snel een rechtsbetrekking mag worden genoemd. Die noodzakelijke rechtsbetrekking hoeft niet te bestaan tussen de partij die inzage vordert en de partij die de inzage kan verstrekken. Er zijn geen goede redenen waarom van een derde die als getuige kan worden gehoord over bijvoorbeeld de vraag hoe hard de auto's die op elkaar zijn gebotst reden, niet ook inzage kan worden verlangd van de door hem van de botsing genomen foto's. ${ }^{30} \mathrm{Ik}$ zie dan ook geen steekhoudende redenen om Huydecoper te volgen waar hij schrijft dat art. 843a Rv de aanspraak op informatie vrij aanzienlijk beperkt door de eis dat er (nauw) verband moet bestaan met een rechtsbetrekking waarbij men partij is. $^{31}$

28 M.J. van Laarhoven, Samenhang in rechtsverhoudingen, p. 90-94.

29 Waarna ik, net als van Laarhoven op p. 94 van haar Samenhang in rechtsverhoudingen, M.A. Loth aanhaal die in de bundel onder redactie van A.M.P. Gaakeer en van hemzelf, Eenheid en verscheidenheid in recht en rechtswetenschap, Deventer Kluwer 2002, in zijn eigen bijdrage 'Tussen eenheid en verscheidenheid: contextualisme in taal, wetenschap en samenleving, p. 19-41, op p. 41 schrijft '... telkens blijkt dat er in het domein van de praktische rede geen zekerheden bestaan, maar dat evenmin telkens alles opnieuw hoeft te worden bedacht, kortom dat alles van de context afhankelijk is.'.

30 Zo ook onder meer Ekelmans, en Westenberg in Van der Korst e.a. Von Schmidt auf Altenstadt pleit in TVC 2002, p. 13 zelfs voor doorhaling van de oneigenlijke beperking van het bestanddeel 'aangaande de rechtsbetrekking waarin men partij is'.

31 Te vinden onder nr. 20 van zijn conclusie bij HR 21 januari 2005, NJ 2005, 249. 


\section{$9 \quad$ Art. 843a lid 2 Rv, de wijze waarop inzage, afschrift of uittreksel wordt verschaft}

Lid 2 van art. 843a Rv vermeldt dat de rechter zo nodig de wijze bepaalt waarop inzage, afschrift of uittreksel zal worden verschaft. De wijze waarop de rechter dit bepaalt, is vooral van belang indien sprake is van 'bewijsbeslag'. Dit beslag wordt in de literatuur dan ook vooral behandeld indien dit tweede lid van art. 843a $\mathrm{Rv}$ aan de orde komt. Omdat hoofdstuk 15 van dit boek is gewijd aan het bewijsbeslag, zal ik daar in deze paragraaf slechts summier aandacht aan besteden.

Volgens Burgerlijke Rechtsvordering ${ }^{1}$ kan de rechter een derde aanwijzen, die inzage zal nemen en een afschrift of uittreksel zal maken. Die derde kan iemand zijn die tot geheimhouding verplicht is, zoals een notaris, zodat niet meer bekend wordt gemaakt dan voor het beoogde doel nodig is. Een sanctie indien de gedaagde geen medewerking verleent, kent art. 843a Rv niet.

In de meeste gevallen zal de inzageverschaffing simpel zijn: de aanvrager dient de kosten voor het maken van de afschriften te betalen en krijgt vervolgens die afschriften. Er wordt hoogst zelden alleen maar inzage verschaft. De feitelijke uitvoering van het recht op inzage betekent in de praktijk bijna altijd 'afgifte van afschriften'. Het inzagerecht zou wat dat betreft inmiddels beter afschriftrecht of kopie-afgifterecht genoemd kunnen worden of misschien zelfs wel afgifterecht zonder meer (waar dan wel een verplichting tot teruggave tegenover staat).

Met behulp van de woorden 'de wijze waarop' in dit lid brengt de rechter met enige regelmaat een nadere beperking aan van 'bepaalde bescheiden' in lid 1. Zo kan bijvoorbeeld een vordering tot inzage in notulen van een bepaalde vergadering worden toegewezen, maar de kans is groot dat die notulen ook opmerkingen bevatten over andere onderwerpen dan het onderwerp van geschil. In een dergelijk geval bepaalt de rechter op grond van dit lid twee dat slechts bepaalde passages uit die notulen ter inzage worden gelegd. ${ }^{2}$ Menken zegt hierover terecht dat de

1 Burgerlijke Rechtsvordering (voormalig Van den Dungen, Kluwer, Deventer losbladig), G.R. Rutgers, art. 843a, aantekening 9. Zie ook Ekelmans die op p. 46-48 enkele voorbeelden geeft en daarbij de de rechter die de houder van de stukken toestond om zelf de selectie te maken en die controleerbaar te maken door een index te verstrekken met daarop vermeld de wel en niet verstrekte stukken, creatief noemt (Rb Den Haag 21 september 2005, JBPR 2005, 25).

2 Rb Rotterdam 3 oktober 1996, JOR 1996, 122 bepalend dat de inzage in de notulen zich moet beperken tot wat daarin is vermeld over het onderwerp 'openbaar bod' en dat dit door tussenkomst van een notaris vastgesteld moet worden. 
bereidheid van een rechter tot een ruime uitleg van lid 1 kan samenhangen met een nuancering door diezelfde rechter op grond van lid $2 .^{3}$

Het lid geeft als mogelijkheden 'inzage, afschrift of uitreksel'. Het woord afgifte wordt niet genoemd. Het hof Den Bosch is van oordeel dat met inachtneming van de ratio van art. 843a $\mathrm{Rv}$ de beginselen van een goede procesorde met zich kunnen brengen dat inzage ook afgifte kan betekenen. ${ }^{4}$

Soms zijn de belangen van de bezitter van de informatie zodanig dat voorkomen moet worden dat deze informatie 'op straat' komt te liggen. Zo zal het bijvoorbeeld, ook zonder nadere toelichting, wel duidelijk zijn dat de inhoud van een due diligencerapport niet bij iedereen bekend mag worden. De rechtbank Breda bepaalt dan ook dat een dergelijk rapport ter voorkoming van ongecontroleerde verspreiding van de daarin opgenomen gevoelige informatie alleen maar op de griffie ter inzage gedeponeerd hoeft te worden. ${ }^{5}$ In het hoger beroep in deze zaak is het hof van oordeel dat het belang om te beschikken over een exemplaar van het due diligencerapport van de partij die inzage vordert, groter is dan het belang van de andere partij om ongecontroleerde verspreiding te voorkomen. Er dient dus een afschrift van het rapport te worden afgegeven. Het hof verbiedt, op voet van art. $29 \mathrm{Rv}$, in het dictum de partij die recht krijgt op een afschrift mededelingen te doen aan derden over de gegevens die haar uit dit rapport bekend worden. ${ }^{6}$

De rechtbank Breda is in een zaak waarin vele gegevens en gegevensdragers in beslag zijn genomen en waarin vervolgens inzage wordt gevraagd, van oordeel dat er zoveel vertrouwelijke gegevens op staan die geheim gehouden moeten worden, dat de machtiging tot inzage uitsluitend wordt verstrekt aan een in te schakelen derde. In het dictum wordt vervolgens onder meer bepaald dat deze derde aan de verzoeker om inzage uitsluitend mededeling mag doen over bepaalde in het vonnis nader omschreven gegevens en dat mogelijk andere aangetroffen informatie uitdrukkelijk niet aan de verzoeker bekend mag worden gemaakt. ${ }^{7}$ Dergelijke derden kunnen, afhankelijk van de informatie waar het om gaat, geheimhouders als notarissen, advocaten en artsen zijn, maar ook accountants worden regelmatig

3 A.A.M. Menken, Exhibitieplicht ex art. 843a Rv, V\&O 1998, p. 56.

4 Hof Den Bosch 4 april 2006, AW 4335. Zie ook Rb Dordrecht 23 juni 2004, AP3695 oordelend dat art. 843a Rv onder omstandigheden recht geeft afgifte te vorderen van bepaalde bescheiden.

5 Rb Breda 14 januari 2004, JOR 2004, 70. In dezelfde zaak is ook het verweer gevoerd dat het rapport ook zuiver adviserende onderdelen kent en dat daar geen inzage in verstrekt hoeft te worden. De rechtbank geeft geen inhoudelijk oordeel over deze vraag, omdat volgens haar deze delen van adviserende aard een onlosmakelijk deel van het rapport uitmaken. Soortgelijk Rb Amsterdam 13 april 2005, JOR 2005, 142.

6 Hof Den Bosch 28 september 2004, JOR 2005, 23.

7 Rb Breda 25 oktober 2006, AZ1374. Gelijksoortig Rb Dordrecht 23 juni 2004, AP3695, Rb Utrecht 18 maart 2009, BH6128 en Rb Utrecht 18 maart 2009, BH6556 welke laatste oordeelt dat rekening kan worden gehouden met het feit dat de overeenkomst waarvan inzage wordt gevorderd een concurrentiegevoelig en vertrouwelijk karakter heeft, door aan de verstrekking van het afschrift de beperking te verbinden dat deze onleesbaar wordt gemaakt voor zover dat absoluut noodzakelijk is ter bescherming van dit belang. 
benoemd. Een accountant heeft weliswaar geen geheimhoudingsplicht met verschoningsrecht maar heeft, gelet op de eigen 'vakregels', wel een geschikt beroep dat het enerzijds mogelijk maakt om het recht op informatieverkrijging te verwezenlijken en anderzijds te voorkomen dat een verzoekende partij vertrouwelijke gegevens verkrijgt.

Uit een vonnis van de rechtbank Haarlem valt af te leiden dat die rechtbank van oordeel is dat een verweer van degene die inzage moet verstrekken inhoudende dat geen inzage verstrekt kan of mag worden gegeven op grond van privacybescherming (nt. JRS: er is in het vonnis geen verdere concretisering gegeven), gepasseerd kan worden door de betreffende stukken ter inzage te geven op het kantoor van verweerder, zonder de stukken af te geven. ${ }^{8}$

Het lid kent geen sanctie indien een partij onwillig is. Het lijkt voor de hand te liggen dat de rechter, mocht een partij onwillig zijn, daaruit analoog aan onder meer artt. 21 en $22 \mathrm{Rv}$, de gevolgtrekking kan maken die hij geraden acht. Er staan de rechter verder geen wetten in de weg om een dwangsom op te leggen om de partij die inzage dient te geven, hiertoe te stimuleren. Klaassen is wat dat betreft van mening dat nadat de rechter heeft geoordeeld dat de plicht tot inzageverstrekking bestaat, er sprake is van een rechtsplicht zodat een dwangsom kan worden opgelegd. ${ }^{9}$ Onder meer de rechtbank Zwolle legt dan ook een dwangsom op de verplichting tot inzageverschaffing en benoemt een advocaat tot onafhankelijk waarnemer die de inzage als taak krijgt opgedragen. ${ }^{10}$ Ik heb geen jurisprudentie gevonden waarin een vordering tot het opleggen van een dwangsom indien de verplichting tot inzageverstrekking niet werd nagekomen, werd afgewezen omdat de wet aan toewijzing van de dwangsom in de weg zou staan.

In het De Telegraaf-BVD-arrest ${ }^{11}$ herhaalt en verfijnt de Hoge Raad de Lightning Casino-norm ${ }^{12}$ dat er een specifieke vorm van inzage bestaat indien wordt gesteld dat gewichtige redenen zich tegen inzage verzetten. De rechter die gesteld wordt voor de vraag of gewichtige redenen geheimhouding met betrekking tot bepaalde stukken rechtvaardigen, zal die vraag in het algemeen niet kunnen beantwoorden zonder kennis te nemen van die stukken. De rechter zal dan ook kunnen verlangen dat de partij die zich op gewichtige redenen beroept, daartoe medewerking verleent door uitsluitend hem ter vertrouwelijke kennisneming (inzage in) de betreffende stukken te verschaffen. Mocht de rechter tot het oordeel komen dat geheimhouding om gewichtige redenen gerechtvaardigd is, dan vervalt de verplichting tot het geven van inzage. Indien de partij die geheimhouding wenst, vindt dat

8 Rb Haarlem 20 augustus 2008, te kennen uit Rb Haarlem 22 juli 2009, BJ3588. Rb Amsterdam 2 april 2008, BC9315 overweegt dat geen rechtsgrond bestaat voor het verzoek om te bepalen dat de stukken slechts kunnen worden ingezien bij de advocaat van de inzageverstrekker.

9 C.J.M Klaassen, Spreken is zilver, zwijgen is fout, NJB 2002, p. 1453.

10 Rb Zwolle 15 mei 2006, AY5717.

11 HR 11 juli 2008, BC8421.

12 HR 20 december 2002, NJ 2004, 4. 
enkel de rechter bij de beoordeling van de inleidende vordering de stukken mag inzien, mag de rechter enkel op grond van die stukken uitspraak doen, indien de wederpartij ondubbelzinnig toestemming heeft gegeven. De rechter die het geding verder behandelt, zal uit het niet verlenen van die toestemming de gevolgtrekking kunnen maken die hij geraden acht.

In de volgende gevallen mag de rechter die over de geheimhouding heeft beslist, op grond van de eisen van een behoorlijke rechtspleging geen verdere beslissing in dezelfde zaak meer nemen:

- De rechter heeft beslist dat een partij niet verplicht is om inzage te verschaffen waarna de partij die de stukken in bezit heeft niet meedeelt dat met het oog op de beoordeling van de inleidende vordering uitsluitend de rechter inzage mag hebben;

- De wederpartij geeft geen toestemming dat enkel de rechter de betreffende stukken mag inzien bij de beoordeling omdat er gewichtige redenen zijn;

- De rechter heeft geoordeeld dat er geen gewichtige redenen zijn voor de inzageweigering maar de betrokken partij volhardt in haar weigering tot inzage.

Het bij het derde gedachtestreepje vermelde, is niet in HR 20 december 2002, NJ 2004, 4 (Lightning Casino) te vinden. Om die reden geeft dit arrest een verfijning van de Lightning Casino-norm (zoals ik enige regels hiervoor schreef). ${ }^{13}$

Met toestemming van de rechter wordt met enige regelmaat bewijsbeslag gelegd. Het verlof strekt zich dan regelmatig verder uit dan strikt noodzakelijk is om praktische redenen. Zo is het tijdrovend om op een harde schijf precies te vinden wat nodig en mag de hele schijf worden gekopieerd. ${ }^{14}$ Het is vervolgens aan de partij die inzage vordert en aan de rechter om op grond van lid 2 omzichtig te formuleren van welke bestanden inzage moet worden verschaft, waarbij bijvoorbeeld gebruik gemaakt kan worden van een elektronische zoekmachine om de informatie te selecteren waarbij een onafhankelijk onderzoeksbureau de selectie op trefwoord zal verrichten. ${ }^{15}$

13 Zie ook Rb Rotterdam 25 januari 2006, NJF 2006, 230, die in het kader van art. 162 Rv in een zaak waarin A de rechtbank heeft verzocht om openlegging van boeken te bevelen, waartegen de eigenaar van de boeken bezwaar heeft, overweegt dat een andere rechter wegens de in art. 6 EVRM bepaalde rechterlijke onpartijdigheid zal beslissen van welke delen in de boeken A bevoegd zal zijn om van de inhoud kennis te nemen.

14 Vergelijk Rb Zutphen 7 mei 2003, JBPR 2003, 66, Rb Amsterdam 2 februari 2005, AT1558, hof Arnhem 13 februari 2007, BA0018 en datzelfde hof op 17 april 2007, NJF 2007, 391.

15 Aldus een voorstel van een eiser die inzage vordert, te kennen uit Rb Utrecht 1 oktober 2008, BF7386. De rechtbank is niet aan een oordeel over dit voorstel toegekomen. 


\section{Art. 843a lid $3 \mathrm{Rv}$, degene die tot geheimhouding verplicht is}

Het derde lid van art. 843a Rv, luidende

'hij die uit hoofde van zijn ambt, beroep of betrekking tot geheimhouding verplicht is, is niet gehouden aan deze vordering te voldoen, indien de bescheiden uitsluitend uit dien hoofde te zijner beschikking of onder zijn berusting zijn',

is pas ingevoerd bij de wijzigingen van het Wetboek van Burgerlijke Rechtsvordering die per 1 januari 2002 in werking zijn getreden. De tekst van dit lid bestond al wel voor 1 januari 2002 en was te vinden in het met ingang van 1 april 1988 opgenomen art. 843b Rv. In de parlementaire geschiedenis bij de totstandkoming van dat art. $843 \mathrm{~b} \mathrm{Rv}$ is alleen maar verwezen naar art. 1922a BW, het artikel dat art. 843 b moest vervangen. De tekst van lid 3 van art. 1922a BW is niet letterlijk overgenomen in 1988 omdat dit lid aangepast moest worden aan de tekst van art. 191 lid 2 onder b Rv (nu art. 165 lid 2 onder b Rv). ${ }^{1}$ Ik sluit niet uit dat de wetgever in 1988 dit lid 3 toen niet ook in art. 843a Rv heeft opgenomen omdat de toenmalige tekst van dit artikel sprak over 'onderhandse akte' en gedacht is dat als er een onderhandse akte bij een geheimhouder ligt, deze akte hem niet is toevertrouwd in zijn hoedanigheid. Het is ook mogelijk dat de wetgever in 1988 de problematiek bij art. 843a Rv over het hoofd heeft gezien omdat het bewijsaspect van dit artikel onvoldoende is onderkend.

De Memorie van Toelichting bij de in 2002 ingevoerde wijziging vermeldt alleen maar 'Het derde lid kwam in wetsvoorstel 24651 niet voor. Een overeenkomstige bepaling komt wel al voor bij artikel $843 \mathrm{~b} \mathrm{Rv}$. Er is geen reden de uitzondering niet ook bij artikel 843a onder te brengen.'. Meer wordt er over dit onderwerp niet gezegd.

Ook in de literatuur over art. 843a Rv wordt dit lid nauwelijks behandeld. Het meest uitvoerig is het losbladig commentaar op het Wetboek van Burgerlijke Rechtsvordering van Kluwer. Daar worden tien regels besteed aan dit lid. De oorzaak daarvan is ongetwijfeld de vanzelfsprekendheid van de regel die is neergelegd in dit lid. Daar waar iemand zich als getuige kan verschonen, dient hij dit recht natuurlijk ook te hebben voor zover van hem inzage in bescheiden wordt 
gevorderd. Dit betekent dus dat bij de uitleg van lid 3 gekeken dient te worden naar art. $165 \mathrm{Rv}$. Dit art. $165 \mathrm{Rv}$ is uitputtend behandeld door Fernhout ${ }^{2}$ en van het hierna volgende is dan ook niets of bijna niets nieuw. Ik merk wel op dat in het boek van Fernhout art. 843a Rv nergens expliciet wordt genoemd.

Art.165 lid 2 aanhef en sub b Rv vermeldt dat de verplichting om te getuigen niet bestaat voor degenen die tot geheimhouding verplicht zijn omtrent hetgeen hun in die hoedanigheid is toevertrouwd. Lid 3 van art. 843a Rv gebruikt hier de woorden uit dien hoofde. Er is niets waaruit blijkt dat de wetgever van mening is dat deze twee zinsnedes niet dezelfde inhoud hebben, dus ik houd hen voor synoniem. Fernhout merkt over de woorden 'hun in die hoedanigheid' in 3.4.8.1 op dat een geheimhouder niet de hele dag door geheimhouder is. Een advocaat maakt wel eens een wandelingetje, pakt de trein, enz. ${ }^{3}$

Is er nog sprake van 'uit dien hoofde' indien een partij, in het vooruitzicht van een mogelijk op art. 843a Rv gebaseerd verzoek, bepaalde stukken deponeert bij een advocaat of notaris? Ik zou zeggen van niet: hier wordt de advocaat of notaris immers alleen ingeschakeld als bewaarder met een 'kluisfunctie'. In een dergelijk geval zal hij verplicht moeten kunnen worden om inzage te verschaffen. Een en ander ligt wel subtiel. Zo schrijft Fernhout in 3.4.8.1.1 dat de President Rb Almelo op 2 oktober 1988, KG 1988, 447 onjuist oordeelde waar deze overwoog dat het door een notaris in depot nemen van een gesloten envelop niet behoorde tot de in de wet aan de notaris opgedragen specifieke taken. Hij noemt dit geen relevant criterium, en dat lijkt mij juist.

Het verschoningsrecht ligt niet voor eens en voor altijd vast. Zo zijn, aldus Fernhout, de werkzaamheden van bijvoorbeeld een notaris van 'gepatenteerd aktenschrijver' ontwikkeld naar adviseur in alle zaken waaraan een juridisch aspect kleeft.

Uit het notaris Van Eijck arrest blijkt dat er geen sprake is van een verschoningsrecht indien uit de omstandigheden moet worden afgeleid dat door betrokkenen geen vertrouwelijkheid is beoogd. ${ }^{4}$ Met de woorden van de Hoge Raad in genoemd arrest: in beginsel kan evenmin van een onder het verschoningsrecht te brengen 'toevertrouwen' sprake zijn wanneer partijen hun mededelingen gedaan hebben ter vastlegging onder leiding van een notaris. Indien een notaris door twee partijen die hebben onderhandeld over een transactie en daarbij een bepaalde mate van overeenstemming hebben bereikt, wordt ingeschakeld voor de vastlegging van die overeenstemming, heeft de notaris geen verschoningsrecht indien hij hierover wordt ondervraagd. De notaris zal dan ter zake van die totstandkoming en de uitleg van de transactie moeten getuigen. Het lijkt mij dat daar waar die notaris dient te

2 F.J. Fernhout, Het verschoningsrecht van getuigen in civiele zaken, Recht en Praktijk dl 131, Kluwer 2004.

3 De thans populaire kretologie dat een persoon 24 uur per dag, zeven dagen per week militair, politieagent, rechter, enz. is, verdient tenminste herbezinning.

4 HR 25 september 1992, NJ 1993, 467. 
getuigen, hij ook verplicht is om inzage in het geschrift waarin die overeenstemming is vastgelegd, te verschaffen. Fernhout geeft wat dit betreft in 3.4.8.2.2 een scherp en genuanceerd stelsel waarin achtereenvolgens vier mogelijkheden aan de orde komen.

Ten eerste bespreekt hij de situatie dat tussen betrokkenen vast staat dat de onderhandelingen en besprekingen niet tot overeenstemming hebben geleid. Het besprokene heeft dan te gelden als vertrouwelijk.

Ten tweede is het mogelijk dat tussen betrokkenen in geschil is of de onderhandelingen tot overeenstemming hebben geleid. Als algemene regel geldt dan dat 'wanneer een advocaat, door een cliënt in de behandeling van enige zaak betrokken, te dier zake besprekingen met een derde bijwoont, welke de strekking hebben tussen den cliënt en den derde een toestand te scheppen of te doen vaststaan met rechtswerking óók jegens dien derde, deze strekking belet den inhoud dier besprekingen als dien advocaat toevertrouwd aan te merken.' .5 Deze regel geldt echter slechts voor die besprekingen waarvan niet op grond van andere omstandigheden moet worden aangenomen dat deze vertrouwelijk zijn geweest. In een dergelijk geval zal de geheimhouder mijns inziens dus desgevraagd inzage dienen te geven in bescheiden die hierop betrekking hebben.

Indien ten derde vast staat dat er overeenstemming is, doch partijen verschillen van mening over de inhoud van elkaars verplichtingen, geldt het besprokene als iets dat van meet af aan heeft behoord tot de wetenschap van partijen. Er bestaat dan ten opzichte van elkaar geen vertrouwelijkheid. Het is immers de bedoeling dat de overeenkomst ook naar buiten toe werking zal hebben. Daar waar volgens Fernhout de vertrouwenspersoon in een geding tussen die partijen over het besprokene moet verklaren, dient volgens mij die vertrouwenspersoon ook inzage te verschaffen.

In de vierde situatie staat tussen betrokkenen vast dat er overeenstemming is bereikt, maar stelt een partij zich op het standpunt dat de gesloten overeenkomst nietig of vernietigbaar is. Ik ben het met Fernhout eens waar deze van mening is dat in een dergelijk geval een verklaring mag worden afgelegd omdat anders degene die zich op het gebrek beroept, de bescherming wordt onthouden die hem toekomt. Inzage in eventuele bescheiden zal dus dan door de geheimhouder verstrekt moeten worden.

In al deze gevallen geldt dat alleen partijen bij de rechtshandeling inzage kunnen vorderen. De partijen die iets met een verschoningsgerechtigde bespreken, behoren er immers op te rekenen dat die verschoningsgerechtigde tegenover derden het zwijgen bewaart. In het merendeel van de gevallen zal dit lid ter sprake komen in een verhouding tot notarissen of advocaten. Toch zullen ook artsen een beroep op dit lid kunnen doen in bijvoorbeeld het volgende geval. Een verzekerde stuurt zijn ziektekostenverzekeraar een declaratie van een doktersingreep. De verzekeraar 
vertrouwt een en ander niet en wenst inzage in de administratie van de dokter. Er is hier zonder meer sprake van een rechtsbetrekking in de zin van lid 1. De dokter kan echter een beroep doen op lid 3.

De rechtbank Arnhem lijkt een kristallen bol gehanteerd te hebben bij een kort geding tegen een huisarts en een apotheker. Eiseres, familielid van een overledene, stelt in kort geding tegen de huisarts en de apotheker van de overledene als gedaagden, dat zij in een lopende bodemprocedure vernietiging van het testament van erflaatster vordert omdat erflaatster ten tijde van het opmaken van het testament onvoldoende compos mentis zou zijn geweest. Om die vernietiging te bereiken, dient eiseres inzage te hebben in de medische gegevens van erflaatster. Gedaagden beroepen zich op hun geheimhoudingsplicht. De rechtbank wijst de vordering toe omdat er voldoende zwaarwegende aanwijzingen bestaan waaruit kan worden afgeleid dat erflaatster ten tijde van het verlijden van het testament niet over haar verstandelijke vermogens beschikte, het voldoende aannemelijk is dat het medisch dossier opheldering over de aanwezigheid van die verstandelijke vermogens kan verschaffen en omdat voldoende aannemelijk is gemaakt dat de overledene, was zij nog in leven geweest, haar toestemming tot inzage in het medisch dossier gegeven zou hebben. ${ }^{6} \mathrm{Ik}$ vraag mij af of dit belang, een erfenis, werkelijk zwaar genoeg is om de geheimhoudingsplicht te doorbreken. Indien een dergelijk geldelijk belang al voldoende is, lijkt mij niet veel van de geheimhoudingsplicht over te blijven. Ik ben het evenmin eens met het laatste deel van de overweging. Een dergelijke speculatie over hetgeen de overledene zou hebben gewild, behoort in de rechtszaal geen onderwerp van debat te zijn. Het is niet aan de nabestaanden en vervolgens aan de rechter om te speculeren over de vraag wat de dode bij leven had gewenst. Voor dat soort situaties is juist het testament de enige kenbron. ${ }^{7}$

De praktijk heeft inmiddels geleerd dat de aan een geheimhoudingsplichtige toevertrouwde gegevens niet altijd geheim blijven en via andere wegen kunnen worden bemachtigd. Indien bemachtiging niet mogelijk is, kan dit soms negatieve gevolgen hebben voor degene ten behoeve van wie de verschoningsgerechtigde zijn recht kan inroepen. Ik noem als voorbeeld HR 20 januari 2006, NJ 2006, 78. Interpolis diende te bewijzen dat $\mathrm{A}$ wist of behoorde te weten dat de klachten die zij aan haar huisarts heeft gemeld, vielen onder 'rug- of Ischiasklachten'. Interpolis roept als getuigen op de huisarts en een neuroloog. De advocaat van A deelt mee dat hij er bezwaar tegen heeft indien die artsen hun geheimhoudingsplicht zouden schenden en de artsen beroepen zich op hun verschoningsrecht. De rechtbank wijst daarop een nieuw tussenvonnis waarin A wordt opgedragen te bewijzen dat zij niet wist of behoorde te weten dat de klachten die zij aan haar huisarts heeft

$\mathrm{Rb}$ Arnhem 15 augustus 2005, AU4760.

Ik heb dat reeds eerder verdedigd in mijn bespreking van De exhibitieplicht in kort bestek door J. Ekelmans, TCR 2008, p. 63. Als wij op deze weg verder gaan, sluit ik niet uit dat Jomanda als deskundige een seance in de zittingszaal komt houden. 
gemeld, vielen onder 'rug- of Ischiasklachten'. De Hoge Raad oordeelt over deze omkering van de bewijslast dat als uitgangspunt terecht heeft gediend dat Interpolis die feiten dient te bewijzen die zij ten grondslag legt aan haar stelling dat er sprake is van verzwijging. Terecht is echter uit het feit dat de getuigen zich grotendeels hebben verschoond omdat A's advocaat hen niet uit de geheimhoudingsplicht heeft willen ontslaan, afgeleid dat op de voet van de laatste zinsnede van art. $150 \mathrm{Rv}$ de eisen van redelijkheid en billijkheid omkering van de bewijslast meebrengen. Gelet op deze uitspraak, lijkt het er niet op dat de Nederlandse rechtspraak op weg is naar een verschoningsrecht in de vorm van een zwijgrecht van een partij over feiten waar de erkende verschoningsgerechtigde geen informatie over hoeft te verschaffen. ${ }^{8}$ De vraag hierbij is wel of de woorden 'gewichtige redenen' in lid 4 van art. 843a Rv niet al min of meer een dergelijk 'verschoningsrecht' geven. Zie daarvoor par. 12.1 .

Een voorbeeld van gegevens van personen waarvan niet met zekerheid gezegd kan worden dat die geheim blijven, zijn de medische gegevens van een slachtoffer indien de aansprakelijke partij (vaak in de persoon van een verzekeraar) inzage wenst in de toestand van het slachtoffer voor en na het ongeval. Zo lijkt de overwegende tendens in de rechtspraak te zijn dat een voldoende gemotiveerd verzoek van de verzekeraar om inzage te hebben in de groene kaart, wordt toegewezen. ${ }^{9}$

Voor de volledigheid wijs ik in het kader van de geheimhouding op de bijzondere regels over geheimhouding in de op 1 januari 2007 in werking getreden Wet op het financieel toezicht (Wft). De toezichthouder kan op grond van art. 1:74 lid 1 Wft ten behoeve van het toezicht van een ieder inlichtingen vorderen. Art.1:89 Wft bepaalt anderzijds, kort gezegd, dat het de toezichthouder verboden is van vertrouwelijke gegevens of inlichtingen verder of anders gebruik te maken dan voor de uitvoering van zijn taak of door de Wft wordt geëist. ${ }^{10}$

In het boek van De Haan en Oosterhuis ${ }^{11}$ komt ook uitgebreid ter sprake de vraag welke bevoegdheden de medewerkers van de NMA hebben en of die door de NMA verkregen vertrouwelijke gegevens voldoende zijn afgeschermd tegen inzage door derden.

8 Van den Reek acht een dergelijk recht gewenst evenals J.G.A. Linssen in zijn noot onder Rb Zutphen 7 mei 2003, Jbpr 2003, 66. Middelkoop schrijft dat voor cliënten van verschoningsgerechtigden mogelijkerwijs een afgeleid verschoningsrecht geldt.

9 Zie onder meer Chr. H. van Dijk, Ter beschikking stellen van de patiëntenkaart: aan wie? In TVP 2006, p. 8-17 en de jurisprudentie zoals besproken in TVP 2006, p. 87-94.

10 Zie verder W.G. de Haan en G. Oosterhuis, Geheimhouding en transparantie in het financieel recht en het mededingingsrecht, Preadviezen commerciële rechtspraktijk, deel I, Uitgeverij Paris, 2008.

11 W.G. de Haan en G. Oosterhuis, Geheimhouding en transparantie in het financieel recht en het mededingingsrecht, Preadviezen commerciële rechtspraktijk, deel I, Uitgeverij Paris, 2008. 
Ik besluit dit hoofdstuk met de volgende merkwaardige casus. ${ }^{12}$ A heeft B als advocaat bijgestaan in een gerechtelijke procedure. Op enig moment draagt A op verzoek van B het zaaksdossier over aan een andere advocaat. Enige tijd na die overdracht stelt B dat A in de betreffende procedure beroepsfouten heeft gemaakt en vordert in een geding schadevergoeding van $\mathrm{A}$. In het betreffende geding vordert A bij incident, kort gezegd, dat B hem afschriften zal verstrekken van het hele door hem aan B afgegeven dossier dat zich inmiddels bij de andere advocaat van B bevindt. B beroept zich vervolgens op het verschoningsrecht van zijn nieuwe advocaat. De rechtbank verwerpt dit beroep omdat de vordering niet tot die nieuwe advocaat is gericht maar tot B. Het verschoningsrecht van die nieuwe advocaat, aldus de rechtbank, geldt niet tegenover B, wanneer deze zijn nieuwe advocaat om afschriften van de door A gewenste stukken zou verzoeken.

$12 \mathrm{Rb}$ Utrecht 23 januari 2008, BC4019. 


\section{De afwijzingsgronden in art. 843a lid $4 \mathrm{Rv}$}

\subsection{Gewichtige redenen}

De parlementaire geschiedenis maakt niet veel woorden vuil aan de vraag wat er wordt bedoeld met 'gewichtige redenen'. De minister verwijst slechts naar art. 22 Rv waar deze woorden ook zijn vermeld. In de Memorie van Toelichting bij dat artikel verwijst de minister ter zake de woorden 'gewichtige redenen' naar art. 8:29 Awb. Hij vermeldt verder dat een weigering door de rechter om zo'n bevel te geven bijvoorbeeld kan zijn gegrond op het feit dat inzage wordt verzocht in vertrouwelijke medische informatie. ${ }^{1} \mathrm{Bij}$ Nota stelt de minister dat bij het criterium gewichtige redenen in de eerste plaats gedacht moet worden aan vertrouwelijke gegevens zoals gegevens betreffende seksuele geaardheid, medische status of financiële positie. Ook kan het gaan om vertrouwelijke bedrijfsgegevens. ${ }^{2}$ Meer wordt over deze woorden niet vermeld. Ook de literatuur heeft weinig aandacht aan dit lid besteed en volstaat eigenlijk met het noemen van dit rijtje. Ik begin maar met de door de minister genoemde 'financiële positie'. Ik vind dat geen reden van groot gewicht, vooral omdat art. $475 \mathrm{~g} \mathrm{Rv}$ een schuldenaar de verplichting oplegt om aan een deurwaarder, die gerechtigd is tegen hem beslag te leggen, desgevraagd zijn bronnen van inkomsten (dus niet hoeveel hij verdient, maar waar hij inkomen verdient) op te geven. Gelet op dit artikel lijkt de opmerking van de minister dat een financiële positie een gewichtige reden kan opleveren om inzage te verhinderen, wat lichtvaardig gemaakt.

Van der Korst schrijft dat de wetgever met deze gewichtige redenen oog heeft gehad voor bedrijfsgeheimen. ${ }^{3}$ Het moet een partij zijn toegestaan om haar bezwaren tegen inzage aan een ander gemotiveerd ter kennis van de rechter te brengen. Bedrijfsgeheimen behoren geheim te blijven.

1 De rechter kan dan in zo'n geval dus terecht de inzagevordering afwijzen. Dit kan een Pyrrusoverwinning opleveren. De vertrouwelijkheid van de informatie, aldus de minister, doet immers niet af aan het feit dat als de betreffende partij het bewijs moet leveren doch de betreffende stukken gelet op het vertrouwelijk karakter niet inbrengt, bij gebrek aan voldoende bewijs de procedure wel eens kan verliezen. Zie ook HR 26 maart 2004, RvdW 2004, 54.

2 Zie p. 154-160 Parl. Gesch. burgerlijk procesrecht.

3 P.J. van der Korst, Bedrijfsgeheimen en transparantieplichten, Deel 92 van de serie vanwege het Van der Heijden instituut, Kluwer, Deventer 2007, p. 107. 
Volgens Ekelmans is uitgangspunt bij de vraag of iets een gewichtige reden is, dat een procespartij niet zonder meer kan weigeren informatie te verstrekken. Ook het grondrecht op eerbiediging van de persoonlijke levenssfeer staat niet zonder meer aan het geven van informatie in de weg. Bij de beantwoording van de vraag of een inbreuk op die levenssfeer mag worden gemaakt, moet een belangenafweging worden gemaakt, waarbij soms het privacybelang het onderspit delft. ${ }^{4}$

Jansen is van mening dat de belangenafweging die de Hoge Raad toepast bij de vraag of iemand een verschoningsrecht heeft, en wel of het belang van de waarheidsvinding moet wijken voor het belang dat een ieder zich vrijelijk en zonder vrees voor openbaarmaking tot deze bepaalde adviseur moet kunnen wenden, ook hier moet worden toegepast. ${ }^{5} \mathrm{Ik}$ vind dat te zwaar. Het professioneel verschoningsrecht dient een beperkt recht te blijven voor enkele beroepsgroepen die bij voorkeur door de wetgever uitputtend zijn opgesomd. Die door Jansen verdedigde belangenafweging past ook niet goed in een voorbeeld dat de minister heeft gegeven. Zo is de minister van mening dat de financiële positie van iemand een zwaarwichtige reden kan zijn, ${ }^{6}$ hetgeen, waar wij geen bankgeheim kennen, toch geen vanzelfsprekende opmerking is.

In de jurisprudentie zijn enige uitspraken te vinden die via analogie bruikbaar kunnen zijn. In HR 11 september 1998, NJ 1999, 664 had een ziektekostenverzekeraar die de door haar betaalde kosten wilde verhalen op twee aansprakelijke artsen waartegen een strafrechtelijk onderzoek was ingesteld, het strafdossier overgelegd. De twee artsen verzetten zich tegen die overlegging omdat door deze overlegging hun recht op privacy was geschonden. De artsen hadden geen concrete feiten en omstandigheden aangevoerd om die stelling te staven en de Hoge Raad is van oordeel dat, voor zover de overlegging van het dossier al als een inbreuk op hun privacy is te beschouwen, het belang van de artsen bij bescherming van hun privacy moet wijken voor het belang van de verzekeringsmaatschappij dat in de procedure de waarheid van de door haar gestelde feiten komt vast te staan. ${ }^{7}$

In het arrest Lightning Casino-Nederlandse Antillen ${ }^{8}$ heeft de Hoge Raad geen antwoord gegeven op de vraag wat onder gewichtige redenen valt. De Hoge Raad heeft wel geoordeeld dat het enkele feit dat de rechter in het kader van een procedure tot openbaarmaking van stukken heeft geoordeeld dat het stuk niet openbaar

4 Ekelmans, p. 37-38

5 T.S. Jansen, Art. 843a Rv in de ondernemingsrechtpraktijk. Verboden te vissen, maar vragen mag. Tijdschrift voor de ondernemingsrechtpraktijk 2009, p. 93.

6 P. 157 Parl. Gesch. burgerlijk procesrecht: 'Bij het criterium gewichtige redenen moet dus in de eerste plaats gedacht worden aan vertrouwelijke gegevens, zoals, bijvoorbeeld, gegevens betreffende de sexuele geaardheid, de medische status of financiële positie. Ook kan het gaan om vertrouwelijke bedrijfsgegevens. Een nadere invulling van dit criterium kan het best worden overgelaten aan de rechtspraak.'

7 De HR overweegt nog dat de artsen niet hebben gesteld dat de maatschappij het dossier op onrechtmatige wijze in bezit heeft gekregen.

8 HR 20 december 2002, NJ 2004, 4, m.nt. Vranken. 
gemaakt hoeft te worden, niet voldoende is om al tot de conclusie te komen dat er sprake is van een zwaarwichtige reden. Vranken breekt in zijn noot onder dit arrest een lans voor wetgeving waarin duidelijk wordt geregeld in welke gevallen bepaalde bescheiden niet ter inzage verstrekt hoeven te worden. Hij is van mening dat niet kan worden volstaan met een dergelijke materiële norm voor het recht op geheimhouding, maar dat er ook een procedure moet komen waarin uiteindelijk de rechter de gegrondheid van het beroep beoordeelt. Dat laatste is (nog steeds) niet door de wetgever verzorgd, maar door de Hoge Raad met de uitspraak Lightning Casino. Opvallend is dat er buiten Vranken in zijn noot in de NJ, niet of nauwelijks op dit arrest is gereageerd. ${ }^{9}$ Dat is eens te meer merkwaardig omdat in de jurisprudentie de problematiek wel aan de orde is geweest.

Zo vordert Leisureplan dat de rechtbank Zutphen de Rabobank veroordeelt om, onder meer, correspondentie af te geven die was gewisseld tussen enerzijds notarissen en advocaten en anderzijds hun cliënten en voorts gespreksverslagen van deze functionarissen en hun cliënten. De rechtbank oordeelt dat inzage niet verstrekt hoeft te worden, omdat aan het maatschappelijk belang dat een ieder zich vrijelijk en zonder vrees voor openbaarmaking van het besprokene om bijstand en advies tot deze functionarissen kan wenden, ernstig afbreuk zou worden gedaan indien er een verplichting zou bestaan tot openbaarmaking van deze correspondentie en gespreksverslagen. ${ }^{10}$ De uitspraak is gewezen met toepassing van het recht van voor 1 januari 2002, doch het lijkt waarschijnlijk dat de rechtbank met deze overweging lid 4 van het nieuwe art. 843a Rv voor ogen heeft gehad. Ik ben het eens met deze overweging. Er komt immers niet veel terecht van de geheimhoudingsplicht en van het verschoningsrecht indien een partij kan worden veroordeeld om correspondentie die zij met advocaten of notarissen heeft gevoerd, ter inzage te geven. ${ }^{11}$ Indien de 'financiële positie' volgens de minister een voorbeeld kan zijn van een gewichtige reden die inzage kan voorkomen zal, indien inzage wordt gevorderd in een briefwisseling met een geheimhouder, die geheimhoudingplicht ook een dergelijke gewichtige reden moeten zijn.

De drie hiervoor door de minister genoemde voorbeelden (seksuele geaardheid, medische status of financiële positie) lijken overigens niet goed te passen in de opvatting van de minister zoals hij deze uitte in het kader van het in 1988 vernieuwde bewijsrecht. Toen werd namelijk de vraag onder ogen gezien of een partijgetuige een verschoningsrecht moest toekomen. ${ }^{12}$ Deze vraag werd ontkennend beantwoord omdat er slechts sprake zou zijn van een conflict tussen de plicht de waarheid te spreken en het directe eigen belang om de procedure te winnen. Er werd dus expliciet geweigerd om de partijgetuige een verschoningsrecht te geven. Enkele jaren later worden er door de minister voorbeelden gegeven van gebieden waarop

9 Ook Lindijer geeft in $\mathrm{nr} 229$ in feite niet meer dan een beschrijving van dit arrest.

10 Rb Zutphen 7 mei 2003, JBPR 2003, 66, m.nt. Linssen.

11 Zie echter ook het slot van hoofdstuk 6.

12 Zo reeds Linssen in zijn noot bij het vonnis van de rechtbank Zutphen in JBPR 2003, 66. 
een procespartij geen inzage hoeft te verstrekken terwijl diezelfde partij, als zij als getuige wordt gehoord, de vragen die worden gesteld die betrekking hebben op deze gebieden, wel moet beantwoorden. Indien het vonnis van de rechtbank Zutphen een voorbode is, lijkt de rechtspraak aldus tot een soort verschoningsrecht te komen dat de minister in 1988 nog stellig afwees. ${ }^{13}$

Linssen schrijft dat het beroep op gewichtige redenen, zoals het risico van openbaring van bedrijfsgeheimen, goed gemotiveerd moet zijn wil het kunnen slagen. Hij raadt degene die dit beroep doet, aan om oplossingen voor te stellen waarbij de andere partij niet in de kou blijft staan, terwijl de geheimen gewaarborgd blijven. Zo zou iemand die tot geheimhouding verplicht is, kunnen worden aangewezen om de informatie te bekijken en verslag te doen. ${ }^{14}$

Het hof Den Haag overweegt in het Pacelli-arrest ${ }^{15}$ dat Visser BV (de schadeveroorzaker en verzekerde) en Gebr. Sluyter BV (de verzekeringsmakelaar van Visser BV) de verzekeringspolis van Visser BV moeten afgeven aan de benadeelde en dat de door de verzekerde genoemde belangen, waaronder het privacybelang en de bescherming van haar concurrentiepositie, onvoldoende zwaarwegend zijn om aan toewijzing van de vordering in de weg te staan. Nadere motivering ontbreekt terwijl die wel gewenst is gelet op het grote belang van de concurrentiepositie. Dit belang kan eventueel in het oog worden gehouden door een bijzondere wijze van inzage te gelasten, doch het arrest zoals gepubliceerd houdt daarover niets in. ${ }^{16}$

Het hof Den Bosch wijst de vordering tot afgifte van de bijlagen bij een intern memo van en aan medewerkers van Rockwool-Grodan af, aangezien het kennelijk

13 Zie ook Van den Reek op p. 247 e.v. die over de heersende opvatting stelt dat die tot het merkwaardige resultaat leidt dat de advocaat-getuige een beroep op zijn verschoningsrecht kan doen, terwijl zijn cliënt, als partij gehoord, dit beroep niet heeft. Uiteindelijk dient het verschoningsrecht toch de betreffende cliënt.

14 Linssen onder Rb Zutphen 7 mei 2003, JBPR 2003, 66.

15 Hof Den Haag 20 mei 2003, S\&S 2004, 59.

16 Zie ook Rb Rotterdam 19 mei 2004, AR3382, JBPR 2004, 77 m.nt. Linssen: Hanjin Shipping heeft in China een lading grondnoten, eigendom van een derde, in ontvangst genomen voor vervoer naar Rotterdam. De noten, door de derde verzekerd bij Fortis, raken beschadigd door brand en explosie aan boord van de boot waarmee zij werden vervoerd. Fortis acht Hanjin Shipping aansprakelijk en start een bodemprocedure en vordert in het met die bodemprocedure gestarte incident onder meer afgifte van de expertiserapporten omtrent de oorzaak van de brand die zijn opgemaakt door de expert van Hanjin Shipping. De rechtbank wijst deze vordering af omdat ' ... het maatschappelijk belang dat een partijexpert vrijelijk en zonder vrees voor openbaarmaking zijn opdrachtgever van advies dient, een weigering van de verplichting tot afgifte rechtvaardigt. Hanjin Shipping is derhalve niet gehouden adviserende (delen van) stukken van haar expert aan Fortis c.s. te verstrekken. Voor zover deze stukken echter een feitelijk/vaststellend deel bevatten met de bevindingen en waarnemingen van de expert, dient Hanjin Shipping deze feitelijke/vaststellende (delen van) stukken aan Fortis c.s. af te geven.' In de bijdrage 'Het recht van expertise' in de 'Bundel Capita Zeerecht', Kluwer 2004, p. 329-335 plaatst R.C.A. van 't Zelfde deze zaak (waarvan ten tijde van het schrijven van de bijdrage de uitspraak nog niet bekend was) in de brede context van de artikelen 8:494 en 495 BW. 
gaat om stukken betreffende afwegingen tussen bedrijfsgenoten ter voorbereiding van de verdediging naar aanleiding van de aansprakelijkheidstelling door Jongerius. Geen van deze bijlagen heeft kennelijk enige externe dienst gedaan. Iedere partij heeft een eigen recht om haar verdediging in vrijheid en beslotenheid voor te bereiden. ${ }^{17}$ Een verwijzing naar lid 4 wordt niet gegeven, maar het kan niet anders of dit moet de grondslag voor de afwijzing zijn geweest. Terecht, lijkt mij. ${ }^{18}$

Er is evenmin sprake van een gewichtige reden indien het verzoek in potentie leidt tot een grote administratieve verzwaring. In de Dexia-zaken (zie hoofdstuk 13) voerde Dexia aan dat het verstrekken van inzage in de klantendossiers, gelet op de vele klanten die zij had, tot hoge financiële lasten zou leiden. Terecht oordeelt onder meer de rechtbank Den Haag dat een dergelijk feit voor risico komt van Dexia. $^{19}$

Een gedaagde in een procedure tot inzage die aanvoert dat hij bij een veroordeling tot verstrekking van inzage zal handelen in strijd met zijn contractuele geheimhoudingsplicht, moet dat verweer in elk geval toelichten door de inhoud van die geheimhoudingsplicht te vermelden en zal tevens moeten stellen dat de persoon die de betreffende plicht heeft bedongen, nog aanspraak op die geheimhouding maakt. ${ }^{20}$

17 Hof Den Bosch 14 oktober 2003, LJN AM7927. Hof Den Bosch 14 oktober 2003, AM7927 en Rb Breda 15 februari 2006, NJF 2006, 217 oordelen dat de verstrekking van privéadressen van werknemers misschien wel een inbreuk vormt op de privacy van die werknemers, maar die inbreuk is niet zwaar genoeg om een zwaarwichtige reden in de zin van lid 4 van art. 843a Rv op te leveren.

18 Zie wat de due diligencerapporten betreft par. 7.1.3 en par. 8.1.

19 Rb Den Haag 19 mei 2005, LJN AY5824. In diezelfde uitspraak oordeelt de rechtbank eveneens dat de vraag of de omstandigheid dat partijen in een conflictsituatie verkeren, evenmin aanleiding kan geven om te weigeren gegevens te verstrekken. Rb Arnhem 26 maart 2008, BC8823 De stelling van gedaagde dat de partij die inzage eist, Ballast Nedam, de informatie misbruikt om insinuerende opmerkingen in processtukken en naar de pers te maken, vormt geen gewichtige reden omdat de rechtbank 'uit ervaring' weet dat dit niet ongebruikelijk is.

20 Rb Utrecht 12 september 2007, BB3722, NJF 2007, 544. Hof Arnhem 25 maart 2008, BC9246 oordeelt waar het recherchebureau Gawain stelt dat hij aan het onderzoeksobject X niet de namen hoeft af te geven van de personen die hij heeft gehoord in het kader van zijn opdracht die hem is gegeven door de werkgever van $\mathrm{X}$, omdat het bureau met die werkgever een contractuele geheimhoudingsplicht is overeengekomen, dat Gawain niet heeft gezegd dat zijn opdrachtgever bezwaar tegen de inzage heeft. Rb Amsterdam 11 september 2008, BF0587 oordeelt ook dat het feit dat partij A en partij B hebben afgesproken dat bepaalde informatie geheim moet blijven, geen gewichtige reden oplevert indien partij C inzage vordert. Ook zo Rb Rotterdam 3 juni 2009, BI9158. $\mathrm{Rb}$ Leeuwarden 24 juni 2009, BI9925 is van oordeel dat toewijzing van een vordering tot inzage dan wel afschrift in de financiële en administratieve boekhouding van v.o.f. A, haar vennoten $X$ en de besloten vennootschap Y en Z, handelend over de periode van 1 januari 2006 tot 1 juli 2007 , er toe zal leiden dat eiser, concurrent van gedaagden, kennis zal kunnen nemen van vertrouwelijke bedrijfsgegevens. Ook als sprake is van onrechtmatige concurrentie, zo overweegt de rechtbank verder, geeft art. 843a Rv nog geen praktisch onbegrensde bevoegdheid tot kennisneming van de financiële en commerciële administratie van de tegenpartij. Rb Zutphen 4 maart 2009, BH7615, NJF 2009, 168: A vordert van B inzage in twee tussen B en C gesloten vaststellingsovereenkomsten. $\mathrm{B}$ voert aan dat hij met $\mathrm{C}$ in het kader van de mediation geheimhouding is overeengekomen 
In het begin van deze paragraaf is vermeld dat uit de parlementaire geschiedenis blijkt dat het begrip gewichtige redenen in art. $22 \mathrm{Rv}$ dezelfde inhoud heeft als dit begrip in lid 4 van art. 843a Rv. Om die reden verdient HR 11 juli 2008 hier vermelding. ${ }^{21}$ In dat arrest overweegt de Hoge Raad dat onder meer uit art. 22 Rv blijkt dat de op partijen rustende verplichting om in het kader van een civiele procedure inlichtingen te verstrekken dan wel stukken over te leggen, niet onder alle omstandigheden geldt. 'Gewichtige redenen', aldus de Hoge Raad,

'kunnen een weigering van een partij om aan die verplichting te voldoen rechtvaardigen. Voor dit laatste is het bestaan van een wettelijke verplichting van deze partij tot geheimhouding van de van haar verlangde inlichtingen of stukken, op zich zelf niet voldoende, omdat slechts van gewichtige redenen sprake kan zijn indien in de concrete omstandigheden van het geval de belangen waarop de geheimhoudingsplicht ten aanzien van de verlangde inlichtingen of stukken zich in het bijzonder richt, zwaarder wegen dan het zwaarwegende maatschappelijk belang dat in rechte de waarheid aan het licht komt.'

Mede uit Lightning Casino c.s.- de Nederlandse Antillen en De Telegraaf - BVD/ AIVD $^{22}$ blijkt dat er gevallen kunnen zijn waarin ten behoeve van de motivering van de stelling dat er sprake is van gewichtige redenen, informatie verstrekt moet worden waarvan een partij nu juist vindt dat dit geheim moet blijven. In een dergelijk geval valt niet uit te sluiten dat alleen de rechter inzage heeft in de betreffende bescheiden teneinde te beoordelen of er inderdaad sprake is van een gewichtige reden. Zoals hiervoor in hoofdstuk 9 is vermeld, brengen de eisen van een behoorlijke rechtspleging met zich dat de rechter die over de gewichtige redenen heeft geoordeeld, geen verdere beslissing in dezelfde zaak meer neemt indien:

met betrekking tot al hetgeen in het kader van de mediation is besproken en overeengekomen en dat hij van $\mathrm{C}$ geen toestemming heeft gekregen om aan A afschriften van de vaststellingsovereenkomsten te verstrekken. B heeft gesteld zelf geen bezwaar te hebben om bedoelde stukken in het geding te brengen, maar wil daar toch vanaf zien ter voorkoming van een nader juridisch geschil met C. Naar het oordeel van de rechtbank is met dit betoog van B geen gewichtige reden gegeven om de vordering af te wijzen. Het belang van een behoorlijke rechtspleging weegt in dit geval zwaarder dan het belang van $\mathrm{C}$ bij niet openbaarmaking. Zie over de bewijsovereenkomst en mediation ook HR 10 april 2009, BG9470.

21 HR 11 juli 2008, BC8421, NJ 2009, 451, m.nt. E.J. Dommering (De Telegraaf-BVD/AIVD).

22 HR 20 december 2002, NJ 2004, 4 respectievelijk HR 11 juli 2008, BC8421, NJ 2009, 451, m.nt. E.J. Dommering. Rb Zutphen 4 januari 2006, AV 1712 oordeelt overeenkomstig HR 20 december 2002, NJ 2004, 4 dat het feit dat de bestuursrechter op grond van de Wet Openbaarheid Bestuur heeft geoordeeld dat een overheidsorgaan de naam van een bepaalde ambtenaar niet hoeft te verstrekken, niet zonder meer een gewichtige reden oplevert. In de procedure op voet van art. 843a Rv gaat het immers om de toegang van een partij tot voor, naar haar mening, in die procedure relevante informatie, terwijl het in de WOB-procedure gaat om de aan ieder toekomende aanspraak op publieke openbaarheid. 
- Hij heeft beslist dat een partij niet verplicht is om inzage te verschaffen waarna de partij die de stukken in bezit heeft niet meedeelt dat met het oog op de beoordeling van de inleidende vordering uitsluitend de rechter inzage mag hebben;

- De wederpartij geen toestemming geeft dat enkel de rechter de betreffende stukken mag inzien bij de beoordeling omdat er gewichtige redenen zijn;

- De rechter heeft geoordeeld dat er geen gewichtige redenen zijn voor de inzageweigering, maar de betrokken partij volhardt in haar weigering tot inzage.

Bij deze problematiek moet wel de juiste processuele volgorde in acht worden genomen. Een wederpartij hoeft niet eerder toestemming te geven dat enkel de rechter de betreffende stukken mag inzien, dan nadat de rechter heeft geoordeeld dat gewichtige redenen zich tegen inzage door die wederpartij verzetten. Een blanco cheque mag niet worden geëist.

De rechter dient immers in beginsel slechts recht te spreken aan de hand van informatie die bij beide partijen bekend is. ${ }^{23}$

Op het medische terrein blijkt zich wat dit onderwerp betreft een bijzondere problematiek voor te doen: vele, zo niet alle ziekenhuizen doen aan intern onderzoek waarbij, kort gezegd, de ene collega een door een andere collega gemaakte fout (en ook een eigen fout veronderstel ik) kan melden. Er vindt dan onderzoek plaats, maar de resultaten daarvan blijven intern. In in elk geval twee gevallen hebben patiënten of familieleden van patiënten getracht inzage in die onderzoeksresultaten te krijgen. In de eerste zaak vordert $\mathrm{X}$ in kort geding veroordeling van de IJsselmeerziekenhuizen om hem afschrift te verschaffen van alle 'feitenrelazen' die zijn opgemaakt in het kader van het door de ziekenhuizen gehouden interne onderzoek naar aanleiding van het overlijden van zijn vrouw na een operatie in de IJsselmeerziekenhuizen. ${ }^{24}$ De ziekenhuizen weigeren om $\mathrm{X}$ inzage te geven in de verslaglegging van het interne onderzoek omdat dit onderzoek is verricht door de Melding Incidenten Patiëntenzorg Commissie (MIP-cie) en vertrouwelijk is. Gewichtige redenen zouden zich verzetten tegen inzage gelet op de aard van het meldingssysteem. Voor het goed functioneren van dit systeem is het van cruciaal belang dat hulpverleners veilig kunnen melden. Een instelling moet kunnen garanderen dat informatie uit het meldingssysteem niet aan derden wordt verstrekt zodat de melder niet bang hoeft te zijn dat op basis van de melding maatregelen tegen

23 Lindijer schrijft in nr 229 dat de Hoge Raad in dit arrest een regeling heeft gegeven ' ... die de rechter in staat moet stellen om - buiten gevallen als bedoeld in art. 843a en 843b Rv- te beoordelen of een partij mag weigeren te voldoen aan haar verplichting als procespartij om bepaalde stukken ... te verstrekken'. Ik zie niet waarom dit arrest niet van toepassing kan zijn op de gevallen van art. 843a en b Rv. Ook Vranken lijkt in zijn noot onder dit arrest in de NJ van mening te zijn dat de regels zoals de Hoge Raad deze formuleert in dit arrest ook van toepassing kunnen zijn in 'art. 843a Rv-gevallen'. Zie ook CvBB 22 januari 2009, BH6932.

24 Rb Zwolle-Lelystad 20 december 2007, BC1286, JA 2008, 24. 
hem worden genomen. Ter toelichting hebben de ziekenhuizen een brief overgelegd van de Inspectie voor de gezondheidszorg die voorstander is van een systeem waarin zorgverleners $100 \%$ veilig incidenten kunnen melden. De rechtbank oordeelt dat vaststaat dat er sprake is van een calamiteit terwijl evenmin is betwist dat het operatieverslag dermate summier was dat op basis daarvan geen conclusies konden worden getrokken en dat onder die omstandigheden het belang van de melder om niet bang te hoeven zijn minder zwaar weegt dan het belang van $\mathrm{X}$ om op de hoogte te raken van de feiten.

Het hof Leeuwarden overweegt in een zaak waarbij een geopereerde uit de operatie ontwaakte met een oogbolperforatie en ex art. 843a Rv inzage wenste in de MIP-melding, dat dit verzoek moet worden beoordeeld aan de hand van de criteria die de Hoge Raad heeft gegeven in zijn arrest van 15 oktober 1999, NJ 2001, 42. ${ }^{25}$ Het hof overweegt vervolgens dat met het effectief uitoefenen van de mogelijkheid tot het anoniem doen van een MIP-melding zwaarwegende maatschappelijke belangen zijn gemoeid, dat er een gerede mogelijkheid bestaat dat zonder het aanvaarden van een geheimhoudingsplicht en het daarop te baseren recht de melding niet over te leggen, genoemde maatschappelijke belangen aanmerkelijk zouden kunnen worden geschaad. Het belang van de individuele rechtzoekende op de waarheidsvinding in zijn zaak moet hiervoor wijken. Een beslissing zoals de geopereerde wenst, levert derhalve op termijn alleen maar verliezers op zodat het belang van de geopereerde moet wijken. ${ }^{26} \mathrm{Ik}$ heb moeite met deze uitspraak. Ten eerste zijn toekomstige rechtzoekenden ook niet geholpen omdat de melding immers geheim blijft en het maar de vraag is of het ziekenhuis wel stappen onderneemt ter voorkoming van soortgelijke fouten. Ten tweede lijkt mij juist het concrete belang van de patiënt om te weten of er een fout is gemaakt zwaarder te wegen bij deze, uiteindelijk, gewone civiele overeenkomst, dan een mogelijke kwaliteitsverbetering (die ook nog eens geheim wordt gehouden). Verder ben ik van mening dat deze problematiek op vele werkvloeren speelt, waarmee met deze uitspraak de deur wel erg wijd is open gezet. Ik zie tenminste niet waarom deze redenering niet zou gelden voor bijvoorbeeld een aannemer die een dergelijk meldingssysteem opzet of een autofabriek. Ook daar werken mensen die fouten maken en die fouten kunnen ernstige gevolgen hebben, terwijl ook daar de werk-

25 De HR gaf in dit arrest een maatstaf die gebruikt moet worden bij het antwoord op de vraag wat een vertrouwensarts van een Bureau Vertrouwensartsen wel en niet moet vertellen ter zake van hetgeen hem uit hoofde van zijn beroep door niet-professionele melders is toevertrouwd.

26 Hof Leeuwarden 9 december 2008, BG6616, NJ 2009, 200, m.nt. J. Legemaate. Dezelfde casus was aan de orde in de uitspraak van het Hof Leeuwarden 28 februari 2007, NJ 2009, 199, maar dan niet op de voet van art. 843a Rv, maar op grond van de stelling dat de gedaagde artsen in onvoldoende mate hadden voldaan aan hun plicht om voldoende feitelijke gegevens te verstrekken omdat zij onder meer de MIP-melding niet hadden overgelegd. Het hof overweegt dat de MIPmelding een intern vertrouwelijk document betreft en dat openbaarmaking naar mag worden aangenomen de bereidheid van ziekenhuispersoneel om incidenten te melden, bepaald niet zal bevorderen, zodat de melding niet hoeft te worden overgelegd. 
nemers die een collega fouten zien maken, liever niet bekend willen worden als zij verklaringen omtrent het slecht presteren van die collega afleggen.

In een Belgische zaak wenst Varec SA, een aannemer aan wie de opdracht niet werd gegund, in een procedure tegen de Belgische staat, alle door de aannemer aan wie wel werd gegund, Diehl, ingebrachte stukken in te zien. Diehl geeft de Belgische staat geen toestemming om Varec al haar stukken te laten inzien, omdat er volgens haar onder meer bedrijfsgeheimen in haar offerte waren opgenomen. Het Hof van Justitie overweegt dat het recht op bescherming van vertrouwelijke gegevens in wezen een materieel recht is, ook al kan de toepassing ervan procedurele gevolgen hebben. Uitgangspunt is verder dat de beroepsinstantie die dient te oordelen in het kader van een beroepsprocedure aangaande het plaatsen van een overheidsopdracht, moet kunnen beslissen dat informatie die is vervat in het dossier betreffende een aanbesteding, niet aan partijen en hun advocaten wordt doorgegeven, indien dit noodzakelijk is om de door het gemeenschapsrecht gewenste bescherming van de eerlijke mededinging of van de rechtmatige belangen van de economische subjecten te verzekeren. Het Hof toetst dit vervolgens aan het volgens het Hof in art. 6 EVRM neergelegde beginsel van hoor en wederhoor. Als gevolg van dit beginsel hebben de procespartijen in de regel het recht kennis te nemen van de bewijzen en de opmerkingen die aan de rechter zijn voorgelegd en hierover hun standpunt kenbaar te maken. In bepaalde gevallen kan het evenwel noodzakelijk zijn dat bepaalde gegevens niet aan partijen worden meegedeeld teneinde de fundamentele rechten van een derde te vrijwaren of een belangrijk algemeen belang veilig te stellen. Beroeps- of handelsactiviteiten van een natuurlijke of rechtspersoon kunnen vallen onder het begrip privéleven en kunnen daarmee een fundamenteel recht zijn, terwijl het Hof van Justitie de bescherming van zakengeheimen als algemeen beginsel heeft erkend. Verder is het behoud van een eerlijke mededinging in het kader van procedures voor het plaatsen van overheidsopdrachten een belangrijk algemeen belang, dat beschermingswaardig is. In dit kader impliceert, aldus het Hof van Justitie, het beginsel van hoor en wederhoor voor partijen derhalve niet het recht op onvoorwaardelijke en onbeperkte toegang tot alle bij de voor de beroepsprocedure verantwoordelijke instantie ingediende gegevens betreffende de aanbestedingsprocedure.

'Het beginsel van bescherming van vertrouwelijke gegevens en van zakengeheimen moet aldus worden toegepast dat het zich verdraagt met de vereisten van een effectieve rechtsbescherming en met de eerbiediging van het recht van verweer van de procespartijen ... en, ... dat de procedure op alle onderdelen het recht op een eerlijk proces eerbiedigt. Daartoe moet de voor de beroepsprocedure verantwoordelijke instantie noodzakelijkerwijs kunnen beschikken over de informatie, daaronder begrepen de vertrouwelijke informatie en de zakengeheimen, die vereist is om met volledige kennis van zaken uitspraak te kunnen doen. ... Gezien de bijzonder ernstige schade die uit de onrechtmatige mededeling van bepaalde informatie aan een concurrent kan voortvloeien, moet voornoemde instantie, alvorens deze informatie mede te delen aan een procespartij, 
het betrokken economische subject de mogelijkheid geven zich erop te beroepen dat de informatie een vertrouwelijk karakter heeft of een zakengeheim uitmaakt.'

Het Hof van Justitie concludeert dat het vertrouwelijke of geheime karakter van bepaalde gegevens moet worden geëerbiedigd, maar rekening houdend met het vereiste van effectieve rechtsbescherming waarbij het aan de nationale instantie is om een en ander tegen elkaar af te wegen. ${ }^{27}$

De Stichting Philadelphia heeft een werknemer na een onderzoek als disciplinaire maatregel overgeplaatst. Van het onderzoek is een rapport opgemaakt, waarin de werknemer inzage krijgt. De werknemer wenst ook inzage in de door de onderzoeker opgemaakte verslagen van de gesprekken die de onderzoeker heeft gevoerd met zijn collega's. De Stichting weigert dit. De werknemer vordert in kort geding inzage in die gespreksverslagen. De rechtbank is van oordeel dat het belang van Philadelphia, die in een protocol heeft vastgelegd dat betrokkenen in het kader van een onderzoek naar grensoverschrijdend gedrag op vertrouwelijkheid van de door hen gegeven informatie mogen rekenen, groter is dan het belang van de werknemer om zijn kansen te kunnen inschatten op winst in een procedure waarin hij terugkeer naar zijn oude werkplek vordert. Het is namelijk aannemelijk dat zonder die garantie werknemers niet snel genegen zullen zijn om grensoverschrijdend gedrag aan de kaak te stellen, met als gevolg dat ongewenste omgangsvormen blijven voortbestaan. ${ }^{28}$ De rechtbank gebruikt de woorden 'zwaarwichtige redenen' niet, maar het kan niet anders of zij heeft aan deze redenen getoetst. Ik vind dit door de

27 Hof van Justitie van de EG 14 februari 2008, NJ 2008, 271. M.R. Mok schrijft in zijn noot onder dit arrest dat art. 10 lid 1aanhef en onder c Wob, waarin een absolute grond tot weigering is opgenomen van bedrijfs- en fabricagegegevens, niet met dit arrest spoort en dat dit onderdeel van lid 1 moet worden overgebracht naar lid 2, het lid dat wel een belangenafweging voorschrijft. Zie ook Rb Den Haag 6 augustus 2009 die als uitgangspunt formuleert dat een aanbestedende dienst gegevens betreffende de gunning van de opdracht niet meedeelt aan derden indien openbaarmaking van die gegevens de toepassing van de Raamwet EEG-voorschriften aanbestedingen in de weg zou staan, in strijd zou zijn met het openbaar belang, de rechtmatige commerciële belangen van ondernemers zou kunnen schaden of afbreuk zou kunnen doen aan de eerlijke mededinging tussen de deelnemers, aldus art. 41 lid 5 van het tussen partijen geldende Besluit aanbestedingsregels voor overheidsopdrachten. Dit uitgangspunt geldt niet indien verzoeker voldoende aannemelijk maakt dat er gegronde redenen zijn om aan te nemen dat de beoordeling van de aanbestedende dienst onjuist is. Rb Leeuwarden 14 september 2009, BJ8523 oordeelt in een zaak waarin aannemer Dijkstra-Koudum bv van Wetterskip Fryslân inzage vordert in afschriften van financiële bescheiden van DJV, een andere aannemer die net als Dijkstra-Koudum op een aanbestedingsproject had ingeschreven en aan wie het project was gegund, dat de vordering moet worden afgewezen, onder meer omdat Wetterskip Frylân als aanbestedende dienst op grond van art. 2.29.9 ARW 2005 geen informatie openbaar dient te maken die de rechtmatige commerciële belangen van een inschrijver zou kunnen schaden. De informatie waarvan inzage wordt gevorderd is zeer concurrentiegevoelig en bekendmaking daarvan zou afbreuk doen aan de commerciële belangen van DJV. Verder is de eerlijke mededinging erbij gebaat dat inschrijvers niet op de hoogte zijn van het marktgedrag van hun concurrenten.

28 Rb Zutphen 20 augustus 2008, JAR 2008, 255. 
rechtbank geschetste werkgeversbelang niet zwaarwichtig genoeg. In deze zaak geeft de werkgever al een toezegging aan informanten/getuigen/collega's dat hun anonimiteit gewaarborgd is zonder dat is gebleken van enige steekhoudende reden daartoe. Indien er geen aanwijzingen bestaan dat de collega over wiens grensoverschrijdend gedrag wordt verklaard, gewelddadig of iets dergelijks wordt, mag geen toezegging tot geheimhouding gedaan worden. Ook Dragstra is die mening toegedaan. Hij vindt dat in dit soort gevallen de werkgever geen geheimhouding mag toezeggen. Door deze toezegging moet de werknemer namelijk via dure en tijdrovende getuigenverhoren achter de inhoud van de gespreksverslagen komen, terwijl de gedachtegang van de rechtbank de deur openzet voor ongecontroleerde afrekening van collega's door collega's, beschermd door vertrouwelijkheid. ${ }^{29}$ De rechtbank overweegt in deze zaak verder nog dat voor het oordeel dat sprake is van gewichtige redenen die zich tegen inzage verzetten, redengevend is dat de werknemer niet volledig afhankelijk is van de inhoud van bedoelde verklaringen om de gegrondheid van de redenen die aan zijn overplaatsing ten grondslag liggen te kunnen onderzoeken. De werknemer kan immers, met het oog op een eventuele procedure tegen Philadelphia, een verzoek indienen tot het houden van een voorlopig getuigenverhoor. Dit is een onjuiste overweging: de rechtbank is van oordeel dat gewichtige redenen zich tegen inzage verzetten omdat de werknemer langs een andere weg aan de informatie kan komen. Hiermee worden twee zelfstandige criteria ten onrechte met elkaar verweven. Indien er immers een zwaarwichtige reden is om inzage te weigeren, mag het niet zo zijn dat iemand via een andere weg, maar uit dezelfde bron (dezelfde werknemer(s)) wel aan die informatie kan komen. Het kan niet zo zijn dat ter bescherming van de pratende werknemer de overgeplaatste werknemer de gespreksverslagen niet mag inzien, terwijl diezelfde pratende werknemer als getuige verplicht is om antwoord te geven. De twee criteria van lid 4 zijn zo verschillend dat ter motivering van de aanwezigheid van het ene criterium niet gewezen mag worden op het andere criterium.

Uit de hiervoor weergegeven literatuur en jurisprudentie laat zich niet een goed te hanteren omschrijving formuleren. Duidelijk is wel dat de belangen op geheimhouding groot moeten zijn voordat tot een afwijzing van een verzoek tot inzage wordt gekomen. Voordat afwijzing in beeld komt, moet allereerst worden gezocht naar wegen om tegemoet te komen aan de wensen van beide partijen. Geheimhouding hoeft niet altijd achterhouden te betekenen, maar kan soms ook worden gewaarborgd door benoeming van een deskundige of door het gedeeltelijk onleesbaar maken van sommige passages. De door de minister genoemde voorbeelden van gewichtige redenen (vertrouwelijke medische informatie en/of medische status,

29 H.A. Dragstra, de exhibitieplicht in het arbeidsrecht, Tijdschrift Recht en Arbeid 2009, afl. mei 2009, p. 17. Ik wijs verder op HR 10 april 2009, BG9470 waaruit kan worden afgeleid dat een enkele overeengekomen geheimhoudingsplicht nog niet de conclusie wettigt dat er een bewijsuitsluitingsovereenkomst is gesloten. 
seksuele geaardheid, financiële positie of vertrouwelijke bedrijfsgegevens) worden door de rechtspraak niet zonder meer gehonoreerd.

\subsection{Redelijkerwijs is een behoorlijke rechtsbedeling ook zonder verschaf- fing van de gevraagde gegevens gewaarborgd}

In par. 2.2.2 is uiteengezet waarom ik het niet eens ben met de zinsnede dat de bescheiden niet ter inzage verstrekt hoeven te worden indien 'redelijkerwijs aangenomen kan worden dat een behoorlijke rechtsbedeling ook zonder verschaffing van de gevraagde gegevens is gewaarborgd'. Een behoorlijke motivering waarom het inzagerecht moet worden achtergesteld bij andere mogelijke bewijsmiddelen als het getuigenverhoor, is door niemand gegeven. Het tegendeel lijkt eerder het geval; er is volop literatuur over de twijfelachtige betrouwbaarheid van getuigenverklaringen. Veel andere bewijsmiddelen dan bescheiden (waaronder mede worden verstaan op een gegevensdrager aangebrachte gegevens, dus ook geluid- en videoopnames) en getuigen zijn er niet. Niet alleen getuigen, maar ook bescheiden zijn niet zonder meer betrouwbaar; alles kan gemanipuleerd worden, maar in abstracto heb ik toch meer vertrouwen in bescheiden als bewijsmiddel dan in getuigenverklaringen als bewijsmiddel. Lindijer is in nr. 212-213 van mening dat ook indien een partij zich niet beroept op een bepaald stuk, zij toch gehouden kan zijn (een afschrift van) dat stuk in het geding te brengen. ${ }^{30}$ Ook daaruit blijkt niet dat er sprake is van subsidiariteit. Eerder het tegendeel: voor stukken geldt kennelijk een norm die niet geldt voor getuigen: er is tot op vandaag niemand die heeft verdedigd dat indien partij A weet dat getuige $\mathrm{Z}$ zijn stellingen ontkracht, A op de wetenschap van die getuige moet wijzen. Lindijer verdedigt verder terecht dat de eisen van een goede procesorde onder omstandigheden kunnen meebrengen dat een partij in hoger beroep terstond alle beschikbare bescheiden dient over te leggen, of althans gemotiveerd moet stellen waarom bepaalde bescheiden ontbreken, waarmee het mij voorkomt dat het failliet van in elk geval deze zinsnede in lid 4 is uitgesproken. Ook uit een groot deel van onderstaande jurisprudentie kan worden afgeleid dat de rechters geen grote waarde hechten aan deze zinsnede in lid 4.

Linssen lijkt dit bestanddeel wel belangrijk te vinden. Hij is van mening dat nadat aan de bestanddelen van art. 843a lid $1 \mathrm{Rv}$ is getoetst, nog aan dit onderdeel van lid 4 getoetst moet worden. ${ }^{31}$ Hij schrijft verder dat indien de rechter het getuigenbewijs overtuigend oordeelt, de beginselen van een behoorlijke procesorde en het beginsel van equality of arms er niet aan in de weg staan dat de rechter het niet nodig oordeelt te bevelen dat een afschrift van het schriftelijk bewijs wordt

30 Hij verwijst daarbij naar HR 30 januari 1998, NJ 1998, 459 (interforce-Rosier).

31 Ik herhaal hier voor de zekerheid dat uit HR 6 oktober 2006, NJ 2006, 547, Jbpr 2007, 6, m.nt. J.G.A. Linssen, AA 2007, p. 371-374, m.nt. H.B. Krans, Meijer-VOF Gebr. Cornelis volgt dat indien geen verweer wordt gevoerd, de rechter niet ambtshalve dient te beoordelen of aan elk in art. 843a $\mathrm{Rv}$ genoemd vereiste is voldaan. 
verstrekt. Hierbij miskent hij dat de rechter, behoudens in het geval van het zogeheten 'voorshandse oordeel', geen tussenoordelen geeft omtrent de bewijswaardering. Indien na de enquête het geleverde bewijs wordt gewaardeerd, zal er meestal eindvonnis worden gewezen. De rechter zal tot op heden in elk geval niet in een tussenvonnis oordelen dat het bewijs nog onvolkomen is en de bewijsleverende partij in staat stellen om een vordering ex art. $843 \mathrm{a} \mathrm{Rv}$ in te stellen. ${ }^{32}$

Ekelmans vindt dit bestanddeel vooral niet erg praktisch. Iets met stukken bewijzen is immers minder bewerkelijk dan door middel van getuigen. Waar volgens hem uit de jurisprudentie blijkt dat er bij de rechters geen sprake is van grote ontvankelijkheid voor verwijzing naar getuigenverhoren indien een verzoeker inzage vraagt, noemt hij dit een terechte opvatting. ${ }^{33}$

Zoals hiervoor opgemerkt, is er inmiddels de nodige jurisprudentie over de vraag of de vordering tot inzage moet worden afgewezen omdat redelijkerwijs een behoorlijke rechtsbedeling ook zonder verschaffing is gewaarborgd.

Zo zijn er de nodige uitspraken over de vraag of de vordering tot inzage moet worden afgewezen als de andere partij stelt dat een getuigenverhoor tot de mogelijkheden behoort. De antwoorden in de jurisprudentie op deze vraag zijn niet gelijk. Zo overweegt het hof Den Bosch in een zaak waarin 7 jaar daarvoor een onderzoek is geweest dat is neergelegd in een rapport, dat al op grond van dit tijdsverloop een verhoor van getuigen niet meer als substituut kan dienen van terbeschikkingstelling van het rapport. De inhoud van een getuigenverklaring is immers afhankelijk van wat de getuige zich herinnert omtrent hem bekende, uit 1997 daterende feiten, waarbij niet onaannemelijk is dat de betrokken partijen niet alle details zullen hebben onthouden. Daar tegenover staat dat in het rapport die feiten in 1997 zijn vastgelegd en het rapport dus een authentieke bron vormt. Het genuanceerde beeld dat het rapport kan verschaffen, kan niet eenvoudig door het horen van getuigen worden verkregen. ${ }^{34}$ Het lijkt mij dat aldus eigenlijk is geanticipeerd op wat de

32 J.G.A. Linssen onder Hof Den Bosch 27 maart 2003, JBPR 2003, 63.

33 Ekelmans, p. 44-45.

34 Hof Den Bosch 28 september 2004, JOR 2004, 23. Ook zo Rb Amsterdam 13 april 2005, JOR 2005, 142 overwegend waar het bescheid waarvan inzage werd gevorderd dateerde van 20 december 2001, dat het eventueel horen van getuigen geen goed alternatief is gelet op het tijdsverloop. Ook zo Rb Amsterdam 24 januari 2007, AZ7826 en Rb Rotterdam 19 maart 2008, BC9708 en Hof Amsterdam 2 december 2008, BG9050, NJF 2009, 39 en Rb Rotterdam 4 maart 2009, BH5652. Rb Rotterdam 5 april 2006, AV9821 overweegt in een internationale transportzaak waarin bewijs onder meer geleverd kan worden door het horen van zich in Spanje bevindende getuigen, maar de rechtbank ook wordt verzocht om met gebruik van artikel $22 \mathrm{Rv}$ de tegenpartij te bevelen om delen van de opgemaakte expertiserapporten in het geding te brengen, dat de getuigen in Spanje wonen en het voorval zich in Spanje heeft voorgedaan, zodat bewijs niet op eenvoudige wijze anderszins te verkrijgen is en beveelt de tegenpartij om de betreffende stukken in het geding te brengen. Vermoedelijk ook zo Rb Rotterdam 5 december 2007, BC0225, NJF 2008, 95. Rb Rotterdam 1 april 2009, BI1747 oordeelt getuigenverhoor minder zinvol, gelet op de aard van de stukken waarin inzage wordt gevorderd (financiële stukken, berekeningen, enz.). Rb Arnhem 
getuigen zich mogelijk nog herinneren, waarmee een voorbeeld is gegeven van de botsing van deze zinsnede met het prognoseverbod. ${ }^{35}$ Overigens is hier natuurlijk juist sprake van een omgekeerde situatie: het hof neemt aan dat een ander bewijsmiddel, met name getuigen, niet tot een behoorlijke rechtsbedeling zal leiden.

Er wordt echter ook regelmatig overwogen dat een getuigenverhoor mogelijk is, waarna de gevorderde inzage wordt worden afgewezen. Zo onder meer hof Arnhem, ${ }^{36}$ rechtbank Amsterdam, ${ }^{37}$ rechtbank Zutphen, ${ }^{38}$ en rechtbank Assen ${ }^{39}$

22 juli 2009, BJ6230, NJF 2009, 411 oordeelt op een verweer dat een behoorlijke rechtsbedeling ook zonder inzage is gewaarborgd omdat getuigen gehoord kunnen worden dat dit veel tijd in beslag neemt en getuigen niet altijd even betrouwbaar en volledig zijn als de schriftelijke informatie. Verder kunnen getuigenverhoren nauwelijks 'minder bezwaarlijk' worden genoemd in vergelijking tot inzage in bescheiden. Deskundigenonderzoeken zijn kostbaar en tijdrovend zodat het uit het oogpunt van een goede procesorde in beginsel de voorkeur verdient om -indien het bewijs ook door middel van inzage in bescheiden kan worden geleverd- zo'n deskundigenonderzoek te voorkomen. Anders Rb Breda 25 oktober 2006, AZ1374 die nadat met succes bewijsbeslag is gelegd omdat eiser stelt dat de beslagene inbreuk makt op aan eiser in eigendom toebehorende intellectuele en industriële eigendom op een vordering tot inzage in die bescheiden (in elk geval papieren en digitaal vastgelegde administratie) overweegt dat het bewijs van een dergelijke onrechtmatige verkoop redelijkerwijs ook langs andere weg kan worden verkregen, waarbij de rechtbank vooral denkt aan het deskundigenbericht. Rb Utrecht 9 april 2008, BC9990 is van oordeel dat inzage in de door eiser genoemde jaarrekeningen en statuten ook bij de Kamer van Koophandel kan worden verkregen en wijst de vordering af omdat redelijkerwijs van eiser kan worden gevergd dat hij die openbare weg afloopt.

35 Zie over dit prognoseverbod onder meer AG Verkade bij HR 9 juli 2004, NJ 2005, 270 en AG Wesseling-van Gent bij HR 29 januari 2010, BK2007 die in nr. 2.28 schrijft dat waar het hof slechts in zijn algemeenheid heeft overwogen dat resultaten en betrouwbaarheid van een getuigenverhoor alleen al door het tijdsverloop kunnen afwijken van aantekeningen van de griffier gemaakt tijdens een arbitragezitting, dit oordeel neerkomt op een (verboden) bewijsprognose.

36 Hof Arnhem 17 april 2007, NJF 2007, 391.

37 Rb Amsterdam 2 februari 2005, AT1558, JOR 2005, 71 overwegende dat het bewijs van het bestaan en/of de inhoud van de bedoelde lijst door verzoeker redelijkerwijs ook langs andere weg kan worden verkregen.

38 Rb Zutphen 23 januari 2008, BC2626 en Rb Zutphen 20 augustus 2008, JAR 2008, 255 afwijzend een vordering van een werknemer tot inzage in de gespreksverslagen op grond waarvan hij wordt overgeplaatst, omdat de werknemer met het oog op een eventuele procedure tegen zijn werkgever een verzoek kan indienen tot het houden van een voorlopig getuigenverhoor, in welk kader hij de collega's die de verklaringen hebben afgelegd kan doen horen. Ook kan hij niet gehoorde collega's als getuigen laten horen. De werknemer had al inzage gehad in het rapport dat mede aan de hand van die verslagen was opgemaakt.

$39 \mathrm{Rb}$ Assen 29 oktober 2008, te kennen uit Hof Leeuwarden 4 augustus 2009, BJ4901, welke rechtbank nadat gebruik is gemaakt van het verlof om bewijsbeslag te mogen leggen en vervolgens inzage daarin wordt gevorderd, de vordering afwijst omdat de beslaglegger ook een voorlopig getuigenverhoor heeft geëntameerd, zodat het mogelijk is om de benodigde informatie ook op andere wijze te verkrijgen en het, aldus de rechtbank, '...niet aannemelijk ...(is) geworden dat inzage in de in beslag genomen gegevens noodzakelijk is om een behoorlijke rechtsbedeling te waarborgen.' 
Het lijkt erop dat als de bewijslast op de andere partij rust, of als het antwoord op de vraag wie bewijs moet leveren nog niet duidelijk is, de vordering tot inzage wordt afgewezen. Hierbij wordt, vooral impliciet, waarschijnlijk aansluiting gezocht bij het criterium dat een behoorlijke rechtspleging ook zonder verschaffing van de gevraagde gegevens is gewaarborgd. Aldus vermoedelijk de rechtbank Rotterdam ${ }^{40}$ rechtbank Den Bosch, ${ }^{41}$ hof Den Haag ${ }^{42}$ en rechtbank Utrecht. ${ }^{43}$

Het verweer van een verkoper van appartementen die de bouwtekeningen bezit waarvan inzage wordt gevorderd, inhoudende dat die tekeningen ook bij de afdeling Bouw en Woningtoezicht van de gemeente ter inzage liggen, wordt gepasseerd omdat ook de verkoper er belang bij heeft dat er duidelijkheid komt omtrent de gestelde gebreken zodat het in strijd is met hetgeen de verkoper maatschappelijk betaamt om zich thans als het ware te verschuilen achter de mededeling dat bepaalde stukken openbaar zijn. De rechtbank stelt verder dat deze proceshouding het bereiken van een oplossing onnodig bemoeilijkt. ${ }^{44}$

Het is goed mogelijk dat meerdere partijen de stukken waarvan inzage wordt gevorderd, bezitten. Art. 843a Rv kent geen regel welke partij in zo'n geval als eerste moet worden aangesproken. Ik ben van mening dat in zo'n geval elke persoon die de informatie bezit, kan worden aangesproken om inzage te verschaffen, en wel des dat als de ene persoon inzage heeft gegeven, de andere van deze plicht is bevrijd. Er is sprake van nevenschikkendheid. De rechtbank Amsterdam overweegt in zo'n geval waarbij enkele banken de informatie hebben, maar de curator in het faillissement van het bedrijf KPNQwest ook, dat de keuze van eiseres om de inzagevordering tegen de banken in te stellen begrijpelijk is en niet onredelijk. Het feit dat A, de partij die inzage vordert, voordat hij die inzagevordering instelde al wist dat de banken hun gepretendeerde vordering op A al hadden overgedragen maakt dit niet anders. ${ }^{45}$

Het is niet altijd duidelijk of een gerecht een eigen criterium hanteert of slordig formuleert. De rechtbank Amsterdam oordeelt bijvoorbeeld dat het bij de toepassing

Rb Rotterdam 7 maart 2007, BA0914, ook oordelend dat indien een eiser inzage wenst omdat hij denkt dat de wederpartij in strijd met de inhoud van de overeenkomst factureert en bang is óf aan het eind van de rit te weinig te hebben betaald met als gevolg betaling van hoge wettelijke rente óf teveel te hebben betaald en dan te blijven zitten met een vordering tot terugbetaling op een niet solvabele debiteur, dit geen risico is waarin sprake is van een situatie waarin een behoorlijke rechtspleging zonder verschaffing van de gevraagde stukken niet is gewaarborgd en Rb Rotterdam 10 juni 2009, BJ8968.

41 Rb Den Bosch 22 maart 2007, BA1352, NJF 2007, 213.

42 Hof Den Haag 9 oktober 2007, BB6971.

43 Rb Utrecht 15 oktober 2008, BG4385.

$44 \mathrm{Rb}$ Alkmaar 30 augustus 2007, BB2608.

45 Rb Amsterdam 11 september 2008, BF0587. 
van art. 843a Rv moet gaan om bepaalde bescheiden waarin informatie is vervat die eiser niet op een andere manier kan verkrijgen. ${ }^{46}$ Deze formulering lijkt in te houden dat de rechtbank van oordeel is dat een vordering alleen maar kan worden toegewezen als de informatie op geen enkele andere manier is te verkrijgen. Aldus legt het een maatstaf aan die niet overeenkomt met de woorden in de Memorie van Toelichting. Die houden namelijk wat dit betreft in dat een vordering kan worden afgewezen indien aangenomen kan worden dat het bewijs van de betreffende feiten redelijkerwijs langs andere weg, bijvoorbeeld door het horen van getuigen, kan worden verkregen. ${ }^{47}$

Het lijkt mij dat aan de hand van de literatuur en de vele uitspraken, inmiddels verdedigd kan worden dat dit bestanddeel van lid 4 niet zeer zwaar (meer) weegt. Het behoort in elk geval in het belang van het op een redelijk eenvoudige en snelle manier vinden van de waarheid niet zwaar te wegen. Voor de volledigheid vermeld ik nog dat Vranken in zijn noot onder het Observatiearrest ${ }^{48}$ schrijft dat de afwijzende beslissing van het hof en de Hoge Raad in die zaak wellicht steunt op een analogie met dit bestanddeel uit lid 4 van art. 843a Rv en daar in elk geval mee spoort. Ik vind dat te speculatief, zeker omdat dit lid pas is in werking is getreden op 1 januari 2002 en het arrest van het hof op 18 mei 2000 is gewezen.

Tot slot: op grond van de hoofdregel van art. $150 \mathrm{Rv}$ rust de stelplicht en bewijslast van de aanwezigheid van dit bestanddeel op de partij die ter motivering van de weigering van de gevorderde inzage hierop een beroep doet.

Rb Amsterdam 24 augustus 2005, AU4935. Uit Rb Zutphen 23 januari 2008, BC2626 (kort geding) blijkt dat de bodemrechter, aldus de voorzieningenrechter, een verzoek van een partij tot exhibitie van stukken bij de tegenpartij heeft afgewezen omdat exhibitie niet noodzakelijk is voor de onderbouwing van haar vorderingsrecht omdat de vorderende partij heeft aangeboden bewijs te leveren van haar stellingen onder meer door het doen horen van klanten als getuigen. Met het woord 'noodzaak' is een zwaarder toetsingscriterium aangelegd dan dit lid geeft. Rb Middelburg 7 mei 2008, BD3047 oordeelt op een vordering tot afschriften van, althans inzage in, correspondentie dat nu de tegenpartij heeft aangevoerd vooralsnog niet te beschikken over dit bewijsmateriaal dat het mogelijke verweer van die tegenpartij zou ondersteunen (de tegenpartij heeft in de hoofdzaak nog niet geantwoord), inzage of afschrift onnodig is voor een behoorlijke rechtsbedeling. De Hoge Raad zou overwegen dat het gelet op het woordgebruik onduidelijk is of de rechtbank het juiste criterium heeft aangelegd. Zie onder meer HR 9 januari 1998, NJ 1998, 363 waarin de rechtbank Zutphen in hoger beroep ten onrechte dacht met de woorden 'in strijd met de redelijkheid en billijkheid' het criterium van art. 6:248 lid 2 BW (in de gegeven omstandigheden naar maatstaven van redelijkheid en billijkheid onaanvaardbaar) gevangen te hebben. De rechtbank Roermond dacht, eveneens ten onrechte, met de woorden 'niet redelijk' dit criterium te hebben gevangen (HR 25 februari 2000, NJ 2000, 471). Voor de volledigheid: het criterium voor afwijzing is immers niet of inzage 'onnodig is voor een behoorlijke rechtsbedeling', maar 'of redelijkerwijs aangenomen kan worden dat een behoorlijke rechtsbedeling ook zonder verschaffing van de gegevens is gewaarborgd'.

47 Parl. Gesch. burgerlijk procesrecht p. 553.

48 HR 31 mei 2002, NJ 2003, 589. Zie daarover uitgebreid par. 7.1.1. 


\section{Inzage en disclosure in de Nederlandse Antillen en Aruba}

Het op 1 augustus 2005 in werking getreden art. 843a in de Wetboeken van Burgerlijke Rechtsvordering in de Nederlandse Antillen en Aruba (hierna in enkelvoud Rv-NA\&A te noemen) is niet helemaal gelijkluidend aan art. 843a Rv in Nederland. De Antilliaanse en Arubaanse tekst luidt als volgt:

1. Hij die daarbij rechtmatig belang heeft, kan op zijn kosten inzage, afschrift of uittreksel vorderen van bepaalde bescheiden of andere gegevensdragers aangaande een rechtsbetrekking waarin hij of zijn rechtsvoorgangers partij zijn, van degene die deze bescheiden of andere gegevensdragers te zijner beschikking of onder zijn berusting heeft.

2. De rechter bepaalt, zo nodig, de wijze waarop en de voorwaarden waaronder inzage, afschrift of uittreksel zal worden verschaft.

3. Hij die uit hoofde van zijn ambt, beroep of betrekking tot geheimhouding verplicht is, is niet gehouden aan deze vordering te voldoen, indien de bescheiden of andere gegevensdragers uitsluitend uit dien hoofde te zijner beschikking staan of onder zijn berusting zijn.

4. Degene die de bescheiden of andere gegevensdragers te zijner beschikking of onder zijn berusting heeft, is niet gehouden aan deze vordering te voldoen, indien daarvoor gewichtige redenen zijn, alsmede indien redelijkerwijs aangenomen kan worden dat een behoorlijke rechtsbedeling ook zonder verschaffing van de gevraagde gegevens is gewaarborgd.

De tekstuele verschillen zijn minimaal: in Nederland worden 'op een gegevensdrager aangebrachte gegevens' geacht tevens bescheiden te zijn; in de Nederlandse Antillen en Aruba is een 'gegevensdrager' een zelfstandige bron en is geen onderscheid gemaakt tussen gegevens op de gegevensdrager en de gegevensdrager zelf. In Nederland kan de rechter op grond van lid 2 alleen de wijze waarop de inzage moet worden verschaft bepalen; in de Nederlandse Antillen en Aruba kan de rechter daarnaast nog 'de voorwaarden waaronder de inzage wordt verschaft' bepalen.

Bij de bespreking van art. 843a Rv-NA\&A moet worden vermeld dat in die twee landen sinds 1 augustus 2005 nog twee andere artikelen bestaan waarin de overlegging van stukken wordt geregeld en wel de artt. 141 en 142 Rv-NA\&A. De artikelen in beide landen zijn, met uitzondering van lid 1 van art. 141, gelijkluidend. 
Art. 141 lid 1 Rv-NA luidt als volgt:

1. De rechter kan in de loop van een geding, op verzoek of ambtshalve, aan partijen of aan een van hen de overlegging bevelen van onder hen berustende boeken, bescheiden en andere gegevensdragers of voorwerpen.

Art. 141 lid 1 Rv-A luidt als volgt:

De rechter kan in de loop van een geding, op verzoek of ambtshalve, aan partijen of aan een van hen de overlegging bevelen van de boeken, bescheiden en andere gegevensdragers, die zij ingevolge de wet moeten houden, maken of bewaren.

De leden 2 en 3 van art. 141 in beide landen luiden als volgt:

2. Partijen kunnen dit weigeren indien daarvoor gewichtige redenen zijn, alsmede indien redelijkerwijs aangenomen kan worden dat een behoorlijke rechtsbedeling ook zonder verschaffing van de gevraagde gegevens is gewaarborgd.

3. De rechter beslist of die weigering gerechtvaardigd is, bij gebreke waarvan hij daaruit de gevolgtrekking kan maken die hij geraden acht.

Art. 142 in beide landen luidt als volgt:

1. De rechter kan op verzoek van een der partijen aan anderen dan partijen, na deze te hebben gehoord of daartoe de gelegenheid te hebben gegeven, bevelen binnen een door de rechter te stellen termijn schriftelijk inlichtingen te verschaffen en onder hen berustende boeken, bescheiden, andere gegevensdragers of voorwerpen over te leggen. Degene tot wie de rechter het bevel richt, is verplicht tot het verschaffen van de gevraagde inlichtingen en het overleggen van de gevraagde boeken, bescheiden, andere gegevensdragers of voorwerpen.

2. De rechter bepaalt, zo nodig, de wijze waarop, en de voorwaarden waaronder de inlichtingen zullen worden verschaft, dan wel de boeken, bescheiden, andere gegevensdragers of voorwerpen zullen worden overgelegd.

3. De rechter wijst het verzoek in elk geval af indien redelijkerwijs aangenomen kan worden dat een behoorlijke rechtsbedeling ook zonder verschaffing der gegevens is gewaarborgd.

4. Het in artikel 144 omtrent het verschoningsrecht van getuigen bepaalde is van overeenkomstige toepassing, maar ook andere gewichtige redenen, waaronder een gevaar voor onevenredige schade aan zijn belangen of die van derden, kunnen een weigering rechtvaardigen.

5. Tegen een afwijzing van het verzoek staat geen hogere voorziening open.

6. Heeft de rechter het bevel gegeven, dan zijn de artikelen 152 en 152a van overeenkomstige toepassing.

Art.141Rv was in beide landen neergelegd in de artt. 6 en $7 \mathrm{Kh}$, waarbij de regeling in de Nederlandse Antillen bij de overplaatsing naar het Wetboek van Burgerlijke Rechtsvordering iets is verruimd. Art.142 NA\&A kent geen voorganger. De inhoud 
van art. 843a Rv-NA\&A was min of meer wel bekend en neergelegd in art. 1904 en 1905 BW-NA\&A. Deze artikelen in dit BW waren bijna gelijkluidend aan de hiervoor in par. 2.1.3 genoemde art. 1922 en $1923 \mathrm{BW} .{ }^{1}$

Zeker bij de invoering van art. $142 \mathrm{Rv}-\mathrm{NA} \& \mathrm{~A}$ is niet over een nacht ijs gegaan. De eerste ontwerper van de vernieuwingen in Rechtsvordering in de twee Caribische landen, prof. mr. J. de Boer, heeft namelijk in 1996 over dit artikel gecorrespondeerd met prof. mr. W.D.H. Asser. In die correspondentie ontraadt Asser invoering van een dergelijk artikel. ${ }^{2}$ Hij geeft hiervoor meerdere redenen. Ten eerste ziet hij geen rechtsgrond. De civiele rechter staat volgens hem namelijk wel in een rechtsverhouding tot de procederende partijen, maar in het algemeen niet in een rechtsverhouding ten aanzien van derden. Een civiele uitspraak is volgens hem vooral ten behoeve van de procespartijen en niet ten behoeve van de niet bij die procedure betrokken gemeenschap, zodat willekeurige derden niet zomaar verplichtingen opgelegd kunnen worden. Hij vindt verder dat het artikel zich systematisch niet laat plaatsen. Het lijkt op de dwanguitgiften van akten, maar niet voldoende om het daar onder te brengen. Hij merkt verder op dat het onduidelijk is waarom de rechter ambtshalve dat verzoek zou kunnen doen. Ik concludeer uit die opmerking dat de tekst van het ontwerp in elk geval wat dat punt betreft is aangepast. Onder de huidige regeling dient immers een partij dit verzoek te doen. Asser wijst er verder op dat ook getuigen niet gedwongen kunnen worden om bescheiden aan de rechter af te geven. Hij wijst hierbij op het hiervoor in de paragrafen 3.3 en 8.4 al genoemde arrest HR 11 maart 1994, NJ 1995, 3 (waarin hij zelf als AG concludeerde). Kortom, Asser zag in 1996 alleen maar beren, hele grote zelfs, op de weg naar de waarheidsvinding bij een door de rechter te geven bevel aan anderen dan de procespartijen om schriftelijk inlichtingen te verschaffen en onder hen berustende boeken, bescheiden, andere gegevensdragers of voorwerpen over te leggen. Dezelfde Asser (samen met Vranken en Groen) laat tien jaar later in het rapport Uitgebalanceerd een ander geluid horen. Op p. 71 staat in par. 6.5.3.2, Disclosure of documents, het volgende:

'Naar aanleiding van wat hiervoor is gezegd in verband met de voorlopige bewijsmaatregelen en de wens van de Raad voor de Rechtspraak de toegang daartoe te beperken, willen wij beklemtonen dat het juist van belang is dat partijen over en weer en zo nodig ook ten opzichte van derden aanspraak kunnen maken op de informatie die nodig is om het proces goed voor te bereiden, te voeren en eventueel na een feitelijke goed

1 Zie over de vernieuwingen in de Wetboeken van Burgerlijke Rechtsvordering in beide Caribische landen J. de Boer, Burgerlijke Rechtsvordering in de West, NJB 2005, p. 1980-1984. Zie ook Hugenholz/Heemskerk/Groefsema, Hoofdlijnen van het burgerlijk procesrecht van de Nederlandse Antillen en Aruba, 2009, Elsevier Juridisch Amsterdam. In nummer 122, bewijs door derden, wordt art. $142 \mathrm{Rv}-\mathrm{NA} \& A$ kort besproken, in nummer 201 wordt melding gemaakt van art. 843a RvNA\&A.

2 Brief van Prof. Mr W.D.H. Asser aan prof. Mr J. de Boer, p.a. Gemeenschappelijk Hof van Justitie van de NA en Aruba van 5 juli 1996. 
gefundeerde inschatting van een toekomstige procespositie te voorkomen. ... Uiteraard moeten de sluizen niet worden opengezet naar kostbare bewijsverrichtingen en moet een excessieve 'frontloading of costs' worden voorkomen. ... De vraag is actueel of ons procesrecht niet beter geëquipeerd dient te zijn ten aanzien van de gedwongen 'disclosure of documents'. Dit houdt in dat een partij of een derde verplicht is ten aanzien van bepaalde stukken die 'disclosable' zijn mee te delen dat hij ze in bezit heeft, wat als gevolg heeft dat de partij ten opzichte van wie de disclosure plaatsvindt het recht heeft de betrokken documenten in te zien.'

De bezwaren die Asser in 1996 zag, zijn niet gezien door de Commissie Ontwerp Wetboek van Burgerlijke Rechtsvordering, ingesteld door de Algemene Ledenvergadering van de Orde van Advocaten op Curaçao. De Commissie maakt namelijk geen opmerkingen over het ontwerp van art. 142 noch over art. 843a. Ook de Arubaanse Orde van Advocaten maakt geen op- of aanmerkingen. De Memorie van Toelichting, aangeboden aan de Staten van de Nederlandse Antillen, Zitting 2002-2003, vermeldt bij art. 142 het volgende:

'In dit artikel - dat in Nederland ontbreekt - wordt, in het belang van de waarheidsvinding, de mogelijkheid geopend dat de rechter, op verzoek, derden beveelt inlichtingen te geven dan wel stukken of voorwerpen over te leggen. Vooral aan de verplichte overlegging van stukken ('disclosure of documents') bestaat in de praktijk behoefte. De mogelijkheid van (voorlopig) getuigenverhoor komt aan deze behoefte slechts ten dele tegemoet. In het huidige recht is immers een getuige wel verplicht mee te delen wat in bepaalde documenten staat, maar hij kan niet verplicht worden om die documenten over te leggen (vergelijk HR 11-3-1994, NJ 1995, 3, r.o. 3.4, met noot van H.J. Snijders onder 4.) De bepaling is in hoofdlijnen ontleend aan artikel 29, eerste lid, van het ontwerp Landsverordening administratieve rechtspraak. ${ }^{3}$ Het gaat hier om een discretionaire bevoegdheid van de rechter. Verwacht mag worden dat de rechter deze bevoegdheid met omzichtigheid hanteert. De derde kan gewichtige redenen hebben om de stukken of voorwerpen niet over te leggen, ook al zijn zij nodig voor een behoorlijke rechtspleging. De rechter dient te beoordelen of de aangevoerde redenen de weigering kunnen rechtvaardigen. De verschoningsgronden van artikel 144 leveren in elk geval een gewichtige reden op, maar de te honoreren gewichtige redenen zijn daartoe niet beperkt; men denke aan het recht op eerbiediging van de persoonlijke levenssfeer. Ook bij twijfel kan -nu het hier een discretionaire bevoegdheid betreft- de rechter na weging der betrokken belangen ervan afzien om de derde tot overlegging te verplichten. Daar-

3 Zie J. de Boer, Burgerlijke Rechtsvordering in de West, NJB 2005, p. 1982. Art. 29 lid 1 van de op 1 december 2001 ingevoerde Lar luidt als volgt: Het Gerecht kan de indiener van het beroepschrift, de andere partijen en andere natuurlijke personen of privaatrechtelijke rechtspersonen verzoeken binnen een door het Gerecht te stellen termijn schriftelijke inlichtingen te verschaffen en onder hen berustende of te hunner beschikking staande stukken over te leggen. Degene aan wie het Gerecht het verzoek richt, is verplicht tot het verschaffen van de gevraagde inlichtingen en het overleggen van de gevraagde stukken. Zie ook art. 8:45 lid 1 AWB:'De rechtbank kan partijen en anderen verzoeken binnen een door haar te bepalen termijn schriftelijk inlichtingen te geven en onder hen berustende stukken in te zenden. 
tegen staat geen hogere voorziening open (vijfde lid). In verband met hoger beroep, indien het bevel is gegeven, zij opgemerkt dat de beslissing van de rechter een incidenteel vonnis is en dat de derde wiens bezwaren door de rechter ontoereikend zijn geoordeeld, partij in het incident is geworden. Wenst de derde tussentijds hoger beroep in te stellen, dan zal, ingevolge artikel 263a, wel verlof van het Hof van Justitie nodig zijn; het verzoek om verlof heeft echter schorsende werking (artikel 263a, vierde en vijfde lid). Weigert de rechter het bevel te geven, dan is daartegen, zoals al opgemerkt, ingevolge het vierde lid van het onderhavige artikel 142 geen hogere voorziening toegelaten. ${ }^{4}$... Bovendien wordt het opzettelijk of wederrechtelijk weigeren van de gevraagde medewerking, bedoeld in artikel 142, eerste lid, strafrechtelijk bedreigd in het nieuwe tweede lid van artikel 198 van het Wetboek van Strafrecht..$^{5}$ In artikel 142, tweede lid, is bepaald dat de rechter zo nodig de wijze van en de voorwaarden voor de 'disclosure' bepaalt. Men denke aan een beperkte inzage of voorinzage, alsmede aan een kostenvergoeding. ${ }^{6}$

Het lijkt niet te gewaagd om te veronderstellen dat de geringe oppositie in de Nederlandse Antillen en Aruba bij het ontwerp van de artt. 141 en 142 Rv te maken heeft met het bestaan van art. 118 Rv-NA\&A Dit sinds 1919 bestaande artikel luidt als volgt:

De rechter in eerste aanleg is bevoegd om, indien hij dit voor de goede en geregelde gang van zaken nodig acht, partijen bij de behandeling van de zaak de nodige voorlichting te geven, hen te ondervragen en zelfs opmerkzaam te maken op de rechts- en bewijsmiddelen, die zij kunnen aanwenden. ${ }^{7}$

Het artikel, door Lewin het paradepaardje van de rechterlijke vrijheid genoemd, ${ }^{8}$ wordt, zeker in eerste aanleg, met enige regelmaat gebruikt en partijen (in elk geval hun raadslieden) zijn min of meer gewend aan meedenkende (en soms zelfs meeprocederende) rechters die het vinden van de materiële waarheid hoog in het vaandel hebben. Juist gelet op dit art. 118 ligt het niet in de lijn der verwachting dat de rechter de regel van art. 142 niet ambtshalve mag toepassen, zoals het eerste ontwerp kennelijk nog wel bepaalde. De toelichting op art. 843a is heel kort:

4 Zie ook HR 30 januari 2004, NJ 2005, 455, m.nt. D.A.

5 Het tweede lid van dit artikel $198 \mathrm{Sr}$ (lid 1 betreft kort gezegd het niet voldoen aan de wettelijke getuigplicht) luidt nu: Met dezelfde straf als genoemd in het eerste lid, onder $2^{\circ}$, wordt degene bedreigd die opzettelijk of wederrechtelijk weigert de gevraagde medewerking, bedoeld in artikel 142, eerste lid, van het Wetboek van Burgerlijke Rechtsvordering, te verlenen.

6 De memorie van toelichting is abuis waar deze vermeldt dat de derde bij een toewijzende beslissing toestemming van het Hof nodig heeft om in hoger beroep te komen. Ten aanzien van hem is deze toewijzing immers een einduitspraak. Deze derde dient dezelfde rechten te hebben als bijvoorbeeld een getuige heeft wiens beroep op verschoning is verworpen en die getuige heeft geen toestemming van het Hof nodig om in hoger beroep te komen. Zo ook Lewin, par. 3.7, Tussentijds hoger beroep.

7 Art. $280 \mathrm{Rv}-\mathrm{NA} \& \mathrm{~A}$ bepaalt dat onder andere dit art. $118 \mathrm{Rv}$ ook in hoger beroep van toepassing is.

8 G.C.C. Lewin, Kroniek burgerlijk procesrecht van de Nederlandse Antillen en Aruba, TCR 2009, p. 89. 
'Artikel 843a correspondeert met de artikelen 1904 en 1905 uit het huidige vierde boek van het BW (van bewijs en verjaring), welk boek is komen te vervallen. De bepaling is echter uitgebreid tot alle bescheiden en andere gegevensdragers. Ook zijn de weigeringsgronden uitgewerkt.'

De parlementaire geschiedenis is verder stil over beide artikelen. Dat is wat merkwaardig. Art. 142 is een ingrijpende vernieuwing, die eigenlijk min of meer uit de lucht is gevallen. In de Antilliaanse noch in de Arubaanse literatuur heb ik enig verlangen naar een dergelijk recht kunnen vinden. Ik heb evenmin jurisprudentie kunnen vinden die een aanleiding kan hebben gevormd om tot een recht te komen als thans is verwoord in art. $142 \mathrm{Rv}-\mathrm{NA} \& \mathrm{~A}$. Een toelichting had verder kunnen verduidelijken hoe de verhouding tussen beide artikelen is.

Ik begin met hetgeen (min of meer) gelijk is geregeld in beide artikelen. Lid 2 van art. 843a Rv-NA\&A is letterlijk gelijk aan lid 2 van art. 142 Rv-NA\&A. Lid 3 van art. 843a Rv-NA\&A kent hetzelfde verschoningsrecht als lid 4 van art. 142 Rv-NA\&A. Het is jammer dat deze leden niet letterlijk gelijkluidend zijn gemaakt. De regeling van lid 4 van art. 843a Rv-NA\&A wordt gedeeltelijk teruggevonden in de leden 3 en 4 van art. 142 Rv-NA\&A. Ook hier is het jammer dat de leden niet zo veel mogelijk letterlijk gelijk zijn gemaakt. De plaatsing van de woorden 'andere gewichtige redenen' in lid 3, waar ook het verschoningsrecht is genoemd, laat nu ruimte voor de vraag of met 'gewichtige redenen' in dit lid 3 van art. 142 Rv-NA\&A misschien iets minder zwaarwichtige redenen worden bedoeld dan de 'gewichtige redenen' zoals genoemd in art. 843a lid 4 Rv-NA\&A.

Opvallend is dat in lid 1 van art. $142 \mathrm{Rv}-\mathrm{NA} \& \mathrm{~A}$ geen enkel in art. 843a RvNA\&A genoemd bestanddeel voorkomt. Het lijkt erop dat een verzoeker wat dat betreft, behoudens de beperkingen van art. 142 Rv-NA\&A leden 2 tot en met 4, geen enkele beperking voor de voeten kan worden geworpen. Een verzoek zoals gedaan door NI c.s. aan de $\mathrm{ABN}^{9}$ zal in elk geval op grond van dit art. $142 \mathrm{Rv}$ NA\&A zonder meer moeten worden toegewezen. Art. 142 Rv-NA\&A kent immers niet het bestanddeel 'rechtsbetrekking'. Het vereiste dat het bij dit artikel om 'bepaalde bescheiden' moet gaan, wordt evenmin gesteld. Het geeft dus, naar niet bij de procedure betrokken derden toe, een zeer ruim recht op inzage.

Het lijkt erop dat art. 843a Rv, 141 en $142 \mathrm{Rv}-\mathrm{NA} \& A$ niet meteen in de juridische praktijk zijn ingedaald. Jurisprudentie is schaars en in een op 11 juni 2009 door het Hof gehouden comparitie in zaak AR 68/05-H-329/06 maakte het Hof op de voet van art. $118 \mathrm{Rv}-\mathrm{NA} \& \mathrm{~A}$ de advocaat van de appellanten attent op het bestaan van art. $142 \mathrm{Rv}$.

Ik heb de volgende jurisprudentie gevonden. In zaak ARnr 129/2005 is Martina door zijn werkgeefster Banco di Caribe $(\mathrm{BdC})$ op staande voet ontslagen omdat hij op 10 oktober 2005 niet op het werk is verschenen. Martina zegt dat hij op 
vakantie was in Nederland en op 9 oktober 2005, de dag van zijn geplande terugreis, te ziek was om te reizen. Tijdens de mondelinge behandeling stemmen partijen in met toepassing van art. $142 \mathrm{Rv}$, voor zover dit artikel de mogelijkheid biedt om derden te bevelen schriftelijke inlichtingen te verschaffen. Het gerecht beveelt vervolgens de huisarts in Nederland tot wie Martina zich had gewend toen hij in oktober 2005 in Nederland was, om antwoord te geven op een aantal vragen, waaronder de vraag wanneer de huisarts Martina op consult heeft gehad, of de huisarts Martina heeft afgeraden om naar Curaçao terug te vliegen en of de ontlasting van Martina inderdaad is onderzocht, en, zo ja, wat de uitslag daarvan is geweest. Bij deze vragen van het gerecht wordt een bericht gevoegd van Martina, waarin Martina de arts ontslaat uit zijn geheimhoudingsplicht. ${ }^{10}$

In de zaak Lubbers-Maduro \& Partners NV zijn de procespartijen het eens geworden dat het Gerecht krachtens art. $142 \mathrm{Rv}$ nadere inlichtingen zal vragen aan Fatum (een verzekeringsmaatschappij). Het Gerecht stelt vervolgens negen vragen betrekking hebbend op de inhoud van een eventuele pensioenverzekering die de werkgever Maduro \& Partners NV voor onder andere haar werknemer Lubbers bij Fatum zou hebben gesloten. ${ }^{11}$

Buleen Holding Inc (hierna Buleen) stelt een bankrekening te hebben bij de Banco Provincial Overseas NV (hierna Banco) en vordert betaling van het saldo, $\$ 1.700 .000$,- althans de som die thans op de rekening staat. In het bij inleidend verzoekschrift (de Nederlandse Antillen en Aruba kennen geen dagvaardingsprocedure) ingestelde incident verzoekt zij het Gerecht Banco te bevelen om over te leggen 'alle stukken, bescheiden, gegevens en gegevensdragers die Banco onder zich heeft, althans behoort te hebben althans kan hebben inzake Buleen'. Het Gerecht wijst de vordering af omdat niet gezegd kan worden dat zonder de verlangde stukken geen behoorlijke rechtsbedeling kan plaatsvinden. Daar komt bij, aldus het Gerecht, dat de omschrijving van de verlangde stukken veel te ruim is. ${ }^{12}$

In een scheiding- en delingsprocedure tussen twee voormalige echtgenoten die in algehele gemeenschap waren getrouwd, beveelt het Gerecht op verzoek van de vrouw de Banco di Caribe op de voet van art. $142 \mathrm{Rv}$ om schriftelijk inlichtingen te verschaffen en bescheiden over te leggen met betrekking tot de vraag wat de

10 Gerecht in eerste aanleg van de Nederlandse Antillen, zittingsplaats Curaçao 19 december 2005 (ik zal hierna nog slechts vermelden 'GEA' en de zittingsplaats). Uit de vervolgbeschikking van 28 april 2006 (maar nu genummerd EJ 52A/2005) blijkt dat de huisarts in Nederland de vragen heeft beantwoord. Uit die antwoorden blijkt dat Martina niet volledig heeft verklaard tijdens de zitting bij het Gerecht, waaruit het Gerecht de gevolgtrekking maakt dat het verzoek van de werknemer moet worden afgewezen en zijn ontslag op staande voet terecht is geweest.

11 GEA Curaçao 22 maart 2006, ARnr. 1056/2001. De antwoorden komen en partijen mogen daarop reageren. Partijen doen dat ook, waarbij een partij zijn reactie 'conclusie na deskundigenbericht' noemt. In het daarop volgende vonnis van het Gerecht van 29 januari 2007, vermeldt het Gerecht zelf dat het bij tussenvonnis van 22 maart 2006 gevraagde deskundigenbericht is uitgebracht.

12 GEA Curaçao 18 december 2005, ARnr. 1453/2005. 
eindopbrengst was van de door de man bij de Banco di Caribe aangehouden investeringsrekening en wat er met de opbrengst is gebeurd. ${ }^{13}$

Het Gerecht op Sint Maarten beveelt in een scheiding- en delingsprocedure tussen twee voormalige echtgenoten die in algehele gemeenschap waren gehuwd, eigenlijk ambtshalve en zonder vermelding van enige rechtsgrond, de man om binnen 1 maand na betekening van het vonnis aan de vrouw schriftelijk een deugdelijke en met bewijsstukken onderbouwde verantwoording af te leggen omtrent de vervreemding van bepaalde aandelen onder verbeurte van een dwangsom van $\$$ $10.000,-$ per dag. ${ }^{14}$

Notaris X maakt een akte van levering op waarin A hypotheek op zijn woning geeft aan de Chase Manhattan Bank. Achteraf blijkt dat de woning de echtelijke woning betreft en dat de echtgenote van A geen toestemming heeft gegeven voor deze hypotheekverlening. De hypotheekverlening wordt vernietigd en de Bank spreekt $\mathrm{X}$ aan voor de door die vernietiging ontstane schade. $\mathrm{X}$ stelt, voor zover van belang, dat de Bank hoogstwaarschijnlijk geen schade zal lijden. De leningsovereenkomst met A is namelijk geldig, de hypotheek is weliswaar nietig, maar de Bank kan de woning als niet bevoorrecht crediteur executeren. Er is weliswaar beweerdelijk een wel bevoorrechte crediteur, en wel de Eilandsontvanger, maar de vordering(en) van die Ontvanger is/zijn om verschillende redenen, waaronder verjaring, niet (meer) inbaar. Om die laatste stelling te onderbouwen, verzoekt $X$ het Hof om art. $142 \mathrm{Rv}$ toe te passen en de Eilandsontvanger in het geding te roepen, hem te horen en te bevelen bepaalde inlichtingen te verschaffen en stukken over te leggen. Het Hof overweegt dat art. $142 \mathrm{Rv}$ de rechter een ruime discretionaire bevoegdheid geeft, waarvan het Hof vooralsnog onvoldoende aanleiding ziet om daarvan gebruik te maken. Meer voor de hand ligt, aldus het Hof, dat de Bank tracht tot executoriale verkoop te komen. ${ }^{15}$

De enige conclusie die ik uit dit kleine aantal uitspraken durf te trekken is dat er in de Nederlandse Antillen en Aruba nog weinig gebruik wordt gemaakt van het recht op inzage of disclosure. Er kan zelfs nog geen antwoord worden gegeven op de vraag of de rechter het artikel omzichtig hanteert. Hij hanteert het zelfs daarvoor te weinig.

13 GEA Curaçao 15 januari 2007, ARnr. 1358/2005. Uit het volgende vonnis in deze zaak, 12 november 2007, BG9118, blijkt dat de Banco di Caribe de gevraagde inlichtingen heeft verschaft.

14 GEA Sint Maarten 16 januari 2007, ARnr. 56/2004.

15 Hof van Justitie van de Nederlandse Antillen en Aruba 22 juni 2007, AR 497/94-H.79/02 (niet gepubliceerd). 


\section{Het inzagerecht en de Wet bescherming persoonsgegevens, de Wet justitiële en strafvorderlijke gegevens en de Wet op de inlichtingen- en veiligheidsdiensten 2002}

Op 1 september 2001 is de Wet van 6 juli 2000, Stb. 302, houdende regels inzake de bescherming van persoonsgegevens (hierna Wbp) in werking getreden. In hoofdstuk 5 van deze wet wordt in art. 33 en 34 de informatieverstrekking aan de betrokkene geregeld. In hoofdstuk 6 worden in art. 35 tot en met 42 de rechten van de betrokkene om verzoeken te doen omtrent de vraag welke hem betreffende persoonsgegevens worden verwerkt, geregeld.

In het kader van de problematiek omtrent de effectenlease (de Dexia-affaire) is deze wet in beeld gekomen. Samengevat betreft het bij deze problematiek gevallen waarin een consument met Dexia een overeenkomst tot effectenlease sluit en een bijbehorende depotovereenkomst. Door de grillen van de economie kan de consument hierdoor heel rijk worden (de effecten kunnen sterk in waarde stijgen) maar ook heel arm. In 2000 en 2001 stortte de beurs in tengevolge waarvan vele effecten dramatisch in waarde daalden. Vele kleine particuliere beleggers verloren hierdoor aanzienlijke bedragen en gingen op zoek naar verhaal. Eén van de stellingen of uitgangspunten ter realisering van dit verhaal was dat de professionele instelling, Dexia dus, de nodige voorzorgsmaatregelen dient te treffen om te voorkomen dat de kleine particulier verliezen lijdt die hij zich niet kan permitteren. ${ }^{1}$ Kort gezegd dient een dergelijke instelling een beleggerprofiel te hebben opgesteld. ${ }^{2}$ Op grond van art. $35 \mathrm{Wbp}$ hebben sommige particulieren aan Dexia gevraagd of zij persoonsgegevens heeft verwerkt en, zo ja, om daarvan een overzicht te geven en om die gegevens te verstrekken waarbij met name werd gevorderd:

- $\quad$ een kopie van de overeenkomst;

- het risicoprofiel;

- de aankoopbewijzen van de aandelen;

- de afschriften van de dividenduitkeringen;

- de inventarisatie van de kredietwaardigheid van de verzoekende particulier;

- een schriftelijke uitwerking van gevoerde telefoongesprekken;

- $\quad$ alle overige documenten die op de verzoekende particulier van toepassing zijn. ${ }^{3}$

1 Zie over deze zorgverplichting onder meer HR 11 juli 2003, NJ 2005, 103.

2 Zie, niet limitatief, de artt. 24 en 35 sub b Bte 1995, art. 28 van de Nadere regeling toezicht effectenverkeer 1999 en art. 28 van de Nadere regeling gedragstoezicht effectenverkeer 2002.

3 Zie bv Rb Amsterdam 19 mei 2005, AT5858. 
Eén van de vele verweren van Dexia was regelmatig dat het geschil tussen partijen mogelijk onderwerp zal worden van een gerechtelijke procedure en dat het op de Wbp gebaseerde verzoek op onaanvaardbare wijze het bepaalde in art. 843a Rv zou doorkruisen. Ik heb geen enkele uitspraak gevonden waarin dit verweer is gehonoreerd. Elk gerecht overweegt terecht min of meer dat uit niets blijkt dat art. 843a Rv een speciesbepaling zou zijn die in de weg staat aan de mogelijkheid om langs andere wegen gegevens te verzoeken. ${ }^{4}$ Zo overweegt het hof Den Bosch dat de omstandigheid dat een verzoeker de eenmaal verkregen gegevens zal gebruiken in een civiele procedure tegen Dexia, ontoereikend is om misbruik van recht aan te nemen. Eventuele processuele schade die Dexia zou lijden, is in dit verband volgens het hof rechtmatige schade. ${ }^{5}$ Het hof ziet verder geen omstandigheden die verhinderen dat de procedure ex art. 843a Rv en de procedure ex art. $35 \mathrm{Wbp}$ naast elkaar lopen. ${ }^{6}$ Nadat het hof verlof heeft verleend om in cassatie te gaan, ${ }^{7}$ oordeelt de Hoge Raad dat de verantwoordelijke, bij de voldoening aan de door art. 35 lid $2 \mathrm{Wbp}$ op hem gelegde verplichting om aan de betrokkene een volledig overzicht van de verwerkte persoonsgegevens te verschaffen, niet kan volstaan met de verstrekking van globale informatie, doch alle relevante informatie over de betrokkene moet verschaffen, hetgeen, afhankelijk van de omstandigheden, vaak zal kunnen -en zo nodig op aanwijzing van de rechter zal moeten- gebeuren door het verstrekken van afschriften, kopieën of uittreksels. ${ }^{8}$ Wat de verhouding tot art. 843a Rv betreft overweegt de Hoge Raad dat deze bepaling niet kan worden beschouwd als een ten opzichte van art. $35 \mathrm{Wbp}$ bijzondere bepaling die aan de daarin vermelde verplichting tot het geven van informatie afbreuk kan doen. Art. 843a Rv, aldus de Hoge Raad,

'... voorziet erin dat degene die daarbij een rechtmatig belang heeft inzage, afschrift of uittreksel van bepaalde bescheiden, ... aangaande een rechtsbetrekking waarin hij

Zie onder meer de in de vorige noot genoemde uitspraak en verder onder meer Rb Den Haag 19 mei 2005, AY5824 en Rb Amsterdam 10 november 2005, AU6428. AG Timmermans is bij HR 26 juni 2009, BD5516 van mening dat in een door aandeelhouders ingestelde aansprakelijkheidsprocedure tegen bestuurders weliswaar bewijs kan worden vergaard via bijvoorbeeld de exhibitieplicht ex art. 843a Rv, maar dat dit geen reden is om het verzoek van die aandeelhouders om een enquête ex boek $2 \mathrm{BW}$ te houden af te wijzen omdat dit enquêterecht eigen doelstellingen kent die binnen het vennootschapsrecht gelegen zijn.

5 Het woord 'schade' lijkt dan niet op zijn plaats, een beter woord zou 'verlies' zijn geweest.

6 Twee door het hof Den Bosch op 16 januari 2006 gewezen arresten, NJF 2006, 191 en 211.

7 Hof Den Bosch 9 februari 2006, NJF 2006, 223.

8 HR 29 juni 2007, AZ4663, NJ 2007, 638. Het arrest van de Hoge Raad in de andere Bosche zaak is ook gewezen op 29 juni 2007, AZ4664 (niet gepubliceerd in de NJ). In een soortgelijke zaak, maar dan met HBU in plaats van Dexia en een andere particulier heeft de Hoge Raad eveneens arrest gewezen op 29 juni 2007, BA3529, NJ 2007, 639. De noot van E.J. Dommering is te vinden onder NJ 2007, 639 maar heeft betrekking op beide in de NJ gepubliceerde arresten. Zie over deze arresten ook P.J.A. de Hert, M. Hildebrandt, S. Gutwirth en R. Saelens, De WBP na de Dexiauitspraken, Privacy \& Informatie 2007, p. 147-157. 
of zijn voorganger partij is, kan vorderen en kan naar gelang de omstandigheden zowel een ruimer als een beperkter toepassingsgebied hebben dan art. $35 \mathrm{Wbp} .{ }^{9}$ Aan een op art. $35 \mathrm{Wbp}$ gebaseerd verzoek, waarvoor (...) geen bijzondere redenen behoeven te worden opgegeven, ligt in het algemeen en ook in een geval als het onderhavige waarin moet worden aangenomen dat geen sprake is van misbruik van recht, een rechtmatig belang ten grondslag. Voorts is het door Dexia aangevoerde feit dat verweerder uit de door Dexia verstrekte stukken informatie kan destilleren die voor hem van nut kan zijn in een procedure, onvoldoende om aan te nemen dat op grond van gewichtige redenen als bedoeld in art. 843a Rv de verstrekking van de door verweerder verzochte informatie achterwege dient te blijven. Niet alleen kent de Wbp in art. 43 eigen uitzonderingsgronden, maar de gewichtige redenen van art. 843a Rv zouden, indien deze bepaling in het onderhavige geval van toepassing zou zijn, aan de verantwoordelijke ook geen mogelijkheid bieden op die grond aan de betrokkene informatie te onthouden, behoudens bijzondere redenen zoals een beroep op vertrouwelijkheid ter bescherming van de rechten of belangen van derden.'

De Hollandsche Bank-Unie voert aan dat zij door inwilliging van het op art. 35 Wbp gebaseerde verzoek wordt geschaad in haar door art. 843a Rv beschermde rechten of vrijheden. Het hof Den Haag verwerpt dit standpunt omdat art. 843a Rv

'... geen rechten of vrijheden ...' verleent ' $\ldots$ aan degene die bepaalde bescheiden onder zich heeft, maar ... juist - indien aan bepaalde, met name ter voorkoming van 'fishing expeditions' gestelde, voorwaarden is voldaan- een uitzondering ...' vormt '... op de hoofdregel dat iemand onder hem rustende bescheiden niet aan een ander ter inzage hoeft af te geven., ${ }^{10}$

Aldus staat als een paal boven water dat de feitenrechters en de Hoge Raad van oordeel zijn dat art. $35 \mathrm{Wbp}$ en art. 843a Rv zonder meer naast elkaar kunnen bestaan, waarbij een op het ene artikel gebaseerde vordering niet kan worden beperkt op gronden ontleend aan het andere artikel. ${ }^{11}$ Hierbij merk ik voor de volledigheid wel op dat art. $35 \mathrm{Wbp}$ geen inzagerecht geeft. Het artikel geeft een

9 Met deze zin lijkt de HR te reageren op de stelling van AG Verkade in zijn conclusie inhoudende dat men misschien kan zeggen dat art. $35 \mathrm{Wbp}$ op het door de Wbp bestreken gebied een lex specialis vormt ten opzichte van art. 843a Rv.

10 Hof Den Haag 22 augustus 2006, AY8858, JOR 2006, 293, m.nt. C.W.M. Lieverse. De tegen de beschikking van het hof ingestelde cassatiemiddelen waren zodanig van inhoud dat de Hoge Raad zich op geen enkele manier hoefde te buigen over art. 843a Rv (HR 29 juni 2007, BA3592, NJ 2007, 639).

11 Simonis en Vermeulen schrijven in 'Inzagerecht en correctierecht in de Wbp: onbekend maakt onbemind', Tijdschrift ArbeidsrechtPraktijk 2009, p. 219-223 op p. 221 zonder toelichting dat art. $35 \mathrm{Wbp}$ in feite een lex specialis is ten opzichte van art. 843a Rv. Die mening valt in elk geval niet te gronden op HR 29 juni 2007, AZ4663, NJ 2007, 638 waar de Hoge Raad juist overweegt dat art. 843a Rv naar gelang de omstandigheden zowel een ruimer als een beperkter toepassingsgebied kan hebben dan art. $35 \mathrm{Wbp}$. Zie ook J.M.A. Berkvens, De beperkingen van het inzagerecht, Tijdschrift voor Financieel Recht 2009, p. 368-376. 
verplichting om een volledig overzicht te verstrekken van verwerkte persoonsgegevens in begrijpelijke vorm. Indien er bijvoorbeeld opnames van telefoongesprekken bestaan waarin over koop en verkoop van aandelen en dergelijke is gesproken, kunnen afschriften daarvan op grond van art. 843a $\mathrm{Rv}$ worden gevorderd. Het is niet zeker dat dergelijke transactiegesprekken ook persoonsgegevens in de zin van de Wbp bevatten. Mede daarom ben ik het niet eens met de opmerking van Lieverse in zijn noot onder dit arrest dat art. $35 \mathrm{Wbp}$ per saldo meer mogelijkheden biedt dan het bepaalde in art. 843a Rv. Naast elkaar vormen zij een stevig duo. Een onderlinge vergelijking ter beantwoording van de vraag welk artikel meer mogelijkheden biedt, is niet goed mogelijk omdat beide artikelen te ongelijk van aard zijn. Dat lijkt ook de Hoge Raad te vinden waar de Raad op 29 juni 2007 oordeelde dat art. 843a Rv niet kan worden beschouwd als een ten opzichte van art. $35 \mathrm{Wbp}$ bijzondere bepaling, (mede?) omdat art. 843a Rv naar gelang de omstandigheden zowel een ruimer als een beperkter toepassingsgebied kan hebben dan art. 35 Wbp. ${ }^{12}$

Een botsing tussen de Wbp en art. 843a Rv kan zich ook voordoen indien partij A aan partij B vraagt om persoonsgegevens van werknemers van partij B zodat partij A deze als getuigen kan oproepen. Een dergelijk verzoek is volgens het hof Den Bosch een verzoek tot de verwerking van gegevens als bedoeld in de Wbp. ${ }^{13}$ Het hof toetst dit verzoek aan art. $8 \mathrm{Wbp}$ en oordeelt vervolgens dat de waarheidsvinding een belang is als genoemd in art. 8 aanhef en sub $\mathrm{f} \mathrm{Wbp} \mathrm{zodat} \mathrm{die} \mathrm{adres-}$ gegevens verstrekt moeten worden, mede omdat het om gegevens gaat die ook

12 HR 29 juni 2007, AZ4663, NJ 2007, 638.

13 Hof Den Bosch 14 oktober 2003, AM7927. Zie ook Rb Utrecht 13 februari 2008, JAR 2008, 83 waar twee vakbonden vorderen dat een werkgever wordt veroordeeld tot verstrekking van een lijst van werknemers en gewezen werknemers. De werkgever stelt onder meer dat die vordering in strijd is met art. $12 \mathrm{Wbp}$, bepalende dat de bewerker van gegevens verplicht is tot geheimhouding en dat alleen de betrokkene zelf om de gegevens of afgifte kan verzoeken. De rechtbank overweegt dat de vakbonden bevredigend en zichtbaar hebben gesteld dat de voldoende bepaalde en gemotiveerd omschreven gegevens nodig zijn om zowel de uitvoering van de $\mathrm{CAO}$ als van een rechterlijk vonnis te kunnen nagaan en dat van onevenredigheid niet is gebleken. Aldus verzet de Wbp zich niet tegen de gevorderde afgifte. Rb Arnhem 22 juli 2009, BJ6230, NJF 2009, 411 oordeelt ook zo waar zij in een geschil waar het gaat om de ledenadministratie van de Internetvakbond en de wijze waarop de ledenraadpleging heeft plaatsgevonden overweegt dat bij de beoordeling dient te worden meegenomen dat inzage in de gevraagde informatie van groot belang is voor de afloop van de procedure. Het feit dat de desbetreffende informatie eventueel vertrouwelijk is, dient daartegen te worden afgewogen. Het recht op bescherming van persoonsgegevens is immers geen absoluut recht en het enkele gegeven dat potentiële leden terughoudend zouden kunnen worden met het aanmelden als lid omdat hun lidmaatschap anders wellicht bekend wordt aan derden prevaleert dan ook niet zonder meer boven het belang van VIA om gemotiveerd te kunnen stellen en zo nodig te bewijzen dat afspraken met betrekking tot het inschrijven van nieuwe leden en het raadplegen van die leden door de Internetvakbond zijn geschonden. 
zijn opgenomen in het openbaar register van de gemeentelijke basisadministratie. ${ }^{14}$ Zijdelings is hierbij het arrest Lycos-Pessers van belang. ${ }^{15}$ In deze zaak is Lycos een 'internetgastheer' die toegang geeft tot een website, door een onbekende gemaakt, waarop was vermeld, kort gezegd, dat Pessers een fraudeur was. Pessers, geen overeenkomst hebbend met Lycos, vordert van Lycos de naam van de websitehouder. Rechtbank en Hof wijzen de vordering toe en de Hoge Raad verwerpt de cassatiemiddelen. Toewijzing van een dergelijke vordering komt niet in strijd met de Richtlijn inzake elektronische handel, PbEG L 178 noch, gelet op de belangenafweging zoals vermeld in art. 8 sub f Wet bescherming persoonsgegevens, maakt zij inbreuk op de bescherming van de persoonlijke levenssfeer van de anonieme websitehouder. ${ }^{16}$

Zie overigens over de Europese regelgeving omtrent 'Data Protection' ook de uitspraak van het EHRM van 4 januari $2007 .{ }^{17}$ Klager, een directeur-grootaandeelhouder in Engeland, had geld geleend van een bank. De bank vorderde op enig moment terugbetaling waartegen de klager zich verweerde. Volgens hem kon de juistheid van zijn verweer mede blijken uit documenten die de bank in bezit zou moeten hebben en hij vorderde inzage daarin. Dit werd geweigerd, waarna de klager van mening was dat het nationale recht in Engeland hem onvoldoende rechten bood. Het Hof overweegt in het kader van art. 8 EVRM (het recht op respect voor het privé leven):

'It was presumably his desire to obtain substantiation of these terms with a possible view to further legal proceedings that motivated his application for access to the data held by the bank, in other words, an oblique application for discovery of documentary evidence. This is therefore not a case where the applicant seeks access to files holding information about his identity or personal history, .... ${ }^{18}$

14 Zie verder nog voor specifieke verplichtingen van het bankwezen tot 1 januari 2007 de Wet Toezicht Kredietwezen, de Wet Toezicht effectenverkeer 1995 (art. 11) en art. 25 van het Besluit Toezicht Effectenverkeer (waarover J.F. Garvelink en P.F. Hopman, Verboden te vissen: informatieplicht van banken en de afdwingbaarheid daarvan in Tijdschrift voor effectenrecht 2004, p. 11-15) en vanaf 1 januari 2007 de Wet op het financieel toezicht, Stb. 2006, 475 en de Invoerings- en aanpassingswet Wet op het financieel toezicht, Stb. 2006, 605.

15 HR 25 november 2005, AU4019, NJ 2009, 550, m.nt. P.B. Hugenholtz onder NJ 2009, 551, JOL 2005, 683.

16 Zie over het arrest van het hof Amsterdam 24 juni 2004, in deze zaak gewezen, A. Ekker, Pessers/ lycos II, JAVI 2004, p. 178-181. Hij pleit voor het maken van een wettelijke regeling wat de problematiek van de doorbreking van anonimiteit op het internet betreft.

17 EHRM 4 januari 2007, NJ 2007, 475.

18 Zie ook HvJEG 29 januari 2008, NJ 2009, 551, m.nt. P.B. Hugenholtz. Het Hof overweegt in overweging 54 dat richtlijn 2002/58 niet uitsluit dat de lidstaten de verplichting opleggen om in het kader van een civiele procedure persoonsgegevens mee te delen. Zie verder D.M. Buné, De naleving van Europese privacy regels bij grensoverschrijdende civiele procedures, Bb 2009, afl. 11,25 . In het artikel is geen verwijzing te vinden naar het in par. 3.3 besproken voorbehoud dat Nederland heeft gemaakt ter zake pre-trial discovery. 
Art. 843a Rv kan verder samenlopen met de Wet Justitiële en strafvorderlijke gegevens (hierna Wjs) en de Wet op de inlichtingen- en veiligheidsdiensten (WIV). In de hiervoor in par. 7.4 genoemde zaak van ICS tegen de Staat speelt zich het volgende af. In de Verenigde Staten loopt een procedure tussen Citibank en ICS, omdat ICS weigert een aantal betalingen, door een derde gedaan met behulp van een creditcard van ICS ten laste van een Citibankrekening, met Citibank te verrekenen. Het betreft allemaal betalingen van die derde aan het in Rotterdam gevestigde bedrijf Ocean waarbij Ocean verhandelbare contracten voor de levering op termijn van wijn verkocht. In het kader van een aangifte tegen Ocean waarin wordt gesteld dat Ocean strafbare feiten zou hebben gepleegd, wordt een doorzoeking verricht en wordt de administratie van Ocean in beslag genomen. ICS is van mening dat zij delen van die administratie nodig heeft in de procedure in de Verenigde Staten tussen haar en Citibank en zij vordert afgifte van kopieën van bepaalde administratieve bescheiden. De Staat verzet zich daartegen omdat die, in het kader van een strafrechtelijk onderzoek in beslag genomen stukken, te beschouwen zijn als strafvorderlijke gegevens in de zin van art. 1 aanhef en sub b Wjs.

Het hof Den Haag stelt voorop dat de Staat niet verplicht kan worden om op voet van art. 843a Rv gegevens te verstrekken die hij ingevolge de Wjs niet mag verstrekken. ${ }^{19}$ Strafrechtelijke verboden gaan dus voor civielrechtelijke rechten. Het hof is vervolgens van oordeel dat het begrip 'gegevens over een natuurlijke of rechtspersoon' ruim moet worden opgevat. Dit begrip betreft aldus niet alleen persoonsgegevens in enge zin, maar ook gegevens die van belang kunnen zijn voor de beantwoording van de vragen van art. 348 en $350 \mathrm{~Sv}$. Nu de administratie van Ocean kan strekken tot bewijs van de aan Ocean ten laste te leggen strafbare feiten, valt die administratie onder dit begrip. Aldus moet het verzoek van ICS worden getoetst aan de artikelen in de Wjs die het verstrekken van strafvorderlijke gegevens aan derden regelen. Het verzoek kan in beginsel worden toegewezen op grond van art. 39f, lid 2 sub a Wjs. Hierin is namelijk vermeld dat aan een derde die strafvorderlijke gegevens verstrekt kunnen worden die noodzakelijk zijn met het oog op de vaststelling, de uitoefening of de verdediging van een recht in rechte. De vraag of die gegevens verstrekt moeten worden, dient beantwoord te worden door het College van procureurs-generaal. Het hof is vervolgens van oordeel dat dit College in redelijkheid heeft kunnen beslissen om de gegevens niet te verstrekken omdat het belang op de verstrekking niet opweegt tegen de daardoor veroorzaakte schending van de privacy.

Aldus oordeelt het hof dat de $\mathrm{Wjs}$ een specialis is, die voorrang heeft op art. 843a Rv. In zijn algemeenheid is het oordeel dat de Wjs vóór het bepaalde in het Wetboek van Burgerlijke Rechtsvordering gaat, juist. Ik ben het niet eens met de overweging omtrent de privacy. Gelet op de jurisprudentie tot heden zou een verzoek van ICS gericht tegen Ocean, inhoudende inzage kansrijk zijn. Ik zie 
daarom niet waarom die zelfde gegevens, die toevallig onder berusting van een derde zijn, op grond van de privacy niet zouden mogen worden afgegeven. Met andere woorden, het College mag bij haar beslissing rekening houden met de privacy maar zal, indien zij het verzoek hieraan toetst, ook moeten bezien of in een civiele zaak tussen de partij die de gegevens verzoekt en de partij die de gegevens onder zich heeft (of had, totdat zij strafvorderlijk in beslag werden genomen), afgifte zou plaatsvinden. Indien die afgifte zou plaatsvinden, kan enkel de privacy door het College niet als argument worden gebruikt om het verzoek af te wijzen. ICS is in cassatie gegaan van dit oordeel, maar heeft in de cassatiemiddelen niet bestreden het oordeel van het hof dat de Staat niet verplicht kan worden op grond van art. 843a Rv gegevens te verstrekken die hij ingevolge de Wjs niet mag verstrekken. Kort gezegd wordt alleen de belangenafweging van het hof in de cassatiemiddelen bestreden. Die afweging laat de Hoge Raad in stand. ${ }^{20}$ Het arrest van de Hoge Raad heeft geen betekenis voor de uitleg van art. 843a Rv.

Enkele journalisten van De Telegraaf hebben op enig moment van een voor anderen dan hen anonieme bron staatsgeheime informatie in de vorm van documenten ontvangen. Zij worden vervolgens object van onderzoek door de BVD/AIVD. De Telegraaf vordert in kort geding vernietiging van de onderzoeksgegevens van de BVD/AIVD. De Wet op de inlichtingen- en Veiligheidsdiensten 2002 (WIV) regelt in met name art. 15 en 85 de absolute verplichting tot geheimhouding en kent in art. 35 tot en met 57 een gesloten en uiterst restrictief verstrekkingenregiem dat inhoudt dat alleen in de daar specifiek genoemde gevallen gegevens en inlichtingen kunnen worden verstrekt. Op grond van de WIV is wel een commissie in het leven geroepen, die toezicht houdt op de rechtmatigheid en toegang heeft tot alle informatie. Bij beweerdelijk onrechtmatig gebruik geldt een speciale klachtenprocedure. De Hoge Raad stelt vast dat de WIV niet uitsluit dat bepaalde inlichtingen en stukken toch aan de rechter en de wederpartij in een civiele procedure worden verschaft. Niet iedere weigering is dus bij voorbaat gerechtvaardigd.

Het hof had in deze zaak de vordering tot vernietiging van door de BVD/AIVD verkregen informatie afgewezen. De Hoge Raad laat deze afwijzing in stand omdat het hof niet verantwoord kon beoordelen welke gegevens zouden behoren te worden verwijderd. Deze afwijzing, aldus de Hoge Raad, sluit niet uit dat nadat de hiervoor

20 HR 21 december 2007, BB9133, NJ 2008, 31. In een art. 843a Rv procedure tegen de Staat waarin een slachtoffer van een geweldsdelict gepleegd door een zich vrij bewegende onder TBS-gestelde inzage in het volledige strafdossier vorderde, overweegt Rb Den Haag 9 april 2008, BC9134 dat de Staat geen inzage in stukken mag verschaffen omdat de Wjs zich daartegen verzet en de Wjs bepaalt dat dit soort verzoeken gericht dient te worden tot het College van PG's. Ook zo Rb Den Haag 6 november 2008, NJF 2009, 8 in een zaak waarin een aangeefster van een zedendelict het dossier van de verdachte wenst in te zien nadat zij te horen heeft gekregen dat de verdachte niet zal worden vervolgd. 
Hoofdstuk 13

genoemde commissie dezelfde vraag heeft beantwoord, De Telegraaf opnieuw bij de burgerlijke rechter een bevel tot vernietiging kan vorderen. ${ }^{21}$ Een soort 'afgifte tot vernietigingsverzoek' is dus rechtens mogelijk. 


\section{Het bewijsbeslag ${ }^{1}$}

In de literatuur is omstreeks 1990 de vraag gerezen of (conservatoir) bewijsbeslag juridisch mogelijk is. ${ }^{2}$ Met andere woorden: kan beslag worden gelegd op bescheiden ter conservering van een bewijspositie. De wet is hier niet expliciet over terwijl in de praktijk een dergelijk beslag zeer wenselijk wordt gevonden omdat, zoals Barendrecht en Van den Reek schreven, het traditionele bewijsrecht tekort schiet in zijn middelen. Zo kan met de traditionele bewijsmiddelen slechts moeizaam bewezen worden dat bijvoorbeeld een ex-werknemer gebruik maakt van bedrijfsgeheimen van zijn vroegere baas of dat producten worden gemaakt waarbij inbreuk wordt gemaakt op merkrechten of auteursrechten. ${ }^{3}$

Vletter-van Dort heeft zich de vraag gesteld of art. 843a Rv zonder meer een grondslag kan bieden voor bewijsbeslag. ${ }^{4} \mathrm{Zij}$ merkt op dat dit bewijsbeslag niet het doel is van dit artikel, maar lid 2 zou misschien voldoende grondslag kunnen bieden. Het directe verband dat er bij conservatoir beslag volgens haar moet bestaan tussen het recht van de beslaglegger en de zaak waarop beslag wordt gelegd, maakt het onzeker of bewijsbeslag, waarmee documenten of zaken veilig worden gesteld die de beslaglegger in een andere procedure nodig heeft om een recht geldend te maken, via het conservatoir beslag kan worden gelegd. Zij is duidelijk over de wenselijkheid van bewijsbeslag: het is wenselijk dat dit mogelijk wordt gemaakt.

1 In dit hoofdstuk wordt alleen aandacht besteed aan het bewijsbeslag op grond van art. 843a Rv. Zie voor het bewijsbeslag op grond van het op 1 mei 2007 in werking getreden art. 1019a e.v. Rv par. 2.3 en M. Rieger-Jansen, Twee jaar ervaring met het bewijsbeslag. Een overzicht van de ontwikkelingen in Nederland en een kijkje over de landsgrenzen, AMI 2009, p. 91-96 en G. van der Wal en F. van Schaick, Handhavingsinstrumenten in het intellectuele eigendomsrecht: het op de loer liggende risico van 'fishing expeditions' vergt kritische rechterlijke toetsing, IER 2009, afl. 3. Zie over dit bewijsbeslag ook T.J.J. Bodewes, Bewijsbeslag. Een onderzoek naar de wettelijke grondslag, Masterscriptie Rijksuniversiteit Groningen, mei 2009 (te vinden op de website van de NJB). Bodewes komt tot de conclusie dat art. 703 jo. art. 843a Rv onvoldoende grondslag bieden voor een algemeen bewijsbeslag.

2 Zie over dit beslag ook Barendrecht en Van den Reek, WPNR 1994, 6155, p. 743 e.v., Van den Reek, p. 244-246, Hoyng in de Schoordijkbundel en de bijdrage van Vranken, 'Aansprakelijkheden en bewijsrecht' in de bundel 'Aansprakelijkheden, opstellen rond het thema ontwikkelingen in het aansprakelijkheidsrecht bij gelegenheid van het 60-jarig bestaan van het Nederlands genootschap van bedrijfsjuristen', Kluwer-Deventer 1990 (ook in het artikel van Hoyng genoemd die dit boek echter per abuis in 1992 laat verschijnen).

3 Barendrecht en Van den Reek, WPNR 1994, p. 743.

4 Vletter-van Dort, p. 260-263. 
Zij is niet heel duidelijk in haar standpunt of een dergelijk beslag zonder wetswijziging gelegd kan worden. Het lijkt haar het meest zinvol om een nieuwe bepaling te ontwerpen.

Dat de wet niet expliciet dit bewijsbeslag regelt, kan merkwaardig worden genoemd omdat de oude voorganger van art. 843a Rv, art. 1922 BW-1838, juist bepaalde dat 'Indien een titel gemeen is tusschen verscheidene personen, is ieder derzelve bevoegd te vorderen, dat die op eene derde plaats in bewaring wordt gebracht ...'. Van Blommestein merkt op dat het woord 'bewaring' hier niet de eigenlijke bewaargeving inhoudt en ook niet de sequestratie maar dat de bepalingen van de gerechtelijke bewaargeving daarop van toepassing zijn. ${ }^{5}$

Hoyng is expliciet in zijn antwoord op de vraag of bewijsbeslag mogelijk is. Hij is van mening dat de woorden 'De rechter bepaalt zo nodig de wijze waarop inzage ... zal worden verschaft' een rechter met durf de mogelijkheid geeft om bewijsbeslag toe te staan waarbij hij bijvoorbeeld een verzoeker machtigt om een door verzoeker aan te wijzen deurwaarder afschrift te laten maken van een groot aantal schriftelijke bescheiden welke zich bevinden in de bedrijfsruimte van de andere partij met machtiging aan de deurwaarder om die schriftelijke bescheiden tijdelijk mee te nemen indien de andere partij de deurwaarder niet ter plekke in de gelegenheid stelt om afschriften te maken. ${ }^{6}$ Hij heeft niet zo'n rechter met durf gevonden in de door hem genoemde zaak. ${ }^{7}$ De voorzieningenrechter van de rechtbank Den Bosch kan toch al wel een beetje een durfal worden genoemd. ${ }^{8}$ Hij verleent namelijk Den Bolderwagen verlof om conservatoir beslag tot afgifte te leggen op bescheiden die betrekking (kunnen) hebben op de (vroegere) rechtsbetrekking tussen haar en De Vesting en/of op de rechtsbetrekking bestaande uit de door De Vesting beweerdelijk gepleegde onrechtmatige daad. De voorzieningenrechter plaatst dit verzoek in de sleutel van art. 843a Rv. Hij merkt daarbij wel op dat het verzoek zich uitstrekt tot de volledige administratie en daarmee te ruim is. In het gegeven verlof geeft de voorzieningenrechter vervolgens zelf een beperktere omschrijving van de stukken die in beslag genomen mogen worden. Linssen juicht in zijn noot de uitspraak toe, maar merkt op dat het de vraag is of de door de voorzieningenrechter genoemde art. 843a, 730 en $709 \mathrm{Rv}$. wel voldoende grondslag bieden voor het gegeven verlof.

Harreman is van mening dat een art. 730 Rv-beslag kan worden gelegd door de rechthebbende ten behoeve van inzage, afschrift of uittreksel van bepaalde bescheiden. De basis voor dit inzagerecht is art. 843a Rv en in het kader van de in dat artikel neergelegde exhibitieplicht (zijn woord) kan op basis van art. 843a lid $2 \mathrm{Rv}$ zo nodig een art. $730 \mathrm{Rv}$-beslag tot afgifte van bescheiden worden gelegd.

\section{P. 52 en 54 e.v.}

Hoyng op p. 109-111 van de Schoordijkbundel.

Barendrecht en Van den Reek noemen in hun artikel in WPNR 1994, 6155 wel zo'n durfal en wel de president van de rechtbank Utrecht in rolnr 92/74.

8 Voorzieningenrechter Rb Den Bosch 27 maart 2002, JBPR 2002, 10 m.nt. Linssen. 
Hij is van mening dat de wetgever voor dit bewijsbeslag ten onrechte aansluiting heeft gezocht bij de regeling van het conservatoir verhaalsbeslag krachtens art. 711 e.v. Rv. Hij vindt dat het bewijsbeslag op de voet van art. 843a Rv gebaseerd moet worden op de regeling van art. 730 e.v. Rv (eventueel jo. art. $709 \mathrm{Rv}$ ). Er wordt immers conservatoir beslag op de bescheiden gelegd strekkende tot (tijdelijke) afgifte aan de beslaglegger. ${ }^{9}$

Zelf meen ik dat die combinatie van artikelen, dus art. $843 \mathrm{a}$ jo. 730 jo. 709 $\mathrm{Rv}$, wel voldoende grondslag biedt voor bewijsbeslag. Waar de wet de mogelijkheid geeft tot inzage van een bescheid, dat zich onder een ander bevindt, ligt het met voortschrijdend inzicht voor de hand om tot een uitleg te komen die het mogelijk maakt om dit inzagerecht uit te oefenen voordat de bezitter van het bescheid zich hiervan kan ontdoen. Dit betekent dat als de wetgever niet expliciet aan de mogelijkheid tot afdwingen heeft gedacht, bezien moet worden of die mogelijkheid via een extensieve en maatschappelijk gewenste uitleg kan worden gevonden. Inzage lukt niet zonder dat er op enig moment sprake is geweest van afgifte. Een eerste stap is dan een extensieve uitleg van art. $730 \mathrm{Rv}$, waarbij het woord recht in dat artikel (hij die recht heeft op afgifte van een roerende zaak ...) wordt uitgelegd als 'bewijsrecht'. ${ }^{10}$ Hij die dus een bewijsrecht heeft op afgifte (lees inzage) ${ }^{11}$, kan die zaak ter bewaring in beslag nemen. Vervolgens wordt op voet van art. 709 Rv een bewaarder aangesteld en wordt inzage gevorderd. De rechter beoordeelt die vordering en, na een positief oordeel, volgt er inzage. Ik voeg aan het vorenstaande nog drie argumenten toe. Ten eerste laat, zoals Hoyng terecht opmerkt, de tekst van art. 843a lid $2 \mathrm{Rv}$ een en ander toe. Ten tweede is het verdedigbaar dat het recht van art. 843a Rv verwordt tot een illusoir recht indien er geen voorbereidende stappen genomen zouden mogen worden om dit recht ook daadwerkelijk te kunnen uitoefenen. Via die redenering ontstaat het recht op bewijsbeslag dus uit art. 843a lid $2 \mathrm{Rv}$ zonder dat dit met zoveel woorden hoeft te worden vermeld. ${ }^{12}$ Ten derde heeft de minister van economische zaken bij brief

9 M.M.L. Harreman, Conservatoire beslagen tot afgifte en levering. Een studie naar de werking en problematiek van het 730 Rv-beslag, mede in rechtshistorisch perspectief, Proefschrift Rotterdam, Den Haag, Boom Juridische uitgevers 2007, p. 43-44. Ekelmans, p. 56-61 werpt de vraag op of bewijsbeslag mogelijk is, waarna een opsomming van jurisprudentie volgt en een instructie hoe te handelen indien verlof om bewijsbeslag te mogen leggen wordt gevraagd en de verdere afwikkeling daarvan indien het verlof wordt gegeven. Hoe hij zelf over een en ander denkt, vermeldt hij niet.

10 Min of meer ook zo Barendrecht en Van den Reek in WPNR 1994, 6155.

11 In Parl. Gesch. Wijziging Rv. e.a.w. (Inv. 3, 5 en 6), p. 332 wordt het volgende opgemerkt: 'Het eerste lid van dit artikel onderscheidt tussen het recht op afgifte van een roerende zaak en het recht op levering van een goed. Bij het eerste moet ... onder meer worden gedacht zowel aan een persoonlijke vordering tot afgifte jegens een huurder of lener na het einde van een overeenkomst ...'.

12 E.M. Wesseling-van Gent noemt op p. 107 en verder in Van der Korst e.a. ook het bewijsbeslag en uit niets blijkt dat zij van mening is dat dit beslag rechtens niet gelegd zou kunnen worden. 
van 28 april 2006 aan de Tweede Kamer vermeld dat dit bewijsbeslag mogelijk is. ${ }^{13}$ Hij vermeldt wat dit betreft in die brief dat in het Nederlandse procesrecht een rechter nog voor de aanvang van een civiele procedure kan bevelen dat relevant bewijsmateriaal moet worden bewaard. Dit kan volgens hem plaatsvinden conform de voorlopige maatregel tot het leggen van conservatoir beslag, waartoe verlof wordt gevraagd aan de voorzieningenrechter. Die verleent dit verlof vervolgens onder de voorwaarde dat binnen een bepaalde termijn een bodemprocedure wordt ingesteld. Aldus is de stelling dat bewijsbeslag thans reeds in het algemeen mogelijk is, verdedigbaar, maar een expliciete wetsbepaling verdient natuurlijk de voorkeur. ${ }^{14}$

Linssen is van mening dat mijn benadering mogelijk iets te ver gaat. ${ }^{15}$ Die mening lijkt vooral te rusten op het feit dat het ex parte karakter van het bewijsbeslag en ook de ingrijpende gevolgen van een dergelijk beslag een zorgvuldige regeling met daarin adequate en effectieve waarborgen voor alle betrokkenen verlangt, terwijl dit in de huidige wetgeving niet is geregeld. De praktijk heeft volgens mij inmiddels uitgewezen dat deze waarborgen door de rechter voldoende adequaat zijn geformuleerd en vervolgens in het oog worden gehouden, zodat alleen die angst niet voldoende tegenwicht biedt. Dit laat onverlet dat een wettelijke regeling natuurlijk beter voorzienbare en misschien ook wel afdwingbare, waarborgen biedt en in elk geval voorkomt dat de ene rechter oordeelt dat bewijsbeslag thans niet mogelijk is, terwijl de andere rechter dit beslag wel toestaat. ${ }^{16}$

13 Kamerstuk 22112, Nieuwe Commissievoorstellen en initiatieven van de lidstaten van de Europese Unie betrekking hebbend op het Groenboek Schadevorderingen wegens schending van communautaire antitrustregels.

14 Min of meer ook zo Rb Rotterdam 3 september 2009, BJ7141 die overweegt dat het Wetboek van Burgerlijke Rechtsvordering weliswaar geen expliciete regeling voor bewijsbeslag kent, maar dat dit niet betekent dat bewijsbeslag in het algemeen niet is toegestaan. De rechtbank legt vervolgens het begrip 'afgifte' in art. $730 \mathrm{Rv}$ zo ruim uit dat het bewijsbeslag daaronder valt. In W.D.H. Asser, J.E. Nijboer en Y.E. Schuurmans, Bewijsrecht: het bewijs geregeld?, Preadvies voor de Nederlandse Vereniging Voor Rechtsvergelijking, Wolf Legal Publishers, Tweede herstelde druk 2010, wordt op p. 37 neutraal vermeld dat in de praktijk het bewijsbeslag met als doel bewaring van bewijs (niet 'inzien van bewijs') voorkomt als een toepassing van het conservatoire beslag tot afgifte van roerende zaken en door rechters wordt toegestaan op grond van art. 843a Rv en art. $730 \mathrm{Rv}$.

15 J.G.A. Linssen, Bewijsbeslag, in De reikwijdte van het beslag, p. 24, Procesrechtelijke reeks NVvP nr. 20, Boom Juridische uitgevers Den Haag, 2009. Linssen doelt dan op mijn benadering zoals weergegeven in mijn AA-cahier. Die is daarin wel iets minder uitgebreid dan hier.

16 Opvallend is wel dat Linssen op p. 53 van de in de vorige noot vermelde publicatie opmerkt dat zijn mening niet betekent dat in afwachting van deugdelijke wetgeving bewijsbeslagen verboden zouden moeten worden. De praktijk heeft er namelijk teveel behoefte aan. Het is wel zeer wenselijk dat de wetgever op korte termijn met een wettelijke regeling komt. 
In de lagere rechtspraak wordt inmiddels uitgegaan van het feit dat bewijsbeslag mogelijk is. Zo vermeldt het vonnis van de rechtbank Dordrecht dat partij Hoogendonk

'... met verlof van de voorzieningenrechter ... onder meer ten laste van gedaagden conservatoir beslag tot afgifte (heeft) gelegd op ... gegevensdragers. ... Hoogendonk vordert dat gedaagden ... worden veroordeeld tot afgifte van de in beslag genomen gegevensdragers ... Om de gestelde gang van zaken te bewijzen dient Hoogendonk te beschikken over de in beslag genomen gegevensdragers.'

Uit deze weergave van hetgeen vooraf is gegaan, valt onmiskenbaar af te leiden dat Hoogendonk bewijsbeslag heeft gelegd in deze zaak waarin Hoogendonk stelt dat gedaagden, ex-werknemers, met zijn bedrijfsgegevens aan de haal én aan het werk zijn gegaan. De rechtbank oordeelt vervolgens over de vraag of de vordering slechts kan worden toegewezen indien komt vast te staan dat de tegenpartij onrechtmatig heeft gehandeld,

'... dat die eis niet kan worden gesteld omdat voor het bewijs van het onrechtmatig handelen de opgevorderde bescheiden nu juist van doorslaggevend belang zijn. ... Zoals de feiten thans liggen moet ervan worden uitgegaan dat Hoogendonk niet in staat zal zijn het gestelde onrechtmatig handelen te bewijzen indien zij niet in staat is de gegevensdragers, waarvan afgifte wordt gevorderd, in de verwante procedure te overleggen.' ${ }^{17}$

Verbazingwekkend is dit toestaan van bewijsbeslag inmiddels niet meer. De op www.rechtspraak.nl te vinden $7^{\mathrm{e}}$ (verbeterde) versie van de beslagsyllabus van februari 2009 die is samengesteld onder verantwoordelijkheid van het Landelijk Overleg van de Voorzitters van de sectoren Civiel van de rechtbanken (LOVC), houdt namelijk onder E. Aanstelling van een gerechtelijk bewaarder (art. $709 \mathrm{Rv}$ ) zonder verdere toelichting het volgende in.

'Bij rekesten voor beslag tot afgifte van roerende zaken ... waarin het gestelde recht op afgifte is gebaseerd op ... art. 843a Rv ... wordt regelmatig verzocht om door de deurwaarder ... onderzoek te mogen laten doen aan de in beslag te nemen zaken. Dergelijke verzoeken moeten niet worden gehonoreerd, aangezien de gerekwestreerde (doorgaans) niet op het beslagrekest wordt gehoord, ... Het doel van een conservatoir beslag is uitsluitend om de bestaande situatie te conserveren en niet om de beslaglegger de mogelijkheid te bieden om met het beslag bewijs

17 Rb Dordrecht 23 juni 2004, AP3695. Ook uit Rb Middelburg 6 juli 2006, AZ0501 en uit Rb Amsterdam 28 maart 2007, BG3882 blijkt dat toestemming tot bewijsbeslag is gegeven. Uit Rb Amsterdam 19 april 2007, BA3673 blijkt dat verlof is gegeven tot het leggen van bewijsbeslag met sequestratie, zonder recht van inzage, op zich bij de vestiging van Banque Artesia liggende bescheiden, geluidsopnames en gegevensdragers over de periode juli 1997-mei 1998. 
te vergaren. Indien de beslaglegger aan de zaken waarop hij beslag wil leggen onderzoek wenst te (doen) verrichten, dient hij een daartoe strekkende vordering ... in te stellen, ... Aan het verlof kan worden toegevoegd:

'...en bepaalt dat de gerechtelijk bewaarder daarvan geen inzage geeft of anderszins informatie omtrent de inhoud ter kennis brengt van de verzoeker of derden totdat door de voorzieningenrechter in kort geding, of door de bodemrechter, anders is bepaald.'

Een andere mogelijkheid is de navolgende beschikking op het beslagrekest:

Gezien aangehecht verzoekschrift;

De voorzieningenrechter:

Verleent verlof om conservatoir beslag te leggen op de in het verzoekschrift onder punt * vermelde bescheiden, gegevensdragers, administratie en documenten van gerekwestreerde. Benoemt deurwaarder * tot gerechtelijk bewaarder en bepaalt dat ten spoedigste nadat het beslag is gelegd door de gerechtelijk bewaarder, al dan niet in samenwerking met een ter zake onafhankelijke deskundige (digitale) kopieën zullen worden gemaakt van bedoelde bescheiden, gegevensdragers, administratie en documenten, welke kopieën de gerechtelijk bewaarder -zonder inzage of informatie omtrent de inhoud ervan aan verzoeker of aan derden te geven- in gerechtelijke bewaring zal nemen in afwachting van een beslissing van de bodemrechter, terwijl de oorspronkelijke bescheiden, gegevensdragers, administratie en documenten terstond na het maken van kopieën aan gerekwestreerde dienen te worden teruggegeven;

Bepaalt dat na de hiervoor bedoelde teruggave de gerechtelijke bewaring beperkt is tot de hiervoor bedoelde kopieën;

Bepaalt (voor zoveel nodig) dat de eis in de hoofdzaak (in ieder geval inhoudende een vordering ex artikel 843a -eventueel juncto artikel 1019a- van het Wetboek van Burgerlijke Rechtsvordering) binnen 14 dagen na het (eerstgelegde) beslag dient te worden ingesteld. ${ }^{18}$

Aldus is duidelijk dat in elk geval het LOVC van mening is dat conserverend bewijsbeslag mogelijk is en dat in een vervolgprocedure moet worden uitgemaakt in welke van de in beslag genomen bescheiden inzage moet worden verschaft (of

18 De $5^{\text {de }}$ verbeterde versie van augustus 2005 makte al melding van dit bewijsbeslag. Opvallend is dat in die versie achter de eerste maal dat de woorden 'artikel 843a Rv' werden genoemd, nog stond '(het zogenaamde 'bewijsbeslag'). Na zo'n tekst is het overigens opvallend dat onder het hoofd 'Bewijsbeslag betreffende rechten van intellectuele eigendom (artikel 1019b lid 1 juncto artikel 1019c lid $1 \mathrm{Rv}$ )' in diezelfde syllabus na een tekst als NB 1 is opgenomen 'Bewijsbeslag in niet-IE zaken (dat doorgaans wordt gebaseerd op artikel $730 \mathrm{Rv}$ juncto 843a Rv) is naar de mening van het LOVC niet onmogelijk (besluit 13 juni 2008). Voor de zuiverheid: ik was toen lid van het LOVC (waarmee niets is gezegd over de wijze van totstandkoming van deze NB 1). 
van welke bescheiden de rechter zelfs van oordeel is dat zij moeten worden afgegeven op grond van art. 843a Rv. Zie hiervoor hoofdstuk 9). ${ }^{19}$

De hiervoor vermelde woorden 'Indien de beslaglegger aan de zaken waarop hij beslag wil leggen onderzoek wenst te (doen) verrichten, dient hij een daartoe strekkende vordering ... in te stellen' hebben, in elk geval impliciet, centraal gestaan in een procedure bij de rechtbank Haarlem. De voorzieningenrechter had verlof tot bewijsbeslag gegeven onder de voorwaarde dat binnen acht weken na het gelegde beslag een dagvaarding in de hoofdprocedure ingesteld diende te zijn. De beslaglegger stelt binnen die acht weken een bodemprocedure in, maar vordert daarin schadevergoeding en geen inzage in de in beslaggenomen stukken. De beslagene stelt dat hiermee niet aan de door de rechter die het beslagverlof heeft verleend gestelde voorwaarde is voldaan, zodat het beslag als vervallen heeft te gelden. De voorzieningenrechter overweegt dat nu de beslaglegger binnen de daarvoor gestelde termijn een procedure aanhangig heeft gemaakt, waarin het beslag kan worden getoetst en die is gericht op het verkrijgen van een voor executie vatbare titel, niet op voorhand valt uit te sluiten dat de bodemrechter van oordeel zal zijn dat de beslaglegger aan de voorwaarde heeft voldaan. ${ }^{20}$

Onder meer de rechtbank Rotterdam oordeelt conform het advies in de beslagsyllabus dat conservatoir bewijsbeslag ter conservering is, niet ter bestudering. ${ }^{21}$ In deze zaak betrof het papieren waarvan niet elke deurwaarder weet hoe zij er uit zien en waar zij te vinden zijn (het betrof specifieke scheepspapieren). Het behoort dan tot de mogelijkheden om een expert mee te nemen. In zijn noot onder dit vonnis wijst Van 't Zelfde erop dat zo'n expert geen geheimhoudingsverplichting heeft en dat er een waarborg moet worden geschapen zodat deze expert niet aan een derde vertelt wat hij heeft gezien. Ik zou zeggen dat waar een deurwaarder een derde voor dit doel meeneemt, de deurwaarder maatregelen moet nemen om te zorgen dat wat deze derde te weten komt, niet wordt verder verteld. Ik denk hierbij aan een geheimhoudingsverklaring.

19 Toegestaan bewijsbeslag blijkt onder meer ook uit Rb Haarlem 2 februari 2007, AZ7827, Rb Den Bosch 21 mei 2008, BD2308, Rb Haarlem 27 juni 2008, BD6672, Rb Utrecht 1 oktober 2008, BF7386, Rb Rotterdam 21 oktober 2008, BG1066 (na verlof conservatoir beslag gelegd tot afgifte van, kort gezegd, scheepstoebehoren ex artikel 843a Rv met bevel tot afgifte ter gerechtelijke bewaring), Rb Utrecht 28 november 2008, BG5823, Rb Haarlem 27 februari 2009, BH6255, Rb Arnhem 16 maart 2009, BH6158, Rb Utrecht 18 maart 2009, BH6128 en Rb Rotterdam 3 september 2009, BJ7141. In HR 31 mei 2002, NJ 03, 589 (vernietiging gemaakte video-opnames) had eiser, die vernietiging van die opnames vorderde, geen zaken in bewijsbeslag genomen. Het Gerecht in eerste aanleg van de Nederlandse Antillen, zittingsplaats Curaçao besliste op 14 december 2007 in AR-nr. 277/2007 (TDS-Groeneveld, niet gepubliceerd) dat bewijsbeslag mogelijk is. Het Hof Den Bosch oordeelt op 17 maart 2009, BI7600 dat de bewijsbeschermende maatregelen van art. $1019 \mathrm{~b} \mathrm{Rv}$ de beslaglegger niet automatisch inzagerecht geven.

20 Rb Haarlem 27 februari 2009, BH6255.

21 Rb Rotterdam 21 oktober 2008, BG1066, Tijdschrift Vervoer\&Recht 2009, p. 27-29, m.nt. R.C.A. van 't Zelfde. 
De genoemde beslagsyllabus is een voorbeeld van de (wijze van) uitvoering door de besturen van de rechtbanken van art. 23 lid 3 RO. Dit artikel bepaalt onder meer dat het bestuur tot taak heeft binnen het gerecht de uniforme rechtstoepassing te bevorderen. Het vaststellen van een landelijke regeling valt daar ook onder. Toch betekent het bestaan van een landelijke regeling als de beslagsyllabus, waaruit in elk geval impliciet kan worden afgeleid dat de sectorvoorzitters van de sectoren civiel van alle rechtbanken van mening zijn dat bewijsbeslag mogelijk is, niet dat elke rechter dit ook als oordeel uitspreekt. Zo overweegt de rechtbank Zutphen dat uit de tekst van art. 843a Rv noch uit haar parlementaire geschiedenis of de op haar betrekking hebbende jurisprudentie afgeleid kan worden dat art. 843a Rv de mogelijkheid biedt bewijsbeslag te doen leggen. Het voordien met toestemming van de rechter gegeven bewijsbeslag werd om die reden weer opgeheven. ${ }^{22}$

Het hof Den Bosch lijkt van oordeel te zijn dat bewijsbeslag op grond van art. 843a Rv niet mogelijk is. Het hof overweegt in een zaak waarin het verzoek tot het leggen van bewijsbeslag door de rechtbank is afgewezen en van welke afwijzing verzoeker hoger beroep heeft ingesteld:

'De afgifte van bewijsmiddelen in de artikelen 843a en $162 \mathrm{Rv}$ hebben een eigen, procesrechtelijke betekenis, in het bijzonder een inzagerecht en om gebruik te kunnen maken van de vergaarde gegevens in een procedure (vgl. HR 31 mei 2002, NJ 2003, 589, subonderdeel 1.3: het inzagerecht leidt niet tot een afgifteplicht). Bovendien verlangt EBM hier expliciet geen afgifte (in de betekenis van goederenrechtelijke overdracht), maar veiligstelling gevolgd door inzage (rechercheren is het woord dat EBM gebruikt). ${ }^{23}$

Het door het hof genoemde arrest is het Observatiearrest (zie daarover uitgebreid par. 7.1.1). De overwegingen van de Hoge Raad die het hof kennelijk heeft

22 Rb Zutphen 23 januari 2008, BC2626. Rb Haarlem 27 juni 2008, BD6672 oordeelt in kort geding waarbij in conventie inzage wordt gevorderd in op grond van bewijsbeslag door de deurwaarder meegenomen stukken, terwijl in reconventie teruggave van die stukken wordt gevorderd, dat na hoor en wederhoor in het kader van de mondelinge behandeling van het kort geding, is gebleken dat de stellingen op grond waarvan het bewijsbeslag zonder hoor en wederhoor was toegestaan, niet voldoende zijn komen vast te staan. De stukken behoren dan ook te worden teruggegeven omdat 'het door de beslaglegger aangedragen bewijsmateriaal veel te mager is voor een zwaar middel als het onderhavige bewijsbeslag'. De rechtbank overweegt dat de principiële vraag of art. 843a Rv een deugdelijke wettelijke basis vormt voor een bewijsbeslag zoals wel wordt geboden door art. 1019b Rv, in het midden kan blijven, mede gelet op de op dit punt in Nederland verschillend oordelende voorzieningenrechters en dat het wachten is op uitspraken van hoven of de Hoge Raad. Ik kan mij voorstellen dat de praktijk van dit soort overwegingen erg ongelukkig wordt: de ene voorzieningenrechter van die rechtbank is van oordeel dat bewijsbeslag mogelijk is: er is immers expliciet toestemming tot bewijsbeslag gegeven; de andere rechter bij dezelfde rechtbank werkzaam in dezelfde sector overweegt dat het niet zeker is of bewijsbeslag mogelijk is (in appel kwam het hof Amsterdam 2 december 2008, BG9051 niet aan een oordeel over het bewijsbeslag toe).

23 Hof Den Bosch 30 mei 2007, BA9007. 
samengevat met de woorden 'het inzagerecht leidt niet tot een afgifteplicht' moeten te vinden zijn onder hetgeen de Hoge Raad in 3.7.1 en 3.7.2 heeft overwogen. De Hoge Raad vermeldt onder 3.7.1 dat de cassatieonderdelen 1.1-1.5 betogen dat het onbegrijpelijk is waarom de vordering van eiser $\mathrm{K}$ om de vrije beschikking te krijgen over kopieën van het door Aegon verzamelde materiaal is afgewezen. De cassatieonderdelen vermelden vervolgens meerdere redenen waarom de vordering wel toewijsbaar is. Hier van belang is de volgende reden, die door de Hoge Raad als volgt is omschreven:

'c. Het 'equality of arms-beginsel noopt ertoe dat $\mathrm{K}$ reeds nu vrijelijk de beschikking krijgt over het door Aegon verzamelde materiaal, zodat hij kan zien wat hij ermee gaat doen en niet hoeft af te wachten of en op welke wijze Aegon het materiaal in de bodemprocedure gaat gebruiken.'

Over het aldus samengevatte middel oordeelt de Hoge Raad als volgt:

'De onder c vermelde klacht berust op de opvatting dat Aegon, ongeacht dienaangaande door de bodemrechter te geven beslissingen verplicht is het door haar verzamelde feitenmateriaal aan $\mathrm{K}$ ter beschikking te stellen, opdat hij dat materiaal desgewenst zelf in het geding kan brengen en de volledigheid en de authenticiteit van het materiaal kan controleren. Die opvatting kan echter niet als juist worden aanvaard, omdat een zovergaande verplichting noch uit het bepaalde in art. 843a Rv, noch uit het beginsel van 'equality of arms' voortvloeit.'

Bij genoemd oordeel neemt de Hoge Raad vervolgens onder meer in aanmerking dat in de bodemprocedure ook de eventuele toelaatbaarheid van het door Aegon verzamelde materiaal aan de orde is. Ik zie niet hoe het hof Den Bosch uit deze citaten heeft kunnen afleiden dat de Hoge Raad in dit arrest heeft geoordeeld dat het inzagerecht niet tot afgifteplicht leidt.

Het hof Leeuwarden constateert dat volgens de bewijsbeslaglegger De Melker de wettelijke grondslag voor het gelegde bewijsbeslag de artt. 843a en $730 \mathrm{Rv}$ zijn. Het hof overweegt dat art. $843 \mathrm{a} \mathrm{Rv}$ geen bevoegdheid tot beslaglegging toekent. Art. $730 \mathrm{Rv}$ ziet op het conservatoir beslag tot afgifte van zaken en levering van goederen en deze bepaling sluit niet aan op art. 843a Rv, dat immers geen vorderingsrecht tot afgifte of levering toekent. Het bewijsbeslag kan dan ook niet op deze artikelen worden gebaseerd. Aldus is de beslaglegging onrechtmatig en heft het hof het gelegde bewijsbeslag op. ${ }^{24}$

24 Hof Leeuwarden 4 augustus 2009, BJ4901. Rb Rotterdam 3 september 2009, BJ7141 oordeelt dat bewijsbeslag wel mogelijk is en vergelijkt de haar voorliggende zaak expliciet met de zaak die het hof Leeuwaarden op 4 augustus 2009 kreeg voorgelegd en wijst op belangrijke verschillen, zoals onder meer dat in haar zaak de bepalingen van de Algemene Wet op het Binnentreden wel waren nageleefd en nog geen inzage in het beslag was geweest. 
Het enkele feit dat de beslagen stukken bedrijfsgeheimen kunnen bevatten, behoort niet in de weg te staan aan het bewijsbeslag. Om te voorkomen dat de inhoud van dergelijke geheimen bekend wordt, dient de wijze van inzage zodanig te worden ingericht dat schade wordt voorkomen. In dergelijke gevallen is het inmiddels zeer gebruikelijk dat een neutrale derde wordt ingeschakeld die de stukken bekijkt (zie hoofdstuk 9).

De regels van het beslagrecht blijven van toepassing zodat er op grond van art. 734 lid $4 \mathrm{Rv}$ geen vrees voor verduistering hoeft te worden gesteld. Barendrecht en Van den Reek lijken dit artikellid over het hoofd te zien omdat zij van mening zijn dat het bij bewijsbeslag ontoelaatbaar is dat een rechter ter zake de omschrijving van de vrees voor verduistering genoegen neemt met een algemene omschrijving. ${ }^{25}$ Los van het bestaan van art. 734 lid $4 \mathrm{Rv}$ zie ik geen reden waarom hier kennelijk als algemene regel zwaardere eisen gesteld zouden moeten worden dan vereist zijn bij een normaal beslag. In abstracto valt immers niet te zeggen dat een gelegd bewijsbeslag meer nadeel voor de beslagene veroorzaakt dan het bevriezen van een bepaald deel van zijn vermogen. Zo zal in de hiervoor genoemde en in par. 7.4.1 genoemde zaak van CdMR-Scheldepoort, Scheldepoort toch nauwelijks of geen last hebben van beslag gelegd op stukken betrekking hebbend op verfspecificaties. Ik zou zelfs eerder geneigd zijn om te zeggen dat, bij een overbodig gestelde vrees voor verduistering er aan de te stellen vrees voor verduistering juist lichte eisen gesteld zouden moeten worden. Daar waar materiële waarheidsvinding van groot belang is en het verkrijgen van bewijsmiddelen die bij de tegenpartij berusten naar ervaringsregels niet simpel is, dienen juist zo weinig mogelijk blokkades aan het verkrijgen van bewijsmiddelen in de weg te staan.

Bij de inhoud van de in art. 734 lid $4 \mathrm{Rv}$ vereiste omschrijving van het in beslag te nemen goed, dient aansluiting te worden gezocht bij het vereiste van 'bepaalde bescheiden' in lid 1 van art. 843a Rv. Op die wijze wordt het vissen naar inzage in stukken voorkomen. 


\section{Processuele verwikkelingen}

Art. 843a Rv staat in het derde boek van het Wetboek van Burgerlijke Rechtsvordering, genaamd 'Van rechtspleging van onderscheiden aard' en in de zevende titel, genaamd 'Enige bijzondere rechtsplegingen'. De desbetreffende titel is een soort vergaarbak en systematisch valt uit deze plaats niet af te leiden op welke wijze het recht op inzage kan worden verwezenlijkt. Ik denk hierbij aan vragen als 'betreft het een zelfstandige procedure die met een dagvaarding moet worden ingeleid', 'is het een incident dat eiser alleen bij dagvaarding en gedaagde alleen bij of voor zijn conclusie van antwoord dient in te stellen', 'is het een vordering of een verzoek', enz.

De wetgever heeft in elk geval geen harde rechtstreeks toepasselijke regels gegeven. Ook indirect valt weinig tot niets over de wijze waarop geprocedeerd moet worden uit de wet af te leiden. De wetgever heeft zich in het verleden eigenlijk alleen maar uitgelaten over de vraag of de vordering binnen of buiten het geding dient te worden ingesteld. In par. 2.2.1 hiervoor is vermeld dat de wetgever nog in 1988 de vordering als een verzoek buiten het geding heeft gezien. De rechtspraak heeft zich hier nooit iets van aangetrokken, waarschijnlijk mede omdat er kennelijk nooit een verweer ter zake is gevoerd. De vordering wordt dan ook zonder enig probleem als zelfstandige vordering ingesteld, maar ook regelmatig bij wijze van incident tijdens een lopende procedure. ${ }^{1}$ Dat laatste is ook logisch: als alle bewijsmiddelen zonder resultaat de revue zijn gepasseerd, moet het, alleen al vanwege de zinsnede 'dat een behoorlijke rechtsbedeling ook zonder verschaffing is gewaarborgd' mogelijk zijn om die vordering op elk moment in de procedure in te stellen.

De rechtbank Zutphen begrijpt uit de gewijzigde eis dat eiser bedoeld heeft een incidentele vordering op de voet van $843 \mathrm{a} \mathrm{Rv}$ in te stellen. Zij overweegt dat zij, gelet op de deformalisering die met de invoering van het nieuwe Wetboek van Burgerlijke Rechtsvordering is beoogd, de gewijzigde eis zal opvatten als een incidentele conclusie. Gedaagden zijn daardoor niet geschaad, nu zij zowel ter

1 Zie onder meer het losbladig commentaar op Rechtsvordering, art. 843a, dat onder nr. 3 nog steeds een paragraaf heeft genaamd 'Strekking' en p. 415-419 van de Parl. Gesch. nieuw bewijsrecht, Kluwer 1988. Veegens-Wiersma I schrijven op p. 116 zelfs nog dat met recht de exhibitieplicht in het geding zoals geformuleerd in art. $1923 \mathrm{BW}$ als overbodig is geschrapt. 
comparitie als in hun akte op de vordering hebben kunnen reageren, hetgeen zij ook hebben gedaan. ${ }^{2}$

Ik zie het nut van deze tournure niet. De wet houdt immers geen beletselen in voor het bij dagvaarding in de hoofdzaak instellen van een vordering tot inzage. Conversie is dan ook niet nodig en heeft, alleen al in verband met de proceskosten, behoorlijke gevolgen. Zie voor een voorbeeld van een procedure waarin bij dagvaarding als zelfstandige vordering in het petitum inzage wordt gevorderd, het op 24 juni 2009 door de rechtbank Leeuwarden gewezen vonnis. ${ }^{3}$ Passend in de aard en strekking van een bodemprocedure is dan de mogelijkheid dat uitputtend onderzoek wordt gedaan naar de vraag of de gestelde rechtsbetrekking wel bestaat. De rechtbank Leeuwarden doet dat in de net genoemde zaak en oordeelt vervolgens, mede aan de hand van afgelegde verklaringen in het gehouden voorlopige getuigenverhoor, dat de gesteld feiten de conclusie van eiser dat er onrechtmatig is gehandeld, niet kunnen dragen. Waar in een incidentele vordering tot inzage de gestelde rechtsbetrekking slechts summierlijk aanwezig moet zijn, waarna met de stukken waarvan inzage wordt gevraagd, het bestaan van die rechtsbetrekking in het vervolg van de procedure voldoende aannemelijk zal worden gemaakt, is er in beginsel bij een bodemprocedure waarin inzage wordt gevorderd, geen vervolg meer.

Zoals hiervoor gesteld, is het belang van het inzagerecht gelegen in het bewijsrecht. Dit specifieke belang brengt met zich dat het incident ook na een tussenvonnis waarin een bewijsopdracht is gegeven, moet kunnen worden ingesteld. Dit wordt miskend door het hof Den Haag. Dit hof overweegt namelijk dat uit het systeem van de wet volgt dat appellant een incidentele vordering ex art. 843a Rv uiterlijk dient in te stellen tegelijkertijd met of in de memorie van grieven. ${ }^{4}$ De Hoge Raad lijkt wel de ruimte aanwezig te achten om op elk moment een vordering tot inzage te doen. Hij overweegt namelijk dat indien in de procedure waarin een voorlopig deskundigenbericht wordt overgelegd, blijkt dat voor de beoordeling daarvan nog gegevens nodig zijn, eventueel art. 843a Rv toepassing kan vinden. ${ }^{5}$ De rechtbank Arnhem wijst een na afloop van een getuigenverhoor ingestelde vordering op de voet van art. 843a Rv eveneens toe. ${ }^{6}$ In dit kader vermeld ik nog een uitspraak van de rechtbank Rotterdam. ${ }^{7}$ In die zaak hebben eisers bij vonnis van 22 januari 2003 een bewijsopdracht gekregen. Het door hen geleverde bewijs is bij tussenvonnis van 12 juli 2006 'geëvalueerd' waarna er deskundigen zijn benoemd om ter zake drie opdrachten, waarvan eisers hebben bewezen dat zij deze hebben gegeven, de rechtbank nader voor te lichten. Eisers hebben bewijsbeslag gelegd op 20 februari 2007 en op 6 maart 2007 en vorderen inzage. De rechtbank

Rb Zutphen 9 mei 2007, BB1491.

Rb Leeuwarden 24 juni 2009, BI9925.

Hof Den Haag 15 november 2005, AX8899, JBPR 2006, 52, m.nt. M.O.J. de Folter.

HR 22 februari 2008, BB5626.

$\mathrm{Rb}$ Arnhem 10 juni 2009, BI8319.

Rb Rotterdam 9 september 2009, BJ8977. 
overweegt dat voor zover het beslag is gelegd om te bewijzen dat eisers meer opdrachten hebben gegeven dan de bewezen drie, het in strijd is met de goede procesorde om enkele jaren na de bewijsopdracht via de band van een art. 843a $\mathrm{Rv}$ verzoek de bewijsvoering te heropenen. Indien eisers andere doelen met het bewijsbeslag hadden dan genoemde bewijsvoering, hebben zij onvoldoende concreet vermeld wat zij met de gevorderde inzage verder nog beogen.

Een vordering tot inzage kan worden ingesteld als zelfstandige vordering, als zelfstandig verzoek, als incident door een eiser in de bodemprocedure, en door de gedaagde als incident in de bodemprocedure. De vordering is in de praktijk ook ingesteld als een voorlopige voorziening op de voet van art. $223 \mathrm{Rv}$. De vraag of een vordering tot inzage wel als voorlopige voorziening kan worden gedaan, wordt in de jurisprudentie verschillend beantwoord. Het hof Den Haag is van oordeel dat de vordering tot afgifte van stukken niet valt aan te merken als een vordering om een voorlopige voorziening omdat er geen sprake is van een voorlopig karakter, ook niet indien de vordering beperkt is tot de duur van de bodemprocedure. ${ }^{8}$ De rechtbank Amsterdam deelt dit oordeel. ${ }^{9}$ Ik sluit mij hierbij aan. Krachtens de tekst van art. $223 \mathrm{Rv}$ kan de rechter op vordering van een partij een voorlopige voorziening voor de duur van het geding treffen, een soort ordemaatregel dus. Een bevel tot inzage is geen ordemaatregel, maar een procedurele bewijsmaatregel die naar haar aard en inhoud niet kan gelden voor alleen de duur van het geding. Gelet op de andere mogelijkheden die een partij heeft, is er ook geen goede reden om de tekst van art. $223 \mathrm{Rv}$ wat dit betreft op te rekken. Een partij kan immers meteen bij het stuk dat de procedure inleidt ook een incidentele vordering indienen en ook gedaagde kan een incidentele vordering indienen voordat hij een conclusie van antwoord neemt. ${ }^{10}$ De rechtbank Arnhem wijst in een bodemprocedure waar in het kader van een voorlopige voorziening een vordering ex art. 843a $\mathrm{Rv}$ is gedaan inhoudende inzage voor de duur van de bodemprocedure door middel van het verschaffen van kopieën van bepaalde bescheiden, deze vordering toe. ${ }^{11}$

In 'normale' kort geding procedures wordt een vordering tot inzage regelmatig toegewezen. Het betreft dan meestal gevallen waarin met verlof van de voorzieningenrechter bewijsbeslag is gelegd. In sommige gevallen vordert dan degene onder wie beslag is gelegd, opheffing en wordt in reconventie meestal inzage gevorderd.

8 Hof Den Haag 24 augustus 2006, AY7534. Idem Rb Utrecht 1 oktober 2008, BF7386.

9 Rb Amsterdam 28 januari 2009, BH5770.

10 M. den Besten, Provisionele vordering tegenover kort geding, Advocatenblad 2007, p. 738 en dezelfde den Besten, Samenloop van voorlopige voorzieningen in het burgerlijk procesrecht, in de bundel Samenloop BWKJ 23, Meijers-reeks, Kluwer 2007, p. 211-238 is van mening dat een partij die wil dat de op grond van een provisionele voorziening ontstane situatie ook nadien voortduurt, in de hoofdzaak een gelijkluidende vordering moet instellen. Ik zie geen redenen waarom dit niet zou kunnen indien de gevorderde voorlopige voorziening een vordering tot inzage inhoudt.

11 Rb Arnhem 10 januari 2007, AZ9268. 
Soms wordt het gelegde bewijsbeslag gevolgd door een inzagevordering in conventie in kort geding en wordt in datzelfde kort geding in reconventie opheffing gevorderd (zie hoofdstuk 14). De rechtbank Utrecht overweegt in zo'n zaak dat een vordering tot inzage inderdaad in beginsel een onomkeerbare situatie teweeg brengt, maar ondanks het feit dat het geen tijdelijke maatregel betreft, in kort geding toch kan worden toegewezen. ${ }^{12}$

De keuze om inzage te vorderen in het kader van een voorlopige voorziening binnen de lopende bodemprocedure dan wel in het kader van een incident heeft, in elk geval in theorie, belangrijke gevolgen. Van het oordeel omtrent een voorlopige voorziening gegeven in een bodemprocedure, kan men op grond van art. 337 lid $1 \mathrm{Rv}$ zonder verlof van de rechtbank in hoger beroep. Van een vonnis in een incident kan men niet in hoger beroep indien er geen tussentijds verlof wordt gegeven. ${ }^{13}$ Het lijkt er echter op dat in elk geval vier hoven deze hoofdregel nuanceren. De hoven Den Haag en Den Bosch achten een hoger beroep tegen een incidenteel tussenvonnis waarin de inzage is toegestaan ontvankelijk. ${ }^{14}$ Het hof Den Bosch heeft dit het meest uitvoerig gemotiveerd en wel als volgt. Rolfers is de partij die in eerste aanleg in een incident inzage heeft gevorderd. Deze vordering was toegewezen. De wederpartij Comepsa stelt tegen dat incidenteel vonnis hoger beroep in. Het hof Den Bosch oordeelt dat Rolfers de inzage ook in een dagvaardingsprocedure had kunnen instellen waarop vervolgens bij eindvonnis zou zijn beslist waartegen wel een rechtsmiddel had opengestaan. Het hof is daarom van oordeel dat Comepsa door de keuze van Rolfers om voor de exhibitievordering bij wege van incident te kiezen in plaats van een aparte dagvaardingsprocedure, door deze keuze, waarop zij geen invloed kan uitoefenen, van een onmiddellijk rechtsmiddel zou kunnen worden beroofd. Bij het instellen van onmiddellijk hoger beroep tegen dit incidenteel vonnis kan Comepsa ook belang hebben omdat de in het incidentele vonnis neergelegde verplichting onmiddellijk uitvoerbaar is, desgevorderd zelfs onder verbeurte van een dwangsom. Dit pleit ervoor om de incidentele exhibitievordering als een zelfstandig onderdeel aan te merken.

Deze motivering kan alleen maar gelden indien het hoger beroep een tussenvonnis betreft waarin de incidentele vordering tot inzage is toegewezen. Het hof Amsterdam overweegt in een zaak waarin een incidentele inzagevordering is afgewezen, waartegen eiser in het incident (tevens eiser in de hoofdprocedure) hoger beroep heeft ingesteld, dat dit incidentele vonnis een tussenvonnis is en dat het feit dat het een vordering betreft die ook in een zelfstandige procedure ingesteld had kunnen worden, dit niet anders maakt. Er staat dan ook geen hoger beroep open. Het hof overweegt verder als volgt:

12 Rb Utrecht 18 maart 2009, BH6128.

13 Behoudens natuurlijk indien de rechter zich op grond van een ingesteld incident bijvoorbeeld onbevoegd heeft verklaard.

14 Hof Den Haag 25 oktober 2005, AU8485, NJF 2005, 452, SES 2006, 54 en hof Den Bosch 23 oktober 2007, BB6845. 
'Het hof is zich ervan bewust dat het in vergelijkbare gevallen ... de desbetreffende appellanten in hun tussentijds hoger beroep ontvankelijk heeft geacht. In die gevallen had de rechtbank echter, anders dan in het onderhavige geval, de incidentele vordering ex art. 843a Rv toegewezen. Het niet openstellen van tussentijds hoger beroep zou dan tot onherstelbare en daarmee onaanvaardbaar te achten gevolgen voor de gedaagde partij hebben kunnen leiden, ... ${ }^{15}$

Het hof Arnhem lijkt deze lijn ook te volgen omdat het in een hoger beroep, ingesteld door een eiser in het incident ex art. 843a Rv wiens vordering was afgewezen, allereerst de zaak weer naar de rol verwijst om appellant in de gelegenheid te stellen om stukken over te leggen waaruit blijkt dat de rechtbank hem verlof heeft verleend tot het instellen van het hoger beroep. ${ }^{16}$

Ik vind deze buitenwettelijke appelmogelijkheid te ver gaan. Er zijn wel meer incidentele vorderingen met verregaande gevolgen en de wens van de wetgever in 2002 hield juist duidelijk in dat een snelle procesgang voorrang heeft op de wens om appel in te stellen van allerlei vonnissen die geen eindvonnis in de zin van art. 337 lid 2 Rv zijn. Dit probleem behoort via de 'Koninklijke' weg te worden opgelost en wel door de rechter tijdig te verzoeken om op de voet van art. 337 lid 2 Rv te bepalen dat van het incidenteel tussenvonnis hoger beroep kan worden ingesteld. ${ }^{17}$ Dat is de juiste gang van zaken en die gang verdient vanwege zijn rechtszekerheid de voorkeur boven casuïstische oordelen over de vraag of de inhoud van een incident belangrijk genoeg is om buitenwettelijk appel toe te staan.

15 Hof Amsterdam 30 september 2008, BG4368. Een dergelijke a-symetrie is ook te zien bij de appelmogelijkheid van een getuige die een beroep doet op zijn verschoningsrecht. Van een toewijzing van dat beroep kunnen partijen alleen in appel gelijk met de einduitspraak; van een afwijzing van dat beroep kan alleen de getuige in hoger beroep, HR 17 november 1966, NJ 1967, 223, HR 17 november 1966, NJ 1967, 224 en HR 7 april 1967, NJ 1967, 225, m.nt. D.J.V. en HR 17 januari 1986, NJ 1987, 352, m.nt. W.L.H.

16 Hof Arnhem 2 december 2008, BH2816. Hof Den Bosch 21 juli 2009, BK3127 komt ook tot nietontvankelijkheid in een appel ingesteld tegen een incidenteel vonnis waarbij de vordering tot inzage was afgewezen.

17 Zie ook F.J.H. Hovens in zijn noot onder hof Den Bosch 12 december 2002, JBPR 2003, 47. Om de verwarring compleet te maken: het hof Leeuwarden 16 juni 2009, BI8910 oordeelt dat wel appel kan worden ingesteld tegen een incidenteel vonnis waarin een vordering ex art. 843a Rv werd afgewezen, omdat over die vordering definitief is beslist. Het hof Arnhem, nevenzittingsplaats Leeuwarden 16 maart 2010, zaaknr. 200.047.647/01 oordeelt met expliciete verwijzing naar voornoemde uitspraak van hof Leeuwarden 16 juni 2009, BI8910 tegengesteld, en oordeelt zelfs '... dat het in dit opzicht maken van een onderscheid tussen toe-of afwijzen van de vordering geen steun vindt in de wet. Voorts overweegt het hof dat de in genoemde hofuitspraken (nt Sijmonsma: hof Den Bosch 21 juli 2009, BK3127 en hof Amsterdam 30 september 2008 (en niet 2009 zoals in de uitspraak is vermeld) BG4368) bedoelde mogelijke nadelige gevolgen voor de gedaagde in geval van een toewijzing ook kunnen dienen ter onderbouwing van een verzoek door de gedaagde aan de rechtbank om tussentijds appel open te stellen. De vraag tot welke gevolgen deze gezichtspunten leiden voor de mogelijkheid van een tussentijds appel van een toewijzende beslissing ligt thans niet voor en laat het hof dan ook onbeantwoord.' 
De Hoge Raad is van oordeel dat een vordering tot inzage niet met zoveel woorden gedaan hoeft te worden om toch als een zodanige vordering te worden uitgelegd. Zo leest hij zelfs een vordering tot inzage ex art. 843a Rv in een zaak waar tijdens de hele procedure tot en met het arrest van het hof dat artikel niet expliciet is genoemd. ${ }^{18}$ Het hof overweegt in deze zaak namelijk slechts dat Meijer, mede gelet op het feit dat hij drie getuigen heeft doen horen, onvoldoende heeft gesteld om de conclusie te kunnen wettigen dat hij in redelijkheid slechts bewijs zou kunnen leveren aan de hand van de in bezit van Cornelis zijnde gegevens. Indien hij dit bewijs slechts aldus zou hebben kunnen leveren zouden de eisen van een goede procesorde met zich hebben gebracht dat Cornelis hem de gegevens uit de vaartijdenboek ter beschikking had behoren te stellen.

Deze overweging van het hof sluit volgens mij niet zodanig bij de tekst van art. 843a Rv aan dat eruit afgeleid kan worden dat er expliciet een vordering op voet van art. 843a $\mathrm{Rv}$ is gedaan, noch dat het hof hieraan getoetst heeft. Ten eerste vormt art. 843a Rv een zelfstandige grondslag en is het dus niet nodig om de eisen van een goede procesorde te vermelden. Ten tweede dient er op grond van de tekst van art. 843a Rv in elk geval een vordering of verzoek te worden ingesteld. Dat lijkt ook vanzelfsprekend omdat het immers niet de rechter is die bewijs verzamelt. Ten slotte is het door het hof geformuleerde criterium, dat 'hij in redelijkheid slechts bewijs zou kunnen leveren aan de hand van het vaartijdenboek' niet gelijk aan wat lid 4 van art. 843a Rv vermeldt. Daar staat immers 'indien redelijkerwijs aangenomen kan worden dat een behoorlijke rechtsbedeling ook zonder verschaffing van de gevraagde gegevens is gewaarborgd'.

Het cassatiemiddel verwijst wel naar art. 843a Rv. Daarin wordt namelijk gesteld dat Meijer het vaartijdenboek vóór de bewijslevering al had gevorderd bij akte. Bij die vordering, aldus het cassatiemiddel, hoefde Meijer niet aan te geven waarom hij in redelijkheid slechts bewijs kon leveren aan de hand van het vaartijdenboek. Cornelis had zondermeer de exhibitieplicht.

AG Strikwerda is van mening dat het hof de vraag of Cornelis het vaartijdenboek aan Meijer ter beschikking had moeten stellen, heeft getoetst aan art. 843a Rv. Hij komt vervolgens tot de conclusie dat het hof kennelijk toepassing heeft gegeven aan lid 4 van dat artikel en dat die toepassing niet onjuist is.

De Hoge Raad is pragmatisch en overweegt dat het hof kennelijk het verzoek van Meijer om Cornelis te gelasten het vaartijdenboek over te leggen, heeft opgevat als een vordering tot exhibitie op grond van art. 843a Rv.

18 HR 6 oktober 2006, NJ 2006, 547 en AA 2007, p. 371-374. Het arrest is ook besproken door K. Teuben in MvV 2006, p. 218-221. Gelet op dit arrest is het mij niet duidelijk waarom de Hoge Raad in zijn arrest van 27 maart 2009, BH1986 bij een op het echtscheidingsconvenant gebaseerde verzoek van de man aan de vrouw om bepaalde bescheiden over te leggen overweegt dat het verzoek betreffende de overlegging van stukken er bovendien in wezen toe strekt dat de rechter wordt verzocht om gebruik te maken van zijn in art. $22 \mathrm{Rv}$ neergelegde bevoegdheid om de vrouw te bevelen bepaalde stukken over te leggen. 
Het gemak waarmee de Hoge Raad concludeert dat er kennelijk een vordering op de voet van art. 843a Rv is gedaan, doet vermoeden dat een dergelijke vordering in tamelijk vage woorden kan worden gedaan, en de rechter een dergelijke vordering snel mag, misschien zelfs wel moet, inlezen. Er hoeft kennelijk niet met zoveel woorden een incident te worden ingesteld. In het kader van het vinden van de materiële waarheid valt dit te prijzen, met dien verstande dat in een dergelijk geval volgens mij het beginsel van hoor en wederhoor als één van de concrete normen van de eisen van een goede procesorde, meebrengt dat de rechter die in een bepaalde stelling een vordering op voet van art. 843a Rv leest, de wederpartij die geen reactie heeft gegeven, expliciet de mogelijkheid geeft om alsnog te reageren. Een dergelijke reactie is zeker nodig omdat de Hoge Raad vervolgens in dit arrest overweegt dat Cornelis geen bezwaren heeft geopperd tegen overlegging door hem van het vaartijdenboek zodat het hof niet de bevoegdheid had om de toewijsbaarheid van de vordering van Meijer te toetsen aan lid 4 van art. 843a Rv.

Ik merk nog op dat de overweging van de Hoge Raad in het arrest van 6 oktober 2006, NJ 2006, 547 dat niet 'ambtshalve' mag worden bezien of alle bestanddelen aanwezig zijn, niet algemeen bekend lijkt te zijn. Er is tenminste een keur aan uitspraken waarin de rechter(s) hun oordeel over een verzoek tot inzage beginnen met de overweging dat voorop wordt gesteld dat, wil een vordering ex artikel 843a Rv kunnen worden toegewezen, in de eerste plaats aan alle drie (volgens sommige rechter(s) vier) in lid 1 van dit artikel gestelde voorwaarden moet zijn voldaan én dat de uitzonderingen van de leden 3 en 4 (de geheimhouders respectievelijk de gewichtige redenen of redelijkerwijs kan worden aangenomen dat een behoorlijke rechtsbedeling ook zonder verschaffing van de gevraagde gegevens is gewaarborgd) zich niet mogen voordoen. ${ }^{19}$ Vervolgens begint het 'afvinken' van alle bestanddelen. Dat is geen juiste procesgang: indien de wederpartij niet aanvoert dat niet is voldaan aan bepaalde bestanddelen, valt er niets af te vinken. Slechts de tegen de inzagevordering gevoerde verweren behoeven behandeling.

Ook het hof Leeuwarden lijkt vrij makkelijk een opmerking uit te leggen als een verzoek tot inzage. Zo spreekt dit hof in een kort geding over 'Het verholen verzoek van geïntimeerde dat Eternit haar dealerslijst uit (de) desbetreffende perioden in het geding moet brengen,... $\cdot{ }^{20}$ Gelet op de belangen van de wederpartij, die alleen al vanwege het beginsel van hoor en wederhoor redelijkerwijs moet hebben kunnen begrijpen dat met bepaalde woorden een verzoek tot inzage wordt gedaan, mag een verzoek niet al te verhullend worden gedaan. Een goed voorbeeld is te vinden in HR 25 januari $2008 .{ }^{21}$ In deze zaak werd als cassatiemiddel voorgedragen dat het hof heeft nagelaten een beslissing te geven op het verzoek van de man in zijn brief an het hof om bepaalde bewijsstukken in het geding te

19 Bijvoorbeeld Rb Rotterdam 4 maart 2009, BH5652.

20 Hof Leeuwarden 13 januari 2009, BH2762.

21 HR 25 januari 2008, BC1256, de HR doet de zaak af met art. 81 RO. 
brengen. Volgens het middel 'doet' het aan het hof gedane verzoek 'denken aan' de artikelen 843a en b Rv. De klacht houdt vervolgens in dat de beschikkingen om deze reden onvoldoende gemotiveerd zijn. AG Langemeijer constateert dat geen vordering ex art. 843a en/of b Rv is ingediend en dat, anders dan in HR 6 oktober 2006, NJ 2006, 547 (Meijer-VOF Gebr. Cornelis) waar het hof een uitlating wel had opgevat als een exhibitievordering, in het onderhavige geval het hof de passage in de brief van de man aan het hof niet heeft opgevat als een vordering of verzoek als bedoeld in art. 843a Rv. De passage in die brief luidde:

'Een aantal nota's heeft de man in het begin van de procedure overhandigd aan de raadsvrouw van de vrouw en zijn derhalve niet (meer) in zijn bezit. De vrouw wordt hierbij uitgenodigd deze nota's in het geding te brengen. Het gaat om nota's van ... en de nota's met betrekking tot het aanbrengen van het alarm en de open haard.'

De AG is van mening dat de 'uitnodiging' in de brief niet kan worden uitgelegd als een vordering als in art. 843a Rv bedoeld omdat dan minstens sprake moet zijn van een sommatie, in elk geval van meer dan een vrijblijvend verzoek. Hij vindt het niet onbegrijpelijk dat het hof in deze uitnodiging niet een vordering in de zin van art. 843a Rv heeft gelezen. ${ }^{22}$

Ik ben dan ook geneigd te zeggen dat het woord vorderen in dit artikel niet letterlijk mag worden genomen, zodat analoog aan de regels ter zake bijvoorbeeld het voorlopig getuigenverhoor, een zelfstandig ingediend verzoekschrift tot een veroordeling tot inzage moet kunnen leiden. De Adviescommissie voor het Burgerlijk Procesrecht denkt daar kennelijk anders over. De Commissie schrijft namelijk dat voorafgaand aan de procedure een 'art. 843a-voorziening' kan worden gevraagd

22 Zie ook Rb Amsterdam 18 januari 2005, JBPR 2006, 56. De rolrechter had daar een incident aangemerkt als een art. 843a Rv verzoek. De rechter die vervolgens vonnis in het incident wees, overwoog dat die kwalificatie ten onrechte was geschied omdat de aanhef van de incidentele conclusie slechts melding maakte van de artikelen 21 en $22 \mathrm{Rv}$ en de bewoordingen van de conclusie en het petitum op geen enkele manier aansloten aan het in art. 843a Rv bepaalde. AG Spier schrijft in zijn conclusie bij HR 31 oktober 2008, BF1179 dat eiser van Dexia overlegging van geluidsbanden vordert, maar dat deze vordering enkel is gebaseerd op de artt. 22 en $162 \mathrm{Rv}$ en dat eiser niet het oog had op een vordering ex art. 843a Rv hetgeen volgens hem mede valt af te leiden uit de omstandigheid dat eiser niet heeft aangeboden om de kosten als bedoeld in art. $843 \mathrm{a}$ lid $1 \mathrm{Rv}$ te dragen. Rb Dordrecht 12 juni 2008, BD4467 overweegt te formalistisch op een expliciet verzoek van Nova in een zaak tegen de Staat der Nederlanden om op grond van art. 843a Rv bepaalde correspondentie over te leggen, dat Nova dit verzoek kennelijk bij wijze van verweer doet terwijl volgens haar een vordering tot inzage of afschrift in beginsel bij dagvaarding of incidentele vordering moet worden ingesteld. In een zaak waarin $\mathrm{X}$, een van fraude en omkoping verdachte ex-werknemer van Crosfield vordert dat het hof Crosfield zal bevelen om bepaalde afroepcontracten over te leggen, overweegt het hof zonder verdere motivering dat het in dit verzoek geen vordering leest als bedoeld in art. 843a Rv (hof Den Bosch 23 december 2008, RAR 2009, 38. 
als voorziening in kort geding en rept niet over de mogelijkheid van een zelfstandig verzoek. ${ }^{23}$

Dat het woord 'vorderen' niet letterlijk mag worden genomen lijkt ook te volgen uit de rechtspraak omdat de Hoge Raad al in 2000 oordeelde dat art. 843a Rv de toewijsbaarheid van de daar bedoelde vordering aan drie cumulatieve voorwaarden verbindt waaronder 'de eiser of verzoeker dient een rechtmatig belang te hebben' ${ }^{24}$ Uit de woorden 'eiser of verzoeker' kan afgeleid worden dat de Hoge Raad van oordeel is dat inzage in een dagvaardingsprocedure kan worden gedaan maar ook in een verzoekschriftprocedure.

Indien mijn conclusie juist is en dus inzage via een verzoekschrift kan worden gevorderd via een weg analoog aan art. $186 \mathrm{Rv}$ (voorlopig getuigenverhoor) en art. $194 \mathrm{Rv}$ (voorlopig deskundigenonderzoek), geldt eens te meer dat een nieuwe regeling zoals Asser, Groen en Vranken bepleiten, niet noodzakelijk is. ${ }^{25}$ Ook Westenberg lijkt ervan uit te gaan dat via een verzoekschrift en zonder dat er al een dagvaardingsprocedure loopt, inzage in bescheiden op de voet van art. 843a Rv kan worden verzocht. ${ }^{26}$

Bij verzoekschrift wendt een werknemer zich tot de rechter-commissaris in het faillissement van Agro Trainingscentrum bv met het verzoek om de curator te bevelen bepaalde stukken uit de administratie aan hem te verstrekken. De werknemer stelt dat de artt. 3:15j BW en/of 843a Rv hem het recht op inzage zouden geven. RC en rechtbank wijzen het verzoek af. AG Verkade schrijft in zijn conclusie, dat art. $69 \mathrm{Fw}$ een beperkte strekking heeft en in beginsel slechts is gegeven om de daarin genoemde invloed tot te kennen op het beheer van de boedel. Via deze weg aan de betreffende informatie komen kan alleen indien zonder meer duidelijk is dat verzoeker in een procedure op de voet van de artt. 3:15j BW en/of $843 \mathrm{a} \mathrm{Rv}$ in het gelijk zou worden gesteld. Daar is geen sprake van. De Hoge Raad doet de zaak af op voet van art. 81 RO. $^{27}$

In hoofdstuk 7 is een aantal uitspraken aan de orde geweest waarin de vordering tot inzage werd afgewezen omdat die vordering prematuur werd geacht. De betreffende rechter was van oordeel dat eerst afgewacht diende te worden of bijvoorbeeld het verweer ter onderbouwing waarvan de inzage werd gevorderd, wel zou worden gevoerd. In dergelijke gevallen mag, nadat het verweer is gevoerd en vervolgens

23 Het woord 'vragen' is overigens wat merkwaardig: in kort geding wordt immers gevorderd.

24 HR 18 februari 2000, NJ 2001, 259, NI-ABN.

25 Asser-Groen-Vranken, Uitgebalanceerd, waar in par. 6.6 onder $\mathrm{h}$ als aanbeveling wordt vermeld dat er aanleiding is om een regeling in te voeren die tot doel heeft een partij te dwingen tot 'disclosure of documents' welke desgewenst en waarnodig op verzoek en onder rechterlijk toezicht, kan worden toegepast. De nieuwe regeling zou dienen aan te sluiten bij hetgeen de Commissie Storme in 1994 ter zake heeft voorgesteld.

26 J.W. Westenberg, Een zoektocht naar de feiten?, p. 42 e.v. in Van der Korst e.a.

27 HR 23 maart 2007, BA0575. 
wederom inzage wordt gevorderd, die vordering niet worden afgewezen op grond van het oordeel dat er een bindende eindbeslissing is gegeven of op grond van het gezag van gewijsde. Daar lijkt de rechtbank Zutphen anders over te denken. In een zaak waarin die betreffende procedure al bij tussenvonnis van 28 juni 2006 een verzoek tot inzage was afgewezen, overwoog de rechtbank bij het later herhaalde verzoek dat de vordering in die zin werd opgevat dat eiser kennelijk stelt dat er sprake is van nieuwe feiten op grond waarvan moet worden teruggekomen op een gegeven eindbeslissing. ${ }^{28}$ Die zin ligt voor de hand, maar de daarop volgende, gelet op de bijzondere aard van het incident, niet. De rechtbank is namelijk van oordeel dat op die eerder gegeven beslissing niet kan worden teruggekomen, behoudens indien bijzondere, door de rechter in zijn desbetreffende beslissing nauwkeurig aan te geven omstandigheden het onaanvaardbaar zouden maken dat de rechter aan de eindbeslissing in kwestie zou zijn gebonden. ${ }^{29}$

Ook rechters doen aan procestactiek. In een moeilijke zaak waarin kennelijk bestuurders door de curator voor het boedeltekort zijn aangesproken, wenst een bestuurder inzage in stukken van de fiscus, zoals belastingaanslagen die zijn verstuurd en/of opgelegd na de datum van het faillissement (of het vertrek van de bestuurder). De rechtbank begint haar oordeel over dit incident met een algemene overweging waarin vermeld wordt dat beide partijen een voldoende toegelicht standpunt hebben, maar gelast vervolgens een comparitie waarbij, ik vind in dreigende procestactiektaal, er

'uitdrukkelijk op gewezen (wordt) dat de onderbouwing van de fiscale schuldenlast niet alleen van belang is voor de procesrechtelijke positie van eiser in het incident maar ook van die van de curator als gedaagde in het incident. Immers de curator zal op enig moment het tekort van de boedel moeten aantonen en in de stellingen van de curator lijkt besloten te liggen dat hij de fiscale schuldenlast niet of slechts moeizaam kan aantonen ....? 30

Ook de beslissing op het verzoek tot inzage wordt vervolgens aangehouden.

Vele uitspraken waarin het verzoek tot inzage wordt toegewezen, worden in kort geding gedaan. Wat indien die inzage is verstrekt terwijl daarna in hoger beroep van die kort geding uitspraak of in een bodemprocedure wordt bepaald dat geen inzage hoeft te worden gegeven? Deze feitelijke situatie heeft zich voorgedaan bij het hof Den Haag. ${ }^{31}$ In die zaak won ICS een arbitrageprocedure waarin zij gebruik had gemaakt van stukken die de Staat der Nederlanden op grond van een

28 Rb Zutphen 11 juni 2008, BD7231.

29 Hetgeen gelet op HR 23 november 2007, NJ 2008, 552 en 25 april 2008, NJ 2008, 553, m.nt. HJS niet meer de juiste toets lijkt te zijn.

30 Rb Rotterdam 18 juni 2008, BD9533.

31 Hof Den Haag 4 mei 2006, NJF 2006, 318, AW8455. 
uitvoerbaar bij voorraad verklaard kort geding vonnis had verstrekt terwijl het hof dit kort geding vonnis vernietigde. De betreffende executie levert een onrechtmatige daad op. ${ }^{32}$ Heeft dit tot gevolg dat de wetenschap verkregen via die onterechte inzage buiten spel dient te blijven? Die vraag raakt het leerstuk van het onrechtmatig verkregen bewijs, een leerstuk dat in het civiele recht nog steeds niet echt doorbreekt. ${ }^{33} \mathrm{Bij}$ dit leerstuk staat voorop dat de Hoge Raad uiterst terughoudend is met het oordeel dat bewijs onrechtmatig is verkregen. ${ }^{34}$ Embregts is terecht van mening dat bij het antwoord op de vraag of bewijs onrechtmatig is verkregen, getoetst kan worden aan de omschrijving van onrechtmatigheid in art. 6:162 lid 2 $\mathrm{BW} .{ }^{35}$ Er is niet gehandeld in strijd met een wettelijke plicht indien inzage is verkregen op grond van een uitspraak die later is vernietigd.

Een uitgeoefend recht op inzage, welk recht later is vernietigd, kan wel een inbreuk op een recht vormen in de zin van art. 6:162 lid 2 BW. Inbreuk op een vermogensrecht is niet goed denkbaar: het eigendomsrecht is immers niet aangetast omdat iemand inzage heeft gehad of een afschrift heeft gemaakt. Door de inzage kan wel inbreuk zijn gemaakt op een persoonlijkheidsrecht als bescherming van de persoonlijke levenssfeer, de privacy. De in de één na laatste voetnoot genoemde arresten geven niet onmiddellijk aanleiding voor de verwachting dat de Hoge Raad in het geval dat een verkregen recht op inzage later is vernietigd, zal oordelen dat door de inzage een zodanige inbreuk op een persoonlijkheidsrecht is gemaakt, dat het door de inzage verkregen materiaal als onrechtmatig verkregen moet worden gekwalificeerd.

Ik acht de inbreuk die is gemaakt door de uitoefening van een door de rechter gegeven recht op inzage, welk recht later is vernietigd, evenmin zodanig groot dat de conclusie kan worden getrokken dat degene die inzage heeft gehad, heeft gehandeld in strijd met hetgeen hem volgens ongeschreven recht in het maatschappelijk verkeer betaamt. Het vonnis waarin toestemming tot inzage werd gegeven, ook al is het vernietigd, acht ik daarvoor een te grote sta in de weg.

Indien toch tot de conclusie wordt gekomen dat het uit die inzage verkregen materiaal onrechtmatig is verkregen, betekent dit niet, zoals Vranken onder het

32 Hoge Raad 16 november 1984, NJ 1985, 547.

33 Aldus W.D.H. Asser in zijn Kroniek van de rechtspleging, NJB 2002, p. 490-499, waar hij overigens blij mee is. Zie wel M. Kremer, Onrechtmatig verkregen bewijs in civiele zaken, serie civiele procespraktijk, Tjeenk Willink 1999 en M.C.D. Embregts, Uitsluitsel over bewijsuitsluiting, Kluwer-Deventer 2003.

34 Zie onder meer HR 16 oktober 1987, NJ 1988, 850 (clandestiene bandopname van een telefoongesprek tussen latere procespartijen), HR 7 februari 1992, NJ 1993, 78, m.nt. H.J.S. (Slemkes-Nool, de al dan niet laakbaar verkregen bandopname van een telefoongesprek), HR 31 mei 2002, NJ 2003, 589, m.nt. J.B.M.V. (het Observatiearrest), en, voor de volledigheid, HR 23 mei 1986, NJ 1987, 702, m.nt. E.A.A. (FIOD-arrest).

35 M.C.D. Embregts, Uitsluitsel over bewijsuitsluiting, Kluwer Deventer-2003, p. 56 e.v. 
Observatiearrest ${ }^{36}$ terecht annoteert, dat het bewijsmateriaal vervolgens ook ontoelaatbaar is. Voordat die conclusie kan worden bereikt, moet eerst de afweging worden gemaakt tussen enerzijds de grofheid van de onrechtmatigheid en anderzijds het belang van de waarheidsvinding. Ik acht die waarheidsvinding zo'n groot goed dat in beginsel het onrechtmatig verkregen bewijs wel toelaatbaar is ${ }^{37}$ Dit beginsel wijkt indien de onrechtmatigheid is gelegen in schending van fundamentele rechten. Zie bijvoorbeeld het hiervoor in par. 6.3 gegeven voorbeeld van het onrechtmatig verkregen DNA of bloedmonster.

Global, gevestigd te Mauritius, heeft met Sungleam als owner een tijdbevrachtingovereenkomst gesloten, die is onderworpen aan Engels recht. Met toestemming van de rechter legt Global conservatoir beslag tot afgifte van scheepstoebehoren omdat Global pretendeert een vordering te hebben omdat de boot te langzaam vaart. Nederlands recht is niet van toepassing, maar de vraag rijst of art. 31 EEX-verordening van toepassing is. De rechtbank overweegt dat de vordering tot inzage van bescheiden niet kan worden beschouwd als een bewarende of voorlopige maatregel in de zin van art. $31 \mathrm{EEX}$-verordening omdat dit artikel een beperkte strekking heeft en primair tot doel heeft om rechten in een bodemprocedure veilig te stellen. Daaronder valt niet te verstaan een vordering die feitelijk enkel ten doel heeft inzicht te verkrijgen in een bewijspositie. ${ }^{38}$

Een processuele verwikkeling is de verhouding tussen art. 1019b Rv enerzijds en de artikelen 1019a en 843a Rv anderzijds. Het hof Den Bosch overweegt ter zake dat zowel de communautaire als de Nederlandse wetgever bewust onderscheid heeft gemaakt tussen maatregelen ter bescherming van bewijs en voorzieningen om inzage te krijgen. In de toelichting op die artikelen is, aldus het hof, bepaald geen steun te vinden voor de opvatting dat de bewijsbeschermende maatregelen van art. 1019b e.v. Rv de beslaglegger tevens een automatisch inzagerecht geven. Na het beslag op de voet van art. $1019 \mathrm{~b} \mathrm{Rv}$ zal dus in een afzonderlijke procedure inzage gevorderd moeten worden. Het bewijsbeslag brengt geen inzagerecht met zich, daarvoor

36 HR 31 mei 2002, NJ 2003, 589. Vergelijk ook EHRM 12 juli 1988, NJ 1988, 851, m.nt. E.A.A. (Schenk-Zwitserland) waarin het Hof overwoog dat het gebruik van onrechtmatig verkregen bewijs geen schending van het fair trial beginsel hoeft te betekenen.

37 Zie echter hof Den Bosch 8 december 2009, BK7639 overwegende dat informatie die is verkregen op grond van een tenuitvoergelegd verlof om een bewijsbeschermende maatregel te nemen, niet mag worden gebruikt in het kader van de beoordeling van de vraag of het toenmalig verlof terecht is gegeven. Het hof overweegt als volgt: 'Het kan immers niet zo zijn dat een partij die bewijsbeschermende maatregelen treft en - geconfronteerd met door de wederpartij in een kort geding aangevoerde feiten en omstandigheden op grond waarvan de maatregelen niet getroffen hadden mogen worden- de resultaten van de litigieuze maatregelen gebruikt ter onderbouwing van de rechtmatigheid daarvan.'.

$38 \mathrm{Rb}$ Rotterdam 21 oktober 2008, BG1066, tevens overwegende dat toestemming tot inzage bezwaarlijk als een voorlopige maatregel kan worden gezien, nu de gevolgen onomkeerbaar zijn. 
dient in een afzonderlijke op basis van de artt. 1019a en 843a Rv te starten procedure toestemming te worden gevraagd. ${ }^{39}$ Die vordering tot inzage hoeft volgens het hof, terecht, niet in een bodemprocedure te worden ingesteld. Die inzagevordering kan ook worden gedaan in het kader van een kort geding.

De Hoge Raad is van oordeel dat de arbitrageprocedure niet past in het keurslijf van art. 843a Rv. Hij oordeelt in een zaak waarin een bij een arbitrage betrokken partij van arbiters een volledig afschrift vordert van het originele verslag van de hoorzitting van het gerecht, dat de procedure die bij een arbitrage-overeenkomst in acht moet worden genomen is uitgewerkt in de desbetreffende bepalingen in het Wetboek van Burgerlijke Rechtsvordering en het eventueel tussen partijen overeengekomen arbitragereglement. Daarbinnen hebben de arbiters beleidsvrijheid die, gelet op de aard van de arbitrageprocedure, niet kan worden doorkruist door een beroep op het algemeen geformuleerde, en niet specifiek op het arbitrale beding toegesneden, art. $843 \mathrm{a} \mathrm{Rv.}{ }^{40}$

39 Hof Den Bosch 17 maart 2009, B9 7704 (te vinden via www.boek9.nl, in zoekvenster invoeren 7704).

40 HR 29 januari 2010, BK2007. Rb Rotterdam 24 juni 2009, NJF 2010, 31 oordeelt dat naast art. 69 Fw (bepalend dat onder meer schuldeisers een door de rechter-commissaris aan de curator te geven bevel kunnen uitlokken om een bepaalde handeling te verrichten) het volgen van een art. 843a $\mathrm{Rv}$ verzoek mogelijk is omdat beide artikelen anderen doelen beogen te behartigen (respectievelijk invloed op de boedel en bewijsbelang). 



\section{Een eigen ontwerp}

Al het voorgaande in beschouwing nemend, ben ik van mening dat een artikel waarin het recht op inzage wordt neergelegd, een ruime bevoegdheid moet geven, zodat de procesdeelnemers bewijs kunnen vergaren, bewijs veilig stellen en inzage in bewijsstukken kunnen krijgen. Partijen en de rechter moeten voldoende instrumenten in handen hebben om de materiële waarheid te kunnen vinden. De rechter moet hierbij, gelet op het principe van de partijautonomie, niet meer kunnen vragen dan een procespartij. Hij mag wel ambtshalve inzage vragen, maar een uitspraak als die van de rechtbank Arnhem van 29 september 2004, ${ }^{1}$ waarbij een inzagevordering in financieringsaanvragen werd afgewezen, maar gedaagde vervolgens op de voet van art. 22 Rv werd gelast om die aanvragen in het kader van een comparitie in het geding te brengen, vind ik ongewenst. Een rechter mag dus ambtshalve vragen wat een partij niet heeft gevraagd, maar niet dat wat een partij niet mag vragen.

In het kader van het bewijsrecht, waar het recht op inzage onder valt zodat dit recht ook opgenomen moet worden in de paragraaf waarin de algemene bepalingen van het bewijsrecht worden geregeld, ${ }^{2}$ dient inzage in alle objecten die bewijs kunnen inhouden of dragen gevraagd te kunnen worden. Een flesje parfum of sportschoenen voor onderzoek naar de vraag of het product vervalst is, een foto, een $\mathrm{cd}, \mathrm{dvd}$, maar ook een auto die bij een botsing is betrokken of kledingstukken die misschien zijn gedragen bij een vechtpartij waarbij bloed is gevloeid, en ook de hond die mij heeft gebeten om aan de hand van bijvoorbeeld gebitafdrukken te kunnen vaststellen dat het inderdaad die hond is geweest die mij heeft gebeten. ${ }^{3}$ Om deze bewijsmiddelen te kunnen verkrijgen, dient een algemeen bewijsbeslag gelegd te kunnen worden, ook op bijvoorbeeld een tandenborstel waarin speeksel kan zitten of een haarborstel waarin haren kunnen zitten.

Ik zie geen bezwaar tegen overname van een artikel als art. 142 Rv-NA\&A. Een dergelijk artikel is passend in een stelsel waarin een ieder als getuige kan

Rb Arnhem 29 september 2004, AR3532, zie par. 8.4.1.

2 Zo ook M. de Tombe-Grootenhuis, Voorstel voor een Europese disclosure, Liber Amicorum Paul Meijknecht, van Nederlands naar Europees procesrecht?!, onder redeactie van E.H. Hondius, A.W. Jongbloed en R.Ch. Verschuur, Deventer, Kluwer 2000, p. 309 en de ABP.

3 Vergelijk ook het voorbeeld van Ligtenberg over de hond die vlees steelt zoals is vermeld in par. 2.1.3. 
worden gedagvaard. Ik zie dan geen te rechtvaardigen onderscheid waarom geen inzage in objecten die iemand onder zich heeft, gevorderd zou kunnen worden.

Het valt niet uit te sluiten dat er vanuit de EG nog de nodige Richtlijnen zullen komen die direct of indirect van invloed zijn op het terrein van het inzagerecht. Bij wijze van voorbeeld noem ik de kennelijk bestaande wensen om het procesrecht in verschillende stromen in te delen zoals snelrecht, consumentenrecht, diepgravende procedures, enz. Om die reden lijkt het minder opportuun om nu al een volledig nieuwe regeling voor te stellen. Dat zou de rechtszekerheid niet bevorderen. Een beperkte wijziging van de regeling van het inzagerecht lijkt wel noodzakelijk. Zolang vanuit bijvoorbeeld de EG via Richtlijnen nog geen verplichting tot disclosure-achtige maatregelen worden opgelegd, vind ik het niet gewenst om een disclosurebepaling op te nemen. Een dergelijke procedure is kostbaar en tijdrovend, terwijl de noodzaak voor een dergelijke procedure nog onvoldoende is gebleken gelet op de stand van zaken in de jurisprudentie omtrent art. 843a Rv. Medestanders vind ik in onder andere Ynzonides, die schrijft dat de procesvoering bepaald gediend zou zijn met een ruimere toepassing van art. 843a Rv, zonder op te schuiven naar ongewenste vistochten of naar Angelsaksich model opgetuigde discovery verplichtingen. Naar zijn mening gaat de Commissie Asser-Vranken-Groen in haar eindrapport Uitgebalanceerd verder dan gewenst, omdat doorgaans pas in de loop van de procedure zal blijken of een eiser echt een zaak heeft, en welke documenten noodzakelijk zijn. Dit proces moet, aldus Ynzonides, niet al te veel naar voren worden gehaald. ${ }^{4}$ Ik onderschrijf die opvatting, met dien verstande dat dit niet alleen voor de eisende partij geldt, maar ook voor de gedaagde partij. Ook die doet regelmatig een vordering tot inzage. Dezelfde mening als Ynzonides heeft Ekelmans die wars is van te grote veranderingen en verkondigt dat de praktijk inmiddels tegen lage kosten tot een bevredigend resultaat komt wat de toepassing van art. 843a Rv betreft. ${ }^{5}$

Het uit de wet verwijderen van het bestanddeel 'rechtsbetrekking waarin hij partij is', zoals von Schmidt auf Altenstadt verdedigt, ${ }^{6}$ gaat mij te ver. Uit de jurisprudentie blijkt dat het een nuttige en aanvaarbare begrenzing geeft, welke bij een ruimhartige uitleg zoals ik hiervoor heb verdedigd, geen sta in de weg is.

Het voorstel van De Tombe-Grootenhuis om partijen te verplichten om bij de aanvang van het geding de voor de beslissing van het geding relevante bescheiden over te leggen, ${ }^{7}$ acht ik minder bruikbaar omdat de kans groot is dat onnodige Juridische uitgevers Den Haag, 2006.

5 Ekelmans (boek), p. 68.

P.J.M. von Schmidt auf Altenstadt, Opening van zaken, TCR 2002, p.13.

7 M. de Tombe-Grootenhuis, Voorstel voor een Europese disclosure, Liber Amicorum Paul Meijknecht, van Nederlands naar Europees procesrecht?!, onder redeactie van E.H. Hondius, A.W. Jongbloed en R.Ch. Verschuur, Deventer, Kluwer 2000, p. 311. 
stukken worden overgelegd. Het komt te vaak voor dat bij de aanvang van een geding, ondanks het bestaan van de mededelingsplicht in art. 111 lid $3 \mathrm{Rv}$, nog onduidelijk is in welke richting de procedure zich begeeft.

Al met al kom ik tot het volgende voorstel.

Artikel 22

1. De rechter kan in alle gevallen en in elke stand van de procedure partijen of een van hen bevelen door hen of een van hen ingenomen stellingen toe te lichten. Partijen kunnen dit weigeren indien daarvoor gewichtige redenen zijn. De rechter beslist of de weigering gerechtvaardigd is, bij gebreke waarvan hij daaruit de gevolgtrekking kan maken die hij geraden acht.

2. De rechter kan in alle gevallen en in elke stand van de procedure partijen of een van hen bevelen die voorwerpen over te leggen waarvan een partij op de voet van artikel 155a inzage, afschrift, uittreksel, overlegging of onderzoek kan verlangen. Op dit bevel zijn de bepalingen van artikel 155a van toepassing.

Artikel $155 a$

1. Hij die daarbij rechtmatig belang heeft, kan op zijn kosten inzage, afschrift, uittreksel, overlegging of onderzoek vorderen van informatie zich bevindend in, op of aan bepaalde voorwerpen aangaande een rechtsbetrekking waarbij hij of zijn rechtsvoorgangers zijn betrokken, van degene die deze voorwerpen te zijner beschikking of onder zijn berusting heeft.

2. De rechter kan op vordering van een partij op diens kosten aan een ander dan partijen, na deze te hebben gehoord of daartoe de gelegenheid te hebben gegeven, bevelen binnen een door de rechter te stellen termijn schriftelijk inlichtingen te verschaffen en voorwerpen over te leggen die deze ander te zijner beschikking of onder zijn berusting heeft.

3. De rechter bepaalt, zo nodig, de wijze waarop, en de voorwaarden waaronder aan het op grond van het eerste of tweede lid gegeven bevel gehoor moet worden gegeven. De rechter kan aan het op grond van het eerste of tweede lid gegeven bevel een dwangsom verbinden. Aan het op grond van het tweede lid gegeven bevel kan hij eveneens gijzeling overeenkomstig artikel 173 verbinden. Indien het op grond van het eerste of tweede lid gegeven bevel niet wordt opgevolgd, kan de rechter bovendien daaruit de gevolgtrekking maken die hij geraden acht.

4. Hij die uit hoofde van zijn ambt, beroep of betrekking tot geheimhouding verplicht is, is niet gehouden aan de in het eerste of tweede lid bedoelde vordering te voldoen, indien de bescheiden uitsluitend uit dien hoofde te zijner beschikking staan of onder zijn berusting zijn. 
5. Degene tot wie de in het eerste of tweede lid bedoelde vordering is gericht, is niet gehouden aan deze vordering te voldoen, indien daarvoor gewichtige redenen zijn.

6. Onder voorwerpen in de zin van dit artikel worden mede verstaan: bescheiden of andere gegevensdragers, dragers van natuurlijke gegevens inbegrepen.

Artikel $155 b$

1. De in artikel 155a bedoelde vordering kan worden ingesteld als incidentele vordering op elk moment tijdens de procedure of als zelfstandige vordering, ook in kort geding.

2. De rechter is bevoegd zijn beslissing op de vordering in het incident als bedoeld in het eerste lid ambtshalve aan te houden in afwachting van de uitkomst van andere bewijsverkrijgende maatregelen.

Zevende afdeling

Van conservatoir beslag tot afgifte van zaken en levering van goederen en van beslag ter inzage op de voet van artikel 155a

\section{Artikel 730}

Ieder die recht heeft op afgifte van een roerende zaak of levering van een goed of die zodanig recht door een rechterlijke uitspraak tot vernietiging of ontbinding kan verkrijgen, dan wel op de voet van artikel 155a inzage, afschrift, uittreksel, overlegging of onderzoek van een voorwerp kan vorderen, kan deze zaak of dit goed ter bewaring van dit recht, of dit voorwerp ter inzage, afschrift, uittreksel, overlegging of onderzoek in beslag nemen.

\section{Artikel $730 a$}

1. Op het in artikel 730 op de voet van artikel 155 a te leggen en gelegde beslag zijn de artikelen 700, eerste en derde lid, 701, 702, 703, 705, 706 en 709 van overeenkomstige toepassing.

2. Het verlof om beslag op de voet van artikel $155 \mathrm{a}$ te mogen leggen wordt verzocht bij verzoekschrift waarin de aard van het te leggen beslag en de reden daarvoor worden vermeld. De voorzieningenrechter beslist na summier onderzoek. Bij het verlof kan de voorzieningenrechter, onverminderd artikel 64, derde lid, tevens verlof verlenen het beslag te leggen op alle dagen en uren. Tegen een krachtens dit artikel gegeven verlof is geen hogere voorziening toegelaten.

3. Wordt de vordering ex artikel 155a in de hoofdzaak afgewezen, en is deze afwijzing in kracht van gewijsde gegaan, dan vervalt daardoor tevens van rechtswege het beslag. 


\section{Samenvatting}

Dit proefschrift is de neerslag van een onderzoek naar de vraag of er een recht bestaat op het verkrijgen van informatie die in handen is van een ander en, zo ja, welke omstandigheden recht op informatie (hierna het recht op inzage of inzagerecht) geven en de reikwijdte van dit recht op inzage. Tevens komt aan de orde de plaats die dit recht op inzage heeft in ons burgerlijk (proces)recht.

In hoofdstuk 2 wordt een beknopt overzicht gegeven van de geschiedenis van het inzagerecht in Nederland. Het inzagerecht is in Nederland voor het eerst verwoord in het op 22 november 1820 aan de Staten Generaal aangeboden ontwerp Burgerlijk Wetboek. Het recht is in dat ontwerp neergelegd in de artikelen 3344 tot en met 3347 BW. Het ontwerp is nooit wet geworden.

Het evenmin in werking getreden BW van 1825 bevat ook een regeling voor het recht op inzage en wel in de artikelen 19 en 24 van de eerste titel van het vierde boek. Deze twee artikelen geven een ruim recht op inzage, waarin de vraag wie eigenaar van het stuk is, niet van belang is. De wetgever had de bedoeling om aan een ieder die bewijsrechtelijke belangen had bij de inhoud van een stuk, het recht te geven op inzage in dat stuk en/of om een afschrift van de inhoud van dat stuk te maken.

Het derde niet in werking getreden ontwerp Burgerlijk Wetboek, dat van 1830, kent een inzagerecht in art. 1932. Inhoudelijk geeft dit artikel een bijna ongeclausuleerd recht op inzage, waarbij ook een derde die een stuk in bezit heeft, verplicht kan worden om inzage in dat stuk te geven aan een partij die in een procedure is betrokken met een andere partij. Het artikel kent wel een processuele beperking in die zin dat tussen bedoelde partijen al wel een geding aanhangig dient te zijn.

In het in 1838 in werking getreden Burgerlijk Wetboek is een recht op inzage opgenomen in de artikelen 1922 en 1923. Deze artikelen zijn blijven bestaan tot 1 mei 1988 en hebben al die tijd een kwijnend bestaan geleid. De belangrijkste reden hiervoor is gelegen in het feit dat men, uitgaande van het beginsel dat niemand verplicht kan worden om bewijs tegen zichzelf aan te dragen, van mening was dat een partij alleen inzage in stukken kon verkrijgen indien hij mederechthebbende op dat stuk was; aldus werden de woorden 'Indien een titel gemeen is tusschen verscheidene personen,' in art. 1922 BW uitgelegd. Van Blommestein, een van de drie mensen die tussen 1885 en 1893 op de artikelen 1922 en 1923 promoveerden, was in zijn proefschrift van mening dat het woord 'gemeen' in art. 1922 BW niet betekende dat er sprake moest zijn van mede-eigendom. Bij arrest van de Hoge Raad van 20 mei 1921, NJ 1921, p. 788 (Weisbard e.a.-de Ridder) 
lijkt het erop dat de Hoge Raad een ruimere uitleg van het woord 'gemeen' voorstaat dan 'mede-eigendom', maar dit wordt pas definitief duidelijk in het arrest HR 31 januari 1947, NJ 1948, 115 (Baus-N.V. De Koedoe). De Hoge Raad overweegt in dat arrest dat het recht op uitlevering van bescheiden in art. $1923 \mathrm{BW}$ is toegekend aan hem, die daarop als bewijsstuk enig recht kan doen gelden. Deze ruime uitleg heeft niet geleid tot toename van het gebruik van deze artikelen die een recht op inzage gaven.

Bij de herziening van het bewijsrecht, in werking getreden op 1 april 1988, werden vele bewijsrechtelijke artikelen uit het BW overgeplaatst naar het Wetboek van Burgerlijke Rechtsvordering. Het inzagerecht kreeg een plaats in de artikelen 843a en 843b Rv, waarbij het recht dat in deze studie wordt behandeld, werd neergelegd in art. 843a Rv. Deze verplaatsing bracht niet met zich dat vaker gebruik is gemaakt van het recht op inzage.

Bij de herziening van het Burgerlijk Procesrecht, in werking getreden op 1 januari 2002, werd art. 843a Rv weer aangepast. Het resultaat is een vrij ruimhartig recht op inzage, waarbij het zoveel mogelijk vinden van de materiële waarheid belangrijker is geworden dan het uitgangspunt dat niemand bewijs tegen zichzelf hoeft in te brengen.

In hoofdstuk 3 wordt het recht op informatie geanalyseerd. De concrete invulling van dit recht blijkt sterk afhankelijk te zijn van het antwoord op de vraag wat belangrijker wordt gevonden: het vinden van de materiële waarheid dan wel dat niemand bewijs tegen zichzelf hoeft in te brengen. De stelling dat niemand bewijs tegen zichzelf hoeft in te brengen, blijkt in het civiele proces geen grondslag te hebben en evenmin is een behoorlijke rechtvaardiging voor die stelling te vinden. Daarentegen heeft de wetgever het vinden van de materiële waarheid steeds belangrijker gevonden, hetgeen zijn neerslag vindt in art. $21 \mathrm{Rv}$, inhoudende dat een partij de van belang zijnde feiten volledig en naar waarheid moet aanvoeren en in art. $22 \mathrm{Rv}$, inhoudende dat de rechter in alle gevallen en in elke stand van het geding partijen kan bevelen inlichtingen te geven of bescheiden over te leggen. Toch blijken er grenzen te zijn bij het vinden van de materiële waarheid. Zo mag een rechter niet zelfstandig grasduinen in overgelegde producties en moet hij op grond van art. $149 \mathrm{Rv}$ als vaststaand aannemen hetgeen de ene partij stelt en de andere partij erkent of onvoldoende gemotiveerd betwist. Onder andere dit art. $149 \mathrm{Rv}$ blokkeert een te grote bemoeizucht van de rechter.

Uit hoofdstuk 4 blijkt dat binnen EU-verband pogingen worden ondernomen om het procesrecht in Europa te harmoniseren. Eén van de initiatiefnemers daartoe is Marcel L.L.V. Storme. Onder zijn voorzitterschap heeft een naar hem genoemde commissie het zogeheten Rapport Storme gepubliceerd. Eén van de 15 onderwerpen die in dit rapport aan de orde zijn gekomen, is 'la découverte des documentsdiscovery'. In het rapport wordt gesignaleerd dat er binnen de landen die lid zijn van de EU grote verschillen bestaan in de wijze waarop inhoud wordt gegeven aan het inzagerecht. De Commissie Storme heeft getracht om een soort gemeenschappelijke deler te vinden tussen al die verschillende soorten inzageregelingen 
en heeft die deler verwoord in een tamelijk omvangrijke wettekst. Het recht op inzage begint bij het recht op het verkrijgen van een lijst van documenten en aan de hand van die lijst mag de wederpartij om inzage in of kopieën van die documenten vragen. Er is tot dusverre niet veel gedaan met het rapport van de Commissie Storme.

In het kader van de bescherming van de interne markt en van de consumenten is de Commissie van de EU van mening dat namaak en piraterij bestreden moet worden. Belangrijk in deze strijd is het verzamelen en bewaren van bewijs. Hierbij kan het recht op informatie, op inzage, een belangrijk middel zijn. Deze gedachte is uitgewerkt in Richtlijn nr. 2004/48/EG. In Nederland is uitvoering aan deze Richtlijn gegeven in de op 1 mei 2007 in werking getreden artikelen 1019a Rv en verder. Deze artikelen geven alleen een regeling indien er sprake is van inbreuk op een recht van intellectuele eigendom.

Inmiddels heeft de Europese Commissie op het terrein van de communautaire antitrustregels al een Groenboek en een Witboek het licht doen zien en in deze boeken wordt op het terrein van het mededingingsrecht een uitgebreid recht op inzage voorgesteld.

Dat de rechtsontwikkeling op dit punt niet stil blijkt te staan, volgt uit hoofdstuk 5. In dat hoofdstuk wordt onder meer de aandacht beschreven die door de Commissie Asser, Vranken en Groen in haar in 2006 gepubliceerde rapport 'Uitgebalanceerd' is besteed aan het recht op inzage. Volgens de Commissie is de huidige regeling van art. 843a Rv niet geschikt en zij stellen voor om een ruimere regeling te maken, waar in het kader van preprocessuele protocollen een preprocessuele exhibitieplicht in de vorm van een pre-action disclosure wordt opgenomen.

Mede naar aanleiding van de wens van minister van justitie Hirsch Ballin tot een soort disclosure, heeft de Adviescommissie voor het Burgerlijk Procesrecht zich op dit onderwerp gestort en een regeling ontworpen. Die regeling berust op een zevental uitgangspunten en is tamelijk lang uitgevallen. Ondanks deze lengte weet de regeling geen duidelijkheid te scheppen op die punten waar de huidige regeling ook (nog) onbeantwoorde vragen oproept. Slechts voor enkele kleine problemen zijn oplossingen bedacht en mede daarom dient de regeling zoals door de Adviescommissie voorgesteld geen wet te worden.

In hoofdstuk 6 wordt de bewijsbetekenis van het recht op inzage uit de doeken gedaan. Het bewijsrecht heeft in Nederland pas laat de aandacht gekregen die het verdient en ook de plaats van het inzagerecht in dat bewijsrecht is pas laat onderkend. In de tijd dat het inzagerecht nog in het Burgerlijk Wetboek was opgenomen, stond het bij de bewijsbepalingen, maar kreeg het niet veel aandacht. In de parlementaire geschiedenis is niet toegelicht waarom de inzageartikelen bij de overplaatsing naar het Wetboek van Burgerlijke Rechtsvordering niet zijn opgenomen bij de regels van het bewijsrecht. Daar waar het vinden van de materiële waarheid steeds belangrijker wordt, wordt het bewijsrecht dat ook en kan het recht op inzage een grote rol spelen. Die rol heeft het de laatste jaren ook gekregen, en wel samen met de artikelen 21 en 22 van het Wetboek van Burgerlijke Rechtsvordering. Aan 
de hand van twee arresten van de Hoge Raad kan tenslotte worden geconcludeerd dat onevenwichtigheden in bewijsmogelijkheden niet alleen opgelost hoeven te worden via de stel- en onderbouwingsplicht, maar ook door de mogelijkheid of misschien zelfs wel de verplichting die de rechter heeft om een bevel te geven aan een partij om een bepaald stuk in het geding te brengen.

In hoofdstuk 7 wordt de literatuur en jurisprudentie over de vier bestanddelen van lid 1 van art. 843a Rv geanalyseerd en wel 'rechtmatig belang', de woorden 'inzage, afschrift of uittreksel', 'bepaalde bescheiden' en, tenslotte, 'aangaande een rechtsbetrekking waarin hij partij is'. Overeenstemming over inhoud en strekking van vooral de bestanddelen 'het rechtmatig belang' en 'een rechtsbetrekking waarin hij partij is' is er niet. De uitleg van die bestanddelen hangt bij elke auteur vooral af van zijn eigen rechtspolitiek standpunt over de vraag hoe belangrijk het vinden van de materiële waarheid is. Hoe belangrijker de auteur het vinden van die waarheid vindt, hoe ruimer de definitie van die begrippen wordt omschreven.

Net als in de literatuur bestaat er in de rechtspraak geen overeenstemming over inhoud en reikwijdte van vooral de bestanddelen 'rechtmatig belang' en 'een rechtsbetrekking waarin hij partij is'. Er is rechtspraak waarin beide begrippen ruim worden uitgelegd, maar ook rechtspraak waarin de rechter uitgaat van een tamelijk enge opvatting.

In hoofdstuk 8 geef ik mijn eigen opvatting over de vier bestanddelen van het eerste lid van art. 843a Rv. Een handzame formulering van de woorden 'rechtmatig belang' is niet te geven. Het belang moet wel een 'stel- of bewijsbelang' zijn. Het belang kan op vele momenten voor of tijdens de procedure aanwezig zijn, en het recht moet dus op elk moment te verwezenlijken zijn. Het verdient de voorkeur om bij de inhoud en reikwijdte van deze twee woorden aan te sluiten bij het te hanteren criterium ter zake de vraag of een getuige al dan niet gehoord mag worden. Het belang moet voldoende concreet zijn omschreven. De inzage moet redelijkerwijs nodig zijn.

Bij voldoende zwaarwegend belang, valt onder de woorden 'inzage, afschrift of uittreksel' ook de afgifte van een stuk. Denk bijvoorbeeld aan de afgifte van een origineel stuk ten behoeve van schriftonderzoek.

Het woord 'bescheid' moet in het kader van het vinden van de materiële waarheid eveneens ruim worden uitgelegd: ook een auto met een deuk erin, veroorzaakt door een botsing, kan een bescheid zijn omdat bijvoorbeeld uit de diepte van de deuk en de omvang daarvan kan worden afgeleid met welke snelheid de andere auto is komen aanrijden. Het woord 'bepaald' in de woordcombinatie 'bepaalde bescheiden' voorkomt dat er wordt gevist naar inzage. Het woord 'bepaald' zegt niets over het aantal bescheiden. Een voldoende bepaalde vordering, kan een vrachtwagen aan stukken opleveren.

De Hoge Raad heeft zich tot dusverre slechts een keer, en wel op 18 februari 2000, NJ 2001, 259, inhoudelijk uitgelaten over één van de vier bestanddelen van dit eerste lid, en wel over het begrip 'een rechtsbetrekking waarin hij partij is'. De Hoge Raad komt in die uitspraak tot het oordeel dat de vereiste rechtsbetrekking 
moet bestaan tussen de vorderende partij en de partij die het stuk onder zich heeft. Dat is echter onjuist: indien $\mathrm{C}$ ter bewaring voor $\mathrm{A}$ een schriftelijke overeenkomst onder zich geeft die is gesloten tussen $\mathrm{A}$ en $\mathrm{B}$, zal C, als de invulling van de andere drie bestanddelen van het eerste lid van art. 843a Rv zich daar ook niet tegen verzetten, inzage in dat stuk moeten geven aan B. De rechtsbetrekking tussen A en B kan eveneens zodanig zijn, dat A aan B inzage moet geven in een tussen $\mathrm{A}$ en $\mathrm{C}$ gesloten overeenkomst. Bij het bepalen van de inhoud van het begrip 'rechtsbetrekking' kan aansluiting worden gezocht bij het begrip 'samenhangende rechtsverhoudingen'. Er dient dan gekeken te worden naar de feitelijke en/of economische samenhang tussen de betrokkenen, het inzicht dat de betrokkenen in deze samenhang hadden, de onderlinge verhouding en hoedanigheid van partijen, de schade en overlast die de vordering tot inzage bij de derde kan veroorzaken en het belang van de waarheidsvinding. Al met al kom ik tot de conclusie dat het bestaan van een rechtsbetrekking vrij snel moet worden aangenomen.

In hoofdstuk 9 wordt lid 2 van art. 843a Rv besproken en wordt een overzicht gegeven van de literatuur en jurisprudentie over de wijze waarop inzage, afschrift of uittreksel wordt verschaft. De rechter kan hier een belangrijke rol hebben en kan creatief te werk gaan, door bijvoorbeeld te bepalen dat slechts inzage in bepaalde delen van een bescheid moet worden gegeven, of door een derde aan te wijzen die de inzage moet verrichten. Het is zelfs mogelijk dat een rechter afgifte van een origineel bescheid gelast op grond van dit lid 2. Art. 843a Rv bevat zelf geen sanctie die kan worden opgelegd als een partij die tot inzageverstrekking is veroordeeld, hieraan geen gehoor geeft. Indien een partij inzage weigert, ligt het voor de hand dat de rechter analoog aan de artikelen 21 en $22 \mathrm{Rv}$, daaruit de gevolgtrekking kan maken die hij geraden acht. De rechter kan verder een dwangsom opleggen, hetgeen bijvoorbeeld de Rb Zwolle heeft gedaan in de op 15 mei 2006, AY5717 gedane uitspraak.

In hoofdstuk 10 wordt lid 3 van art. 843a Rv besproken. Dit lid komt in de literatuur en jurisprudentie nauwelijks of niet aan de orde, hetgeen vooral veroorzaakt lijkt te worden door de vanzelfsprekendheid van dit lid en het feit dat de problematiek al redelijk diepgaand aan de orde is geweest bij art. $165 \mathrm{Rv}$. In dit hoofdstuk komt verder aan bod dat de achterstand die een procespartij kan hebben omdat de inhoud van bepaalde informatie onder een geheimhouder berust, kan worden ingehaald. Zo accordeerde de Hoge Raad bij arrest van 20 januari 2006, NJ 2006, 78 de door de rechtbank gegeven omkering van de bewijslast nadat een procespartij zijn huisarts en neuroloog niet uit hun geheimhoudingsplicht wilde ontslaan.

Art. 843a lid $4 \mathrm{Rv}$ bepaalt dat de inzage niet verstrekt hoeft te worden als daarvoor gewichtige redenen zijn of als redelijkerwijze aangenomen kan worden dat een behoorlijke rechtsbedeling ook zonder verschaffing van de gegevens is gewaarborgd. Dit lid wordt in hoofdstuk 11 besproken. Voorbeelden van dergelijke gewichtige redenen zijn volgens de parlementaire geschiedenis vertrouwelijke medische informatie zoals seksuele geaardheid of vertrouwelijke bedrijfsgegevens 
of de financiële positie van een partij. Buiten de in de parlementaire geschiedenis genoemde voorbeelden, kunnen ook grondrechten als het recht op privacy een gewichtige reden vormen die aan inzage in de weg staan. De Hoge Raad heeft bij arrest van 20 december 2002, NJ 2004, 4 geoordeeld dat het enkele feit dat een rechter in het kader van een procedure tot openbaarmaking van stukken heeft geoordeeld dat het stuk niet openbaar gemaakt hoeft te worden, niet voldoende is om tot de conclusie te komen dat er sprake is van een zwaarwichtige reden. Ook hier kunnen de gewichtige redenen 'onklaar' worden gemaakt doordat een rechter bijvoorbeeld een neutrale derde de inzage laat doen. Verdedigd wordt dat er niet te snel mag worden geconcludeerd dat er sprake is van gewichtige redenen. Tenslotte wordt in dit hoofdstuk verdedigd dat de beperking inhoudende dat inzage niet verstrekt hoeft te worden als redelijkerwijze aangenomen kan worden dat een behoorlijke rechtsbedeling ook zonder verschaffing van de gegevens is gewaarborgd, beter geschrapt kan worden. Het voegt niets toe en kan te gemakkelijk leiden tot verboden prognoses of tot het aannemen van het bestaan van een hiërarchie in bewijsmiddelen die niet bestaat.

In hoofdstuk 12 komen de inzage- en disclosureregel in de Nederlandse Antillen en Aruba aan de orde. Hier wel disclosure omdat naast het art. 843a Rv in beide landen, bijna letterlijk gelijkluidend aan art. 843a Rv-Ned, de Nederlandse Antillen en Aruba wel een regeling hebben waarbij een derde, C, een bevel kan krijgen om inzage in stukken die hij onder zich heeft, te verschaffen. De regeling kent niet de beperkingen van lid 1 van art. 843a Rv. Dit betekent dat de stukken waar het in art. $142 \mathrm{Rv}$ omgaat, geen betrekking hoeven te hebben op de rechtsbetrekking A-B. Jurisprudentie over deze artikelen in de Nederlandse Antillen en Aruba is schaars en er bestaat geen noemenswaardige literatuur over.

In hoofdstuk 13 komt de inzageproblematiek bezien in het licht van de Wet bescherming persoonsgegevens, de Wet justitiële en strafvorderlijke gegevens (Wjs) en de Wet op de inlichtingen- en veiligheidsdiensten (WIV) aan de orde. De Wet bescherming van persoonsgegevens is ter sprake gekomen in de zogeheten Dexiaaffaire, waar verschillende banken aan de hand van deze wet inzage door klanten in hun eigen klantdossier probeerden te voorkomen. Deze pogingen zijn gestrand. Botsingen tussen het inzagerecht van art. 843a Rv en de Wjs komen voor indien een partij inzage vraagt in strafvorderlijke gegevens die de Staat onder zich heeft. In de rechtspraak is uitgemaakt dat wat dit onderwerp betreft de $\mathrm{Wjs}$ een specialis is die voorrang heeft op art. 843a Rv. De Hoge Raad heeft wat de WIV betreft op 11 juli 2008, NJ 2009, 451, geoordeeld dat de WIV niet uitsluit dat bepaalde inlichtingen en stukken toch aan de rechter en de wederpartij in een civiele procedure worden verschaft.

Het is mogelijk dat een partij aan inzage probeert te ontkomen door stukken weg te werken. Om dat te voorkomen, zouden die stukken, voordat een partij tot het besef komt dat het verstandig is om stukken te laten verdwijnen, veilig gesteld moeten kunnen worden. De vraag of dit kan via het zogeheten bewijsbeslag wordt behandeld in hoofdstuk 14. Uit dit hoofdstuk blijkt dat al in vele gevallen verlof 
tot bewijsbeslag is gegeven. Ook de voorzitters van de sectoren civiel bij de rechtbanken zijn van mening dat bewijsbeslag mogelijk is en hebben daarvoor een regeling opgenomen in de zogeheten 'Beslagsyllabus'. De regeling is te vinden in de $5^{\text {de }}$ verbeterde versie van 2005 en vervolgens, in gewijzigde vorm, gehandhaafd tot en met de huidige $7^{\mathrm{e}}$ versie van februari 2009. Er zijn inmiddels ook uitspraken waarin dit verlof wordt geweigerd of teruggedraaid. Ook op dit terrein is geen sprake van een eenduidige opvatting. Het blijkt zelfs voor te komen dat rechter X, werkzaam bij rechtbank A verlof tot bewijsbeslag geeft, waarna dit beslag als zonder wettelijke grondslag door rechter $\mathrm{Y}$, werkzaam bij dezelfde rechtbank A, wordt opgeheven.

In hoofdstuk 15 passeren verschillende processuele verwikkelingen de revue. Het betreft hier onder meer de vraag op welke momenten inzage kan worden gevorderd, of inzage meermalen kan worden gevorderd, of inzage moet worden gevorderd of kan worden verzocht, hoe expliciet een vordering tot inzage moet worden gedaan en wat rechtens is indien het kort gedingvonnis waarbij verlof tot inzage is verleend en van welk verlof gebruik is gemaakt, in hoger beroep wordt vernietigd of indien in een bodemprocedure wordt geoordeeld dat geen inzage verstrekt had hoeven te worden. Verdedigd wordt dat de op grond van een later vernietigde uitspraak verkregen wetenschap als hoofdregel wel bruikbaar blijft als bewijsmiddel: onrechtmatig verkregen brengt niet automatisch ontoelaatbaar met zich.

In hoofdstuk 16 wordt tenslotte een voorstel gedaan voor een ontwerpwettekst van het recht op inzage. Dit voorstel geeft in verband met het belang van het vinden van de materiële waarheid een ruimhartig recht op inzage met de daarbij behorende mogelijkheid om bewijsbeslag te leggen. Verder wordt in het voorstel het bereik van de artikelen $22 \mathrm{Rv}$ en $155 \mathrm{a} \mathrm{Rv}$ gelijk getrokken: de rechter mag niet meer dan een procespartij. 



\section{Summary}

This dissertation is a reflection of a study to examine the question as to whether there is a right to obtain information in the control of another person, and if so, under what conditions such a right to information (hereinafter referred to as 'right of access') is afforded and what is its scope of application. In addition, the position of this right within the system of Dutch substantive private law and civil procedure is discussed.

Chapter 2 offers a concise overview of the history of the law governing access to information in the Netherlands. The right of access was first referred to in the Draft Civil Code (BW) as presented to the States General on 22 November 1820. It was laid down in Articles 3344 through 3347 of the Draft BW, but never became law.

Articles 19 and 24 of Title 1, Book Two, of the 1825 Civil Code, which also failed to come into effect, contained rules governing access as well. The two articles provide for a broad right of access, under which the owner of the document is irrelevant. The legislator intended to afford any person having a probative interest in the contents of the document a right to inspect it and/or to make a copy of its contents.

The third Draft of the Civil Code that did not come into effect, the 1830 Draft, provides for a right of access in Article 1932. As to substance, the article affords a virtually unqualified right of access, under which a third party, who has the document in his possession, may also be obliged to allow a litigant involved in civil proceedings with another party access to the document. The article does provide for a procedural limitation in the sense that proceedings must have been instituted between the parties in question.

The Civil Code that came into effect in 1838 contains a right of access in Articles 1922 and 1923. The articles remained in force until 1 May 1988, but have always led a lingering existence. The main reason for this is the view obtaining at the time that, based on the premise that no person can be obliged to present evidence against himself, a party could only obtain access to documents if he was jointly entitled to the document; the phrase: 'If various persons share a common legal ground (titel)' in Article 1922 BW was thus interpreted. In his dissertation, Van Blommestein, one of three persons who between 1885 and 1893 wrote a dissertation on Articles 1922 and 1923, was of the opinion that the word 'common' in Article 1922 BW did not imply joint ownership. In its judgment of 20 May 1921 (HR 20 Mei 1921, NJ 1921, pp. 788 [Weisbard e.a. - de Ridder]), the Netherlands 
Supreme Court seems to attribute a much broader meaning to the word 'common' than merely 'joint ownership'. This only becomes definitively apparent, however, in its Judgment of 31 January 1947 (HR 31 Januari 1947, NJ 1948, 115 [Baus-N.V. De Koedoe]). In this judgment, the Supreme Court reasoned that the right, provided in Article $1923 \mathrm{BW}$, to the surrender of records is afforded to those, who may rely on it for evidentiary purposes. This broad interpretation did not lead to an increase in the use of the articles governing such a right of access.

On the occasion of the review of the law of evidence, which came into effect on 1 April 1988, many articles dealing with evidentiary matters were transferred from the Civil Code (BW) to the Code of Civil Procedure (Rv). The rules governing access to information were laid down in Articles 843a and 843b Rv. The right that is the object of this study was laid down in Article 843a Rv. The transfer did not lead to more frequent reliance on the article.

On the occasion of the review of the Code of Civil Procedure, which came into force on 1 January 2002, Article 843a Rv was amended once again. The result was a rather generous right of access, under which uncovering the actual truth has gained more in significance than the premise that no person is obliged to present evidence against himself.

The right of access to information is analysed in Chapter 3. The precise substance of this right proves to depend heavily on the answer to the question as to what is deemed more important: uncovering the actual truth, or the proposition that no person is obliged to produce evidence against himself. It turns out that the proposition that no person is obliged to produce evidence against himself has neither a legal basis in civil procedural law nor can it be satisfactorily justified. In contradistinction, the legislator has increasingly attached more weight to uncovering the actual truth. This is reflected in Article $21 \mathrm{Rv}$, which prescribes that a party is under a duty to assert the relevant facts fully and truthfully, and in Article $22 \mathrm{Rv}$, which provides that in all instances and in all stages of the dispute the court may order the parties to provide information or to submit records. Nevertheless, it became evident that there are limits to uncovering the actual truth. For instance, the court may not independently browse through the exhibits submitted and pursuant to Article $149 \mathrm{Rv}$ it must accept as established all facts asserted by the one party that are acknowledged by the other party or insufficiently contested by the latter. This is one of the articles that bar too much interference by the court.

As Chapter 4 shows, attempts are made, within the context of the European Union, to harmonise civil procedure within Europe. One of the initiators of this endeavour is Marcel L.L.V. Storme. Under his chairmanship, a commission bearing his name has published the 'Storme Report' (Rapport Storme). 'La découverte des documents-discovery' is one of the fifteen subjects discussed in the report. It is stated in the report that there are major differences among the EU member-state countries in the way in which the right of access is conceived of. The Storme Commission has attempted to find some sort of common denominator between all these varying rules governing access to information. It has laid down this 
denominator in a -rather voluminous- legislative draft. The law governing access to information commences with the right to receive a list of documents. On the basis of this list, the other party may request to inspect these documents or to receive copies thereof. Not much has action thus far taken place in connection with the Storme Report.

As regards protection of the internal market and consumer protection, the European Commission has taken the view that there is a need to combat counterfeiting and piracy. An important aspect in this battle is the gathering and protecting of evidence. The right to information, to access information, may serve as an important instrument here. This thought has been developed in Directive 2004/48/ EC. In the Netherlands, the Directive has been implemented by way of Articles 1019a Rv ff, which came into effect on 1 May 2007. These articles only provide for such a right of access to information where infractions of intellectual property occur.

In the meantime, the European Commission has published a Green Paper and a White Paper dealing with EC anti-trust law, in which an extensive right of access is proposed in the field of competition law.

It follows from Chapter 5 that legal development has not ceased in the Netherlands either. In its report from 2006, entitled 'Uitgebalanceerd', the Asser, Vranken and Groen Commission pays the necessary attention to the right of access. According to the Commission, its current regulation in Article 843a of the Code of Civil Procedure (Rv) is not well-suited. It proposes to create a more comprehensive set of rules, including a pre-action duty to produce evidence, in the form of pre-action disclosure, within the context of pre-action protocols.

In part as a result of the desire expressed by the Minister of Justice, Hirsch Ballin, to arrive at some form of disclosure, the Civil Procedure Advisory Commission (Adviescommissie voor het Burgerlijk Procesrecht) has taken this task upon itself and has devised a set of rules. The regulation departs from seven premises and has turned out rather lengthy. In spite of its length, the regulation has not managed to create clarity on those points in relation to which the current regulation also raises questions; questions which as yet remain unanswered. Solutions have been found for minor problems only and this is partly the reason why the regulation as proposed by the Advisory Commission must not become law.

The probative importance of the right of access is explained in Chapter 6. The law of evidence has received the attention it deserves rather late and the position within the law of evidence of the rules governing access has been recognised rather late as well. When the right of access was still incorporated into the Dutch Civil Code, it had been placed with the provisions governing evidence, where it received little attention. No explanation is found in parliamentary history as to the reason why upon their transfer to the Code of Civil Procedure the articles governing access were not included in the rules governing evidence. Now that uncovering the actual truth is gaining in importance, the relevance of the law of evidence increases as well and the right of access may play a larger part. In recent years, the right was 
given such a part, in effect, in connection with Articles 21 and 22 of the Code of Civil Procedure. On the basis of two judgments passed by the Netherlands Supreme Court, the conclusion may be drawn that imbalances in the possibilities to adduce evidence do not solely have to be remedied by the duty to assert the facts and the duty to substantiate the assertions, but also by the possibility, or perhaps even a duty, for the court to order a party to introduce a specific document into the proceedings.

In Chapter 7 an analysis is made of the literature and the case law relating to the four components of Article 843a, paragraph 1, Rv: 'lawful interest' (rechtmatig belang), the words 'inspection, copy or excerpt' (inzage, afschrift of uittreksel) and 'specific records' (bepaalde bescheiden) and lastly 'as regards a legal relationship in which he is involved as a party' (aangaande een rechtsbetrekking waarin hij partij is). There is no consensus as to the content and portent of, in particular, the components 'lawful interest' and 'a legal relationship in which he is involved as a party'. The interpretation of the two components by scholarly writers depends to a major extent on their own legal-political view of the importance of uncovering the actual truth. The more important such uncovering is deemed by the author, the broader the definition given by him or her to these concepts.

As in the literature, there is no consensus in case law as to the content and scope of application of, in particular, the components 'lawful interest' and 'a legal relationship in which he is involved as a party'. In some instances, the courts have interpreted the two concepts extensively, but there are also decided cases in which the court has departed from a rather narrow perspective.

In Chapter 8 the author presents his own view of the four components of Article 843a, paragraph 1, Rv. A manageable paraphrase of the words 'lawful interest' cannot be given. The interest must relate to the assertion or the substantiation of the facts. The interest may manifest itself at any stage whether before or during the court proceedings, and for this reason a party must be in a position to exercise the right at any moment. It is to be preferred that the content and scope of application of these two words correspond with the criterion to be applied to the question of whether a witness may be heard or not. The interest must be sufficiently specified. Access must be reasonably necessary.

Where the interest is sufficiently serious, the words 'inspection, copy or excerpt' also include surrender of a document, such as the turning over of an authentic document for the purpose of document comparison.

Within the context uncovering the actual truth, the word 'record' (bescheid) must also be interpreted broadly: a car, which has been dented as a result of an accident, may be a 'record', because the speed with which the other car had approached may be inferred from the depth and measurement of the dent. The word 'specific' (bepaald) in the phrase 'specific records' (bepaalde bescheiden) precludes requests for random access. 'Specific' does not limit the number of records. A sufficiently specified request may yield a truckload of documents. 
Thus far, the Netherlands Supreme Court has only once, in its Judgment of 18 February 2000 (HR 18 Februari 2000 NJ 2001, 259), made a reference as to the content of one of the four components of the first paragraph, i.e. in relation to the term ('a legal relationship in which he is involved'). In the judgement, the Supreme Court arrives at the conclusion that the required legal relationship must exist between the claimant and the party who is in control of the document. However, this conclusion is not correct: if $\mathrm{C}$ has in his possession a written agreement entered into between A and B for the purpose of safekeeping it for A, C must allow $B$ access to that document, providing the practical outcome of the three other components of Article 843a Rv do not preclude this. The legal relationship between A and B could also be such that A must allow B access to an agreement entered into between A and C. In determining the content of the term 'legal relationship', consideration should be given to the concept of 'connecting legal relationships' (samenhangende rechtsverhoudingen), namely the actual and/or economic connection between the parties in question; the parties' insight into the connection; the mutual relationship and capacity of the parties; the damage and nuisance the application for access may cause to third parties; and the interest of uncovering the truth. All things considered, the author arrives at the conclusion that the existence of a 'legal relationship' must be fairly readily assumed.

In Chapter 9, paragraph 2, Article 843a Rv is discussed. An overview is provided of the literature and decided cases in the way in which inspection may be granted, or copies or excerpts may be provided. The court may play an important role here and may deal with the matter creatively by determining, for instance, that access must be granted to parts of the document only, or by assigning a third party to conduct the inspection. Pursuant to paragraph 2, the court could even order the surrender of an authentic document. Article 843a Rv does not provide for a sanction to be imposed in the event of a failure by a party ordered to provide access, to comply with the order. It stands to reason that, analogous to Articles 21 and $22 \mathrm{Rv}$, the court may draw its own conclusions as it sees fit, if a party refuses access. The court may impose a periodic fine (dwangsom/astreinte), as was ordered, for instance, by the District Court of Zwolle in its Judgment passed on 15 May 2006 (AY5717).

Paragraph 3 of Article 843a Rv is discussed in Chapter 10. The paragraph hardly figures in the literature or in decided cases. This seems to be mainly the result of its self-explanatory nature and the fact that the issue has been reasonably comprehensibly dealt with in relation to Article $165 \mathrm{Rv}$. The chapter also deals with the possibility to undo any disadvantage a litigant may suffer, because certain information rests with a person bound to secrecy. In its Judgment of 20 January 2006 (HR 20 Januari 2006 NJ 2006, 78), the Supreme Court affirmed the decision by the District Court to switching the burden of proof after a litigant refused to release his physician and his neurologist from their obligation of non-disclosure.

Article 843a, paragraph 4, Rv provides that access does not have to be granted if there are serious reasons for disallowing such access, or if it can be reasonably 
assumed that proper administration of justice is also ensured without the presentation of this data. Paragraph 4 is discussed in Chapter 11. According to parliamentary history, examples of the above serious reasons are confidential medical data, such as a person's sexual orientation, or confidential commercial data, or a party's financial position. In addition to the examples referred to in parliamentary history, fundamental rights, such as the right to privacy, may constitute a serious reason for disallowing access. In its Judgment of 20 December 2002 (HR 20 December 2002, NJ 2004, 4), the Supreme Court held that the sole fact that a court had ordered, within the context of judicial proceedings in which disclosure of documents was requested, that the document did not have to be disclosed, was not in itself sufficient to arrive at the conclusion that a serious reason obtained. Also in this case, serious reasons may be rendered 'inactive', where a court has a neutral third party inspect the information, for instance. The author defends the position that the conclusion that serious reasons obtain, must not be readily drawn. Lastly, the author argues in this chapter that the restriction that access does not have to be granted if it may be reasonable assumed that, even without the presentation of the data, proper administration of justice is ensured, should be abolished, as it is of little added value and may easily result in prohibited prognostication or in the assumption of a (non-existent) hierarchy in the means of evidence.

Chapter 12 deals with the access and disclosure rules that are applicable in the Netherlands Antilles and Aruba. In addition to the operation of an Article 843a $\mathrm{Rv}$ in the two countries, the wording of which is almost literally that of the Dutch Article 843a Rv, 'disclosure' is also regulated there. A rule exists in the Netherlands Antilles and Aruba, whereby a third party, C, may be ordered to grant access to documents that are in its control. The limitations formulated in the Dutch paragraph 1 of 843a Rv are absent here. This means that the documents referred to in Article $142 \mathrm{Rv}$ do not have to pertain to the legal relationship between A and B. There are very few decided cases relating to the articles in the Netherlands Antilles and Aruba and no relevant literature to speak of has been found.

The issues relating to access in the light of the Dutch Personal Data Protection Act (Wet bescherming persoonsgegevens), the Dutch Judicial and Procedural Criminal Data Act (Wet justitiële en strafvorderlijke gegevens) (Wjs) and the Dutch Intelligence and Security Services Act (Wet op de inlichtingen- en veiligheidsdiensten) (WIV) are discussed in Chapter 13. The Personal Data Protection Act played a role in the 'Dexia' case, in which several banks, relying on the Act, tried to prevent their clients gaining access to their own client files. The attempts failed. The right of access of Article 843a Rv and the Wjs collide where a party requests access to procedural criminal data in the control of the State. It was established in case law that, where this subject is concerned, the $\mathrm{Wjs}$ is considered a lex specialis that supersedes Article 843a Rv. As regards the WIV, the Supreme Court ruled on 11 July 2008 (HR 11 Juli 2008, NJ 2009, 451) that the Act does not preclude that in civil proceedings certain intelligence and documents must be made available to the court and the other party. 
A party may attempt to avoid access by removing documents. In order to prevent such an act, these documents should be preserved before a party realises that it would be sensible to make them disappear. The question as to whether this can be done by seizing evidence (bewijsbeslag) is discussed in Chapter 14. It becomes evident in this chapter that leave to seize evidence has been granted already in many cases. The presiding judges of the private law divisions of the Dutch District Courts are of the opinion that seizing evidence is possible and have laid down relevant rules in the 'Seizure Syllabus' ('Beslagsyllabus'). The rules are found in the 5th improved 2005 version of the Syllabus and have been maintained, in amended form, up to and including the current 7 th version dating from February 2009. In the meantime, judgments have been passed, in which leave to seize evidence has been refused or revoked. No unequivocal consensus exists on this issue as well. It has even transpired that Judge X, sitting in District Court A, may grant leave to seize evidence, upon which the seizure is lifted by judge $\mathrm{Y}$, sitting in the same District Court, on the grounds of there being no basis in statutory law for the seizure.

Chapter 15 features several procedural issues, among whom the question of the moment at which an application for access may be made; whether an application for access may be made more than once; whether the right of access must be exercised by application or request; the degree of explicitness of the application for access; and what is valid in law if the judgment in preliminary relief proceedings, by which leave to gain access has been granted and access has actually been gained, is reversed on appeal, or where it is held in proceedings on the merits that there had been no necessity for the access. The author defends the position that the knowledge obtained as a result of a decision that was subsequently reversed, will in principle remain to serve as a means of evidence: unlawfully obtained evidence does not automatically imply inadmissible evidence.

In the final Chapter 16, the author proposes a legislative draft governing the right of access. In view of the importance of uncovering the actual truth, the proposal provides for a generous right of access that includes the possibility of seizing evidence. In addition, the same scope is proposed for both Article 22 and 155a Rv: the court must not have more rights than a litigant.

Translated by Louise Rayar 

Bijlagen 



\section{Bijlage I}

De tweede titel van boek 1 van het Wetboek van Burgerlijke Rechtsvordering van de Nederlandse Antillen en Aruba (hierna Rv-NA) heet 'De wijze van procederen voor de rechter in eerste aanleg'. Afdeling 4 van die titel bevat de algemene bepalingen van bewijsrecht. Afdeling 5 betreft akten en vonnissen en wordt gevolgd door de twee hierna afgedrukte artikelen 141 en 142 die de volledige afdeling 5A vormen. Deze afdeling 5A heet 'Overlegging van boeken, bescheiden, andere gegevensdragers of voorwerpen en het verschaffen van inlichtingen'. Afdeling 5A wordt gevolgd door afdeling 6, genaamd 'Getuigen'.

\section{Artikel 141}

1. De rechter kan in de loop van een geding, op verzoek of ambtshalve, aan partijen of aan een van hen de overlegging bevelen van de boeken, bescheiden en andere gegevensdragers, die zij ingevolge de wet moeten houden, maken of bewaren.

2. Partijen kunnen dit weigeren indien daarvoor gewichtige redenen zijn, alsmede indien redelijkerwijs aangenomen kan worden dat een behoorlijke rechtsbedeling ook zonder verschaffing van de gevraagde gegevens is gewaarborgd.

3. De rechter beslist of die weigering gerechtvaardigd is, bij gebreke waarvan hij daaruit de gevolgtrekking kan maken die hij geraden acht.

Artikel 142

1. De rechter kan op verzoek van een der partijen aan anderen dan partijen, na deze te hebben gehoord of daartoe de gelegenheid te hebben gegeven, bevelen binnen een door de rechter te stellen termijn schriftelijk inlichtingen te verschaffen en onder hen berustende boeken. bescheiden, andere gegevensdragers of voorwerpen over te leggen. Degene tot wie de rechter het bevel richt, is verplicht tot het verschaffen van de gevraagde inlichtingen en het overleggen van de gevraagde boeken, bescheiden, andere gegevensdragers of voorwerpen.

2. De rechter bepaalt, zonodig, de wijze waarop, en de voorwaarden waaronder de inlichtingen zullen worden verschaft, dan wel de boeken, bescheiden, andere gegevensdragers of voorwerpen zullen worden overgelegd.

3. De rechter wijst het verzoek in elk geval af indien redelijkerwijs aangenomen kan worden dat een behoorlijke rechtsbedeling ook zonder verschaffing der gegevens is gewaarborgd.

4. Het in artikel 144 omtrent het verschoningsrecht van getuigen bepaalde is van overeenkomstige toepassing, maar ook andere gewichtige redenen, waaronder een gevaar voor onevenredige schade aan zijn belangen of die van derden, kunnen een weigering rechtvaardigen. 
5. Tegen een afwijzing van het verzoek staat geen hogere voorziening open.

6. Heeft de rechter het bevel gegeven, dan zijn de artikelen 152 en 152a van overeenkomstige toepassing. 


\section{Bijlage II}

De Franse tekst van art. 4, La decouverte des documents van Rapprochement DJ

4.1 La liste des documents

4.1.1 Chacune des parties est tenue de notifier aux autres la liste des documents qu'elle possède ou auxquels elle a accès et qui, ayant trait aux divers aspects du litige, n'ont pas déjà été verses aux débats:

a) lorsque le droit national l'impose ou

b) lorsque le juge requiert, les parties entendues ou appelées.

4.1.2 La liste des documents precise ceux que la partie se refuse à produire ou à communiquer sur le fondement d'une cause légitime de non-production ou de non-communication. 4.1.3 Les causes légitimes de non-production ou de non-communication sont celles que determinant les règles de droit national.

4.2 Communication et controle des documents

4.2.1 Sous réserve des conditions énoncées à 4.2.2, la partie qui notifié une liste de documents conforme aux dispositions de 4.1 communique aux autres parties ou leur permet d'examiner et de prendre copie de tout document mentionné dans cette liste et pour lequel aucune cause légitime de non communication n'a été invoquée.

4.2.2 Si, à la demande d'une partie, le juge estime que la communication ou l'examen et la reproduction d'une document mentionné dans la liste vise aux articles precedents doit causer à l'auteur de cette liste ou à un tiers un prejudice excessif, il peut, les autres parties entendues ou appelées, relever cette partie de l'obligation édictée par l'article 4.2.1 à l'égard du document considéré.

4.3 Ordre de production ou de communication

Les parties entendues ou appelées, le juge peut, s'il l'estime nécessaire à la solution du litige, ordonner la production ou la communication d'un document:

a) lorsqu'il tient pour non-légitime la cause de non-production ou de non-communication invoquée,

b) lorsqu'il est prouvé que, bien que non-inclus dans la liste notifiée par une partie, le document est en la possession de celle-ci ou qu'elle y a accès, et qu'il concerne une question relative au litige.

4.4 Conséquences de la non-production ou non-communication

Le juge ne peut prendre en considération un document qui n'a pas été produit ou communiqué à chacune des parties avant toute procédure d'administration des preuves ou avant l'audience des plaidoiries, à moins qu'il n'en soit décidé autrement, les parties entendues ou appelées. 
4.5 Tierces parties

4.5.1 Le juge peut, à la demande d'une partie, et sous les conditions énoncées à 4.5.2, ordonner la production ou la communication de tout document détenu par un tiers ou auquel celui-ci accès, et qui concerne une question relative au litige.

4.5.2 le juge n'ordonne la production ou la communication du document visé à 4.5.1

a) que constation faite, après que les parties et le tiers aient été entendus ou appelés,

i) que le document dont il s'agit est en la possession du tiers ou qu'il y a accès.

ii) que la production ou communication de ce document est nécessaire à la solution du litige,

et

iii) qu'il ne pourrait être justifié d'un motif légitime de non-production ou de non-communication s'il était en la possession d'une partie ou si cell-ci y avait accès, et

b) que si la partie qui demande la production ou la communication du document s'engage à indemniser le tiers concerné des frais qui lui sont raisonnablement occasionneés. 


\section{Bijlage III}

\section{Kamerstukken}

7729 ontwerp van boek 6 van het NBW, nr. 59

10377, Nieuwe regeling van het bewijsrecht in burgerlijke zaken.

17779, Vaststelling en invoering van de titels 7.7 (Opdracht) en 7.15 (Vaststellingsovereenkomst) van het Nieuwe BW

19529, Vaststelling van titel 7.17 (verzekering) en titel 7.18 (lijfrente) van het nieuwe Burgerlijk Wetboek. De Memorie van Antwoord aan de Eerste Kamer is genummerd B.

19574, Wijziging van bepalingen die verband houden met de persoonlijke verschijning van partijen in civiele procedures

22112, nr. 439, Nieuwe Commissievoorstellen en initiatieven van de lidstaten van de Europese Unie.

23024, Wijziging van het BW, Kh en enige andere wetten ter zake van het voeren van een administratie, is in Kamerstuk 3, de in het vergaderjaar 1992-1993 ingediende

25753, Wijziging van Boek 2 van het BW en van enige andere wetten in verband met de verkorting van de bewaartermijn van boeken, bescheiden en andere gegevensdragers.

26855, Herziening van het burgerlijk procesrecht voor burgerlijke zaken, in het bijzonder de wijze van procederen in eerste aanleg.

27026, Wijziging van de Wet gelijke behandeling van mannen en vrouwen en van Titel 7.10 van het BW ter uitvoering van de EG-richtlijn inzake de bewijslast in gevallen van discriminatie op grond van geslacht.

30336, Regels inzake het toezicht op en de handhaving van de voorschriften voor financiële verslaggeving van effectenuitgevende instellingen alsmede tot wijziging van enige wetten (Wet toezicht financiële verslaggeving).

30392, Aanpassing van het Wetboek van Burgerlijke Rechtsvordering, de Auteurswet 1912, de Wet op de naburige rechten, de Databankwet, de Handelsnaamwet, de Wet van 28 oktober 1987, houdende regelen inzake de bescherming van oorspronkelijke topografieën van halfgeleiderproducten (Stb. 484), de Zaaizaad- en plantgoedwet 2005 en de Landbouwkwaliteitswet ter uitvoering van Richtlijn nr. 2004/48/EG van het Europees Parlement en de Raad 
Bijlage III

van 29 april 2004 betreffende de handhaving van intellectuele eigendomsrechten (PbEG L 195).

30951, Herbezinning burgerlijk procesrecht.

31358, Wijziging van enige bepalingen van Rv en het BW teneinde naast het in deze bepalingen gestelde vereiste van schriftelijkheid ook ruimte te bieden aan de ontwikkelingen op het gebied van elektronisch verkeer. 


\section{Geraadpleegde literatuur}

Asser/Anema-Verdam, mr C. Asser's handleiding tot de beoefening van het Nederlands burgerlijk recht, Vijfde deel, Bewijs, 1953, aangehaald als Asser/Anema-Verdam.

$\mathrm{Mr}$ C. Asser's handleiding tot de beoefening van het Nederlands burgerlijk recht, Algemeen Deel door J.B.M. Vranken, Tjeenk Willink 1995, aangehaald als Asser/Vranken Algemeen Deel 1995.

$\mathrm{Mr}$ C. Asser's handleiding tot de beoefening van het Nederlands burgerlijk recht, Algemeen Deel door J.B.M. Vranken, Kluwer 2005, aangehaald als Asser/Vranken Vervolg.

C. Asser, P. Clausing en J.H. Wansink, Bijzondere overeenkomsten, Deel VI De verzekeringsovereenkomst, Kluwer-Deventer 2007.

W.D.H. Asser, H.A. Groen, J.B.M. Vranken m.m.v. I.N. Tzankova, Een nieuwe balans, interimrapport fundamentele herbezinning Nederlands burgerlijk procesrecht, Boom Juridische uitgevers 2003, angehaald als Een nieuwe balans.

W.D.H. Asser, H.A. Groen, J.B.M. Vranken m.m.v. I.N. Tzankova, Uitgebalanceerd. Eindrapport fundamentele herbezinning Nederlands burgerlijk procesrecht, Boom Juridische uitgevers 2006, aangehaald als Uitgebalanceerd.

W.D.H. Asser, Bewijsrecht in de nieuwe wet, PP 2002, p. 26-30.

W.D.H. Asser, J.E. Nijboer en Y.E. Schuurmans, Bewijsrecht: het bewijs geregeld?, Preadvies voor de Nederlandse Vereniging Voor Rechtsvergelijking, Wolf Legal Publishers, Tweede herstelde druk 2010.

Adviescommissie voor het Burgerlijk Procesrecht, advies over gegevensverstrekking in burgerrechtelijke zaken (discovery), TCR 2008, p. 123-130, aangehaald als ABP.

J.M. Barendrecht en W.A.J.P. van den Reek, Exhibitieplicht en bewijsbeslag, WPNR 6155 (1994), p. 739-745, aangehaald als Barendrecht en Van den Reek.

J.L.M. van der Beek, Enkele opmerkingen over het inzagerecht, Tijdschrift voor Gezondheidsrecht 1984, p. 80-81.

C.H. Beekhuis, Het nieuwe Nederlandse wetsontwerp voor het bewijsrecht, Tijdschrift voor Privaatrecht 1970, p. 83-154.

A.J.E. van den Bergen, De wet bescherming persoonsgegevens in de financiële praktijk, Tijdschrift voor financieel recht 2005, p. 296-306.

J.M.A. Berkvens, De beperkingen van het inzagerecht, Tijdschrift voor Financieel Recht 2009, p. 368-376.

M. den Besten, Provisionele vordering tegenover kort geding, Advocatenblad 2007, p. 736740.

M. den Besten, Samenloop van voorlopige voorzieningen in het burgerlijk procesrecht, in de bundel 'Samenloop', BWKJ 23, Meijers-reeks, Kluwer 2007, p. 211-238.

A.F. van Blommestein, De artt. 1922 en 1923 van het Burgerlijk Wetboek (proefschrift, 80 p.), Leiden, P. Somerwil, 1885, aangehaald als Van Blommestein. 
T.J.J. Bodewes, Bewijsbeslag. Een onderzoek naar de wettelijke grondslag, masterscriptie Nederlands Recht, RUG mei 2009 (website NJB, NJB 2009, p. 2546).

J. de Boer, De elektronische schriftelijke vorm, NJB 1992, p. 670-672.

J. de Boer, Het NBW in de West, NJB 2001, p. 289-294.

J. de Boer, Burgerlijke Rechtsvordering in de West, NJB 2005, p. 1980-1984.

R. van Boneval Faure, Het Nederlandsche burgerlijk procesrecht, IV-I, Leiden 1896, aangehaald als Van Boneval Faure.

M. Brink, Due diligence. Een beschouwing over het due diligence onderzoek volgens het Nederlandse recht, Den Haag, Boom Juridische uitgevers 2009.

M.M. van den Broek, Gedwongen overlegging due diligence rapport, V\&O 2004, p. 122-125.

Bronnen van de Nederlandse codificatie sinds 1798, I, Stukken van algemene aard de gedrukte ontwerpen van 1804 en hun voorgeschiedenis, verzameld door H. AA, uitgegeven door J.Th. de Smidt en A.H. Huussen Jr, Keming en zoon N.V. over den dom te Utrecht 1968.

D.M. Buné, De naleving van Europese privacy regels bij grensoverschrijdende civiele procedures, Nieuwsbrief Bb 2009, afl. 11, 2 juni 2009.

Burgerlijke Rechtsvordering (voormalig Van den Dungen, Kluwer, Deventer losbladig), G.R. Rutgers, art. 843a.

S.M. Christiaan en W.J. Hengeveld, Februari-arresten: de patiëntenkaart; partijen wikken, de deskundige beschikt, TVP 2008, p. 51-56.

T. Claassens, Discovery in de VS voor procedures in Nederland, Advocatenblad 2004, p. 754-760, aangehaald als Claassens.

E.M. Deen, De patiëntenkaart en de beschikkingen van de Hoge Raad van 22 februari 2008, TVP 2009, p. 41-48.

Chr.H. van Dijk, Ter beschikking stellen van de patiëntenkaart:aan wie? in TVP 2006, p. 8-17.

H.A. Dragstra, de exhibitieplicht in het arbeidsrecht, Tijdschrift Recht en Arbeid 2009, afl. mei 2009, p. 15-18.

H. Drion, Praten over rechtsvinding, de verhouding wet-rechter en het NBW, NJB 1983, p. $1220-1223$.

F.W.E. Eijsvogels en C. de Meyer, Enkele procesrechtelijke aspecten van $\mathrm{h}$ andhaving van intellectuele-eigendomsrechten na implementatie van de Handhavingsrichtlijn, Tijdschrift voor Computerrecht 2009, p. 12-20.

J. Ekelmans, De exhibitieplicht in de praktijk: de ruime mogelijkheden tot opvragen van bescheiden, TCR 2005, p. 59-68, aangehaald als Ekelmans TCR.

J. Ekelmans, Een onbalans in de eindbalans: de exhibitieplicht revisited, TCR 2006, p. 101102.

J. Ekelmans, De exhibitieplicht in kort bestek, Uitgeverij Paris 2007, aangehaald als Ekelmans.

J. Ekelmans, Dient de verplichting om medische bescheiden te verstrekken gebaseerd te worden op artikel 843a Rv?, TVP 2007, p. 29-37.

J. Ekelmans, U.S. disclosure and discovery of documents, TvPP 2009, p. 179-187.

A. Ekker, Pessers/lycos II, JAVI 2004, p. 178-181.

M.H. Elferink, Inzage in de patiëntenkaart, TVP 2003, p. 111-119 
M.C.D. Embregts, Uitsluitsel over bewijsuitsluiting, Kluwer Deventer-2003

F.J. Fernhout, Het verschoningsrecht van getuigen in civiele zaken, proefschrift 2004, Uitgeverij Gianni.

F.J. Fernhout, Het verschoningsrecht van getuigen in civiele zaken, Serie Recht en Praktijk 131, Kluwer 2004, aangehaald als Fernhout.

E.O.H.P. Florijn, Ontstaan en ontwikkeling van het nieuwe Burgerlijk Wetboek, proefschrift 1994, Universiteits Pers Maastricht.

M. Freudenthal, Internationale bewijsverkrijging: van Haagse en Europese samenwerking in NIPR 2002, p. 109-117, aangehaald als Freudenthal.

A.M.P. Gaakeer en M.A. Loth (redactie), Eenheid en verscheidenheid in recht en rechtswetenschap, Deventer Kluwer 2002.

J.F. Garvelink en P.F. Hopman, Verboden te vissen: informatieplicht van banken en afdwingbaarheid daarvan, Tijdschrift voor Effectenrecht 2004, pag 11-15.

I. Giesen, Bewijs en aansprakelijkheid. Een rechtsvergelijkend onderzoek naar de bewijslast, de bewijsvoeringslast, het bewijsrisico en de bewijsrisico-omkering in het aansprakelijkheidsrecht, Boom Juridische uitgevers Den Haag 2001.

P.P.J.N. van Ginneken, Centrale Raad wil patiënt meer rechten geven, Tijdschrift voor Gezondheidsrecht 1983, p. 237-255.

M.F.J. Haak en I.W. VerLoren van Themaat (redactie), De mogelijkheden voor civielrechtelijke handhaving van de mededingingsregels in Nederland.' Een inventarisatie in opdracht van het Ministerie van Economische Zaken, Amsterdam, 3 november 2005, aangehaald als 'Haak en VerLoren van Themaat'.

J. de Haan, Eendrachtig recht vormen? Het beginsel van concordantie van rechtspraak, NJB 2008, p. 2456-2460.

W.G. de Haan en G. Oosterhuis, Geheimhouding en transparantie in het financieel recht en het mededingingsrecht, Preadviezen commerciële rechtspraktijk, deel I, Uitgeverij Paris, 2008.

M.M.L. Harreman, Conservatoire beslagen tot afgifte en levering. Een studie naar de werking en problematiek van het $730 \mathrm{Rv}$-beslag, mede in rechtshistorisch perspectief, Proefschrift Rotterdam, Den Haag, Boom Juridische uitgevers 2007.

J.M. Hebly, Exhibitieplicht bij rogatoire commissie, TCR 2001, p. 1-3.

P.J.A. de Hert, M. Hildebrandt, S. Gutwirth en R. Saelens, De WBP na de Dexia-uitspraken, Privacy \& Informatie 2007, p. 147-157.

S. Hoogeveen, Fishing expeditions versus exhibitieplicht, Advocatenblad 2005, p. 678-681.

W.A. Hoyng, Vier procesrechtelijke wensen in 'In het nu wat worden zal' (Schoordijkbundel), p. 105-118, Kluwer 1991.

Hugenholz/Heemskerk/Groefsema, Hoofdlijnen van het burgerlijk procesrecht van de Nederlandse Antillen en Aruba, 2009, Elsevier Juridisch Amsterdam.

J.B. Huizink, Kort-geding-vonnis World Online; recht op informatie?, WPNR 6412 (2000), p. 553-555.

M.A.J.G. Janssen, Criteria voor de beoordeling van een verzoek om een voorlopig getuigenverhoor of voorlopig deskundigenbericht, JBPR 2005, p. 216-228. 
T.S. Jansen, Art. 843a Rv in de ondernemingsrechtpraktijk. Verboden te vissen, maar vragen mag. Tijdschrift voor de ondernemingsrechtpraktijk 2009, p. 89-94.

A.W. Jongbloed, A.L.H. Ernes, J. Feikema, R. Groen, J.B.A.M. Groenendaal, E. van der Hoeden, G.J. Knijp, A.C. Meulenkamp, J. Nijenhuis, R.J. Oonk, B.M. Paijmans en P.M.F. Schreurs, Herbalans. Beschouwingen naar aanleiding van het rapport Uitgebalanceerd, Ars Aequi Libri Nijmegen 2007.

A. Keizer, Exhibitieplicht bij overnamegeschillen, V\&O 2008, p. 53-57.

C.J.M Klaassen, Spreken is zilver, zwijgen is fout, NJB 2002, p. 1450-1458.

M.E.L. Klein, De verplichting tot het overleggen van bescheiden in het familie- en erfrecht, EB Tijdschrift voor scheidingsrecht 2009, p. 68-71.

A. Kolder en J.F. Schultz, De patiëntenkaart: knel- en strijdpunt, TVP 2007, p. 5-17.

P.J. van der Korst, J.W. Westenberg, R.M. Hermans en E.M. Wesseling-van Gent, Het verzamelen van feiten en bewijs: begrenzing versus verruiming, een kruisbestuiving tussen civiel procesrecht en ondernemingsprocesrecht, Boom Juridische uitgevers 2006, aangehaald als Van der Korst e.a. De in dit boek staande artikelen zijn ook verschenen als 'Geschriften van de Vereniging Corporate litigation', 2005-2006.

P.J. van der Korst, Bedrijfsgeheimen en transparantieplichten, Deel 92 uit de serie vanwege het Van der Heijden instituut, Kluwer-Deventer 2007, aangehaald als Van der Korst.

P.J. van der Korst, Discovery in het Nederlands burgerlijk procesrecht. 'Advies over gegevensverstrekking in burgerrechtelijke zaken' van de Adviescommissie voor Burgerlijk Procesrecht becommentarieerd, TCR 2009, p. 140-143.

H.B. Krans, De Principles of Transnational Procedure en het Nederlandse bewijsrecht, TCR 2009, p. 58-66.

M. Kremer en E. Rehbock, Discovery en andere wegen der (ge)lijdelijkheid, Ars Aequi 1998, p. 448-457.

J. van Kuyk, De beteekenis van 'gemeen' in de artt. 1922 en 1923 B.W., WPNR 16 juli 1921, nr. 2690.

M.J. van Laarhoven, Over derdenwerking van overeenkomsten en samenhangende rechtsverhoudingen, NTBR 2006, p. 48-59.

M.J. van Laarhoven, Samenhang in rechtsverhoudingen, Wolf legal publishers 2006.

N.K.F. Land, bewerkt door J. Eggens, Verklaring van het burgerlijk wetboek, zesde deel, boek IV, Haarlem 1933.

S.C. de Lange, Due diligence openbaar. Exhibitieplicht in overnamegeschillen, Fusie en Overname 2006, p. 13-15.

R.B. Ledeboer, Eenige opmerkingen over de verplichting tot overlegging van schriftelijke bewijsstukken (proefschrift, 60 p.), Amsterdam, De firma Holdert \& Co, 1888, aangehaald als Ledeboer.

P.M. Leerink, Schorsing van de dekking wegens te late premiebetaling, AV\&S 2009, p. 9299.

G.C.C. Lewin, Concordantie en maatschappelijke opvattingen, TAR 2008, p. 194-199.

G.C.C. Lewin, Kroniek burgerlijk procesrecht van de Nederlandse Antillen en Aruba, TCR 2009, p. 89-92.

G.C.C. Lewin, Het hoger beroep en het cassatieberoep in burgerlijke zaken in de Nederlandse Antillen en Aruba, Serie Burgerlijk Proces \& Praktijk, deel VII, Kluwer 2010, aangehaald als Lewin. 
W.A.J. van Lierop en E.H. Pijnacker Hordijk, Privaatrechtelijke aspecten van het mededingingsrecht, Preadvies 2007 uitgebracht voor de Vereniging voor Burgerlijk Recht, Kluwer 2007.

H. Ligtenberg, De exhibitieplicht in het Nederlandsche recht (proefschrift, 139 p. ), Leiden, Eduard Ijdo 1893, aangehaald als Ligtenberg.

V.C.A. Lindijer, De goede procesorde, serie burgerlijk proces en praktijk, Kluwer 2006, aangehaald als Lindijer.

J.G.A. Linssen, Bewijsbeslag, in De reikwijdte van het beslag, p. 21-33, Procesrechtelijke reeks NVvP nr. 20, Boom Juridische uitgevers Den Haag, 2009.

J.H.A. Lokin \& W.J. Zwalve, Hoofdstukken uit de Europese codificatiegeschiedenis, Wolters-Noordhof/Egbert Forsten Groningen 1992.

M.A. Loth, Tussen eenheid en verscheidenheid: contextualisme in taal, wetenschap en samenleving, p. 19-41 in de bundel van A.M.P. Gaakeer en M.A. Loth (redactie), Eenheid en verscheidenheid in recht en rechtswetenschap, Deventer Kluwer 2002.

N.J. Margetson, De grenzen van de exhibitieplicht, Praktisch Procederen 2007, p. 143-146.

H.P.A.J. Martius, Enige opmerkingen aangaande wetsvoorstel 31.358 in het Nederlands Tijdschrift voor Handelsrecht 2008, p. 237-251.

H.P.A.J. Martius, Hoe schriftelijk is elektronisch? Over post, e-post en e-akte, WPNR 6710 (2007), p. 452-459.

H.P.A.J. Martius, Elektronisch handelsrecht, De juridische aspecten van elektronische communicatie in het handelsrecht, Deel 8 in de NTHR-reeks, uitgeverij Paris, 2008.

A.I.M. van Mierlo en J.H. van Dam-Lely, Procederen bij dagvaarding in eerste aanleg, Serie burgerlijk proces en praktijk, Kluwer 2003.

A.A.M. Menken, Exhibitieplicht ex art. 843a Rv, V\&O 1998, p. 53-56, aangehaald als Menken.

K.I.A. Middelkoop, Due diligence rapporten: plicht tot overleggen?, V\&O 2005, p. 196-199.

J.J.F. Noordziek, Geschiedenis der Beraadslagingen gevoerd in de Tweede Kamer der StatenGeneraal, over het ontwerp van Burgerlijk Wetboek. Onder toezigt der Commissie voor de huishoudelijke aangelegenheden der Tweede Kamer, Zittingjaar 1824-1825, Den Haag Martinus Nijhoff 1878, aangehaald als Noordziek.

De Parlementaire Geschiedenis van het Nieuwe Burgerlijk Wetboek. Parlementaire stukken systematisch gerangschikt en van noten voorzien. Invoering Boeken 3, 5 en 6, wijziging van het Wetboek van Burgerlijke Rechtsvordering, de Wet op de Rechterlijke Organisatie en de Faillissementswet, aanpassing van de overige wetten, door W.H.M. Reehuis en E.E. Slob, Kluwer 1992, aangehaald als Parl. Gesch. Wijziging. Rv e.a.w. (Inv. 3, 5 en 6).

De Parlementaire Geschiedenis. Herziening van het burgerlijk procesrecht voor de burgerlijke zaken, in het bijzonder de wijze van procederen in eerste aanleg door A.I.M van Mierlo en F.M. Bart, Kluwer 2002, aangehaald als Parl. Gesch. burgerlijk procesrecht.

De Parlementaire Geschiedenis van de nieuwe regeling van het bewijsrecht in burgerlijke zaken door G.R. Rutgers en R.J.C. Flach, Kluwer 1988, aangehaald als Parl. Gesch. nieuw bewijsrecht.

A. Pitlo, Bewijs en verjaring, Gouda Quint 1968. 
R.E.N. Ploum, Exhibitieplicht: nachtmerrie of noodzaak? p. 55-62, Leidse procesrechtelijke geschriften onder redactie van T.A.W. Sterk en H. Carels, november 1990, Gouda Quint.

W.A.J.P. van den Reek, Mededelingsplichten in het burgerlijk procesrecht, Tjeenk Willink 1997, aangehaald als Van den Reek.

W.A.J.P. van den Reek en C.J.J.C. van Nispen, Informatieplicht van partijen en bewijsgaring. Verslag van de discussie in Ontwerp aanpassing Wetboek Burgerlijke Rechtsvordering onder redactie van J.G.A. Linssen en J.B.M. Vranken, Tjeenk Willink 1997.

C.H. van Rhee, Ons tegenwoordig sukkelproces. Nederlandse opvattingen over de toekomst van het burgerlijk procesrecht rond 1920, Tijdschrift voor Rechtsgeschiedenis 2000, p. 331-346.

M. Rieger-Jansen, Twee jaar ervaring met het bewijsbeslag. Een overzicht van de ontwikkelingen in Nederland en een kijkje over de landsgrenzen, AMI 2009, p. 91-96.

W. van Rossem's verklaring van het Nederlands wetboek van burgerlijke rechtsvordering, door R.P. Cleveringa, Deel I, vierde druk, Tjeenk Willing-Zwolle, 1972.

G.R. Rutgers en Lisette R. Wisse, Art. 162 Rv: rara avis in exhibitieland, Ondernemingsrecht 2005, p. 91-93.

A.C. van Schaick, Het Burgerlijk recht de baas? Over de verwevenheid van burgerlijk recht en burgerlijk procesrecht, Kluwer 2009, oratie.

F.G. Scheltema, Nederlandsch burgerlijk bewijsrecht, deel II, Tjeenk Willink 1938, aangehaald als Scheltema.

P.J.M. von Schmidt auf Altenstadt, Opening van zaken, TCR 2002, p. 8-14.

Van Schoonhoven, Inzage bij banken: een recht te ver?, Computerrecht 2006, p. 200-205.

J. Schrover, Verplichte HIV-test versus het nemo teneturbeginsel, AA 2009, p. 298-305.

J.R. Sijmonsma, Enkele aspecten van de inzageplicht van at. 843a Rv, Praktisch Procederen 2005, p. 145-152.

J.R. Sijmonsma, Art. 843a Wetboek van Burgerlijke Rechtsvordering ont(k)leed, Ars Aequi Libri 2007, aangehaald als Sijmonsma.

J.R. Sijmonsma, De regiefunctie van de rechter, Praktisch Procederen 2008, p. 10-14.

J.R. Sijmonsma, bespreking van De exhibitieplicht in kort bestek door J. Ekelmans, TCR 2008, p. 60-64.

W.H. Simonis en K.P.D. Vermeulen, Inzagerecht en correctierecht in de Wbp: onbekend maakt onbemind, Tijdschrift ArbeidsrechtPraktijk 2009, p. 219-223.

H.J. Snijders, C.J.M. Klaassen, G.J. Meijer, Nederlands burgerlijk procesrecht, 2007, aangehaald als Snijders c.s.

C.W. Star Busmann, bewerkt door L.E.H. Rutten, Hoofdstukken van burgerlijke rechtsvordering, Haarlem 1972.

M. Storme (ed), Rapprochement du Droit Judiciaire de l'Union européenne/Approximation of Judiciary Law in the European Union, Kluwer Rechtswetenschappen België, Martinus Nijhoff Publishers, Dordrecht 1994, aangehaald als Rapprochement DJ.

H.W.P.B. Taminiau en C.A.M. Swagemakers, Procedurele obstakels voor de zieke werknemer, Arbeid Integraal 2007, p. 109-124.

Th.B. ten Kate, Het request-civiel, J.B. Wolters/Groningen 1962.

K. Teuben, De verplichting tot het overleggen van stukken ex art. 843a Rv, MvV 2006, p. 218-221. 
R.P.J.L. Tjittes, Een mededelingsplicht voor een procespartij als tegemoetkoming aan een onredelijk bewijsrisico voor diens wederpartij, NJB 1988, p. 1128-1130.

M. de Tombe-Grootenhuis, Voorstel voor een Europese disclosure, Liber Amicorum Paul Meijknecht, van Nederlands naar Europees procesrecht?!, onder redeactie van E.H. Hondius, A.W. Jongbloed en R.Ch. Verschuur, Deventer, Kluwer 2000, p. 301-313.

P. van Uchelen en B. Verbunt, Vordering tot overlegging van due diligence rapporten ex art. 843a Rv, Ondernemingsrecht 2005, p. 54-58.

H. Uittien, Gedwongen verstrekking van due diligence-rapportages, Tijdschrift voor de ondernemingsrechtpraktijk 2007, p. 19-23.

Veegens-Wiersma, Het nieuwe bewijsrecht in burgerlijke zaken, I. Algemene grondslagen en verdeling van de bewijslast, Tjeenk Willink Zwolle, 1973, aangehaald als VeegensWiersma I.

Veegens-Wiersma, Het nieuwe bewijsrecht in burgerlijke zaken, 2. Bewijs door geschriften, Tjeenk Willink 1988, aangehaald als Veegens-Wiersma 2.

J.A.C. van Veersen, Exhibitieplicht ex art. 3:15j BW; een ondergeschoven kindje, V\&O 2006, p. 6-10.

R.R. Verkerk, Procesrechtelijke aspecten van het wetsvoorstel handhaving intellectuele eigendom, TCR 2006, p. 110-115.

R.J. Verschoof, H.M.M. Steenberghe, Y.E. Schuurmans, De regiefunctie van de rechter, Boom Juridische uitgevers 2008.

E.T. Visser, Het exhibitionisme in arbeidszaken en de fundamentele herbezinning, Arbeidsrecht 2007, afl. 6-7 p. 14-17.

H.M. Vletter-van Dort, Gelijke behandeling van beleggers bij informatieverstrekking, Kluwer-Deventer 2001, Serie Instituut voor het Ondernemingsrecht dl 37, verkort aangehaald als Vletter-van Dort.

J.C. Voorduin, Geschiedenis en beginselen van Nederlandsche Wetboeken, V. Deel, Burgerlijk Wetboek, art. 1269-2030, de beraadslaging deswege gehouden door de Tweede Kamer der Staten Generaal, Utrecht, Robert Natan, Akademie-Boekhandelaar 1838, verkort aangehaald als Voorduin.

M. Voorhoeve, Waarheid bij de gerechtelijke vaststelling van het vaderschap van de verwekker, bijdrage aan de bundel 'Rechten van het kind en ouderlijke verantwoordelijkheid', p. 43-58, Ars Aequi 2008.

J.B.M. Vranken, Het professionele (functionele) verschoningsrecht, Preadvies voor de Nederlandse Juristen-Vereniging, Tjeenk Willink, Zwolle 1986.

J.B.M Vranken, Mededelings-, informatie- en onderzoeksplichten in het verbintenissenrecht, Tjeenk Willink 1989, aangehaald als Vranken.

J.B.M. Vranken, Aansprakelijkheden en bewijsrecht in de bundel Aansprakelijkheden, opstellen rondom het thema ontwikkelingen in het aansprakelijkheidsrecht bij gelegenheid van het 60 -jarig bestaan van het Nederlands genootschap van bedrijfsjuristen, Kluwer 1990.

G. van der Wal en F van Schaick, Handhavingsinstrumenten in het intellectuele eigendomsrecht: het op de loer liggende risico van 'fishing expeditions' vergt kritische rechterlijke toetsing, IER 2009, afl. 3. 
E.M. Wesseling-van Gent, To fish or not to fish, that's the question, Het verzamelen van feiten en bewijs: begrenzing versus verruiming, een kruisbestuiving tussen civiel procesrecht en ondernemingsprocesrecht, Nederlandse Vereniging voor Procesrecht, Boom Juridische uitgevers Den Haag 2006 (zie hiervoor in de lijst ook onder 'Van der Korst en anderen').

B.T.M. van der Wiel, De exhibitieplicht (te) terughoudend opgevat, NbBW 2004, p. 58-60.

B.T.M. van der Wiel, De rechtsverhouding tussen procespartijen, serie recht en praktijk 128, Kluwer 2004, aangehaald als Van der Wiel.

H.W. Wiersma, Recht op meewerking bij bewijsvoering in Effectieve rechtsbescherming en constitutionele rechtsorde, Nederlandse Vereniging voor Procesrecht, Tjeenk Willink Zwolle 1983, p. 73-88.

W.P. Wijers en A.J. Haasjes, Exhibitie in het (ondernemings)recht, O \& F 2006, p. 49-62, aangehaald als Wijers en Haasjes.

J.H.B.M. Willems en H.C.B. van der Meer, Uitwisseling van medische gegevens van zieke werknemers - niet alles wat kan mag, en niet alles wat mag kan-, Het Verzekeringsarchief 2009, p. 64-72

J.W. Winter, Center Parcs, art. 843a Rv, discovery op z'n Hollands, TVVS 1997, p. 55-56.

B. Winters en J. Vossenberg, Vissen in het enquêterecht, Vennootschap\&Onderneming 2005, p. 62-65.

M. Ynzonides, P. Ingelse, F.B. Bakels, Beschouwingen over het Eindrapport Fundamentele Herbezinning Nederlands Burgerlijk Procesrecht', Procesrechtelijke reeks NVvP nr. 16, Boom Juridische uitgevers Den Haag, 2006.

R.C.A. van 't Zelfde, Het recht van expertise, in de Bundel Capita Zeerecht, Kluwer 2004, p. $329-335$. 


\section{Jurisprudentieregister}

Een achter een uitspraak vermeld nummer bestaande uit zes aangesloten tekens, de eerste twee letters en de laatst vier cijfers, is het Landelijk Jurisprudentie Nummer, LJN. Via dat nummer is de uitspraak op rechtspraak.nl digitaal te vinden.

Een achter een uitspraak vermeld nummer bestaande uit de letter $\mathrm{B}$ en vervolgens het cijfer 9 en vervolgens een gedachtestreepje gevolgd door drie of meer cijfers, betreft een publicatie die te vinden is via www.boek9.nl, waarna in het dan verschenen zoekvenster de cijfers achter het gedachtestreepje moeten worden vermeld.

\section{EHRM}

- 12 juli 1988, NJ 1988, 851, m.nt. E.A.A. (Schenk-Zwitserland)

- 27 oktober 1993. NJ 1994, 534, m.nt. H.J.S. en E.J.D. (Dombo-arrest)

- 4 januari 2007, NJ 2007, 475

\section{HvJEG}

- 4 oktober 2007, NJ 2008, 37, m.nt. M.R.Mok (Rampion)

- 29 januari 2008, NJ 2009, 551, m.nt. P.B. Hugenholtz

- 14 februari 2008, BC8918, NJ 2008, 271, m.nt. M.R. Mok

\section{Hoge Raad}

- 23 maart 1849 , WvhR 1036

- 12 november 1875, WvhR 3917

- 12 december 1879, WvhR 4455

- 20 oktober 1911, W 9283 (Schlesinger-Snijders)

- 20 mei 1921, NJ 1921, pag. 788-791 (Weisbard c.s.- de Ridder)

- 18 december 1925, NJ 1926, pag. 228-231 (N.V. Batava Margarine FabriekenSalomonsky), m.nt. E.M.M.

- 31 januari 1947, NJ 1948, 115 (Baus-N.V. Apotheek en Drogisterij de Koedoe)

- 12 juni 1953, NJ 1954, 61 (Vaderschapsactie, bloedonderzoek)

- 24 mei 1957, NJ 1959, 10 (C.V. van Vliet en Co.-N.V. Financieringsmij Vricon), m.nt. D.J.V.

- 12 december 1958, NJ 1961, 270

- 10 juni 1966, NJ 1966, 390, m.nt. G.J.S. (onderbouwingsplicht gedaagde)

- 16 november 1984, NJ 1985,547

- 23 mei 1986, NJ 1987, 702

- 9 januari 1987, NJ 1987, 928 
- 24 mei 1987, NJ 1988, 500

- 16 oktober 1987, NJ 1988, 850, (Driessen-van Gelder), m.nt. E.A.A.

20 november 1987, NJ 1988, 500, m.nt. W.L.H.

- 27 november 1987, NJ 1988, 722

- 30 juni 1989, NJ 1990, 382, m.nt. J.B.M.V.

- 19 april 1991, Rek.nr. 7744 (Cybul-Towerbank International INC, niet gepubliceerd)

- 20 september 1991, NJ 1992, 552, m.nt. J.B.M.V.

- 7 februari 1992, NJ 1993, 78

- 25 september 1992, NJ 1993, 467

- 18 juni 1993, NJ 1994, 347 (HIV-onderzoek)

- 5 november 1993, NJ 1994, 154, m.nt. P.A.S.

- 11 maart 1994, NJ 1995, 3, m.nt. H.J.S.

- 13 januari 1995, NJ 1997, 175, m.nt. Ch.J.H.B.

- 24 maart 1995, NJ 1998, 414 (toelatingsgronden voor voorlopig getuigenverhoor)

- 22 december 1995, NJ 1996, 300

- 23 februari 1996, NJ 1996, 434

- 13 september 1996, NJ 1996, 731

- 4 oktober 1996, NJ 1998, 45 (Goosen-Goosen \& Dekkers)

- 3 januari 1997, NJ 1997, 451 (zoektocht identiteit biologische vader), m.nt. J.d.B.

- 17 oktober 1997, NJ 1998, 241 (criteria voor verwijzing naar schadestaatprocedure)

- 7 november 1997, NJ 1998, 268, m.nt. Ma, JOR 1998, 9, m.nt. C.M. Grundmanvan de Krol

- 30 januari 1998, NJ 1998, 459 (Interforce-Rosier's Beleggingsmaatschappij), m.nt. J.B.M.V.

- 20 maart 1998, NJ 1998, 548 (criteria voor verwijzing naar schadestaatprocedure)

- 11 september 1998, NJ 1999, 664, m.nt. M.M.M.

- 22 januari 1999, NJ 2000, 305

- 15 oktober 1999, NJ 2001, 42 (inhoud mededelingsplicht vertrouwensarts)

- 18 februari 2000, NJ 2001, 259 (News International PLC c.s.-ABN AMRO Bank), m.nt. P.V.

- 22 september 2000, NJ 2001, 647, m.nt. J.d.B.

- 29 september 2000, NJ 2001, 95, m.nt. T.K.

- 28 september 2001, NJ 2002, 104 (Rowa - Hooters)

- 19 oktober 2001, NJ 2001, 653 (criteria voor verwijzing naar schadestaatprocedure)

- 31 mei 2002, NJ 2003, 589 (observatiearrest), m.nt. J.B.M.V.

- 13 september 2002, AE3383, NJ 2003, 400

- 20 december 2002, NJ 2004, 4, Lightning Casino cs - de openbare rechtspersoon de Nederlandse Antillen, m.nt. J.B.M.V. (vervolgd door HR 28 april 2006, NJ 2006, 283)

- 19 september 2003, NJ 2005, 454 (van Hulst, geen opfrisplicht getuige), m.nt. D.A.

- 12 december 2003, NJ 2004, 117 (bloedende patiënt-bloedende arts)

- 19 december 2003, NJ 2005, 181

- 3 september 2004, NJ 2004, 586

- 24 september 2004, AO9069, NJ 2008, 587 (Vleesmeesters-Alog), m.nt. C.E. du Perron 
24 december 2004, AR4980

- 21 januari 2005, NJ 2005, 249, AS3534

- $\quad 3$ juni 2005, NJ 2005, 324

- 24 juni 2005. NJ 2006, 46

- 23 september 2005, JOR 2005, 264, (de Staatssecretaris van Financiën-X Holding B.V.), m.nt. P.v.d.Korst

- 25 november 2005, AU4019, NJ 2009, 550, m.nt. P.B. Hugenholtz onder NJ 2009, 551, JOL 2005, 683 (Lycos-Pessers)

- 25 november 2005, AU2403

- 20 januari 2006, NJ 2006, 78 (bewijslastomkering bij weigering ontslag geheimhoudingsplicht)

- 28 april 2006, NJ 2006, 283 (Lightning Casino Sint Maarten N.V. c.s.-de openbare rechtspersoon de Nederlandse Antillen II)

- 6 oktober 2006, NJ 2006, 547, JBPR 2007, 6, m.nt. J.G.A. Linssen, AA 2007, pag. 371-374, m.nt. H.B. Krans (Meijer-VOF Gebr. Cornelis; vervolg: hof Den Bosch 30 oktober 2007, BB8632)

- 16 maart 2007, AZ6530, NJ 2007, 232 (prognoseverbod)

- 23 maart 2007, BA0575

- 29 juni 2007, BA3529, NJ 2007, 639 (Hollandsche Bank Unie)

- 29 juni 2007, AZ4663, NJ 2007, 638 (Dexia)

- 29 juni 2007, AZ4664, Dexia

- 21 december 2007, BB9133, NJ 2008, 31 (International Card Services B.V.-de Staat der Nederlanden)

- 25 januari 2008, BC1256

- 15 februari 2008, BC1860, NJ 2008, 106

- 22 februari 2008, BB5626, L\&S 2008, 6

- 22 februari 2008, BB3676, L\&S 2008, 7, m.nt. C. Roijackers

- 30 mei 2008, BC5012, NJ 2008, 311

- 11 juli 2008, BC8421, NJ 2009, 451, m.nt. E.J. Dommering (Uitgeversmaatschappij De Telegraaf B.V. - De Staat der Nederlanden)

- $\quad 31$ oktober 2008, BF1179

- 30 januari 2009, BG5847, RvdW 2009, 252, JAR 2009, 56 (Vissers-De Champignonspecialist)

- 27 maart 2009, BH1986, NJ 2009, 254, m.nt. S.F.M.W

- 10 april 2009, BG9470 (geheimhoudingsverplichting in mediationovereenkomst)

- 26 juni 2009, BD5516

- 18 september 2009, BI5906, Nj 2009, 566, m.nt. J.W. Zwemmer, RvdW 2009, 1045

- 2 oktober 2009, BJ1257, NJ 2009, 478

- 23 oktober 2009, BJ7331

- 20 november 2009, BJ7322

- 29 januari 2010, BK2007 (inzage in proces-verbaal arbitragezitting)

\section{Hoven}

- Hof Den Haag 14 december 1979, NJ 1981, 651

- Hof Den Haag 20 april 1993, S\&S 1995, 11 
- $\quad$ Hof Den Bosch 15 mei 1996, AG3025 (cassatie HR 7 november 1997, NJ 1998, 268)

- $\quad$ Hof Den Bosch 27 maart 2003, JBPR 2003, 63, m.nt. J.G.A. Linssen

- Hof Den Haag 20 mei 2003, S \& S 2004, 59 en AV\&S 2003, pag. 221, m.nt. N. van Tiggele-van der Velde

- Hof Den Bosch 14 oktober 2003, AM7927

- $\quad$ Hof Den Bosch 28 september 2004, AS6740, JOR 2005, 23, m.nt. P.v.d.Korst

Hof Arnhem 17 mei 2005, AT6104

Hof Den Haag 25 oktober 2005, AU8485, NJF 2005, 452, S\&S 2006, 54

Hof Amsterdam 10 november 2005, AU8223, JOR 2006, 14

- Hof Den Bosch 15 november 2005, AX8899, JBPR 2006, 52, m.nt. M.O.J.d.Folter

Hof Den Bosch 16 januari 2006, NJF 2006, 191

Hof Den Bosch 16 januari 2006, NJF 2006, 211

- Hof Den Bosch 9 februari 2006, AV1483 en AV1486, NJF 2006, 223

- $\quad$ Hof Den Bosch 4 april 2006, AW4335, JBPR 2007, 12, m.nt. J.G.A. Linssen onder 2007, 6

- $\quad$ Hof Den Haag 4 mei 2006, AW8455 NJF 2006, 318

- $\quad$ Hof Den Bosch 30 mei 2006, JBPR 2007, 13, m.nt. J.G.A. Linssen

- Hof Den Haag 22 augustus 2006, AY8858, JOR 2006, 293, m.nt. C.W.M.Lieverse

- Hof Den Bosch 22 augustus 2006, AZ0605

- Hof Den Haag 24 augustus 2006, AY7534

Hof Arnhem 29 augustus 2006, AY9096

Hof Arnhem 13 februari 2007, BA0018

Hof Leeuwarden 28 februari 2007, NJ 2009, 199

Hof Arnhem 17 april 2007, NJF 2007, 391

Hof Den Bosch 30 mei 2007, BA9007

Hof Den Haag 12 juni 2007, S\&S 2009, 34

Hof Den Bosch 14 augustus 2007, rolnr. C0600659/MA

Hof Den Haag 9 oktober 2007, BB6971

Hof Arnhem 16 oktober 2007, BB5511

Hof Den Bosch 16 oktober 2007, BB6402

Hof Den Bosch 23 oktober 2007, BB6845

Hof Amsterdam 25 oktober 2007, BC1415

Hof Den Bosch 30 oktober 2007, BB8632

Hof Den Haag 22 november 2007, BB8556, NJF 2008, 3

Hof Arnhem 18 december 2007, BC5303

Hof Arnhem 25 maart 2008, BC9246

Hof Den Haag 11 april 2008, BD0694, NJF 2008, 245

Hof Amsterdam 17 juni 2008, BE2917

Hof Amsterdam 30 september 2008, BG4368

Hof Amsterdam 25 november 2008, NJF 2009, 31

Hof Amsterdam 2 december 2008, BG9050, NJF 2009, 39 (aantekeningen griffier)

Hof Amsterdam 2 december 2008, BG9051 (Autoplanning B.V.)

Hof Arnhem 2 december 2008, BH2816

- Hof Leeuwarden 9 december 2008, BG 6616, NJ 2009, 200, m.nt. J. Legemaate

Hof Den Bosch 23 december 2008, BH0130, RAR 2009, 38

- $\quad$ Hof Leeuwarden 13 januari 2009, BH2762 
- $\quad$ Hof Den Bosch 17 maart 2009, BI7600, B9-7704 en IER 2009, 42 (waar ten onrechte is vermeld dat het een uitspraak is van de Rb Den Bosch)

- Hof Arnhem 31 maart 2009, BI2138

- Hof Arnhem 28 april 2009, BI4184

- Hof Leeuwarden 16 juni 2009, BI8910

- $\quad$ Hof Den Bosch 21 juli 2009, BK3127

- Hof Leeuwarden 4 augustus 2009, BJ4901

- Hof Arnhem 3 november 2009, NJF 2010, 25

- Hof Den Bosch 8 december 2009, BK7639

- Hof Arnhem, Nevenzittingsplaats Leeuwarden 16 maart 2010, BL7896

\section{Rechtbanken}

- $\quad$ Rb Rotterdam 23 februari 1990, S\&S 1995, 11

- $\quad$ Rb Amsterdam 23 februari 1995, KG 1995, 136

- $\quad$ Rb Utrecht 9 april 1996, KG 1996, 158

- $\quad$ Rb Amsterdam 15 mei 1997, KG 1997, 212

- $\quad$ Rb Amsterdam 22 mei 2000, KG 2000, 129.

- Rb Maastricht 7 maart 2002, AE0630

- $\quad$ Rb Amsterdam 4 september 2002, AG8155, JOR 2002, 176

- $\quad$ Rb Zutphen 7 mei 2003, AI1718, JBPR 2003, 66, m.nt. J.G.A. Linssen

- $\quad$ Rb Den Haag 23 oktober 2003, JOR 2004, 63

- $\quad$ Rb Breda 14 januari 2004, JOR 2004, 70

- $\quad$ Rb Zwolle 24 februari 2004, AO5169

- Rb Rotterdam 19 mei 2004, AR3382, S\&S 2005, 64

- Rb Dordrecht 23 juni 2004, AP3695

Rb Amsterdam 7 juli 2004, AP8458

Rb Arnhem 29 september 2004, AR3532

- Rb Amsterdam 3 november 2004, AR5041, NJF 2005, 22

- Rb Rotterdam 25 november 2004, NJF 2005, 2

- Rb Amsterdam 18 januari 2005, JBPR 2006, 56, m.nt. de Folter onder 2006, 52

- Rb Amsterdam 2 februari 2005, AT1558, JOR 2005, 71

- $\quad$ Rb Zwolle 8 februari 2005, AS9413

- $\quad$ Rb Rotterdam 23 februari 2005, BB6038, S\&S 2009, 85

- $\quad$ Rb Amsterdam 13 april 2005, JOR 2005, 142

- $\quad$ Rb Amsterdam 19 mei 2005, AT5858

- $\quad$ Rb Den Haag 19 mei 2005, AY5824

- $\quad$ Rb Den Haag 27 juli 2005, AU5178

- $\quad$ Rb Almelo 28 juli 2005, AU0215

- $\quad$ Rb Arnhem 15 augustus 2005, AU4760

- $\quad$ Rb Amsterdam 24 augustus 2005, AU4935

- $\quad$ Rb Den Haag 21 september 2005, AV7698, JBPR 2006, 25, m.nt. M.A.J.G. Janssen, B9-954

- $\quad$ Rb Amsterdam 10 november 2005, AU6428

- $\quad$ Rb Arnhem 21 december 2005, AV1977

- $\quad$ Rb Zutphen 4 januari 2006, AV1712

- $\quad$ Rb Dordrecht 5 januari 2006, AU9320, S \& S 2006, 104 
- $\quad$ Rb Middelburg 18 januari 2006, AY7116

- Rb Rotterdam 25 januari 2006, NJF 2006, 230

- $\quad$ Rb Breda 15 februari 2006, NJF 2006, 217

- Rb Groningen 29 maart 2006, AV7614

- $\quad$ Rb Zwolle 30 maart 2006, AY5714

- $\quad$ Rb Middelburg 5 april 2006, AZ0931

- Rb Rotterdam 5 april 2006, AV9821

- Rb Amsterdam 6 april 2006, B9-1899

Rb Arnhem 12 april 2006, AY0152

Rb Arnhem 19 april 2006, AX7332

- Rb Zwolle-Lelystad 15 mei 2006, AY5717

- Rb Rotterdam 17 mei 2006, HA ZA 04-757, AX9002

- Rb Rotterdam 17 mei 2006, HA ZA 04-3288, AX 6815, NJF 2006, 388

- $\quad$ Rb Rotterdam 5 juli 2006, AY3959

- Rb Middelburg 6 juli 2006, AZ0501

- $\quad$ Rb Rotterdam 19 juli 2006, AZ4042, NJF 2006, 556

- $\quad$ Rb Amsterdam 7 september 2006, AY7784

- $\quad$ Rb Amsterdam 5 oktober 2006, AY9545

- $\quad$ Rb Breda 25 oktober 2006, AZ1374

- $\quad$ Rb Arnhem 10 januari 2007, AZ9268

- $\quad$ Rb Zutphen 17 januari 2007, BA4428

- $\quad$ Rb Amsterdam 24 januari 2007, AZ7826, JOR 2007, 108

- $\quad$ Rb Arnhem 31 januari 2007, AZ9595

- $\quad$ Rb Haarlem 2 februari 2007, AZ7827

Rb Rotterdam 7 maart 2007, BA0914

- Rb Den Haag 21 maart 2007, BC5652

Rb Zutphen 21 maart 2007, BA8996

Rb Den Bosch 22 maart 2007, BA1352, NJF 2007, 213

- $\quad$ Rb Amsterdam 28 maart 2007, BG3882, ook gepubliceerd onder BA3125

- $\quad$ Rb Arnhem 11 april 2007, BA5534

Rb Utrecht 18 april 2007, BA3557

- $\quad$ Rb Amsterdam 19 april 2007, BA3673

- $\quad$ Rb Dordrecht 3 mei 2007, BA5179

- $\quad$ Rb Zutphen 9 mei 2007, BB1491

- $\quad$ Rb Zwolle-Lelystad 11 mei 2007, BA5021

- $\quad$ Rb Arnhem 1 juni 2007, BA9615

Rb Rotterdam 4 juli 2007, BA9918

- $\quad$ Rb Zwolle-Lelystad 6 juli 2007, BB9222

- Rb Arnhem 25 juli 2007, BB1988

Rb Den Haag 25 juli 2007, BB2652

- $\quad$ Rb Arnhem 15 augustus 2007, BB2025

- Rb Alkmaar 30 augustus 2007, BB2608

- Rb Utrecht 12 september 2007, BB3722, NJF 2007, 544, JOR 2007, 265

- $\quad$ Rb Maastricht 3 oktober 2007, HA ZA 07-551

- $\quad$ Rb Arnhem 26 oktober 2007, BB8052

- $\quad$ Rb Rotterdam 5 december 2007, BC0225, NJF 2008, 95

- $\quad$ Rb Den Haag 5 december 2007, BB9517 
Rb Dordrecht 19 december 2007, BC1176

- $\quad$ Rb Den Haag 19 december 2007, BC0911, NJF 2008, 55

- $\quad$ Rb Utrecht 19 december 2007, BC0686

- Rb Zwolle-Lelystad 20 december 2007, BC1286, JA 2008, 24

- $\quad$ Rb Rotterdam 9 januari 2008, BC4119

- $\quad$ Rb Utrecht 23 januari 2008, BC4019

- $\quad$ Rb Zutphen 23 januari 2008, BC2626

- $\quad$ Rb Rotterdam 30 januari 2008, HA ZA 07-674

- $\quad$ Rb Utrecht 13 februari 2008, JAR 2008, 83

- $\quad$ Rb Den Haag 20 februari 2008, B9-5659

- $\quad$ Rb Zwolle-Lelystad 5 maart 2008, BD8262

- $\quad$ Rb Den Haag 5 maart 2008, BC6812

- $\quad$ Rb Maastricht 12 maart 2008, BC6796

- $\quad$ Rb Rotterdam 19 maart 2008, BC9708

- $\quad$ Rb Arnhem 26 maart 2008, BC8823

- $\quad$ Rb Den Haag 27 maart 2008, B9-6004

- $\quad$ Rb Utrecht 2 april 2008, BC8153

- $\quad$ Rb Amsterdam 2 april 2008, BC9315, NJF 2008, 237

- $\quad$ Rb Den Haag, 9 april 2008, BC9134

- $\quad$ Rb Utrecht 9 april 2008, BC9990

- $\quad$ Rb Den Bosch 16 april 2008, BC9695, NJF 2008, 228, JA 2008, 68, m.nt. J. Ekelmans

- $\quad$ Rb Den Haag 16 april 2008, B9-6133

- $\quad$ Rb Rotterdam 7 mei 2008, BD4074

- $\quad$ Rb Middelburg 7 mei 2008, BD3047

- $\quad$ Rb Dordrecht 7 mei 2008, BD0461

- $\quad$ Rb Alkmaar 21 mei 2008, BD2570

- $\quad$ Rb Den Bosch 21 mei 2008, BD2308

- $\quad$ Rb Utrecht 28 mei 2008, BD2666

- $\quad$ Rb Rotterdam 4 juni 2008, BD9249

- $\quad$ Rb Zutphen 11 juni 2008, BD7231

- $\quad$ Rb Dordrecht 12 juni 2008, BD4467

- $\quad$ Rb Haarlem 18 juni 2008, BD6490

- $\quad$ Rb Rotterdam 18 juni 2008, BD9533

- Rb Amsterdam 19 juni 2008, BD4818 (appel: hof Amsterdam 2 december 2008, BG9050)

- $\quad$ Rb Haarlem 27 juni 2008, BD6672 (appel: hof Amsterdam, 2 december 2008, BG9051)

- $\quad$ Rb Amsterdam 3 juli 2008, B9-6521

- $\quad$ Rb Haarlem 16 juli 2008, BD7632

- $\quad$ Rb Breda 18 juli 2008, BD7674

- $\quad$ Rb Zutphen 23 juli 2008, BD8506

- $\quad$ Rb Amsterdam 23 juli 2008, B9-6517

- $\quad$ Rb Maastricht 29 juli 2008, BD9036

- $\quad$ Rb Rotterdam 29 juli 2008, BD9031

- Rb Breda 31 juli 2008, BD9054

- $\quad$ Rb Zutphen 20 augustus 2008, JAR 2008, 255 
- Rb Amsterdam 27 augustus 2008, BF3963

Rb Arnhem 3 september 2008, BF0614

- Rb Amsterdam 11 september 2008, BF0587, Rechtspraak Financieel Recht 2009,

18, Journaal Ondernemingsrecht (effectenrecht) 2009, 119

- $\quad$ Rb Utrecht 1 oktober 2008, BF7386

- $\quad$ Rb Rotterdam 8 oktober 2008, BG3804

- $\quad$ Rb Utrecht 15 oktober 2008, BG4385

- $\quad$ Rb Rotterdam 21 oktober 2008, BG1066, Tijdschrift Vervoer\&Recht 2009, pag. 27-29, m.nt. R.C.A. van 't Zelfde

- $\quad$ Rb Arnhem 21 oktober 2008, BG3613

- $\quad$ Rb Utrecht 29 oktober 2008, BG3678

- $\quad$ Rb Assen 29 oktober 2008, te kennen uit hof Leeuwarden 4 augustus 2009, BJ4901

- $\quad$ Rb Rotterdam 5 november 2008, BG4453

- $\quad$ Rb Den Haag 6 november 2008, NJF 2009, 8

- $\quad$ Rb Utrecht 28 november 2008, BG5823

- $\quad$ Rb Dordrecht 17 december 2008, BG7840

- $\quad$ Rb Amsterdam 31 december 2008, BH1550, NJF 2009, 85

- $\quad$ Rb Haarlem 7 januari 2009, BH2081

- Rb Utrecht 21 januari 2009, B9-7517

- $\quad$ Rb Amsterdam 28 januari 2009, BH5770

Rb Alkmaar 18 februari 2009, BH5897

- Rb Zwolle-Lelystad 25 februari 2009, BH9274

- $\quad$ Rb Haarlem 27 februari 2009, BH6255

- Rb Rotterdam 4 maart 2009, BH5652

- $\quad$ Rb Zutphen 4 maart 2009, BH7615, NJF 2009, 168

- Rb Rotterdam 5 maart 2009, BH6004

- $\quad$ Rb Dordrecht 12 maart 2009, BH5742

- $\quad$ Rb Arnhem 16 maart 2009, BH6158

- $\quad$ Rb Utrecht 18 maart 2009, BH6128

- Rb Utrecht 18 maart 2009, BH6556

- $\quad$ Rb Dordrecht 23 maart 2009, BH7581

- $\quad$ Rb Rotterdam 1 april 2009, BI1747

- Rb Leeuwarden 15 april 2009, BI3631, Rechtspraak Notariaat 2009, 72

- Rb Arnhem 22 april 2009, BI3338

- $\quad$ Rb Den Haag 26 mei 2009, B9-7928

Rb Rotterdam 3 juni 2009, BI9158, NJF 2009, 403.

- Rb Utrecht 5 juni 2009, BI6346, Rechtspraak Financieel Recht 2009, 78

Rb Arnhem 10 juni 2009, BI8319

- $\quad$ Rb Rotterdam 10 juni 2009, BJ8968, NJF 2010, 30

- Rb Leeuwarden 24 juni 2009, BI9925

- $\quad$ Rb Rotterdam 24 juni 2009, NJF 2010, 31

Rb Arnhem 26 juni 2009, BJ4425

- $\quad$ Rb Den Bosch 16 juli 2009, BJ2913

- $\quad$ Rb Haarlem 22 juli 2009, BJ3588

- $\quad$ Rb Amsterdam 22 juli 2009, BJ4427

- $\quad$ Rb Arnhem 22 juli 2009, BJ6230, NJF 2009, 411 
- $\quad$ Rb Den Haag 6 augustus 2009, BJ4946

- Rb Rotterdam 12 augustus 2009, BJ5752

- $\quad$ Rb Rotterdam 3 september 2009, BJ7141

- $\quad$ Rb Rotterdam 9 september 2009, BJ8977

- Rb Leeuwarden 14 september 2009, BJ8523

- $\quad$ Rb Utrecht 21 oktober 2009, BK2302, NJF 2009, 505

Raad van Toezicht op het Schadeverzekeringsbedrijf

- 6 oktober 1992, VR 1993, 121

Nederlandse Antillen en Aruba

Gemeenschappelijk Hof van Justitie van de Nederlandse Antillen en Aruba

22 juni 2007, AR 497/94-H.79/02

Gerecht in Eerste Aanleg van de Nederlandse Antillen

- Curaçao,19 december 2005, AR 129/2005 (vervolgd bij uitspraak van 28 april 2006 (maar nu genummerd EJ 52A/2005)

- Curaçao, 18 december 2006, ARnr. 1453/2005

- Curaçao, 22 maart 2006, ARnr. 1056/2001

- Curaçao, 28 april 2006, EJ52A/2005

- Curaçao, 15 januari 2007, ARnr. 1358/2005

- Curaçao, 12 november 2007, BG9118

- $\quad$ Sint Maarten, 16 januari 2007, ARnr. 56/2004 



\section{Trefwoordenregister}

Er wordt verwezen naar de paragraafnummers.

Aanbesteding / 11.1

Aanvullende eed / 6.2

Activisme, rechterlijk / 3.1, 6.1

Afgifte / 7.2, 8.2, 9

Akte, authentiek / 2.2.1, 2.2.2, 7.3, 8.3.1

Akte, onderhands / 2.2.1, 2.2.2, 7.3,

8.3.1, 10

Antitrustregel(s) / 2.3, 4.3

Arbitrage / 7.1.1, 15

Bedrijfsgeheimen / 11.1, 14

Bekende inhoud / 7.3

Bescheiden (bepaald) / 2.2.2, 2.3

Beslagsyllabus / 14

Bewaarplicht / 2.3

Bewijsbeslag / 4.2, 7.2, 9, 14, 15

Bewijsprognose / 2.2.2, 11.2

Bewijsstuk, verloren gegaan / 2.3

Binnen/buiten het geding / 2.2.1, 2.3, 15

Code Louis / 2.1.3

Disclosure / 2.3, 3.3, 4.1, 5.1, 12

Discovery / 3.3, 4.1, 5.3.1, 6.1

Discretionaire bevoegdheid / 3.2

DNA-onderzoek / 5.3.3.1, 6.3, 7.2, 7.3, 8.2, 8.3.1

Dwangsom / 9

Due diligence(rapport) / 3.2, 6.3, 7.1.1, 7.1.3, 7.4, 9

Edent / 2.1.4

Eigendom, gemeenschappelijk / 2.1.4

Elektronisch akte / 2.3

Financieel onderzoek / 3.2
Fishing expedition / 2.3, 7.1.1, 7.3, 8.3.2, 13

Geheimhouder / 4.1, 10, 11.1

Gerechtelijke eed / 6.2

Geheimhoudingsplicht / 4.1, 9, 10, 11.1

Getuigenverhoor / 8.1, 11.2

Gewichtige reden(en) / 3.1, 9, 11.1

Groene kaart / 7.1.2

Herroeping, herziening / 2.1.3, 3.1, 6.2

Incidentele vordering / 15

Informatie-artikelen / 3.2

Informatie(verschaffings)plicht / 3.1, 5.3, 5.3.3.1, 6.2

Intellectuele eigendom / 2.3, 4.2, 8.2, 15

Lijdelijk(heid) / 3.1, 3.2, 6.1, 7.1.1

Mededelingsplicht / 2.1.4

Mededinging(sregels) / 2.3, 4.3

Melding incidenten patiëntenzorg (mip) / 7.1.2, 11.1

Nemo cogitur edere contra se / 2.1.3, 2.1.4, 2.4, 3.1

Nevenschikkend / 2.2.2

Noodzakelijkheidscriterium / 7.1.1, 8.1

Nutsverbruikgegevens / 7.1.1

Omkering(sregel) / 6.1, 6.3

Onderzoek (naar executie- of verhaalsmogelijkheid) / 3.2, 3.3, 7.1.1

Onderzoekstaak (rechterlijke, van de rechter) / 3.1 
Onrechtmatig verkregen bewijs / 15

Ontoelaatbaar bewijs / 15

Ordonnantie 1667 / 2.1.3

Overlegging / 2.3

Patiëntenkaart / 7.1.2

Persoonsgegevens / 13

Piraterij / 4.2

Polis / 2.3, 7.3, 7.4

Pre-trial / 3.3, 5.1

Principles of transnational civil procedure (PTCP) / 3.3

Privacy / 13

Proces-verbaal (zittings) / 7.3, 15

Prognose / 8.1

Prognoseverbod / 8.1, 11.2

Rechtmatig belang / 5.3.3.3, 7.1.1, 8.1

Rechtsbetrekking / 2.2.2, 7.4, 8.4

Request civiel / 2.1.3, 6.2

Rogatoire commissie / 2.2.2, 3.3
Samenhangende rechtsverhoudingen / 8.4

Strafdossier / 7.2, 13

Subsidiariteitsbeginsel / 2.2.2, 11.2

Titel, gemeen of gemene / 2.1.4

Vaartijdenboek / 6.3, 7.1.1, 15

Verhaalsonderzoek / 3.3, 7.1.1

Vernietiging (van bewijsmateriaal) / 7.1.1

Verschoning(srecht) / 4.1, 11.1 Vertrouwelijk(e) stukken of informatie / 3.2

Verzekeringspolis / 2.3, 7.3, 7.4

Vissen / 2.3, 3.3, 7.1.1, 7.3, 7.4, 8.1, 8.3.2

Voorlopig getuigenverhoor / 8.1, 11.2, 15

Voorlopige voorziening / 15

Vrijwaring / 7.4 


\section{Curriculum vitae}

Johannes Romke Sijmonsma is geboren op 8 december 1958 in de Noordoostelijke Polder (Creil). In 1977 behaalde hij het diploma Atheneum A aan de Scholen Gemeenschap te Lelystad. Hij studeerde rechten in Groningen van 1977 tot 1982. Van 1982 tot 1986 was hij wetenschappelijk medewerker bij de Vakgroep Privaatrecht van de Juridische Faculteit van de Universiteit van Amsterdam en van 1986 tot 1990 RAIO bij de Arrondissementsrechtbank Maastricht. In 1990 werd hij rechter-plaatsvervanger en in 1991 rechter in die Arrondissementsrechtbank. Van 1996 tot 2001 was hij lid van het Gemeenschappelijk Hof van Justitie van de Nederlandse Antillen en Aruba. Hij was vanaf 1997 tot 2001 part-time docent aan de Universiteit van de Nederlandse Antillen. Vanaf 1 oktober 2001 tot 1 december 2008 was hij weer rechter in, en vanaf 2003 vice-president van de Arrondissementsrechtbank Maastricht, waar hij vanaf 1 november 2006 tevens waarnemend voorzitter van de sector civiel was. Vanaf 1 december 2008 is hij weer lid van het Gemeenschappelijk Hof van Justitie van de Nederlandse Antillen en Aruba. 
